UNIVERSIDADE DE SÃO PAULO

ESCOLA DE COMUNICAÇÕES E ARTES

MARIANA REZENDE DOS PASSOS

Mito e narrativa: a (des)construção da imagem pública de Lula no contexto da crise política de 2016 


\title{
Mito e narrativa: a (des)construção da imagem pública de Lula no contexto da crise política de 2016
}

\author{
(Versão corrigida)
}

Tese apresentada ao Programa de Pós-Graduação em Ciências da Comunicação da Escola de Comunicações e Artes - Universidade de São Paulo como pré-requisito para a obtenção do título de Doutora.

Área de concentração: Interfaces Sociais da Comunicação

Orientação: Prof. Dr. Paulo Roberto Nassar de Oliveira

SÃO PAULO 
Autorizo a reprodução e divulgação total ou parcial deste trabalho, por qualquer meio convencional ou eletrônico, para fins de estudo e pesquisa, desde que citada a fonte.

Catalogação na Publicação

Serviço de Biblioteca e Documentação

Escola de Comunicações e Artes da Universidade de São Paulo

Dados fornecidos pelo(a) autor(a)

Passos, Mariana Rezende dos

Mito e narrativa: a (des) construção da imagem pública de Lula no contexto da crise politica de 2016 / Mariana Rezende dos Passos. -- São Paulo: M. R. Passos, 2017.

326 p.: il.

Tese (Doutorado) - Programa de Pós-Graduação em Ciências da Comunicação - Escola de Comunicações e Artes / Universidade de são Paulo.

Orientador: Paulo Roberto Nassar de Oliveira

Bibliografia

1. Lula 2. Mito político 3. Imagem pública 4. Novas narrativas 5. Crise politica I. Nassar de Oliveira, Paulo Roberto II. Título. 
Nome: PASSOS, Mariana Rezende dos.

Título: Mito e narrativa: a (des)construção da imagem pública de Lula no contexto da crise política de 2016

Tese apresentada ao Programa de Pós-Graduação em Ciências da Comunicação da Escola de Comunicações e Artes - Universidade de São Paulo como pré-requisito para a obtenção do título de Doutora.

Aprovada em:

\section{Banca examinadora}

$\operatorname{Prof}(\mathrm{a}) . \operatorname{Dr}(\mathrm{a})$

Instituição:

Julgamento:

$\operatorname{Prof(a).~Dr(a).~}$

Instituição:

Julgamento:

$\operatorname{Prof}(\mathrm{a}) . \operatorname{Dr}(\mathrm{a})$.

Instituição:

Julgamento:

$\operatorname{Prof}(\mathrm{a}) . \operatorname{Dr}(\mathrm{a})$

Instituição:

Julgamento: 


\section{AGRADECIMENTOS}

Agradeço aos meus pais, Alberto e Márcia, por terem sido meu porto seguro durante esses quatro intensos anos de trabalho e por serem meus maiores exemplos de perseverança e dedicação. Aos meus irmãos, Carolina e Eduardo, por me darem forças diante das adversidades, pela amizade, conselhos de vida e momentos de descontração. Aos meus sobrinhos, Maria e João, pelo amor incondicional. E à Ana pela paciência e carinho e por ter me ajudado nos momentos de incertezas. Eu não teria chegado até aqui sem vocês.

Ao meu orientador, professor Paulo Nassar, pela oportunidade de desenvolver essa pesquisa, por ter depositado confiança em meu trabalho e pelos conselhos profissionais.

À professora Heloiza Matos por ter me acolhido tão bem desde o início do doutorado.

À amiga Érica Anita por dividir comigo as ansiedades da vida acadêmica e aos integrantes do Grupo de pesquisa de Novas Narrativas, em especial Gustavo Carbonaro e Emiliana, pelo constante compartilhamento de ideias.

E agradeço, em especial, à minha querida professora Teresinha Cruz Pires (minha primeira e eterna orientadora) pelo apoio constante, por dividir comigo seu vasto conhecimento e sempre me lembrar que, por mais doloroso que seja, o ato de pesquisar vale muito a pena. 


\section{RESUMO}

PASSOS. Mariana Rezende dos. Mito e narrativa: a (des)construção da imagem pública de Lula no contexto da crise política de 2016. 2017. 326 f. Tese (Doutorado em Ciências da Comunicação) - Escola de Comunicações e Artes, Universidade de São Paulo, São Paulo, 2017.

A presente pesquisa investiga como se deu o processo de (des)construção da imagem pública de Lula durante a crise política brasileira de 2016 e como foram acionadas as narrativas do mito político nesse processo. Para atingirmos esses objetivos analisamos a circulação de narrativas no Twitter que mencionavam a palavra-chave "Lula" e que foram publicadas durante quatro contextos ocorridos naquele ano, quais sejam: as manifestações sociais a favor do impeachment de Dilma Rousseff que se deram em 13 de março; as protestações sociais contra o golpe ocorridas em 18 de março, a votação do processo de impeachment na Câmara dos Deputados, em 17 de abril, e no Senado Federal, em 12 de maio. Os procedimentos adotados para a realização da investigação basearam-se em pesquisa teórica sobre os conceitos de mito, narrativa e imagem pública política, bem como sobre a circulação desses conceitos nas sociedades midiatizadas. Além disso, realizamos pesquisa bibliográfica sobre a trajetória política de Lula, bem como acerca da crise política instituída no Brasil desde as manifestações sociais ocorridas em junho de 2013 com vistas a: a) compreender a polarização de sentidos entre as narrativas do impeachment e do golpe, na medida em que essa discussão se mostrou central nas conversações civis predominantemente após a autorização da instauração do processo de impeachment de Dilma Rousseff, em dezembro de 2015; e b) contextualizar os quatro períodos da crise política de 2016 supramencionados. Feito o percurso teórico, a pesquisa empírica baseou-se na análise de redes sociais para que fosse possível investigar os tipos de perfis ou de usuários do microblog (classificados em seis categorias, a saber: perfis de lideranças políticas, de veículos jornalísticos, de blogs jornalísticos, de formadores de opinião, de militância ou de usuários comuns) que foram fundamentais na circulação de informação sobre Lula nos períodos investigados. Baseou-se igualmente na análise de narrativas, destinada à compreensão do conteúdo dessas informações em circulação.

Palavras-chave: Lula. Mito político. Imagem pública. Novas narrativas. Crise Política. 


\begin{abstract}
PASSOS, Mariana Rezende dos. Myth and narrative: the (de)construction of Lula's public image in the context of the $\mathbf{2 0 1 6}$ political crisis. 2017. $326 \mathrm{f}$. Tese (Doutorado em Ciências da Comunicação) - Escola de Comunicações e Artes, Universidade de São Paulo, São Paulo, 2017.
\end{abstract}

The present research investigates the process of (de)constructing of the public image of Lula during the Brazilian political crisis of 2016 and how the narratives of the political myth were triggered in this process. In order to reach these objectives, we analyzed the circulation of narratives on Twitter that mentioned the keyword "Lula" and that were published during four contexts that occurred in that year, namely: the social demonstrations in favor of Dilma Rousseff's impeachment that occurred on 13 March; the social protests against the coup on March 18, the impeachment vote in the Chamber of Deputies on April 17 and in the Federal Senate on May 12. The procedures adopted to carry out the research were based on theoretical research on the concepts of myth, narrative and public political image, as well as on the circulation of these concepts in mediatized societies. In addition, we carried out a bibliographical research on Lula's political trajectory, as well as on the political crisis instituted in Brazil since the social demonstrations that took place in June 2013, with a view to: a) understanding the polarization of meanings between the narratives of impeachment and the narratives of the coup, inasmuch as this discussion was central to civilian conversations predominantly after the authorization of Dilma Rousseff's impeachment process in December 2015; and b) contextualize the four contexts of the political crisis of 2016 mentioned above. The empirical research was based on the analysis of social networks so that it was possible to investigate the types of microblogging profiles or users (classified into six categories, to be specific: political leaders, journalistic vehicles, journalistic blogs, opinion leaders, militants or common users) that were fundamental in the circulation of information about Lula in the periods investigated. It was also based on the analysis of narratives, aimed at understanding the content of this information in circulation.

Keyworkds: Lula. Political Myth. Public Image. New narrratives. Political Crisis. 


\section{SUMÁRIO}

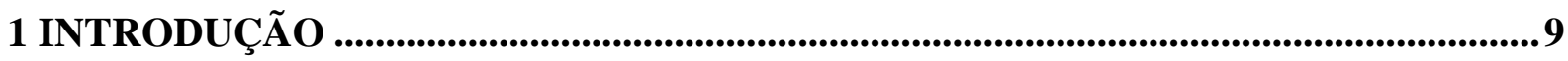

2 MITO, NARRATIVA E IMAGEM PÚBLICA POLÍTICA ............................................20

2.1 Mito político: principais abordagens .....................................................................................20

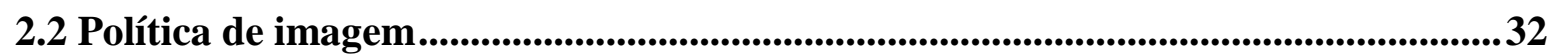

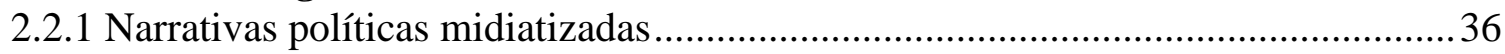

2.2.2 Públicos em rede: a circulação de narrativas políticas em tempos de mídias sociais

\section{A TRAJETÓRIA DE LULA E A CONTEXTUALIZAÇÃO DA CRISE POLÍTICA}

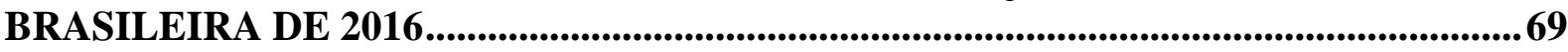

3.1 A trajetória política de Lula: de operário a presidente do Brasil ............................69

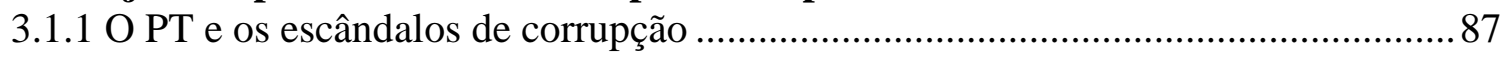

3.1.2 Reeleição e celebrização da imagem pública política de Lula ................................ 95

3.2 De Lula a Dilma Rousseff ...................................................................................103

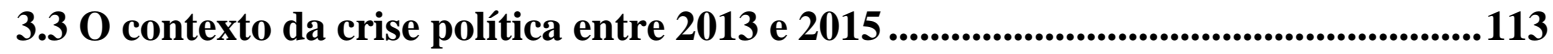

3.2.1 A instauração do processo de impeachment ......................................................... 129

3.3 Narrativas em disputa: impeachment versus golpe..................................................130

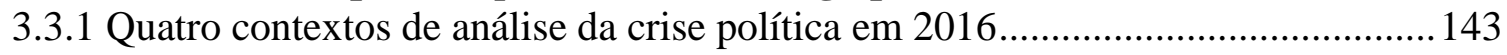

4 PROCEDIMENTOS METODOLÓGICOS ................................................................162

4.1 Twitter: ambiente e lógica de funcionamento ...................................................162

4.2 Coleta de dados e pré-observação empírica ..........................................................168

4.3 Análise empírica ............................................................................................................175

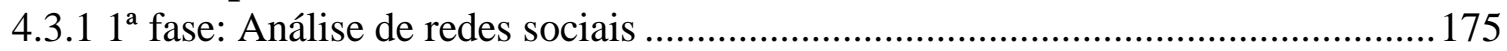

4.3.1.1 Análise de redes sociais: fundamentos......................................................... 175

4.3.1.2 Aplicação da análise de redes sociais para o Twitter................................... 180

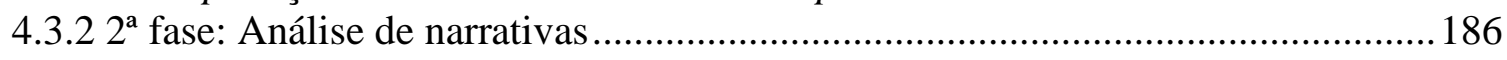

\section{AS REDES SOCIAIS NO TWITTER NOS QUATRO CONTEXTOS DA ANÁLISE}

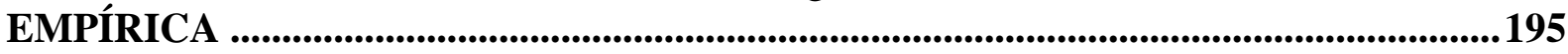

5.1 Contexto 1: Manifestações sociais a favor do impeachment .................................195

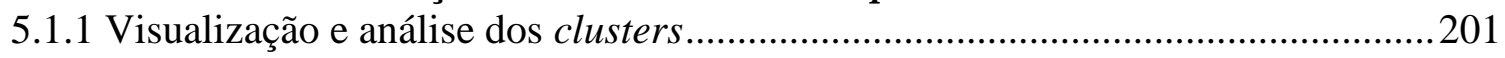

5.2 Contexto 2: Manifestações sociais contra o golpe....................................................209

5.2.1 Visualização e análise dos clusters................................................................213

5.3 Contexto 3: Votação na Câmara dos Deputados ...................................................219

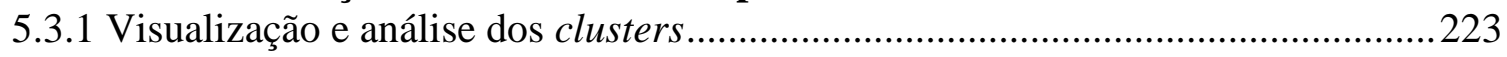

5.4 Contexto 4: Votação no Senado........................................................................228

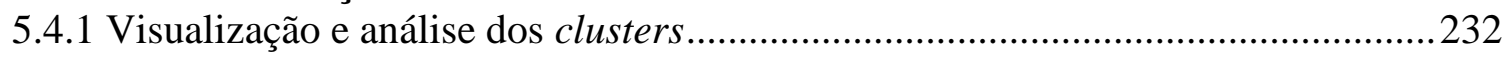

5.4 A rede polarizada: opositores versus apoiadores...............................................237 
6 AS NARRATIVAS DE (DES)CONSTRUÇÃO DA IMAGEM PÚBLICA DE LULA NO CONTEXTO DA CRISE POLÍTICA DE 2016 .........................................................240

6.1 Narrativas de desconstrução...............................................................................240

6.1.1 Escândalos de corrupção: a conspiração de Lula ....................................................241

6.1.2 O fim do salvador: o "impeachment de Lula" ..................................................259

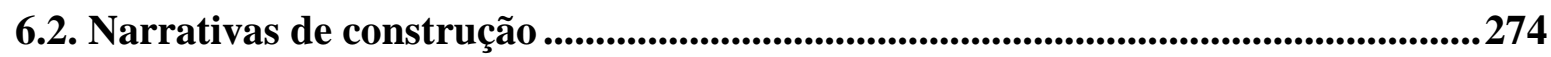

6.2.1 A conspiração contra o salvador: o golpe em Lula ............................................2 275

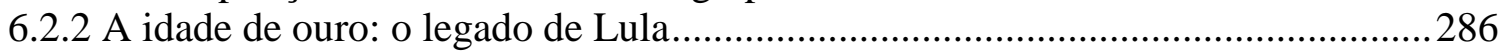

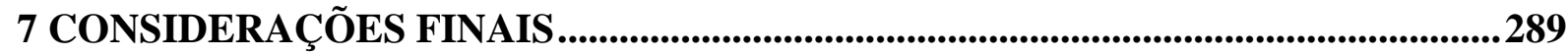

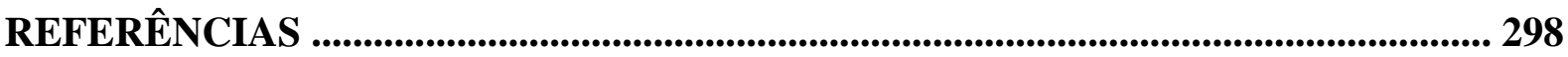




\section{INTRODUÇÃO}

A figura de Luiz Inácio Lula da $\operatorname{Silva}^{1}$ se faz presente no imaginário coletivo ${ }^{2}$ brasileiro há quase três décadas - quando ele se candidatou pela primeira vez à Presidência do Brasil em 1989. A sua trajetória política, como se sabe, não teve início a partir desse episódio, mas, sim, quando ele assumiu a liderança do Sindicato dos Metalúrgicos do ABC Paulista, entre as décadas de 1970 e 1980, durante a dura repressão do governo militar brasileiro. Ao liderar as maiores greves trabalhistas de que se tem notícia no país (entre 1978 e 1980) e ao ser um dos principais fundadores do Partido dos Trabalhadores (PT) em $1980^{3}$, Lula se consagrou, à época, como o herói da classe trabalhadora brasileira e como uma das figuras políticas basilares na luta pela redemocratização do país durante as manifestações que ficaram conhecidas como "Diretas Já”, ocorridas em 1983 e 1984.

O reconhecimento de Lula enquanto liderança política se constituiu em apoio eleitoral para sua candidatura a deputado federal pelo estado de São Paulo em 1986, quando foi o mais votado. Impulsionado pelo alto índice de votação para o cargo legislativo, o então deputado petista se candidatou à Presidência do Brasil por três vezes consecutivas antes de conseguir ser eleito - em 1989 (primeiras eleições desde a redemocratização do Brasil), 1994 e 1998. Mesmo após as três derrotas, Lula voltou a se candidatar em 2002 e venceu as eleições derrotando José Serra, do Partido da Social Democracia Brasileira (PSDB), no segundo turno com expressivos $61,27 \%$ dos votos (cerca de 52 milhões de votos) contra 38,72\% (cerca de 33 milhões de votos) do seu opositor ${ }^{4}$. Por esses números, Lula se tornou o presidente com maior votação nominal registrada nas 19 eleições diretas para presidente do Brasil. A partir de então o presidente petista passou a ser figura central - ou mesmo protagonista - do cenário político brasileiro.

\footnotetext{
${ }^{1}$ A partir desta introdução e em toda esta tese utilizaremos apenas o nome Lula, ao nos referirmos a Luís Inácio Lula da Silva.

${ }^{2}$ De acordo com abordagem proposta por Gilbert Durand (1997, p. 14), o imaginário pode ser compreendido como "[...] conjunto das imagens e das relações de imagens que constitui o capital pensado do homo sapiens [...]", a estrutura essencial na qual se constituem todos os processamentos do pensamento humano.". Seguindo a mesma perspectiva de Durand (1997), Bronislaw Baczko (1985, p. 309) defende que "[...] através dos seus imaginários sociais uma colectividade designa a sua identidade; elabora uma certa representação de si; estabelece a distribuição dos papéis e das posições sociais; exprime e impõe crenças comuns; constrói uma espécie de código de "bom comportamento", designadamente através da instalação de modelos formadores tais como o do "chefe", o "bom súbdito", o "guerreiro corajoso", etc. [...] O imaginário social é, pois, uma peça efetiva e eficaz do dispositivo de controlo da vida colectiva e, em especial, do exercício da autoridade e do poder. Ao mesmo tempo, ele torna-se o lugar e o objecto dos conflitos sociais.".

${ }^{3} \mathrm{O}$ reconhecimento oficial do PT como partido político pelo Tribunal Superior de Justiça Eleitoral ocorreu em fevereiro de 1982.

${ }^{4}$ Dados do Tribunal Superior Eleitoral obtidos em: $<$ http://www.tse.jus.br/eleicoes/eleicoes-anteriores/eleicoes2002/resultados-das-eleicoes-2002>. Acesso em: 01 jan. 2016.
} 
Devido ao escândalo de corrupção conhecido como "mensalão", que desde então pautou as notícias dos principais jornais e revistas em 2004 (no segundo ano do primeiro mandado do petista), a reputação do PT se desgastou diante do eleitorado brasileiro. A partir desse desgaste uma das estratégias comunicacionais centrais da campanha de Lula à reeleição em 2006 foi o afastamento da imagem do então presidente à de seu partido. Interessante pontuar que em decorrência desse distanciamento intensificou-se o personalismo político do governo Lula, o que contribuiu em grande medida para o surgimento do lulismo - em diferenciação ao petismo - o que reforça, mais uma vez, o protagonismo do então presidente petista.

Luciana Panke (2010, p. 179) exemplifica o distanciamento entre as imagens de Lula e do PT a partir do Horário Gratuito Político Eleitoral (HGPE) da campanha presidencial de 2006, no qual foi possível observar a desvinculação da representação de Lula à cor vermelha - cor simbólica do PT e dos partidos de esquerda. Além disso, a autora aponta para a centralização dos discursos de Lula na importância das ações positivas do primeiro mandato, como a criação do Programa Bolsa Família (PBF), iniciado em 2003, e no reforço da imagem do Lula estadista e do homem do povo de forma a agregar forte apelo emocional. Sobre esse reforço da imagem de Lula como homem do povo ressaltamos a intensa utilização do bordão "Lula, guerreiro do povo brasileiro", que se tornou um dos principais "gritos de guerra" da militância desde então.

Mesmo após intensa cobertura dos escândalos de corrupção e as duras críticas a Lula realizadas pelos veículos jornalísticos hegemônicos do país, ele se reelegeu em 2006 no $2^{\circ}$ turno com considerável diferença de votos: obteve 60,87\% de preferência (cerca de 58 milhões de votos) contra 39,17\% (cerca de 37 milhões de votos) de seu oponente, Geraldo Alckmin $(\mathrm{PSDB})^{5}$. Com os 58 milhões de votos conquistados, Lula obteve cerca de 6 milhões de votos a mais do que em 2002 e estabeleceu novo recorde em eleição no país ${ }^{6}$. Ele deixou a Presidência do Brasil em 2010 com a marca histórica de $80 \%$ de aprovação de seu governo e $87 \%$ de aprovação pessoal, como indicou pesquisa realizada pelo Instituto Brasileiro de Opinião Pública e Estatística (Ibope) e encomendada pela Confederação Nacional da Indústria (CNI) em dezembro de 2010. (CONFEDERAÇÃO NACIONAL DA INDÚSTRIA, 2010).

A popularidade adquirida durante os dois mandatos corroborou para que Lula pudesse transferir seu prestígio eleitoral a Dilma Rousseff - candidata vitoriosa pelo PT à Presidência

\footnotetext{
${ }^{5}$ Dados do Tribunal Superior Eleitoral obtidos em: $<$ http://www.tse.jus.br/eleicoes/eleicoes-anteriores/eleicoes2006/resultado-da-eleicao-2006>. Acesso em: 01 jan. 2016.

${ }^{6}$ Válido ressaltar que no segundo turno das eleições presidenciais de 2006 foram contabilizados cerca de 10 milhões de votos válidos a mais em relação ao mesmo turno das eleições ocorridas em 2002. Dados do Tribunal Superior Eleitoral obtidos em: <http://www.tse.jus.br>. Acesso em: 01 jan. 2016.
} 
do Brasil em 2010. Importante destacar que a imagem pública de Lula foi importante não só para a candidatura de Dilma, mas influenciou também a dos seus opositores que não ousaram criticar o governo Lula e optaram por apresentar propostas políticas de continuidade do governo lulista. Como bem apontam Telles e Pires (2013, p. 6), “a associação ao prestígio de Lula tornou-se a principal alternativa no marketing dos candidatos.".

Para exemplificar essa perspectiva chamamos atenção para o momento no qual o principal adversário de Dilma nas urnas, José Serra, do PSDB, em entrevista a uma rádio em Recife (Pernambuco), ainda como pré-candidato, pediu aos entrevistadores que evitassem comparações entre ele e Lula e afirmou: "O Lula está acima do bem e do mal. Não me compare a ele.”. (SERRA, J. apud SERRA, B., 2010, grifo nosso). Nota-se que essa estratégia discursiva de impor a Lula uma condição de estar "acima do bem e do mal” reforça a característica mítica dele ao considerá-lo superior ao homem comum ou ordinário. Percebe-se que mesmo após ter deixado a Presidência Lula continuou sendo figura central dos contextos políticos no país.

Tal visibilidade voltou a ser intensificada em junho de 2013, no terceiro ano do primeiro mandato de Dilma, quando ocorreram manifestações sociais que tomaram conta das ruas de todo o país. A pauta inicial dos protestos - o aumento de 20 centavos no preço das passagens de transporte público nas principais capitais do país - proposta pelo Movimento Passe Livre (MPL), foi minimizada a partir de uma onda de insatisfação popular, representada por manifestantes pertencentes predominantemente à classe média brasileira, que trazia consigo reivindicações amplas e diversificadas, como, por exemplo, o fim da corrupção e melhorias em saúde e educação.

Ao analisar essa visibilidade da figura de Lula diante do contexto das manifestações de junho de 2013 destacamos o estudo realizado por Raquel Recuero (2014a) em relação ao discurso dos veículos jornalísticos no Twitter durante os dias 3 e 20 de junho de 2013. Essa investigação demonstrou que, principalmente nos perfis oficiais da Folha de S. Paulo, do portal de Notícias UOL e do portal de Notícias R7, havia notícias que associavam o nome de Lula aos protestos. Oportuno chamar atenção também para o trabalho realizado por Fábio Malini et al (2014), a partir do exame de hashtags ${ }^{7}$ relacionadas às manifestações postadas no Twitter entre os dias 15 e 17 de junho de 2013. Com base na análise dos dados coletados em pesquisa, Malini

\footnotetext{
7 "Uma hashtag constitui-se em uma etiqueta de "contexto" no Twitter, que aponta de forma específica um termo que não apenas constrói contexto, mas igualmente permite que o tweet seja buscado e recuperado também pela etiqueta. Em geral é representada pelo sinal "\#".”. (RECUERO, 2014b, p. 2). Pontuamos que a hashtag foi criada pelo Twitter e depois passou a ser utilizada em outras mídias sociais.
} 
el al (2014) afirmaram que \#lulaéocancerdobrasil (Lula é o câncer do Brasil) foi uma das principais hashtags utilizadas pelos usuários.

A figura de Lula voltou a ser central no contexto político brasileiro com a divulgação (2014) de mais um escândalo de corrupção descoberto pela chamada Operação Lava Jato e denominado pela imprensa de "petrolão". Sobre essa posição nuclear de Lula diante dos acontecimentos à época é válido relembrar que a revista Veja, na sua edição de 29 de outubro de $2014^{8}$, divulgou matéria de capa com uma fotografia de Dilma e Lula e o título "Eles sabiam de tudo", em referência ao fato de as duas figuras políticas serem condizentes com o escândalo de corrupção.

Mesmo com a crise de reputação instituída desde as manifestações de 2013 e intensificada pelo escândalo do "petrolão" o PT conseguiu sua quarta vitória consecutiva ao reeleger Dilma no segundo turno das eleições de 2014 com 51,64\% dos votos válidos contra 48,36\% das preferências obtidas por Aécio Neves (PSDB) - foi a eleição mais acirrada desde a redemocratização do Brasil (AMARAL; RIBEIRO, 2015). Quando Dilma assumiu o segundo mandato, em 2015, o governo petista viu-se diante da intensificação não só da crise de reputação, mas também da conjuntura econômica e política que contribuiu para o amplo descontentamento do povo àquela gestão. Tal insatisfação pôde ser percebida a partir de nova onda de manifestações sociais contrárias ao governo de Dilma ocorrida naquele mesmo ano.

A principal razão dessas manifestações, diferentemente das reivindicações dispersas dos protestos de 2013, passou a ser especificamente a crítica ao governo petista, sobretudo a reivindicação pelo impeachment da presidenta. Para além da temática do impedimento, pontuamos, novamente, a centralidade da imagem pública de Lula diante daquele contexto político. Sobre tal cenário a socióloga Natália Scartezini (2016) aponta que os atos públicos de 2015 enfatizaram forte apelo antilulista e lembra que a palavra de ordem "Lula nunca mais" passou a ser uma das mais bradadas pelos manifestantes. Ressaltamos, ainda, que um dos símbolos daquelas manifestações foi um boneco inflável gigante que retratava a figura de Lula como presidiário (em referência à possibilidade de sua prisão). Tal boneco foi apelidado de "pixuleko", nome copiado de uma das fases da operação Lava Jato.

A instauração do processo de impedimento da presidenta em dezembro de 2015 acirrou a polarização política iniciada em março de 2016, quando ocorreram manifestações tanto favoráveis quanto contrárias ao processo de impeachment. Para além dessa polarização é necessário mencionar, novamente, a intensa visibilidade - ou mesmo centralidade - da imagem

\footnotetext{
${ }^{8}$ Edição 2397, ano 47, nº 44.
} 
pública de Lula diante do contexto político brasileiro contemporâneo mediante momentos específicos, tais como: a) a condução coercitiva do ex-presidente, em 04 de março de 2016, determinada pelo Ministério Público de São Paulo, na $24^{a}$ fase de investigação da Operação Lava Jato; b) a operação na qual a PF-SP catalogou 136 objetos recebidos por Lula durante seus dois mandatos à frente do governo - essa operação ocorreu na mesma data de 04 de março de 2016 e igualmente fazia parte da $24^{a}$ fase de investigação da Operação Lava Jato; c) o pedido de prisão preventiva de Lula apresentado por três promotores do MP-SP - Cássio Conserino, José Carlos Blat e Fernando Henrique Araújo, em 09 de março de 2016; d) a nomeação de Lula para ocupar o cargo de ministro da Casa Civil do governo de Dilma Rousseff em sucessão a Jaques Wagner, ocorrida em 17 de março de 2016, e o posterior impedimento de sua posse pelo ministro do Supremo Tribular Federal (STF), Gilmar Mendes; e) o discurso proferido por Lula durante as maiores manifestações contra o processo de impeachment ocorridas na Avenida Paulista, na cidade de São Paulo, em 18 de março.

Ainda sobre a centralidade da figura de Lula diante do contexto político de 2016 ressaltamos a pesquisa sobre intenção de voto para a eleição presidencial de 2018 realizada pelo Instituto DataFolha e divulgada em 11 de abril de 2016 na qual ele foi apontado como o candidato à Presidência do país pelos entrevistados. Naquela sondagem foram oferecidos aos respondentes quatro cenários possíveis, sendo que em três deles Lula dividia a liderança com Marina Silva, do partido Rede Sustentabilidade, e em uma das possibilidades ele foi apontado como o principal postulante ${ }^{9}$. A mesma pesquisa mediu o índice de rejeição eleitoral dos nomes incluídos nos cenários apresentados e, apesar do resultado favorável a Lula, o nome do expresidente foi o que teve o maior índice de rejeição pelos entrevistados. (DATAFOLHA, 2016b). Nota-se, portanto, dubiedade em relação à figura de Lula no entendimento do eleitorado brasileiro.

A partir da contextualização acima elaborada torna-se necessário pontuar que a construção da figura do ex-presidente em decorrência de sua trajetória política se deu sob forte influência da narrativa do mito. Sendo formado no imaginário coletivo, o mito político, de acordo com Girardet (1987), "exerce [...] uma função explicativa, fornecendo certo número de

\footnotetext{
${ }^{9}$ O primeiro dos três cenários no qual Lula e Marina Silva disputavam a liderança das intenções de voto dos entrevistados incluía como candidato à Presidência o nome de Aécio Neves (PSDB) - então presidente do PSDB, senador pelo estado de Minas Gerais, e maior opositor a Dilma Rousseff nas eleições presidenciais de 2014; no segundo cenário a concorrência foi disputada com Geraldo Alckmin (PSDB) - então governador do estado de São Paulo e oponente a Lula em 2006; e no terceiro cenário estava o nome de José Serra (PSDB) - na época senador por São Paulo e adversário a Dilma Rousseff nas eleições de 2010 e a Lula nas eleições presidenciais de 2002. O quarto cenário, no qual Lula liderou as intenções de voto, trazia o nome de Sérgio Moro (sem partido), juiz federal responsável pela Operação Lava Jato.
} 
chaves para a compreensão do presente, constituindo uma criptografia através da qual pode parecer ordenar-se o caos desconcertante dos fatos e dos acontecimentos.”. (GIRARDET, 1987, p. 13). Além da função explicativa, Girardet (1987) considera que o mito político exerce a função de mobilização, já que "por tudo o que veicula de dinamismo profético, o mito ocupa um lugar muito importante [...] nas revoluções.”. (GIRARDET, 1987, p. 13).

Como se vê, Girardet (1987) compreende o mito político enquanto narrativa - explicativa e mobilizadora de uma determinada coletividade - e, por ser uma estratégia discursiva o mito político se torna instrumento de poder (força motriz) capaz de transformar ambientes sociopolíticos. O autor esclarece, ainda, que a narrativa do mito político é acionada preferencialmente em situações de crise em que há necessidade de transformação ou de ausência de representatividade política.

Sendo uma narrativa, o mito político, para Girardet (1987), pode ser compreendido a partir de quatro pilares principais: a narrativa da conspiração, do salvador, da idade de ouro e da unidade. Esse estudioso entende que para se criar o mito político há que existir a ruptura no imaginário social que faça com que todos se reúnam contra (ou a favor de) um bem comum; essa seria a fase da conspiração. O salvador seria o pai da pátria ou um messias responsável por levar aquela sociedade a tempos melhores e mais prósperos - que são sempre recordados e revividos pela chamada idade de ouro. Já a unidade é a narrativa responsável por cortejar com uma suposta união e harmonia dentro de uma determinada sociedade; sendo, portanto, a consequência e a busca maior do mito político.

Para que se compreenda a circulação do relato do mito político nas sociedades contemporâneas deve-se ter como ponto de partida que a figura política mitificada é representação ou imagem de alguém ou algo. Sendo imagem o mito político participa de um jogo intrínseco à esfera da política ${ }^{10}$ - a disputa por visibilidade. Essa perspectiva encontra eco em Maria Helena Weber (2000), segundo a qual a política é e sempre foi algo para ser visto “A política busca visibilidade" (WEBER, 2000, p. 11). Complementa que o fato de ser bem visível não necessariamente tem como caráter a desqualificação do campo político. Como se

\footnotetext{
${ }^{10}$ A concepção de política deriva do adjetivo polis que significa "tudo o que se refere à cidade e, consequentemente, o que é urbano, civil, público, e até mesmo sociável e social.”. (BOBBIO, 1998, p. 954). Dessa forma, a política no sentido clássico da palavra é concebida como aquilo que "concerne a todos os indivíduos num determinado espaço de relações (a polis).”. (GOMES, 1994, p. 53). Devido à amplitude do conceito, é necessário pontuar que ao nos falar em política nesta tese nos referimos às relações de poder estabelecidas entre governantes e governados ou representantes e representados. Interessa-nos, portanto, a visibilidade dessas ações de poder - seja em períodos eleitoras ou não. O campo político ao qual nos referimos então diz respeito ao que Pierre Bourdieu (1989, p. 164) chama de campo de forças ou um campo de lutas "em que se geram, na concorrência entre os agentes que nele se acham envolvidos, produtos políticos, problemas, programas, análises, comentários, conceitos, acontecimentos [...].”. (BOURDIEU, 189. p. 164).
} 
vê, a autora entende a política como espetáculo, discurso, narrativa e, de tal forma, algo para ser visto, explorado, encenado. É por meio da visibilidade que a política continua em busca de “credibilidade, opiniões e voto" (WEBER, 2000, p. 11).

Percebe-se então que outro conceito tão importante quanto o de mito político e o da narrativa é o de imagem pública, que diz respeito ao processo pelo qual se constrói a narrativa desejada (pelos atores ou instituições políticas) e que vai se transformar em relato percebido (pelos espectadores/eleitores). Sendo assim

a imagem pública é resultante da imagem conceitual, emitida por sujeitos políticos em disputa de poder e recuperada na soma das imagens abstratas (o intangível, a imaginação), com as imagens concentradas (o tangível, os sentidos). (WEBER, 2004, p. 262).

Feita a contextualização da tríade conceitual "mito, narrativa e imagem pública política", torna-se necessário ressaltar a centralidade da mídia ${ }^{11}$ na circulação desses mitos, narrativas e imagens nas sociedades contemporâneas. Esse protagonismo dos media na circulação de narrativas políticas pode ser compreendido pelo conceito de midiatização (FAUSTO NETO, 2008; HJARVARD, 2012; VERÓN, 2014; HEPP, 2014), que confere caráter central dos meios de comunicação na sociedade, de modo que esses deixam de ser apenas transportadores de sentidos ou espaços de interação e se tornam matrizes de produção e organização de sentido.

Sendo assim, para que se compreenda a esfera política contemporânea é necessário compreender que a luta por poder significa também uma batalha constante de imagens e narrativas em disputa pela visibilidade midiática. Essa disputa por visibilidade é compreendida por Gomes (2004) a partir da expressão “política de imagem”, que "indica a prática política naquilo que nela está voltado para a competição pela produção e controle de imagens públicas de personagens e instituições políticas.”. (GOMES, 2004, p. 242). Pontua-se, portanto, que o entrelaçamento entre os meios de comunicação e o campo político garante à mídia poder decisório sobre quais assuntos e imagens políticas se tornarão públicos e sob que circunstâncias, ou seja, se essas imagens serão veiculadas de forma positiva, negativa, distorcida ou modificada.

Essa política de imagem apresenta como principal função a construção e desconstrução de imagens públicas - de atores, partidos ou projetos políticos -, sendo que a construção é feita,

\footnotetext{
${ }^{11}$ Compreendemos o termo "mídia" como um "conjunto das instituições que utiliza tecnologias específicas para realizar a comunicação humana. [...] a instituição mídia implica sempre a existência de um aparato tecnológico intermediário para que a comunicação se realize.”. (LIMA, 2006, p. 53). Dessa forma, utilizamos o termo em referência a meios de comunicação, tais como emissoras de rádio e televisão, jornais, revistas, cinema e a internet.
} 
predominantemente, pelos imagemakers (conhecidos como marqueteiros políticos) ou por assessores de comunicação, bem como por apoiadores/militantes de determinado ator, partido ou projeto político. Já a desconstrução da imagem pública política se dá na recepção dessa imagem e pode ser realizada pelos meios de comunicação e pelos cidadãos que consomem as representações reproduzidas por esses meios.

Outra característica importante em relação à circulação dos mitos, narrativas e imagens na contemporaneidade diz respeito à intensa e crescente utilização da internet, predominantemente, das chamadas mídias sociais como Twitter ${ }^{12}$ e Facebook ${ }^{13}$ que se configuram como um espaço público contemporâneo (GOMES, 2014) onde os públicos em rede (BOYD, 2010) estabelecem conversações civis (MARQUES, J., 2006) ou conversações informais (MARQUES, A., 2010) sobre assuntos políticos diversos. Nesses espaços de discussão pública online variadas narrativas política se entrecruzam e o processo de (des)construção de imagens públicas é constante.

Após os apontamentos acima apresentados em relação à visibilidade - e até protagonismo - da imagem pública de Lula no imaginário coletivo brasileiro, bem como sobre o papel influente da política de imagem nas sociedades contemporâneas nos cabe questionar: como se dá o processo de (des)construção da imagem pública de Lula no contexto da crise política de 2016? Quem são os personagens mais influentes tanto na construção como na desconstrução da imagem pública do ex-presidente em tal período? Quais as principais temáticas acionadas como estratégias de ambos os grupos?

Com base nesses questionamentos, outros nos parecem igualmente relevantes e dizem respeito especificamente à influência das narrativas do mito na construção da imagem pública de Lula ao longo de sua trajetória política e no contexto de crise que vivemos atualmente no país.

Como visto, a narrativa do mito político é acionada, preferencialmente, em situações de crise em que há ausência de representatividade política ou necessidade de grandes transformações; sendo assim, nos cabe indagar: as narrativas do mito político são acionadas no processo de (des)construção da imagem pública de Lula no período atual? De que forma esse acionamento ocorre, ou seja, quem aciona essas narrativas e que tipos de narrativas são acionados?

Como forma de melhor atender aos questionamentos acima elaborados optamos por delimitar o recorte de análise da crise política de 2016 em quatro contextos principais ocorridos

\footnotetext{
12 Disponível em: <www.twitter.com $>$.

${ }^{13}$ Disponível em: <www.facebook.com>.
} 
entre março e maio de 2016 em decorrência do processo de impeachment de Dilma Rousseff, quais sejam: as manifestações sociais a favor do impedimento ocorridas em 13 de março, as protestações sociais contra o golpe, em 18 de março; a votação do processo de impeachment na Câmara dos Deputados, em 17 de abril, e no Senado Federal, em 12 de maio.

A principal fonte de dados para a presente pesquisa parte de mensagens publicadas no Twitter-microblog no qual é possível publicar textos de até 140 caracteres - durante os quatro contextos citados e que mencionavam a palavra-chave "Lula". A decisão de utilizar essa mídia social se justifica pelo fato de que as conversações informais ocorridas nesse ambiente são objeto de estudos que buscam compreender aspectos da opinião pública contemporânea, na medida em que esse microblog representa hoje uma das principais mídias sociais e importante espaço de conversações sobre assuntos políticos. Como exemplo, podemos citar as protestações ocorridas no Irã que eclodiram após a reeleição de Mahmoud Ahmadinejad em 2009 e repercutiram em grande escala no microblog, bem como as revoluções ocorridas principalmente no Oriente Médio e Norte da África em 2010 e 2011, que ficaram conhecidas pelos jornalistas do ocidente como a "Primavera Árabe". Após esses dois acontecimentos históricos, outros fatos políticos ao redor do mundo também passaram a influenciar na criação e circulação de informações e, por vezes, se tornam os assuntos mais comentados no microblog - como é o caso das manifestações sociais ocorridas no Brasil a partir de 2013.

Um fator interessante que faz ser ainda mais forte o entrelaçamento entre contextos políticos e o Twitter é a constante utilização dessa mídia social pelos presidentes de inúmeros países. De acordo com a pesquisa Twiplomacy Study, realizada em 2016 pela consultoria de comunicação Burson-Marsteller, o Twitter é a mídia social que mais possui contas oficiais de governos e líderes políticos, com destaque para a América Latina, na qual os líderes e governos de todos os países da região possuem conta oficial no Twitter. Importante mencionar que esses perfis são alguns dos mais influentes no mundo.

Além disso, quatro características desse microblog também justificam a sua escolha como fonte de dados para esta pesquisa empírica, quais sejam: a) a persistência: os conteúdos e informações publicados no microblog são automaticamente registrados e arquivados; b) a replicabilidade: o compartilhamento das informações é feito de forma mais rápida, já que elas são constituídas por dados (bits); c) a escalabilidade: o Twitter apresenta alto potencial de alcance e de compartilhamento das informações; e d) a buscabilidade: o conteúdo publicado no microblog pode ser encontrado, coletado e armazenado a partir do auxílio de softwares específicos - ou mesmo na própria página do Twitter.

Assim, a presente tese tem por objetivo principal investigar o processo de (des)construção 
da imagem pública de Lula no Twitter durante a crise política de 2016 e como foram acionadas as narrativas do mito político nesse processo. A partir desse objetivo geral elaboramos os específicos: a) explorar a literatura existente sobre o conceito de mito político; b) lançar luz sobre a relação entre mito, narrativa e imagem pública política; c) compreender a circulação de narrativas políticas nas sociedades contemporâneas midiatizadas e, especificamente, como ocorre essa circulação em tempos de mídias sociais; d) contextualizar a trajetória de Luiz Inácio Lula da Silva e a crise política brasileira de 2016; e) compreender a lógica e o funcionamento do processo de trocas informacionais que ocorre no ambiente do Twitter; e f) averiguar empiricamente o processo de (des)construção da imagem pública política de Lula no Twitter durante a crise política de 2016 e as narrativas do mito político acionadas nesse processo. Com vistas a atingirmos esses objetivos elaboramos a tese em seis capítulos.

No Capítulo 2 lançamos luz acerca da tríade conceitual da presente pesquisa: mito, narrativa e imagem pública política. Para tanto discorremos sobre as principais abordagens clássicas e contemporâneas sobre o conceito de mito político, bem como a importância dele enquanto perspectiva de análise de cenários políticos atuais. Além disso, destacamos a abordagem apresentada por Girardet (1987) como a principal concepção de mito político que será utilizada na pesquisa, ou seja: o mito enquanto narrativa de representação. Essa estratégia discursiva de representação circula nas sociedades contemporâneas a partir da política de imagem na qual há um processo de construção e desconstrução de imagens públicas políticas que ocorre no e pelos media. Dessa forma, o capítulo objetiva também discutir o entrelaçamento entre o campo da política e o campo da mídia - dos meios de comunicação tradicionais às chamadas mídias sociais - e as formas de circulação de narrativas políticas nas sociedades contemporâneas midiatizadas.

No Capítulo 3 apresentamos o objeto de pesquisa desta tese: a imagem pública política de Luiz Inácio Lula da Silva. Para tanto contextualizamos a trajetória política do ex-presidente com vistas a lançarmos luz sobre a influência das narrativas do mito político nessa trajetória, bem como sobre a centralidade da imagem pública de Lula diante do contexto político brasileiro. Nesse capítulo também descrevemos a conjuntura da crise política no Brasil intensificada entre março e maio de 2016 em decorrência do processo de impeachment de Dilma Rousseff a partir dos quatro contextos já mencionados: as manifestações sociais a favor do impedimento de Rousseff, no dia 13 de março; os atos públicos contra o golpe ocorridos em 18 de março, a votação do processo de impeachment na Câmara dos Deputados, em 17 de abril, e no Senado Federal, em 12 de maio.

Abordamos ainda a polarização política estabelecida nesses quatro contextos, aqui 
caracterizada como disputa de sentidos ocorrida entre a narrativa do impeachment que foi legitimada em grande medida pela imprensa hegemônica e pelos opositores ao governo petista favoráveis ao afastamento da presidenta da República; e a narrativa do golpe, acionada pelo próprio PT, por militantes do partido e por centrais sindicais, bem como por intelectuais e formadores de opinião que consideravam o processo de impeachment como um golpe de estado e uma afronta à democracia brasileira.

Feita a contextualização teórica apresentada nos capítulos anteriores, o Capítulo 4 tem por objetivo esclarecer o ambiente e a lógica de funcionamento do Twitter, plataforma da qual foram extraídos os dados para a realização da pesquisa empírica. Além disso, o capítulo objetiva a descrição e o detalhamento do processo metodológico adotado na exploração dos dados coletados. Ressaltamos que, após a pré-observação das informações obtidas no Twitter o estudo foi dividido em duas fases: a primeira delas, realizada no Capítulo 5, consiste na análise de

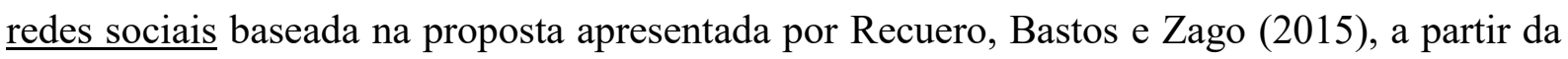
qual foi possível averiguar os tipos de perfis no microblog que participaram do processo de (des)construção da imagem pública política de Lula. Essa tipificação foi classificada em seis categorias de perfis ${ }^{14}$ : perfis de lideranças políticas, de veículos jornalísticos, de blogs jornalísticos, de formadores de opinião, de militância ou de usuários comuns. Essa observação possibilitou compreender quais perfis no microblog se apresentaram como mais influentes na circulação das narrativas sobre Lula nos contextos analisados.

A segunda fase, realizada no Capítulo 6, se refere à análise de narrativas, que foi baseada no método de análise de conteúdo proposto por Bardin (1977) e Bauer (2008). A segunda etapa permitiu observar as principais temáticas acionadas pelos usuários do Twitter ao buscarem desconstruir ou construir a imagem pública de Lula, bem como as narrativas do mito político utilizadas por esses internautas. As narrativas do mito político foram averiguadas em quatro categorias baseadas na definição proposta por Girardet (1987): a da conspiração, do salvador, da unidade e da idade de ouro.

Por fim apresentamos as Considerações Finais, que, longe de serem conclusivas, propõem necessárias reflexões acerca dos resultados obtidos nas análises realizadas na pesquisa empírica sobre a (des)construção da imagem pública de Lula diante do contexto político brasileiro contemporâneo. Buscamos igualmente nas considerações finais apresentar apontamentos que possam contribuir para a realização de pesquisas futuras sobre o tema em questão.

\footnotetext{
${ }^{14}$ Essas categorias foram construídas com base no que Thiago Moraes e Doacir Quadros (2016) denominam "tipo de jogador" (ou tipos de usuários do Twitter).
} 


\section{MITO, NARRATIVA E IMAGEM PÚBLICA POLÍTICA}

Neste capítulo objetivamos explorar a literatura existente em relação às variadas abordagens sobre a questão do mito político a partir de estudos de autores clássicos e contemporâneos, lançar luz sobre a relação entre mito político e os conceitos de narrativa e de imagem pública política e compreender como se dá a circulação das narrativas políticas nas sociedades contemporâneas midiatizadas.

\subsection{Mito político: principais abordagens}

Definir com precisão o conceito do mito político consiste tarefa arriscada já que o mesmo é utilizado de formas diversas, seja em pesquisas acadêmicas ou na linguagem corriqueira. Torna-se necessário, portanto, buscar compreender quais as transformações desse conceito diante das constantes mudanças pelas quais passou a sociedade e qual a sua influência nos contextos sociais contemporâneos.

Como bem apontou Luis Felipe Miguel (2000) em seu livro Mito e discurso político, no qual fez importante análise dos discursos dos candidatos à Presidência do Brasil em 1994, o conceito de mito político pode ser uma chave para compreensão de "um aspecto crucial, embora insuficientemente estudado, do jogo político: a mecânica que leva as pessoas comuns (cidadãos, eleitores) à adesão a partidos, movimentos ou personalidades.”. (MIGUEL, 2000, p. 9). Ainda para o autor, tal adesão "se manifesta em diferentes graus de ativismo, da militância cotidiana ao simples voto numa eleição. Pode ser apaixonada ou desconfiada, perene ou passageira.”. (MIGUEL, 2000, p. 10). O mito político se torna, portanto, um importante método de compreensão de contextos sociais na atualidade.

Relevante destacar, no entanto, que o mito político não é fenômeno novo, mas, pelo contrário, tornou-se um aspecto que, desde sempre, influenciou os jogos de poder e a esfera política. Na linguagem popular é comum perceber o conceito de mito enquanto narrativa fictícia relacionada, principalmente, à fantasia. O mesmo se faz quando tal expressão passa a ser empregada na Antropologia e na história das religiões; porém, por esta perspectiva, a mitificação tem maior relação com as narrativas de criação do mundo. A utilização do conceito de mito, no entanto, é limitadora do entendimento do mesmo. Ressalta-se, dessa forma, a necessidade de compreensão sobre as principais abordagens e estudos já realizados sobre o mito político para que seja possível observar as principais influências dessas perspectivas no funcionamento do conceito nos dias atuais. 
Para iniciarmos esta discussão apresentamos as ideias do filósofo alemão Ernst Cassirer (1976) discutidas em obra publicada em 1946. Ao discorrer sobre as sociedades nos séculos XVIII e XIX, Cassirer (1976) afirmou que naquele período houve mudança radical nas formas de pensamento político-social e a mais significativa delas foi a aparição da forma de pensamento mítico que se tornou mais forte do que o pensamento cientifico. Percebe-se pela perspectiva desse autor nítida distinção entre mito e razão, que acabava por inferiorizar todo e qualquer pensamento que pudesse fugir a um suposto cientificismo ${ }^{15}$ dos fenômenos sociais. Ressaltamos que a conotação pejorativa (o mito como fantasia, mentira, ficção) em relação a fenômenos que escapam a uma racionalidade pré-determinada irá perpassar variadas abordagens sobre o conceito de mito político sobre as quais discorreremos a seguir. De acordo com Cassirer (1976), o mito é um inimigo que deve ser combatido pelo conhecimento racional e científico.

O pesquisador considera que

\begin{abstract}
O conhecimento cientifico e o domínio da técnica obtêm todos os dias novas e importantes vitórias. Mas na vida prática e social do homem, a derrota do pensamento racional para ser completa e irrevogável. Neste domínio, o homem moderno parece ter esquecido tudo quanto aprendeu no decorrer de sua vida intelectual. Aqui regressa aos períodos mais rudimentares da cultura humana. Aqui o pensamento racional e científico reconhece abertamente a sua derrota; rende-se ao seu mais perigoso inimigo (o mito). (CASSIRER, 1976, p. 20).
\end{abstract}

O sociólogo e cientista político Harold Lasswell (1979), reconhecido por seus estudos pioneiros sobre a psicologia política, aborda em A linguagem da política (1949) a questão do mito aproximando o conceito dos estudos de linguística. Lasswell (1979) entende que o mito político é composto por uma "fórmula política" que descreve e preceitua a estrutura social. A partir dessa fórmula política são instituídas as doutrinas e percepções políticas do poder vigente, ou seja, é a partir da fórmula - transformada em linguagem - que o poder ganha forma e conteúdo normativo. Esse conteúdo, ainda segundo o autor, é baseado em símbolos-chave e slogans que "aplicam pontos específicos da doutrina e da fórmula às questões do momento.". (LASSWELL, 1979, p. 21). Como exemplos desses símbolos-chave, Lasswell (1979) cita os termos de "direitos", "igualdade", "liberdade" e "democracia", presentes na doutrina dos Estados Unidos. A função desses símbolos é a de "proporcionar uma experiência comum a todos os cidadãos de um Estado, desde o mais poderoso chefe ao mais humilde leigo ou

\footnotetext{
${ }^{15}$ O cientificismo sobre o qual Cassirer (1976) discorre nesse contexto se constituiu em uma concepção filosófica que teve seu auge principalmente no século XIX. Os cientificistas pressupunham superioridade da ciência sobre todas as outras formas de percepção e explicação da vida humana, como a religião e os mitos. Essa perspectiva cultuava, portanto, a racionalidade em detrimento das compreensões sensíveis da realidade humana.
} 
filósofo.”. (LASSWELL, 1979, p. 22). Para Laswell (1979), o mito político é, portanto, linguagem e instrumento de poder.

Da mesa forma, Roland Barthes (2013) - pesquisador francês especialista em linguística e semiótica - em textos publicados entre 1954 e 1956 afirma que "o mito é uma fala" (BARTHES, 2013, p. 199), ou seja, uma forma de comunicação e transmissão de determinada mensagem. Para o autor, por ser fala o mito tem a função de mascarar a realidade e, por isso, ele não pode ser compreendido por si só já que é uma significação de outra coisa. O mito, para Barthes (2013) é, portanto, uma máscara do real sobreposto em uma narrativa. “[...] o mito tem efetivamente uma dupla função: designa e notifica, faz compreender e impõe.”. (BARTHES, 2013, p. 208).

Barthes (2013) compreende o mito como ameaça que rouba a linguagem para dar outro significado a determinado discurso. Vê-se, portanto, por essa perspectiva, que o mito evacua o real e transforma o discurso político em "fala despolitizada". Essa pode ser mais bem compreendida pelos conceitos de "natureza" e "história" que, de acordo com Barthes (2013) são, ao mesmo tempo, opostos e complementares: a natureza se refere ao que é natural; é o objeto ou o acontecimento em si mesmo - já a história é uma narração ou a forma como os acontecimentos "naturais" passam a ser compreendidos. A história, portanto, ressignifica a natureza. Sendo assim, natureza e história são, a todo o momento, confundidas pelos mitos.

Para exemplificar suas ideias, Barthes (2013) dá o exemplo da capa de uma revista em que aparece a foto de um jovem soldado negro segurando a bandeira da França. A figura em si nada precisa significar, mas o mito da glória da conquista francesa e a pele negra do jovem soldado roubam a linguagem primeira para dar outro significado ao objeto da foto - essa é passagem da história à natureza. $\mathrm{O}$ mito passa a ser a verdade primeira:

\begin{abstract}
Passando da história à natureza, o mito faz uma economia: abole a complexidade dos atos humanos, confere-lhes a simplicidade das essências, suprime toda e qualquer dialética, qualquer elevação para lá do visível imediato, organiza um mundo sem contradições, porque sem profundeza, um mundo plano que se ostenta em sua evidência, e cria uma afortunada clareza: as coisas, sozinhas, parecem significar por elas próprias. (BARTHES, 2013, p. 235).
\end{abstract}

Pode-se compreender tanto a perspectiva de Lasswell (1979) como a de Barthes (2013) como extensão da abordagem apresentada por Georges Sorel ${ }^{16}$ (1992) no livro Reflexões sobre a violência, publicado em 1908, no qual o autor aproxima o conceito de herói político ao de

\footnotetext{
${ }^{16}$ Sorel (1992) foi um dos primeiros autores a falar especificamente sobre o conceito de mito político ainda na primeira década do século XX.
} 
“força motriz". Segundo o estudioso, o mito político - enquanto fala - é o motor responsável por impulsionar revoluções por meio de imagens, narrativas e discursos, ou seja, o mito é um instrumento de ação política.

Sorel (1992) utilizou como base para sua argumentação a greve geral proletária na França no início do século XX. Em sua perspectiva, a paralisação era exemplo claro de atos intuitivos e emocionais de uma classe que, segundo o próprio Sorel (1992), não possuía capacidade racional para levar a cabo seus projetos. Sendo assim, de acordo com o pesquisador, para se tornar "força motriz" ou combustível para acionar revoluções o mito precisa rejeitar a razão. Caso a razão interfira no mito ele passa, então, a não existir; em outras palavras, caso as imagens e narrativas constitutivas do mito sejam apreendidas por meio da racionalidade o herói estaria suscetível a contestações e descrenças. A concepção irracional do mito proposta por Sorel (1992) é ainda hoje bastante contestada por pesquisadores de outras correntes de pensamento. Torna-se válido ressaltar, no entanto, que a ideia do mito político enquanto "força motriz" é a principal contribuição do mito soreliano para a compreensão do funcionamento do mito político nas sociedades contemporâneas.

Antonio Gramsci (1978), em obra publicada em 1954, busca nas ideias do mito soreliano a base conceitual para definir questões-chave sobre o Estado moderno ${ }^{17}$. Gramsi (1978) considera que o mito político, durante o período por ele pesquisado, se assemelhava à dramaturgia e à fantasia. Dessa forma,

\begin{abstract}
o processo de formação de uma determinada vontade coletiva, para um determinado fim político, é representado não através de inquisições e classificações pedantescas de princípios e critérios de um método de ação, mas como qualidades, traços característicos, deveres, necessidades de uma pessoa concreta, tudo o que faz trabalhar a fantasia artística de quem se quer convencer e dar forma mais concreta às paixões políticas. (GRAMSCI, 1978, p. 3).
\end{abstract}

Para esse estudioso, o mito político não passa de "afeto", "febre" e "fanatismo de ação". Nessa concepção o mito político é relacionado ao poder enquanto visão elitista, ou seja, o mito político é introduzido por aqueles que detêm o poder e uma racionalidade superior sob uma massa de pessoas inertes e sem outra opção a não ser aderir à linguagem proposta.

A perspectiva do "poder simbólico" proposta pelo sociólogo Pierre Bourdieu (1989) já no final do século XX colabora para uma melhor compreensão sobre as perspectivas do conceito

\footnotetext{
${ }^{17} \mathrm{O}$ conceito de "Estado moderno" faz referência à concepção de formação da sociedade - ou nação - que se tornou predominante na Europa, principalmente no século XV, após o declínio do sistema feudal e impulsionado pela ascensão da burguesia.
} 
de mito acima apresentadas. Bourdieu (1989) defende que as narrativas carregadas de simbologia, como o mito, servem ao imaginário coletivo de forma a delegar poder - poder entendido como a capacidade de mobilização ou adesão a um interesse específico.

Dessa forma, quanto maior o controle simbólico do imaginário coletivo maior será o poder de dominação, coordenação ou manipulação desse imaginário. As formas simbólicas são, portanto, armas e técnicas de poder. Bourdieu (1989) ressalta que o poder simbólico só se torna possível a partir da relação entre quem detém o poder e quem credita esse poder, ou seja, é uma relação entre representantes e representados ${ }^{18}$. "O poder simbólico é um poder que aquele que lhe está sujeito dá àqueles que o exerce [...]. É um poder que existe porque aquele que lhe está sujeito crê que ele existe.”. (BOURDIEU, 1989, p. 188). Pela visão de Bourdieu (1989), portanto, o mito político só existe de modo relacional, ou seja, "só existe na representação e pela representação, na confiança e pela obediência.”. (BOURDIEU, 1989, p. 188).

Necessário ressaltar que as perspectivas apresentadas acima (SOREL, 1992; CASSIRER, 1976; LASSWELL, 1979; BARTHES, 2013; GRAMSCI, 1978; BOURDIEU, 1989) nasceram no século XX sob forte influência social e teórica do positivismo e cientificismo, influência essa que buscava compreender a sociabilidade e os tensionamentos do campo político por um viés determinista, ou seja, apegado a uma suposta racionalidade dos fenômenos político-sociais da época.

Tiziano Bonazzi (1998), em Dicionário de Política, organizado por Bobbio, Matteucci e Pasquino, elabora importante contextualização sobre as abordagens do conceito de mito político apresentadas anteriormente, bem como sobre a influência dos aspectos simbólicos - ou irracionais - na esfera política. De acordo com Bonazzi (1998), o conceito de mito se tornou problemático para os pensadores do século XX por ter se tornado

uma questão intelectual e prática que o pensamento político não conseguiu determinar
e identificar, quer pela dificuldade de definir suas relações com a mitologia, quer pela
dificuldade de o distinguir do conceito de 'ideologia', quer, enfim por haver estado
no centro de toda a polêmica entre racionalismo e irracionalismo. (BONAZZI, 1998,
p. 754).

Para Bonazzi (1998), tal problemática surgiu principalmente a partir dos apontamentos feitos por Sorel (1992) em relação à greve da classe operária francesa do início do século XX, sobre a qual discorremos anteriormente. Esse período, de acordo com Bonazzi (1998), foi

\footnotetext{
${ }^{18}$ O conceito de representação de Bourdieu (1989) é amplo no sentido de que comporta todo e qualquer tipo de relação em que alguém (não-detentor de poder) credita ou confia em outrem (detentor de poder) para representalo diante de circunstâncias políticas e/ou sociais. A representação é uma relação entre "mandatários e mandantes" (BOURDIEU, 1989, p. 188).
} 
caracterizado por uma crise teórica e prática do pensamento democrático-liberal "quer em seu aspecto positivista quer em sua confiança de poder generalizar para todos os indivíduos o racionalismo utilitarista em que se fundava.”. (BONAZZI, 1998, p. 755). E foi no seio dessa crise que se passou a buscar novas formas de se compreender o âmbito social e político constata-se crescimento naquela ocasião da psicologia social e dos estudos sobre a comunicação de massa. Essa nova forma de compreender o mundo deixa de ser estritamente racional e abre espaço para a compreensão sensitiva, intuitiva e emocional.

Bonazzi (1998) reforça, entretanto, que, de acordo com o mito soreliano, a irracionalidade deve ser combatida. Esse combate à irracionalidade parte do ponto de que essa tendência às emoções nas ações políticas passou a ser cooptada pela direita conservadora e autoritária. Os regimes ditatoriais de direita na Europa passaram a utilizar da noção da irracionalidade para justificar seus propósitos e alcançar projetos políticos. Por esse motivo autores e pesquisadores do campo da ciência política esvaziaram o sentido do mito e passaram a considerá-lo sem utilidade para as análises políticas. Esse esvaziamento se deu pelo fato de os autores considerarem que os atos irracionais e intuitivos eram "desvios" do bom funcionamento da política. Sendo assim, o mito político no século XX passou a ser

\footnotetext{
malvisto pelos moderados, como se fosse um símbolo da fraqueza humana, e rejeitado pelas esquerdas que o consideram uma teoria quimérica e sutilmente reacionária [...], o Mito político do século XX, como categoria de pensamento e instrumento de ação, continua ligado especialmente aos movimentos políticos de direita e a teorias autoritárias e irracionalistas de grupos e partidos fascistas e pré-fascistas. (BONAZZI, 1998, p. 756).
}

Dessa forma, para as ciências políticas - na primeira metade do século XX - o mito político transformou-se numa "narração de eventos passados que dá a estes um significado especial para o presente e serve para fortalecer a autoridade de quem detém o poder.”. (BONAZZI, 1998, p. 757). Interessante notar, no entanto, que no momento em que o conceito de mito político passou a ser menosprezado pela ciência política, a sociologia passou a se interessar pelas consequências do mesmo na sociedade. Pela perspectiva sociológica o mito político passou a visto como fenômeno social-coletivo e não como uma teoria científica.

Isto abriu um amplo campo à pesquisa, na medida em que foi possível identificar sociologicamente a presença do Mito político em todas aquelas situações, especialmente de rápidas mudanças e crises, em que grupos sociais ou partidos sintetizam as exigências políticas de seus membros sob forma de teorias estruturadas em torno de símbolos e fatos simbólicos ou tentam expressar e explicar com as mesmas formulações teóricas as expectativas políticas fundamentais e não organizadas de uma classe, povo ou nação. (BONAZZI, 1998, p. 757). 
Assim como o campo da Sociologia, os estudos históricos também impulsionaram as pesquisas sobre o mito político. Bonazzi (1998) ressalta que tais estudos buscaram compreender o conceito de mito político a partir de pesquisas sobre a mitologia clássica (mitologias de criação do mundo). O objetivo principal dessas abordagens era compreender como os mitos clássicos se comportariam em uma situação "política”. Por essa perspectiva, compreende-se que ambos os mitos, o clássico e o político, são instrumentos de alocação de poder, mas a diferença básica está nos tipos de sociedade: as sociedades dos mitos clássicos possuíam intensa relação de interdependência de todas as instituições - família, casa, crenças, religiões, economias etc. -; já nas sociedades atuais em que se dá a presença do mito político o poder é parcialmente independente e gerenciável.

A principal aproximação entre o poder da mitologia clássica e o poder do mito político moderno de acordo com essas abordagens apresenta-se sob a forma de situação de crise, ou seja, ambos os mitos estão mais propensos a surgir em momentos em que a sociedade, a comunidade, o Estado ou os cidadãos, anseiam por transformações. A desintegração das sociedades primitivas não destruiu a existência do mito, mas apenas realocou suas funções e formas - transformando-o em mito político (bem como em outras formas de herói). Por esta perspectiva histórica o mito é inextinguível, faz parte e constitui a sociedade como tal.

Seguindo a perspectiva dos estudos históricos acima citados, o filósofo e historiador das religiões Mircea Eliade (2013) foi um dos principais autores a ter buscado, ainda no século XX, ultrapassar a ideia do mito como algo oposto à racionalidade aproximando o conceito de mito à realidade social. No livro Mito e Realidade, publicado em 1963, Eliade (2013) compreende tal conceito como uma narrativa explicativa de como algo surgiu:

[...] o mito narra como, graças às façanhas dos Entes Sobrenaturais, uma realidade passou a existir, seja uma realidade total, o Cosmo, ou apenas um fragmento: uma ilha, uma espécie vegetal, um comportamento humano, uma instituição. É sempre, portanto, a narrativa de uma "criação": ele relata de que modo algo foi produzido e começou a ser. (ELIADE, 2013, p. 11).

Para o autor, compreender os mitos e ritos sociais é uma forma de reconhecer tais conceitos como fenômenos humanos, de cultura e criação do espírito e não como "irrupção patológica de instintos, bestialidade ou infantilidade.”. (ELIADE, 2013, p. 9). O mito, na concepção de Eliade (2013), é algo próximo à realidade justamente por demonstrar que tal realidade existe; por exemplo, os mitos sobre a origem da morte resultam verdadeiros porque são provados pela mortalidade do homem. $\mathrm{O}$ autor faz diferenciação clara entre as fábulas e os 
mitos ao afirmar que "Tudo o que é narrado nos mitos concerne diretamente a eles, ao passo que os contos e as fábulas se referem a acontecimentos que, embora tendo ocasionado mudanças no Mundo [...], não modificaram a condição humana como tal.”. (ELIADE, 2013, p. 15).

Um ponto importante e que deve ser destacado nas ideias de Eliade (2013) diz respeito ao que o autor intitula como "mobilidade de origem": os mitos ao buscarem narrar e compreender a era grandiosa de um passado distante passam a tentar compreender também o futuro. Interessante pontuar que, de acordo com o cientista político Luis Felipe Miguel (2000), essa "mobilidade de origem", característica intrínseca ao mito, é encontrada de forma expressiva em discursos políticos. Miguel (2000) afirma que

\footnotetext{
O discurso político [...] sempre expõe uma representação do futuro. Ao propor a alteração ou a permanência de práticas e instituições sociais, ele projeta a imagem da sociedade que advirá. A reflexão sobre o passado (e o presente) é necessária, mas na medida em que cria um sentido apropriado a justificar essa projeção. (MIGUEL, 2000, p. 28).
}

Raoul Girardet (1987), reconhecido historiador francês, também seguiu a abordagem dos estudos históricos ao publicar o livro Mitos e mitologias políticas ao final da década de 1980. Sua obra se tornou uma das fontes mais importantes para a construção conceitual do mito político na contemporaneidade. Para o autor, todas as perspectivas apresentadas anteriormente que buscaram compreender a questão do mito político contribuíram com apontamentos importantes sobre o conceito, mas "nenhuma parece suscetível de esgotá-lo, nem mesmo de abarcar seu conteúdo". (GIRARDET, 1987, p. 13).

Girardet (1987) chamou atenção para o desafio que envolve os estudos sobre o mito político pela amplitude que tal narrativa alcança na sociedade e, portanto, pela falta de delimitação de espaço de análise. Ele defende que o mito escapa e escapará sempre, por alguns aspectos, às análises pretendidas. "Visto do exterior, o mito corre o risco de não mais oferecer senão uma imagem fossilizada, seca [...]; talvez seja possível reduzi-lo, mas é vão sonhar em aboli-lo totalmente.”. (GIRARDET, 1987, p. 24). Mas o autor reforça que é por conta desse desafio que o pesquisador deve encarar os seus objetivos de conhecer e compreender como se desenvolve a sociedade a partir do imaginário coletivo.

Necessário ressaltar, no entanto, que o conceito de imaginário, assim como o de mito político, é de difícil definição tendo sido explorado nos campos de estudo da Psicanálise, Antropologia, Hermenêutica, Sociologia, História e estudos da religião. Um dos autores mais notáveis na literatura sobre o tema foi o filósofo, antropólogo e cientista social Gilbert Durand (1997), que ao longo da segunda metade do século XX publicou obras importantes como As 
estruturas antropológicas do imaginário (DURAND, 1997) e O imaginário: ensaio acerca das ciências e da filosofia da imagem (DURAND, 1998). Na visão deste pesquisador, o imaginário pode ser compreendido como "[...] conjunto das imagens e das relações de imagens que constitui o capital pensado do homo sapiens [...], a estrutura essencial na qual se constituem todos os processamentos do pensamento humano.”. (DURAND, 1997. p. 14).

Influenciado pelas obras de Durand (1997), o historiador polonês Bronislaw Baczko (1985) buscou definir o que intitulou "imaginação social" como uma força reguladora da vida coletiva. Nesse sentido, o autor afirma que

[...] através dos seus imaginários sociais uma colectividade designa a sua identidade; elabora uma certa representação de si; estabelece a distribuição dos papéis e das posições sociais; exprime e impõe crenças comuns; constrói uma espécie de código de "bom comportamento", designadamente através da instalação de modelos formadores tais como o do "chefe", o "bom súbdito", o "guerreiro corajoso", etc. [...] O imaginário social é, pois, uma peça efetiva e eficaz do dispositivo de controlo da vida colectiva e, em especial, do exercício da autoridade e do poder. Ao mesmo tempo, ele torna-se o lugar e o objecto dos conflitos sociais. (BACZKO, 1985, p. 309).

Seguindo a mesma abordagem de Baczko (1985), o linguista francês Patrick Charaudeau, (2013) em Discurso político, publicado em 2005, descreveu os imaginários coletivos como forma de representação social de determinados sistemas de pensamento, ou seja, de ordenamentos de saberes e crenças que têm por objetivo explicar determinada sociedade ou coletividade. Por se tratarem de discursos circulantes, o autor intitula essas imagens de "imaginários sociodiscursivos". Alguns desses discursos podem ser racionalizados por textos e mensagens reproduzidas em instituições como escolas e igrejas, ao passo que outros circulam de maneira não consciente "nos julgamentos implícitos veiculados pelos enunciados, pelas maneiras de falar, pelos rituais sociolinguageiros, pelos julgamentos de ordem ética, estética, etc.” (CHARAUDEAU, 2013, p. 205).

No âmbito da política

[...] circulam imaginários sobre o comportamento que o político deve adotar, conforme a situação que se encontre: campanha eleitoral, alocução televisiva, debate, reunião, etc., imaginários relativos ao ethos que ele deve construir para si em função de uma expectativa coletiva dos cidadãos, imaginários de opinião que sustentam os programas eleitorais [...]. Frequentemente, esses imaginários se sobrepõem e constroem espécies de arquétipos coletivos inconscientes. (CHARAUDEAU, 2013, p. 207).

Sendo constituído no imaginário coletivo, o mito político, de acordo com Girardet (1987), “exerce [...] uma função explicativa, fornecendo certo número de chaves para a compreensão 
do presente, constituindo uma criptografia através da qual pode parecer ordenar-se o caos desconcertante dos fatos e dos acontecimentos.”. (GIRARDET, 1987, p. 13). Além da função explicativa, Girardet (1987) considera que o mito político, como visto anteriormente, exerce a função de mobilização, já que "por tudo o que veicula de dinamismo profético, o mito ocupa um lugar muito importante [...] nas revoluções.”. (GIRARDET, 1987, p. 13). Dessa forma, o autor compreende o mito político como narrativa que, a partir do imaginário coletivo, exerce funções explicativas e mobilizadoras.

Pontua-se que o conceito de narrativa sugerido por Girardet (1987) é o mesmo desenvolvido pelo linguista e semiólogo lituano Greimas no livro Semântica Estrutural, publicado originalmente em $1966^{19}$. Influenciado pelo viés estruturalista, Greimas (1973) buscou em seu estudo demonstrar a existência de uma estrutura narrativa - ou uma narratividade - que pode ser estabelecida e encontrada em qualquer tipo de texto. Tal estrutura se manifesta de forma a "expor uma série de acontecimentos encadeados em uma ordem determinada pelo narrador, através de palavras, imagens ou uma combinação das mesmas.". (REIS, 2016). Essa estrutura da narrativa proposta por Greimas (1973) segue a mesma perspectiva explorada por Barthes (1971) em obra intitulada Análise estrutural da narrativapesquisas semiológicas, publicada em 1971. De acordo com esse autor,

\begin{abstract}
[...] a narrativa pode ser sustentada pela linguagem articulada, oral ou escrita, pela imagem, fixa ou móvel, pelo gesto ou pela mistura ordenada de todas estas substâncias; está presente no mito, na lenda, na fábula, no conto, na novela, na epopeia, na história, na tragédia, no drama, na comédia, na pantomima, na pintura [...], no vitral, no cinema, nas histórias em quadrinhos, [...], na conversação. Além disto, sob estas formas quase infinitas, a narrativa está presente em todos os tempos, em todos os lugares, em todas as sociedades; a narrativa começa com a própria história da humanidade; não há [...], em parte alguma, povo algum sem narrativa; todas as classes, todos os grupos humanos têm suas narrativas, e frequentemente estas narrativas são apreciadas em comum por homens de cultura diferente, e mesmo opostas. (BARTHES, 1971, p. 19).
\end{abstract}

Compreendido o conceito de narrativa adotado por Girardet (1987), pontua-se que a principal contribuição de sua obra para o tema do mito político se constitui na proposta de compreender tal conceito a partir de quatro grandes narrativas, quais sejam: a conspiração, o salvador, a idade de outro e a unidade. Discorreremos a seguir sobre elas.

1) a Conspiração: para que o mito político estabeleça sua força há que existir uma ruptura no imaginário coletivo que faça com que todos estejam unidos contra um "mal" exterior. Nesse modelo cria-se, portanto, um complô diante de um "outro" (imaginário ou não) ameaçador

${ }^{19}$ O livro Semântica estrutural, de Greimas, só foi publicado no Brasil em 1973. 
capaz de interromper ou prejudicar as "boas" ações pretendidas pelo mito político em questão. A conspiração é, portanto, "[...] definida e desenvolvida a partir de um obscuro sentido de ameaça, testemunho de incerteza e pânico". (GIRARDET, 1987, p. 62);

2) o Salvador: essa narrativa é responsável por dar vida ao herói ou ao messias responsável por elevar determinada sociedade à condição de prosperidade. O salvador não é, necessariamente, representado por uma única figura política, apesar de ser essa a sua forma mais predominante. Ele pode comparecer, por exemplo, na imagem de uma classe social - por exemplo, a operária - ou por uma corporação - como a militar. Sobre esse modelo Girardet (1987) afirma que

\begin{abstract}
Graças ao Salvador, e através dele, existem, para um certo número de homens, as mesmas emoções a partilhar, os mesmos fervores e as mesmas esperanças. Estão presentes também, no calor de uma comunhão reconquistada, os mesmos signos e os mesmos apelos, as mesmas palavras de ordem, as mesmas referências, e as mesmas certezas. Em torno dele na submissão, na devoção e no entusiasmo, uma vida coletiva se reestrutura, as fidelidades se reconstituem, as trocas afetivas se estabelecem, uma nova trama social se consolida. (GIRARDET, 1987, p. 95).
\end{abstract}

3) a Idade de Ouro: a era dourada ou a idade de ouro é a narrativa responsável por transformar o mito político em nostalgia; difere presente e passado e constrói um fetiche sob esse último. Sendo assim, a Idade de Ouro funciona da mesma forma que a "mobilidade de origem" apresentada por Eliade (2013), na qual o imaginário coletivo - por meio do mito flerta com um passado supostamente próspero na intenção de se promover um futuro tão bom quanto. Dessa forma,

A nostalgia das idades de ouro findas desemboca geralmente na espera e na pregação profética de sua ressurreição. É bem raro, inversamente, que os messiânicos revolucionários não alimentem sua visão do futuro com imagens ou referências tiradas do passado. (GIRARDET, 1987, p. 15).

4) a Unidade: é a narrativa responsável por cortejar com uma suposta união e harmonia dentro de uma determinada sociedade. É, portanto, a consequência e a busca maior do mito político e que traduz a idealização de que o plano político será colocado em prática. Interessante observar que para Miguel (2000) a unidade é algo que pressupõe a política, sendo, portanto, uma tarefa criadora da política. Dessa forma,

[...] todo projeto político busca uma unidade capaz de levá-lo adiante, de implantá-lo. Para que ganhe visibilidade, ele precisa reunir uma multiplicidade de individualidades, interesses e ambições num projeto comum. Deve incorporar o 
particular num geral e, de maneira reversa, tornar o geral integrante dos particulares. (MIGUEL, 2000, p. 39).

Miguel (2000) elabora uma crítica à narrativa da unidade por compreendê-la como uma tentação frequente do mito em construir uma harmonia fictícia, ou seja, "substituir a construção da unidade (que pressupõe a diferença) pelo apelo a uma unidade preexistente". (MIGUEL, 2000, p. 39). Para o mito político, a sociedade é um ser único que deve sempre buscar retornar a essa unidade a partir de um imaginário coletivo. Para o autor, portanto, o mito é uma forma política da rejeição à política por apresentar aversão ao conflito - algo que, segundo o autor, faz parte e mostra-se necessário para o funcionamento da política. Essa perspectiva de Miguel (2000) se aproxima da ideia de Barthes sobre a "fala despolitizada" do mito político e ainda vai além ao pontuar que "o mito político é um discurso antipolítico que se quer politicamente eficaz.". (MIGUEL, 2000, p. 42).

Como cientista político Miguel (2000) se preocupa com as questões sobre a ética e a democracia contemporâneas e a relação dessas com os mitos políticos, daí o surgimento de um conceito sobre a "rejeição à política". Para o autor, o mito político bloqueia a ética ao "bloquear os mecanismos de identificação e representação que são essenciais à luta política enquanto embate entre propostas na sociedade". (MIGUEL, 2000, p. 49). Dessa forma, para o autor o mito político - instituído no campo das campanhas eleitorais - é um mascaramento no qual os candidatos não apresentam propostas adequadas à realidade e ainda expõem programas baseados em ideais democráticos subjetivos.

Preocupado com as questões do funcionamento da democracia e do processo eleitoral, Miguel (2000) exibe um ponto de vista bastante plausível já que tal "mascaramento" pode impedir que a democracia se constitua, de fato, como representativa de ideais e apelos presentes na sociedade. Mas se analisado sob o âmbito da Comunicação - campo de estudo da presente pesquisa -, o sentimento é um ponto intrínseco ao processo de junção entre mídia e política. Até mesmo Miguel (2000) aponta para a importância do sentimento no processo político já que, para o autor, "a política não é, nem pode vir a ser, um espaço feito só de razão. Elementos irracionais estão presentes em todo o campo político.”. (MIGUEL, 2000, p. 36). Sem a paixão e o sentimento a política perde o seu fascínio e atração e, além disso, ela se torna mera técnica e "administração das coisas". A política é palco de conflitos sociais e envolve tanto os julgamentos factuais (racionais) quanto os juízos de valor (irracionais). (MIGUEL, 2000).

Esta análise recorre a Georges Balandier (1980), que, no livro O poder em cena, publicado em 1980, expôs com clareza a importância do simbólico na esfera da política e a necessidade 
de se compreender as disputas de poder não só a partir de aspectos racionais. O estudioso entende que

\begin{abstract}
O poder estabelecido unicamente sobre a força ou sobre a violência não controlada teria uma existência constantemente ameaçada; o poder exposto debaixo da iluminação exclusiva da razão teria pouca credibilidade. Ele não consegue manter-se nem pelo domínio brutal e nem pela justificação racional. Ele só se realiza e se conserva pela transposição, pela produção de imagens, pela manipulação de símbolos e sua organização em um quadro cerimonial. (BALANDIER, 1980, p. 7).
\end{abstract}

Consideramos, assim, de suma importância compreender o mito político como categoria de análise social em contextos contemporâneos e, para tanto, torna-se necessário o entendimento desse conceito como constitutivo do cenário político e não como anomalia. Como bem aponta Bonazzi (1998), o mito político constitui a parte mais organizada das atividades simbólicas, "a que mais incide na dinâmica e nas transformações do poder.”. (BONAZZI, 1998, p. 759). Iluminar, portanto, as questões sobre a manifestação da política simbólica, emotiva e subjetiva é um passo importante para se compreender transformações intrínsecas às sociedades contemporâneas.

\title{
2.2 Política de imagem
}

A contextualização sobre as principais abordagens do conceito de mito político realizada até aqui permite a elaboração de alguns apontamentos que nos parecem imprescindíveis para a compreensão de tal conceito. São eles: a) o mito político é uma narrativa simbólica compartilhada num determinado imaginário coletivo e por meio dele; b) por ser narrativa, o mito político se torna instrumento de poder (força motriz) capaz de transformar ambientes sociopolíticos. Dessa forma o mito político é acionado, preferencialmente, em situações de crise em que há necessidade de transformação ou de ausência de representatividade política.

Ao avançarmos na discussão sobre o mito político faz-se necessário compreender como essa representação, enquanto narrativa, circula no imaginário coletivo das sociedades contemporâneas. Consideramos que a chave para essa compreensão é o entendimento de que o mito político é, também, imagem e enquanto imagem ele só se manifesta ao se tornar visível. Maria Helena Weber (2000), no livro Comunicação e Espetáculos da Política, publicado em 2000, enfatiza que a política é e sempre foi algo para ser visto. "A política busca visibilidade". (WEBER, 2000, p. 11). A autora ressalta, ainda, que essa visibilidade não necessariamente tem como caráter a desqualificação do campo político. Ela entende a política como espetáculo, 
discurso, narrativa e, de tal forma, algo para ser visto, explorado, encenado. É por meio da visibilidade que a política continua em busca de "credibilidade, opiniões e voto". (WEBER, 2000, p. 11).

Ressaltamos, dessa forma, que o conceito de imagem na política não é algo concebido apenas nas sociedades contemporâneas. A renomada obra $O$ Príncipe, publicada no século XVI pelo historiador e filósofo político italiano Maquiavel (1995), é um dos estudos pioneiros sobre a importância da imagem no campo político. Nesse livro Maquiavel (1995) descreve um método pelo qual os príncipes na Europa medieval poderiam adquirir e/ou manter-se no poder ${ }^{20}$. Um dos principais pontos desse processo proposto por Maquiavel (1995) enfatiza que para conquistar ou permanecer no poder o líder deve se dedicar à sua imagem, ou seja, ele precisa parecer ser qualificado mais do que realmente possuir qualidades específicas. Para o autor, governar é fazer crer. (MAQUIAVEL, 1995). O Príncipe, de Maquiavel (1995), é, portanto, construído sob uma narrativa repleta de simbolismos imagéticos capaz de atender aos anseios do imaginário coletivo - e, assim, dominá-lo.

Feita esta ressalva, pontuamos que o conceito de imagem que utilizamos neste estudo é o mesmo apresentado por Maria Helena Weber (2004) no texto Imagem pública, publicado em 2004 no livro sobre comunicação e política organizado por Antonio Rubim. O conceito de imagem pública, de acordo com a cientista, diz respeito ao processo no qual se constrói uma narrativa desejada (pelos atores ou instituições políticas) e que vai se transformar em narrativa percebida (pelos espectadores/eleitores). “A imagem pública é resultante da imagem conceitual, emitida por sujeitos políticos em disputa de poder e recuperada na soma das imagens abstratas (o intangível, a imaginação), com as imagens concentradas (o tangível, os sentidos).”. (WEBER, 2004, p. 262).

Além da concepção de imagem por Maria Helena Weber (2004) apresentada acima, consideramos a perspectiva de Wilson Gomes (2004) como necessária para a compreensão do conceito. De acordo com o autor, três aspectos compõem a imagem pública política: mensagem, fatos e configurações. Em sua visão,

Em outros termos, forma-se a imagem de alguém a partir do que ele diz ou do que é dito sobre ele, do que ele faz, da sua capacidade reconhecida de fazer e do que dele é feito e, enfim, a partir do como ele se apresenta: roupas, [...] símbolos, emblemas, posturas corporais, aparências exterior. Não se trata, imediatamente, daquilo que alguém faz ou diz realmente - no sentido comum do advérbio. Trata-se daquilo que

\footnotetext{
${ }^{20}$ Ressalta-se que no período medieval o poder era compreendido enquanto presente divino, ou seja, quem detinha o poder (os reis e príncipes) era predestinado a ocupar tal posição. Maquiavel (1995), em "O Príncipe”, propõe um novo método de compreensão em que a conquista ou a manutenção do poder passou a ser compreendida não mais como condição externa (presente divino), mas, sim, como ação e atividade humana.
} 
se considera que ele faça ou diga, daquilo que se reconhece como sendo suas mensagens, ações e apresentação. (GOMES, 2004, p. 268).

Após definirmos o conceito de imagem pública política torna-se necessário pontuar que o que de fato se altera no campo político contemporâneo em relação à imagem é a concepção de que essas imagens são mediadas predominantemente pelos veículos de comunicação. Como bem aponta Wilson Gomes (2004),

\begin{abstract}
O fenômeno da imagem pública, particularmente na sua forma política, parece ser tão antigo quanto o próprio fenômeno da vida pública. [...], a preocupação com a imagem, fama, nome, reputação das figuras e instituições políticas parece ter acompanhado sempre as práticas políticas [...]. Não é, portanto, a simples existência do fenômeno em nossa época que faz com que ele ocupe lugar central nas questões sobre política contemporânea. O que traz ao centro da cena é a sua vinculação à esfera da visibilidade pública e a sua relação estreita com os meios de comunicação de massa. (GOMES, 2004, p. 262).
\end{abstract}

Portanto, para que se compreenda a esfera política contemporânea é necessário compreender que a luta por poder é, também, uma batalha constante de imagens e narrativas em disputa pela visibilidade midiática. Maria Helena Weber (2004) defende que

[...] a imagem pública da política, enquanto dispositivo acionado pelos pactos e disputas de poder, entre sujeitos, instituições e mídias, é o fator axial de funcionamento da comunicação contemporânea, entre organizações, indivíduos e sociedades que necessitam de visibilidade favorável nos planos pessoal, institucional, político e mercadológico. (WEBER, 2004, p. 262).

Gomes (2004) intitula como "política de imagem" o fenômeno contemporâneo que “indica a prática política naquilo que nela está voltado para a competição pela produção e controle de imagens públicas de personagens e instituições políticas.”. (GOMES, 2004, p. 242). O autor ressalta que essa política de imagem não é uma substituição de práticas políticas anteriores, como já dito, mas sim, uma reorganização da esfera política diante da onipresença da mídia.

Gomes (2004) entende que alguns fatores foram determinantes para transformar a política de imagem em um processo intrínseco à esfera política contemporânea: o advento do modelo de sociedades democráticas, o aparecimento do modelo das sociedades de massa, o predomínio da comunicação de massa como lugar e como recurso expressivo no qual e pelo qual se realiza a esfera daquilo que é socialmente visível. (GOMES, 2004, p. 262). Sobre a política de imagem Gomes (2004) destaca, ainda, três principais funções: 
a) Uma das funções é a de criação, produção e construção de imagens públicas por profissionais de comunicação para assegurar a presença dos atores e instituições políticas nos espaços públicos. Esse papel é percebido em três fases: a primeira é feita pelos imagemakers ou assessores; a segunda, concebida posteriormente pela imprensa que recria a imagem estabelecida pelos profissionais e coloca essa imagem em circulação pela mediação dos veículos de comunicação. Já a terceira fase diz respeito ao público que é receptor e consumidor das imagens públicas. Acerca da função da política de imagem, considera-se de suma importância a perspectiva de Maria Helena Weber (2004) apresentada a seguir:

\footnotetext{
Os sujeitos políticos dependem da imagem pública e as informações que a constituirão estão vinculadas à demarcação das diferenças, das qualidades do sujeito político em relação aos outros. Poderá ser próxima à imagem desejada quando forem acionados os especialistas e técnicas de produção e circulação de mensagens estratégicas sobre seu projeto e seu estilo. Poderá ser uma imagem distante da desejada quando as referências ao projeto e ao estilo são produzidas em outros lugares, em "redes de circulação de imagens", onde a disputa é permanente. (WEBER, 2004, p. 294, grifo nosso).
}

Essas "redes de circulação de imagens" de que trata a autora dizem respeito à cena pública midiática (WEBER, 2004) na qual as imagens públicas são, a todo tempo, transformadas ou mesmo desconstruídas a partir de critérios estabelecidos, seja pela imprensa, seja pelo receptor/eleitor/cidadão.

b) Outra função da política de imagem é a de enquadrar personagens reais a perfis considerados ideais de acordo com expectativas geradas pelo público - muitas dessas expectativas são captadas por meio de pesquisas de opinião. Nessa função, portanto,

não se trata [...] de criar uma imagem para um ator político, por exemplo, mas de adaptar o ator político a uma imagem ideal ou a uma imagem esperada. [...] não se trata de criar uma imagem para um ator real, mas arranjar um ator real para uma imagem.”. (GOMES, 2004, p. 280).

c) A terceira função da política de imagem é a de administrar e gerenciar as imagens públicas já construídas. Gomes (2004) ressalta que a imagem pública somente se dá na recepção, ou seja, a imagem só é concebida quando atinge os públicos aos quais se destina. Dessa forma,

administrar a imagem pública significa justamente tentar mantê-la conforme a intenção da emissão, tentar evitar que as sucessivas codificações, decodificações e 
recodificações dos sinais transtornem de tal modo a interpretação que a mensagem recebida se distancie da imagem-modelo da mensagem emitida. (GOMES, 2004, p. 283).

Desta forma, a política de imagem apresenta uma dualidade entre a construção (e posterior administração) da imagem pública - feita pelos imagemakers ou mesmo pelos apoiadores de determinado político, candidato, partido ou projeto político - e a desconstrução dessa imagem - que pode ser feita através dos meios de comunicação ou mesmo pelos cidadãos ao receberem as imagens veiculadas pelos media.

A centralidade dos processos midiáticos nessa disputa política por imagem é, como se vê, peça-chave no entendimento do funcionamento do mito político nas sociedades contemporâneas. É na cena pública midiática que os mitos políticos, enquanto imagem e narrativa, são construídos ou desconstruídos.

\subsubsection{Narrativas políticas midiatizadas}

Partindo do pressuposto acima estabelecido de que os mitos, as imagens e as narrativas políticas na contemporaneidade se mantém visíveis a partir da circulação dos mesmos nos meios de comunicação, faz-se necessário compreender como se dá a íntima relação entre mídia e política. Para iniciarmos essa discussão partimos da perspectiva adotada por Charaudeau (2013), segundo a qual,

[...] para existir, toda sociedade tem [...] necessidade de uma medição social, de um sistema de valores mais ou menos mitificado que, para desempenhar seu papel de cimento identitário, deve ser partilhado pelo conjunto de membros da comunidade. Para tanto é preciso que sua circulação seja assegurada pelo suporte de uma instância social que tenha autoridade [...]. (CHARAUDEAU, 2013, p. 282, grifo nosso).

Essa instância social provida de autoridade, ainda de acordo com o autor, se constituiu de formas diversas ao longo do tempo: a Igreja na Idade Média; a imprensa nascente e a escola no século XVIII; as instâncias de organização da produção no século XIX; os meios de informação das massas no século XX. Já a partir da segunda metade do século XX foram as mídias as responsáveis por desempenhar "o papel de suporte a ponto de terem midiatizado totalmente a sociedade contemporânea: elas são portadoras de imaginários sociais que têm influência sobre as opiniões sem que se saiba verdadeiramente qual é essa influência.”. (CHARAUDEAU, 2013, p. 282). 
A onipresença da mídia na vida da sociedade contemporânea é também analisada por Stig Hjavard (2012) no artigo Midiatização: teorizando a mídia como agente de mudança social e cultural, publicado em 2012. Para esse autor

\begin{abstract}
A sociedade está permeada pela mídia de tal maneira que ela não pode mais ser considerada com algo separado das instituições culturais e sociais. Nestas circunstâncias, nossa tarefa [...] é tentar entender as maneiras pelas quais as instituições sociais e os processos culturais mudaram de caráter, função e estrutura em reposta à onipresença da mídia. (HJARVARD, 2012, p. 54).
\end{abstract}

Nessa linha de raciocínio, Muniz Sodré (2006), reconhecido pesquisador brasileiro na área da Comunicação, defende em importante obra, As estratégias sensíveis: afeto, mídia e política (2006), que a influência dos meios de comunicação nas sociedades criou um novo tipo de sociabilidade intitulada de bios midiático ou bios virtual, que deve ser compreendido para além da simples influência tecnológica da mídia. Para esse autor, a mídia constitui e se torna o vínculo principal dos processos sociais e políticos contemporâneos:

\begin{abstract}
$\mathrm{Na}$ "objetualização" do comum emerge hoje como duplo exteriorizado, ou ecossistema tecnológico, uma forma virtualizada de vida, a que chamamos de "bios virtual" (cuja manifestação mais evidente é a dimensão midiática) [...] essa realidade só é possível porque a modelização ou as imagens já estão inscritas na própria cultura, na mediação do sujeito consigo mesmo. O novo bios é tão-só uma exacerbação do processo, que se torna socialmente relevante porque intervém nas relações espáciotemporais, estas por meio das quais percebemos o mundo e agimos sobre ele. [...] O bios midiático é uma transformação técnica do espaço-tempo, adequada às novas estruturas e configurações da vida social. (SODRÉ, 2006, p. 99).
\end{abstract}

O conceito de midiatização, ainda em construção, foi (e ainda é) tema de pesquisa de uma variada gama de pesquisadores (FAUSTO NETO, 2008; HJARVARD, 2012; VERÓN, 2014; HEPP, 2014) que buscam compreendê-la como processo que confere um caráter central dos meios de comunicação na sociedade, de modo que esses deixam de ser apenas transportadores de sentidos ou espaços de interação e se tornam matrizes de produção e organização de sentido. Sendo assim, a "cultura das mídias" passa a ser a referência para as práticas sociais, os processos interacionais e a organização social.

Recorre-se também ao escritor francês Guy Debord (1997), que apresentou no livro $A$ sociedade do espetáculo, publicado em 1967, alguns dos primeiros indícios da manifestação da mídia nas instâncias sociais e como isso afetou a disseminação de acontecimentos pelo viés espetaculoso. Um tanto quanto pessimista em relação à espetacularização da sociedade, Debord (1997) afirma que o espetáculo significa representação. Ou seja, na sociedade espetáculo tudo é representado, nada é real. Válido ressaltar que Debord (1997) escreveu sobre a sociedade do 
espetáculo num contexto do capitalismo em que máquina, homem e mercadoria estavam em constante e crescente unificação. Em contradição, quanto mais o homem produz, mais ele se sentia distanciado de sua realidade e de suas necessidades. Daí o surgimento das representações, ou seja, a fabricação de imagens que não necessariamente traduzem a vontade real do ser produtor. Desse modo, o autor vai dizer que a sociedade deixou de se importar com o ter para se importar com o parecer. "O espetáculo é o capital em tal grau de acumulação que se torna imagem.”. (DEBORD, 1997, p. 25).

Como bem aponta Antonio Rubim (2002), há dois pontos sobre a visão de Debord (1997) que são questionáveis: o primeiro deles seria a redução da concepção de espetáculo às lógicas do capitalismo, ou seja, "o espetáculo de tal modo estaria comprometido com a forma mercadoria e a ideologia burguesa, que teria interditada qualquer possibilidade libertadora.”. (RUBIM, 2002). O segundo ponto diz respeito à contraposição entre real e representação:

A valorização, sempre positiva, da pretensa relação 'direta' com o real e a
desvalorização constante da mediação, em uma contemporaneidade marcada
exatamente pela complexidade e profusão de mediações, de antemão, fragilizam [...]
uma reflexão que pretende pensar [...] a atualidade. (RUBIM, 2002, p. 2).

Em relação ao campo específico da política, há uma ampla discussão sobre a influência da mídia na visibilidade pública dos atores políticos (partidos, instituições, governantes etc.). $\mathrm{O}$ rádio, o cinema e, posteriormente, a televisão sofreram duras críticas ao serem julgados responsáveis pela depreciação da política, ou seja, incriminados por corromper e deformar o debate de ideias. É simplório, como elucida o linguista Jean-Jacques Courtine (2003), dizer que os meios de comunicação e a manifestação do espetáculo na política são responsáveis por uma suposta crise do discurso político nas sociedades ocidentais. É necessário entender mais a fundo o que significa a política-espetáculo e qual a sua importância para o funcionamento do campo político atual.

A propaganda política veiculada em massa, que se tornou importante principalmente a partir da primeira metade do século XX, mudou consideravelmente o funcionamento da política contemporânea ao intensificar a relevância da imagem pública política. Esse tipo de propaganda era direcionado para a promoção de regimes totalitários como o de Stálin, na Rússia (antiga União Soviética), e o Hitler, na Alemanha, e foi um impulso para o aprimoramento dos estudos sobre comunicação e política.

Jean Marie Domenach (1963), autor do livro A propaganda política, publicado em 1950, ao analisar a fundo o processo de propaganda política durante a Segunda Guerra Mundial enfatiza a ideia de que tal tipo de propaganda é parte intrínseca do campo político: 
Desde que existem competições políticas, isto é, desde o início do mundo, a propaganda existe e desempenha seu papel. [...] assaz consciente dos processos que tornam amados os chefes e divinizam os grandes homens, Napoleão compreendeu perfeitamente que um Governo deve preocupar-se sobretudo em obter o assentimento da opinião pública. 'Para ser justo, não é suficiente fazer o bem, é igualmente necessário que os administrados estejam convencidos. A força fundamenta-se na opinião. Que é o Governo? Nada, se não dispuser da opinião pública. "”. (DOMENACH, 1963, p. 9).

Esse pesquisador citou a evolução do que intitula "técnicas de propaganda" como principal fator impulsionador das transformações da relação entre mídia e política a partir do século XX. Tais técnicas, de acordo com o autor, são a difusão da escrita impressa, a difusão da palavra pelo rádio - principal meio utilizado pelas propagandas do nazismo - e a difusão da imagem pela televisão, cinema e fotografia.

Com a ampliação da influência dos meios de comunicação na imposição e manutenção desses regimes autoritários, parte dos pesquisadores passa a compreender a midiatização como algo que desqualificava o sistema político e conspira "contra um uso maduro da razão por parte dos novos públicos de massa". (GOMES, 2011). Por essa perspectiva, a imprensa e a propaganda política manipulam uma "massa" de cidadãos incapaz de decodificar a informação recebida, ou seja, a informação transmitida pelos media é recebida sem contestações pelo público/espectador (daí o surgimento da expressão "comunicação de massa”). Dessa forma, a mídia oferece "apenas sobras e distorções, impedimentos ao verdadeiro conhecimento". (GOMES, 2011).

Por essa abordagem, portanto, a consequência imediata da midiatização seria a transformação dos atores políticos em simples imagem incorporando o código midiático e seguindo regras impostas pela mídia. O que ocorreria, então, por essa via, seria a "morte da política" ou um processo de "despolitização", ou seja, o esvaziamento das funções da política e do ator político para se tornarem mera representação midiatizada. Gomes (2011) cita obras como Public Opinion (LIPPMANN, 1922), Propaganda Technique in the World War (LASSWELL, 1927), The people's choice (LAZARSFELD, BERELSON, GAUDET, 1944), Experiments on Mass communication (HOVLAND; LUMSDAINE, SHEFFIELD, 1949) e Voting (BERELSON, LAZARSFELD, McPHEE, 1954), publicadas entre as décadas de 1920 e de 1950, como exemplos de estudos sob essa perspectiva.

A ideia da midiatização como algo negativo é criticada por Hjavard (2012). Para o autor, a midiatização pode e precisa ser questionada, mas não se deve pressupor que a dependência dos meios de comunicação pelas instituições sociais seja "sinônimo de declínio na esfera 
pública ou da desintegração da sociedade civil.”. (HJAVARD, 2012, p. 65). É necessário compreender, portanto, que os meios de comunicação não são meros reprodutores de discursos, já que influenciam diretamente alguns aspectos da esfera política. Mas observar essa influência não significa dizer que a política passou a ser apenas cena ou encenação de meios publicitários, ou que os discursos políticos se tornaram mero espetáculo, mas, sim, que a centralidade inevitável - da mídia no jogo político faz com que este incorpore algumas regras impostas pelos meios de comunicação.

Esse estudioso sugere que midiatização deva ser compreendida como

[...] o processo pelo qual a sociedade, em um grau cada vez maior, está submetida a ou torna-se dependente da mídia e de sua lógica. Esse processo é caracterizado por uma dualidade em que os meios de comunicação passaram a estar integrados às operações de outras instituições sociais ao mesmo tempo em que também adquiriram o status de instituições sociais em pleno direito. Como consequência, a interação social - dentro das respectivas instituições, entre instituições e na sociedade em geral - acontece através dos meios de comunicação. (HJARVARD, 2012, p. 64, grifos do autor).

Essa análise recebe também a contribuição de Gomes, que, em livro publicado em 2004 e intitulado Transformações da política na era da comunicação de massa, lança luz a toda essa discussão em relação à influência dos meios de comunicação no cenário político. Este autor chama atenção para a necessidade de se entender que a política apresenta inúmeras variáveis e que dar crédito aos meios de comunicação como únicos ou principais índices de transformação deste cenário tão amplo é, no mínimo, arriscado. De acordo com o estudioso, os termos “política-espetáculo", "espetáculo político", e até mesmo a "espetacularização do poder" são de uso comum na literatura sobre a comunicação política, mas a maioria dos estudos que utilizam tais termos nem sequer explica o que significaria esse espetáculo, como se o conceito já estivesse formado e seu significado, apreendido como algo institucionalizado.

O problema em não se compreender ao certo o conceito de espetáculo é fazer com que ele vire apenas uma palavra-chave ou uma designação pejorativa de fenômenos políticos. É necessário perceber que na sociedade contemporânea, o espetáculo político deixa de ser considerado mera ficção ou mascaramento e passa "a ser produzido também como modo de sensibilização, visando à disputa do poder e, como construtor de legitimidade política.”. (RUBIM, 2004, p. 189).

O conceito de política espetáculo abriga, segundo Gomes (2004), três sentidos principais citados pelos autores que estudam esse campo de conhecimento: a política em cena, a dramaturgia política e a espetacularização da política. Para esse pesquisador, a definição 
mais utilizada pela literatura em comunicação política sobre o tema da política espetáculo reflete a política em cena, ou seja, o espetáculo, sendo, portanto, entendida no sentido de algo cênico, elaborado para ser visto. Há dois pontos importantes nesse sentido da política espetáculo: a visibilidade, ou seja, a atuação dos agentes políticos e a passividade dos espectadores. Por essa via, ao mesmo tempo em que a política contemporânea está cada vez mais relacionada à visibilidade, principalmente proporcionada pelos meios de comunicação, ela também exige cada vez menos atividade do espectador, ou seja, há cada vez menos participação ativa do cidadão nos âmbitos políticos.

A dramaturgia política, segunda instância da política espetáculo, é ainda caracterizada pelo sentido cênico, mas apresenta um aspecto teatral, dramatúrgico. Alguns pontos são importantes nesse sentido: os papéis colocados aos atores políticos, os personagens da cena, a estrutura da narrativa, os efeitos emocionais etc. É no emprego da política espetáculo enquanto dramaturgia que se apresentam as principais críticas aos meios de comunicação, como ressalta Gomes (2004):

[...] nesse sentindo, a aproximação entre política e espetáculo é frequentemente feita de maneira pejorativa: a política ter-se-ia degradado em espetáculo - o que equivale a dizer que teria perdido autenticidade e espontaneidade. Perder-se-ia a política genuína com o predomínio da "política para os meios de comunicação", quando os agentes políticos jogam para o público e as ações políticas se representam para as câmeras. (GOMES, 2004, p. 390).

O terceiro modo de se entender a política espetáculo é feito a partir de um deslocamento do sentido do "espetáculo" para a palavra "espetacular". Aqui, o espetáculo passa a designar uma espetacularização da política, ou seja, a política torna-se algo grandioso, excepcional. Para Gomes (2004), a característica de cena e de dramaturgia ainda está presente, mas como pano de fundo. O que de fato caracteriza a espetacularização da política é transformar o campo político em algo que é notável ou admirável.

Esse autor (2004) sugere ainda um quarto sentido à ideia da política espetáculo: o simulacro político. Por esse viés, o espetáculo é algo que não só se dá a ver, mas é algo que impede de ver outras coisas. Ou seja, é simulação do real. É uma linguagem que se sobrepõe ao sentido primeiro dos discursos. Nota-se que esta abordagem de simulacro político é bem próxima da perspectiva do mito político apresentada por Cassirer (1976), Lasswell (1979), Barthes (2013) e Sorel (1992), em que o mito seria uma forma de mascaramento da realidade. 
O ponto em comum entre as quatro acepções averiguadas por Gomes (2004) (política em cena, dramaturgia política, espetacularização da política e simulacro político) é a política espetáculo enquanto cena, ou seja, algo para ser visto. Esse pesquisador reforça:

[...] a política-espetáculo é a política que emprega a sua presença na esfera de visibilidade pública como estratégia para a obtenção do apoio ou do consentimento dos cidadãos. A política-espetáculo é a política que se exibe, mostra-se, faz-se presença, impõe-se à percepção do cidadão. (GOMES, 2004, p. 403).

Salientamos aqui, portanto, que a configuração contemporânea da mídia não transformou a política como um todo; ela transformou alguns aspectos do campo político. Como bem aponta Gomes (2004), o campo político se dá a partir de constituintes interiores (diálogos e deliberações internas do poder) e exteriores (visibilidade pública). Dessa forma,

A política [...] funciona com base em vários sistemas de práticas e a política midiática é simplesmente um dos sistemas de práticas da política contemporânea, isto é, um conjunto sistemático de habilitações, de atores e de representações pelos quais se realiza a atividade política contemporânea. (GOMES, 2004, p. 424).

A política espetáculo não é, portanto, como pode parecer, algo novo ou transformador da política, pois esta sempre se deu por meio da cena, do teatro, do jogo de poder simbólico como já visto em tópicos anteriores deste capítulo. O poder político, logo, é dotado de cerimônias, ritos e encenação. E não é por isso que deva ser desqualificado. Como bem aponta Rubim (2002), o que ocorre a partir da midiatização dos processos políticos não deve ser entendido como contraposição entre a "política anterior" e a "política atual encenada", já que isto supõe que em algum momento da história do campo político houve uma política que não comportasse encenação - o que é uma inverdade. O que deve ser entendido, no entanto, é um novo tipo de formação social pautado pela mediação das ações do campo político e das disputas de poder pelos meios de comunicação.

Nesse sentido, Rubim (2002, p. 4) chama atenção para o fato de que

A ágora grega, o senado romano, a coroação do rei, o parlamento moderno, a posse
de presidente, as manifestações de rua, as eleições, enfim toda e qualquer
manifestação da política, anterior ou posterior à nova circunstância societária, supõe
sempre encenação, ritos etc. A mudança acontecida, portanto, não diz respeito à
dimensão estética ou espetacular da política, mas à potência e à modalidade de seu
acionamento em uma nova formação social. (RUBIM, 2002, p. 4).

Esta análise adquire novas percepções. Da mesma forma que Gomes (2004), Miguel (2002) buscou esclarecer alguns pontos imprescindíveis para a compreensão da política 
midiatizada sobre os quais discorreremos a seguir. Ressalta-se que todos os aspectos apresentados por Miguel (2002) são imprescindíveis para a compreensão da circulação dos mitos políticos enquanto imagens públicas no imaginário coletivo das sociedades contemporâneas:

a) Um primeiro ponto sobre a relação entre política e mídia foi discutido por Miguel (2002) a partir da ideia de uma formação do capital político ${ }^{21}$. O autor distingue dois tipos de capital político - o "delegado", "aquele ligado à ocupação de um determinado cargo institucional, seja ele um mandato parlamentar ou executivo, uma função de confiança num escalão governamental ou uma posição de poder na estrutura partidária” (MIGUEL, 2002, p. 168), e o capital "transferido" - quando outro tipo de capital é transferido para a área da política, ou seja, o ator político faz parte de outro campo profissional e o capital adquirido nessa profissão de origem é levado para o campo político na forma de prestígio.

Para esse pesquisador, com a centralidade da mídia, o sucesso ou fracasso de determinado político ou partido - ou a construção de seu capital político - passa a sofrer influência da visibilidade midiática proporcionada pelos meios de comunicação com a participação desses atores políticos em talk-sows, noticiários etc. Dessa forma, “os agentes que detêm maior capital político são capazes de orientar o noticiário (e, por consequência, a agenda pública) através de entrevistas e declarações.”. (MIGUEL, 2002, p. 173).

b) O segundo ponto de que trata Miguel (2002) sobre a política midiatizada está relacionado às transformações do discurso político. Para o autor, a reorganização dos agentes políticos sob regras da mídia modificou os modos do discurso político, mas ele reforça que isso não significa que os discursos estejam padronizados ou esvaziados de sentido. Afirmar isto é supor que, em algum momento, existiu um discurso político puro e livre de influências externas, mas outros fatores pré-televisão e mídias de massa, como a técnica retórica ou o timbre de voz, também influenciavam os modos discursivos. A mídia não é, portanto, a única responsável pela alteração ou por corromper os discursos políticos.

\footnotetext{
${ }^{21}$ Miguel (2003), ao basear-se na abordagem apresentada pelo sociólogo Pierre Bourdieu afirma que o capital político "indica o reconhecimento social que permite que alguns indivíduos, mais do que outros, sejam aceitos como atores políticos e, portanto, capazes de agir politicamente [...]. É necessário capital para avançar na carreira [política], ao mesmo tempo em que a ocupação de cargos mais elevados na hierarquia do campo político representa uma ampliação do capital.". (MIGUEL, 2003, p. 115). Sendo assim "o capital político é [...] uma espécie de capital de reputação, um capital simbólico ligado à maneira de ser conhecido.”. (FRITSCH, 2011).
} 
O agente político passou a adaptar sua fala - antes longa e demorada, transmitida em palanques, comícios etc. - para a lógica mais viável dos meios de comunicação, bem como a produzir e reproduzir discursos mais breves, abreviados, reduzidos. "Na medida em que os meios de comunicação de massa alteram a forma do discurso político, eles possuem um impacto significativo sobre a produção do imaginário e dos mitos.”. (MIGUEL, 2004, p. 381).

c) Como terceiro ponto importante para a compreensão da relação entre mídia e política destacamos, ainda, o papel dos meios de comunicação enquanto "instrumento de contato entre a elite política e os cidadãos comuns". (MIGUEL, 2004, p. 8). Como bem aponta este autor, o fácil acesso à mídia por parte dos cidadãos faz com que ocorra uma substituição das instituições políticas tradicionais - como os partidos políticos -, o que reduz significativamente a importância dessas instituições. Ainda de acordo com o investigador, dentre as funções dos partidos políticos duas se apresentam na literatura como principais: uma delas é a de "serem ferramentas que permitem que a cúpula mobilize seus apoiadores e, por meio deles, alcance o conjunto dos cidadãos" (MIGUEL, 2004, p. 8); e a outra é de recolherem "demandas das pessoas comuns, permitindo assim que elas cheguem às esferas de exercício do poder.”. (MIGUEL, 2004, p. 8).

Com a midiatização dos processos políticos essas duas funções - antes restritas às instituições políticas - passam a ser realizadas na e pela mídia e dessa forma "os meios de comunicação de massa suprem, em grande parte, ambas as funções, contribuindo para o declínio da política de partidos.”. (MIGUEL, 2004, p. 8). Este autor ressalta, no entanto, que é perigoso afirmar que a política perdeu suas especificidades e se rendeu a toda e qualquer regra imposta pela mídia. Ele afirma: "partidos e redes tradicionais de apoio ainda são, em geral, indispensáveis para o êxito em uma disputa eleitoral.”. (MIGUEL, 2004, p. 9).

Sobre esse aspecto da possibilidade de declínio da importância dos partidos políticos, torna-se necessário pontuar o engrandecimento, nas sociedades contemporâneas, da política personalista que se constituiu em enaltecimento de um único líder em detrimento de um partido ou projeto político. Acerca desse aspecto, recorre-se a Bernardo Manin (1995), em texto intitulado As metamorfoses do governo representativo e publicado em 1995, segundo o qual nas democracias contemporâneas "os partidos continuam a exercer um papel essencial, mas tendem a se tornar instrumentos a serviço de um líder.”. (MANIN, 1995, p. 14).

A partir deste pressuposto Manin (1995) discorre sobre a alternância da "democracia de partido", na qual as agremiações políticas se mantinham em forte e estável relação de confiança com o eleitorado, para uma atual "democracia do público", que reserva destaque para a 
personalidade carismática dos candidatos. $\mathrm{O}$ autor apresenta como principal causa dessa transformação o advento da comunicação de massa.

Manin (1995), assim como Miguel (2004), compreende que a mídia afeta "a natureza da relação de representação: os candidatos se comunicam diretamente com seus eleitores através do rádio e da televisão dispensando a mediação de uma rede de relações partidárias.". (MANIN, 1995, p. 13). Além disso, para o autor, a mídia passou a privilegiar as qualidades pessoais dos líderes em detrimento dos projetos políticos do mesmo. Dessa forma, "na opinião dos eleitores [...] a confiança pessoal que o candidato inspira é um critério de escolha mais adequado do que o exame dos projetos para o futuro.”. (MANIN, 1995, p. 13). Ele afirma, no entanto, que a “democracia do povo", caracterizada pela personalização da política, não deve ser culpada, como se pode imaginar, por uma suposta crise de representação política. A "democracia do povo", ele defende, nada mais é que um "deslocamento e um rearranjo da mesma combinação de elementos" (MANIN, 1995, p. 18) que sempre esteve presente na democracia representativa.

\begin{abstract}
A existência de um eleitorado bem informado e interessado, que pode ser empurrado de um lado para o outro, estimula os políticos a expor suas ideias diretamente ao público. Pode-se conquistar o apoio de uma maioria a uma determinada orientação política falando diretamente ao eleitorado. O debate de temas específicos não fíca mais restrito aos muros do Parlamento [...], nem às comissões consultivas entre partidos [...]; o debate se processa no meio do próprio povo. Em consequência, o formato de governo representativo [atual] [...] se caracteriza pela presença de um novo protagonista, o eleitor flutuante, e pela existência de um novo fórum, os meios de comunicação de massa. (MANIN, 1995, p. 18).
\end{abstract}

Faz-se necessário pontuar que essa política personalista abre espaço significativo para a manifestação das narrativas do mito político na contemporaneidade, especificadas por Girardet (1987), quais sejam: a conspiração, o salvador, a idade de ouro e a unidade. Em torno dessas narrativas constrói-se, portanto, a imagem pública política de um líder capaz de representar os anseios do imaginário social - no qual se percebe um declínio da importância das instituições políticas, tais como os partidos políticos.

d) $\mathrm{O}$ quarto ponto que se deve levar em consideração na política midiatizada é o entrelaçamento entre os meios de comunicação e o campo econômico ${ }^{22}$. Os jornais impressos ou televisionados sempre fizeram parte de grandes empresas de comunicação com interesses políticos próprios, passando a imprensa, também, a compor e estabelecer cenários políticos favoráveis a determinados veículos de comunicação. Nesse sentido, a comunicação

\footnotetext{
${ }^{22}$ Miguel (2004) trata especificamente do contexto dos meios de comunicação tradicionais, mas compreendemos que as mídias digitais e o advento dos portais de notícia online também fazem parte desse processo.
} 
tomou a si o papel não só de ditar tendências de visibilidade política, mas também de deter poder político. Como bem aponta Gomes (1994), “os meios de comunicação [...] são propriedade privada. E podem representar grupos e sujeitos políticos interessados em intervir, através dos meios, nos debates em que se decidem os negócios públicos.”. (GOMES, 1994, p. $62)$.

Os meios de comunicação não são, como se vê, meros instrumentos de publicidade - ato de tornar público - de assuntos políticos, mas são instituições e enquanto instituições eles participam ativamente do jogo político. Dessa forma, se o sujeito midiático (meio de comunicação) e o sujeito político (candidato, partido ou grupo político) conseguem entrar em consenso a partir de interesses comuns, "o que era um obstáculo torna-se uma enorme vantagem política sobre aqueles que foram excluídos por essa atitude seletiva.”. (GOMES, 1994, p. 62).

O domínio dos meios de comunicação em relação aos assuntos que se tornam públicos, ou seja, o poder que os media ou a imprensa passaram a deter sob a esfera de visibilidade pública da política, é uma das principais transformações da política midiatizada. "[...] a comunicação retém, em grande parte, o momento de publicização da política. Isso significa poder.”. (RUBIM, 1994, p. 45). A imprensa, enquanto instituição econômica, passou a realizar o agendamento de assuntos que são relevantes à audiência e a moldar a imagem pública dos atores, partidos e instituições políticas. Os agende políticos passaram a "pautar sua ação por critérios de "noticiabilidade"" (MIGUEL, 2002, p. 172) e a incorporar regras do campo da mídia e a se guiar por elas. Em outras palavras, a política de imagem passou a ser um jogo de poder no qual detém mais força o sujeito político que consegue se estabelecer da forma mais positiva e por mais tempo sob os holofotes dos media.

A partir dos apontamentos acima realizados elencamos algumas características necessárias para a compreensão da circulação das narrativas do mito político na contemporaneidade. São elas: a) a manifestação da política espetáculo por intermédio dos meios de comunicação; b) as novas formas de construção ou formação do capital político; c) as transformações do discurso político; d) o papel dos meios de comunicação enquanto instrumento de contato entre elite política e cidadãos comuns; a substituição das instituições políticas, tais como os partidos, e a ampliação da política personalista; e) e o entrelaçamento entre os meios de comunicação e o campo econômico que garante à mídia um poder decisório sobre quais assuntos ou imagens políticas se tornarão públicos e sob que circunstâncias, ou seja, se essas imagens serão veiculadas de forma positiva, negativa, distorcida ou modificada. 
2.2.2 Públicos em rede: a circulação de narrativas políticas em tempos de mídias sociais

Como visto no tópico anterior, os estudos sobre a relação entre política e os meios de comunicação tradicionais se voltaram, em grande medida, para a possibilidade de atores e partidos políticos promoverem suas imagens públicas diante da facilitação da mediação dos meios de comunicação como rádio e televisão, e também para o poder adquirido pela imprensa de dar visibilidade a pautas previamente determinadas por interesses específicos. Dessa forma, na tentativa de compreendermos a circulação e visibilidade do mito, das narrativas e das imagens públicas políticas na contemporaneidade, devemos compreender também as transformações pautadas pela constante e crescente utilização da internet em todo o mundo, bem como para a importância da comunicação em rede na circulação das narrativas políticas.

Necessário ressaltar, no entanto, que não pretendemos nesta pesquisa contrapor a internet aos meios de comunicação tradicionais tais como televisão, jornal impresso e rádio. A abordagem de convergência midiática na qual os meios de comunicação tradicionais e os atuais online se sobrepõem, ou seja, permeiam a sociedade de forma conjunta, nos parece mais interessante que a perspectiva de contraposição desses meios. De tal forma compreendemos que não há substituição tecnológica, mas, sim, complementariedade de possibilidades midiáticas em constante desenvolvimento e avanço nas sociedades contemporâneas.

Pontuamos, portanto, que ao discorrermos neste tópico sobre a influência da internet na circulação das narrativas políticas na contemporaneidade não pretendemos limitar a análise à circulação ao ambiente online. O que propomos, em contrapartida, é incentivar a reflexão sobre as novas possibilidades de visibilidade e circulação das narrativas políticas a partir do compartilhamento de informações em rede proporcionada pela internet - principalmente no ambiente das chamadas mídias sociais, foco da nossa pesquisa. Feita esta observação, a seguir lançaremos luz sobre estudos, abordagens e perspectivas que nos conduzam a melhor entendimento dos novos modos de circulação de narrativas e imagens políticas.

De acordo com Langdon Winner (1986), há autores que dizem que os artefatos, tais como televisão, rádio, automóvel, telefone, bem como a internet, são democratizadores, ou seja, provedores de liberdade e justiça social. Dessa forma não há uma nova invenção que escape a esse rótulo, mas constatar que essas tecnologias são estritamente políticas, em um primeiro momento, mostra-se equivocado. De acordo com o cientista, "todos nós sabemos que as pessoas têm política, não as coisas. Descobrir virtudes ou pecados em agregados de aço, plástico, transistores, elementos químicos e artifícios materiais parece completamente equivocado.”. (WINNER, 1986, p. 20). 
Buscamos, então, em Pierre Lévy (1999), um dos mais reconhecidos pesquisadores sobre a cibercultura, a compreensão de que a tecnologia computacional - e por consequência, a internet - é, como qualquer outra técnica, um agente de ideias e projetos sociais, estratégias de poder e interesses econômicos. Dessa forma, ele destaca que

[...] a emergência do ciberespaço acompanha, traduz e favorece uma evolução geral da civilização. Uma técnica é produzida dentro de uma cultura, e uma sociedade encontra-se condicionada por suas técnicas. E digo condicionada, não determinada. Essa diferença é fundamental.”. (LÉVY, 1999, p. 25).

Válido ressaltar que cibercultura é um conceito utilizado por Pierre Lévy (1999) em referência a um novo tipo de cultura e sociabilidade que teria sido criado junto à ascensão dos computadores e aparatos tecnológicos digitais. A cibercultura é, portanto, “[...] um conjunto de técnicas (materiais e intelectuais), de práticas, de atitudes, de modos de pensamento e de valores que se desenvolvem juntamente com o crescimento do ciberespaço.”. (LÉVY, 1999, p. 17). Lévy (1999) compreende que esse "conjunto de técnicas", ao condicionar as formas de sociabilidade humana abre possibilidades sociais, culturais e políticas que não poderiam ser imaginadas ou pensadas num mundo anterior à insurgência do ciberespaço. Importante ressaltar que, de acordo com esse estudioso, o termo ciberespaço - que surge da interconexão mundial de computadores - não delimita apenas a materialidade da comunicação digital, "mas também o universo oceânico de informações que ela abriga, assim como os seres humanos que navegam e alimentam esse universo". (LÉVY, 1999, p. 17).

Seguindo a mesma perspectiva de Winner (1986) e Lévy (1999), Evgeny Morozov (2011) compreende que, longe de ser um artefato inerentemente político, a internet deve ser, antes de tudo, compreendida no contexto em que estiver inserida. Sabe-se que a internet importa, mas ainda não está claro para qual finalidade, sua lógica nunca poderá ser entendida se for descontextualizada. É equivocado perceber o meio digital como determinista de apenas uma força, libertadora ou opressora.

O que Winner (1986) apresenta como alternativa para melhor compreensão do contexto atual do pensamento social e político é a chamada "teoria de política tecnológica", que propõe evitar o determinismo social - que infere que não importa a tecnologia em si, mas o sistema social no qual ela está inserida - bem como o determinismo tecnológico leigo - que acredita no potencial da tecnologia em si mesma, sua dinâmica interna sem nenhuma influência externa para moldar a sociedade segundo seus padrões. $\mathrm{O}$ autor sugere, enfim, que "prestemos atenção 
às características dos objetos técnicos e aos significados dessas características." (WINNER, 1986, p. 21).

A "teoria de política tecnológica" não substitui, mas complementa a determinação social da tecnologia ao compreender que as tecnologias podem ser de dois tipos: as que têm consequências políticas, como a internet - que dependem fortemente do contexto social, econômico e político em que estão inseridas - e as inerentemente políticas, a exemplo das armas químicas. No que se relaciona a essas ultimas cabe às autoridades, governos e afins a decisão de adotá-las ou não, pois têm em si mesmas o poder de mudar drasticamente uma determinada forma particular de vida política. (WINNER, 1986).

Tal perspectiva permite estabelecer interessante paralelo entre os pontos de vista deste autor com o de Yochai Benkler (2006), para quem a internet não é em si política, mas possui consequências políticas e fez surgir uma economia em rede que substitui a antiga economia industrial das mídias de massa (predominante da segunda metade do século XIX até o final do século XX). Essa economia em rede é peça-chave para a compreensão do espaço público e da política contemporânea.

A relação entre web, a economia e a sociedade contemporânea é abordada por Manuel Castells (2003) na obra intitulada A Galáxia da Internet: reflexões sobre a Internet, os negócios e a sociedade, publicada em 2001, na qual o sociólogo espanhol afirma ser necessário compreender a internet como uma base tecnológica intrínseca ao que ele chama de "era da informação" proporcionada por uma sociedade em rede. Para o autor, portanto,

[...] A Internet é o tecido de nossas vidas. Se a tecnologia da informação é hoje o que a eletricidade foi na Era Industrial, em nossa época a Internet poderia ser equiparada tanto a uma rede elétrica quanto ao motor elétrico, em razão de sua capacidade de distribuir a força da informação por todo o domínio da atividade humana. Ademais, à medida que novas tecnologias de geração e distribuição de energia tornaram possível a fábrica e a grande corporação como os fundamentos organizacionais da sociedade industrial, a Internet passou a ser a base tecnológica para a forma organizacional da Era da Informação: a rede. (CASTELLS, 2003, p. 7, grifo nosso).

A concepção de Castells (2003) sobre a rede como nova forma organizacional da era da informação segue a mesma perspectiva adotada por Lévy (1999) em relação ao conceito de ciberespaço. De acordo este autor, o ciberespaço, que também é chamado de rede, deve ser compreendido como:

[...] o novo meio de comunicação que surge da interconexão mundial de computadores. $\mathrm{O}$ termo especifica não apenas a infra-estrutura material da comunicação digital, mas também o universo oceânico de informações que ela abriga, 
assim como os seres humanos que navegam e alimentam esse universo. (LÉVY, 1999, p. 17).

A partir das perspectivas acima discutidas, consideramos o conceito de rede como de suma importância para a compreensão da política de imagem (GOMES, 2004) em tempos de mídias sociais. Pontuamos que os estudos sobre redes sociais passaram a ser relevantes para o entendimento da sociedade com início no século XX, como bem destaca Raquel Recuero (2011). A compreensão das relações sociais a começar da lógica da rede visa substituir a clássica abordagem de compreensão dos fenômenos a partir do estudo de cada uma de suas partes separadamente (paradigma analítico-cartesiano). Na abordagem da economia em rede, portanto, um fenômeno só pode ser compreendido caso se observe não suas partes isoladas, mas, sim, suas partes em interação.

Com a consolidação da internet como um dos principais meios de comunicação social, tais redes sociais sofrem alterações significativas ao migrarem do plano face a face para o âmbito online. O advento das chamadas "mídias sociais", como Facebook e o Twitter ${ }^{23}$, principalmente a partir de 2004, ampliou os estudos sobre as novas formas de sociabilidade mediadas pelo computador e as características específicas dos fluxos de informação e das trocas comunicacionais geradas a partir dessa mediação.

É comum a utilização dos termos "mídias sociais" ou "redes sociais" em referência às plataformas online que são mais utilizadas pelos usuários, mas torna-se necessário compreender as especificidades desses meios e o que os diferem de outros tipos de páginas ou sites na internet. Deve-se entender que essas plataformas não são redes sociais, mas, sim, "espaços utilizados para a expressão das redes sociais na Internet.”. (RECUERO, 2011, p. 102). O Facebook e o Twitter são, portanto, sites de rede sociais (SRS), ou seja, ambientes online “[...] que não eram, originalmente, voltados para mostrar redes sociais, mas que são apropriados pelos atores com este fim.”. (RECUERO, 2011, p. 104).

Pontua-se que as redes sociais (tanto online como offline) são constituídas por atores sociais (ou nós) e pelas conexões (ou arestas) que tais atores estabelecem entre si. Sendo assim, "o que chamamos de mídia social se refere a um fenômeno emergente, que tem início com a apropriação dos sites de rede social pelos usuários. Essa apropriação, que horizontaliza ainda

\footnotetext{
${ }^{23}$ Facebook e o Twitter estão entre as mídias sociais mais acessadas no mundo. Chamamos atenção para o fato de que o Twitter, um microblog no qual é possível publicar mensagens de até 140 caracteres, é o principal ambiente de coleta de dados da pesquisa empírica desta tese. Sendo assim, analisaremos o funcionamento do mesmo em detalhes no capítulo 5, no qual discorremos sobre a metodologia de pesquisa adotada neste estudo.
} 
mais os processos de comunicação, dá outra força ao papel dos nós na rede". (RECUERO, BASTOS, ZAGO, 2015, p. 29).

Torna-se oportuno mencionar que as mídias sociais ${ }^{24}$ tiveram início em 1997 com o advento do SixDegrees, site muito básico se comparado aos que conhecemos hoje em dia, mas que já proporcionava aos usuários a criação de conexões e a visualização de redes de amigos de outros internautas. Por não obter o sucesso esperado e o apoio financeiro necessário para seu crescimento, o SixDegrees saiu do ar em 2000. Desde então vários SRS foram criados, mas somente em 2003/2004 apareceram os primeiros a obter sucesso e significativa aderência dos usuários da internet em todo o mundo. Como exemplo citamos o Friendster, o Orkut - que obteve seu maior sucesso no Brasil - e o MySpace. Este último, lançado em 2004, é considerado o primeiro SRS que realmente conquistou adesão em massa em âmbitos mundiais ao abrir espaço para divulgação gratuita de bandas e grupos musicais. A adesão, principalmente de adolescentes - o site permitia o acesso de usuários com menos de 18 anos - fez com que o MySpace se tornasse fenômeno global e uma nova tendência na comunicação online.

Ainda em 2004 foi lançado o Facebook, que inicialmente se destinava apenas a estudantes da universidade de Harvard, nos EUA, e tinha por objetivo conectar os perfis daqueles alunos. No mesmo ano o sistema abriu possibilidade para utilização de usuários de outras universidades e, posteriormente, para alunos do ensino médio de todo o território dos Estados Unidos. Já em 2006 se tornou o principal SRS e também o mais rentável, ao permitir o acesso a qualquer usuário de internet no mundo. Ainda em 2006, surgiu o Twitter que, junto ao Facebook, tornou-se um dos principais sites de rede social conhecidos atualmente.

Diante de tantas possibilidades, as mídias sociais, na classificação de Boyd e Ellison (2008), se diferenciam de outras formas de Comunicação Mediada pelo Computador (CMC) por possibilitarem aos usuários: a) construir um perfil público ou semipúblico em um determinado sistema; b) criar uma lista de outros usuários com quem eles podem se relacionar; c) visualizar e examinar suas próprias listas de conexões, bem como as relações feitas pelos outros usuários no mesmo sistema. Ainda de acordo com os autores (BOYD; ELLISON, 2008), a principal característica das mídias sociais não é a sua capacidade de fazer com que indivíduos estabeleçam conexões, mas, sim, a possibilidade de tornar visíveis as redes de conexões criadas pelos seus usuários.

\footnotetext{
${ }^{24}$ Optamos, no presente estudo, pela utilização do termo mídia social em referência a plataformas online, tais como Facebook e Twitter, devido à maior facilidade de assimilação dessa terminologia pelos variados públicos - de leigos a especialistas.
} 
Essa particularidade da rede voltada para o usuário proporcionou uma nova organização das comunidades online a partir de outras formas de sociabilidade e de compreensão do espaço público. Boyd (2010) caracteriza essa nova compreensão do espaço público a partir das mídias sociais como "públicos em rede". Dessa forma, os públicos em rede são, simultaneamente, o espaço construído por meio das tecnologias em rede e o imaginário coletivo que emerge como resultado da interseção entre as pessoas, a tecnologia e a prática.

Boyd (2010) defende que, por ser baseada em dados (ou bits), a configuração dos públicos em rede facilita a inserção dos usuários nas redes de conexões que são criadas por meio dessas mídias sociais que, por sua vez, introduzem novas possibilidades de interação e por isso proporcionam inéditas configurações do espaço público ao ampliarem, registrarem e distribuírem as informações e as ações sociais de forma mais rápida.

A pesquisadora discorre sobre quatro características consideradas imprescindíveis para que se compreenda a nova configuração do espaço público em rede: a) persistência: conteúdos e informações online são automaticamente registrados e arquivados; b) replicabilidade: o compartilhamento das informações é feito de forma mais rápida, já que são constituídas por dados (bits); c) escalabilidade: o potencial de alcance e de compartilhamento das informações; d) buscabilidade: o conteúdo nessas redes sociais pode ser encontrado a partir de pesquisa.

Já de acordo com as características específicas dos públicos em rede, Boyd (2010) elabora como pontos principais: a) audiências invisíveis: nem todas as audiências identificadas, ou seja, nem todos os participantes são discerníveis nas redes; b) contextos em colapso: não há limites espaciais, sociais e temporais nas redes de conexões; c) a confusa divisão entre público e privado: sem o controle dos conteúdos a diferenciação entre o que é público ou privado é quase impossível de ser feita. Acerca dessas especificidades, a estudiosa destaca:

\begin{abstract}
As mudanças trazidas por tecnologias em rede são mais profundas do que aquelas causadas pela mídia anterior. Já que o conteúdo e expressões disponibilizado aos públicos em rede são persistentes e reproduzíveis por predefinição, a possibilidade de ações serem dimensionadas, pesquisáveis e, portanto, visualizadas é ampliada. Espaços físicos são limitados por tempo e espaço, mas online as pessoas podem se conectar umas às outras em grandes distâncias e dialogar com conteúdo gerado assincronamente por períodos extensos. Isto permite que as barreiras físicas à interação sejam superadas e reduz o custo da comunicação entre pessoas de lugares muito distantes. (BOYD, 2010, p. 13, tradução nossa) ${ }^{25}$.
\end{abstract}

\footnotetext{
${ }^{25}$ The changes brought on by networked technologies are more pervasive than those by earlier media. Because content and expressions contributed to networked publics is persistent and replicable by default, the possibility of acts being scaled, searchable, and thus viewed is heightened. Physical spaces are limited by space and time, but, online, people can connect to one another across great distances and engage with asynchronously produced content over extended periods. This allows people to work around physical barriers to interaction and reduces the cost of interacting with people in far-off places. (BOYD, 2010, p. 13).
} 
A partir da perspectiva dos públicos em rede proposta por Boyd (2010) faz-se necessário compreender, também, outras abordagens sobre a questão do espaço público contemporâneo, e, para tanto elaboraremos a seguir uma breve contextualização das variadas abordagens sobre a esfera pública.

Estudioso dessa temática, Habermas (2002) discorreu sobre a transformação dos aspectos principais da esfera pública das antigas ágoras gregas para a esfera pública burguesa do século XVIII - quando a opinião pública passou a ser considerada uma crítica ao Estado e uma forma de pressioná-lo em decisões que representavam o anseio da burguesia. Pelo conceito habermasiano, o espaço público ou esfera pública burguesa

[...] pode ser compreendida inicialmente como a esfera das pessoas privadas reunidas em um público; elas reivindicam esta esfera pública regulamentada pela autoridade, mas diretamente contra a própria autoridade, a fim de discutir com ela as leis gerais da troca na esfera fundamentalmente privada, mas publicamente relevante, as leis do intercâmbio de mercadorias e do trabalho social [...]. (HABERMAS, 2002, p. 42).

De acordo com Habermas (2002), a) a esfera pública não é uma coisa, lugar ou instituição social; b) a esfera pública concretiza-se em debates singulares, mas isso não nos autoriza falar em esferas públicas; c) uma discussão é ou não pública em virtude dos meios e regras de procedimento empregadas na sua realização, e não em função do status dos argumentantes; d) esfera pública é debate público - prática social, obediente a regras de procedimento e conforme certas circunstâncias.

Além das características acima apresentadas é válido ressaltar que a esfera pública sobre a qual Habermas (2002) discorreu em Mudança estrutural da esfera pública era elitista e excludente por limitar a participação do debate a homens pertencentes à burguesia ascendente. Por conta dessa percepção, a abordagem habermasiana sobre o espaço público no Estado moderno passou a receber duras críticas.

$\mathrm{O}$ avanço dos meios de comunicação na vida pública principalmente a partir do século XIX (como visto anteriormente) - momento em que ocorre importante tensionamento ou indiferenciação entre o conceito de público e privado - levou ao declínio do espaço público, na visão de Habermas (2002). Dessa forma,

A vinculação e submissão da esfera pública aos meios de comunicação de massa, que antes intermediavam os interesses públicos e privados e agora apresentavam uma dimensão comercial e mercantilizada da informação, marcavam a degeneração e a despolitização da esfera pública moderna. Sobrevivia, porém, o espaço de 
publicização, mas já sem o poder do debate. A imprensa tornava-se o símbolo do declínio da esfera pública. (GUEDES, 2010, p. 4).

Gomes (2008), ao discorrer sobre a proposta habermasiana de esfera pública, buscou vislumbrar a possibilidade de existência de formas de discussão pública na sociedade contemporânea - intensamente influenciada pelos media - capazes de serem caracterizadas como esfera pública “dotada de valor, alcance e sentido democráticos” (GOMES, 2008, p. 118). O autor apresenta dois questionamentos importantes: seria a esfera pública contemporânea uma esfera pública autêntica? Qual o formato e a natureza da esfera pública contemporânea?

Para responder a essas perguntas, Gomes (2008) partiu de quatro abordagens tradicionais que tratam da questão da esfera pública contemporânea e que se pautam em duas premissas básicas da esfera pública: deliberação e visibilidade:

1) A primeira abordagem é a mais cética em relação à autenticidade da esfera pública contemporânea e exclui a possibilidade de existência da deliberação na cena política midiatizada. Por este ponto de vista,

\footnotetext{
[...] a esfera pública midiática é, [...], uma esfera de representação pública de posições geradas de forma não-pública. Porque discursiva, ganha a aparência de esfera pública. Na realidade, é esfera pública encenada, espetacular, espaço de exibição, vitrine de opiniões em disputa pela atenção e adesão. (GOMES, 2008, p, 124).
}

2) Uma segunda abordagem, já pouco mais otimista, afirma que não há possibilidade de existência de democracias sem que existam espaços para deliberação -, ou seja, para essa perspectiva existe probabilidade de existência da esfera pública autêntica na contemporaneidade desde que ela se estabeleça em contextos democráticos. "É, por conseguinte, tanto mais democrática uma sociedade quanto mais inclusiva a sua esfera pública deliberativa, quanto mais as suas instâncias deliberativas ganharem forma de discussão pública [...]”. (GOMES, 2008, p. 129).

3) O terceiro enfoque compreende que há uma esfera pública contemporânea autêntica, mas não a entende como prioritariamente espaço de deliberação. Essa posição sinaliza que é necessária a criação de um terceiro termo para a melhor compreensão do que ocorre na esfera pública contemporânea: meios de comunicação/ visibilidade/deliberação. 
4) Já a quarta via de compreensão, apesar de admitir as dificuldades da existência de uma esfera pública deliberativa, entende que a esfera de visibilidade não exclui necessariamente a de deliberação: “[...] a extinção da argumentação não é da natureza dos meios. Tanto é verdade, que vemos discussão política acontecendo dentro e fora da cena midiática.”. (GOMES, 2008, p. 132).

A partir dessas distintas argumentações, Gomes (2008) elabora outro questionamento, qual seja: se a esfera midiática não consegue ser nem integralmente nem universalmente esfera da deliberação pública, como ainda podemos perceber, então, a existência da esfera pública diante da onipresença da cena política midiática? A solução encontrada por Gomes (2008) se desdobra em dois sentidos do espaço público contemporâneo: a esfera de visibilidade pública (cena pública) e a esfera de discussão pública (esfera pública). O autor reforça que se há perda de qualquer um dos dois sentidos na esfera pública - visibilidade ou deliberação - isso constitui perda da qualidade da democracia. Desse modo, ele compreende a esfera de visibilidade pública como a cena social, aquela dimensão da vida social que é visível, acessível, disponível ao conhecimento e domínio públicos; ela que responde a demandas de sociabilidade e de comunicação. Já na esfera de discussão pública também é fundamental a ideia de exposição, de visibilidade, mas nela o propósito é outro: não se expõe para provocar um mero conhecimento comum, mas para que possa existir uma deliberação em relação aos assuntos que foram tornados públicos e visíveis.

A esfera de visibilidade pública, no sentido proposto, é essencial para a existência da esfera pública contemporânea por dois motivos: 1) a discussão necessita da exposição proporcionada pela cena pública; 2) a cena pública torna disponíveis - mesmo que não os produza - os temas de interesse público que vão ser discutidos na esfera pública. Mas não se deve confundir cena pública com esfera pública - erro que, segundo Gomes (2008), é cometido por Habermas. "A esfera de visibilidade social nunca teve a obrigação de transformar-se em esfera do debate público e nenhuma sociedade parece ter sentido a necessidade de transformála nisso.”. (GOMES, 2008, p. 137).

Para que a discussão pública seja relevante (importância compreendida como a qualidade democrática das discussões), são necessários alguns pontos importantes: 1) a extensão do público para o qual essas deliberações são visíveis; 2) extensão ou alcance das coisas visíveis ao público; 3) volume das discussões públicas em andamento; 4) alcance das deliberações que se pretendem públicas. 
Gomes (2008) concorda com Habermas (2002) sobre o aspecto de que a discussão pública não pode ser mera conversa fiada, caso queiramos admiti-la com valor político. Mas atenta para o fato de que na esfera pública habermasiana a discussão limitada a especialistas pode vir a se tornar mero concílio de sábios e, portanto, não se expandir ao público como um todo e não ser acessível a todos. Com isso se perderia todo o sentido da esfera pública como domínio social da formação da opinião e da vontade coletivas. Dessa forma, é "a visibilidade que ancora a discutibilidade na democracia.". (GOMES, 2008, p. 162).

Seguindo a mesma perspectiva da esfera de visibilidade pública apresentada por Gomes (2008), Éllida Guedes (2010), em artigo intitulado Espaço público contemporâneo: pluralidade de vozes e interesses, também apresenta considerações pertinentes para esta discussão. Para a autora, enquanto a imprensa originou a esfera pública burguesa restrita a poucos atores sociais privilegiados no século XVIII, a midiatização contribui para a existência da pluralidade de vozes e interesses do espaço público contemporâneo, como se vê:

O espaço público equipara-se, assim, a um campo de interesses e de disputa, onde o conflito e a obrigatoriedade da negociação são iminentes. A dicotomia conflito $\mathrm{X}$ negociação está posta em um mundo plural em saberes, mediado e impactado pelas tecnologias da comunicação, onde surgem novos espaços participativos, novos mecanismos de controle e novas vozes. (GUEDES, 2010, p. 11).

Necessário pontuar que o próprio Habermas (2003), 28 anos após a publicação de "Mudança estrutural da esfera pública", reconsiderou sua abordagem sobre o tema do espaço público na obra publicada em 1990, Direito e Democracia. Guedes (2010), ao discorrer sobre a transição na abordagem habermasiana, explica que a esfera pública passou a ser descrita por Habermas de forma a "enfatizar uma concepção de público pluralista, capaz de elaborar resistência às representações dos meios de massa e de criar suas próprias intervenções.”. (GUEDES, 2010, p. 5). Desta forma, a nova abordagem apresentada por Habermas sobre a esfera pública passou a vislumbrar a existência de novas formas de discussão pública, no entanto, essas novas formas de discussão, na visão habermasiana, ainda são dominadas pelos meios de comunicação.

A esfera pública [passou] a ser descrita [...] como uma rede de comunicação de conteúdos, de tomadas de posição e de opiniões, em sintonia com a prática comunicativa cotidiana. Observa-se, pois, a ampliação do espectro de possibilidades de participação e de deliberação públicas, para além da classe burguesa [...] com abertura para segmentos da sociedade civil. (GUEDES, 2010, p. 6). 
Especificamente sobre a relação entre internet e espaço público - ou os públicos em rede (BOYD, 2010) - consideramos a abordagem de Gomes (2008) sobre a esfera de visibilidade pública, apresentada anteriormente, a mais adequada para se entender as discussões públicas sobre assuntos políticos que ocorrem na contemporaneidade, principalmente no âmbito das mídias sociais. Gomes (2006) reforça que para se compreender essa esfera de visibilidade pública deve-se ter como pressuposto a ideia de que a esfera pública contemporânea não pode ser percebida a partir da existência ou não de espaços democráticos de deliberação (no sentido habermasiano), mas, sim, pela ampliação de espaços para a conversação civil. Dessa forma,

[...] é preciso reconhecer uma diferença importante entre a deliberação política,
entendida como a produção da decisão, e a fala pública acerca dos negócios políticos.
Nas constituições liberais, a deliberação (no sentido de decisão) política é reservada
para a esfera política, que, por outro lado, foi autorizada a exercê-la pela esfera civil.
Se não exerce diretamente a decisão política, a esfera civil, por outro lado, produz
discursos, impressões, opiniões e até debates sobre a agenda política, aquilo que acho
que podemos apropriadamente chamar de conversação civil. Não sustenta a idéia de
conversação civil a noção de debate, de disputa, mas simplesmente a idéia de fala
pública, de expressão, de publicação. O debate é apenas uma das espécies do gênero
da conversação, que inclui ademais desde a fofoca até o jornalismo, passando por
todas as formas de expressão discursiva sobre os negócios públicos. (GOMES, 2006,
p. 58).

No entanto, como bem aponta João Pissara Esteves (2007) em artigo sobre as novas mídias e a democracia deliberativa, a internet ainda não mostrou "nada que nos permita acreditar que estamos na eminência, ou que seja sequer exequível, que todos nós, de um momento para o outro vamos passar a discutir e decidir sobre tudo". (ESTEVES, 2007, p. 210). A ideia de que a internet é um ambiente muito diferente e até mesmo evolutivo dos processos sociais que ocorriam no período pré-midiatizado, inclusive com a comunicação de massa, é uma ideia um tanto quanto perigosa.

Seguindo a abordagem de Manuel Castells (2012) publicada no texto Internet e sociedade em rede, propomos uma compreensão da internet não como algo novo capaz de transformar toda a estrutura política, porém como "um instrumento que desenvolve, mas que não muda os comportamentos; ao contrário, os comportamentos apropriam-se da internet, amplificam-se e potencializam-se a partir do que são.”. (CASTELLS, 2012, p. 273). Desta forma, a internet e as mídias sociais não são causas de uma transformação radical nos processos políticos, mas elas possibilitam a ampliação, como visto anteriormente, de conexões sociais que ultrapassam os limites e barreiras físicas que podem vir a possibilitar a modificação de comportamentos políticos tanto dos partidos, instituições e atores políticos como dos próprios cidadãos. 
Reforçamos, assim, a ideia de que a internet pode ser um instrumento de mudanças políticas ao transformar, como bem aponta Gomes (2014), os aparatos digitais em "arenas essenciais da discussão pública sobre temas de interesse político.”. (GOMES, 2014, p. 17). Tais arenas não são o centro das discussões atuais sobre a política, mas configuram-se parte importante da deliberação pública no contexto atual. As mídias sociais, para Gomes (2014), podem ser consideradas, portanto, espaços públicos contemporâneos na medida em que

[...] não são apenas meios de circulação de informação ou de produção de informação e opinião pública, mas são, sobretudo radares por meio dos quais o cidadão pode perceber, identificar e considerar os temas e problemas políticos que circulam na opinião circundante e, ademais, contribuir para formar fluxos predominantes de temas e questões sobre os quais se concentra a atenção pública. (GOMES, 2014, p. 19).

Torna-se necessário, portanto, compreender a internet e as mídias sociais como instrumentos de facilitação de criação de redes conectivas e espaços públicos tanto de visibilidade como de conversação sobre assuntos públicos. Como se sabe, nesses ambientes os públicos em rede são capazes de consumir e compartilhar informação de forma mais rápida e, ainda, argumentar e discutir sobre temas diversos de forma a possivelmente obter retorno em ações políticas concretas a partir da extensa e crescente visibilidade proporcionada pelo ambiente online.

Toda essa arquitetura do espaço público se traduz em novas formas de se perceber a política, principalmente no que tange às conversações cotidianas sobre assuntos que envolvem contextos políticos. Alguns exemplos se tornaram emblemáticos na configuração política a partir dos públicos em rede. A campanha de Barack Obama à Presidência dos Estados Unidos da América em 2008, por exemplo, é considerada um marco na relação entre a comunicação política e a internet. Naquele período, a estratégia eleitoral da campanha de Obama foi pautada na comunicação que interligava as mídias sociais e a tradicional comunicação de massa. $\mathrm{O}$ sucesso da campanha gerou significativo aumento do número de pesquisas sobre a propaganda política e as estratégias para conquista de voto.

Já no que diz respeito às conversações e fluxos informativos existentes nas mídias sociais, o Twitter se caracterizou como importante foco de pesquisas no mundo todo sobre o compartilhamento de informações em tempo real e a capacidade de mobilização política dos usuários a partir de diversas manifestações sociais ocorridas na primeira década dos anos 2000 . Tais protestos transformaram profundamente as relações entre os movimentos sociais e a internet a partir de duas conjunturas importantes: 
1) O primeiro contexto envolve as protestações ocorridas no Irã que eclodiram após a reeleição de Mahmoud Ahmadinejad em 2009 e repercutiram em grande escala no Twitter. Após a vitória de Ahmadinejad os opositores apontaram fraude na contagem dos votos, a população iraniana se revoltou com o resultado e o Twitter se tornou a principal fonte de comunicação entre os cidadãos, já que o SMS (mensagens enviadas por celular), até então principal forma de comunicação no país, tinha sido bloqueado pelo governo. A hashtag \#iranelection (com 220 mil tweets por dia) reunia não só mobilizações para protestos de rua, mas também informações em tempo real sobre os acontecimentos - a grande imprensa havia igualmente sido censurada.

Em represália aos protestos, o governo decidiu bloquear o acesso dos iranianos ao Twitter e a solução encontrada pelos manifestantes foi a de alterar a localização de seus perfis no site para que pudessem continuar se comunicando e disseminando novas informações. A censura do governo iraniano às formas de comunicação da população no episódio de 2009 gerou novas formas de se perceber a utilização do Twitter. Na visão de Antoun, e Malini,

\begin{abstract}
$\mathrm{Na}$ prática, a narrativa noticiosa baseada em hashtags foi utilizada para troca de informação mútua, organização tática dos protestos, globalização dos fatos, localização de testemunhas/fontes, relatos multimídia de registros do cotidiano, promoção de ideologias, conversação social e agendamento da mídia. (ANTOUN; MALINI, 2010, p. 293).
\end{abstract}

Pesquisa realizada pela Pew Research Center sobre os protestos ocorridos no Irã aponta que $98 \%$ dos assuntos dos links mais compartilhados no Twitter em todo o mundo entre 15 a 19 de junho de 2009 se referiam aos protestos no Irã e apenas $2 \%$ englobavam outros assuntos. De acordo com os pesquisadores,

\begin{abstract}
A ênfase dos milhares de tweets analisados sobre o Irã na semana passada mudou à medida que a história evoluiu e o potencial das mídias sociais se tornou mais aparente. Inicialmente, a maior parte do tráfego do Twitter incluiu links sobre os próprios eventos, alguns dos quais alegavam ser daqueles testemunhando eventos de primeira mão. No fim da semana, as principais histórias sobre o assunto foram sobre como os usuários poderiam se organizar e agir online. (PEW RESEARCH CENTER, 2009, tradução nossa). ${ }^{26}$
\end{abstract}

\footnotetext{
${ }^{26}$ In the thousands of tweets analyzed about Iran last week, the emphasis shifted as the story evolved and the potential of social media became more apparent. Initially, most of the Twitter traffic included links about the events themselves, a few of which claimed to be from those witnessing events first-hand. Later in the week, the top tweeted stories focused more on how users could organize and take action online. (PEW RESEARCH CENTER, 2009).
} 
No final daquela semana, grande parte dos tweets envolvia maneiras de se tirar proveito e vantagem do Twitter para ampliação dos protestos:

\begin{abstract}
$\mathrm{Na}$ manhã de 18 de junho, mais de 30.000 tweets incluíam links para o site "helpiranelection.com" que incentivava os usuários do Twitter a mudarem a cor de seu avatar (uma foto utilizada no âmbito online para representar o usuário) para a cor verde - símbolo do movimento do protesto. Muitos dos usuários que acessaram esta página incluíram a mesma mensagem: "Mostre o apoio à democracia no Irã, adicione a sobreposição verde ao seu avatar do Twitter com apenas um clique.". (PEW RESEARCH CENTER, 2009, tradução nossa). ${ }^{27}$
\end{abstract}

As manifestações sociais iranianas que ficaram conhecidas como "movimento verde" ou "onda verde" - justamente pela cor verde que fora adotada nas mídias sociais como forma de identificação de quem apoiava a causa - não obtiveram os resultados esperados; não houve, por exemplo, anulação da eleição de 2009 ou a retirada de Ahmadinejad do poder. Além disso, os protestos se tornaram extremamente violentos com centenas de manifestantes presos e perseguidos; muitas das perseguições eram realizadas pelo governo iraniano por meio de coleta de dados do Twitter e de monitoramento das informações compartilhadas, bem como dos usuários mais ativos nas mobilizações online.

Na perspectiva de Barreto,

[...] a onda verde que invadiu o Twitter e o Facebook durante a luta do povo iraniano contra o governo autoritário se virou contra eles, a partir do momento em que a revolta falhou e estas mesmas mídias servem hoje como banco de dados para a busca e apreensão de pessoas por esse regime. (BARRETO, 2011, p. 165).

Torna-se oportuno retomar aqui as ideias de Morozov (2011) sobre a utopia da internet como meio de libertação e democratização. Para o autor, a repercussão do poder do Twitter nos protestos no Irã em 2009 revela a ideia equivocada de países ocidentais, principalmente dos Estados Unidos e da União Europeia, de analisar a internet como tecnologia inerentemente política. O mito da revolução online iraniana faz parte de algo maior: o entendimento de que a internet pode derrubar ditadores. Para Morozov (2011), essa crença no poder libertador valida a ideia de que regimes autoritários censuram a internet por temê-la, mas ignora o fato de que a mesma está mudando a cultura de resistência e oposição e que governos ditatoriais podem encontrar uma forma de transformar a internet em poderosa arma de opressão.

\footnotetext{
${ }^{27}$ By the morning of June 18, more than 30,000 tweets included links to a Web page helpiranelection.com which encouraged Twitter users to change the color of their avatar (a picture used online to represent one's self) to greenthe symbol of the protest movement. Many of those who linked to this page included the same message: "Show support for democracy in Iran add green overlay to your Twitter avatar with 1-click. (PEW RESEARCH CENTER, 2009).
} 
2) O segundo contexto envolve revoluções ocorridas principalmente no Oriente Médio e Norte da África ${ }^{28}$ em 2010 e 2011 que ficaram conhecidas pelos jornalistas do ocidente como a "Primavera Árabe"29. Elas tiveram início a partir do descontentamento da população diante do autoritarismo dos governos dos países envolvidos. De acordo com Vivian Vieira (2013), que elaborou um estudo sobre o papel da comunicação digital na Primavera Árabe, outro motivo inicial dos protestos árabes foi

[...] a propagação de informações e opiniões sobre os regimes fechados relacionandoos à corrupção e abusos de poder, que até então estavam escamoteados e abafados aumentando a revolta e a crença da população na possibilidade de mudança política. Esta propagação ocorreu a partir do vazamento de informações que reverberavam abusos por parte dos ditadores. (VIEIRA, 2013, p. 11).

Os protestos da Primavera Árabe também tiveram como principal meio de divulgação e mobilização as mídias sociais, já que os meios de comunicação mais tradicionais eram controlados pelos governos ditatoriais naqueles países. O Twitter foi importante não só para mobilizar a população para participar dos movimentos, mas também para divulgar informações e conteúdos em tempo real do que estava ocorrendo na região já que os governos locais, por censurarem os meios de comunicação, não estavam noticiando o resto do mundo sobre o que estava acontecendo. Consciente da importância das mídias para o movimento, o governo do Egito cortou o acesso à internet entre os dias 25 de janeiro e 02 de fevereiro de 2011, como forma de esgotar a possibilidade de mobilização. Mas essa medida não foi suficiente e grupos pequenos com alto conhecimento em tecnologia continuaram enviando informações para o exterior. Além disso, "o fato de as pessoas não terem mais o acesso à internet, causou revoltas ou despertou maior interesse ao que estava ocorrendo em seu país, de modo que estimulou as pessoas a saírem às ruas, intensificando os protestos”. (VIEIRA, 2013, p. 17).

Diferentemente dos protestos iranianos, a Primavera Árabe teve consequências políticas favoráveis aos manifestantes com a queda dos chefes de Estado dos principais países envolvidos na revolução: Zine Al Abidine Ben Ali, então presidente da Tunísia; Hosni Mubarack, presidente do Egito (que renunciou após 18 dias de protestos); e Muammar al-Gaddafi, na época presidente da Líbia.

\footnotetext{
${ }^{28}$ Houve protestos na Tunísia, Egito, Líbano, territórios palestinos, Jordânia, Iraque, Kuwait, Emirados, Omã, Arábia Saudita, Sudão (Norte), Argélia, Marrocos, Síria, Iêmen e Líbia (VIEIRA, 2013, p. 10).

29 Tanto a expressão "Twitter Revolution" como a "Primavera Árabe" não são unanimes na literatura acadêmica especializada. Como não é nossa pretensão discutir a fundo esses processos, tais termos serão utilizados nesta pesquisa apenas a título de facilitação na referência aos dois eventos.
} 
Importante ressaltar que o meio digital não foi o único responsável pela ocorrência das manifestações na Primavera Árabe. Como bem apontam Tufekci e Wilson (2012), o ativismo político nos países em que ocorreram os protestos já se fazia presente na organização social antes da utilização das mídias sociais.

Essa é também a percepção de Vieira, para quem

[...] o acontecimento é muito mais amplo do que reduzido a uma plataforma digital, ainda que se reconheça que esta desempenhou um papel bastante significante para o desenvolvimento dos acontecimentos, sobretudo na disseminação para outros países da região, que compartilhavam semelhantes problemas, ainda que de naturezas distintas. (VIEIRA, 2013, p. 19).

Os dois acontecimentos históricos acima relatados se tornaram referência para a configuração das manifestações políticas contemporâneas. A partir deles, outros fatos políticos ao redor do mundo também passaram a ser influenciadores na criação e circulação de informações e por vezes se tornam os assuntos mais comentados no microblog. Um fator interessante que faz ser ainda mais forte o entrelaçamento entre contextos políticos e o Twitter é a constante utilização dessa mídia social pelos presidentes de inúmeros países.

De acordo com pesquisa intitulada Twiplomacy Study realizada em 2016 pela consultoria de comunicação Burson-Marsteller, o Twitter é a mídia social que mais possui contas oficiais de governos e líderes políticos. Como pode ser visto dos dados apresentados na Tabela 1, o estudo identificou um total de 793 contas no Twitter que pertencem a presidentes ou agências governamentais de 173 países distintos, todos esses perfis juntos possuem audiência total de 324 milhões de seguidores.

Tabela 1 - Total de contas de líderes políticos ou governos por site de rede social

\begin{tabular}{cccc}
\cline { 2 - 3 } & $\begin{array}{c}\text { Contas de líderes } \\
\text { políticos ou de } \\
\text { governos }\end{array}$ & $\begin{array}{c}\text { \% de países no } \\
\text { mundo }\end{array}$ & $\begin{array}{c}\text { Seguidores, curtidas, } \\
\text { usuários }\end{array}$ \\
\hline Twitter & 793 & $90 \%$ & 325.039 .622 \\
Facebook & 537 & $88 \%$ & 255.927 .664 \\
Instagram & 300 & $71 \%$ & 30.213 .526 \\
Google+ & 271 & $67 \%$ & 22.270 .176 \\
LinkedIn & 155 & $40 \%$ & 5.664 .432 \\
Youtube & 346 & $78 \%$ & 3.093 .433 \\
Vine & 47 & $13 \%$ & 805.517 \\
Periscope & 93 & $29 \%$ & 727.600 \\
Snapchat & 15 & $6 \%$ & 0 \\
\hline
\end{tabular}

Fonte: Twiplomacy Study, 2016. 
A América Latina tem posição de destaque nesse estudo, pois os líderes e governos de todos os países da região possuem uma conta oficial no Twitter e, além disso, esses perfis são alguns dos mais influentes no mundo. A ascendência do perfil no Twitter é medida não só pelo número de seguidores, mas também pelo de compartilhamentos ou retweets ${ }^{30}$ que a conta recebe, ou seja, sua potencialidade de atingir públicos maiores pela replicabilidade da informação gerada. No ranking dos 50 perfis mais influentes do microblog dentre os líderes mundiais, o Twitter de Nicolás Maduro, então presidente da Venezuela, ocupa o sexto lugar é mais influente do que a conta de Barack Obama, presidente dos Estados Unidos, que ocupa o oitavo lugar -, e o perfil de Maurício Macri, então presidente da Argentina, está em décimo primeiro lugar. (TWIPLOMACY STUDY, 2016).

Um outro estudo realizado pela agência comScore, publicado em 11 de agosto de 2010 mostrou que durante o boom de crescimento do Twitter entre junho de 2009 e junho de 2010, o microblog cresceu $109 \%$ em relação à população mundial e $305 \%$ em relação à população latino-americana, sendo Brasil, Índia e Venezuela os três principais países responsáveis pelo crescimento do número usuários no mundo (a Indonésia apresentou o maior crescimento, $20,8 \%$, seguida pelo Brasil com $20,5 \%$ e pela Venezuela com crescimento de $19,0 \%)^{31}$. Dados dessa mesma pesquisa mostram, ainda, que um dos principais fatores que impulsionaram a elevação do número de usuários venezuelanos no microblog em 2010 foi a criação de uma conta no Twitter para o ex-presidente da Venezuela, Hugo Chávez, em março daquele ano. (COMSCORE, 2010).

De acordo com nossa pesquisa de mestrado defendida em 2012 sobre o conteúdo do Twitter de Chávez, esse líder venezuelano utilizava o Twitter de forma intensa e, por vezes, atendia pedidos da população que chegavam via tweets. "Apenas três meses depois de criar uma conta na rede social o presidente venezuelano postou que havia recebido em torno de 288.000 pedidos de ajuda de cidadãos pela rede online.”. (PASSOS, 2012, p 74). Chávez também utilizava o Twitter para fazer anúncios - em primeira mão - de políticas públicas e econômicas que seriam adotadas pelo seu governo e anunciou diretamente no microblog após sua reeleição em 2012 a nomeação de novos ministros. Sobre o conteúdo do Twitter do mandatário dois pontos são importantes de serem destacados: a polarização política que se formou no âmbito

\footnotetext{
${ }^{30}$ Retweet é o mecanismo pelo qual um determinado usuário do Twitter compartilha uma publicação realizada por outro usuário no microblog. Discorreremos de forma detalhada sobre esse mecanismo no capítulo sobre os procedimentos metodológicos adotados na pesquisa empírica da presente tese (capítulo 4).

${ }^{31} \mathrm{~A}$ pesquisa foi realizada a partir de questionário submetido à pessoas com mais de 15 anos que utilizam a Internet em residências ou em locais de trabalho e exclui os acessos por meio de lan houses, cafés ou telefonia móvel.
} 
das conversações venezuelanas online no microblog e a utilização do perfil de Chávez no Twitter como uma das primeiras fontes de informação (por vez a única) sobre atividades de seu governo. Em outras palavras,

o Twitter de Chávez proporcionou uma guerrilha comunicacional online entre os chavistas e a oposição [...]; 2) o discurso do mandatário venezuelano no microblog passou a ser pauta para inúmeras matérias em importantes jornais ao redor do mundo (PASSOS, 2012, p. 104).

A importância do Twitter como meio de circulação de informações e de trocas conversacionais possibilitou o surgimento de vasto campo de estudo e o microblog se tornou objeto de diversas pesquisas acadêmicas em todo o mundo. Java et al (2007) investigaram os motivos pelos quais as pessoas utilizam o microblog. Oportuno mencionar que, por ter sido realizada ainda em 2007, a descoberta dos autores correspondia à utilização inicial dos usuários. Foram quatro as principais aditividades encontradas pelos autores na utilização do Twitter no primeiro ano do microblog: 1) postagens sobre atividades pessoais diárias (esse motivo está diretamente ligado à proposta inicial do Twitter de ser uma espécie de diário em 140 caracteres); 2) conversações entre os usuários; 3) compartilhamentos de informações e URLs (links que direcionam para outros sites); 4) relatos sobre as notícias mais recentes, bem como de eventos atuais (JAVA et al, 2007).

Em outra pesquisa, Kwak et al (2010) buscaram compreender se o Twitter é mídia que se assemelha mais a uma rede social ou a um meio de informação jornalística. Os resultados desse estudo mostram que há pouca semelhança entre a utilização dessa mídia e a criação de redes sociais sólidas devido à não reciprocidade necessária das conexões estabelecidas no microblog. Porém, dados encontrados pelos autores enfatizam que o poder do Twitter se encontra na possibilidade de o usuário criar e participar de redes sociais menos densas - mas não menos amplas - em que circulam informações (de caráter jornalístico) principalmente a partir da função de retweet. De acordo com os autores (2010),

O Twitter com sua API aberta que possibilita o rastreamento de dados, com sua natureza unilateral das conexões e seu mecanismo de retweet para retransmitir informações oferece uma oportunidade sem precedentes para cientistas, sociólogos, linguistas e físicos no estudo sobre o comportamento humano.”. (KWAK et al., 2010, p. 10 , tradução nossa). ${ }^{32}$

\footnotetext{
32 Twitter with its open API to crawl, one-sided nature of relationship, and the retweet mechanism to relay information offers an unprecedented opportunity for computer scientists, sociologists, linguists, and physicists to study human behavior. (KWAK et al, 2010, p. 10).
} 
Herring e Honey (2009) buscaram compreender, a partir de 36.987 tweets coletados, a conversação no microblog como forma de criação colaborativa de informação. Os autores se pautaram, principalmente, na utilização do @ (que um usuário usa para citar outro) como forma de averiguar a recorrência de tweets direcionados. A pesquisa conclui que

[...] apesar de ser um ambiente "ruidoso" e apresentar uma interface que não é especialmente propícia à conversação, trocas curtas e dinâmicas ocorrem com relativa frequência [no Twitter], além de longas conversas com múltiplos participantes que são surpreendentemente coerentes. Essas conversas são facilitadas em grande medida pelo uso do sinal @ como um marcador de endereçamento (i.e., para direcionar um tweet para um usuário específico) e a capacidade de "seguir" outros usuários, o que auxilia no rastreamento de conversas. (HERRING; HONEY, 2009, p 1, tradução nossa). ${ }^{33}$

Ainda sobre essas conversações online, Boyd, Golder e Lotan (2010) pesquisaram as funções do retweet e, de acordo com esses autores, ele pode ser compreendido tanto como uma forma de difundir informações como de participar de conversações. A investigação foi feita a partir de 720.000 tweets coletados e revelou que, apesar de o retweet ser considerado muitas vezes apenas uma alternativa para copiar e repostar dados, ele pode contribuir também para a conversação online: "Compartilhar tweets não significa somente enviar mensagens a novas audiências, mas também validar e se envolver com outras pessoas.". (BOYD, GOLDER, LOTAN, 2010, p.1, tradução nossa). ${ }^{34}$

Nessa mesma linha de investigação, Recuero e Zago (2012), assim como Boyd, Golder e Lotan (2010), estudaram a função do retweet em conversações no microblog. O conceito trabalhado pelas autoras (2012) é o da "economia do retweet" que concede a) referenciabilidade ao usuário que criou o tweet respostado; b) acesso a usuários que inicialmente não conseguiram visualizar a informação compartilhada (por não fazer parte da rede de conexões em que ela foi criada); e c) rapidez ou o menor tempo necessário à difusão de narrativas, já que a informação chega mais rapidamente a outras redes de conexões que não a original.

Além de pesquisas sobre a forma e a estrutura da circulação de informações no Twitter, outros estudos surgiram, especificamente no âmbito da comunicação política, em relação à capacidade de a circulação de informação online possibilitar a constituição em efetivos espaços

\footnotetext{
33 [...] despite a 'noisy' environment and a interface that is not especially conducive to conversational use, short, dynamic exchanges occur relatively often, along with somo longer conversations with multiple participantes that are surprisingly coherent. These conversations are facilitated in large measure by use of the @ sign as a marker of addressivity (i.e., to direct a tweet to a specific user) and the ability to "follow" other users, which aid users in tracking conversations (HERRING; HONEY, 2009, p. 1).

34 Spreading tweets is not symply to get messages out to new audiences, but also to validate and engage with others". (BOYD; GOLDER; LOTAN, 2010, p. 1).
} 
de deliberação pública (STROMER-GALLEY; WICHOWSKI, 2011; STROMER-GALLEY, 2007; DAHLBERG, 2001), bem como de a internet ter aumentado o nível de engajamento ou ativismo político (STANLEY; WEARE; MUSSO, 2004; NORRIS, 2001).

Há amplas divergências entre os autores que pesquisam a temática da democracia digital e tais dissensões acabam polarizando a discussão entre dois grupos: um primeiro que acredita no potencial e nas vantagens democráticas da internet e, portanto, em uma espécie de esfera pública virtual; e um segundo que é mais cético ou até mesmo crítico à ideia apresentada pelo grupo anterior. Em um quadro descritivo elaborado por Gomes (2005) em seu estudo sobre internet e participação política em sociedades democráticas é possível visualizar as principais questões em que se baseiam os dois grupos.

De acordo com os chamados "ciberotimistas", as características que evidenciam o caráter democrático da internet são: 1) superação dos limites de tempo e espaço para a participação política; 2) extensão e qualidade do estoque de informações online; 3) comodidade, conforto, conveniência e baixo custo de se receber e compartilhar informações; 4) facilidade e extensão do acesso; 5) ausência de filtros e controles; 6) interatividade e interação; 7) oportunidade para vozes minoritárias ou excluídas.

Já em relação aos "cibercéticos" ou críticos, outras especificidades são mais importantes nessa análise: 1) a desconfiança quanto à qualificação da informação política compartilhada; 2) a desigualdade no acesso; 3 ) o interesse do usuário pela política não aumenta com o advento da internet; 4) a predominância ainda existente dos meios de massa; 5) o sistema político ainda continua fechado sem grandes alterações quanto à participação efetiva dos cidadãos nas decisões; 6) a relação entre liberdade de expressão e a constante aparição de grupos extremistas (racistas, homofóbicos, xenófobos, conservadores); 7) a constante vigilância por parte dos governos de tudo que se faz e se produz via internet.

Para além dessa polaridade, consideramos de suma importância avaliar e considerar as particularidades de cada plataforma online e os variados contextos em que essas se inserem para que seja possível compreender quais as reais possibilidades e potencialidades da internet. $\mathrm{Na}$ perspectiva de Jamil Marques (2006), há que se diferenciar, por exemplo, as conversações ocorridas nas mídias sociais e as ocorridas em outros meios online, como os fóruns de discussão. Em relação aos últimos, a possibilidade de eles se constituírem em esfera pública deliberativa pode ser maior devido à estrutura deste tipo de plataforma - as conversas muitas vezes possuem mediadores e há tópicos específicos nas discussões. $\mathrm{O}$ autor pontua: 
Há momentos em que, sem dúvida, a internet se comporta como esfera pública eficaz, inclusive em termos deliberativos-decisórios. Todavia, geralmente, estes eventos ocorrem quando os grupos atingidos por esta deliberação, ao mesmo tempo em que são especializados ou dedicados a determinada temática, não são muito extensos. É o caso de uma lista de discussão. (MARQUES, 2006, p. 181).

Já em relação às mídias sociais, o caráter amplo e sem mediação das trocas de informações ocorridas nesse meio, em específico no Twitter, se aproxima mais do conceito de conversação civil (MARQUES, 2006). Tais conversações têm caráter "pouco organizado, informal e sem ordem temática pré-estabelecida" (MARQUES, 2006, p. 169) e se constituem em debates não deliberativos ou debates informativos e que "visam fornecer aos interessados uma maior capacidade de reflexão dos prós e contras de determinada matéria (ou apenas mantêlos a par do assunto).”. (MARQUES, 2006, 168).

Outra abordagem que também se aplica à circulação de narrativas ocorridas no Twitter é o da conversação informal ${ }^{35}$ de que trata Ângela Marques (2010). De acordo com a autora, nesse tipo de conversação

[...] os interlocutores são chamados a posicionar-se diante dos outros, a formular argumentos convincentes e solicitar respostas e justificações dos demais parceiros de interação a respeito de um problema que deixa, então, de pertencer ao pano de fundo das questões problemáticas latentes. (MARQUES, 2010, p. 319).

Considera-se, portanto, que a conversação civil ou conversação informal que ocorre no Twitter se encontra mais próxima ao nível da formação de opinião do que ao de tomada de decisões políticas. Como já argumentamos anteriormente, a esfera de visibilidade pública onde ocorrem as conversações informais - é tão importante quanto a esfera de deliberação pública, e é nesse lugar de fala (esfera de visibilidade pública) que há a cena social visível, acessível e disponível ao conhecimento público.

Outra característica dessa conversação é a sua estrutura em rede que faz com que as narrativas em circulação no Twitter se tornem amplas e visíveis. Recuero (2012) conceitua esse processo de circulação de narrativas informais no Twitter como "conversações em rede" sendo a característica mais importante desse tipo de diálogo o "espalhamento entre grupos sociais pelas conexões entre os indivíduos”. (RECUERO, 2012, p. 127). As conversas em rede são definidas como

[...] conversações que utilizam-se das conexões estabelecidas entre os atores nos sites de rede social para se espalhar para outros grupos. Essas conversações emergem da

\footnotetext{
${ }^{35}$ Nesta tese utilizaremos os termos "conversação civil" e "conversação informal" como sinônimos.
} 
intersecção de várias redes sociais [círculo de pessoas a quem estamos conectados] e são construídas e delimitadas, em suas características, pela apropriação desses grupos dos sites de rede social. São fundamentalmente conversações amplificadas, emergentes e complexas, nascidas da interconexão entre os atores. (RECUERO, 2012, p. 122).

Ao se estabelecer como um meio que possibilita a circulação de narrativas e contranarrativas criadas pelos próprios usuários e a ampliação do alcance dessas narrativas para outros públicos, o Twitter se torna uma mídia social de extrema relevância na contemporaneidade. Para Lucia Santaella e Renata Lemos (2010), o microblog "possibilita o entrelaçamento de fluxos informacionais e o design colaborativo de ideias em tempo real, modificando e acelerando os processos globais de mente coletiva" (SANTAELLA; LEMOS, 2010, p. 66). Além disso, as autoras caracterizam o Twitter como "termômetro' social e político, instrumento de resistência civil, palco cultural, [e] arena de conversações contínuas.”. (SANTAELLA; LEMOS, 2010, p. 66).

A partir de toda a reflexão acima elaborada sobre as mídias sociais - especificamente o Twitter - e em face da importância das mesmas no compartilhamento e na circulação de informações torna-se de suma importância, portanto, considerar as conversações em rede que ocorrem nesses ambientes como fonte de observação e compreensão da circulação das imagens públicas políticas na contemporaneidade. Dessa forma, pretendemos, na presente pesquisa, esclarecer não só a estrutura desses diálogos e como eles se formam, mas principalmente qual o conteúdo das narrativas que estão em circulação nas mídias sociais.

Com vistas a contextualizarmos as narrativas políticas que serão analisadas na presente pesquisa - e que são, portanto, nosso objeto de estudo -, no capítulo a seguir lançaremos luz sobre a trajetória política de Luiz Inácio Lula da Silva, ex-presidente do Brasil, bem como sobre a crise política brasileira ocorrida no ano de 2016. 


\section{A TRAJETÓRIA DE LULA E A CONTEXTUALIZAÇÃO DA CRISE POLÍTICA BRASILEIRA DE 2016}

O presente capítulo tem por objetivos principais: a) explorar a trajetória política de Lula, bem como a influência de sua imagem pública nos dois mandatos de sua sucessora política, Dilma Rousseff; b) compreender a disputa de sentidos entre as narrativas do impeachment e a do golpe estabelecidas no cenário político brasileiro a partir de 2015; e c) decompor a crise política ocorrida entre março e maio de 2016 em quatro contextos de análise que serão utilizados como pano de fundo para a pesquisa empírica realizada nos capítulos 5 e 6 .

\subsection{A trajetória política de Lula: de operário a presidente do Brasil}

A trajetória política de Lula teve início quando ele trabalhava como torneiro mecânico na metalúrgica Villares, em São Bernardo do Campo (São Paulo), e a convite de seu irmão mais velho passou a frequentar assembleias do Sindicato dos Metalúrgicos, em 1968. A partir de sua participação tomou gosto pelo sindicalismo e integrou a chapa que venceria as eleições seguintes para presidência da entidade. Seu primeiro cargo político, portanto, foi o de suplente no Sindicato dos Metalúrgicos de São Bernardo do Campo e Diadema, cargo que assumiu em 1969. (PARANÁ, 2009; BEZERRA, 2011).

De acordo com Luciana Panke (2010), no livro Lula: do sindicalismo à reeleição: um caso de comunicação, política e discurso, entre 1969 e 1972 Lula passou a enfrentar inúmeras divergências e descontentamentos dentro do sindicato por não concordar com atitudes que eram tomadas pela diretoria. A autora explica que

Por enfrentar o desconhecido mundo sindical, [Lula] acreditava que o sindicato deveria ser na prática, o que se esperava na teoria: uma entidade engajada e preocupada com a melhoria de vida dos trabalhadores representados. (PANKE, 2010, p. 54).

Impulsionado pelo descontentamento e decidido a melhorar as condições oferecidas pelo sindicato, Lula foi eleito primeiro-secretário em 1972 e presidente da entidade nas eleições de 1975 e 1978. No mesmo período em que o operário assumiu a presidência do sindicato, o regime militar brasileiro instaurado no país desde o golpe militar em 1964 aumentou a repressão aos direitos trabalhistas, limitando as possibilidades de reivindicação sindicalista.

Consideramos o período em que Lula foi líder sindical como o marco inicial na construção de sua imagem pública, já que passou a ser reconhecido pelo seu poder de 
mobilização e articulação política. De acordo com Bezerra (2011) em pesquisa sobre o "mito Lula", o estopim para seu reconhecimento se deu a partir de diversas greves trabalhistas ocorridas entre 1978 e 1980 que atingiram empresas em todo o Brasil.

Como bem aponta Ricardo Antunes (1995), as greves daquele período foram consideradas o ápice do chamado "novo sindicalismo"36 e tiveram início em maio de 1978, quando trabalhadores de grandes empresas, como Saab-Scania, Ford e Mercedez-Benz, cruzaram os braços em reinvindicação por melhores condições de trabalho e maiores salários. As greves trabalhistas realizadas em 1978 foram caracterizadas por movimentos isolados, sem que houvesse um núcleo único de organização. Esse aspecto difuso das greves de 1978, na percepção de Bezerra (2011), contribuiu para que o movimento fosse percebido como espontâneo, ou seja, não articulado a partir de um viés político. Mas esse pesquisador ressalta que "é inegável a participação prévia do sindicato na conscientização dos metalúrgicos, sobretudo, através da comunicação sindical, das assembleias e do trabalho intensivo dos diretores de base.”. (BEZERRA, 2011, p. 111).

Diferente do ano de 1978 em que ocorreram greves isoladas, 1979 foi marcado pela convocação de uma greve geral publicamente assumida pelo Sindicato dos Metalúrgicos do ABC (região da Grande São Paulo formada pelos municípios de Santo André, São Bernardo do Campo, São Caetano e Diadema) ocorrida naquele março. O principal impacto na construção da imagem pública de Lula no período se deu por meio de assembleias ocorridas em março de 1979 que, devido ao número excessivo de participantes, tiveram que ser realizadas no Estádio Municipal da Vila Euclídes, em São Bernardo do Campo (São Paulo). Nas reuniões, que contavam com a média de participação de 80 mil pessoas, Lula proferia discursos acalorados e emotivos em um palanque improvisado no meio do estádio. Nas primeiras assembleias, em que não havia microfones, os participantes que estavam mais próximos a Lula repassavam a fala do líder sindical para os que estavam mais afastados do centro. A multidão de trabalhadores gritava o nome de Lula em coro em diversos momentos em forma de manifestar adesão ao seu discurso (BEZERRA, 2011; PANKE, 2010). Naquele período as greves passaram a ser aprovadas por outros setores da sociedade, como a Igreja, os professores, estudantes, bem como a família dos trabalhadores em greve, o que ampliou ainda mais a potencialidade do movimento sindical.

\footnotetext{
${ }^{36} \mathrm{O}$ novo sindicalismo simbolizava uma ruptura com as antigas formas de estruturação dos sindicatos que, devido a limitações impostas pelo regime militar, tornaram-se extremamente hierarquizados, o que gerava limitação, impotência e acomodação dos líderes sindicais. O novo sindicalismo surgiu, então, como forma de rompimento com a "organização sindical vigente" (BEZERRA, 2011, p. 96) e apresentava como principal função recuperar o sindicalismo enquanto entidade e "assumir as lutas e reivindicações de seus representados.". (BEZERRA, 2011, p. 96).
} 
Devido à amplitude do movimento, em 22 de março de 1979, o ministro do trabalho, Murilo Macedo, decidiu intervir e reprimir as manifestações grevistas do ABC paulista e caçar o mandato dos dirigentes dos sindicatos, inclusive o de Lula. Mesmo com a intervenção, a greve geral continuou até o dia 27 de março, quando ficou decidido, em assembleia no Estádio de Vila Euclides (da qual participaram cerca de 80 mil trabalhadores), que haveria uma trégua de "45 dias, acordada entre os patrões e a diretoria cassada do Sindicato. A trégua previa a suspensão da greve e a reabertura das negociações.”. (ABC DE LUTA, 1979). Apesar do fim da greve geral, os trabalhadores continuaram mobilizados pelo Sindicato dos Metalúrgicos do $\mathrm{ABC}$, que intervia com boletins entregues nas portas das fábricas.

A amplitude do movimento grevista e a liderança sindical de Lula diante de tais movimentos fez surgir significativa divulgação de sua imagem pelos meios de comunicação do país. Necessário ressaltar, no entanto, que o período das greves gerais do ABC, ou seja, final da década de 1970 e início dos anos 1980, a imprensa no Brasil vivia sob censura imposta pelo governo ditatorial. Como bem aponta Antunes (1995), a visibilidade de qualquer movimento social que contrariasse o governo vigente era limitada.

Mesmo com pouca visibilidade do movimento grevista da época na mídia, alguns exemplos podem ser analisados: 1) O Grupo Globo ${ }^{37}$, que até aquele momento não divulgava informações sobre as greves do ABC, em 20 de março de 1979 publicou reportagem no Jornal Nacional em que apareciam imagens de uma das assembleias ocorridas no Estádio Municipal de São Bernardo do Campo. Na reportagem em questão a imagem de Lula discursando para os milhares de participantes da assembleia teve destaque muito breve, mas a visibilidade midiática do ato fez com que a narrativa de sua figura pública enquanto líder se tornasse mais forte ${ }^{38}$. (GREVES..., 2013). 2) Em 24 de março de 1979, por ocasião da repressão ao movimento grevista, o jornal Folha de S. Paulo publicou uma matéria intitulada "Lula: o fim de um líder? ", na qual há uma relação direta entre o fim da greve e um suposto "fim" de Lula, que era compreendido como a liderança máxima do movimento. (ABC..., 1979).

\footnotetext{
${ }^{37}$ O Grupo Globo - fundado em junho de 1925 por Irineu Marinho e herdado por Roberto Marinho - é o maior conglomerado jornalístico do Brasil e da América Latina e atua, principalmente, nos seguimentos de televisão, jornal, revista e rádio. A principal empresa do Grupo Globo é o canal Rede Globo de Televisão que, hoje em dia, é o maior do país e o segundo maior no mundo. (GRUPO GLOBO, 2015).

${ }^{38}$ Apesar da veiculação, em 20 de março de 1979, da matéria sobre as assembleias do sindicato ocorridas no estádio municipal de São Bernardo do Campo, é válido ressaltar que a Rede Globo foi extremamente omissa em relação às greves gerais trabalhista ocorridas entre 1978 e 1979. Miguel (2003, p. 291) demonstra essa omissão a partir do exemplo de matérias veiculadas pela emissora em que "imagens antigas dos pátios das montadoras, repletos de veículos, eram apresentadas como novas, para demonstrar que a produção prosseguia a pleno vapor.”.
} 
Nota-se, pelos exemplos acima citados, que a imagem de Lula passou a ser utilizada como símbolo de resistência ao momento de repressão militar por que passava o país. Merece destaque:

\begin{abstract}
Os meios de comunicação de massa viam Lula com bons olhos. Ele era um grande mobilizador da classe trabalhadora contra a ditatura militar, um regime que, naquela época, depois da crise econômica de 1973, já não interessava a tanta gente. Além disso, por nunca ter construído nenhum tipo de vínculo com partidos ou organizações de esquerda, era tido como um homem em quem se podia confiar. [....] Não era uma ameaça, mas um aliado. E um aliado importante. (PARANÁ, 2009, p. 126).
\end{abstract}

Lula, ao discorrer sobre o fato de sua imagem pública ter sido utilizada pela imprensa nacional na época da redemocratização do Brasil, afirmou:

\begin{abstract}
Acho que fui [usado] realmente, e eu queria continuar sendo usado da forma que fui por mais 50 anos. Porque eu sempre disse tudo que eu queria, e ela [a imprensa] sempre publicou grande parte do que eu queria dizer e graças a isso é que a gente chegou onde chegou. Eu não nego que a imprensa teve uma atuação enorme no nosso trabalho. Por quê? Porque a Televisão, o Rádio, o Jornal passaram a publicar coisas que eram proibidas até 1977. Então a dona-de-casa no intervalo da novela ouvia falar em sindicato, o cara que tava com o radinho trabalhando ouvia falar em sindicato, o cara que lia jornal, a classe média que é muito volúvel, que dança de acordo com a situação econômica, que tinha mentalidade de que dirigente sindical era corrupto ou subversivo, começava também a ver que existia um outro tipo de dirigente sindical. Um grupo de pessoas honestas que estavam dispostas a levar uma luta séria. Então a imprensa foi muito favorável no sentido de abrir esse espaço. (LULA apud DANTAS JÚNIOR, 1981, p. 52).
\end{abstract}

Em 1980, mesmo após a repressão do movimento grevista ocorrida no ano anterior, houve a maior de todas as greves gerais do $\mathrm{ABC}$ paulista - teve início no dia $1^{\circ}$ de abril de $1980 \mathrm{e}$ durou 41 dias. A "Greve dos 41 dias", como ficou conhecida, exigia, entre outras pautas, autonomia e liberdade sindical, garantias no emprego, direito de greve e salário mínimo unificado. Pela amplitude do movimento, as paralisações entre 1978 e 1980, passaram a representar "o reaparecimento do movimento sindical na cena política do país.". (ZANETTI, 1993).

Em represália ao movimento, o governo militar brasileiro prendeu Lula e outros dirigentes sindicais no dia 19 de abril de 1980. No dia $1^{\circ}$ de maio (Dia Internacional do Trabalho) daquele ano, mesmo com os líderes do sindicato presos, cerca de 100 mil trabalhadores se reuniram em manifestação em São Bernardo do Campo (São Paulo), o que só confirmou o já instituído poder de mobilização e a popularização dos líderes sindicais. Lula deixou a prisão em 20 de maio daquele mesmo ano, foi julgado pela Justiça Militar em novembro de 1981 e condenado a pena de 3 a 6 meses de prisão, mas, posteriormente, o 
Supremo Tribunal Militar anulou o processo. Após deixar a prisão, Lula declarou publicamente por meio de entrevistas a veículos jornalísticos que continuaria a luta pelos direitos dos trabalhadores e pela redemocratização do Brasil (BEZERRA, 2011).

Ressalta-se que, apesar da amplitude do movimento trabalhista, as reivindicações e as propostas apresentadas pelo sindicato nos piquetes estabelecidos entre 1978 e 1980 não foram atendidas e, após a prisão de Lula e de outros líderes, o movimento passou a perder força. Bezerra (2011) pontua, no entanto, que o principal resultado obtido a partir das greves ocorridas naquele período foi a capacidade de mobilização e conscientização para a necessidade de uma organização política que pudesse ir além dos interesses próprios e específicos dos operários, ou seja, que incluísse questões e reivindicações de toda a esfera social da classe trabalhadora brasileira. (BEZERRA, 2011, p. 118).

Impulsionados pela conscientização política, Lula e outros líderes sindicais criaram, em fevereiro de 1980, o Partido dos Trabalhadores (PT), que se tornou um dos principais partidos de esquerda e oposição ao regime militar no país. David Samuels (2004), em texto sobre as bases do petismo, discorre que em sua fundação, o PT

[...] uniu militantes políticos de esquerda, militantes das comunidades de base da Igreja Católica que seguiam a "Teologia da Libertação", intelectuais moderados e líderes de sindicatos e de movimentos sociais. A heterogeneidade e sua criação de baixo para cima o tornaram único na história dos partidos no Brasil e, talvez, na América Latina. (SAMUELS, 2004, p. 223).

O reconhecimento oficial do PT como partido político pelo Tribunal Superior de Justiça Eleitoral ocorreu em fevereiro de 1982. Válido ressaltar que, apesar de ter sido criado em 1980, a ideia da formação desse partido surgiu no bojo das greves trabalhistas de 1978 e $1979^{39}$

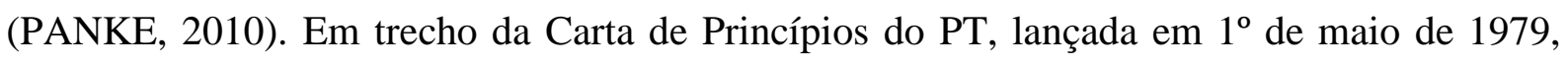
citado a seguir, nota-se que o partido se define a partir de narrativas expressivas, tais como: "partido das massas populares", "liberdades democráticas" e "participação política”. Essas expressões passaram a constituir parte essencial dos discursos políticos de Lula desde então, como se vê:

O PT não pretende criar um organismo político qualquer. O Partido dos Trabalhadores define-se, programaticamente, como um partido que tem como objetivo acabar com a relação de exploração do homem pelo homem. O PT define-se também como partido das massas populares, unindo-se ao lado dos operários, vanguarda de toda a

\footnotetext{
${ }^{39}$ Lula também foi um dos principais articuladores na criação da Central Única dos Trabalhadores (CUT), em São Bernardo do Campo durante o $1^{\circ}$ Congresso Nacional da Classe Trabalhadora (CONCLAT), em 1983, que também se tornou símbolo importante nas conquistas e lutas dos movimentos sindicais no Brasil.
} 
população explorada, todos os outros trabalhadores - bancários, professores, funcionários públicos, comerciários, bóia-frias, profissionais liberais, estudantes etc. - que lutam por melhores condições de vida, por efetivas liberdades democráticas e por participação política. (CARTA, 2016, p. 6, grifo nosso).

Pontua-se ainda que, por ser um dos principais fundadores do PT, Lula passou a falar com propriedade que seu partido era a esperança para os brasileiros e que todas as correntes contrárias a esse movimento deveriam ser temidas. 'Obtém-se com as expressões 'esperança' e 'medo' a caracterização de dois sentimentos opostos que agregam a essência humana. Lula, personificando a esperança, torna-se um símbolo desse valor.”. (PANKE, 2010, p. 74, grifo nosso). Com um discurso predominantemente pautado na narrativa de salvador, herói dos trabalhadores e única esperança para o Brasil, Lula se conectou de forma ainda mais forte às classes populares brasileiras.

Ainda como reforço a essa proximidade com a classe popular, Lula reforçava em seus discursos a narrativa da superação baseada em sua trajetória pessoal ${ }^{40}$, como pode ser observado, a seguir, em trecho de seu discurso também publicado no livro de Dantas Júnior (1981):

Falar sobre mim é a mesma coisa que falar sobre, quem sabe, milhões de brasileiros, que saíram do Nordeste ou saíram do campo, para vir arriscar a sorte na cidade grande. A gente vivia lá em Pernambuco, na cidade de Garanhuns, uma cidade pequena, onde o meu pai tinha um pedaço de terra e trabalhava como lavrador. (LULA apud DANTAS JÚNIOR, 1981, p. 12).

Observa-se que ao utilizar tal narrativa Lula se torna, ao mesmo tempo, parte constituinte de seu público e líder do mesmo. Como bem aponta, Girardet (1987),

Oradores de caráter quase sagrado, é em primeiro lugar pelo Verbo que agem, é pela palavra que pretendem decidir o curso da história (...). É pelo poder específico do Verbo que se opera, com efeito, essa estranha comunhão que faz com que, dirigindose o chefe político à multidão, seja igualmente a multidão que se exprima nele, com ele. (GIRARDET, 1987, p. 79).

\footnotetext{
${ }^{40}$ A trajetória pessoal de Lula é marcada por dificuldades enfrentadas devido à extrema pobreza vivenciada durante sua infância e adolescência. Lula nasceu em 27 de outubro de 1945, na cidade de Garanhuns, sertão de Pernambuco. Foi o sétimo de oito filhos de Dona Lindu (como era conhecida sua mãe) e Aristildes Inácio da Silva, um casal de lavradores. Lula e sua família, assim como muitas famílias brasileiras, se retiram do Nordeste do Brasil em busca de melhores condições de vida no Sudeste ${ }^{40}$. Em São Paulo, Lula começou a frequentar a escola somente aos 10 anos e conseguiu completar o primário em 1956. Desde pequeno trabalhou vendendo pipoca, amendoim, ou engraxando sapatos. Aos 14 anos conseguiu o primeiro emprego em uma metalúrgica e, ao mesmo tempo em que trabalhava, fez um curso de torneiro mecânico pelo Serviço Nacional de Aprendizagem Industrial (SENAI), conseguindo concluir o curso aos 18 anos. (PARANÁ, 2009; BEZERRA, 2011).
} 
Pontuamos que após a criação do PT, Lula se tornou um dos principais líderes das manifestações sociais conhecidas como "Diretas Já". Ocorridas em 1983 e 1984, tais atos públicos reivindicavam o fim da ditadura militar e clamavam por eleições presidenciais $\operatorname{diretas}^{41}$. O período é analisado por Lima:

\begin{abstract}
Os partidos de oposição se uniram numa bem-sucedida campanha de mobilização popular - as Diretas Já - que visava pressionar o Congresso Nacional a aprovar uma proposta de Emenda Constitucional [...] que estabelecia a eleição direta para presidente da República a partir de 1985. [...] iniciou-se, então, uma série de concentrações populares que, com o correr do tempo, assumiram tal proporção que conseguiram transformar o clamor por eleições [diretas] num amplo consenso nacional. (LIMA, 2006, p.73).
\end{abstract}

Em matéria publicada pelo jornal Folha de S. Paulo sobre as manifestações ocorridas em 16 de abril de 1984 na cidade de São Paulo, Lula foi citado como "o orador mais aplaudido da noite [...]" (SÃO PAULO..., 1984). Essa narração confirmou a importância da liderança do operário na luta pela redemocratização do país que culminou em forte apoio eleitoral para sua candidatura a deputado federal pelo estado de São Paulo, em 1986. Lula foi o deputado federal mais votado naquele ano com 600 mil votos e tomou posse em fevereiro de 1987. Ele se tornou líder do PT na Câmara dos Deputados e, no mesmo ano, participou da Assembleia Nacional Constituinte, responsável pela elaboração da Constituição Federal de 1988.

Em dezembro de 1987, por ocasião do $5^{\circ}$ Encontro Nacional do PT, foi oficializada a candidatura de Lula às eleições presidenciais de 1989 (primeiras eleições desde a redemocratização do Brasil $)^{42}$. A candidatura foi apoiada pelo Partido Verde (PV), pelo Partido Socialista Brasileiro (PSB) e pelo Partido Comunista do Brasil (PCdoB), adesão formalizada em 29 de março de 1989 com a criação da chapa Frente Brasil Popular (FBP) (PANKE, 2010).

Pontuamos que no período em questão, a campanha eleitoral midiatizada se pautava essencialmente pelo Horário Gratuito Político Eleitoral (HGPE) transmitido pelos canais de televisão. Dessa forma, Luna e Maia (2005) apontam que a campanha do PT em 1989 foi marcada "pela sofisticação no uso da mídia e as produções para o HGPETV foram baseadas num programa que procurava se assemelhar à TV comercial, especialmente à Rede Globo [...].”. (LUNA; MAIA, 2005, p. 99).

\footnotetext{
${ }^{41}$ As eleições diretas para presidente e vice-presidente da República foram aprovadas em votação no Congresso Nacional em 8 de maio de 1985. Ainda em 1985 houve eleições indiretas e Tancredo Neves foi eleito presidente do Brasil, mas faleceu antes mesmo de assumir o cargo. José Sarney, vice-presidente na chapa de Tancredo Neves, assumiu a Presidência e ocupou o cargo até março de 1990.

${ }^{42}$ O candidato a vice-presidente na chapa de Lula em 1989 foi José Paulo Bisol, do Partido Socialista Brasileiro (PSB).
} 
Em pesquisa sobre as campanhas eleitorais brasileiras no HGPE de 1989, Afonso de Albuquerque (1999) afirma que, em resumo, a campanha eleitoral petista enfatizou o problema da "exploração de uma classe (trabalhadora) por outra (capitalista)" (ALBUQUERQUE, 1999, p. 157), como o principal obstáculo à melhoria das condições de vida dos brasileiros e, dessa forma, a conquista do poder pelos trabalhadores seria a única solução. Albuquerque (1999) reforça que a imagem pública política de Lula construída pelo HGPETV foi

[...] a de um trabalhador, alguém que conhece os problemas fundamentais dos brasileiros porque os experimentou pessoalmente. A sua relação com os telespectadores/eleitores foi retratada, assim, como uma relação de identidade e coparticipação no processo político. (ALBUQUERQUE, 1999, p. 157).

Observa-se, novamente, o recurso da narrativa de pertencimento como forma de proximidade e identidade de Lula com a classe trabalhadora, estratégia utilizada em seus discursos como líder sindical, como visto anteriormente.

Outro importante destaque dos discursos de Lula em sua campanha no HGPE de 1989, de acordo com Albuquerque (1999), foi o constante ataque da Frente Brasil Popular aos canais de televisão, principalmente a Rede Globo. De acordo com a campanha de Lula, os meios de comunicação não mostravam a campanha petista de forma correta ou verdadeira. Assim, logo nas primeiras veiculações do HGPE Lula passou a enaltecer que seus espaços seriam "alternativos" e "democráticos" e, para tanto, foi criado o programa intitulado "Rede Povo"43, que passou a ser a principal marca da propaganda política-eleitoral de Lula:

Ao longo da campanha, vários candidatos se valeram de estilos comunicativos próprios da "programação normal" das emissoras de televisão, de modo a tornarem os seus programas mais atraentes para o telespectador. O programa de Lula foi, porém, o único a se apresentar, explícita e sistematicamente, como um programa de televisão ou, mais precisamente, como uma emissora independente de televisão: a "Rede Povo". (ALBUQUERQUE, 1999, p. 169)

Albuquerque (1999) destaca um trecho do HGPE de Lula em que o candidato fala sobre a "Rede Povo":

[...] nós da Frente Brasil Popular [...] vamos convidar você para participar com a gente dessa TV democrática, participar com a gente da Rede Povo, para fazer desses 58 dias de programa de televisão, nesses 58 dias de campanha política, a televisão mais democrática dessa país, aonde a figura principal não é o candidato: a figura principal é você. Vem participar com a gente, e participe desse momento extraordinário de democracia que vamos viver. (LULA apud ALBUQUERQUE, 1999, p. 169).

\footnotetext{
${ }^{43}$ Nota-se que o nome "Rede Povo" é um contraste explícito ao nome "Rede Globo", o que enfatiza a crítica da Frente Popular a esse canal de televisão em específico.
} 
A partir da criação da "Rede Povo", o HGPE da campanha de Lula passou a produzir e divulgar frases de efeito, tais como: "Está no ar uma emissora de tevê diferente"; "Aqui você vê o povo na tevê"; "Aqui você vê a verdade na tevê"; "Aqui você vê o que não vê nas outras tevês"; "Veja o que as outras tevês não mostraram" (ALBUQUEQUE, 1999). Sobre isso, o estudioso aponta que:

\footnotetext{
Mais do que meramente demarcar a diferença da "Rede Povo" com relação às demais emissoras, tais lemas traduzem uma crítica implícita aos meios de comunicação de massa do país, caracterizados como fundamentalmente comprometidos com a manutenção da ordem existente. (ALBUQUERQUE, 1999, p. 170).
}

Importante destacar, nas observações feitas pelo pesquisador e acima elencadas sobre a campanha eleitoral de Lula no HGPE de 1989, a influência da narrativa da conspiração (que, como visto no capítulo anterior, é uma das que compõem o mito político) em dois momentos principais: primeiro, ao nomear os capitalistas como inimigos dos trabalhadores; segundo, ao criticar e se opor enfaticamente aos meios de comunicação, principalmente à Rede Globo. Naqueles dois momentos, Lula intensificou a identificação com seu eleitor de forma a concentrar a narrativa em torno de um complô em que há um "outro" ameaçador capaz de interromper ou prejudicar as "boas" ações por ele pretendidas.

Após veiculação do HGPE no primeiro turno, Lula avançou para o segundo na disputa com Fernando Collor de Melo, então candidato do PRN (Partido da Renovação Nacional). Sobre o segundo turno das eleições de 1989 é válido ressaltar, ainda que de forma breve, o momento histórico que envolveu um debate entre os dois candidatos em disputa, produzido e veiculado pela Rede Globo durante o "Jornal Nacional” -, um dos programas com maior audiência na televisão brasileira àquela época. Durante a transmissão do debate foram apresentadas falas de Lula em que o mesmo se apresentava de forma radical e extremista; já as falas de Collor enalteciam suas qualidades e sua alta capacidade para governar o país. O episódio da manipulação da Rede Globo no debate eleitoral de 1989 foi amplamente estudado como um caso específico de influência sistêmica da mídia brasileira no poder político (MIGUEL, 1999a; RUBIM, 2003a; LIMA, 2006; GOMES, 2006). 
Collor venceu as eleições no segundo turno com 52,03\% dos votos (cerca de 35 milhões de votos) ${ }^{44}$ contra $49,97 \%$ de votos conquistados por Lula (cerca de 31 milhões de votos) ${ }^{45}$. Após as eleições de $1989^{46}$, Lula foi candidato à Presidência em outras duas eleições consecutivas: em 1994 e em 1998. A seguir discorreremos brevemente sobre a trajetória e a imagem pública política de Lula nos dois pleitos eleitorais ${ }^{47}$.

Ao analisar a campanha eleitoral de 1994, Miguel (2000) afirma que a notoriedade e o respaldo que Lula havia conquistado em sua trajetória como líder da classe trabalhadora passou a carregar aspectos negativos que se transformaram em "preconceitos contra o trabalhador braçal ignorante e o líder grevista, e, portanto, baderneiro.”. (MIGUEL, 2000, p. 160). Dessa forma, a principal narrativa utilizada na segunda campanha eleitoral de Lula foi a de luta contra os preconceitos e a de reafirmação de sua difícil trajetória pessoal.

Como forma de se aproximar do eleitor/trabalhador - sem dependência da mediação dos veículos de comunicação - a campanha eleitoral de Lula em 1994 foi marcada pelas chamadas "Caravanas da Cidadania", que consistiam em visitas de Lula e sua equipe de campanha a diversas cidades do Brasil. As caravanas foram marcadas por discursos emotivos e simbólicos em que Lula utilizou, novamente, a descrição de superação como forma de proximidade com seu público (PANKE, 2010). Citamos abaixo um exemplo desses discursos:

\footnotetext{
Sei que existe um preconceito contra mim. Mas a elite sabe que eu sou um vencedor. Uma criança nordestina que não morreu de fome até os cinco anos já venceu na vida. Um nordestino que desembarcou de um pau-de-arara em São Paulo fugindo da seca, e não virou marginal é um vencedor. Eu aprendi uma profissão, criei um partido político e ajudei a fundar uma central sindical. A elite sabe que eu sou um vencedor. (LULA apud BEZERRA, 2010, p, 53).
}

Marcelo Gomes (2006), em pesquisa sobre a imagem pública de Lula em campanhas eleitorais, ressalta que devido às mudanças restritivas na legislação eleitoral do pleito de 1994 as "Caravanas da Cidadania" não alcançaram a visibilidade midiática esperada e, portanto, a

\footnotetext{
${ }^{44}$ Apesar da vitória, Collor permaneceu apenas dois anos na Presidência, por sofrer o primeiro impeachment da história da América Latina, em 1992. Quem assumiu a Presidência foi seu vice, Itamar Franco.

${ }^{45}$ Dados do Tribunal Superior Eleitoral obtidos em: < http://www.tse.jus.br/eleicoes/eleicoes-anteriores/eleicoes1998/resultados-das-eleicoes-de-1994>. Acesso em: 01 jan. 2016

46 Em 1990, após sua primeira derrota eleitoral, Lula foi um dos principais fundadores do chamado Foro de São Paulo, criado durante um seminário internacional realizado pelo PT. O Foro de São Paulo, que existe até os dias atuais, reúne partidos e movimentos de esquerda de variados países da América Latina e do Caribe e apresenta como objetivo inicial estabelecer debates para discutir alternativas às políticas e medidas econômicas mais conservadoras (ou neoliberais).

${ }^{47}$ O candidato a vice-presidente na chapa de Lula em 1994 foi Aloizio Mercadante, do PT. Já em 1998, o candidato a vice de Lula foi Leonel Brizola, do Partido Democrático Trabalhista (PDT).
} 
proximidade de Lula com o eleitor ficou comprometida. Sobre essa restrição, Gomes (2006) explica que:

Tamanha foi a influência da mídia, principalmente da linguagem televisiva, dentro e fora do HGPE, nas eleições de 1989 que, em 1995, decidiu-se tomar providências para limitar essa influência. A lei 8.713/93, artigo 76, [proibiu] externas, efeitos especiais e participações de outros no discurso do candidato na TV. Tudo deveria ser feito em estúdio e os VT's não poderiam ser editados. (GOMES, 2006, p. 125).

O principal oponente de Lula no pleito eleitoral de 1994 foi Fernando Henrique Cardoso (FHC), do Partido da Social Democracia Brasileira (PSDB) ${ }^{48}$. De acordo com Miguel (2000), FHC foi apresentado a partir do seu HGPE de pelo menos três formas, 1) como o estudioso dos problemas do Brasil, professor e autor de livros; 2) como o governante firme e duro com seus propósitos, capaz de realizar tudo o que almejava; 3) e aquele que tentava se identificar com o povo. Todas as três formas de FHC eram resumidas em uma única qualidade: competência. “A imagem do candidato era construída e desconstruída diversas vezes, ficando, no final, a cargo do eleitor/espectador a incumbência de escolher os fragmentos que preferisse.”. (MIGUEL, 2000, 163). Além dessas três formas de apresentação, o programa de FHC utilizou a narrativa da estabilidade econômica que se baseava, principalmente, no chamado "Plano Real" 49 . Esse relato, como estratégia comunicativa, visava tranquilizar a população quanto ao crescimento econômico do país. (MIGUEL, 2000).

A carreira política de FHC - como senador e ministro - e seu vasto currículo acadêmico - como intelectual, sociólogo, cientista político - acrescentavam notoriedade à imagem pública do candidato em contraposição à "falta de preparo" e "inexperiência" de Lula, narrativas que eram reforçadas pelos opositores petistas e pela imprensa (GOMES, 2006). Sendo assim, Miguel (2000) ressalta que as narrativas em disputa entre Lula e FHC no pleito de 1994 se basearam, predominantemente, na batalha entre a experiência baseada em racionalidade (apresentada por FHC) e a experiência baseada em vivência (apresentada por Lula).

FHC venceu as eleições no primeiro turno com 53,06\% dos votos (cerca de 35 milhões de votos) sob a força da narrativa da estabilidade econômica a partir da criação do Plano Real, estratégia que visava tranquilizar a população quanto ao crescimento econômico do país. Lula obteve $31,71 \%$ dos votos (cerca de 21 milhões de votos) e foi o segundo candidato mais votado $^{50}$.

\footnotetext{
${ }^{48}$ O candidato a vice-presidente na chapa de FHC em 1994 foi Marco Maciel, do Partido Frente Liberal (PFL).

${ }^{49} \mathrm{O}$ pacote econômico do Plano Real foi lançado por FHC em fevereiro de 1994 quando ele ainda era Ministro da Fazenda do governo de Itamar Franco.

${ }^{50}$ Dados do Tribunal Superior Eleitoral obtidos em: $<$ http://www.tse.jus.br/eleicoes/eleicoes-anteriores/eleicoes-
} 
Mesmo derrotado, Lula continuou se dedicando às Caravanas da Cidadania e, em 1998, se candidatou pela segunda vez à Presidência do país. Importante pontuar que FHC, durante seu primeiro mandato, aprovou uma emenda constitucional que possibilitava a reeleição presidencial, e, dessa forma, pôde se candidatar novamente.

A campanha presidencial daquele ano, nas considerações de Marcelo Gomes (2006), foi marcada pelo silenciamento da mídia perante o pleito eleitoral. O motivo, de acordo com o pesquisador, foi estratégico no sentido de que os principais meios de comunicação, principalmente a Rede Globo, viam com bons olhos a permanência de FHC no poder, bem como a manutenção da política e economia vigente e buscaram não gerar visibilidade a possíveis críticas ou informações negativas sobre o primeiro mandato de FHC. Em análise sobre a omissão da mídia diante do pleito eleitoral de 1998, com ênfase no Jornal Nacional, veiculado pela Rede Globo, Miguel (1999a) aponta que, dessa forma, a imprensa

[...] transmitiu uma visão distorcida da realidade brasileira e sonegou de seus espectadores dados importantes para que eles fizessem suas escolhas políticas. Negando espaço para enquadramentos divergentes das questões públicas, em especial da crise econômica, contribuiu para esvaziar o debate e, portanto, para degradar o exercício da democracia no Brasil. (MIGUEL, 1999a, p. 9).

Em relação à forte influência da mídia tanto nas eleições presidências de 1994 e quanto na de 1998, Rubim (2003a) aponta que houve "um alinhamento da quase totalidade da mídia brasileira no pleito de 1994, ao assumir e fazer propaganda gratuita e paga, do Plano Real, passaporte de Fernando Henrique Cardoso para a vitória presidencial” (RUBIM, 2003a, p. 44), bem como um "silenciamento deliberado da eleição de 1998, quando FHC ganhou sua reeleição em uma disputa que quase não existiu [...] deixando exposta uma convergência de interesses entre o governo e as empresas de comunicação midiática”. (RUBIM, 2003a, p. 44).

As três derrotas de Lula (em 1989, 1994 e 1998) foram estudadas por André Singer (2009), para quem todas elas apresentaram um mesmo fundamento: o conservadorismo popular que fora acionado pela inflação descontrolada porque passava a economia brasileira na época e o medo da instabilidade do capital. Em outras palavras, era preferível um candidato que apresentasse propostas de manutenção da ordem do que Lula, que, ao incentivar greves, paralisações e manifestações trabalhistas, transparecia uma imagem de liderança instável, radical, e, portanto, desestabilizadora. A disputa por uma imagem pública que atendesse aos 
anseios sociais - e, como visto, às ambições dos meios de comunicação hegemônicos - foi, dessa forma, uma das principais definidoras das três eleições.

Após ter perdido três eleições consecutivas para a Presidência da república, Lula se candidatou pela quarta vez em 2002 conseguindo reverter o contexto anterior. São muitas as variáveis que levaram Lula a vencer a eleição daquele ano e podemos citar, por exemplo, a crise socioeconômica pela qual passava o Brasil e a baixa popularidade do segundo governo de FHC - fatos que garantiram maior espaço para Lula se tornar uma opção viável à Presidência do país no lugar do continuísmo oferecido pelo PSDB (RUBIM, 2003a; MIGUEL, 2003). Mas, como o nosso objetivo é o de explorar a trajetória política e a imagem pública de Lula, iremos ressaltar dois pontos principais: 1) a nova configuração da mídia diante do espaço de visibilidade dos candidatos à eleição em 2002 e 2) a forte influência das estratégias de comunicação elaboradas pelos imagemakers (GOMES, 2004) - ou especialistas em marketing político - que reestruturaram a imagem pública de Lula.

1) Em relação à nova configuração da mídia, Miguel (2003) explica que, após a omissão da campanha eleitoral de 1998, a imprensa - predominantemente a Rede Globo - aumentou significativamente a visibilidade da disputa eleitoral em 2002. Por essa razão, esse estudioso intitula as eleições de 2002 como as "eleições visíveis". Em um comparativo sobre as edições do Jornal Nacional (telejornal veiculado pela Rede Globo) entre as campanhas de 1998 e os dois turnos das eleições de 2002, Miguel (2003) aponta que nas semanas em que foram analisadas as edições do jornal em 1998 apenas 36,1\% delas apresentavam reportagens sobre as eleições, já no primeiro turno da disputa de 2002 esse número aumentou para 97,6\%.

Sobre esse acontecimento, Antonio Rubim (2002) discorre que "as eleições de 2002 no Brasil foram, sem dúvida, vividas sob o signo da visibilidade. Ela emergiu como uma das marcas diferenciais mais expressivas e, inclusive, aceita pela maioria, senão a totalidade, dos analistas do episódio eleitoral.”. (RUBIM, 2002, p. 326). Para Rubim (2002), as disputas eleitorais brasileiras anteriores a $2002(1989,1994,1998)$ tiveram influência decisiva da mídia, como visto anteriormente, mas sempre de forma a valorizar ou favorecer a imagem de um candidato especifico. Já no pleito de 2002 essa visibilidade se deu de forma mais "imparcial"51. $\mathrm{O}$ autor ressalta, no entanto, que mesmo não intervindo de forma a privilegiar um candidato

\footnotetext{
${ }^{51}$ Miguel (2003), sobre as eleições presidenciais brasileiras de 2002, utiliza o termo "imparcial' entre aspas por reconhecer que sob o signo da imparcialidade a mídia, em realidade, apresenta outras ferramentas para limitar o debate político, como, por exemplo, o agendamento de temas específicos que pode vir a privilegiar determinados candidatos.
} 
especifico, a imprensa teve papel primordial ao decidir os assuntos que teriam maior ou menor visibilidade durante a campanha eleitoral. Dessa maneira, os partidos e seus candidatos tiveram que se enquadrar nos quesitos de noticiabilidade que foram impostos no momento. Sendo assim, assuntos relacionados à economia - principalmente aqueles que se destinavam à continuidade da política econômica neoliberal vigente - foram os que receberam maior destaque.

Interessante perceber que Lula gastou quase metade do seu tempo no horário do HGPE com análises de conjuntura da economia nacional e foi o candidato que mais discutiu a política econômica. Sua campanha, então, conseguiu adquirir maior visibilidade e notoriedade diante do eleitorado brasileiro. O PT, diferentemente da forte oposição que sempre fez à situação econômica do país, “optou por não remar contra a maré, adaptando-se ao modelo discursivo dominante", reforça Miguel. (2003).

2) Feita a observação sobre a intensa cobertura midiática das eleições de 2002 , discorreremos sobre as estratégias de comunicação que reestruturaram a imagem pública de Lula nas campanhas eleitorais daquele ano.

Um primeiro ponto que devemos levar em consideração sobre essa reestruturação diz respeito à nova postura política assumida pelo PT em 2002, que, ao contrário das tentativas anteriores nas quais o partido apresentava ideais radicais ligados a ideologias de esquerda, se uniu a um partido de centro-direita ao escolher José Alencar, do Partido Liberal (PL), que pertencia à classe empresarial brasileira, para o cargo de vice-presidente. Além disso, Lula assinou e publicou uma carta-compromisso intitulada "Carta aos Brasileiros", que basicamente visava tranquilizar o empresariado quanto à estabilidade da economia e quanto ao crescimento econômico. (RUBIM, 2003b). De acordo com Panke (2010), a "Carta aos brasileiros" foi recebida "por setores conservadores da economia como um sinal de 'boa vontade' do então candidato Luiz Inácio Lula da Silva.”. (PANKE, 2010, p. 90).

A reestruturação de posicionamento político permitiu, entre outros fatores, que os discursos de Lula passassem a atingir não apenas um público restrito, ou seja, a classe trabalhadora, mas, também, o empresariado. Em trecho de uma fala do candidato petista durante o HGPE de 2002, citado a seguir, é possível perceber a estratégia comunicacional de aproximação com o a classe empresarial brasileira: "Quero aproveitar pra (sic) dizer também aos empresários que o Brasil precisa muito deles [...].”. (LULA apud PANKE, 2010, p. 104). Como bem aponta Antonio Rubim (2003b) em pesquisa sobre as estratégias de comunicação eleitoral de Lula em 2002, o PT não mais direcionava sua palavra apenas aos trabalhadores, mas, sim, ao "povo brasileiro". 
Sobre a alteração nos discursos de Lula, Andréa Moreira Albuquerque e Isaltina Gomes (2004) apontam que a imprensa, no pleito eleitoral de 2002, passou a tratar Lula como um concorrente que não mais causava estranheza ou medo, mas, sim, um candidato capaz de unir todos os brasileiros para um bem comum. Dessa forma, o discurso do medo - utilizado durante as três primeiras campanhas eleitorais disputadas por Lula - foi substituído pelo discurso da esperança (ALBUQUERQUE; GOMES, 2004). É possível observar, como exemplo da nova postura da mídia diante de Lula, a capa da revista Isto É, publicada em 9 de agosto de 2002 (edição número 1715), que continha uma fotografia de Lula com semblante sorridente e calmo e o título em letras maiúsculas: "Lula não assusta mais".

$\mathrm{O}$ segundo ponto que destacamos ser ainda mais significativo quanto à mudança de estratégia de construção da imagem de Lula diz respeito à tática de comunicação políticoeleitoral do PT. Uma primeira observação sobre essa estratégia deve ser feita em relação ao valor monetário de mais de R\$ 35 milhões investidos pelo PT no pleito de 2002, o maior montante que o partido já havia designado em campanhas eleitorais até então. Sobre esse investimento e sobre o processo de mudança de estratégia comunicativa da campanha de Lula em 2002, Panke (2010) elabora alguns importantes apontamentos:

Naquele ano [em 2002], observou-se que a quarta candidatura de Lula à Presidencia
trazia mudanças estratégicas de comunicação. Mais do que mostrar o "novo" Lula,
era necessário também apresentar o "novo" PT. Era preciso, naquele momento,
desfazer a imagem do candidato como uma ameaça ao Brasil e enfatizar uma das suas
supostas qualidades que era a capacidade de articulação e negociação. (PANKE, 2010,
p. 101).

Com vistas a atingir os objetivos desejados pelo partido (e discorridos por Panke (2010) na citação acima), o PT contratou o publicitário Duda Mendonça como o marqueteiro (ou imagemaker) responsável por dar vida à nova imagem do então candidato à Presidência da república pelo PT. A partir de então a campanha petista exibida no HGPE deixou de lado o tom até então agressivo do radical sindicalista e metalúrgico e abriu espaço para um Lula muito mais calmo, com visual mais polido (nas eleições anteriores Lula não abriu mão da barba espessa, das roupas informais e da imagem de trabalhador de chão de fábrica, enquanto na eleição de 2002 passou a usar ternos e gravatas) e linguagem mais clara. Esse reposicionamento de imagem fez surgir o slogan do "Lulinha paz e amor".

Rubim (2003b) aponta alguns fatores intrínsecos a esse processo:

A construção da imagem "Lulinha paz e amor" - substituindo a imagem do Lula radical - foi produzida por um conjunto complexo de expedientes que conjugavam 
desde a progressiva moderação do discurso político de Lula e do PT, [...] até o quase abandono da propaganda negativa e dos ataques aos candidatos adversários e o uso intensivo de jingles e músicas, como estratégia configurada para o horário eleitoral. (RUBIM, 2003b, p. 14).

A imagem pública de Lula foi reestruturada de forma a apresentá-lo como o candidato confiável, conciliador e negociador capaz de articular alianças que possibilitassem o melhor resultado político, econômico e social para o país. A imagem anterior que transparecia um Lula ríspido e extremista foi substituída, então, por outra necessária ao imaginário coletivo daquele momento: a do Lula que tinha um compromisso com o povo brasileiro (com todas as camadas sociais, do mais rico ao mais pobre), de negociar e articular alianças que proporcionassem o crescimento do Brasil e a saída da estagnação econômica na qual que se encontrava o país. (RUBIM, 2003b).

Ressalta-se, no entanto, que a reestruturação do discurso de Lula de forma a apresentá-lo como um grande articulador e negociador - o que contribuiu para atingir e alcançar outros públicos que não somente a classe trabalhadora - colaborou, também, na construção de uma imagem positiva do mesmo. Tal reconstrução da fala do candidato não foi substituída pelo discurso já característico de sua trajetória política em que há forte influência da narrativa da superação e do pertencimento à classe trabalhadora.

Como bem aponta Bezerra (2011), a principal plataforma do governo petista apresentada na campanha em 2002 foi intitulada "Um Brasil para Todos - Crescimento, Emprego e Inclusão Social”, sendo "o cerne do programa [...] promover a inclusão social ao combater a miséria e a fome, através de subsídios de renda mínima e geração de emprego, além das reformas política, agrária, previdenciária, trabalhista e tributária.”. (BEZERRA, 2011, p. 119). Sendo assim, na campanha eleitoral de 2002, o "antigo" Lula se uniu ao "novo" Lula de forma a construir uma narrativa de crença na esperança de um líder que governaria para todos.

Interessante ressaltar, como bem aponta Bezerra (2011), que o carisma de Lula, característica que se fez presente na imagem do mesmo desde o início da sua trajetória política, foi amplamente explorada na campanha eleitoral de 2002. O conceito de carisma na política advém, principalmente, de estudos feitos por Max Weber (1999) em obra intitulada Economia e Sociedade. Em sua discussão acerca dos modos de dominação política, Weber (1999) compreende que a dominação carismática é contrária à dominação burocrática e tradicional. $\mathrm{O}$ líder carismático é, portanto, o político por vocação e se torna peça fundamental no jogo político. Para Weber (1999), carisma é 
Uma qualidade extraordinária de uma pessoa, quer seja tal qualidade real, pretensa ou presumida. "Autoridade carismática", portanto, refere-se a um domínio sobre os homens, seja predominantemente externo ou interno, a que os governados se submetem devido a sua crença na qualidade extraordinária da pessoa específica. (WEBER, 1999, p. 289).

Fausto Neto (2003), em texto sobre a campanha eleitoral de 2002, citou um trecho de uma entrevista de Duda Mendonça concedida à revista Isto É em que o mesmo discorre sobre as estratégias comunicacionais investidas na campanha petista e a utilização da dominação carismática de Lula:

O Lula é uma figura emocional. É isso o que quero resgatar. Nas outras campanhas vi o Lula muito duro, aprisionado. Não falava com emoção. Lula falando, comove. Sem apoio do marketing, da TV, ele fazia o ABC se arrepiar. Como? Sem nenhuma orientação. Todos os outros são, de alguma maneira, fabricados. O que não vi em outras campanhas é isso: Lula”. (DUDA MENDONÇA apud FAUSTO NETO, 2003, p. 72).

Lula venceu as eleições de 2002 derrotando José Serra (PSDB) no segundo turno com expressivos 61,27\% dos votos (cerca de 52 milhões de votos) contra 38,72\% (cerca de 33 milhões de votos) do seu opositor ${ }^{52}$. Por esses números, Lula se tornou o presidente com maior votação nominal registrada nas 19 eleições diretas para presidente do Brasil. Além disso, até aquele momento, Lula teve "a segunda maior votação da história mundial, perdendo apenas para o norte-americano Ronald Reagan, nas eleições de 1984, quando obteve mais de 54 milhões de votos.”. (PANKE, 2010).

Em discurso proferido na Avenida Paulista, na cidade de São Paulo, por ocasião da comemoração da vitória petista na eleição, Lula recorreu, novamente, à narrativa da esperança ao afirmar:

Vou fazer o esforço maior que um ser humano possa fazer para que a gente possa fazer nosso povo voltar a sorrir, devolver a alegria, devolver a esperança, fazer a economia voltar a crescer, gerar riquezas para gerar os empregos que tanta gente precisa neste país. (LULA apud PANKE, 2010, p. 100).

Necessário pontuar que a campanha eleitoral de Lula em 2002, como pôde ser observado a partir da análise acima, foi estruturada de maneira a enfatizar duas importantes narrativas do mito político apontadas por Girardet (1987): a narrativa do salvador em que a imagem pública política de Lula foi construída de forma enaltecer a liderança do mesmo no sentido de ser a

\footnotetext{
52 Dados do Tribunal Superior Eleitoral obtidos em: <http://www.tse.jus.br/eleicoes/eleicoes-anteriores/eleicoes2002/resultados-das-eleicoes-2002>. Acesso em: 01 jan. 2016.
} 
esperança dos brasileiros para a superação dos percalços econômicos e sociais por que passava o país; e a narrativa da unidade que se fez presente na construção de um discurso voltado não mais para um público em específico, mas para "todo o povo brasileiro", discurso esse que induz à suposta união e harmonia de toda a sociedade brasileira. É exatamente nesse ponto da ausência de conflitos sociais e da articulação política dos extremos (AB'SÁBER, 2011) que Lula constrói a sua forte característica a favor do consenso e o "modo lulista de gerir a vida pública" (AB’SÁBER, 2011, p. 15).

O sucesso de Lula em conquistar apoio em todas as camadas sociais do Brasil não se deve somente a essa inclinação para o consenso, mas, também, "a um excepcional conjunto de dons pessoais, uma mescla de sensibilidade social afetuosa e frio cálculo político, ou [...] avaliação racional e inteligência emocional, para não falar no jovial bom humor e encanto pessoal.”. (ANDERSON, 2011, p. 24).

Lula assumiu a Presidência do Brasil no dia $1^{\circ}$ de janeiro de 2003 após três derrotas consecutivas (1989, 1994 e 1998) e 22 anos na oposição. Sobre a transição da imagem pública do "Lula candidato" ao "Lula presidente", Bezerra (2011) elabora uma importante reflexão sobre a relação estabelecida entre a continuidade das narrativas de superação do líder operário e o acréscimo das novas narrativas do líder estadista:

\footnotetext{
A transfiguração política do Presidente Lula ocorreu de maneira que ele mudasse, mas continuasse a ser. Nesse sentido, o líder operário se transfigura em Presidente da República sem deixar de ser líder de massa e homem do povo. Em suas aparições públicas, o discurso de autoridade maior da nação era sempre perpassado por paródias e pelas habituais metáforas. Um Presidente que fala a língua do povo, que troca afetos com seus seguidores, que faz de seu bom humor recurso para palavras de esperança, otimismo e auto-estima. Sentimentos estes empregados como força motriz na mobilização do imaginário popular que juntamente com a ideia de inclusão e ascensão social para os mais pobres, constituíram a marca de seu governo. (BEZERRA, 2011, p. 204, grifo nosso).
}

Pontuamos, portanto, que as narrativas de esperança, otimismo e autoestima do brasileiro se tornaram fortes influências nos discursos do Lula presidente. Essas narrativas foram constantes tanto na campanha quanto no mandato do presidente petista porque ele passou a representar a possibilidade de ascensão social (que ele próprio havia conquistado). A imagem pública de Lula, a partir da narrativa da unidade e do salvador, como visto anteriormente, passou a representar, portanto, a quebra de preconceitos e barreiras sociais até então enraizadas no imaginário social e coletivo do Brasil (RUBIM, 2003b; FAUSTO NETO, 2003; PANKE, 2010; BEZERRA, 2011).

Tal percepção pode ser vista em: 
Desde a campanha eleitoral de 2002 Lula adotara o apelo a autoestima. Por esta ocasião, tal estratégia busca estabelecer um elo com sua própria história de ascensão e justifica o voto no então candidato petista. Ora, num país tradicionalmente governado por representantes da elite e no qual a população mais pobre negou três vezes consecutivas o voto em um homem advindo das fileiras do sindicalismo, exoperário com formação de torneiro mecânico, era necessário uma mudança de pensamento, sobretudo, despertar a crença em si mesmo para poder eleger um igual. (BEZERRA, 2011, p. 204).

Como exemplo da circulação das narrativas de esperança, otimismo e autoestima no imaginário coletivo a partir da vitória de Lula podemos citar as pesquisas de opinião realizadas logo no início do primeiro mandato do petista já como presidente do país. Em pesquisa realizada entre os dias 19 e 23 de janeiro de 2003, encomendada pela Confederação Nacional do Transporte (CNT) e realizada pelo instituto Sensus, nota-se que quanto ao índice de expectativa em relação a Lula, 78,4\% dos entrevistados afirmaram ter perspectiva positiva. Já em relação à satisfação com o presidente, em outubro de 2002, quando FHC ainda ocupava o cargo, o índice era de 24,3\%, já em janeiro de 2003 subiu para 56,6\% - a avaliação negativa de Lula era de apenas 2,3\%. Em relação ao desempenho do presidente, em outubro de 2002 apenas 32,7\% aprovavam o desempenho de FHC, enquanto em janeiro de 2003, 83,6\% diziam aprovar o desempenho de Lula. (CONFEDERAÇÃO NACIONAL DO TRANSPORTE, 2003).

\subsubsection{O PT e os escândalos de corrupção}

Apesar dos altos índices de popularidade de Lula, o terceiro ano de seu primeiro mandato (2005) se tornou um marco negativo na imagem pública do petista devido à divulgação de esquemas de corrupção - sendo o mais conhecido deles o "mensalão" "53, no qual estavam envolvidas figuras políticas pertencentes ao PT e muito próximas a Lula, como o tesoureiro

\footnotetext{
${ }^{53}$ Em resumo, o "mensalão" faz referência a um esquema de corrupção ocorrido entre 2005 e 2006 em que houve compra de votos de parlamentares do Congresso Nacional (predominantemente de deputados de partidos da base aliada do governo, como o PL, o PP, o PMDB e o PTB) para que votassem a favor de medidas e projetos estabelecidos pelo governo petista. O termo "mensalão" surgiu devido à variação da palavra "mensalidade" que diz respeito a pagamentos realizados mês a mês.
} 
nacional do PT, Delúbio Soares ${ }^{54}$; o então presidente do partido, José Genoíno ${ }^{55}$, e o ministrochefe da Casa Civil e um dos fundadores do PT, José Dirceu ${ }^{56}$.

Luis Felipe Miguel e Aline Coutinho (2007), ao realizarem investigação acerca da cobertura midiática da crise política de 2005, apontam que a revista Veja e o jornal Folha de S. Paulo $^{57}$ tiveram papel central na divulgação do escândalo do "mensalão", bem como na crítica ao governo petista. Sobre essa divulgação, Miguel e Coutinho (2007) discorrem que, em maio de 2005,

\begin{abstract}
A revista Veja iniciou a denúncia de um esquema de corrupção nos Correios, empresa pública gerida por um dos partidos da base de sustentação do governo. O caso ganhou nova dimensão após a entrevista bombástica do então deputado Roberto Jefferson ao jornal Folha de S. Paulo, em 6 de junho de 2005. Nela, Jefferson afirmou que o governo pagava mesadas para deputados votarem a seu favor e cunhou o termo "mensalão". Daí em diante, os principais jornais diários e as revistas semanais de informação passaram a competir por novas denúncias e evidências contra autoridades da República [...]. (MIGUEL; COUTINHO, 2007, p. 98).
\end{abstract}

Ainda sobre o incisivo papel da mídia impressa naquele período, os pesquisadores apontam que em todos os editoriais ${ }^{58}$ investigados nos três principais jornais brasileiros (Folha de S. Paulo, O Estado de S. Paulo e O Globo) 26,2\% tratavam da crise do 'mensalão', o que fazia dessa temática a mais divulgada no período analisado (entre maio e dezembro de 2005). Também de acordo com a pesquisa, dentre os editoriais que tratavam da questão do "mensalão",

\footnotetext{
${ }^{54}$ Delúbio Soares, expulso do PT ainda em outubro de 2005 após aprovação do diretório nacional do partido, em novembro de 2012 foi condenado pelo Supremo Tribunal Federal (STF) a 8 anos e 11 meses de prisão por formação de quadrilha e corrupção ativa (em março de 2016 recebeu perdão de pena pelo ministro Luís Roberto Barroso do STF, mas em 2016 virou réu novamente devido no escândalo conhecido como "petrolão"). (SAIBA..., 2012)

${ }^{55}$ José Genoíno renunciou à presidência do PT em julho de 2005 após envolvimento nos escândalos do mensalão e foi condenado inicialmente a 6 anos e 11 meses de prisão pelos crimes formação de quadrilha e corrupção ativa em outubro de 2012 pelo STF. Preso em novembro de 2013, em 2014 foi absolvido do crime de formação de quadrilha e sua pena passou para 4 anos e 8 meses. (SAIBA..., 2012)

${ }^{56}$ José Dirceu pediu demissão do cargo de Ministro da Casa Civil em junho de 2005 devido às acusações de corrupção e voltou a ocupar o antigo cargo de deputado federal pelo PT. Já em $1^{\circ}$ de dezembro teve o mandato cassado (se tornou o primeiro político do PT a ter mandato cassado na história do partido). Em novembro de 2012 foi condenado pelo STF a 10 anos e 10 meses de prisão. Para além do escândalo do mensalão, Dirceu foi condenado por envolvimento em outros escândalos - como o "petrolão" em 2016. (SAIBA..., 2012)

${ }^{57}$ A revista Veja - criada em 1968 pelo Grupo Abril (fundado em 1950) - e o jornal Folha de S. Paulo - criado em 1921 pelo Grupo Folha (fundado no mesmo ano) - se constituem, atualmente, como os principais conglomerados jornalísticos do Brasil, juntamente com o Grupo Globo e o Grupo Estado (responsável pela publicação do jornal O Estado de S. Paulo). De acordo com dados oficiais do Instituto Verificador de Circulação (IVC) referentes a dezembro de 2016, a revista Veja (maior revista em número de exemplares em circulação no Brasil) possui média mensal de 861.072 exemplares em circulação de sua edição impressa, já na versão digital a mesma revista apresenta uma média de 260.500 exemplares em circulação. Já o jornal Folha de S. Paulo possui uma média diária de circulação de 145.662 exemplares em sua versão impressa e 167.612 em sua versão digital - devido a esses números o jornal se torna o terceiro mais vendido no país em edição impressa (atrás do jornal Super Notícia e do jornal O Globo) e o primeiro mais acessado em edição digital. (JORNAIS..., 2017).

${ }^{58} \mathrm{O}$ editorial de um jornal ou revista é definido como um artigo em que há a expressão do ponto de vista do jornal/revista ou do redator-chefe. É, portanto, uma matéria jornalística opinativa e, por isso, não tem compromisso com a imparcialidade.
} 
$68,6 \%$ deles tinham como personagem mais frequente o PT e 59,5\% citavam mais frequentemente o nome de Lula. Os editoriais destacavam a corrupção como principal motor da crise política, sendo a corrupção do PT e seus líderes $(57,2 \%)$ e a da administração petista (54\%) o motivo mais citado.

Também é possível observar o papel intrínseco da mídia no escândalo no "mensalão" a partir das longas sessões das Comissões Parlamentares de Inquérito (CPIs) ${ }^{59}$ - rotuladas pela mídia como "CPI do mensalão" (LIMA, 2006) - que passaram a ser transmitidas ao vivo pela TV Senado. As imagens eram repassadas gratuitamente a outros canais de televisão, o que deu ao escândalo um caráter de novela com relatos prolongados, personagens importantes e enredos chamativos. Aquele período foi analisado por Alessandra Aldé e Fábio Vasconcellos (2008), segundo os quais

[...] a audiência da TV Senado chegou a alcançar cerca de três milhões e meio de televisores. Antes de maio de 2005, quando a crise eclodiu, o canal apresentava nove horas de programação; depois, passou para 13 horas ao vivo e, numa das sessões das CPIs, chegou a ficar 17 horas no ar. (ALDÉ; VASCONCELLOS, 2008, p. 63).

Pontuamos que a corrupção ainda é um conceito de difícil apreensão e delimitação tanto no campo acadêmico quanto nas esferas social, política e econômica. O cientista político Fernando de Barros Filgueiras (2004), que buscou compreender tal conceito a partir de estudos realizados por juristas, economistas e sociólogos, entende que o ponto em comum dentre essas teorias é o de que a corrupção sobrepõe interesses privados ao interesse público. Ele elabora uma crítica ao fato de que tais teorias compreendem a corrupção não a partir da "capacidade de vida comum entre os indivíduos" (FILGUEIRAS, 2004, p. 126), mas, sim, por uma ética prédeterminada, ou seja, "como uma não efetivação das leis, como uma função da modernização, ou [...], como um crescimento excessivo da burocracia do Estado.”. (FILGUEIRAS, 2004, p. 126).

Mas o pesquisador ressalta, no entanto, que a coletividade - ou a vida comum entre os indivíduos - é definidora do valor da ética nos negócios públicos e, assim sendo, o que

\footnotetext{
59 "As CPIs [...] destinam-se a investigar fato de relevante interesse para a vida pública e para a ordem constitucional, legal, econômica ou social do País. Têm poderes de investigação equiparados aos das autoridades judiciais, tais como determinar diligências, ouvir indiciados, inquirir testemunhas, requisitar de órgãos e entidades da administração pública informações e documentos, requerer a audiência de Deputados e Ministros de Estado, tomar depoimentos de autoridades federais, estaduais e municipais, bem como requisitar os serviços de quaisquer autoridades, inclusive policiais. Além disso, essas comissões podem deslocar-se a qualquer ponto do território nacional para a realização de investigações e audiências públicas e estipular prazo para o atendimento de qualquer providência ou realização de diligência sob as penas da lei, exceto quando da alçada de autoridade judiciária.". (CÂMARA DOS DEPUTADOS, 2015).
} 
determinaria um governo "bom" (ou não corrupto) seria a confiança dessa comunidade nas suas instituições, levando em consideração "não a racionalidade estreita, mas o sentimento de justiça, de igualdade, de liberdade, de tolerância e outros sentimentos afins.”. (FILGUEIRAS, 2004, p. 126). A partir dessa perspectiva, Filgueiras (2004) elaborou uma proposta de compreensão do conceito de corrupção - diferente daquelas que foram por ele analisadas. Para o autor,

[...] a corrupção é uma ação praticada por qualquer ator social visando a obtenção de vantagens pessoais - materiais ou imateriais - que contrarie as normas institucionalizadas do sistema político, legitimamente aceitas pela sociedade por meio de seus sistemas de solidariedade, tendo em vista os valores e a confiança dos cidadãos em função das estruturas de socialização das normas da comunidade política. (FILGUEIRAS, 2004, p. 144).

A corrupção é, portanto, uma ação transgressora que interfere diretamente na confiança depositada pelos cidadãos nas instituições políticas ou econômicas. José Álvaro Moisés e Raquel Meneguello (2013), em estudo sobre a corrupção política e a democracia, reforçam que ao sobrepor interesses privados ao interesse coletivo a corrupção "frauda [...] o princípio de igualdade política inerente à democracia, pois os seus protagonistas podem obter ou manter poder e benefícios políticos desproporcionais aos que alcançariam através de modos legítimos e legais de competir politicamente.”. (MOISÉS; MENEGUELLO, 2013, p. 164). A corrupção, dessa forma, pode enfraquecer a confiança na democracia ao "comprometer o princípio segundo o qual neste regime ninguém está acima da lei e contribui para o esvaziamento dos mecanismos de responsabilização de governos”. (MOISÉS; MENEGUELLO, 2013. p. 164).

Esta análise recebe outros contributos. De acordo com Érica Anita Baptista e Patrícia Contreiras (2016), para que se possa compreender a corrupção deve-se subdividi-la em dois pontos distintos: a corrupção e a percepção da corrupção - "a corrupção trata da ocorrência do problema, enquanto a percepção explica a sensação que os cidadãos têm na interpretação do seu entorno.”. (BAPTISTA; CONTREIRAS, 2016, p. 25). Dessa forma, as estudiosas (2016) atentam para o fato de que um determinado cidadão - o brasileiro, por exemplo - percebe a corrupção a partir de determinado referencial cultural, das regras sob as quais a sociedade está inserida e vive e como essa sociedade interpreta desvios ou ações transgressoras.

A partir da contextualização do conceito de corrupção, pontuamos que a percepção da corrupção pelos cidadãos está diretamente associada aos meios de comunicação, na medida em que eles são os responsáveis por dar visibilidade às ações transgressoras cometidas pelas instituições. Tal perceptibilidade se dá, geralmente, em forma de escândalos políticos. De 
acordo com Thompson (2002), o conceito de escândalo se refere a ações ou acontecimentos que apresentam as seguintes características:

1) sua ocorrência ou existência implica a transgressão de certos valores, normas ou códigos morais;

2) sua ocorrência ou existência envolve um elemento de segredo ou ocultação, mas elas são conhecidas ou firmemente criadas como existentes por outros indivíduos que não os envolvidos (chamaria a esses indivíduos de não-participantes);

3) alguns não-participantes desaprovam as ações ou acontecimentos e podem sentir-se ofendidos pela transgressão;

4) alguns não-participantes expressam sua desaprovação denunciando publicamente as ações ou acontecimentos;

5) a revelação e condenação das ações e acontecimentos podem prejudicar a reputação dos indivíduos responsáveis por eles. (THOMPSON, 2002, p. 40, grifo nosso).

Governos, empresas ou atores sociais a todo o tempo cometem atos infratores e ações transgressoras que se enquadram no sentido da corrupção, mas essas só passam a ser escândalo caso se tornem visíveis ao olhar do público, ou dos não participantes. Esse pesquisador reforça:

[...] atividades corruptas podem se tornar foco de escândalo somente se elas se tornarem conhecidas e os não-participantes estiverem fortemente convencidos de que elas existem, em outras palavras, a corrupção tem de se tornar pública para se tornar um escândalo. (THOMPSON, 2002, p. 57).

Dessa forma, quando os veículos jornalísticos tornam públicas as transgressões políticas, essas passam a ser escândalo político-midiático (THOMPSON, 2002). Esses tipos de escândalos não são apenas veiculados pelos meios de comunicação, mas "constituídos por formas midiáticas de comunicação" (THOMPSON, 2002, p. 59), ou seja, são elaborados, construídos e veiculados sob as regras da mídia.

Essa questão é também abordada por Lima (2006, p. 13):

Como a mídia se tornou a arena decisiva em que as relações do campo político são criadas, sustentadas e, ocasionalmente destruídas, a apresentação e a repercussão dos escândalos políticos midiáticos não são características secundárias ou acidentais. Ao contrário, são parte constitutivas dos próprios escândalos políticos midiáticos. (LIMA, 2006, p. 13).

Ressaltamos, no entanto, que o papel da imprensa pode ser considerado importante também no sentido de revelar e tornar públicas ações de corrupção política antes desconhecidas. A atuação da mídia é investigada por diferentes estudiosos, como se pode ver a seguir. "Os meios de comunicação são importantes fontes de informação para os cidadãos (...) e muitas investigações sinalizam que a percepção da corrupção sofre influências da cobertura midiática.”. (BAPTISTA; CONTREIRAS, 2016, p. 23). Mas há que se compreender que sob o signo de "guardiões do interesse público" (THOMPSON, 2002, p. 60), jornalistas, imprensa e os donos 
dos meios de comunicação encontram nos escândalos políticos os critérios de noticiabilidade sobre os quais discorremos no capítulo anterior. As políticas de imagem e de visibilidade (GOMES, 1994) fazem com que a mídia classifique os escândalos como os assuntos que chamam mais atenção do público e são, portanto, mais vendáveis.

Além de atender aos critérios de noticiabilidade, o escândalo político midiático pode se prolongar no tempo e se manter em efervescência na medida em que a imprensa continua se ocupando dele ao estimular a sequência da narrativa por fluxos de informação que contêm "novas denúncias, a entrada em cena de uma testemunha bomba, a introdução de novos fatos produzidos pelo jornalismo investigativo ou mesmo pela simples reprodução das declarações dos agentes envolvidos (acusadores e denunciados) [...].”. (AZEVEDO, 2010, p. 14). Como bem apontam Aldé e Vasconcellos (2008), durante toda a continuidade da narrativa do escândalo político na mídia há um constante jogo de troca entre imprensa e atores políticos já que,

[...] a mídia recorre aos escândalos como forma de atrair a atenção das audiências, reafirmando também sua importância político-social; os atores políticos, por outro lado, ao fornecerem novas declarações e narrativas, na tentativa de contribuir para percepções positivas junto ao público acerca do seu próprio papel nos acontecimentos, confirmam e reforçam o papel da imprensa. (ALDÉ; VASCONCELLOS, 2008, p. $61)$.

Nesse jogo de trocas, portanto, a articulação principal deixa de ser a informação e passa a ser o seu potencial de publicação. O furo de reportagem/a descoberta de uma ação transgressora poderia ser aplicado pela imprensa como informação com vistas a gerar debate acerca das possibilidades de melhoria dos processos políticos. Entretanto, o escândalo midiático contribui em grande medida na construção ou desconstrução de imagens públicas de atores políticos.

Em relação ao escândalo do "mensalão" e à influência da mídia brasileira na desconstrução de imagens públicas, Lima (2006) faz reflexão acerca do que chama de "presunção de culpa". Pontuamos que essa expressão surge a partir de uma outra oposta, a "presunção de inocência", que, de acordo com a Ordem dos Advogados do Brasil (OAB) estabelece

[...] que todo e qualquer acusado deve ser considerado inocente até a decisão final, contra a qual não caiba mais recurso, independente da acusação que lhe seja imputada. Ou seja, ninguém pode ser considerado culpado antes da sentença final, que advirá após lhe ser garantida a ampla defesa e o contraditório, dentro do devido processo legal.”. (D’URSO, 2007) 
A “presunção de culpa”, portanto, diz respeito à presunção de que um acusado é culpado de determinado ato criminoso mesmo que não haja provas contra o mesmo. Nessa linha de raciocínio, Lima (2006) argumenta que a "presunção de culpa" foi intensamente utilizada pela imprensa brasileira ao noticiar a possível participação de figuras políticas no escândalo do "mensalão" com o objetivo de "lançar todo tipo de insinuações, acusações, ilações, generalizações e suspeições" (LIMA, 2006, p. 16).

Para exemplificar sua perspectiva, Lima (2006) utiliza a matéria veiculada pela revista Época $^{60}$ em 12 de agosto de 2005, cujo título estampou: "Lula sabia”. Lima (2006) reforça que essa matéria foi destaque nos telejornais da Rede Globo, em especifico no Jornal Nacional, "no qual uma das manchetes foi: 'O presidente e o vice-presidente, José Alencar, sabiam das negociações"”. (LIMA, 2006, p. 30). A matéria em questão tinha como principal discurso e argumentação a fala do ex-deputado Valdemar Costa Neto, do PL, proferida em entrevista exclusiva à revista em que o mesmo relatou sobre um acordo de $\mathrm{R} \$ 10$ milhões que seriam pagos ao PL em troca de apoio político. Lima (2006) ressalta, no entanto, que "em nenhum momento da entrevista publicada Valdemar Costa Neto afirma que o presidente Lula sabia da origem ou do futuro do dinheiro que pagaria o acordo.”. (LIMA, 2006, p. 30). Ressaltamos que, com o exemplo acima discorrido, nosso objetivo não é averiguar a veracidade da informação veiculada tanto pelo periódico Época como pelo Jornal Nacional, mas, sim, demonstrar que a veiculação do escândalo a partir da presunção de culpa contribuiu fortemente para a desconstrução da imagem pública política dos supostos envolvidos no esquema do "mensalão".

Sendo assim, ao centralizar a crise política de 2005 na questão da corrupção do governo Lula, a imprensa, ao mesmo tempo em que foi responsável pela revelação das ações transgressoras, concentrou seus esforços na degradação das reputações das figuras políticas em questão $^{61}$. A partir dessas considerações torna-se relevante, então, investigar o termo reputação, que, para Thompson (2002), significa "a relativa apreciação e estima concedida a um indivíduo ou instituição, por outros. Quando mais alta a apreciação e maior o conjunto de indivíduos que a sustentam, tanto mais alta a reputação de alguém.”. (THOMPSON, 2002, p. 297).

\footnotetext{
${ }^{60}$ Ressaltamos que a revista Época pertence ao Grupo Globo e também se constitui em uma das revistas com maior índice de circulação no país, atrás apenas da revista Veja. De acordo com os dados apresentados pelo IVC relativos a dezembro de 2016, a revista Época apresenta média mensal de circulação no país de 215.819 de exemplares impressos e 50.362 de exemplares em sua versão digital. (JORNAIS..., 2017).

${ }^{61}$ Necessário pontuar que os principais detratores da imagem pública política tanto do PT como de Lula durante esse período foram o Grupo Globo, os jornais Folha de S. Paulo e Estado de S. Paulo e as revista Veja e Época. (ALDÉ, MENDES, FIGUEIREDO, 2007; MIGUEL, COUTINHO, 2007; BARREIROS, AMOROSO, 2008; LIMA, 2006).
} 
Compreendemos este conceito de reputação como sinônimo do conceito de imagem pública política, ao qual já discorremos nesta tese.

Os escândalos político-midiáticos, ao fixarem atenção e dedicarem tempo a enaltecer os casos de corrupção envolvendo personalidades políticas específicas, se tornam possíveis esvaziadores de reputação (THOMPSON, 2002) e, portanto, são capazes de gerar crises de imagem pública. "Os escândalos políticos são esvaziadores potenciais de reputação em um campo onde a reputação é uma fonte vital de poder.”. (THOMPSON, 2002, p. 301, grifo nosso).

Podemos exemplificar o impacto negativo do escândalo do mensalão na imagem pública de Lula a partir da pesquisa de opinião realizada pelo DataFolha em 10 de agosto de 2005 e divulgada no dia 12 de agosto daquele ano. De acordo com a consulta, o percentual de entrevistados que aprovavam o desempenho de Lula nunca tinha sido tão baixo desde que ele assumiu a Presidência do país. A investigação mostrou que o percentual de entrevistados que avaliava o governo como ótimo ou bom caiu quatro pontos desde 21 de julho de 2005, data da sondagem anterior, passando de $35 \%$ para $31 \%$. Já o percentual dos que consideravam o governo Lula ruim ou péssimo aumentou de $23 \%$ para 26\%. (DATAFOLHA, 2005).

Bezerra (2011) também exemplifica o desgaste da imagem pública de Lula a partir de outra pesquisa, essa realizada pelo Instituto Ibope e publicada em 23 de agosto de 2005, na qual foi observado aumento significativo da desconfiança do povo brasileiro em Lula, já que 52\% dos entrevistados disseram não confiar no então presidente.

O desgaste da imagem pública de Lula, exemplificado pelas pesquisas de opinião divulgadas ao final de 2005, no entanto, não obteve o mesmo reflexo negativo em pesquisas sobre intenção de voto para as eleições presidenciais de 2006. Em um comparativo entre as pesquisas de opinião realizadas em 2005 e disponibilizado pelo Portal de notícias Uol, é possível perceber que em cinco sondagens sobre intenção de voto espontâneas (na qual o entrevistado nomeia espontaneamente um candidato em que pretende votar), realizadas entre fevereiro e dezembro daquele ano, Lula foi apontado como o principal candidato nas eleições de $2006^{62}$. (RODRIGUES, 2006).

Em consultas realizadas a partir de janeiro de 2006 pelos principais Institutos de pesquisa do país (Ibope, VoxPopoli, DataFolha e Sensus), a possibilidade de voto naquele candidato petista se tornou ainda maior. Em levantamento realizado pelo Instituto Ibope entre 8 e 11 de março de 2016, 27\% dos entrevistados afirmavam espontaneamente que votariam em Lula se ele se candidatasse às eleições. Em pesquisa realizada pelo mesmo instituto entre os dias $28 \mathrm{e}$

\footnotetext{
${ }^{62}$ As pesquisas foram realizadas pelo Instituto Sensus em fevereiro e maio de 2005 e pelo Instituto DataFolha em junho, agosto e dezembro do mesmo ano.
} 
31 de maio de 2006 o índice de entrevistados que afirmavam espontaneamente que votariam em Lula subiu para 33\%. (RODRIGUES, 2006).

Entendemos, portanto, que apesar da crise política instituída a partir de 2005 devido aos escândalos de corrupção e à constante tentativa da imprensa em desgastar a imagem pública política de Lula, ele ainda era a principal opção do eleitoral brasileiro para continuar ocupando o cargo de presidente do país. No tópico a seguir analisaremos as principais estratégias comunicacionais utilizadas na campanha de Lula à reeleição em $2006^{63}$ que contribuíram para amenizar o desgaste político sofrido por seu governo desde 2005, principalmente devido ao escândalo do mensalão, quais sejam: a intensificação do personalismo político do governo Lula a contar do afastamento entre sua imagem pública e a imagem do PT, além da intensificação da propaganda em torno do continuísmo das conquistas sociais adquiridas durante o seu primeiro governo $(2003-2006)$.

\subsubsection{Reeleição e celebrização da imagem pública política de Lula}

Antes de contextualizarmos o pleito eleitoral de 2006 é necessário ressaltar que, devido aos constantes ataques à sua imagem pública, Lula passou a se defender das acusações de envolvimento no escândalo do "mensalão" alegando inocência no caso. Um dos principais recursos do discurso do então presidente ao declarar ser inocente, se deu sob a influência da narrativa da conspiração ao se considerar "perseguido" e "traído", principalmente, pela imprensa e pela elite brasileira (BEZERRA, 2011). Nota-se o retorno à narrativa da conspiração já utilizada durante suas três tentativas de ser eleito presidente (1989, 1994 e 1998), quando acusou os meios de comunicação e o empresariado brasileiro de serem contrários à causa dos trabalhadores. Em um trecho do pronunciamento oficial de Lula veiculado em 12 de agosto de $2005^{64}$ pelos meios de comunicação de televisão e rádio, no qual o mesmo discursou sobre a repercussão do escândalo do "mensalão", é possível observar a influência da narrativa da conspiração:

\footnotetext{
Quero dizer a vocês, com toda a franqueza, eu me sinto traído. Traído por práticas inaceitáveis das quais nunca tive conhecimento. Estou indignado pelas revelações que aparecem a cada dia, e que chocam o país. O PT foi criado justamente para fortalecer a ética na política e lutar ao lado do povo pobre e das camadas médias do nosso país. Eu não mudei e, tenho certeza, a mesma indignação que sinto é compartilhada pela

${ }^{63} \mathrm{O}$ candidato a vice-presidente na chapa de Lula em 2006 foi, novamente, José Alencar, do PL.

${ }^{64} \mathrm{O}$ discurso de Lula foi veiculado no mesmo dia em que a revista Época publicou a matéria intitulada "Lula sabia", sobre a qual nos referimos anteriormente.
} 
grande maioria de todos aqueles que nos acompanharam nessa trajetória. (OLIVEIRA, 2012, grifo nosso).

No mesmo pronunciamento Lula recorreu também à narrativa da esperança, que havia sido a principal estratégia de seu discurso midiático durante a campanha de 2002, como pode ser percebido no trecho a seguir:

Quero dizer a vocês: não percam a esperança. Eu sei que vocês estão indignados e eu,
certamente, estou tão ou mais indignado do que qualquer brasileiro. E nós iremos
conseguir fazer com que o Brasil consiga continuar andando para frente, marchando
para o desenvolvimento, para o crescimento da riqueza e para a distribuição de renda.
E eu tenho certeza que posso contar com o povo brasileiro. (OLIVEIRA, 2012, grifo
nosso).

Mesmo com as tentativas de defesa dos discursos de Lula, a pauta da "crise política" e a forma como a imprensa passou a tratar o momento político pelo qual atravessava o país a partir de 2005 devido aos escândalos de corrupção, tornou-se a principal temática na disputa eleitoral para a Presidência da República ocorrida em 2006. Exemplificamos a importância dessa temática no pleito eleitoral a partir de dois pontos principais que se entrecruzam: 1) o primeiro deles diz respeito ao alinhamento entre os partidos de oposição ao PT e a imprensa no sentido de que os primeiros aproveitaram do momento de desestabilização da imagem pública petista intensificada pela mídia para construir suas principais argumentações durante a campanha eleitoral ${ }^{65}$. Dessa forma, no pleito eleitoral de 2006,

[...] ocorreu um processo de retroalimentação entre o campo político (os partidos de oposição) e o campo jornalístico (a mídia) que terminou formatando e definindo a agenda-setting da campanha presidencial. [...] praticamente todos grandes jornais e as revistas semanais, ao criticarem duramente o governo e o PT pelo suposto envolvimento no escândalo, favoreciam indiretamente a oposição ou a apoiava abertamente [...]. (AZEVEDO, 2010, p. 17).

2) O segundo ponto diz respeito à opinião pública diante da pauta da corrupção e da crise política. A partir de uma pesquisa realizada pelo ESEB (Estudo Eleitoral Brasileiro) em 2006 observou-se que $30 \%$ dos eleitores brasileiros indicavam que a corrupção e os escândalos midiáticos decorrentes de tais práticas seriam o principal tema das campanhas políticas daquele ano e apenas $10 \%$ enfatizavam as questões sobre economia como pontos importantes. Além disso, $42 \%$ dos eleitores apontavam a corrupção como o pior problema político do Brasil - em 2002 esse número era de apenas 2\%. (RENNÓ, 2007).

\footnotetext{
${ }^{65}$ Outros autores também apontaram para essa influência da imprensa do pleito eleitoral de 2006 no sentido de desestabilizar a imagem pública tanto do PT como de Lula (ALDÉ, MENDES, FIGUEIREDO, 2007; KUCINSKI, 2007; RUBIM, 2007; COIMBRA, 2007).
} 
Para além dos dois pontos acima discorridos, é oportuno ressaltar que em março de 2006 outro escândalo de corrupção envolvendo políticos petistas veio à tona, o que contribuiu ainda mais para que essa pauta se tornasse peça-chave nos discursos do pleito eleitoral daquele ano. O fato em questão foi intitulado de "escândalo do dossiê" e "envolveu dirigentes da campanha presidencial de Lula da Silva e do postulante do PT ao governo de São Paulo, senador Aloísio Mercadante" (ALMEIDA, 2007, p. 134) em compras de dossiê contra o então candidato ao governo de São Paulo, José Serra (PSDB). Sobre esse escândalo, Jorge Almeida (2007) aponta que "a prisão de parte dos envolvidos, as denúncias de que a compra do dossiê partiu das coordenações das campanhas petistas e a ampla divulgação massiva de tudo isso" (ALMEIDA, 2007, p. 134) causaram mais um impacto negativo na imagem pública do PT.

Feitas essas observações sobre a pauta da crise política no processo eleitoral de 2006, destacamos que a partir do profundo desgaste da imagem pública do PT devido à intensa divulgação dos desdobramentos da corrupção, uma das principais estratégias comunicacionais da campanha de Lula em $2006^{66}$ se refletiu no afastamento entre a imagem pública do então presidente e a imagem do PT (PANKE, 2010; ANDERSON, 2011). Panke (2010) exemplifica esse distanciamento a partir do HGPE de Lula, que passou a desvincular a cor vermelha representação simbólica do PT e partidos de esquerda - dos programas da campanha do então presidente. Dessa forma, "o vermelho era mesclado com as cores da bandeira [do Brasil] em um efeito de fusão entre as cores. A logomarca do partido [PT], na vinheta de abertura, foi estilizada em verde e amarelo.”. (PANKE, 2010, p. 173). A partir do distanciamento entre a figura de Lula e a de seu partido intensificou-se o personalismo político do governo Lula, o que contribuiu em grande medida para o surgimento do chamado "lulismo".

Pontuamos que, como bem aponta Bezerra (2011), "não há consenso quanto à definição do lulismo" (BEZERRA, 2011, p. 245). Diversos autores lançaram luz sobre a ocorrência e as lógicas de funcionamento do lulismo a partir de distintas perspectivas baseadas, principalmente, na abordagem de um realinhamento do apoio eleitoral a Lula percebido a partir de 2006.

Alguns estudos buscaram compreender o lulismo pela perspectiva do voto personalista, ou seja, a consolidação da imagem pública do então presidente no imaginário coletivo brasileiro seria uma das principais justificativas do voto em Lula (SAMUELS, 2008; BAQUERO, 2007). Já outros autores buscaram compreender o lulismo refletido nos programas de assistência social

\footnotetext{
${ }^{66}$ A campanha eleitoral de Lula em 2006 foi coordenada pelo publicitário João Santana, famoso por coordenar campanhas vitoriosas no Brasil, como a de Dilma Rousseff em 2010 e 2014 (que veremos em detalhes mais adiante); e na Venezuela, como o pleito de Hugo Chávez (2012) e Nicolás Maduro (2013).
} 
instituídos no primeiro mandato do seu governo e que resultaram em apoio massivo (a seu governo) das camadas mais pobres do país (CARRARO et al, 2007; SINGER, 2012).

Sobre a segunda perspectiva destacamos a importância da abordagem apresentada por Singer (2012), que buscou compreender o realinhamento do apoio eleitoral a Lula sobretudo a partir do avanço de um dos mais importantes feitos de seu governo: o Programa Bolsa Família (PBF), que teve início no final de 2003, mas conquistou êxito e teve grande visibilidade em 2005. O PBF, na visão de Singer (2009), se tornou viável durante o governo de Lula devido a resultados econômicos obtidos no Brasil naquele período, como, por exemplo, a volta do crescimento impulsionado essencialmente pelos bons ventos na economia externa, o que gerou receita favorável. Em informação coletada no portal oficial do governo federal (http://bolsafamilia.datasus.gov.br), o programa é definido como:

[...] o maior e mais ambicioso programa [da] história do Brasil. O Bolsa Família nasce para enfrentar o maior desafio da sociedade brasileira, que é o de combater a fome e a miséria, e promover a emancipação das famílias em situação de maior pobreza no país. [...] O Bolsa Família é um programa federal destinado às famílias em situação de pobreza e extrema pobreza, com renda per capita de até $\mathrm{R} \$ 154$ mensais, que associa à transferência do benefício financeiro do acesso aos direitos sociais básicos saúde, alimentação, educação e assistência social. Através do Bolsa Família, o governo federal concede mensalmente benefícios em dinheiro para famílias mais necessitadas. (BRASIL, 2015).

A análise da medida se amplia e recorre às considerações de Aidar Prado e Andréia Moassab (2011), segundo os quais "o programa foi criado tendo em vista o alívio imediato da pobreza e a superação da fome, através da transferência direta de renda.”. (PRADO; MOASSAB, 2011, p. 3). Em relação às consequências ou ganhos do PBF, André Singer (2009) aponta brevemente que

Em 2004, o PBF recebeu verba 64\% maior e, em 2005, ano do "mensalão", teve um aumento de outros $26 \%$, mais do que duplicando o número de famílias atendidas, de 3,6 milhões para 8,7 milhões, em dois anos. Entre 2003 e 2006, a Bolsa Família viu o seu orçamento multiplicado por treze, pulando de $\mathrm{R} \$ 570$ milhões de reais para 7,5 bilhões de reais, atendendo a cerca de 11,4 milhões de famílias perto da eleição de 2006. (SINGER, 2009, 91).

O impacto político-social do PBF é também investigado por Perry Anderson (2011), no livro O Brasil de Lula, ao discorrer sobre a "força" da iniciativa, devido principalmente ao simbolismo que carrega em relação à superação da pobreza e da miséria no país. Nessa linha de raciocínio, Anderson (2011) considera, portanto, que o Bolsa Família é notório 
[...] não apenas porque tem ajudado [...] a reduzir a pobreza e a estimular a demanda nas regiões mais carentes do país. Mas também devido à mensagem simbólica contida no programa: a de que o Estado se preocupa com as condições de todos os brasileiros, não importa o quão miseráveis ou oprimidos, como cidadãos sociais em seu país. (ANDERSON, 2011, p. 29, grifo nosso).

O simbolismo do PBF contribuiu para que o governo Lula se tornasse o principal responsável por praticamente liquidar a pobreza do Brasil, bem como contribuir para a ascensão de uma parte da população antes economicamente incapacitada à chamada "nova classe média". (PRADO; MOASSAB, 2011). Sendo assim, na percepção de Singer (2012), o realinhamento eleitoral e o surgimento do lulismo se deram a partir do momento que Lula passou a obter apoio "fervoroso" (SINGER, 2012) das camadas mais pobres do Brasil - que Singer (2012) intitula de "subproletariado" - e também das regiões Norte e Nordeste do Brasil devido às conquistas sociais obtidas, sobretudo, do PBF. A contrapartida das camadas mais pobres do país impulsionou a reversão do quadro que havia se estabelecido em 1989, quando Lula recebeu maior apoio da elite e dos estados do Sul e do Sudeste. Dessa forma,

\footnotetext{
O lulismo, que emerge junto com o realinhamento, é (...) o encontro de uma liderança, a de Lula, com uma fração de classe, o subproletariado, por meio do programa cujos pontos principais foram delineados entre 2003 e 2005: combater a pobreza, sobretudo onde ela é mais excruciante tanto social quanto regionalmente, por meio da ativação do mercado interno, melhorando o padrão de consumo da metade mais pobre da sociedade, que se concentra no Norte e no Nordeste do país, sem confrontar os interesses do capital. (SINGER, 2012, p. 15).
}

Interessante aspecto do qual trata Singer (2012) sobre a questão do lulismo é que esse passou a ser um fenômeno que agrega eleitores (de camadas mais pobres), tanto os enquadrados no espectro político de esquerda, quanto os que se encaixam à direita. É nesse ponto em que o lulismo surge como "uma força nova" (SINGER, 2012) na política brasileira, já que se distancia completamente do petismo para se tornar uma alternativa ao confeccionar "via ideológica própria, com a união de bandeiras que não pareciam combinar.”. (SINGER, 2012, p. 74).

Ressaltamos que não é objetivo do nosso trabalho investigar os motivos que poderiam ter ocasionado o realinhamento do apoio eleitoral a Lula a partir de 2006, mas, sim, lançar luz sobre a imagem pública política do ex-operário durante sua candidatura à reeleição e, para tanto, nos parece apropriado utilizar tanto a perspectiva do personalismo do governo Lula (influenciado, em grande medida, pela crise política enfrentada pelo PT devido aos escândalos de corrupção), quanto a abordagem da importância dos programas de assistência social proporcionados em seu primeiro mandato. Pontuamos que esses parâmetros foram as bases para a elaboração das estratégias comunicacionais do HGPE de Lula em 2006. 
Na visão de Bezerra (2011), para que se possa compreender a campanha eleitoral de Lula em 2006 deve-se destacar a relação entre novos e antigos lugares de fala do ex-presidente. Dando suporte a esse posicionamento, a imagem de Lula em sua campanha para a reeleição se alternou entre o passado "como homem simples, nordestino, militante sindical" (BEZERRA, 2011, p. 235) e o presente, como o Lula estadista. O discurso da mudança, sempre presente nas campanhas do PT ao longo de todas as eleições anteriormente disputadas, foi substituído pelo da continuidade.

Na mesma perspectiva apresentado por Bezerra (2011), Panke (2010) discorre sobre o HGPE e demonstra que a campanha eleitoral de Lula se baseou em pontos específicos, entre as quais se destacam: a) centralização dos discursos na importância das ações positivas do primeiro mantado; b) utilização de dados estatísticos que comprovassem os avanços econômicos e sociais do governo; c) reforço da imagem do Lula estadista e do homem do povo, de forma a agregar forte apelo emocional. Sobre esse reforço da imagem de Lula como homem do povo ressaltamos a intensa utilização do bordão "Lula, guerreiro do povo brasileiro", que se tornou um dos principais "gritos de guerra" da militância a partir de então; a desvinculação de Lula com as cores do PT e com o partido (como já discorremos anteriormente); d) recorrência à narrativa da necessidade de continuidade do avanço dos programas sociais, principalmente o PBF; d) e recorrência à narrativa da ascensão social, da dignidade e da qualidade de vida. (PANKE, 2010, p. 179).

Lula conseguiu se reeleger em 2006 no $2^{\circ}$ turno com considerável diferença de votos: obteve $60,87 \%$ dos votos contra $39,17 \%$ de seu oponente, Geraldo Alckmin (PSDB) ${ }^{67}$. Com os 58 milhões de votos conquistados, Lula obteve quase 6 milhões de votos a mais do que em 2002 e estabeleceu novo recorde de votação no país. Em relação a esse resultado, Singer (2009) aponta que "é plausível a suspeita [...] de que a eleição de 2006 comprove ter Lula se elevado 'à condição de condottiere e de mito"”. (SINGER, 2009, p. 94, grifo nosso).

Em nossa percepção, após sua reeleição Lula pôde desfrutar de um segundo mandato muito mais confiante, pautado essencialmente pelo crescimento expressivo da economia brasileira. Acerca desse desenvolvimento econômico, Anderson (2011) e Singer (2012) apontam dois pontos principais: 1) o primeiro deles foi a crise econômica vivenciada pelos países mais desenvolvidos, o que permitiu que o Brasil conquistasse espaço considerável no mercado internacional; 2) o segundo aspecto foi impulsionado pelo fenômeno que os economistas chamaram de boom de commodities. Tal fenômeno foi caracterizado pela alta do

\footnotetext{
${ }^{67}$ Dados do Tribunal Superior Eleitoral obtidos em: $<$ http://www.tse.jus.br/eleicoes/eleicoes-anteriores/eleicoes2006/resultado-da-eleicao-2006>. Acesso em: 01 jan. 2016.
} 
preço dos produtos de commodities como soja, açúcar, álcool, minério de ferro, petróleo, carne, laranja, etc., impulsionada pelo constante crescimento da economia da China. Em proveito disso o Brasil passou a exportar tais produtos e a atrair grande montante do capital chinês. (AGÊNCIA BRASILEIRA DE PROMOÇÃO DE EXPORTAÇÕES E INVESTIMENTOS, 2011). Essa onda favorável da economia brasileira facilitou também a quitação simbólica da dívida externa com o FMI, já que "a relação dívida externa/PIB, que chegara a 42\% em 2002, foi reduzida para 16\% em 2006.”. (SINGER, 2012, 178).

Em 2002 o Brasil ocupava a $13^{\mathrm{a}}$ posição no ranking das maiores economias do mundo e já em 2011, ao fim do mandato de Lula, o país chegou a ocupar o $6^{\circ}$ lugar, superando a GrãBretanha. (COSTAS, 2016). "Sob Lula, o país emergiu como uma potência global. Ao final, sua vasta popularidade foi um reflexo não apenas das melhorias de ordem material, mas também de orgulho coletivo para o país.”. (ANDERSON, 2011, p. 32).

Sob os holofotes e a atenção do mundo, o Brasil conquistou em 2007 a oportunidade de sediar a Copa do Mundo de Futebol de 2014. E em 2009 o Rio de Janeiro foi escolhido como sede da Olimpíada de 2016. Essas vitórias do Brasil como sede dos eventos esportivos mais importantes do mundo igualmente confirmaram a importância e a força da imagem pública de Lula.

Entre os líderes mundiais o mesmo acontecia. Obama, em 2009, durante reunião da cúpula do G-20 chegou a tecer vários elogios a Lula, afirmando que o presidente era o político mais popular do mundo. Na ocasião, Obama se dirigiu à Lula e disse: "Esse é o cara. [...] Eu o amo. Ele é o político mais popular da Terra.”. (OBAMA apud JAKETAPPER, 2009, tradução nossa $^{68}$ ). A revista britânica The Economist, que possui reconhecimento internacional, dedicou a capa de sua edição de 12 de novembro de 2009 à ascensão da economia brasileira (retratada imageticamente pelo Cristo Redentor - símbolo do Rio de Janeiro - decolando como um foguete). Com o título Brazil takes off (O Brasil decola), a matéria da revista trazia dados e fatos que indicavam que a economia brasileira estava finalmente a ponto de emergir como potência mundial. (BRAZIL..., 2009).

Com a popularidade adquirida durante os dois mandatos como presidente do Brasil, a imagem pública de Lula passou a adquirir da mesma forma a característica de celebridade, como bem apontam Serelle, Pires e Castro (2010), sendo tal celebrização outro ponto intrínseco ao processo de heroificação de sua imagem pública. Para exemplificar a perspectiva de que Lula teria alcançado ares de celebridade, Serelle, Pires e Castro (2010) citam o exemplo de duas

68 "That's my man right here. [...] "Love this guy. He's the most popular politican on Earth.". (OBAMA apud JAKETAPPER, 2009). 
pesquisas, ambas realizadas ao final do segundo mandato de Lula, em 2009: a primeira, organizada pelo Instituto DataFolha, revelou que o ex-presidente era o brasileiro mais confiável em um ranking de 27 personalidades nacionais - entre cantores, atores, compositores, jornalistas etc. A outra consulta, esta feita pela agência Young and Rubican, apontou Lula como a segunda "marca" mais forte entre as celebridades brasileiras, o ex-presidente ficou atrás apenas de Ayrton Senna.

Ainda para Serelle, Pires e Castro (2010), Lula ter se tornado celebridade é resultado de um conjunto de fatores resultante da construção da sua imagem pública. O primeiro deles refere-se à projeção midiática alcançada pelos atributos pessoais de Lula, enquanto o segundo diz respeito ao seu papel de líder "com potência mítica lacunar, referente ao romantismo revolucionário latino-americano, mas domesticado pelo pragmatismo neoliberal, logo arrojado e apropriado, o que [...] condensa, de forma carismática, as tensões contextuais.”. (SERELLE; PIRES; CASTRO, 2010, p. 9).

Lula deixou a Presidência do Brasil em 2010 com a marca histórica de $80 \%$ de aprovação de seu governo e $87 \%$ de aprovação pessoal, como indicou pesquisa Ibope encomendada pela Confederação Nacional da Indústria (CNI) em dezembro de 2010 (CONFEDERAÇÃO NACIONAL DA INDÚSTRIA, 2010). A partir da construção da imagem de Lula como liderança carismática e heroica, da eliminação da extrema pobreza no país, do crescimento das vagas de emprego, da estabilidade da economia; além do intenso e crescente otimismo do povo brasileiro em relação a seu país, o presidente mais bem avaliado da história do país conseguiu trazer à tona em seus discursos, já ao fim de seu segundo mandato, a narrativa que Girardet (1987) intitula como a idade de ouro.

Essa expressão, a idade de ouro, de acordo com Girardet (1987), tem aspectos nostálgicos por remeter a tempos antigos de prosperidade. Essa lembrança é acionada pelo imaginário coletivo e tende a buscar conectividade com heróis que já se estabeleceram como mitos no imaginário social. O passado, portanto, é idealizado de forma a ser vivenciado mais como utopia do que pode ser o presente ou o futuro. A narrativa proposta pelo lulismo, como se vê, se pauta nos "bons tempos de Lula", que pretendem, como construção midiática e também parte do imaginário coletivo, serem recordados como o período em que houve crescimento econômico e diminuição das desigualdades sociais. Foi quando, finalmente, o povo brasileiro pôde se perceber otimista em relação aos rumos do Brasil.

Como veremos no tópico a seguir, a eleição presidencial de 2010 se tornou um exemplo claro de como a narrativa da idade de ouro do lulismo foi apropriada enquanto discurso político, 
principalmente na campanha eleitoral de Dilma Rousseff, candidata pelo PT à sucessão de Lula na Presidência da República ${ }^{69}$.

\subsection{De Lula a Dilma Rousseff}

A década de 2000 foi marcante para a política latino-americana por terem ocorrido três transições de governos com uma característica similar: presidentes com forte apelo popular e com imagem pública consolidada no imaginário coletivo foram bem-sucedidos ao eleger seus sucessores. Uma dessas transições ocorreu na Argentina, em 2007, quando Cristina Kirchner foi eleita para seu primeiro mandato como presidente de seu país, após seu marido, Néstor Kirchner, deixar o cargo. Outra transição ocorreu na Venezuela, após a morte de Hugo Chávez, em março 2013, e a eleição de seu sucessor, Nicolás Maduro, no mesmo ano.

Já a terceira transição que é objeto de análise desse tópico, ocorreu no Brasil, em 2010, quando Dilma Rousseff foi eleita presidente após dois mandatos consecutivos de Lula. Lançaremos luz sobre essa transição a partir da reflexão sobre como a imagem pública de Lula foi acionada enquanto estratégia comunicacional na campanha eleitoral de Dilma, e, para tanto, apresentaremos em primeiro lugar uma breve biografia de Rousseff e, em seguida, a forma como ocorreu a transferência de prestígio político nas eleições de 2010.

Dilma nasceu em 14 de dezembro de 1947, em Belo Horizonte (Minas Gerais). É filha do imigrante búlgaro Pedro Rousseff e da professora Dilma Jane da Silva, e, diferentemente de Lula, nasceu e cresceu numa família de classe média alta. Dilma, que tinha aulas particulares de francês e de piano em casa, estudou em renomado colégio da capital mineira, o Colégio Nossa Senhora de Sion, e obteve o diploma do ensino médio pelo Colégio Estadual Central instituição que se tornou um centro de mobilização do movimento estudantil em Minas Gerais. (AMARAL, 2011).

Sua vida política começou cedo, ainda aos 16 anos, quando ela passou a fazer parte de organizações de combate ao regime militar. Em 1969 conheceu seu ex-marido, o advogado gaúcho Carlos Franklin Paixão de Araújo - juntos sofreram perseguição da justiça militar. Dilma foi presa e torturada por quase três anos (entre 1970 e 1972). Livre da cadeia, em 1973, ela se mudou para Porto Alegre com o marido. Lá retomou os estudos na Universidade Federal do Rio Grande do Sul e, em 1975, começou a trabalhar como estagiária na Fundação de

\footnotetext{
${ }^{69} \mathrm{O}$ candidato a vice-presidente na chapa de Dilma Rousseff em 2010 foi Michel Temer, do PMDB.
} 
Economia e Estatística (FEE), órgão do governo gaúcho. Em 1976 deu à luz a única filha do casal, Paula Rousseff Araújo. (AMARAL, 2011).

Em 1979, Dilma participou da fundação do partido de esquerda liderado por Leonel Brizola, o Partido Democrático Trabalhista (PDT). Ela trabalhou na assessoria da bancada do PDT do Rio Grande do Sul entre 1980 e 1985 e em 1986 se tornou secretária da Fazenda pelo mesmo Estado. Com o retorno da democracia, Dilma participou ativamente da campanha de Brizola para a Presidência do Brasil em 1989 - quando Lula disputou a sua primeira eleição. No segundo turno das eleições, Dilma foi às ruas apoiar a candidatura de Lula. (AMARAL, 2011).

Em 1993, se tornou secretária de Energia, Minas e Comunicação do Rio Grande do Sul, nomeada pelo então governador do estado gaúcho, Alceu Collares. Em 1998, o PDT e o PT firmaram aliança para a eleição de Olívio Dutra para governador do Rio Grande do Sul, e Dilma continuou ocupando o mesmo cargo. Em 2000 ela se filiou ao PT e foi a partir daí que chamou a atenção de Lula, já que o Rio Grande do Sul foi um dos poucos estados que não sofreram com o racionamento de energia em 2001, período em que Dilma ainda chefiava a secretaria de Energia daquele estado. Já em 2002 Rousseff foi convidada a participar da equipe de transição entre os governos de Fernando Henrique Cardoso (1995-2002) e Lula (2003-2010) e, com a eleição de Lula, Dilma ocupou o cargo de ministra de Minas e Energia. (AMARAL, 2011).

Em 2005, ano em que foi divulgado o esquema do "mensalão", Dilma passou a chefiar a pasta da Casa Civil, substituindo José Dirceu, e se tornou, assim, a primeira mulher a ocupar tal cargo. Como ministra, Dilma assumiu a direção de programas-chave no governo de Lula, como o Programa de Aceleração do Crescimento (PAC), em 2007, e o Minha Casa, Minha Vida, em 2009. No mesmo período também passou a coordenar a comissão encarregada de definir as regras para a exploração das recém-descobertas reservas de petróleo na camada présal. (AMARAL, 2011).

Lula passou a enaltecer o PAC como um dos principais programas de seu governo e a se referir a Dilma como a "mãe do PAC". Como veremos à diante, a imagem pública de Dilma enquanto "mãe" se tornou essencial durante sua campanha eleitoral à Presidência. O PAC tinha por principal objetivo promover a retomada do planejamento e execução de grandes obras de infraestrutura social, urbana, logística e energética do país, contribuindo para o seu desenvolvimento acelerado e sustentável (BRASIL, 2016). Em 2011, quando Dilma assumiu a Presidência do Brasil, foi lançado o PAC 2, que visava ampliar a aprimorar a fase anterior. (AMARAL, 2011). 
Apesar de extensa carreira profissional e ocupação de cargos de liderança no governo Lula, Dilma não era figura reconhecida por grande parte do eleitorado brasileiro antes da campanha para Presidência da república, em 2010. A escolha de Rousseff como candidata pelo Partido dos Trabalhadores se deu, portanto, sob uma especificidade interessante do contexto político brasileiro da época. Devido aos escândalos de corrupção e às várias condenações e acusações de importantes membros do PT - e braços direito de Lula, como José Dirceu e Antônio Palocci -, a base do partido se esvaziou e isso gerou relevante ausência de nomes reconhecidos e legitimados para a concorrência nas eleições de 2010 e que poderiam dar continuidade ao governo petista. Tal carência de legitimação da imagem pública dos membros do partido impulsionou a escolha de Dilma para o pleito eleitoral de 2010 e, como bem aponta Joyce Martins (2012), em estudo sobre a imagem pública de Dilma na campanha de 2010, a então candidata passou a representar uma possibilidade de redenção da imagem do PT.

Para Anderson (2011), a escolha de Dilma não se deu somente devido às suas ações junto ao governo Lula, mas algumas características de sua imagem pública também contribuíram para essa decisão. Anderson (2011) afirma que Dilma "não era um produto do PT, no qual ingressou apenas em 2000. [...] [e] era uma mulher, em torno de quem seria muito mais fácil investi-la com seu próprio carisma do que o teria sido com um homem.”. (ANDERSON, 2011, p. 46).

É exatamente sobre a questão do carisma que se situa o ponto mais crítico da transferência de imagem de um político a seu candidato sucessor. O cientista político Antônio Lavareda em entrevista concedida em setembro de 2009 à revista Isto É afirmou que a transferência de voto de Lula a Dilma era completamente possível, mas a transferência de carisma beirava o inatingível por ser algo já enraizado no imaginário coletivo e social muito bem construído desde o primeiro mandato de Lula. Na mesma entrevista, quando questionado sobre as dificuldades que Dilma enfrentaria no pleito eleitoral de 2010, Lavareda apontou que seu maior desafio seria substituir a figura do presidente no imaginário do eleitorado da base lulista. $\mathrm{O}$ autor indagou ainda se Dilma teria capacidade de empolgar os eleitores e substituir uma figura com a dimensão mítica de Lula. (LAVAREDA, 2009).

Sabe-se que aspectos econômicos, políticos e sociais intrínsecos ao contexto brasileiro da época contribuíram para que Dilma vencesse as eleições em 2010, mas o que nos cabe averiguar aqui é de que forma a imagem pública de Dilma, antes praticamente inexistente no quadro político-midiático brasileiro, se tornou crível pelo eleitorado e passou a contribuir para que ela se tornasse presidente do Brasil. Importante salientar que não pretendemos apontar explicações para o resultado das eleições de 2010, mas buscamos iluminar brevemente alguns pontos 
estratégicos da construção de sua imagem pública na campanha eleitoral de 2010, ancorada à representação já consolidada de Lula.

Com essa finalidade recorremos então a Telles e Pires (2013), em estudo sobre a influência do lulismo na campanha eleitoral de Dilma em 2010. Em sua perspectiva, a relevância da imagem de Lula na decisão das eleições de 2010 não foi impactante apenas para a campanha de Dilma, mas naquela disputa o ex-presidente foi "a principal valência mobilizada para ativar o eleitor" (TELLES; PIRES, 2013, p.2) e todos os outros candidatos sentiram o peso desse fato. Durante aquela campanha os adversários de Dilma preferiram, então, não atacar ou denegrir a imagem de Lula. Assim, "as campanhas ocorreriam ao redor de 'qual seria o melhor candidato para representar as melhorias realizadas por Lula.”. (TELLES; PIRES, 2013, p. 8).

Para exemplificar essa perspectiva chamamos atenção para o momento no qual o principal adversário de Dilma nas urnas, José Serra do PSDB, em entrevista a uma rádio em Recife (Pernambuco), ainda como pré-candidato, pediu aos entrevistadores que evitassem comparações entre ele e Lula e afirmou: "O Lula está acima do bem e do mal. Não me compare a ele.”. (SERRA, J. apud SERRA, B., 2010, grifo nosso). Acreditamos que a expressão "está acima do bem e do mal" reforça a narrativa de salvador sobre a qual a imagem de Lula foi construída.

Uma das possibilidades de se compreender a importância dada à confiança em Lula nas campanhas eleitorais em 2010 parte da ideia do continuísmo que se pauta, entre outros fatores, na tendência ao voto retrospectivo no qual o eleitorado avalia as condições políticas, econômicas e sociais implantadas pelo governo da situação e, caso a julgue favorável, procura votar nos candidatos que propõe esta continuidade (TELLES; PIRES, 2013). Dessa forma, com os altos índices de aprovação tanto da gestão de Lula como de sua pessoa, os eleitores estavam mais confiantes no candidato que estivesse disposto a manter as práticas e projetos políticos do ex-presidente.

Pesquisa citada por Bramatti (2010) realizada pelo instituto DataFolha em maio de 2010 (meses antes do início oficial da campanha eleitoral, ou seja, período em que os nomes dos candidatos à Presidência ainda não estavam claros para grande parte do eleitorado) revelou um dado interessante e que ilustra bem a influência de Lula naquela disputa eleitoral: $23 \%$ dos possível eleitores de José Serra, o aspirante da oposição, afirmaram que com certeza votariam no candidato apoiado por Lula e outros $26 \%$ afirmaram que talvez escolhessem um indicado pelo ex-presidente. Já dentre os possíveis eleitores de Dilma, 76\% afirmaram que votariam com certeza no candidato apoiado por Lula. Como bem aponta Bramatti (201) esses dados mostram 
que, independente do postulante em questão, parte considerável do eleitorado gostaria que houvesse a continuidade do governo de Lula.

Ainda de acordo com Telles e Pires (2013), "o eixo das campanhas de 2010 foi a disputa pela representação do terceiro mandato de Lula, já que o ex-presidente não pode disputar o governo". Dessa forma, "a associação ao prestígio de Lula tornou-se a principal alternativa no marketing dos candidatos.”. (TELLES; PIRES, 2013, p. 6).

Como apontamos anteriormente, a imagem pública de Dilma antes do início da campanha oficial para Presidência era pouco reconhecida por grande parte dos brasileiros. Mas, no início de 2010, Lula já demonstrava publicamente, em vários eventos em que eles estavam juntos para divulgação do Programa de Aceleração do Crescimento (PAC), seu interesse em Rousseff como sua sucessora. Lula chegou a ser multado diversas vezes pelo Tribunal Superior Eleitoral por suposta propaganda antecipada. Uma dessas propagandas teria ocorrido durante a inauguração das instalações do Sindicato dos Trabalhadores em Processamento de Dados de São Paulo (Sindpd/SP). Naquela ocasião o então presidente afirmou:

[...] eu penso que a cara do Brasil vai mudar muito. E quem vier depois de mim, e eu, por questões legais, não posso dizer quem é; espero que vocês adivinhem, espero, quem vier depois de mim já vai encontrar um programa pronto, com dinheiro no Orçamento, porque eu estou fazendo o PAC II, porque eu preciso colocar dinheiro no Orçamento para 2011, para que as pessoas comecem a trabalhar. (LULA apud PASSARINHO, CARNEIRO 2010, grifo nosso).

Já em outro evento em 25 de março de 2010 na cidade de Osasco (São Paulo), em ocasião da inauguração de apartamentos populares, Lula voltou a falar sobre a continuidade de seu governo e insinuou, novamente, a possibilidade de Dilma ser sua candidata: "O que estamos fazendo aqui é reparação [em relação aos governos anteriores] e isso eu tenho certeza que vai continuar, mas eu não posso dizer o nome”. (LULA apud MOREIRA, 2010). O público presente no evento em questão começou a entoar gritos de apoio a Dilma. Antes do início da campanha oficial já estava claro, portanto, que Lula lançaria Dilma como candidata pelo PT.

A legitimação da imagem de Dilma como candidata, no entanto, passou a ocorrer de fato durante o HGPE - que teve início (no primeiro turno) em 17 de agosto e terminou em 30 de setembro de 2010 e o segundo turno durou entre 16 e 29 de outubro de 2010 . No total, foram 42 programas televisivos de propaganda que compunham a campanha da candidata do PT.

Telles e Pires (2013), ao analisarem o HGPE de Dilma Rousseff, concluíram que, no primeiro turno Lula foi citado 98 vezes e o PT, apenas em duas ocasiões. Já no segundo turno “o termo PT não foi mencionado, verbalmente, nenhuma vez ao passo que Lula foi mencionado 
123 vezes.”. (TELLES; PIRES, 2013, p. 14, grifo nosso). As autoras (2013) apontam que Dilma fora, então, apresentada como candidata do lulismo e não do petismo - o que evidencia a importância da imagem pública de Lula na construção da representação de Dilma.

Consideramos, portanto, como bem apontam Telles e Pires (2013) que no pleito eleitoral de 2010 o que houve não foi transferência de afeto ou de carisma de Lula para Dilma, mas, sim, de prestígio político (TELLES; PIRES, 2013), ou seja, o ethos institucional de Lula facilitou a construção do ethos discursivo de Rousseff e esse processo se deu, principalmente durante o Horário Gratuito Político Eleitoral (HGPE) de 2010.

Necessário, então, analisar ethos. Amossy (2008) compreende o termo como sendo o caráter que o orador mostra em seu discurso com o objetivo de causar boa impressão, ou seja, é o seu jeito de ser e de se mostrar durante a retórica discursiva. Dessa forma, uma argumentação é formada basicamente pelo ethos (o eu), pelo pathos (a parte sensível e emotiva do discurso) e pelo $\log o s$ (a racionalidade). Ponto interessante na literatura sobre o ethos na retórica é a divisão entre os estudos pragmáticos e os sociológicos. De acordo com Amossy (2008), a linha pragmática compreende que o ethos só é construído durante o discurso e dentro dele, ou seja, o ethos é "puramente interno ao discurso" (AMOSSY, 2008, p. 122). Já o entendimento apoiado na linha sociológica defende que a construção do ethos se dá previamente, ou seja, é exterior e anterior ao discurso - dito por outras palavras, o discurso será eficaz ou não dependendo da posição social do orador e de sua legitimidade diante do auditório a quem se refere. (AMOSSY, 2008).

Amossy (2008) propõe uma nova e interessante perspectiva sobre o ethos ao compreender que a imagem de si no discurso é construída tanto pelo ethos pré-discursivo (ou ethos institucional) como pelo ethos discursivo, ou seja, ambos se relacionam e ocorrem simultaneamente no discurso. Durante a argumentação serão necessários elementos de legitimação externa e interna ao discurso, pois o que transforma a retórica é um jogo de formulação de imagens entre o orador e seu auditório. É como o estudioso coloca:

O bom andamento da troca exige que à imagem do auditório corresponda uma imagem do orador. De fato, a eficácia do discurso é tributária da autoridade de que goza o locutor, isto é, da ideia que seus alocutários fazem de sua pessoa. (AMOSSY, 2008, p. 124).

Um fato determinante de legitimação do ethos é, portanto, “o saber prévio que o auditório possui sobre o orador" (AMOSSY, 2008, p. 124) e, dessa forma, a estratégia da campanha eleitoral de Dilma em ancorar a imagem de Dilma na imagem já consolidada de Lula parte do 
princípio de que o ethos institucional do ex-presidente foi o que validou o ethos discursivo de Dilma. Interessante ressaltar que essa estratégia já havia sido revelada antes mesmo do início da veiculação do HGPE, quando o então presidente do PT, José Eduardo Dutra, concedeu entrevista à revista Veja e declarou:

O Lula estará na campanha. Dentro da lei, será nosso principal militante e cabo eleitoral da Dilma. Nos horários de folga, fim de semana, programas de TV, ele estará presente. A partir da propaganda de TV, vamos ampliar o conhecimento da nossa candidata, o conhecimento da população de que Dilma é candidata do governo, é a candidata do Lula. E não há dúvida de que hoje nós contamos com o cabo eleitoral mais decisivo na eleição, que é o apoio que o governo e o Lula têm. O Lula vai eleger a Dilma. (DUTRA apud MARTINS, 2012, p. 3).

Ao também analisarem o HGPE de Dilma, Lucas Gardin e Luciana Panke (2015) refletem sobre interessante questão da relação entre o ethos institucional de Lula e o ethos discursivo de Dilma. Na percepção desses autores, elementos-chave da imagem pública do ex-presidente foram transformados em elementos-chave na imagem de Dilma como candidata, tais como a narrativa do herói, do líder e de "pai do povo"70:

a) em relação à narrativa do herói, Dilma passou a ser mostrada como uma guerreira por ter sofrido e enfrentado a tortura na época da ditadura e ter superado os percalços daquela fase em sua vida. Ressalta-se, no entanto, que essa narrativa foi a menos explorada;

b) no que tange a narrativa do líder, Dilma passou a ser mostrada como gestora eficiente, com aptidões técnicas suficientes para legitimar sua posição como boa candidata. Para tanto, muitas vezes foram utilizadas expressões como "no governo de Lula e Dilma", ou "com Lula e Dilma", como forma de fazer o eleitor compreender que o governo de Lula deu certo pelo fato de o ex-presidente ser um exímio líder, mas, também, por Dilma ser uma boa gestora “[...] pelo menos uma vez por programa, Dilma foi apontada com coautora de Lula.”. (GARDIN; PANKE, 2015, p. 175);

c) quanto à narrativa de "pai do povo" - a mais mencionada entre as três -, Dilma passou a ser considerada como a "mãe do povo brasileiro". Como visto no capítulo anterior, a imagem de Lula foi construída sob forte apelo popular e, dessa forma, ele passou a ser percebido como um pai ou um provedor. Relevante pontuar que essa narrativa paternalista é uma das principais características do mito do salvador. Para Girardet (1987), “o apelo ao salvador responde a uma situação de vacuidade: é a busca de um pai ausente ou a substituição de uma paternidade recusada por uma imago paterna idealizada.”. (GIRARDET, 1987, p. 186, grifo do autor).

\footnotetext{
${ }^{70}$ Compreendemos o conceito de "povo" como "um subconjunto oposto à camada privilegiada". (PIRES, 2011, p. 144).
} 
Construir, portanto, a imagem de Rousseff como "mãe do povo brasileiro" foi de suma importância para a validação do ethos discursivo de Dilma.

Também em análise do HGPE de Dilma em 2010, Pires (2011) constatou que houve diversas referências ao termo "mãe do povo" durante a veiculação do programa eleitoral da candidata petista. A pesquisadora exemplifica essa referência a partir de um jingle veiculado no primeiro programa da campanha eleitoral de HGPE de Dilma, que foi ao ar em 17 de agosto de 2010. Tal jingle era composto pela seguinte frase: "Agora as mãos de uma mulher vão nos conduzir / Eu sigo com saudade, mas feliz a sorrir / Pois sei, o meu povo ganhou uma mãe / Que tem um coração que vai do Oiapoque ao Chuí.”. (PIRES, 2011, p. 157, grifo nosso). Nesse mesmo programa um depoimento de Dilma igualmente ilustra bem a alusão à construção de seu ethos discursivo como "mãe do povo". Na declaração em questão Dilma afirmou: "Quero fazer com cuidado de mãe o que precisa ainda ser feito. Este é o meu sonho”. (PIRES, 2011, p. 157, grifo nosso).

A estudiosa ressalta que no HGPE de Dilma, exibido no dia 26 de agosto de 2010, é possível perceber no depoimento da costureira nordestina Marilene Dantas a estratégia de utilizar o ethos de "pai do povo" instituído a Lula para ajudar a construir o ethos de "mãe do povo" de Dilma. No testemunho em questão a costureira afirma:

\footnotetext{
A comunidade chama Lula de pai. Porque realmente foi um homem que se preparou para isso. Para dirigir o seu país, mas pensando na igualdade, pensando na classe lá embaixo. Ele entrou com essa luz para os pobres. Está entendido. O pai do povo é ele [Lula]. E espero que a Dilma Rousseff seja a mãe do povo. (MARILANE DANTAS apud PIRES, 2011, p.157).
}

De acordo com Gardin (2012), outro ponto importante do HGPE de Dilma foi a constante tentativa de entrelaçamento entre a biografia já conhecida e consolidada de Lula e a história de vida ainda em construção de Dilma. Assim, aspectos interessantes como o fato de Lula ter sido o primeiro presidente operário e Dilma poder ser a primeira mulher a ocupar a Presidência do Brasil eram destaque durante os programas. Em um dos HGPE exibidos durante o primeiro turno há um trecho, reproduzido por Gardin (2012), que ilustra bem este fato: presidente do Brasil. (GARDIN, 2012, p. 137). 
Para corroborar com essa perspectiva de Gardin (2012), vale ressaltar que durante o último programa do HGPE de Dilma no primeiro turno das eleições de 2010 há um discurso de Lula no qual ele utilizou - mais uma vez - seu ethos institucional para transformar Dilma, antes desconhecida, na candidata certa para a continuidade do lulismo. No programa o então presidente declarou: "Você que acredita em mim e acha bom o meu governo, não tenha dúvida: vote na Dilma. Igual a mim, a Dilma gosta dos pobres, respeita a vida, a paz, a liberdade e as religiões. Votar na Dilma é votar em mim com a certeza de um governo ainda melhor.". (GARDIN; PANKE, 2015, p. 178)

Como visto anteriormente, Amossy (2008) considera que a nova retórica constituída pelo ethos institucional e o ethos discursivo possibilita ao orador, no momento da fala, utilizar a credibilidade de suas imagens prévias e, ao mesmo tempo, modificar, transformar ou criar novas imagens. Dessa forma, quando Lula afirma que votar em Dilma é o mesmo que votar nele, ele aproveita de sua imagem já consolidada no imaginário coletivo brasileiro - principalmente o imaginário coletivo do eleitorado lulista - para validar a imagem de Dilma. Ela se torna, portanto, "representante simbólica de Lula". (TELLES; PIRES, 2013, p. 26).

Dilma venceu as eleições no segundo turno com 56,05\% dos votos (cerca de 55 milhões de votos) contra o candidato oposicionista José Serra (PSDB) que conquistou 43,95\% dos votos (cerca de 43 milhões de votos) $^{71}$. Em pesquisa realizada pelo centro de Estudos Eleitorais Brasileiros (ESEB/CESOP) logo após as eleições, foi identificado um importante indicador da influência da imagem política de Lula na construção da candidatura de Dilma: a pesquisa mostrou que o fato de Dilma ser mulher e ter origem de movimentos e partidos de esquerda não estava relacionado com o fato do eleitorado simpatizar com a figura da mesma, mas tinha a ver com a construção de sua imagem como "mãe do povo"; constatou-se que havia uma conexão importante com a simpatia pela candidata. $\mathrm{O}$ resultado mais interessante, no entanto, foi em relação à Dilma ser continuidade do governo Lula - neste aspecto "a força da correlação entre avaliação do governo Lula e gostar da candidata era grande.”. (CASTAÑEDA; VEIGA, 2012, p. 63).

Essa investigação também corrobora, portanto, com nosso principal argumento de que houve transferência de prestígio eleitoral, ou seja, o ethos institucional de Lula facilitou a construção do ethos discursivo de Rousseff. Nessa perspectiva, Anderson (2011) arriscou dizer que a vitória de Dilma Rousseff foi o maior triunfo eleitoral de Lula. Fato é que a importância

\footnotetext{
${ }^{71}$ Dados do Tribunal Superior Eleitoral obtidos em: $<$ http://www.tse.jus.br/eleicoes/eleicoes-anteriores/eleicoes1998/resultados-das-eleicoes-de-2010>. Acesso em: 01 jan. 2016.
} 
da influência da imagem pública de Lula mesmo no fim do seu mandato como presidente atesta a validade do ex-presidente como importante símbolo do imaginário coletivo brasileiro.

Dilma Rousseff assumiu a Presidência do Brasil em janeiro de 2011 como a primeira mulher a ocupar o cargo no país. De acordo com pesquisa do Instituto DataFolha realizada nos dias 15 e 16 de março de 2011, Dilma obteve maior aprovação em seus três primeiros meses de governo do que seus antecessores, ou seja, foi mais bem avaliada que FHC e Lula no comparativo com o mesmo período analisado (DATAFOLHA, 2011). Tal índice de aprovação foi de 47\% em março de 2011 e subiu para impressionantes 59\% em janeiro de 2012, após um ano de mandato, como indicou consulta também realizada pelo DataFolha nos dias 17 e 18 de janeiro de 2012. (DATAFOLHA, 2012a).

Já em abril de 2012 a aprovação de Dilma atingiu o recorde de 65\% dos entrevistados, que consideravam seu governo ótimo ou bom de acordo com apuração realizada também pelo DataFolha nos dias 15 e 16 de março do mesmo ano. Em relação ao desempenho pessoal de Dilma 68\% dos respondentes aprovavam a presidente. Apesar de Dilma alcançar avaliação melhor do que Lula no mesmo período, a maioria dos entrevistados (57\%) nessa mesma pesquisa disse ver o seu governo igual ao de Lula. Pelo que se verificou em tais pesquisas a contribuição de Lula para a eleição de sua sucessora foi extremamente bem-sucedida ao transmitir credibilidade a Dilma, mas contraditoriamente a essas estatísticas uma outra se sobressai: mesmo com o bom desempenho de Dilma, 57\% dos entrevistados afirmaram que preferiam Lula para presidente em 2014, o que reforça a enorme influência da imagem pública de Lula mesmo após ter deixado a Presidência do país. (DATAFOLHA, 2012).

Ao estudar esse cenário, Singer (2012) ressalta que a boa avaliação da opinião pública pode ser compreendida a partir da reflexão sobre a relativa facilidade que o governo Dilma teve de implantar políticas econômicas nos primeiros anos de mandato por receber grande apoio no Congresso Nacional. No entanto, em 2013 (terceiro ano de mandato), o governo sob comando de Dilma começou a sofrer as primeiras consequências diretas do agravamento da crise econômica externa que resultou em quedas bruscas do crescimento da economia brasileira. Ao discorrerem sobre as dificuldades enfrentadas pelo governo Dilma ao propor o continuísmo do crescimento econômico ocorrido durante os mandatos de Lula, Rodrigo Teixeira e Eduardo Pinto (2012) ressaltam que, durante o segundo mandato de Lula (2007 a 2010),

[...] a economia brasileira entrou em um novo regime de crescimento, puxado pela demanda, no qual as políticas de distribuição de renda e o crescimento do mercado interno, com a incorporação de ampla parcela da população antes excluída do consumo de massas, tiveram papel fundamental. (TEIXEIRA; PINTO, 2012, p. 935). 
No entanto, a partir de 2010, esse crescimento entrou em recessão e o modelo de redistribuição de renda e de aumento do salário mínimo antes em vigor no governo Lula se viu limitado:

[...] os limites ao modelo de crescimento baseado no mercado interno e na redistribuição da renda, combinado com a manutenção de juros elevados e apreciação cambial, mostraram-se claros. (...) O consumo cresce sem expansão da produção industrial devido ao vazamento da renda para o exterior com o aumento das importações de manufaturas e desarticulação das cadeias produtivas domésticas (aumento do conteúdo importado). Consequentemente, reduz-se o poder multiplicador das políticas sociais de transferência de renda e aumento do salário mínimo. (TEIXEIRA; PINTO, 2012, p. 935, grifo nosso).

O resultado da recessão, somado aos desdobramentos dos escândalos de corrupção que envolveram políticos importantes do PT desde 2005, foi percebido já em meados do primeiro mandato de Dilma, quando, em junho de 2013 eclodiram manifestações sociais em todo o país que ficaram popularmente conhecidas como as “Jornadas de Junho”, demarcando assim o início da crise política brasileira. Tais manifestações alcançaram proporções tão significativas que foram consideradas (até aquele momento) o segundo maior movimento social ocorrido no Brasil, atrás apenas dos protestos das Diretas Já, entre 1983 e 1984.

\subsection{0 contexto da crise política entre 2013 e 2015}

Os protestos de junho de 2013 foram, inicialmente, articulados pelo Movimento Passe Livre (MPL), coletivo que se considera apartidário e que tem como principal reivindicação o transporte público gratuito. Apesar de ter ganhado força em 2013, o MPL principiou suas atividades ainda em 2003, "quando, em resposta ao aumento das passagens, iniciou-se em Salvador uma série de manifestações que se estenderam por todo o mês de agosto daquele ano, que ficou conhecida como a Revolta do Buzu.”. (MOVIMENTO PASSE LIVRE - SÃO PAULO, 2013, p. 13). Além de tais manifestações, outras eclodiram em 2004 em Florianópolis, Sul do país, quando estudantes protestaram também contra o aumento de passagens do transporte público naquela cidade (iniciativa que ficou conhecida como a "Revolta da Catraca") e o aumento da passagem acabou por ser revogado, dando credibilidade ao movimento. A partir daí surgiu a necessidade de criação de uma movimentação articulada que, primeiramente, tinha como bandeira o passe livre estudantil e somente depois se expandiu a bandeira de luta para a reapropriação do espaço urbano pelos trabalhadores. Como se vê, 
Surge então um movimento social de transportes autônomo, horizontal e apartidário, cujos coletivos locais, federados, não se submetem a qualquer organização central. Sua política é deliberada de baixo, por todos, em espaços que não possuem dirigentes, nem respondem a qualquer instância externa superior. (MOVIMENTO PASSE LIVRE - SÃO PAULO, 2013, p. 15).

Outras revoltas contra o aumento de passagens voltaram a ocorrer em Vitória (2006), Teresina (2011), Aracaju e Natal (2012) e Porto Alegre e Goiânia já no início de 2013 - as duas últimas foram o estopim para a grande manifestação em junho daquele mesmo ano.

Em 22 de maio de 2013, a prefeitura de São Paulo divulgou notícia sobre o aumento da passagem do transporte público, que subiria dos $R \$ 3,00$ para $R \$ 3,20$. Outras capitais brasileiras também teriam reajuste e aumento dos preços, como Rio de Janeiro, Belo Horizonte, Natal, Salvador e Manaus. O MPL decidiu, então, organizar novos protestos contrários à medida e o primeiro convocou a população para o dia 6 de junho daquele mesmo ano na cidade de São Paulo. Convocadas predominantemente por meio das mídias sociais, tais manifestações tinham como principal pauta a revogação do aumento de $\mathrm{R} \$ 0,20$ na passagem do transporte público. Em relação à importância decisiva das mídias sociais nas manifestações de 2013, Marcos Bastos, Raquel Recuero e Gabriela Zago (2014), refletem:

Facebook e Twitter desempenharam um papel importante na organização das reivindicações públicas ao facilitarem a comunicação entre manifestantes e transmitir ao vivo as manifestações. [...] A informação geográfica [gerada pelas mídias sociais] era essencial para difundir informações aos leitores e ativistas, já que os protestos ocorreram em várias cidades brasileiras simultaneamente. (BASTOS; RECUERO; ZAGO, 2014, p. 1, tradução nossa). ${ }^{72}$

Acreditamos que as manifestações de junho de 2013 foram as primeiras significativas manifestações sociais no Brasil predominantemente organizadas por intermédio das mídias sociais e, portanto, são consideradas um marco decisivo no entrelaçamento entre a internet e a esfera política no país. Além da organização e mobilização dos manifestantes pelas páginas do Facebook ou perfis no Twitter, o grande revelador do poder da internet nessas manifestações se deu a partir da transmissão de informações pelo coletivo online intitulado "Mídia Ninja" (a sigla NINJA faz referência a Narrativas Independentes, Jornalismo e Ação).

\footnotetext{
72 Facebook and Twitter reportedly played an important role in the organization of public outcries, facilitating communication between protestors and live streaming the demonstrations [...] Geographic information was essential to provide context to readers and activists as protests were taking place in several Brazilian cities simultaneously. (BASTOS; RECUERO; ZAGO, 2014, p. 1).
} 
Esse coletivo foi fundado em 2011 em parceria com o "Circuito Fora do Eixo"73 e obteve maior repercussão a partir da criação da página oficial no Facebook, inaugurada em março de 2013. A definição do coletivo pelos idealizadores do Mídia Ninja, como pode ser observada a seguir, exemplifica a discussão estabelecida no capítulo anterior sobre os públicos em rede e o compartilhamento de informações que ocorre por meio das conexões online:

Somos a Mídia NINJA: Narrativas Independentes, Jornalismo e Ação. Uma rede de comunicadores que produzem e distribuem informação em movimento, agindo e comunicando. Apostamos na lógica colaborativa de criação e compartilhamento de conteúdos, característica da sociedade em rede, para realizar reportagens, documentários e investigações no Brasil e no mundo. (MÍDIA NINJA, 2016).

De acordo com Valle et al (2015), em estudo sobre a cobertura do Mídia Ninja nas manifestações de junho de 2013, o principal objetivo do coletivo era transmitir imagens ao vivo direto das manifestações. Para tanto os membros do Mídia Ninja participavam dos protestos e transmitiam as imagens - muitas vezes captadas por aparelhos celulares móveis - em tempo real diretamente do local dos protestos. Essa transmissão ao vivo e in loco tinha como proposta estabelecer uma contraproposta ou uma contranarrativa às imagens e informações veiculadas pelos principais meios de comunicação do país.

Importante ressaltar que o coletivo Mídia Ninja adquiriu amplo espaço na divulgação real time das manifestações em grande medida devido ao ocultamento das manifestações de junho de 2013 - sobretudo as primeiras jornadas - pelos principais meios de comunicação do Brasil. Das poucas vezes em que se observou cobertura jornalística dos protestos, a principal narrativa midiática era de que os manifestantes eram "baderneiros", inferiorizando, portanto, a importância das manifestações. (VALLE et al, 2015).

Outra causa para a ampliação da visibilidade do Mídia Ninja se deu devido à repulsa sofrida por repórteres dos principais meios de comunicação do país quando passaram a dar visibilidade às manifestações. Um exemplo dessa aversão ocorreu em 17 de junho de 2013, em manifestação no Largo da Batata, na cidade de São Paulo. Na ocasião o reconhecido repórter da Rede Globo, Caco Barcellos, foi hostilizado pelos participantes do protesto ao ser chamado de “manipulador". (BUCCI, 2016). Os conglomerados jornalísticos do país estavam, portanto,

\footnotetext{
${ }^{73}$ O Circuito Fora do Eixo "[...] é uma rede de coletivos culturais surgida no final de 2005. Em 2012, totalizava mais de 200 espaços culturais no Brasil, estando presente em 27 estados e em mais de 15 países da América Latina. Iniciada por produtores e artistas de estados brasileiros fora do eixo Rio-São Paulo, inicialmente focava no intercâmbio solidário de atrações musicais e conhecimento sobre produção de eventos, mas cresceu para abranger outras formas de expressão, como: audiovisual, teatro, artes visuais e música.”. (VALLE et al, 2015).
} 
com a credibilidade em baixa durante as manifestações ocorridas naquele período, o que contribuiu para o avanço do Ninja como mídia alternativa.

As manifestações de junho de 2013, ao serem estudadas por Singer (2013), têm os protestos subdivididos em etapas distintas ${ }^{74}$, sendo que a primeira etapa ocorreu nos dias 6,10 , 11 e 13 de junho e, de acordo com o pesquisador, essa fase tinha um objetivo especifico:

[...] a redução do preço das passagens do transporte publico. As iniciativas seguiram o modelo adotado pelo Movimento Passe Livre (MPL) em anos anteriores. Convocados pelas redes sociais, os manifestantes percorriam e paralisavam grandes vias públicas por horas a fio, ao final havendo escaramuças com a polícia. Foi isso que aconteceu na primeira (avenida Paulista) e na segunda (zona oeste paulistana) jornada, com a cifra de presentes subindo, ao que parece, de 2 mil para 5 mil pessoas. (SINGER, 2013, p. 24).

O confronto com a Polícia Militar (PM) foi ponto notório dos movimentos sociais daquele período e a intensificação dos embates entre PM e manifestantes fez com que o governador de SP, Geraldo Alckmin, aumentasse ainda mais o número de politicais nas ruas para os movimentos que ocorreram em 13/06/2013. "A partir daí inicia-se repressão violentíssima, que se espalha por ampla região da pauliceia, tendo a PM atuado sem controle por horas, atingindo transeuntes e jornalistas de maneira indiscriminada.". (SINGER, 2013, p. 25).

Em sequência deu-se início à segunda etapa dos movimentos, quando, de acordo com Singer (2013), o grande público (mobilizado, em grande medida, pela imprensa) se sensibilizou com a causa do MPL, bem como os manifestantes que enfrentavam a violência policial nas ruas. Em protestos convocados para 17 de junho, 75 mil pessoas (número divulgado pelo Instituto DataFolha) foram às ruas de São Paulo e as manifestações se espalharam para outras cidades brasileiras. Nessa segunda etapa do movimento os protestos deixaram de ser "apenas pelos R $\$ 0,20$ ”, e passaram a apresentar pautas diversas. Alguns manifestantes protestavam contra a corrupção política, reclamavam dos altos gastos em estádios e reformas para a Copa do Mundo de Futebol em 2014 e outros bradavam por melhorias nos setores da saúde e da educação. (SINGER, 2013).

Em 19 de junho o aumento da passagem do transporte público foi revogado na capital de São Paulo e também na do Rio de Janeiro e novas manifestações foram convocadas para o dia 20 como forma de comemoração pela conquista. No entanto, de acordo com Singer (2013), tendo sido invadidas por outras pautas além da já conhecida reinvindicação contra a alta dos preços das passagens dos transportes públicos, as manifestações, a partir de 20 de junho,

\footnotetext{
${ }^{74}$ Singer (2013) baseia sua análise nas manifestações ocorridas na cidade de São Paulo, que foram as maiores registradas no país em número de manifestantes.
} 
tomaram rumos diferentes dos inicialmente propostos pelo MP, dando início à terceira fase do movimento. "Na quinta, 20, em suposta comemoração, a onda atinge o ponto máximo, com demonstrações em mais de 100 cidades, algumas delas gigantescas, alcançando, no conjunto, cerca de 1,5 milhão de participantes.”. (SINGER, 2013, p. 26).

De acordo com pesquisa realizada pelo Instituto IBOPE em capitais de sete estados (SP, RJ, MG, RS, PE, CE, BA) e em Brasília no dia 20 de junho, a maioria dos manifestantes se encontrava na faixa etária entre 14 e 24 anos (43\%), sendo que desse total 49\% possuíam colegial completo ou ensino superior iniciado e $43 \%$ já haviam concluído o nível superior. Em relação à renda, prevaleceu o número de manifestantes com rendimento familiar entre 2 e 5 salários mínimos (30\%); enquanto aqueles com renda familiar acima de 5 e até 10 salários mínimos representavam $26 \%$ dos manifestantes. A porcentagem dos que exerciam função remunerada chegou a 76, enquanto 52\% se declararam estudantes. (CONFEDERAÇÃO NACIONAL DO TRANSPORTE, 2013).

Essa consulta demonstra que o perfil dos manifestantes era predominantemente de jovens escolarizados de classe média. Quando questionados sobre quais eram as reivindicações que os levaram a participar das manifestações, as respostas espontâneas foram: o transporte público $(37,6 \%)$, o ambiente político $(29,9 \%)$ e a saúde $(12,1 \%)$, sendo que dentre os entrevistados que indicavam o ambiente político como principal reinvindicação, 24,2\% afirmaram participar das manifestações devido à corrupção e desvios de dinheiro público. Observa-se, portanto, que a partir do dia 20 de junho, as manifestações que até então possuíam pauta definida sobre o aumento das passagens dos transportes públicos foram cooptadas por pautas e reinvindicações mais amplas, contrárias, principalmente, às instituições e atores políticos brasileiros.

O pesquisador Saad-Filho (2013) aponta que é necessário salientar o decisivo papel da imprensa na transformação das pautas das manifestações. Como discorrido anteriormente, no início dos protestos do mês de junho a mídia brasileira ocultava a cobertura dos protestos, mas, já na segunda fase das manifestações (a partir do dia 17 de junho) ela passou a dar cobertura total e, mais do que isso, a apoiar os protestos. A cobertura massiva e constante dos protestos colaborou para que as manifestações se ampliassem significativamente, principalmente em relação ao número de manifestantes. Esse autor salienta que, a partir da segunda fase das jornadas, os protestos começaram a ser retratados pela imprensa como expressão da energia e juventude popular em rejeição ao sistema político disfuncional do país. Dessa forma,

Ao trocar de lado a imprensa principal imediatamente se envolveu em uma tentativa em grande escala para liderar as mobilizações, oferecendo cobertura total, mesmo que isso custasse a não veiculação de algumas telenovelas amadas pelo público. Sob a aparência de "cobertura" a TV e os principais jornais foram efetivos em convocar pessoas para as ruas e - mais importante - patrocinaram a multiplicação e des- 
radicalização de suas demandas. Por exemplo, em um show popular da manhã na TV Globo, um dos apresentadores mais conhecidos do Brasil ensinou as mães a ajudar seus filhos a fabricar bonitos cartazes para levarem à sua próxima manifestação. (SAAD-FILHO, 2013, p. 658 , tradução nossa) ${ }^{75}$

Na perspectiva de Singer (2013), a transição da pauta dos movimentos - do aumento da passagem para a corrução - se deu devido à modificação no perfil dos manifestantes que, inicialmente representava uma "nova esquerda" trazida à tona pelo MPL, e, após o dia 20 de junho, passou a ser constituído por manifestantes "apolíticos" ou "antipartidários" insatisfeitos "com tudo e com todos" que faziam parte da esfera política brasileira. O autor ressalta:

O fato é que, a partir do momento em que importantes setores de classe média foram para a rua, o que havia sido um movimento da nova esquerda passou a ser um arco-iris, em que ficaram juntos desde a extrema-esquerda até a extrema-direita. As manifestações adquirem, a partir daí um viés oposicionista que não tinha antes, tanto ao governo federal quanto aos governos estaduais e municipais. (SINGER, 2013, p. 34).

Essa transição ocorrida nos movimentos de junho de 2013, na visão de Cardoso e Di Fátima (2013), fez surgir a narrativa do "mito do inesperado" entre intelectuais, instituições e políticos à época. Os autores (2013) exemplificam essa narrativa a partir de um trecho do discurso de Lula proferido no $19^{\circ}$ Foro de São Paulo, que reúne partidos de esquerda da América Latina. O ex-presidente afirmou que os movimentos de junho de 2013 “que aconteceram no Brasil pegaram de surpresa todos os partidos de esquerda, pegaram de surpresa todos os partidos de direita, todo o movimento sindical.”. (LULA apud CARDOSO; DI FÁTIMA, 2013, p. 151). O descontentamento dos manifestantes, portanto, gerou surpresa e impacto significativo no poder político.

Apesar do teor antipartidário das manifestações, o governo de Dilma passou a ser um dos principais focos de críticas dos manifestantes a partir da segunda fase dos protestos. De acordo com Cardoso e Fátima (2013), fundamentalmente dois fatores podem explicar a insatisfação: o primeiro, e mais óbvio, se deu devido ao fato de o governo de Dilma ser a gestão vigente à época e, por isso, seria, na percepção dos manifestantes, o principal responsável pelos problemas enfrentados pelo país; o segundo fator diz respeito diretamente ao distanciamento

\footnotetext{
${ }^{75}$ Having switched sides, the mainstream press immediately engaged in a full-scale attempt to lead the mobilizations, offering blanket coverage, even at the expense of some beloved telenovelas (soap operas). Under the appearance of 'coverage', the TV and the main newspapers effectively called people to the streets, and - very importantly - sponsored the multiplication and de-radicalization of their demands. For example, in a popular morning show on TV Globo, one of Brazil's best-known presenters taught mothers how to help their children manufacture tasteful placards for their next demonstration. (SAAD-FILHO, 2013, p. 658).
} 
entre a classe média (principal camada da população que participou das manifestações na segunda fase dos protestos) e as administrações petistas, afastamento esse ocorrido após os escândalos de corrupção divulgados em 2005, como visto anteriormente.

Em pesquisa realizada pelo instituto DataFolha, publicada em 29 de junho, é possível observar o reflexo dessa crítica ao governo Dilma a partir da queda vertiginosa dos índices de aprovação do mesmo. De acordo com a investigação em questão,

\footnotetext{
A avaliação positiva do governo da presidente Dilma Rousseff (PT) caiu 27 pontos em três semanas - período que coincide com a onda de protestos pelo país - e atingiu seu menor patamar desde o início do mandato. São $30 \%$ os brasileiros que consideram a gestão da petista ótima ou boa atualmente, ante $57 \%$ na primeira semana de junho. (DATAFOLHA, 2013).
}

Para além da análise do desgaste da imagem pública de Dilma e de seu governo, torna-se necessário ressaltar alguns apontamentos importantes sobre a imagem pública de Lula durante as manifestações de junho de 2013. De forma a lançarmos luz sobre essa reflexão discorreremos sobre duas pesquisas que analisaram a circulação de informações sobre as manifestações no âmbito das mídias sociais - visto que os protestos geraram amplo fluxo de conversação nesse ambiente.

Raquel Recuero (2014a), em estudo sobre o discurso dos veículos jornalísticos no Twitter durante os dias 3 e 20 de junho de 2013, demonstrou que, principalmente nos perfis oficiais da Folha de S. Paulo, do Portal de Notícias UOL e do Portal de Notícias R7, havia notícias que associavam o nome de Lula aos protestos. Além disso, a pesquisa apontou que o tema "Lula e Dilma" foi um dos mais presentes nas notícias veiculadas pelo perfil da Folha de S. Paulo; enquanto o termo "Lula" (associado aos nomes de Dilma e Fernando Haddad - então prefeito de São Paulo pelo PT) - se enquadrou como a principal temática acionada pelas notícias veiculadas pelo Portal R7 no Twitter durante a cobertura das manifestações de junho de 2013.

Apesar de Recuero (2014a) não ter analisado o conteúdo das postagens dos portais e, portanto, não estabelecer indícios se a imagem pública de Lula fora acionada pelos portais de forma pejorativa ou construtiva diante dos acontecimentos de junho, é necessário ressaltar a importância dos três portais de notícia - Folha de S. Paulo, do Portal de Notícias UOL e do Portal de Notícias R7 - na circulação de informações sobre as manifestações ocorridas naquele período. Recuero (2014a) ressalta que devido ao fato de as mensagens postadas por esses sites no Twitter receberem número elevado de compartilhamentos, o que amplifica a circulação dessas mensagens, a informação que é transmitida por eles passa a pautar as conversações e a circulação de informações no microblog. 
Para exemplificar a influência das informações veiculadas pelos três portais e, portanto, do acionamento da imagem pública de Lula nas notícias sobre as manifestações, lançamos luz sobre a investigação realizada por Fábio Malini et al (2014) a partir da análise de hashtags que diziam respeito às manifestações postadas no Twitter entre os dias 15 e 17 de junho de 2013. Os autores propuseram quatro categorias de análise dessas hashtags: as de caráter convocatório, as de caráter informativo, as que expressam um desejo e as que expõem uma crítica. A partir dessa classificação e com base na análise dos dados coletados em pesquisa, Malini el al (2014) afirmaram que \#lulaéocancerdobrasil (Lula é o câncer do Brasil ${ }^{76}$ ) foi uma das cinco principais hashtags utilizadas pelos usuários na categoria de exposição de crítica. Nota-se, portanto, que a imagem pública de Lula, ao ser acionada pelos portais de notícia, entrou em circulação na conversação em rede estabelecida no Twitter. Mas, como pôde ser observado a partir das publicações dos usuários do microblog, esse acionamento foi feito de forma a desconstruir a imagem pública do ex-presidente.

Necessário correlacionar o resultado obtido e apresentado na pesquisa de Malini et al (2014) com uma publicação veiculada pelo portal de notícias da Rede Globo (G1) na data de 20 de junho de 2013 em sessão intitulada "cartazes das manifestações". Tal publicação foi ilustrada com uma fotografia na qual manifestantes de São Paulo eram retratados segurando uma faixa com os dizeres: "Lula, o câncer do Brasil! Investiguem o chefe da quadrilha" e assinada pelos "Revoltados Online" que se destacou durante junho de 2013. Nota-se, por essa publicação, que os manifestantes, além de considerarem Lula uma malignidade para o país, chamavam-no mesmo de "chefe da quadrilha"78 em referência ao ex-presidente como sendo o suposto líder do grupo de políticos brasileiros corruptos. (CARTAZES..., 2013).

Observa-se, portanto, que as manifestações de junho de 2013 desgastaram em grande medida a imagem pública tanto de Dilma e do PT, quanto a de Lula. Esse estrago se intensificou sobremaneira em 2014, após a divulgação de mais um caso de corrupção descoberto pela

\footnotetext{
${ }^{76}$ A expressão "Lula é o câncer do Brasil" foi utilizada no contexto em questão como forma de responsabilizar Lula pelos males enfrentados pelo país. Dessa forma Lula seria uma "doença maligna" que prejudicaria a "saúde" e o "bem-estar" do país.

77 Discorreremos em maiores detalhes sobre o "Revoltados Online" mais adiante.

78 O termo "quadrilha" deve ser compreendido nesse contexto como um "bando de ladrões, assaltantes ou malfeitores.”. (FERREIRA, 1986, p. 1164).
} 
chamada Operação Lava Jato ${ }^{79}$ e denominado pela imprensa como "petrolão"80. Tal esquema teve início em 2004 e consistia em desvios de dinheiro da Petrobrás a partir de contratos superfaturados que se convertiam em benefícios para empreiteiras ${ }^{81}$ e para agremiações políticas. Diferentemente do escândalo político ocorrido em 2005 que se concentrou no PT, o escândalo de corrupção da Petrobrás passou a envolver quantidade maior de grupos como, por exemplo, o Partido Movimento Democrático Brasileiro (PMDB) e o Partido Progressista (PP).

Nota-se, no entanto, que ao intitular o escândalo como "petrolão" a imprensa passou a fazer clara referência ao escândalo do "mensalão" e, portanto, ao PT e assim os governos petistas passaram a ser, novamente, o centro das atenções nos noticiários na imprensa brasileira retomando a "presunção de culpa" sobre a qual Lima (2006) discorreu em relação ao escândalo de 2005. Como exemplo da "presunção de culpa" é válido relembrar que a revista Veja, na sua edição 2397, ano 47, nº 44 de 29 de outubro de 2014, divulgou matéria de capa com uma fotografia de Dilma e Lula e o título "Eles sabiam de tudo", em alusão ao escândalo da Petrobrás. Apesar de essa edição só ter sido colocada em circulação no dia 29 de outubro, a revista decidiu divulgar a capa no dia 24 de outubro, apenas 2 dias antes da data de votação para o segundo turno das eleições de 2014 em que Dilma estava concorrendo à reeleição. Importante pontuar que, novamente, há um acionamento da imagem pública de Lula mesmo após ele ter deixado a Presidência em 2010, o que confere um caráter de suma importância do ex-presidente ainda durante o mandato de Dilma.

Mesmo com a crise de imagem instituída desde as manifestações de 2013 e intensificada pelo escândalo do "petrolão", o PT conseguiu sua quarta eleição consecutiva ao reeleger Dilma no segundo turno das eleições de $2014^{82}$ com $51,64 \%$ dos votos válidos contra $48,36 \%$ dos votos obtidos por Aécio Neves (PSDB) - foi a votação mais acirrada desde a redemocratização do Brasil (AMARAL; RIBEIRO, 2015). O PSDB pediu auditoria do resultado da votação alegando "descrença quanto à confiabilidade da apuração dos votos e à infalibilidade da urna eletrônica" (MATAIS; ROSA; BULLA, 2014) o que contribuiu de sobremaneira para o acirramento da disputa política - e polarização - entre PT e PSDB.

\footnotetext{
${ }^{79}$ A Operação Lava Jato é uma "investigação conduzida no Brasil pela Policia Federal relativa a um esquema de corrupção que envolve a Petrobras. A magnitude e a importância do caso decorrem dos altos valores envolvidos, do tempo e, sobretudo, da natureza dos implicados, uma vez que percorre agentes públicos e privados.". (BAPTISTA, 2017, p. 6). O principal responsável pela operação e pelo comando das investigações da Lava Jato é o juiz Sérgio Moro da $13 .^{a}$ Vara Criminal Federal de Curitiba.

${ }^{80} \mathrm{O}$ "petrolão" é considerado o maior esquema de corrupção já descoberto no Brasil. Em novembro de 2015 a Polícia Federal (PF) estimou um rombo nos cofres públicos do país no valor de cerca de $\mathrm{R} \$ 42$ bilhões. (DIONÍSIO, 2015).

${ }^{81}$ Dentre as empreitaras envolvidas citamos a Odebrecht, Andrade Gutierrez, UTC, OAS, Camargo Correia e Queiroz Galvão.

${ }^{82}$ Michel Temer, do PMDB, foi novamente eleito vice-presidente pela chapa de Dilma Rousseff.
} 
Necessário observar que durante a campanha eleitoral do PT em 2014, o ethos institucional de Lula foi mais uma vez utilizado como forma de legitimação do governo Dilma. Exemplificamos essa perspectiva a partir dos programas do HGPE do partido nos quais a frase "no governo Lula e Dilma" foi amplamente explorada no sentido de dar credibilidade à narrativa de que o governo de Dilma era também o governo Lula e, portanto, Dilma seria a melhor candidata para, mais uma vez, dar continuidade ao lulismo. Como bem apontam Luiz Ademir Oliveira, Thamires Franco Martins e Paulo Roberto Leal (2015), é possível perceber a estratégia de aproximação, quando, em um dos discursos proferidos durante o HGPE em 2014,

[Lula] destacou que o seu segundo mandato foi melhor que o primeiro e que ele tinha a certeza que com Dilma também seria assim. Ele ressaltou que a Dilma era a candidata ideal para dar continuidade no país que estava crescendo e desenvolvendo, que a Dilma estava vencendo a pior crise da economia mundial sem diminuir o emprego e sem cortar salários. Ele enfatizou que, com esse novo Brasil, as portas para educação foram abertas, a casa própria, renda, carne na mesa, carro, viagem de avião etc, deixaram de ser privilégio de poucos e passaram a ser de muitos. (OLIVEIRA; MARTINS; LEAL, 2015, p. 13).

Em análise realizada por Michele Goulart Massuchin et al. (2016), os pesquisadores apontam que, no entanto, o "patrono político" de Dilma - expressão utilizada pelos autores para se referirem a Lula - foi citado durante o HGPE do PT apenas 3,4\% de todo o tempo utilizado pelos candidatos. O ethos institucional do ex-presidente fora mencionado de forma menos personalista e mais em relação às conquistas de seu governo. Essa estratégia de ocultamento da personalidade já instituída de Lula fora incorporada como forma de enaltecer a legitimidade e credibilidade do ethos discursivo que Dilma havia tentado conquistar durante seu primeiro mandato.

Necessário pontuar que, apesar da reeleição, o governo não foi capaz de superar a crise de imagem instituída especialmente após o início da Operação Lava Jato, em 2014. Para além do colapso de imagem ressaltamos, também, a intensificação da crise econômica que pode ser observada a partir do comparativo entre os índices apresentados desde o início do governo de Dilma até o fim de seu primeiro mandato: em 2010, ao final do mandato de Lula, o país apresentava um crescimento do Produto Interno Bruto (PIB) de 7,5\% - enquanto ao final do primeiro mandato de Dilma o índice caiu para 0,5\%. (SALES, 2016).

Em 2015, no início de seu segundo mandato, Dilma nomeou Joaquim Levy para ocupar o cargo de Ministro da Fazenda. Levy foi responsável por adotar medidas econômicas conservadoras - intituladas de "ajuste fiscal" - opostas às que foram prometidas durante a campanha eleitoral da petista em 2014 de continuidade do desenvolvimentismo dos governos 
Lula. Além de não cumprir com o prometido, as medidas econômicas adotadas no segundo mandato de Dilma muito se assemelhavam às propostas oferecidas pelo seu opositor, Aécio Neves, durante a campanha eleitoral e, portanto, foram consideradas, pelo próprio PT, como erros graves que passaram a beneficiar mais os grandes empresários (principalmente aos bancos) do que a classe popular. Como se vê, o segundo mandato de Dilma desestabilizou o interior do próprio partido (que se viu dividido sobre as medidas adotas pela presidenta) e perdeu apoio da classe trabalhadora e dos militantes (base que sempre foi imprescindível ao PT). (ALMEIDA, 2016, p. 56).

Necessário pontuar também que o governo de Dilma perdeu apoio considerável do Legislativo a partir do segundo mandato, o que agravou sobremaneira a crise política. $\mathrm{Na}$ análise realizada por Rodrigo de Almeida (2016) - então secretário de imprensa de Dilma Rousseff - Dilma passou a ser acusada de não saber dialogar com os parlamentares, característica que se revelou "[...] mortal por se tratar do cargo de presidente da República, que, goste-se ou não, requer mesuras, apoio mútuo e moeda de troca permanente para manter viva a agenda de interesse do governo.”. (ALMEIDA, 2016, p. 56). Soma-se à essa suposta "falta de diálogo" da presidenta ao fato de que o Congresso eleito para 2015 é considerado o mais conservador desde 1964, fato que contribuiu para a agravar o tensionamento entre as relações entre o Executivo e o Legislativo. (SOUZA; CARAM, 2015).

A crise de imagem, a crise econômica e a crise política acabaram por refletir em queda expressiva na aprovação do governo. Em pesquisa realizada pelo Ibope em março de 2015, primeiro ano do segundo mandato de Dilma, observou-se que a presidenta alcançou o pior índice de popularidade de seu governo desde quando a assumiu a Presidência em 2011. A consulta demonstrou que no comparativo entre dezembro de 2014 e março de 2015 a aprovação do governo Dilma caiu de 52\% para 19\%, e, além disso, o percentual de entrevistados que consideravam o governo ótimo ou bom caiu de $40 \%$ para apenas $12 \%$. Ainda de acordo com a mesma sondagem, 78\% dos entrevistados afirmaram desaprovar a maneira de Dilma governar o país e expressivos $74 \%$ diziam não confiar na presidente. (CONFEDERAÇÃO NACIONAL DA INDÚSTRIA, 2015).

Esse descontentamento pôde ser percebido a partir de uma nova onda de manifestações sociais contrárias ao governo de Dilma ocorridas em várias cidades do país, principalmente nas capitais em 15 de março de 2015 (manifestações similares a essa ocorreram, também, em 12 de abril, 16 de agosto e 13 de dezembro de 2015) ${ }^{83}$. A manifestação ocorrida em São Paulo se

\footnotetext{
${ }^{83}$ Em 08 de março de 2015, por ocasião do Dia Internacional da Mulher, Dilma fez um discurso em rede nacional que acabou por gerar manifestações em diversas cidades do país que ficaram conhecidas como "panelaço", devido
} 
tornou o maior protesto - em número de participantes - da história da capital paulista e contou com a participação de 210 mil pessoas (de acordo com o instituto DataFolha). As mídias sociais voltaram a ter papel fundamental na organização dos protestos e na mobilização para a participação nos mesmos. Constatamos, no entanto, diferenças significativas entre as manifestações de junho de 2013, ocorridas durante o primeiro mandato de Dilma e sobre as quais discorremos anteriormente, e as manifestações realizadas a partir de 2015.

A primeira diferença que deve ser esclarecida diz respeito à pauta dos protestos. Como visto anteriormente, em junho de 2013 as temáticas dos manifestantes eram generalizadas, ou seja, diluídas entre diversificadas reinvindicações (tais como revogação do aumento do preço da passagem do transporte público, melhorias em saúde e educação, fim da corrupção), ao contrário daquelas agendadas a partir de 2015, que passaram a apresentar como principal reinvindicação o impeachment de Dilma Rousseff.

Para além da temática do impeachment, Natália Scartezini (2016) aponta que as manifestações iniciadas 2015 enfatizaram também um forte apelo antipetista e antilulista. A socióloga Scartezini (2016) lembra que as palavras de ordem “'Fora Dilma', 'Fora PT', 'Lula nunca mais', 'CorruPTos' e 'Impeachment Já' foram algumas das principais insígnias bradadas nas ruas [...].”. (SCARTEZINI, 2016, p. 192, grifo nosso). Ressaltamos que um dos principais símbolos daquelas manifestações foi um boneco inflável gigante que retratava a figura de Lula com um presidiário (em referência à possibilidade de prisão de Lula). Tal boneco foi intitulado de "pixuleko", apelido dado a uma das fases da operação Lava Jato.

Sobre o aspecto antilulista e antipetista destacamos que, principalmente durante a campanha eleitoral de 2006, como visto anteriormente, houve uma tentativa - pelos imagemakers - de desvinculação da imagem pública de Lula à do PT devido as constantes denúncias do escândalo do "mensalão". A intenção, percebida durante o HGPE, era a de desassociar o nome do ex-presidente ao de seu partido. Nota-se, no entanto, que a partir das manifestações de 2015 a imagem de Lula voltou a ser acionada de forma a associá-lo ao PT; dessa forma a narrativa Lula é o PT e o PT é Lula - utilizada desde a criação do partido em 1980 até a eleição de 2002 - voltou a ser mencionada, mas de forma pejorativa pelos manifestantes opositores.

A segunda relevante diferença entre as manifestações de 2013 e as de 2015 pode ser percebida a partir do perfil dos manifestantes. Sobre essa diferenciação Scartezini (2016) discorre que os manifestantes que participaram dos protestos em 2013 provinham de classes em sinal de protesto à fala da presidenta. (TAJIBA; TRINDADE; TEIXEIRA, 2015). 
sociais mais variadas; o índice de negros nas protestações era um pouco mais elevado, bem como o de pessoas com baixo nível de escolaridade. Já nas manifestações ocorridas em 2015 esse perfil se alterou de forma a constituir-se, em vasta maioria, por homens brancos, de classes sociais elevadas e com alto nível de escolaridade. Ela argumenta:

Poderíamos resumir dizendo: ainda que uma considerável parcela da classe média urbana tenha participado dos dois momentos históricos, em 2013 foram às ruas a classe média e a classe média-baixa proletarizada, enquanto em 2015 foram às ruas a classe média e a pequena burguesia. (SCARTEZINI, 2016, p. 187).

O protesto ocorrido na cidade de São Paulo em 15 de março de 2015 apresenta um claro exemplo desse novo perfil dos militantes. Tal manifestação contou com a participação de cerca de 200 mil pessoas ${ }^{84}$. Em relação ao perfil dos participantes, uma pesquisa realizada pelo Instituto DataFolha ${ }^{85}$ revelou que a maioria dos entrevistados se declarou do sexo masculino (68\%), de cor branca (69\%), com idade entre 36 e 50 anos (37\%), com ensino superior (76\%), integrante da população economicamente ativa (85\%) e recebia entre 5 e 20 salários mínimos (49\%). (DATAFOLHA, 2015a).

Outra característica do perfil desses manifestantes foi percebida pela exacerbação do nacionalismo ${ }^{86}$ observada maiormente pela utilização da bandeira do Brasil como símbolo dos protestos, bem como pela utilização do Hino Nacional que, por vezes, era proferido como um “grito de guerra". Por esse motivo os manifestantes pró-impeachment passaram a ser intitulados de "verde-amarelos". "Em todos os protestos contra o governo, as cores verde e amarelo predominaram e o 'amor à pátria' aparecia nos cartazes e nos corpos enrolados com a bandeira do Brasil.”. (TAGATIBA; TRINDADE; TEIXIEIRA, 2015).

A terceira divergência importante entre as manifestações de 2013 e os protestos ocorridos a partir de 2015 diz respeito ao fato de que os últimos foram organizados predominantemente por grupos opositores ao governo petista e liderados "por jovens de classes média e alta e com alta instrução acadêmica" (SCARTEZINI, 2016, p. 190) e que se autodenominam como apartidários (que não seguem ou não têm filiação com nenhum partido político) ou suprapartidários (que não se subordinam a nenhum partido).

\footnotetext{
${ }^{84}$ De acordo como Instituto DataFolha, essa manifestação superou, em número de participantes, aquelas ocorridas em junho de 2013 e passou a ser a segunda maior manifestação registrada na capital paulista desde as "Diretas Já". DATAFOLHA, 2015a).

${ }^{85}$ A pesquisa foi realizada com os manifestantes que participaram dos protestos ocorridos na cidade de São Paulo.

${ }^{86}$ Essa exarcebação do nacionalismo, no entanto, fez gerar um impacto negativo nas manifestações por terem atraído ou - mesmo ter sido cooptada - por grupos favoráveis ao retorno da ditadura militar. (SCARTEZINI, 2016).
} 
Apesar do apelo do apartidarismo ou suprapartidarismo, tais grupos possuem posicionamentos à direita do espectro político que podem ser percebidos, dentre outros fatores, na defesa do liberalismo econômico, das privatizações e do conservadorismo; e na crítica a programas de assistência social (o PBF foi incisivamente criticado pelos manifestantes). (SCARTEZINI, 2016; TATAGIBA, TRINDADE, TEIXEIRA; 2015; ANDERSON, 2016; ORTELLADO, SOLANO, 2016). Dentre os grupos acima mencionados, três se destacaram: o Movimento Brasil Livre (MBL), o "Vem pra Rua" e o Revoltados Online (ROL) ${ }^{87}$. A organização das manifestações e a mobilização para as mesmas se deram essencialmente - e de maneira intensa - pelas mídias sociais a partir de páginas oficiais no Facebook, canais de vídeo no YouTube e perfis no Twitter.

O posicionamento à direita, característico dos grupos organizadores das manifestações, tem um reflexo direto no perfil dos manifestantes. Tatagiba, Trindade e Texeira (2015), baseados em pesquisa realizada pelo Instituto Datafolha ${ }^{88}$, apontam que a grande maioria dos manifestantes dizia se localizar entre o centro e a direita no espectro político-ideológico. E, quando questionados sobre a adesão político-partidária, a maioria afirmou não ter um partido favorito, mas, dentre os que disseram ter preferência por um o PSDB apareceu como o mais citado.

Importante destacar sobre essa escolha partidária que o próprio PSDB declarou publicamente o apoio aos grupos organizadores e às manifestações, em nota publicada no site oficial do partido em 11 de março de 2015. A seguir citamos um trecho da nota em questão:

\begin{abstract}
O Partido da Social Democracia Brasileira (PSDB) se solidariza com as manifestações de indignação dos brasileiros diante da flagrante degradação moral e do desastre econômico-social promovidos pelo governo Dilma Rousseff. O PSDB defende a livre manifestação de opinião e o direito à expressão dos cidadãos e, portanto, apoia os atos pacíficos e democráticos convocados para o próximo dia 15 de março em todo o país. (PARTIDO DA SOCIAL DEMOCRACIA BRASILEIRA, 2015).
\end{abstract}

Ressaltamos, no entanto, que durante as primeiras manifestações, ocorridas em 15 de março, o partido anunciou que apoiava os manifestantes, porém não era favorável à pauta do impeachment. Em palestra realizada no dia 18 de março, FHC declarou posição contrária ao impedimento de Dilma e afirmou: "O impeachment é como a bomba atômica, não serve para usar, só para intimidar.”. (FHC apud LIMA, 2015). Em matéria publicada pelo jornal Estado

\footnotetext{
${ }^{87}$ Necessário pontuar que o ROL apresenta uma diferença ideológica em relação aos outros dois grupos citados por posicionar-se de forma favorável à intervenção militar no Brasil. (FIRMINO, 2016).

${ }^{88} \mathrm{~A}$ pesquisa foi realizada com os manifestantes que participaram dos protestos pró-impeachment em 16 de agosto de 2015 na cidade de São Paulo.
} 
de S. Paulo em 11 de março de 2015, Aécio Neves, então presidente do PSDB, justificou que seu partido era favorável às manifestações, embora a pauta do impeachment não fizesse parte da agenda do PSDB no momento. (VENCESLAU, 2015).

A estratégia do PSDB em se afastar da pauta do impeachment foi alterada, principalmente, a partir de agosto, quando ocorreram novas manifestações reivindicando a saída da presidenta Dilma. No dia 06 de agosto, o partido utilizou seu tempo de propaganda política na TV para convocar os brasileiros a participarem das manifestações que ocorreriam 10 dias depois, em 16 de agosto. O vídeo em questão, veiculado em rede nacional, teve duração de 30 segundos e a pauta principal de convocação foi argumentada a partir do suposto cansaço do povo brasileiro diante de "tanta mentira e tanta corrupção" (PARTIDO DA SOCIAL DEMOCRACIA BRASILEIRA, 2015a). Ao final aparece a logomarca do partido e os dizeres "PSDB: oposição a favor do Brasil".

Além das manifestações pró-impeachment, o ano de 2015 também foi tomado por uma onda de protestos convocados, predominantemente, por centrais sindicais. A primeira dessas jornadas ocorreu em 13 de março de 2015 e foi convocada e organizada pela Central Única dos Trabalhadores (CUT), pelo Movimento dos Sem Terra (MST) e pela União Nacional dos Estudantes (UNE). A maior dessas manifestações, a do dia 13 de março em São Paulo contou com cerca de 41 mil manifestantes sendo menos expressiva (em número de participantes) do que as ocorridas em 15 de março (pró-impeachment). (MENDONÇA, 2015).

Necessário ressaltar que, apesar dos organizadores serem tradicionalmente apoiadores do governo petista, as manifestações organizadas pelas centrais sindicais tinham forte apelo crítico ao governo Dilma devido às medidas econômicas adotadas em seu segundo mandato. De acordo com o manifesto publicado na página oficial da CUT na internet, os protestos de 13 de março de 2015 tinham como principal motivo a defesa: 1) da democracia e da reforma política; 2) da Petrobrás; e 3) dos direitos da classe trabalhadora. Nota-se, portanto, que não houve pauta que identificasse apoio explícito ao governo Dilma. No entanto, a imprensa dedicou-se a divulgar as manifestações organizadas pelas centrais sindicais como manifestações "pró-Dilma".

O então presidente da CUT, Vagner Freitas, em discurso durante o $12^{\circ}$ Congresso Nacional da CUT, realizado dia 6 de março de 2015, em Brasília (Distrito Federal), declarou que "setores da velha mídia" estariam cometendo um erro ao tentar "estabelecer comparação entre os atos do dia 13 e outras convocações que ocorreram por meio das redes sociais. Os atos do dia 13 têm nome e endereço. É a CUT, a UNE, o MST, as centrais parceiras, os movimentos sociais.”. (FREITAS apud CARVALHO, 2015). 
Um exemplo dessa comparação estabelecida pela imprensa pode ser observado em matéria veiculada pela Veja e publicada no portal online dessa revista no dia 16 de março de 2015. No texto fica perceptível a polaridade estabelecida entre as manifestações próimpeachment e aquelas organizadas pelas centrais sindicais. No título da reportagem a publicação questiona: "Do tamanho à espontaneidade dos participantes, por que os atos contra e a favor da presidente Dilma Rousseff são tão díspares?”. (6 DIFERENÇAS..., 2015, grifo nosso). Além da divisão entre dois polos contrários, a matéria cita diferenças entre as manifestações de forma a, claramente, identificar os protestos pró-impeachment como mais expressivos e importantes que os protestos convocados pelas sindicais.

A CUT e outras centrais sindicais somente se uniram em organização de novos protestos a partir de agosto de 2015 (ocorreram outras manifestações em 20 de agosto). Pontuamos, no entanto, que os organizadores voltaram a enfatizar que a reinvindicação continuava sendo a defesa da democracia (e não do governo Dilma) por acreditarem que o processo de impeachment da presidenta seria inconstitucional.

Mesmo com o tom enfático de não ser um protesto favorável ao governo Dilma, a imprensa continuou divulgando tais manifestações de maneira a identificar oposição entre os atos públicos. Mais um exemplo dessa polaridade pode ser observado em matéria publicada em 20 de agosto de 2015 (data em que ocorreram as segundas manifestações puxadas pelas centrais sindicais), no portal online de notícias da Rede Globo (G1) intitulada Manifestantes fazem atos em defesa de Dilma em 25 estados e no DF. A reportagem em questão argumenta que as manifestações das centrais sindicais se deram em "reação a atos pró-impeachment", o que intensifica o tom opositor entre os dois tipos de protestos. (MANIFESTANTES FAZEM..., 2015).

Necessário chamar atenção para o fato de que o PT apoiou publicamente os protestos ocorridos em 13 de março e 20 de agosto de 2015, mas houve contradições e desentendimentos entre o partido e as centrais sindicais, pois, como visto, as entidades protestavam também contra o governo petista e as medidas econômicas adotadas por Dilma.

No dia 12 de dezembro daquele ano deputados e senadores do PT se reuniram com o então presidente do partido, Rui Falcão, durante o Diretório Nacional do PT, em Brasília (DF), de forma a procurar unir as pautas das centrais sindicais à agenda do partido para dar foco e direcionamento aos protestos que ocorreriam quatro dias depois. (BRANDÃO, 2015). Entendemos, pois, que a principal diferença entre as manifestações ocorridas em 16 de dezembro e as duas anteriores diz respeito à organização e mobilização para os protestos que, contou, então, com a participação do PT e de sua militância. 


\subsubsection{A instauração do processo de impeachment}

Em 07 de outubro de 2015 o Tribunal de Contas da União (TCU) decidiu, por unanimidade, rejeitar as contas apresentadas pelo governo de Dilma ao final do primeiro mandato, alegando crime de responsabilidade fiscal. Esse tipo de ilicitude, na visão do juiz e desembargador Luiz Fernando Whitaker da Cunha (2015), compreende os atos

[...] cometidos em razão de certos cargos públicos [...] os atribuíveis ao Presidente da República, por atentarem contra a Constituição Federal, devendo esses delitos serem definidos em lei especial [...], que deverá estabelecer normas de processo e julgamento, sendo certo que, mesmo tentados, são seus agendes passíveis da perda de cargo, com inabilitação, para o exercício de qualquer função pública. (CUNHA, 2015, p. 35).

A principal denúncia apresentada pelo TCU em relação ao crime de responsabilidade praticado pelo governo de Dilma Rousseff baseou-se nas chamadas "pedaladas fiscais" "89, que, como explica Ricardo Lodi Ribeiro (2015), constituem:

[...] o apelido dado ao sistemático atraso nos repasses de recursos do Tesouro Nacional para que o Banco do Brasil, a Caixa Econômica Federal e o BNDES paguem benefícios sociais como o Bolsa-Família, Minha Casa Minha Vida, seguro desemprego, crédito agrícola etc. Como as instituições financeiras pagam em dia os benefícios, o atraso no repasse dos recursos públicos gera contratualmente o pagamento de juros pelo governo aos bancos públicos. (RIBEIRO, 2015, p. 3).

Esse cenário é analisado por Ricardo Glasenapp e Alessandra de Farias (2016), para quem o parecer do TCU em relação ao crime de responsabilidade fiscal do governo petista se tornou o argumento central do pedido de impeachment ${ }^{90}$ de Dilma Rousseff elaborado pelos juristas Hélio Bicudo, Miguel Reale Júnior e Janaina Paschoal ${ }^{91}$, que tiveram apoio irrestrito de partidos da oposição, principalmente do PSDB. Esse pedido foi entregue ao presidente da Câmara dos Deputados, Eduardo Cunha (PMDB), em 21 de outubro de 2015 e, então, analisado por uma

\footnotetext{
${ }^{89} \mathrm{O}$ enquadramento (ou não) das "pedaladas fiscais" como crime de responsabilidade foi amplamente discutido entre juristas, acadêmicos e especialistas no tema, porém não nos cabe, nessa pesquisa, argumentar sobre a legalidade ou ilegalidade da prática em questão ou se a mesma se enquadra ou não, perante a Constituição, como crise de responsabilidade fiscal. Nosso objetivo é apenas contextualizar os fatos ocorridos.

${ }^{90}$ De acordo com Aníbal Pérez-Liñán (2007), "nos sistemas presidenciais, o termo "impeachment" descreve um julgamento particular do presidente que permite ao Congresso (às vezes com o acordo necessário do Poder Judiciário) retirar o presidente do cargo.”. (PÉREZ-LIÑÁN, 2007, p. 6, tradução nossa).

${ }^{91}$ Pontuamos que esse não foi o único pedido de impeachment de Dilma Rousseff recebido pelo Congresso Nacional. De acordo com a Lei de número 1.079, de abril de 1950, qualquer cidadão pode denunciar ao Congresso um presidente ou ministro de Estado, o que pode aumentar significativamente o número de pedidos, embora a grande maioria seja arquivada por não atender aos pré-requisitos básicos - como a comprovação da acusação. $\mathrm{O}$ governo de Dilma foi o que mais recebeu pedidos de impeachment desde a redemocratização do Brasil - um total de 48 (até abril de 2016), sendo 34 deles somente em 2015.
} 
comissão de parlamentares que apresentou parecer favorável à denúncia. Eduardo Cunha autorizou a instauração do processo em 02 de dezembro daquele ano ${ }^{92}$.

No mesmo dia 02 de dezembro, Dilma fez um pronunciamento oficial em sua defesa e afirmou ter recebido "com indignação a decisão do senhor presidente da Câmara dos Deputados de processar pedido de impeachment contra mandato democraticamente conferido a mim pelo povo brasileiro.”. (DILMA ROUSSEFF apud CALGARO; MATOSO, 2015). Por ocasião do pronunciamento, Dilma argumentou ainda, que eram "inconsistentes e improcedentes" as fundamentações do pedido de impeachment, e afirmou não ter praticado qualquer ato ilícito.

\subsection{Narrativas em disputa: impeachment versus golpe}

A partir da descrição da conjuntura político-social estabelecida a partir de 2015 - qual seja: as manifestações sociais e a instauração do processo de impeachment - ressaltamos a predominância de dois grupos opostos: os ativistas pró-impeachment, que possuem forte apelo antipetista e antilulista e participam de protestos organizados por grupos de direita opositores ao governo do PT; e os manifestantes contrários ao impeachment que participam de protestos organizados e mobilizados, em um primeiro momento, pelas centrais sindicais, e já ao fim do ano de 2015 contaram com a organização e mobilização também do PT e da militância petista.

Essa divisão entre as manifestações fez emergir indagações sobre a possibilidade de polarização política na sociedade brasileira - expressa, em predominância, nas mídias sociais. Os estudos elaborados por Fernando Lattman-Weltman (2015), bem como os de Esther Solano, Pablo Ortellado e Márcio Moretto (2017), apresentam perspectivas complementares sobre a concentração política no Brasil, pois ambas as abordagens compreendem que essa radicalização não é fenômeno recente no país, embora tenha se intensificado principalmente a partir de 2005 , após o escândalo do "mensalão" e radicalizou-se a partir das eleições de 2014.

De acordo Lattman-Weltman (2015), a crescente e constante utilização da internet que, como discutido no capítulo anterior, amplia os locais de participação argumentativa, corroborou

\footnotetext{
92 Na história recente da América Latina (décadas de 1990 e 2000) seis presidentes enfrentaram processos de impeachment sendo eles: Fernando Collor de Mello (Brasil, 1992), que renunciou ao cargo da Presidência horas antes da votação do impeachment - o processo teve continuidade mesmo após sua renúncia; Carlos Andrés Pérez (Venezuela, 1993), que foi destituído do cargo; Ernesto Samper (Colômbia, 1996) - conseguiu evitar a consolidação do impeachment e permaneceu no cargo; Abdalá Bucaram (Equador, 1997), foi afastado por ter sido declarado mentalmente incapaz de ocupar o cargo de presidente do país; Raúl Cubas Grau (Paraguai, 1999) que, assim como Collor, renunciou ao cargo pouco antes da votação do processo de impeachment; e Luis González Macchi (Paraguai, 2002) - não foi destituído do cargo porque não houve votos suficientes no Senado que justificasse a legalidade do impedimento. (BRANDÃO, 2016, p. 84).
} 
também para a ampliação de espaços nos quais há maior possibilidade de conflitos argumentativos ou disputas narrativas polarizadas. De acordo Lattman-com Weltman (2015),

[...] a popularização do acesso às redes e à vertiginosa oferta de conteúdo informacional via Internet, vem favorecendo a ampliação exponencial da participação argumentativa de um universo cada vez mais amplo e diversificado de indivíduos que anteriormente, por uma série de razões, poderiam permanecer isolados uns dos outros, sem espaço ou oportunidade de interação comunicativa e de desenvolvimento. (LATTMAN-WELTMAN, 2015, p. 4).

No entanto, para que se compreenda o fenômeno da polarização política no Brasil Lattman-Weltman (2015) propõe, em primeiro lugar, o entendimento das posições ocupadas pelos militantes ou simpatizantes (de partidos ou ideais políticos), que são "indivíduos que, por várias razões, ultrapassam certo limiar de envolvimento na vida política e no consumo mais intenso de informações políticas" (LATTMAN-WELTMAN (2015, p. 3) e pelos cidadãos comuns (maioria no país), que

[...] pouco investem de seu tempo e recursos no acompanhamento do mesmo mundo da política, e que, independentemente de suas eventuais idiossincrasias ou supostas inconsistências, seguem possuindo a prerrogativa de decidir as disputas eleitorais e dando a palavra final e decisiva em democracias autênticas (como a brasileira, atual). (LATTMAN-WELTMAN, 2015, p. 3).

De acordo com Lattman-Weltman (2015), ao contrário do que pode parecer os militantes/simpatizantes - por serem consumidores mais ávidos das informações políticas - são mais suscetíveis à influência dessas informações. Por essa abordagem, vê-se, portanto, que é de se esperar que a polarização ocorra, na verdade, apenas no núcleo constituído pelos militantes/simpatizantes.

No entanto, Lattman-Weltman (2015) ressalta que, com a facilidade do acesso a informações políticas (jornalísticas) pelas mídias sociais, há um novo contingente de cidadãos comuns que passaram a "vivenciar a vida política com as características típicas" (LATTMANWELTMAN, 2015, p. 19) dos militantes/simpatizantes - mas o pesquisador chama atenção também para o fato de que esse contingente de pessoas que agora milita ou simpatiza por um partido ou causa política possui um perfil ideológico mais à "direita". Assim o estudioso reflete que essa alteração ocorrida do cidadão comum ao militante/simpatizante

[...] tende a favorecer não somente a radicalização de posições e preferências, como também a fazer do novo simpatizante/militante um consumidor mais ávido da oferta informacional midiática, tornando-o, portanto, na verdade, mais influenciável por essa mesma. (LATTMAN-WELTMAN, 2015, p. 19). 
A polarização, no entendimento desse estudioso, é, em realidade, uma radicalização das opiniões políticas dos cidadãos que, a partir dos espaços online de argumentação, passam a ter maior possibilidade de expor alegações distintas. Baseado na abordagem apresentada pelo filósofo político Carl Schmitt (1992) em obra intitulada O Conceito de Político, LattmanWeltman (2015) argumenta que esse posicionamento político radical se intensifica por meio de uma disputa entre "amigos" - com posições políticas iguais - e "inimigos" - que possuem posicionamento político oposto.

De acordo com Carl Schmitt (1992) o fenômeno político - ou o conceito de político - é o lugar próprio do embate entre amigos versus inimigos, lugar este em que há sempre uma fala proferida por alguém contra outrem. O campo político é, portanto, um campo de antagonismos entre "nós" e "eles". "Assim como o domínio da moral é determinado pelas noções de bem e mal, o estético pelas de belo e feio, o econômico pelas categorias do lucro, a política pode ser definida a partir da distinção amigo-inimigo.”. (SILVA, 2008).

Bernardo Ferreira (2004), estudioso da abordagem schmittiana, ressalta, no entanto, que nem todo embate é uma luta política - o que leva o embate ao nível de luta política é a possibilidade limite da "guerra" aqui compreendida como aniquilação do inimigo. Desta forma,

\footnotetext{
o outro se torna o meu inimigo quando aquilo que ele é representa para mim a negação daquilo que eu sou, daí a possibilidade de combatê-lo para preservação da minha própria forma de existência. [...] A inimizade constitui, portanto, a expressão mais radical da experiência da alteridade, ou seja, a circunstância em que a diferença é percebida como uma negação absoluta. (FERREIRA, 2004, p. 42).
}

Da mesma forma que Latman-Weltan (2015), os autores Solano, Ortellado e Moretto (2017) compreendem essa radicalização argumentativa ou a polarização da política brasileira contemporânea como "binarização social em dois supostos bandos confrontados, não só de adversários e, sim, de inimigos”. (SOLANO; ORTELLADO; MORETTO, 2017, p. 159). Essa disputa entre "amigos" e "inimigos" é intensificada pelo consumo de informações midiáticas (a partir de um contingente de veículos jornalísticos que possuem posições político-ideológicas claramente distintas). A mídia, portanto, se torna um instrumento intrínseco ao processo de polarização argumentativa observada nos tempos atuais.

Recorre-se novamente a Lattman-Weltman (2015), pela sua ênfase de que esse fenômeno de radicalização argumentativa oposta no Brasil atual tem facilitado o surgimento de grupos como, por exemplo, o MBL o Vem pra Rua e o ROL, que 
[...] se assumem como sendo de "direita", algo que interrompe uma longa trajetória de relativa marginalização desse tipo de identidade. E certamente o forte ressentimento acumulado por tais grupos ao correr de décadas de hegemonia de identidades de centro-esquerda - mas acima de tudo o longo período de hegemonia eleitoral do PT no comando do país - acirram ainda mais os ânimos de seus membros e ideólogos. (LATTMAN-WELTMAN, 2015, p. 20).

A disputa "nós" versus "eles" (petistas e antipetistas, por exemplo), ao mesmo tempo que é capaz de gerar novas formas de pertencimento societário, reproduz "preconceitos e supostos índices de distinção e hierarquização social e cultural" (LATTMAN-WELTMAN, 2015, p. 4) que intensificam os radicalismos e podem gerar desgaste ou diluição do debate público.

Ainda de acordo com as duas perspectivas acima apresentadas, acrescentamos a abordagem de Rodrigo Carreiro e Wilson Gomes (2017) sobre o acirramento das disputas argumentativas online. Esses pesquisadores, ao explorarem a polarização política nesses ambientes discorrem que, somado à disputa entre amigos e inimigos ocorre um “comportamento de defesa identitária de pontos de vistas ou valores.". (CARREIRO, GOMES, 2017, p. 20).

Essa defesa identitária da qual tratam Carreiro e Gomes (2017), lança luz sobre os desacordos ocorridos no âmbito online que, em grande medida, ocorrem no sentido de proteger determinado ambiente (seja uma página no Facebook, um perfil no Twitter ou ainda numa rede de pessoas conectadas entre si) da possibilidade de "invasão" de pessoas consideradas "de fora". Dessa forma, "a discordância se impõe para que se demonstre autoridade perante os usuários que não fazem parte daquela 'rede' identitária específica, além de ser um modo de manutenção do pensamento corrente e da coesão interna.”. (CARREIRO, GOMES, 2017, p. 21).

Pontuamos que a crise política instituída, predominantemente, após a reeleição de Dilma, intensificou-se sobremaneira durante o ano de 2016 devido à aceitação da instauração da ação de impeachment da presidente na Câmara dos Deputados, e os desdobramentos desse processo ao longo do ano. Como vistas a contextualizarmos a crise política em 2016, utilizaremos as perspectivas acima discorridas sobre a polarização política observada com maior intensidade nas mídias sociais, como base para o entendimento de um fenômeno simbólico que julgamos ser intrínseco ao período político brasileiro contemporâneo.

Compreendemos tal fenômeno como uma disputa de sentidos entre duas narrativas principais: a) a narrativa do impeachment, acionada pelo grupo favorável à destituição de Dilma da Presidência da República e opositor ao governo petista e; b) e a narrativa do golpe, acionada pelos militantes contrários ao impedimento, mas não necessariamente apoiadores do governo de Dilma. Discorreremos sobre as duas narrações a seguir. 


\section{- $\underline{\text { Narrativa do impeachment }}$}

Para que possamos contextualizar e lançar luz sobre a narrativa do impeachment, devemos retornar ao pleito eleitoral de 2014 em que Dilma foi reeleita em $2^{\circ}$ turno com número de votos pouco maior que de seu principal opositor, Aécio Neves (2016). Como apontado anteriormente, a possibilidade de ingovernabilidade de Dilma diante de um Congresso Nacional conservador, bem como do desfalecimento de sua base aliada, começou a gerar dúvidas sobre a continuidade do governo da presidenta.

Em 24 de outubro de 2014, o jornalista Merval Pereira (2016), em seu blog vinculado ao jornal O Globo foi um dos primeiros a utilizar, publicamente, o termo "impeachment" e a possibilidade da ocorrência do mesmo no segundo mandato de Dilma. Como justificativa para essa possibilidade de impeachment, Pereira (2016) cita a matéria publicada pela revista Veja na mesma data de 24 de outubro, em que Lula e Dilma são acusados de "saberem tudo" sobre o esquema de desvio de dinheiro no escândalo do "petrolão". Baseado no argumento de que, caso fosse comprovado que o ex-presidente Lula e Dilma estariam envolvidos em esquemas de corrupção, Pereira (2014) afirmou que o impeachment da presidenta seria “inevitável” e que o país corria o risco de estar condenado "a uma crise institucional das grandes com membros do Congresso, governadores e até a presidente eleita envolvidos em um processo criminal mais grave do que o mensalão.”. (PEREIRA, 2014). A partir do pleito eleitoral de 2014, portanto, já se observava a mobilização pela possibilidade de afastamento de Dilma do cargo da Presidência, caso fosse reeleita.

Como já discorrido nesta tese, a partir de março de 2015 manifestações por todo o país passaram a pedir pelo impeachment da então presidenta, impulsionadas por grupos à direita do espectro político e apoiadas fortemente pelo principal partido da oposição, o PSDB. Ao final daquele ano o pedido de impeachment, baseado na argumentação dos crimes de responsabilidade fiscal que teriam sido cometidos pelo governo de Dilma Rousseff, foi aceito e protocolado pelo então presidente da Câmara dos Deputados, Eduardo Cunha (PMDB). Desde então, a narrativa do impeachment passou a ser intensamente utilizada não só em atos públicos, mas também, e sobretudo, pela imprensa e pela oposição.

Em editorial publicado pelo Estado de S. Paulo, em 13 de março de 2016, o jornal demonstrou sua posição em relação ao afastamento da então presidenta e passou a legitimar, publicamente, a narrativa do impeachment. A coluna tinha como título "Chegou a hora de dizer: basta!", em alusão a um suposto cansaço da “maioria dos brasileiros" diante da corrupção dos 
governos petistas. A editoria do periódico argumentou, ainda, que o impeachment poderia ter sido evitado caso Dilma tivesse tido a "grandeza de renunciar ao cargo". (CHEGOU..., 2016). Nota-se a utilização da narrativa do salvador ao acionar um suposto poder grandioso que, de acordo com o jornal, Dilma não possui.

O gesto de renúncia, de acordo com o jornal, seria nobre diante da situação caótica em que o país se encontrava, mas como Dilma se negou a deixar o cargo o impeachment seria “inevitável e aceleraria a urgentíssima transição para um governo munido da legitimidade indispensável para reunificar o País e conduzi-lo para longe da tormenta.”. (CHEGOU..., 2016). Necessário observar que a legitimação da narrativa do impeachment, no editorial em questão, é feita de forma a nomear os "inimigos do país", quais sejam: Dilma, Lula e o PT (que o jornal intitula de "lulopetismo"), e assim argumentar que, mesmo sendo um processo "traumático" o impedimento da presidenta seria a única forma de livrar o país da crise. A coluna enfatiza:

[...] já ficou reiteradamente claro que Dilma, Lula e os petistas são incapazes de pensar senão em salvar seus mesquinhos interesses, além da própria pele. Diante disso, resta aos cidadãos brasileiros mostrarem seu poder, proclamando, inequivocamente, que não admitem mais que o lulopetismo, desonesto e incompetente, continue encastelado no governo. (CHEGOU..., 2016).

Um mês após a publicação desse editorial pelo Estado de S. Paulo, em 17 de abril de 2016, o PSDB publicou uma nota no site oficial do partido na qual constava sete pilares argumentativos para a legitimação da narrativa do impeachment. Esses sete pilares eram baseados nos sete pecados capitais (em referência à religião católica) que teriam sido cometidos por Dilma e que justificariam o seu afastamento do cargo da Presidência. (PARTIDO DA SOCIAL DEMOCRACIA BRASILEIRA, 2016).

Pontuamos que essa nota publicada pelo PSDB foi baseada em matéria do jornal Folha de S. Paulo e intitulada "Veja os sete pecados capitais que levaram Dilma ao inferno político", publicada, também, em 17 de abril de 2016. Dessa forma, consideramos que as ideias do jornal foram apropriadas pelo partido como um processo de retroalimentação entre o campo político e o campo jornalístico - mesmo processo que fora observado por Azevedo (2010) no pleito eleitoral de 2006.

Discutiremos, a seguir, sobre cada um dos sete pontos apresentados no referido texto para que seja possível observar, em detalhes, a forma como foi utilizado o discurso dos "pecados" com vistas a afirmar que o impeachment seria, em verdade, consequência dos atos culposos da então presidente e, por isso, era legitimo e necessário. 
1) O pecado da soberba: De acordo com a publicação, Dilma passou a colecionar desafetos devido à "falta de tato político" e ao "temperamento difícil". A matéria afirma que "a inaptidão para lidar com o Congresso Nacional fez com que a petista perdesse aliados e quase toda a sua base de sustentação. $O$ isolamento pode ser fatal a um presidente da República.”. (PARTIDO DA SOCIAL DEMOCRACIA BRASILEIRA, 2016).

2) O pecado da avareza: A presidente teria cometido o pecado da avareza ao não cumprir com promessas realizadas pelo seu governo após as manifestações de junho de $2013^{93}$.

3) O pecado da inveja: Para os legitimadores do discurso, Rousseff não soube lidar com o PMDB, principal aliado do governo, o que levou ao rompimento de tal relação ${ }^{94}$. Dessa forma, "a inveja está no fato da presidente não conseguir lidar com o fato de que, caso o impeachment seja aprovado, terá que entregar o seu cargo a Temer.”. (PARTIDOS DA SOCIAL DEMOCRACIA BRASILEIRA, 2016).

4) O pecado da preguiça: $O$ partido ressalta que o pecado da preguiça foi praticado pelo governo de Dilma Rousseff a partir do momento em que ela não soube conduzir a economia brasileira, levando a mesma à maior recessão dos últimos tempos. Os legitimadores da narrativa do impeachment apontam erros tais como "populismo, gestão falha da Petrobrás e uma nova matriz econômica que destruiu a estabilidade econômica conquistada pelo Plano Real" (PARTIDOS DA SOCIAL DEMOCRACIA BRASILEIRA, 2016) como principais causas do retorno da inflação, do aumento do desemprego, da volta de milhões de brasileiros à condição de pobreza e da queda do PIB.

5) O pecado da luxúria: O partido acusa Dilma de ter feito uma campanha eleitoral em 2014 "luxuriante" por ter lançado mão "de diversas mentiras com o intuito de se manter no poder.". (PARTIDOS DA SOCIAL DEMOCRACIA BRASILEIRA, 2016).

6) O pecado da ira: Esse teria sido cometido por Rousseff após o anúncio de rompimento do presidente da Câmara, Eduardo Cunha (PMDB-RJ), com o governo federal em julho de 2015. A ira, da qual trata o PSDB, diz respeito a um suposto desgosto de Dilma diante da decisão de Cunha.

\footnotetext{
93 As promessas não cumpridas sobre as quais trata o texto publicado pelo PSDB, dizem respeito ao pronunciamento oficial do governo, em 24 de junho de 2013, logo após as manifestações. Nessa declaração Dilma anunciou cinco pactos "em favor do Brasil", sendo eles: pacto pela responsabilidade fiscal, pacto pela reforma política, pacto pela saúde: "importação" de médicos estrangeiros para trabalhar nas zonas interioranas do país e mais vagas para estudantes de medicina, pacto pelo transporte público e pacto pela educação pública. (CALGARO, MOROMURA, 2013).

${ }^{94}$ Esse rompimento entre PT e PMDB será mais detalhado à adiante.
} 
7) O pecado da gula: De acordo com os legitimadores da narrativa do impeachment a gula do governo Dilma deu-se a partir dos inúmeros escândalos de corrupção que, de acordo com a publicação, "chegou a níveis inimagináveis, vindo à tona pelas investigações da Operação Lava Jato.”. (PARTIDOS DA SOCIAL DEMOCRACIA BRASILEIRA, 2016). O PSDB ressaltou ainda que "para complicar a situação da presidente, Dilma viu o seu próprio nome ser envolvido nas denúncias [e] a investigação também chegou ao seu mentor, o ex-presidente Lula.”. (PARTIDO DA SOCIAL DEMOCRACIA BRASILEIRA, 2016).

A partir das observações acima discorridas concluímos que a principal argumentação da narrativa do impedimento, legitimada pelos juristas responsáveis pela denúncia, pela imprensa, pelo principal partido de oposição (PSDB) e pelos grupos organizadores das manifestações próimpeachment, baseia-se, sobretudo, nos erros cometidos pelo "lulopetismo" e que acabaram por gerar a impopularidade e a ingovernabilidade de Dilma Rousseff, bem como - e em menor medida - nos supostos crimes de responsabilidade fiscal que teriam sido praticados pelo governo Dilma.

\section{- Narrativa do golpe}

A narrativa do golpe começou a ganhar notoriedade, principalmente a partir das manifestações de 2015, quais sejam: as organizadas pelas centrais sindicais e apoiadas pelo PT que tinham como uma das pautas principais a reinvindicação contra o impedimento de Dilma Rousseff e a defesa da democracia. Apesar das divergências entre os organizadores desses atos públicos, que, como dito anteriormente, criticavam as medidas econômicas do governo Dilma ao mesmo tempo que recriminavam o impeachment (ou seja, havia incoerência entre criticar o governo e defender a permanência do mesmo), a narrativa do golpe serviu para unir as pautas entre as centrais sindicais, o PT e a militância.

Oportuno citar Carlos Barbé (1998), que, em verbete sobre a expressão “Golpe de Estado" (coup d'État) publicada no Dicionário de Política organizado por Bobbio, Matteucci e Pasquino, explica que tal expressão sofreu alterações significativas ao longo do tempo. $\mathrm{O}$ pesquisador esclarece que as diferenças entre o emprego da expressão três séculos atrás e o seu uso atualmente "vão, desde a mudança substancial dos atores (quem o faz), até a própria forma do ato (como se faz).”. (BARBÉ, 1998, p. 545). Barbé (1998) aponta apenas um elemento que 
se manteve invariável ao longo dos anos, qual seja: “o Golpe de Estado é um ato realizado por órgãos do próprio Estado.”. (BARBÉ, 1998, p. 545).

Esse autor ressalta, ainda, que a expressão golpe de Estado foi primeiramente utilizada na obra de Gabriel Naudé, publicada em 1639, intitulada Considerações políticas sobre o golpe de Estado (Considérations politiques sur le coup d'État), na qual o esclarecimento designava os atos "levado a cabo pelo soberano para reforçar o próprio poder. Esta decisão [era] geralmente tomada de surpresa, para evitar reações por parte daqueles que deverão sofrer as consequências.”. (BARBÉ, 1998, p. 545). A expressão passou a ganhar mais eloquência com o advento dos Estados modernos e do constitucionalismo, quando o golpe de Estado passou a fazer referência "às mudanças no Governo feitas na base da violação da Constituição legal do Estado, normalmente de forma violenta, por parte dos próprios detentores do poder político.”. (BARBÉ, 1998, p. 545).

Já nos tempos modernos, a expressão golpe de Estado passou a ser empregada de formas diversas fazendo surgir uma "verdadeira proliferação de golpes, embora com características bem diferentes” (p. 545). Na visão desse estudioso, a proliferação da expressão ganhou força a partir do início dos anos 1970, quando, segundo ele, mais da metade dos países do mundo tinha sofrido algum tipo de golpe de Estado, "por conseguinte, tornou-se mais habitual como método de sucessão governamental do que as eleições e a sucessão monárquica.”. (BARBÉ, 1998, p. 545). Ainda sobre os golpes ocorridos durante a segunda metade do século XX, Barbé (1998) ressalta que os atores principais desses golpes passaram a ser os militares - daí a intensificação da utilização da expressão "golpe militar" que consiste em:

[...] apoderar-se, por parte de um grupo de militares ou das forças armadas em seu conjunto, dos órgãos e das atribuições do poder político, mediante uma ação repentina, que tenha uma certa margem de surpresa e reduza, de maneira geral, a violência intrínseca do ato com o mínimo emprego possível de violência física.”. (BARBÉ, 1998, p. 545).

A América Latina, predominantemente nas décadas de 1960 e 1970, se constituiu como um dos maiores exemplos dessa proliferação de golpes - com ênfase nas forças militares sobre a qual discorre Barbé (1998). Em 1963, o então presidente do Equador, Carlos Junior Arosemena Monroy, foi deposto de seu cargo após um golpe militar; no Brasil em 31 de março de 1964, João Goulart foi deposto do cargo de presidente do Brasil, também após golpe militar. Já em 1966, na Argentina, o golpe militar depôs o então presidente Arturo Illia; em 1971 o governo de Juan José Torres, na Bolívia, também foi deposto pelos militares. (PASSOS; 
MICHELSOHN; LIMA, 2009). Após essa onda de ações militares ocorridas no fim do século $\mathrm{XX}$, a expressão "golpe" passou a ser característica do imaginário coletivo latino-americano.

Necessário pontuar, no entanto, que a partir do século XXI os golpes de Estado passaram a ser constituídos de outras maneiras (sem força ou violência física) e por outros atores (não mais os militares, mas parlamentares, por exemplo). Esses "novos" golpes passaram a ser considerados como "golpes brancos" ou "golpes pós-modernos", sobre os quais se baseiam a narrativa de golpe utilizada no contexto político brasileiro atual.

Um dos primeiros empregos dessa narrativa na contemporânea conjuntura do Brasil pode ser percebido em texto escrito por Expedito Solaney, secretário nacional de Políticas Sociais da CUT. No documento, publicado no site oficial da CUT em 01 de abril de 2015, Solaney (2015) afirmou: "neste março de 2015 estamos na iminência não de um golpe militar, como ocorreu em 64, mas em médio prazo, de um golpe branco [...]. Aqui se fala no impeachment, ou impedimento da presidenta.". (SOLANEY, 2015, grifo nosso). Nota-se, portanto, que o "golpe" sobre o qual discorre o narrador do trecho supracitado diz respeito à possibilidade de impeachment de Dilma Rousseff, ou seja, iguala-se a narrativa do golpe à narrativa da destituição inconstitucional da presidenta de seu cargo. A narrativa do golpe pressupõe, portanto, uma ameaça explícita e perigosa à prática democrática da política brasileira.

Como forma de legitimar a narrativa do golpe, o próprio PT passou a utilizar o termo enfaticamente em diversos discursos a partir de meados de 2015. Uma das primeiras vezes em que o partido usou o termo "golpe" foi em nota publicada e divulgada em 07 de junho de 2015 e direcionada à Câmara dos Deputados, cujo trecho reproduzimos a seguir:

\begin{abstract}
A Bancada do PT na Câmara repudia veementemente as manobras flagrantemente golpistas conduzidas pela oposição, com o PSDB à frente. O partido tucano, que apenas na sigla inclui alguma referência ao ideário socialdemocrata, assumiu de vez, e sem qualquer pudor, a camisa do golpismo, sob liderança do seu presidente, o senador Aécio Neves, derrotado nas eleições de 2014. [...] Se o PSDB deseja voltar a governar o País, precisa, antes, vencer as eleições. O voto e a liberdade de escolha são valores imprescindíveis de um regime democrático e devem ser protegidos contra quaisquer tentações golpistas. [...] Não aceitaremos qualquer tipo de golpe e, juntamente com a sociedade brasileira, estaremos vigilantes, atentos e mobilizados para frear quaisquer movimentos que tenham por objetivo interromper o mandato garantido pela população e pela Constituição Federal à presidenta Dilma Rousseff. (SIBÁ, 2015).
\end{abstract}

É possível observar pela nota acima que a narrativa do golpe, além de ser delimitada pelo discurso da "defesa à democracia", concentra o simbolismo da narrativa na figura do "inimigo", ou seja, no suposto culpado pelo ataque inconstitucional à presidenta. $\mathrm{O}$ inimigo instituído pelo PT no documento é constituído pela oposição, pelo PSDB e pelo senador Aécio Neves. 
Além da utilização da narrativa do golpe em discursos do partido, a própria presidenta Dilma também passou a enfatizar essa expressão em pronunciamentos públicos. Em 16 de setembro de 2015, em entrevista a uma emissora de rádio de Presidente Prudente (SP), Dilma declarou que a possibilidade de impeachment seria uma "versão moderna do golpe", como pode ser observado no trecho a seguir:

Todos os países que passaram por dificuldades, você não viu nenhum país propondo a ruptura democrática como forma de saída da crise. Esse método, que é querer utilizar a crise como um mecanismo para você chegar ao poder, é uma versão moderna do golpe. Atualmente, o que nós temos de fazer é o seguinte: unirmo-nos todos juntos e o mais rapidamente, independente das nossas posições e interesses pessoais ou partidários, tomarmos o partido do Brasil”.' (DILMA ROUSSEFF apud SENA, 2015, grifo nosso).

A narrativa do golpe utilizada pelo PT e por Dilma passou a ser ainda mais enfática a partir de outubro de 2015, quando as contas do governo foram rejeitadas pelo TCU e o pedido de impedimento da presidenta chegou à Câmara dos Deputados. No dia 13 de outubro, por ocasião do $12^{\circ}$ Congresso da Central Única dos Trabalhadores (Concut), em São Paulo, Dilma afirmou: "Eu me insurjo contra o golpismo e suas ações conspiratórias e não temo seus defensores. Pergunto com toda a franqueza: quem tem força moral, reputação ilibada e biografia limpa suficientes para atacar a minha honra?”. (DILMA ROUSSEFF apud SENA, 2015, grifo nosso). Ainda no mesmo discurso, ela atacou novamente os adversários e opositores de seu mandato ao afirmar que a inconformidade dos mesmos diante dos resultados das eleições de 2014 "transformou-se em um claro desejo de retrocesso político, de ruptura institucional [...]. Isso tem nome. É um golpismo escancarado.”. (DILMA ROUSSEFF apud SENA, 2015, grifo nosso).

A partir de 2016 vários livros, artigos e ensaios foram publicados com base na narrativa do golpe, o que também serviu como legitimação desse discurso. Em texto publicado no livro Por que gritamos golpe?, Luis Felipe Miguel (2016a) argumentou que o golpe ou "o impedimento da presidente [...] sem crime de responsabilidade claramente identificado" foi uma "afronta aberta às regras estabelecidas [e] marcou a ruptura do entendimento de que o voto é o único meio legítimo de alcançar o poder.”. (MIGUEL, 2016a, p. 32). Na mesma linha de raciocínio, o filósofo e sociólogo Michael Löwy (2016), em capítulo publicado na mesma obra, discorreu que era necessário "dar nome aos bois" e identificar o processo de impeachment como um golpe de Estado “pseudolegal, 'constitucional', 'institucional', parlamentar ou o que se preferir, mas golpe de Estado.”. (LÖWY, 2016, p. 64). 
O jornalista Mauro Lopes (2016) utiliza a argumentação de que o conglomerado jornalístico brasileiro dominante, constituído pelas famílias dos Marinho (Grupo Globo), dos Civita (Grupo Abril/Veja), dos Frias (Grupo Folha) e dos Mesquita (Grupo Estado), foi responsável por criar “opinião e atmosfera para o golpe de Estado contra o governo de Dilma Rousseff, eleito por 54 milhões de pessoas [...].”. (LOPES, 2016, p. 120). De acordo com Lopes (2016), a mídia deixou de fazer seu papel de registro e reflexão do cotidiano social para tornarse um partido político opositor ao governo petista ao mobilizar a população para participar de manifestações sociais contra o governo, ao divulgar vazamentos de investigações em articulação com a operação Lava Jato e ao publicar editoriais, pesquisas e artigos contrários ao mandato de Dilma (LOPES, 2016, p. 121). Esse autor acrescenta:

As quatro famílias, seguidas pelas demais, operaram numa rede nacional oficial do golpe, numa articulação inédita na história do jornalismo no país - a competição, ícone maior do capitalismo e do discurso de todos esses meios, foi deixada de lado em prol de uma colaboração aberta para derrubar o governo. (LOPES, 2016, p. 121).

Ainda de acordo com Lopes (2016), a principal arma dos "golpistas" (em referência à imprensa brasileira) é negar a narrativa do golpe por meio da legitimação do discurso do impeachment. Sobre essa negação o ator aponta: "negar o golpe é essencial para a construção simbólica dos golpistas.”. (LOPES, 2016, p. 121). A polarização de sentidos sobre a qual discorremos anteriormente entre os modelos de fala do golpe e do impeachment se torna clara a partir dessa afirmação do jornalista.

Em outro livro também publicado em 2016 e intitulado Golpe 16, o organizador da obra, jornalista Renato Rovai (2016), afirma que o golpe em Dilma seria "pós-moderno", ou seja, "um tipo de ação antidemocrática que prescinde de tanques nas ruas, prisões, fechamento do Congresso e censura midiática" (ROVAI, 2016, p. 9). Por ser pós-moderno, o golpe de 2016 é “filho de um arranjo midiático, econômico, político e de setores importantes do Judiciário". (ROVAI, 2016, p. 9). Observa-se que, da mesma forma que Lopes (2016), Rovai (2016) também considera central a participação da imprensa nesse golpe.

$\mathrm{Na}$ mesma perspectiva apresentada por esses dois autores, em texto publicado no livro 2016: o ano do golpe, Miguel (2016b) aponta a mídia como uma das principais articuladoras do golpe em Dilma. De acordo com o pesquisador, alinhados na narrativa do golpe

[...] os meios de comunicação cumpriram papel determinante na geração do clima de opinião [...], desde as primeiras manifestações de inconformismo como resultado de segundo turno das eleições de 2014. A mídia cumpriu papel crucial na produção da ideia de que os governos do PT eram responsáveis isolados pela corrupção, 
minimizando as denúncias contra opositores e dando aos casos que envolviam o expresidente Lula um destaque muito superior àquele que seu interesse jornalístico intrínseco justificaria. (MIGUEL, 2016b, p. 109).

Válido ressaltar que a estratégia de nomear a imprensa hegemônica do Brasil ${ }^{95}$ como uma "imprensa golpista" foi intensificada pelos militantes petistas a partir do escândalo do mensalão em 2005. Na ocasião os partidários do governo petista e jornalistas contrários à mídia hegemônica passaram a utilizar a expressão "PIG" ou Partido da Imprensa Golpista como forma de culpabilizar os principais jornais e revistas brasileiros pelo posicionamento explicitamente contrário ao PT e por agirem como um partido de oposição ao governo petista. A expressão PIG (termo que na língua inglesa significa "porco") foi popularizada por Paulo Henrique Amorim, jornalista responsável pelo blog intitulado "Conversa Afiada" - um dos principais portais de notícia online de esquerda no Brasil ${ }^{96}$. Ao discorrer sobre tal expressão, Amorim afirma

Em nenhuma democracia séria do mundo jornais conservadores, de baixa qualidade técnica e até sensacionalistas, e uma única rede de televisão (a Globo), têm a importância que têm no Brasil. Eles se transformaram num partido político - isto é o PiG, Partido da Imprensa Golpista. (AMORIM, 2008).

De acordo com Roberto Grün (2014, p. 63) o surgimento do PIG pode ser compreendido como uma "lapidação de um artefato cultural e político eficiente para contrapor a militância petista e adjacentes à ofensiva que visava assegurar a hegemonia cultural de seus adversários e suas consequências na esfera política.”. Nota-se, portanto, que em 2016 houve um reavivamento da narrativa da "mídia golpista" que já havia sido acionada pelos militantes petistas em momentos passados.

Necessário ressaltar, no entanto, que dentre os veículos jornalísticos de grande circulação

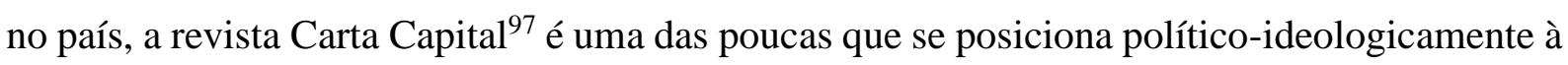
esquerda e, portanto, tende a favorecer pautas menos elitistas ou mesmo favoráveis aos governos petistas. Em 05 de abril de 2016, em editorial escrito por Mino Carta (diretor de redação e principal responsável pela criação da revista), a Carta Capital passou a ser, também, legitimadora da narrativa do golpe. O texto, intitulado “É golpe, sim!", logo de início afirmava

\footnotetext{
95 Representada pelo Grupo Globo, Grupo Estado, Grupo Folha e Grupo Abril.

96 O Blog Conversa Afiada foi originalmente criado em 2006 com vinculação ao portal de notícias iG (Internet Group). Em 2008 Paulo Henrique Amorim foi demitido do portal e decidiu por criar outro blog com domínio próprio, mas manteve nome Conversa Afiada. Importante pontuar que a expressão PIG, popularizada por Amorim passou a ser utilizada pelo mesmo como "PiG" em alusão ao portal de notícias que o teria demitido.

${ }^{97}$ A revista Carta Capital - que possui publicação semanal - pertence à Editora Confiança e foi fundada em 1994 por Mino Carta, atual diretor de redação da revista.
} 
que "a arrogância e a desfaçatez dos conspiradores passaram da conta" (CARTA, 2016). A coluna daquela edição segue a mesma perspectiva adotada pelos manifestantes contrários ao golpe e acusa Dilma de ter cometido erros graves em relação, principalmente, às medidas econômicas estabelecidas a partir de seu segundo mandato. No entanto, Mino Carta ressalta que "nada, porém, do que a acusam sustenta a conspirata e justifica o impedimento". (CARTA, 2016).

Ainda em legitimação à narrativa do golpe, Miguel (2016b) discorre sobre a influência e participação do poder Legislativo e do poder Judiciário na queda do governo Dilma. O autor exemplifica essa ascendência a partir do distanciamento e enfraquecimento da relação entre o Executivo e os demais poderes, evidenciados em julho de 2015, quando Eduardo Cunha (PMDB), então presidente da Câmara, assumiu publicamente o seu rompimento político com o governo de Dilma Rousseff. Para Miguel (2016b), a principal linha de defesa dos partidários do impeachment era afirmar que o golpe se tratava de um "julgamento político" e, com isso, afirmavam que não era necessária a existência ou não de provas sobre crime de responsabilidade.

A partir da contextualização sobre a narrativa do golpe acima discorrida é possível perceber que os atores responsáveis pelo golpe, de acordo com os legitimadores desse discurso, formaram uma aliança entre a oposição (concentrada na figura do PSDB que, supostamente, não aceitou a derrota nas eleições em 2014), a imprensa e os poderes Legislativo e Judiciário. Além desses atores, o pesquisador Jessé Souza (2016) acrescenta ainda no livro A radiografia do golpe a classe média conservadora como também responsável pelo golpe em Dilma Rousseff. Ressaltamos, ainda, que a principal argumentação utilizada pelos legitimadores da narrativa do golpe se baseou na questão da defesa da democracia brasileira que estaria sendo ameaçada pelo processo de impeachment em curso.

\subsubsection{Quatro contextos de análise da crise política em 2016}

Feita a observação sobre a disputa de sentidos estabelecida entre as narrativas do impeachment e do golpe, o presente tópico tem por objetivo decompor a crise política de 2016 em quatro contextos de análise ocorridos entre março e maio de 2016, quais sejam: 1) as manifestações sociais a favor do impeachment ocorridas em 13 de março; 2) as manifestações sociais contra o golpe em 18 de março; 3) a votação na Câmara dos Deputados em 17 de abril, com resultado favorável à continuidade do processo de impeachment; 4) a votação no Senado em 12 de maio e o consequente afastamento de Dilma do cargo da Presidência do Brasil pelo 
prazo de até 180 dias. Os quatro contextos serão posteriormente utilizados como recorte analítico para a pesquisa empírica da presente tese.

\section{- Contexto 1: Manifestações sociais a favor do impeachment}

Assim como ocorrido em 2015, o mês de março de 2016 foi tomado por nova onda de manifestações sociais pelo país impulsionadas, predominantemente, pela decisão de Eduardo Cunha, então presidente da Câmara dos Deputados, pela aceitação do pedido de impeachment de Dilma Rousseff. Oportuno mencionar que alguns acontecimentos do início de março de 2016 também contribuíram em grande medida para a realização de novas manifestações contrárias ao governo. Em relação a esses eventos elencamos três principais que merecem destaque:

1) a condução coercitiva ${ }^{98}$ de Lula pelo Ministério Público de São Paulo (MP-SP) em ordem estabelecida pelo juiz Sérgio Moro, em 04 de março, durante a $24^{a}$ fase de investigação da Operação Lava Jato. Na ocasião Lula foi levado a depor no escritório do MP-SP no aeroporto de Congonhas (São Paulo). No mesmo dia, além da condução coercitiva e do depoimento de Lula ao MP, a Polícia Federal (PF) cumpriu mandado de busca e apreensão na casa do expresidente, em São Bernardo do Campo (SP) e no Instituto Lula ${ }^{99}$, na cidade de São Paulo (PF CUMPRE..., 2016), bem como em um apartamento triplex, na cidade de Guarujá (SP), que, de acordo com investigação do MP, teria sido destinado a Lula em um esquema de propina e lavagem de dinheiro. (BURNIER, 2016).

A cobertura midiática dos acontecimentos acima discorridos foi intensa - como exemplo, citamos a cobertura realizada pelo Jornal Nacional, veiculado pela Rede Globo, no qual foram dedicados $80 \%$ do tempo total do programa à divulgação dos fatos ocorridos (em um programa com duração de 1 hora e 20 minutos). (FARIA, 2016). Em extensa análise sobre o programa,

\footnotetext{
${ }^{98}$ De acordo com o desembargador Cândido Ribeiro (apud RIBEIRO, I; 2016), a condução coercitiva pode ser definida como: "[...] instrumento de restrição temporária da liberdade conferido à autoridade judicial para fazer comparecer aquele que injustificadamente desatendeu à intimação e cuja presença seja essencial para o curso da persecução penal, seja na fase do inquérito policial, seja na da ação penal.”. (RIBEIRO, C; apud RIBEIRO, I; 2016). Ainda de acordo com Riberto (2016) para que se compreenda o conceito da condução coercitiva deve-se levar em consideração dois requisitos: a existência de uma intimação/comunicação regular para comparecimento ao ato; e a recusa injustificada de quem foi intimado e não compareceu ao ato.

${ }^{99} \mathrm{O}$ Instituto Lula, criado em 2011 (após o segundo mandato de Lula como presidente do Brasil), é uma fundação suprapartidária, sem fins lucrativos que se dedica a pesquisas de desenvolvimento no eixo da cooperação entre Brasil com a África e América Latina. De acordo com o portal online do Instituto, a fundação pretende estimular, em outros países, "o exercício pleno da democracia e a inclusão social aliada ao desenvolvimento econômico" que estão "entre as principais realizações do governo Lula". (MISSÃO, 2016).
} 
Barbosa (2016) aponta sete momentos em que a cobertura do telejornal foi tendenciosa no sentido de divulgar informações majoritariamente contrárias a Lula ou que buscavam desconstruir a imagem do ex-presidente.

Sobre o programa em questão Barbosa (2016) discorre que: a) no primeiro bloco houve 21 minutos de matérias sobre os fatos ocorridos em 04 de março e apenas 50 segundos dedicados à exposição de falas em defesa ao ex-presidente; b) no segundo bloco do programa foram dedicados mais 15 minutos sobre a operação em contrapartida aos 20 segundos com a posição de Lula e outros 20 segundos dedicados à fala de Paulo Okamotto, presidente do Instituto Lula; c) no terceiro bloco, (e, portanto aos 40 minutos desde o início do programa), foi ao ar a primeira fala do ex-presidente em matéria de 7 minutos que transmitia discurso por ele proferido à imprensa e à militância na sede do Diretório Nacional do PT no mesmo dia da operação (no mesmo bloco houve, ainda, mais um minuto e 15 segundos de uma fala de Dilma em tom crítico à operação realizada naquele dia).

Necessário destacar alguns pontos importantes sobre o discurso de Lula acima citado (pontos que não foram divulgados pelo Jornal Nacional), sendo que um deles se refere ao fato de que o ex-presidente afirmou não ter recusado prestar depoimento e, por isso, a condução coercitiva teria sido infundada e desnecessária. Um segundo ponto de destaque diz respeito à utilização da narrativa da conspiração recorrentemente utilizada por Lula ao considerar-se vítima do processo ocorrido e ao afirmar que se sentiu um "prisioneiro" diante da condução determinada por Moro. Como base argumentativa de seu discurso, Lula utilizou dois conceitos importantes: a) o conceito de escândalo político-midiático (THOMPSON, 2002), ao discorrer sobre a espetacularização das operações realizadas pelo MP e pela PF. A utilização desse conceito pode ser percebida pelo seguinte trecho do seu discurso: "Se o Ministério Público quisesse me ouvir, era só ter mandado um ofício que eu ia - como sempre fui. Não devo e não temo. Estamos vivendo um processo em que a pirotecnia e o show midiático valem mais do que qualquer coisa.”. (LULA apud HOFFMANN, 2016, grifo nosso); b) e o conceito de presunção de culpa (LIMA, 2006), ao afirmar que a imprensa o estaria acusando de supostos crimes sem que tivesse havido acusação factual ou provas concretas. É possível observar a presença desse conceito no trecho a seguir:

Antigamente você tinha a denúncia de um crime, você ia investigar se existia aquele crime para prender o criminoso. Hoje a primeira coisa que você faz é determinar quem é o criminoso, depois que você nominou o criminoso, colocou a cara dele na imprensa, você então vai criar os crimes que ele cometeu. (LULA apud HOFFMANN, 2016). 
d) Após a divulgação de trechos do discurso de Lula, o jornal dedicou dois minutos de matérias sobre o que Barbosa (2016) chamou de "destaques negativos" da operação de 04 de março na imprensa internacional. Barbosa (2016) ressaltou que o Jornal Nacional "informou que o mercado reagiu positivamente aos fatos, com alta na Bolsa de São Paulo e queda no valor dólar” (BARBOSA, 2016), o que indicava que a operação contra Lula teria sido favorável à economia do país; e) Barbosa (2016) indica que "um dos principais assuntos em discussão ao longo do dia, a legalidade da condução coercitiva de Lula [...], não mereceu a atenção do Jornal Nacional.”. (BARBOSA, 2016). A autora chama atenção ainda para o fato de que quatro especialistas em direito penal participaram de um programa jornalístico no canal de TV a cabo GloboNews naquele 04 de março e, de forma unânime, disseram que a condução coercitiva de Lula não tinha fundamento legal, mas o Jornal Nacional não noticiou essas falas.

Importante ressaltar que no dia 04 de março de 2016 Lula discursou na quadra do Sindicato dos Bancários, no centro da cidade de São Paulo, em ato apoiado por centrais sindicais e a militância petista. Na ocasião o ex-presidente afirmou se sentir injustiçado e vítima de perseguições das elites do país. Ressaltou ainda: "Hoje é o dia da indignação para mim. Já sofri muito, fui preso quando era presidente do sindicato dos metalúrgicos, já perdi eleições. Em todas as vezes que sofri revés, me comportei como democrata.”. (SILVA, 2016a). E destacou, ainda, que em decorrência da Operação da Lava Jato seus opositores teriam "cutucado o cão com a vara curta", em alusão a terem o perturbado e, por isso, estava se disponibilizando a ser candidato pelo PT à Presidência do Brasil em 2018. Lula afirmou:

Se alguém pensa que vai me calar com perseguição e denúncia, não sabe que eu sobrevivi à fome. Não sou vingativo, não carrego ódio, mas tenho consciência do que eu posso fazer por esse povo. E do que eles querem de mim. Se estão precisando de alguém para animar esta tropa, o animador está aqui. (SILVA, 2016a).

Durante o mesmo pronunciamento o ex-presidente afirmou que se tornou "o melhor presidente da República que este país já teve", e que passou a ser "o melhor presidente do começo do século 21 no mundo inteiro.”. (SILVA, 2016a).

2) O terceiro momento que devemos ressaltar em relação ao primeiro contexto da crise política de 2016 também diz respeito à operação ocorrida em 04 de março de 2016, realizada pela PF-SP como parte da $24^{\text {a }}$ fase da Operação Lava Jato. Naquela iniciativa PF catalogou 136 objetos recebidos por Lula durante seus dois mandatos como presidente da república. Dentre 
os objetos constavam um crucifixo e joias. O acervo de objetos pertencentes ao ex-presidente estava preservado em uma sala-cofre de uma agência do Banco do Brasil, em São Paulo, desde janeiro de 2011 (BRANDT et al., 2016). Apesar de a operação ter ocorrido em 04 de março, as notícias sobre o acervo encontrado pela PF passaram a ser veiculadas apenas em 11 de março, o que contribuiu para a produção de mais um episódio que ligava a imagem pública de Lula à Operação Lava Jato e, portanto, a escândalos de corrupção.

A divulgação midiática sobre a apreensão dos objetos foi feita de forma a, novamente, presumir culpa ao ex-presidente, como pode ser observado pela matéria intitulada "Passaram a mão no nosso Cristo, Jesus! Estava num cofre de Lula" ${ }^{100}$, publicada pela revista Veja no dia 11 de março e escrita pelo colunista Reinaldo Azevedo. A matéria explicita acusação de que Lula teria retirado do Palácio do Planalto um crucifixo que, de acordo com o jornalista, pertencia ao patrimônio público e, por isso, teria sido roubado pelo ex-presidente ${ }^{101}$. Reinaldo Azevedo, ao fim do texto, intitula Lula de "apedeuta" (pessoa ignorante, sem instrução) e afirma que o mesmo "já não sabe distinguir o que lhe pertence do que pertence ao Brasil. Nunca soube!”. (AZEVEDO, 2016a). Por essa afirmação, Azevedo faz clara referência à possibilidade de Lula ter envolvimento em esquemas de corrupção ao discorrer sobre a incapacidade do expresidente em distinguir entre seus bens privados e os bens públicos do país.

3) $\mathrm{O}$ terceiro acontecimento diz respeito ao pedido de prisão preventiva de Lula apresentado por três promotores do MP-SP - Cássio Conserino, José Carlos Blat e Fernando Henrique Araujo - em 09 de março. No pedido em questão os promotores pontuavam irregularidades na suposta compra realizada pelo ex-presidente Lula do apartamento triplex em Guarujá (SP) e condenavam Lula por lavagem de dinheiro e falsidade ideológica. O pedido em questão também se baseava no escândalo de corrupção conhecido como "Caso Bancoop" que é investigado pelo MP-SP e "apura irregularidades na transferência de empreendimentos da Cooperativa Habitacional dos Bancários (Bancoop) para a construtora OAS - uma das empresas

\footnotetext{
${ }^{100}$ A expressão "passar a mão", que consta no título da matéria, é utilizada na linguagem informal no Brasil como referência a roubo ou a pegar algo que não lhe pertence.

${ }^{101}$ A polêmica envolvendo tal crucifixo não é recente e teve início no início de 2011, quando Lula desocupou o gabinete da Presidência da República no Palácio do Planalto, ao fim de seu segundo mandato. Após a retirada do crucifixo da parede do gabinete houve indagações sobre a ausência do objeto, o que gerou dúvidas quanto à possibilidade de Lula ter tomado para si objeto de patrimônio público. Em 26 de fevereiro de 2011 a revista Época divulgou ampla matéria sobre os esclarecimentos quanto ao crucifixo, afirmando que o objeto em questão se tratava de um presente do ex-presidente, recebido em 2003 por José Alberto de Camargo (o dono original do crucifixo era Dom Mauro Morelli, bispo de Duque de Caxias - RJ). O texto da revista Época esclarece, ainda, que o objeto, sendo presente pessoal recebido por Lula, teria sido retirado do Palácio do Planalto ao fim de seu mandato, mas, no entanto, o destino do crucifixo não foi divulgado, sendo que o mesmo teria permanecido "escondido" até o momento em que a PF, em 04 de março de 2016, encontrou os o acervo pertencente a Lula. (SANCHES, 2011).
} 
investigadas na Operação Lava Jato.”. (CASO..., 2016). De acordo com o MP “o dinheiro que deveria ter sido aplicado na construção dos imóveis foi desviado para financiar campanhas eleitorais do PT.”. (CASO..., 2016). Importante ressaltar que a revista Veja foi o primeiro veículo jornalístico a denunciar tal escândalo de corrupção em sua edição publicada em 10 de março de 2010.

O pedido de prisão preventiva foi amplamente criticado por juristas e até mesmo por políticos de partidos da oposição. Sobre o ocorrido, o senador Cássio Cunha, então líder do PSDB no Senado, afirmou em entrevista publicada no portal de notícias G1 que, no pedido em questão, não estavam presentes "os fundamentos que autorizam o pedido de prisão preventiva" (CÁSSIO CUNHA apud POLÍTICOS..., 2016). Cássio Cunha afirmou que o Brasil estaria vivendo "um momento incomum na vida nacional" e que, por isso, era necessário ter prudência. (CÁSSIO CUNHA apud POLÍTICOS..., 2016).

Interessante ressaltar que, para além da acusação de lavagem de dinheiro e falsidade ideológica, os promotores responsáveis pelo pedido de prisão de Lula utilizaram o argumento de que o ex-presidente estaria ameaçando o bom funcionamento da legislação brasileira ao criticar publicamente a Operação Lava Jato, durante discurso no Diretório Nacional do PT, no dia 04 de março. No texto do pedido, os promotores ainda acusaram Lula de "inflamar a população a se voltar contra investigações criminais a cargo do Ministério Público, da Polícia, [...] [e] contra decisões do Poder Judiciário.”. (SÃO PAULO, 2016). A seguir é possível observar o trecho do pedido de prisão em que os promotores citam tais acusações:

109)Entendem os promotores de justiça subscritores que o denunciado LUIZ INÁCIO
LULA DA SILVA atentou contra a ordem pública ao desrespeitar as instituições que
compõem o Sistema de Justiça, especialmente a partir do momento em que as
investigações do Ministério Público do Estado de São Paulo e da Operação Lava Jato
(MPF - Curitiba) se voltaram contra ele; 110) Do alto de sua condição de ex
autoridade máxima do país, o denunciado LUIZ INÁCIO LULA DA SILVA jamais
poderia inflamar a população a se voltar contra investigações criminais a cargo do
Ministério Público, da Polícia, tampouco contra decisões do Poder Judiciário; 111) E
foi isso que o denunciado LUIZ INÁCIO LULA DA SILVA fez, valendo-se de toda
sua "força político-partidária", ao convocar entrevista coletiva após ser conduzido
coercitivamente para ser ouvido em etapa da Operação Lava Jato. (SÃO PAULO,
2016, grifo nosso).

Os promotores argumentaram que a conduta de atentado à ordem pública de Lula poderia ser comprovada pelo "acompanhamento periódico da imprensa livre a respeito de suas manifestações e opiniões quando as investigações começaram a se voltar contra ele [Lula]" (SÃO PAULO, 2016). Os representantes do Ministério Público exemplificam essa argumentação a partir de matéria publicada em 07 de fevereiro de 2016 pelo jornal Estado de 
S. Paulo, com o título: "Lula se queixa de Dilma e do avanço das investigações". A reportagem ressalta suposição de que Lula estaria fazendo crítica à falta de apoio da presidenta e também à continuidade e o avanço das investigações da Operação Lava Jato.

Na percepção dos promotores, a notícia veiculada pelo jornal seria um "demonstrativo evidente de que [Lula] não aceitava ser investigado, como se fosse autoridade à parte do espectro de atenção jurídica.”. (SÃO PAULO, 2016). Os acusadores afirmaram, ainda, que, de acordo com o que foi veiculado na imprensa, Lula desejaria "estar acima da lei".

Oportuno observar que ao contrário de Lula, que criticou a cobertura da imprensa afirmando ter ocorrido um "show midiático" a partir da presunção de culpa estabelecida pelos meios de comunicação diante dos fatos de 04 de março, os promotores exaltaram tal midiatização intitulando-a de "acompanhamento periódico da imprensa livre", como se a mídia estivesse prestando um nobre favor à opinião pública ao divulgar os fatos sucedidos.

Ressaltamos, ainda, que enquanto Lula utilizou a narrativa da conspiração ao afirmar que estaria sendo perseguido pela mídia, seus opositores/acusadores utilizam a construção do salvador ao afirmarem que, de acordo com a imprensa, Lula se considerava "acima da lei" e que possuía "forças" que poderiam "inflamar a população", ou seja, Lula seria um líder com capacidade de mobilizar reações públicas a seu favor, habilidade que se institui como intrínseca à sua imagem pública. Em ambos os casos há nítida influência da mídia no desenrolar dos acontecimentos.

Feitas as observações sobre os três eventos de março de 2016 que contribuíram para a ocorrência das manifestações contrárias ao governo Dilma, contextualizaremos os atos públicos no dia 13 de março daquele ano, assim como o impacto desses acontecimentos nas mesmas. Ressaltamos que tais protestações, devido à expressividade do número de participantes, foram ainda maiores que as ocorridas tanto em junho de 2013, em março 2015 e, também, as ocorridas na década de 1980, pelas Diretas Já. Houve protestos em cerca de 240 cidades brasileiras, com destaque para a que ocorreu em São Paulo, que, de acordo com dados do Instituto DataFolha, contou com a participação de 500 mil pessoas - o que consolidou o protesto como o maior já ocorrido na capital paulista.

Podemos afirmar que as manifestações pró-impeachment de 13 de março de 2016 são estruturalmente similares às ocorridas no ano anterior, já que também foram organizadas, predominantemente, por intermédio das mídias sociais pelos grupos consolidados durante as manifestações de 2015, quais sejam: o MPL, o Vem pra Rua e o ROL. 
Ao realizarmos um comparativo entre os atos públicos de março de 2015 e os do mesmo mês no ano seguinte, a partir de pesquisas realizadas pelo Instituto DataFolha ${ }^{102}$ é possível observar similaridades também no perfil dos manifestantes: em 13 de março de 2016 a maioria dos participantes das manifestações também era formada por homens (57\%), de cor branca (77\%), com ensino superior (77\%) e que faziam parte da população economicamente ativa (82\%), com destaque para os assalariados registrados (31\%). A média de idade contabilizada foi de 45,5 anos. Em relação à preferência partidária os dados também são similares: $68 \%$ dos entrevistados que participaram das manifestações de 13 de março de 2016 disseram não possuir um partido político de preferência - mas, dentre os que afirmaram optar por um deles $21 \%$ citou o PSDB. Além disso, 8 em cada 10 entrevistados garantiram ter votado em Aécio Neves (PSDB) no segundo turno das eleições de 2014, e, ao serem questionados sobre qual teria sido o melhor presidente do país, 60\% dos entrevistados citaram, espontaneamente, FHC (PSDB). O nome de Lula não foi referido pelos entrevistados. (DATAFOLHA, 2016a).

Ainda de acordo com a mesma pesquisa, $70 \%$ dos entrevistados afirmaram já ter participado de manifestações contrárias ao governo de Dilma Rousseff, o que justifica a similaridade no perfil dos participantes. Importante mencionar da mesma forma que $95 \%$ dos entrevistados disseram apoiar o impeachment de Dilma Rousseff.

O Instituto Ibope, em pesquisa realizada entre os dias 17 e 20 de março de 2016 em 143 municípios sobre as manifestações de 13 de março, elencou os principais motivos descritos espontaneamente pelos entrevistados para a participação nos atos públicos. Destacamos alguns: protestar contra a corrupção; clamar contra o governo federal/ presidente da república/ Dilma; pedir o impeachment da presidenta Dilma Rousseff; bradar contra o PT, contra os políticos em geral, contra os governos em geral, contra o ex-presidente Lula. (CONFEDERAÇÃO NACIONAL DA INDÚSTRIA, 2016). Observa-se que o aspecto antilulista e antipetista apontado por Scartezini (2016) nas manifestações de 2015 teve continuidade nas protestações de 2016.

Um ponto de destaque sobre as manifestações de 13 de março de 2016 foi o processo de consolidação da celebrização da imagem pública de Sérgio Moro, juiz responsável pela Operação Lava Jato. Esse enaltecimento já havia sido observado nos protestos de 2015, mas se intensificou durante 2016. Sobre esse processo Almeida (2016) aponta que

os homenageados do dia [13 de março] eram Sergio Moro, o Ministério Público e a Polícia Federal. Máscaras do juiz, enormes cartazes com o rosto dele e faixas com os

\footnotetext{
${ }^{102}$ As pesquisas foram realizadas com manifestantes que participaram dos protestos na cidade de São Paulo.
} 
dizeres 'Somos Moro' reforçavam a fama conquistada e celebrada pelo juiz. (ALMEIDA, 2016, p. 182).

Necessário ressaltar dois pontos importantes sobre a celebrização de Moro: o primeiro deles diz respeito à forte influência da narrativa do salvador, utilizada de forma a enaltecer a imagem pública de Moro como a única liderança capaz de salvar o Brasil da crise ao investigar, julgar e prender os políticos corruptos. Já o segundo aspecto tem a ver diretamente com a relação que o grupo pró-impeachment faz de que Moro é o único capaz de deter Lula (que seria um dos principais, se não o principal, responsável pela corrupção no país). Essa conexão também apresenta estreita ligação com as operações parciais da Lava Jato ocorridas no início de março e detalhadas anteriormente.

\section{- Contexto 2: Manifestações sociais contra o golpe}

As manifestações contra o golpe ocorreram em 18 de março de 2016 em 26 estados brasileiros e no Distrito Federal. Tais atos públicos tiveram a mesma estruturação das manifestações ocorridas um ano antes e foram organizadas predominantemente pelas centrais sindicais apoiadas pelo PT. Um ponto que merece destaque sobre a coordenação das protestações em 2016 diz respeito ao fortalecimento do Frente Brasil Popular, movimento que leva o mesmo nome da coligação do PT que disputou as eleições de 1989. Esse coletivo originou-se em 5 de setembro de 2015 em Belo Horizonte na Assembleia Legislativa de Minas Gerais por ocasião da Conferência Nacional Popular. O Frente Brasil Popular se define como uma coalisão entre:

Brasileiras e brasileiros de todas as regiões do país, cidadãos e cidadãs, artistas, intelectuais, religiosos, parlamentares e governantes, assim como integrantes e representantes de movimentos populares, sindicais, partidos políticos e pastorais, indígenas e quilombolas, LGBT, negros e negras, mulheres e juventude [...]. (FRENTE BRASIL POPULAR, 2015).

O fortalecimento do Frente Brasil Popular ${ }^{103}$ como um dos principais organizadores das manifestações contra o golpe fez ressurgir a importância da militância - que estava silenciada desde o início do segundo mandato de Dilma, quando houve um distanciamento entre movimentos sociais e o governo.

103 Também participam da Frente Brasil Popular "parlamentares e dirigentes de diversos partidos e correntes partidárias, entre os quais o PT, o PCdoB, o PSB, PMDB, PCO, PCML, Refundação Comunista e o PDT. Também participam diversos intelectuais e jornalistas que atuam em diferentes espaços da mídia popular e que compartilham desse esforço.”. (FRENTE BRASIL POPULAR, 2015). 
Assim como ocorrido em 2015, a principal reivindicação dos militantes de 18 de março de 2016 era a defesa da democracia, assim como o repúdio ao golpe. Essa reclamação, no entanto, não implicava necessariamente em defesa do governo de Dilma Rousseff, já que menos da metade dos participantes dos atos (48\%) declarou aprovar a administração da presidenta - 39\% consideravam o governo regular e 14\% julgavam a gestão dela como ruim ou péssima. (DATA FOLHA, 2016). Apesar disso a imprensa noticiou os protestos como atos "pró-Dilma" ou "pró-governo". Como exemplo, citamos duas matérias: uma veiculada pelo portal de notícias G1 - Manifestantes fazem maiores atos a favor de Dilma desde o ano passado e publicada em 18 de março; e outra Manifestações pró-governo levam milhares às ruas de todo o país, divulgada em 20 de março pelo portal de notícias UOL.

Antes de contextualizarmos as manifestações de 18 de março de 2016 destacamos a importância de dois acontecimentos ocorridos anteriormente aos protestos. Discorreremos sobre cada um deles a seguir:

1) $\mathrm{O}$ primeiro evento que deve ser ressaltado se refere à nomeação de Lula para ocupar o cargo de ministro da Casa Civil do governo de Dilma Rousseff em sucessão a Jaques Wagner. O anúncio não oficial de que o ex-presidente assumiria o cargo foi feito no dia 16 de março de 2016 no perfil oficial no Twitter de Rui Falcão, então presidente no PT. Na informação Falcão afirmou: “Terça-feira [22 de março] é a posse do Lula, o ministro da Esperança!” (FALCÃO, 2016, grifo nosso). No discurso proferido por Dilma na mesma data, em ocasião da oficialização da nomeação de Lula para o cargo, a presidenta afirmou que, em seu governo, o ex-presidente Lula teria "os poderes necessários [...] para ajudar o Brasil. Tudo o que ele puder fazer para ajudar o Brasil será feito, tudo". (DILMA ROUSSEFF apud MATOSO, 2016).

De acordo com Almeida (2016), a nomeação de Lula para o cargo significava, para grande parte dos auxiliares mais próximos a Dilma:

[...] a salvação de um governo acuado e incapaz de sair das cordas: sem articulação política eficiente no Congresso, nem uma base de apoio parlamentar consistente, mergulhado numa crise econômica sem precedentes e com dificuldade de retomar o diálogo com o empresariado [...]. (ALMEIDA, 2016, p. 179, grifo nosso).

Almeida (2016) ressalta, ainda, que Lula era considerado como detentor de:

[...] uma capacidade política que faltava para a relação com o Congresso, a liderança que faltava para gerir o governo e animar a militância, o discurso de entusiasmo que faltava para voltar a fazer os agentes econômicos acreditarem numa saída para a crise que não passasse pelo fim do governo. (ALMEIDA, 2016, p. 179, grifo nosso). 
Necessário pontuar a forte influência da narrativa do salvador observada tanto no discurso de Rui Falcão, no Twitter, como na fala de Dilma e, também, nas observações elaboradas por Almeida (2016). Esse modelo de pronunciamento foi acionado a partir de quatro conceitoschave, quais sejam: salvação, liderança, esperança e poder. Observa-se que a aliança entre os quatro conceitos retoma a imagem pública política de Lula que foi construída, predominantemente, durante a sua candidatura às eleições presidenciais de 2002.

Ressaltamos que a nomeação de Lula para o ministério gerou controvérsias em relação à possibilidade de Dilma ter nomeado o ex-presidente apenas com intuito de blindá-lo da investigação da Operação Lava Jato, na medida em que, caso efetivamente se tornasse ministro, Lula conseguiria obter foro privilegiado e seria, então, investigado pelo Supremo Tribunal Federal e não pelo juiz Sérgio Moro. (ALMEIDA, 2016; VILLAVERDE; 2016).

2) O segundo acontecimento a ser contextualizado diz respeito ao áudio de uma conversa telefônica entre o ex-presidente e Dilma Rousseff ocorrida no mesmo dia em que foi oficializada a nomeação de Lula para o ministério, ou seja, no dia 16 de março de 2016 . A gravação do diálogo pôde ser realizada após o juiz federal Sérgio Moro (principal responsável pela Operação Lava Jato) ter retirado o sigilo de grampos telefônicos do ex-presidente Lula. O áudio da conversa foi, então, disponibilizado para os principais veículos de comunicação do Brasil (em primeira mão para a Rede Globo) e divulgado - repetidamente - durante o dia 16. O trecho da conversa em questão está transcrito a seguir:

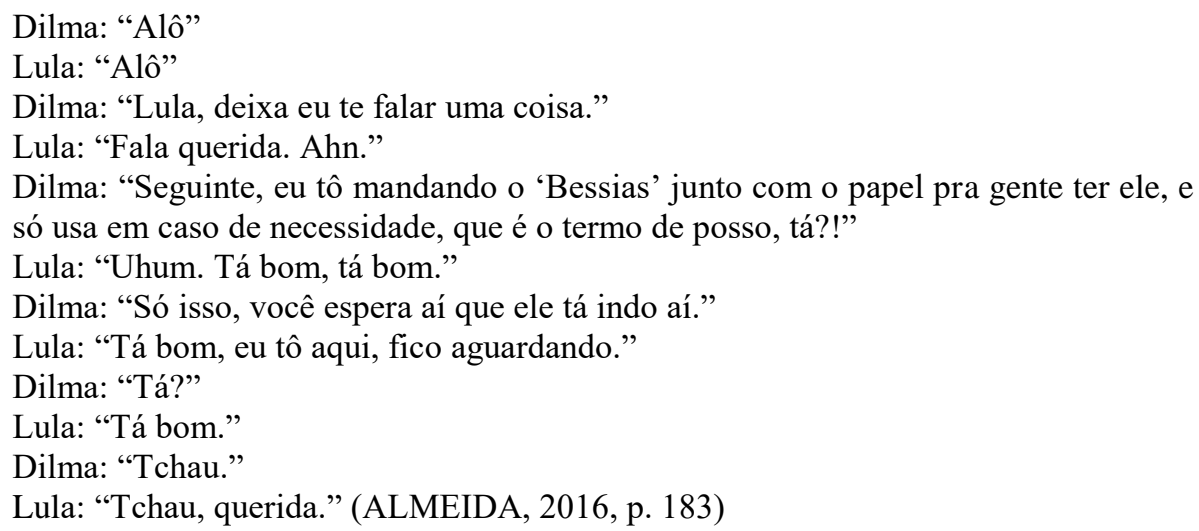

Houve divergência quanto ao ocorrido em relação a dois pontos principais: o primeiro deles refere-se à possibilidade de Sérgio Moro ter infringindo a lei ao retirar o sigilo de grampos telefônicos de Lula e ao disponibilizar o áudio da conversa logo em seguida para a Rede Globo; 
e o segundo ponto diz respeito à especulação de que tal conversa seria um indício de que a então presidenta estaria nomeando Lula apenas com intuito de blindá-lo ante a investigação da Operação Lava Jato. (ALMEIDA, 2016; VILLAVERDE; 2016).

3) A terceira ocorrência diz respeito à posse de Lula como ministro, que ocorreu logo após a oficialização de sua nomeação, em 17 de março (e não em 22 de março como havia afirmado o então presidente do PT, Rui Falcão, em seu perfil no Twitter). Durante a cerimônia de posse dos novos ministros de seu governo, Dilma discursou sobre a nomeação do expresidente e enfatizou, novamente, a narrativa do salvador ao acionar conceitos-chave - tais como "grandeza", "humildade", "liderança" e "incomparável capacidade" de entender o povo -, referências intrínsecas à imagem pública de Lula. Em trecho desse discurso, citado abaixo, é possível notar essa estratégia comunicacional:

\begin{abstract}
Todo mundo sabe que as dificuldades, muitas vezes, costumam criar grandes oportunidades. As circunstâncias atuais me dão a magnífica chance de trazer para o governo o maior líder político desse País. Uma pessoa que, além de ser um grande líder político, é um grande amigo e um companheiro de lutas e de conquistas. Seja bem-vindo, querido companheiro, ministro Luiz Inácio, ministro Lula. Eu conto com a experiência do ex-presidente Lula. Conto com a identidade que ele tem com esse País, com o povo desse País. É com isso que eu conto. Conto com sua incomparável capacidade de olhar nos olhos do nosso povo e de entender esse povo, de querer o melhor para esse povo e também de ser entendido e por ele amado. A sua presença aqui, companheiro Lula, prova que você tem a grandeza dos Estadistas e a humildade dos verdadeiros líderes. Prova que não há obstáculos à nossa disposição de trabalhar juntos pelo Brasil.”. (ROUSSEFF, 2016, grifo nosso).
\end{abstract}

Ainda no mesmo pronunciamento, Dilma acionou a narrativa do golpe ao denunciar a divulgação da conversa telefônica entre ela e o ex-presidente Lula. Sobre o ocorrido, Rousseff afirmou que "convulsionar a sociedade brasileira em cima de inverdades, de métodos escusos, de práticas criticáveis, viola princípios e garantias constitucionais, viola os direitos dos cidadãos e abre precedentes gravíssimos. Os golpes começam assim.". (ROUSSEFF, 2016, grifo nosso). Almeida (2016) ressalta que o trecho em questão demarcou o tom dos discursos do governo a partir dali e esclarece que a expressão "Não vai ter golpe" passou a se tornar um "grito de guerra”. (ALMEIDA, 2016, p. 188).

Feitas as observações sobre os ocorridos acima descritos contextualizaremos as manifestações contra o golpe ocorridas em 18 de março de 2016 (um dia após a nomeação de Lula como ministro) e o impacto desses acontecimentos nos atos públicos aqui analisados. 
O maior protesto em número de participantes registrado nessa data ocorreu na cidade de São Paulo, onde de acordo com o Data Folha, compareceram 95 mil pessoas ${ }^{104}$. Na pesquisa citada anteriormente realizada pelo instituto DataFolha sobre os protestos ocorridos em São Paulo (DATAFOLHA, 2016) observou-se que, diferentemente do que se podia imaginar, o perfil dos militantes era bastante semelhante ao perfil observado nos atos pró-impeachment ocorridos em 13 de março. A maioria dos entrevistados que participaram das manifestações contra o golpe se autodeclarou do sexo masculino (58\%), com idade média de 39 anos, ensino superior completo (78\%), renda familiar mensal de 5 salários mínimos ou mais (52\%) e fazer parte da população economicamente ativa (80\%), com destaque para os registrados em carteira assinada (32\%). A principal diferença se encontra na etnia, pois nos protestos de 13 de março $77 \%$ dos entrevistados se declararam brancos e em 18 de março esse índice caiu para 62\%, abrangendo também manifestantes pardos $(20 \%)$ e pretos (14\%).

Na mesma pesquisa realizada pelo DataFolha, quando consultados sobre qual teria sido o melhor presidente do Brasil, 88\% citaram, espontaneamente, o nome de Lula. Getúlio Vargas ficou em segundo lugar, tendo sido escolhido por 3\% dos entrevistados. Já Dilma Rousseff foi citada por apenas $1 \%$ dos manifestantes. Além disso, o PT foi o partido preferido por $48 \%$ dos entrevistados e o Partido Socialismo e Liberdade (PSOL), tradicional agremiação política de esquerda no Brasil, apareceu em segundo, com o voto de $8 \%$ dos manifestantes. Esses dados demonstram interessante paralelo com a intensificação da participação da militância, constituída pela Frente Brasil Popular nos protestos contra o golpe a partir de 2016. O retorno da imagem de Lula ao centro das discussões político-midiáticas em março de 2016 - tanto pela Operação Lava Jato como pela sua nomeação como ministro da Casa Civil - contribuiu, em grande medida, para reascender o apoio militante ao lulismo.

Ainda em relação às manifestações de 18 de março, o principal destaque dos protestos diz respeito à participação de Lula nos atos públicos em São Paulo. O ex-presidente discursou por cerca de 20 minutos em cima de um caminhão de som, ao lado de outras figuras políticas do PT, como o então prefeito da cidade de São Paulo, Fernando Haddad. Sobre o discurso proferido por Lula aos manifestantes destacamos alguns pontos:

a) Lula explicou que sua presença no governo era necessária, tendo em vista a crise pela qual passava o país: "Eu entrei pra ajudar a presidenta Dilma, porque precisamos

\footnotetext{
${ }^{104}$ Houve divergência na contagem do número de participantes já que os organizadores do evento divulgaram o número de 500 mil manifestantes - o que igualaria, quantitativamente, tal protesto ao ocorrido em 13 de março de 2016.
} 
reestabelecer a paz e a esperança e provar que esse país é maior que qualquer coisa no planeta Terra.”. (SILVA, L; 2016, grifo nosso). Interessante observar que, ao se considerar peça-chave no reestabelecimento da ordem, Lula acionou uma das principais funções do mito político, que é apresentar-se como salvação ao imaginário coletivo durante períodos críticos e conturbados.

b) Em outro trecho do mesmo discurso, citado a seguir, Lula enfatiza a narrativa da unidade ao afirmar que seria necessário "juntar todo mundo" para que fosse possível sair do momento de crise que país estava enfrentando. Nota-se, pelo mesmo fragmento, que o expresidente citou o bordão "Lulinha paz e amor", que foi utilizado durante sua campanha eleitoral de 2002.

\footnotetext{
Quando a companheira Dilma me chamou, relutei muito, desde agosto do ano passado, a voltar ao governo. Quando aceitei ir ao governo, voltei a ser Lulinha paz e amor. Não vou ao governo para brigar. Eu vou lá para ajudar a companheira Dilma a fazer as coisas que tem que fazer por esse país. [...] Em época de crise, a gente junta todo mundo e [...] faz o que pode naquele momento [...]. (SILVA, L; 2016, grifo nosso).
}

c) As narrativas de esperança, do otimismo e da autoestima, que também foram recorrentemente utilizadas como estratégia comunicacional da construção da imagem pública de Lula na campanha eleitoral de 2002, voltaram a ser acionadas pelo expresidente durante o discurso na manifestação de 18 de março de 2016. O trecho a seguir ilustra essa observação:

\footnotetext{
Este país tem o povo mais extraordinário. Vocês estão lembrados que em 2007, 2008 a gente fazia pesquisa no mundo e o Brasil, o povo brasileiro, era o povo mais alegre do planeta Terra. E nós precisamos recuperar o humor desse país, a alegria de ser brasileiro, a autoestima de ser brasileiro, é isso que está em jogo. (SILVA, L; 2016, grifo nosso).
}

d) Nesse pronunciamento o ex-presidente acionou, também, a narrativa da conspiração ao acusar os meios de comunicação de influenciar os brasileiros a participarem das manifestações pró-impeachment e relembrou que, nos protestos de 15 de março de 2015, contrários ao governo Dilma e ao PT, o metrô de São Paulo (administrado por equipe do governador do estado, Geraldo Alckmim, do PSDB, partido oposicionista), liberou as catracas para que os manifestantes pudessem circular livremente entre as estações, o que facilitou o aumento do número de participantes nos atos daquele dia. O modelo da 
conspiração fica ainda evidente quando Lula, em trecho que pode ser observado a seguir, divide a argumentação entre "nós" (a classe trabalhadora que enfrenta dificuldades e supera obstáculos) versus "eles" (a elite influenciada pela imprensa):

\begin{abstract}
Essas pessoas que estão aqui não estão aqui porque tiveram metrô de graça, não estão aqui porque foram convocadas pelos meios de comunicação a semana inteira; estão aqui porque sabem o valor da democracia, estão aqui porque sabem o que é uma filha de uma empregada doméstica chegar a uma universidade, porque sabem o que é um jovem que não tinha esperança fazer um curso técnico, essas pessoas que estão aqui sabem o valor que é um coveiro de cemitério que estuda e vira um diplomata, um médico. É esse país que essas pessoas querem. (SILVA, L; 2016).
\end{abstract}

e) Por fim, vale ressaltar que Lula utilizou a narrativa do golpe como um dos argumentos fundamentais contra o processo de impeachment de Dilma Rousseff, o que fez com que o ex-presidente se tornasse um dos principais legitimadores dessa narrativa durante a crise política de 2016. O trecho a seguir ilustra essa observação:

O que está em jogo [...] não é tentar antecipar as eleições dando um golpe na Dilma. Nós temos que dizer pra eles que nós que estamos nessa praça lutamos pra derrubar o regime militar, pra conquistar a democracia e não vamos aceitar mais nem um golpe nesse país. (SILVA, L; 2016, grifo nosso).

Na noite de 18 de março de 2016, logo após o discurso proferido por Lula nas manifestações contra o golpe, o ministro do Supremo Tribular Federal (STF), Gilmar Mendes, decidiu por suspender a posse do ex-presidente para o Ministério da Casa Civil, tendo o mesmo ocupado o cargo por apenas um dia. A ação para a suspensão da posse de Lula foi apresentada a Gilmar Mendes pelo PSDB a partir de arguição escrita pelos advogados Afonso Assis Ribeiro, Gustavo Kanffer e Flávio Costa Pereira. Na ação os advogados argumentaram que a nomeação de Lula para o cargo de ministro tinha como finalidade exclusiva "alterar - artificialmente - a competência para julgamento criminal do ex-presidente" (OMS; CASADO, 2016), ou seja, a justiça considerou que Lula estaria, de fato, buscando blindar-se das investigações de Sérgio Moro e da Operação Lava Jato.

\title{
- Contexto 3: Votação do impeachment na Câmara dos Deputados
}

Em 17 de março de 2016 foi instituída uma comissão especial ${ }^{105}$ do processo de impeachment na Câmara constituída por 65 deputados federais para investigar a veracidade das

105 Presidida por Rogério Rosso (PSD-DF), a comissão teve como relator Jovair Arantes (PTB-GO). 
acusações sobre os tais crimes de responsabilidade fiscal supostamente realizados pela gestão Dilma $^{106}$. O governo federal pôde apresentar defesa após a ocorrência de 9 sessões ou assembleias realizadas pela Comissão Especial do Impeachment. José Eduardo Cardozo, então advogado-geral da União, foi o responsável pela defesa e baseou sua argumentação no fato de que o governo não teria cometido crime de responsabilidade fiscal. Por ocasião de sua fala, Cardozo utilizou a narrativa do golpe e afirmou que o impeachment estaria sendo realizado em desconformidade com a Constituição. (CÂMARA DOS DEPUTADOS, 2016).

Mesmo com os argumentos de defesa, em 11 de abril a comissão votou pela continuação do processo de impeachment por 38 votos a favor e 27 votos contra. O resultado favorável apresentado pela Comissão Especial do Impeachment possibilitou que o processo de impeachment fosse, então, votado pela Câmara dos Deputados, presidida por Eduardo Cunha (PMDB), no dia 17 de abril de 2017.

O debate anterior à abertura da votação na Câmara (que teve início dois dias antes) durou quase 43 horas e se tornou a sessão mais longa da história da Câmara. Tanto o debate como a votação foram transmitidos ao vivo em rádio, televisão e internet, o que colaborou para transformar o ato em um reality show político-midiático. Por 367 votos favoráveis, 137 contrários $^{107}$ e 7 abstenções, a Câmara dos Deputados aprovou, em 6 horas de votação, a continuidade do processo de impeachment de Dilma ${ }^{108}$. (SIQUEIRA, 2016).

Necessário chamar atenção para o fato de que a fundamentação dos votos apresentados pelos parlamentares pouco se valeu da existência ou não do crime de responsabilidade de que estava sendo acusado o governo Dilma. Pelo contrário, os deputados justificaram seus votos pela "família", ou por "Deus" ou "pelo povo brasileiro", entre outros motivos que não os factuais da acusação do impeachment. Sobre a votação em questão ressaltamos a perspectiva apresentada por Villaverde (2016) que discorre que

\begin{abstract}
A maior parte dos 367 deputados que votaram pelo afastamento de Dilma não citou qualquer ponto do parecer dos juristas em análise naquela sessão. Isso também foi verdade para o outro lado, que teve 137 votos. O cálculo para cada voto foi estritamente político, e não técnico [...]. (VILLAVERDE, 2016, p. 233).
\end{abstract}

Para reforçar a perspectiva apresentada por Villaverde (2016) citamos uma matéria publicada na página oficial da Câmara dos Deputados logo após a votação. O texto apontou que a maioria dos

\footnotetext{
106 Necessário destacar que em 29 de março de 2016 a bancada do PMDB noticiou publicamente o rompimento com o governo Dilma Rousseff, o que contribuiu sobremaneira para a intensificação da crise no governo petista. ${ }^{107}$ Apenas deputados do PT, do Psol e do PCdoB não deram votos favoráveis ao processo de impeachment.

${ }^{108}$ Para que o processo de impeachment fosse aprovado na Câmara eram necessários, no mínimo, 342 votos favoráveis (ou dois terços do total de deputados que constituem a Câmara) à sua continuidade.
} 
deputados que votaram a favor do impeachment de Dilma não se baseou nas acusações contra a presidente, mas, sim, no fato de ela não ter condições de governabilidade por falta de apoio de parlamentares e da população brasileira. A matéria cita a fala do líder da Minoria ${ }^{109}$, deputado Miguel Haddad (PSDB-SP), em que o mesmo afirma:

\footnotetext{
Não há canto nenhum desse País em que se possa vislumbrar no rosto das pessoas algum sinal de esperança. Vamos decidir com o nosso voto o futuro de um país destroçado por uma presidente que, com sua arrogância, humilhou o Parlamento e governou de costas para a população.”. (SIQUEIRA, 2016).
}

Já em relação aos que votaram contra a continuidade do impeachment ressaltamos que, grande parte, utilizou como argumentação do voto a defesa da democracia e o repúdio ao golpe. Citamos como exemplo dessa argumentação a justificativa proferida pelo deputado Marcos Maia (PT): "Pelos trabalhadores e pelas trabalhadoras desse Brasil. Pela democracia, pelo respeito ao voto soberano do povo brasileiro que elegeu a presidenta Dilma com 54 milhões de votos, o meu voto é não a esse golpe.”. (MAIA apud COSTA, 2016).

\section{- Contexto 4: Votação do impeachment no Senado Federal}

Após aprovado o processo de impeachment pela Câmara dos Deputados a decisão pela continuidade do processo passou ao Senado Federal, que também instituiu uma comissão especial, em 26 de abril de 2016, da qual o senador Raimundo Lira (PMDB-PB) foi o presidente e Antonio Anastasia (PSDB-MG), o relator. Todas as quatro audiências realizadas pela comissão especial no Senado foram transmitidas ao vivo em televisão, rádio e internet.

Durante essas audiências foram recebidos convidados tanto de defesa como de acusação para a realização de debates em relação ao processo de impeachment. Os convidados que estiveram presentes para a acusação do governo Dilma foram os juristas Miguel Reale Júnior, Janaína Paschoal e Hélio Bicudo (responsáveis pelo pedido de impeachment apresentado à Câmara dos Deputados em outubro de 2015) e o ex-ministro do STF, Carlos Velloso. Já os convidados para defesa do governo foram o então advogado-geral da União, José Eduardo Cardozo; o então ministro da Fazenda, Nelson Barbosa; a então ministra da Agricultura, Kátia

\footnotetext{
${ }^{109}$ De acordo com regimento disponível na página oficial da Câmara dos Deputados, “A Minoria é o maior partido ou bloco parlamentar em oposição ao pensamento da Maioria sobre o Governo Federal (Poder Executivo). Assim, se a Maioria é favorável ao Governo, a Minoria será o maior partido entre aqueles contrários ao entendimento do Governo.”. (CÂMARA DOS DEPUTADOS, 2016).
} 
Abreu, e o ex-presidente da Ordem dos Advogados do Brasil (OAB), Marcello Lavenère. (IMPEACHMENT..., 2016)

Os convidados de acusação ao governo de Dilma Rousseff foram recebidos em 28 de abril por ocorrência de uma das audiências da Comissão Especial do Impeachment no Senado. Exemplificaremos as falas da acusação pelo discurso proferido por Janaina Pascoal que defendeu que a denúncia do impeachment foi formada pela tríade: escândalo do petrolão, pedaladas fiscais e investigações da Operação Lava Jato. Sobre as pedaladas fiscais a jurista afirmou que

[...] foram a maior fraude que já vi na minha vida. Faz 20 anos que advogo no crime, nunca vi nada igual. O governo não podia tomar empréstimo dessas instituições e não só permitiu, mandou, que elas antecipassem esses pagamentos por muitos meses a fio, principalmente em 2014, ano eleitoral. (PASCOAL apud OLIVEIRA, 2016).

Já a defesa do governo de Dilma Rousseff foi ouvida pela Comissão em 29 de abril. O destaque aqui para as justificativas apresentadas por essa defesa a partir do discurso realizado por José Eduardo Cardozo, então advogado-geral da União, chama atenção para a ênfase na ausência de crime de responsabilidade fiscal e na ilegalidade do processo de impeachment. Importante ressaltar que em seu pronunciamento Cardozo utilizou, intensamente, a narrativa do golpe de forma didática, buscando diferenciar os conceitos de golpe e o de impeachment, como pode ser observado no trecho a seguir:

[...] a pergunta que se coloca é: o impeachment é um golpe de Estado? Respondo: pode ser e pode não ser. Se estiver de acordo com a Constituição, se houver crime de responsabilidade, se forem fatos graves, se for um atentado à Constituição, se for respeitado o devido processo legal, não é golpe. Mas se o impeachment for feito em desconformidade com a Constituição, sem clara observância da situação constitucional no que diz respeito aos crimes de responsabilidade, sem o devido processo legal, aí o impeachment é golpe sim. (CARDOZO apud AZEVEDO, 2016b).

Após realizar a diferenciação entre os conceitos, Cardozo utilizou sua própria argumentação como forma de justificar que o impeachment que estava sendo julgado na Comissão Especial do Impeachment do Senado enquadrava-se, portanto, no significado a ele atribuído para o termo "golpe”. Dessa forma, Cardozo aponta:

Afirmo isso justamente como premissa para sustentar que esse processo de impeachment não está sendo realizado em conformidade com a Constituição. Não há crime de responsabilidade. Houve um pretexto. Houve uma flagrante ilegalidade nesse processo no período em que ele se fez realizar na Câmara. E é por isso que digo: em se consumando o impeachment nesses moldes, efetivamente haverá um golpe. (CARDOZO apud AZEVEDO, 2016b). 
Após a ocorrência das quatro sessões da Comissão Especial do Impeachment, no dia 06 de maio, foi aprovada, por 15 votos a favor e 5 votos contra, a abertura da votação à continuidade do processo de impeachment pelo Senado, a partir do relatório apresentado por Anastasia (PSDB).

A votação do processo de impeachment no Senado Federal, que teve duração de 20 horas, ocorreu em 12 de maio de 2016 e também se tornou um reality show político-midiático, pois foi transmitida por todos os principais meios de comunicação do país. Por 55 votos a favor e 22 contra, o Senado decidiu pela abertura do processo $^{110}$. Sobre as justificativas de votos dos senadores, Villaverde (2016) ressalta que o padrão estabelecido pelos deputados se repetiu no Senado e "apenas uma minoria dos parlamentares baseou seu voto no mérito do processo" (VILLAVERDE, 2016, p. 239), ou seja, nos crimes de responsabilidade fiscal. Esse pesquisador aponta que, novamente, a votação se deu por questões políticas (a favor ou contra a permanência do governo) e não técnico-judiciais.

O resultado da votação no Senado afastou Dilma Rousseff do cargo da Presidência inicialmente pelo período de 180 dias até o julgamento final do impeachment pelo Senado. Devido ao afastamento, Michel Temer (PMDB), vice de Dilma, assumiu o cargo de presidente do país em um governo provisório.

${ }^{110} \mathrm{O}$ Senado Federal é constituído por um total de 81 senadores e para que fosse aceita a abertura do processo de impeachment era necessária maioria simples de votos favoráveis, ou seja, 41 votos. 


\section{PROCEDIMENTOS METODOLÓGICOS}

A partir dos dois capítulos anteriormente apresentados, quais sejam: o capítulo em que apresentamos os conceitos teóricos a serem explorados na presente pesquisa e o capítulo no qual lançamos luz sobre a trajetória de Lula bem como sobre o contexto da crise política brasileira de 2016, pontuamos que o presente capítulo visa apresentar os procedimentos metodológicos adotados na pesquisa empírica, que tem por objetivo investigar o processo de (des)construção da imagem pública política de Lula no Twitter durante a crise política de 2016 e como foram acionadas as narrativas do mito político nesse processo.

Isto posto, o primeiro tópico visa a compreensão do Twitter como o ambiente em que será realizada essa análise e, para tanto, apresentamos as principais características dessa mídia social e seu modo de funcionamento. No segundo tópico discorremos sobre os métodos utilizados para a coleta dos dados a serem analisados, a pré-observação das informações recolhidas e o recorte do corpus de análise. Já no terceiro e último tópico apresentamos detalhadamente as duas fases metodológicas empregadas para a análise dos dados obtidos, sendo que a primeira foi realizada a partir da apreciação de redes sociais e a segunda consiste no estudo de conteúdo das narrativas em circulação no Twitter.

\subsection{Twitter: ambiente e lógica de funcionamento}

Criado há 10 anos (em março de 2006) por Jack Dorsey, Evan Williams e Biz Stone, sócios da empresa Odeo, nos EUA (RECUERO, 2011), o Twitter $^{111}$ é uma das mídias sociais mais conhecidas e utilizadas no mundo. A ideia inicial dos desenvolvedores do projeto era fazer com que ele se tornasse uma espécie de "SMS ${ }^{112}$ da internet" com postagens de no máximo 140 caracteres, sendo que essa limitação do número de letras e tipos prevalece até os dias atuais. Devido a essa especificidade de publicações curtas o Twitter passou a ser considerado um microblog ${ }^{113}$, no qual seus usuários publicam mensagens sobre assuntos diversos de forma rápida e objetiva, o que contribuiu amplamente para o acesso a informações em tempo real.

\footnotetext{
111 Disponível em: <http://www.twitter.com>.

112 SMS é a sigla referente a Short Message Service. Trata-se de um serviço de mensagens de até 140 caracteres trocadas via telefones celulares.

113 Blog é o termo que deriva da palavra "weblog" que, por sua vez, vem da junção dos termos, em inglês, "web" (rede) e "log" (registro). Os blogs que se popularizaram, principalmente a partir dos anos 2000, são páginas na internet dedicadas à criação de conteúdo sobre assuntos pessoais ou temas específicos.
} 
O Twitter $^{114}$ funciona a partir da lógica de seguidores na qual um usuário escolhe outro para acompanhar e pode decidir quem o seguirá. (RECUERO, 2011). Dessa forma, o microblog passou a se diferenciar estruturalmente de outras mídias sociais, como o Facebook $^{115}$, por não haver necessariamente conexões recíprocas entre os usuários, ou seja, um usuário pode "seguir" outro, mas não precisa ser "seguido" de volta. Isso faz com que as redes de conexões no Twitter sejam criadas preferencialmente pelo capital social cognitivo, ou seja, em relação às narrativas e aos fluxos informativos escolhidos pelo usuário e não em relação às pessoas (ou amigos, como no caso do Facebook).

O microblog permite a seus usuários criarem perfis ou páginas particulares (pessoais ou de marcas, empresas, instituições etc.) personalizadas a partir das seguintes características principais: o nome do usuário (ou nickname), uma breve biografia/descrição do mesmo (ou bio), a localização desse usuário, dois recursos imagéticos (uma fotografia que acompanha o nome do perfil e outra imagem que pode ser utilizada como "capa" e que fica inserida no cabeçalho da página particular de cada perfil) e o conteúdo das mensagens publicadas pelo usuário. É permitido ao usuário da plataforma publicar mensagens próprias ou compartilhar conteúdo produzido por outro perfil no microblog (esse compartilhamento é chamado de retweet), assim como "curtir" postagens publicadas por outros perfis - tanto os retweets quanto as mensagens que foram curtidas constam na página particular do usuário ${ }^{116}$.

No seu início o Twitter logo perguntava a seus usuários: “O que você está fazendo?”, indagação que imprimia um tom mais pessoal e privado aos conteúdos gerados no microblog. Mas, como bem apontam Mischaud (2007) e Honeycutt e Herring (2009), a maior parte das pessoas não respondia a essa pergunta ao publicar mensagens no Twitter. A partir de 2009, com o crescimento e expansão considerável do número de usuários, a pergunta principal do microblog passou a ser: “O que está acontecendo?” (Figura 1).

\footnotetext{
${ }^{114}$ Interessante pontuar que o símbolo do site, o desenho de um pássaro azul, possui ligação direita com o termo "twitter" que, em inglês, refere-se ao som emitido pelos pássaros, podendo ser utilizado como verbo, como "gorjear" ou "piar", ou como substantivo "gorjeio" ou "pio" e que também pode ser compreendido como algo breve. (LIMA, 2016).

${ }^{115}$ Disponível em: < http://www.facebook.com>.

${ }^{116}$ Ressaltamos que o usuário do Twitter tem possibilidade de bloquear seu perfil e, dessa forma, somente as pessoas que o seguem podem ver suas publicações. Apenas os perfis de caráter "público" podem ser acessados livremente.
} 
Figura 1 - Recorte da tela inicial do Twitter

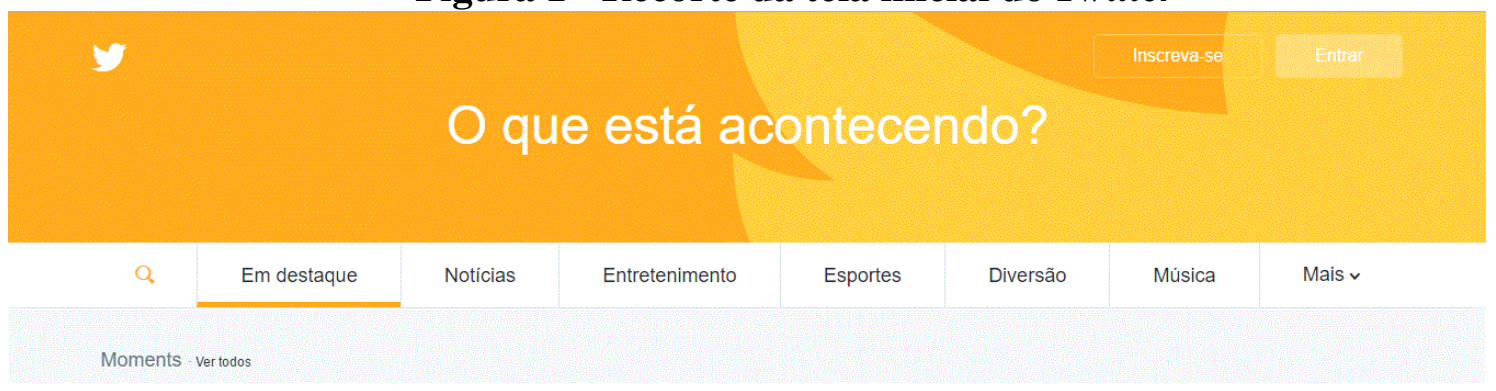

Tal mudança foi estruturada pela demanda percebida na própria utilização dos usuários do site, que deixaram de usá-lo apenas como diário pessoal e passaram a tê-lo também como forma de criação e compartilhamento de conteúdo e informações sobre acontecimentos ao redor do mundo. Sobre essa mudança na pergunta-título, Biz Stone (2009), um dos criadores do Twitter, argumentou:

O modelo fundamentalmente aberto do Twitter criou um novo tipo de rede de informação que superou, há muito tempo, o conceito de atualizações de status pessoal. O Twitter ajuda você a compartilhar e descobrir o que está acontecendo agora em relação a todas as coisas, pessoas e eventos que você gosta. 'O que você está fazendo?' Não é a pergunta certa mais [...]. O Twitter agora pergunta: 'O que está acontecendo?'". (STONE, 2009, tradução nossa). ${ }^{117}$

O microblog teve outras mudanças significativas que também foram impulsionadas pela própria utilização dos usuários, como, por exemplo: o símbolo “@” passou a ser um link direto para o perfil de um usuário (inicialmente isso era feito manualmente). $\mathrm{O}$ comando de retweet (repostar tweets de outro usuário) transformou-se numa ferramenta disponível no site (inicialmente se acrescentava manualmente um "RT" antes da mensagem para demonstrar que o usuário estava repostando algo que não era de sua própria autoria, mas, sim, de outra conta no Twitter); as hashtags ${ }^{118}$ passaram a ser rastreáveis e a fazer parte dos "trending topics" ou assuntos mais comentados no site. Essa lista com os temas mais comentados pode ser no âmbito mundial ou filtrada por país. (BOYD; GOLDER; LOTAN, 2010). Além disso, o microblog

\footnotetext{
117 "The fundamentally open model of Twitter created a new kind of information network and it has long outgrown the concept of personal status updates. Twitter helps you share and discover what's happening now among all the things, people, and events you care about. "What are you doing?" isn't the right question anymore [...]. Twitter now asks, "What's happening?". (STONE, 2009).

118 Como apontamos no segundo capítulo, as hashtags são palavras-chave utilizadas para contextualizar as conversas do Twitter sobre determinado tópico. Ressaltamos, ainda, como bem apontam Recuero et al (2015) que a apropriação da hashtag pelos usuários do Twitter pode apresentar funções variadas devido ao fato de as mesmas terem significado socialmente construído, ou seja, podem ser compartilhadas com variados sentidos (por exemplo, tópicos sobre celebridades, datas comemorativas, assuntos de cunho pessoal ou ainda servir como forma de demarcar o contexto de protestos e manifestações sociais).
} 
passou a disponibilizar ao usuário ferramentas de postagem de fotos, vídeos e gifs em seus tweets.

Como apontado anteriormente, o ano de 2009 foi um marco no crescimento do Twitter, que começou a receber atenção de celebridades, políticos, empresas, grandes marcas e do público em geral (esse último impulsionado, em grande medida, pela crescente utilização do microblog como forma de mobilização para manifestações político-sociais, como visto no capítulo anterior). Em novembro de 2008 o site possuía cerca de 5 milhões de usuários e já em maio de 2009, apenas 6 meses depois, esse número aumentou para 11 milhões de perfis. Em estudo realizado pela Synomos em 2009, constatou-se que, 72.5\% dos 11 milhões de usuários tinham se cadastrado nos primeiros 5 meses daquele ano. (INSIDE..., 2009).

O Brasil tornou-se destaque na utilização do Twitter, primordialmente a partir de 2010, quando o país passou a liderar o aumento global do uso do microblog. Como visto no segundo capítulo desta tese, de acordo com estudo realizado pela comScore, o Brasil, juntamente com Indonésia e Venezuela, passou a conduzir naquele ano o crescimento da audiência global do site. Também em 2010 a língua portuguesa ocupou a terceira posição entre as mensagens postadas no Twitter (atrás apenas da língua japonesa e do inglês norte-americano) - além disso, o Brasil passou a ser o país do qual originava o quarto maior volume de postagens no microblog (após os EUA, Japão e Indonésia). (BRITISH BROADCASTING CORPORATION BRASIL, 2010).

Já a partir de 2012 o Brasil se tornou o segundo país em número de usuários cadastrados nessa mídia social ${ }^{119}$. De acordo com estudo elaborado pelo instituto francês de pesquisa Semiocast $^{120}$ divulgado em 31 de janeiro de 2012, o Brasil havia ultrapassado o Japão no número de usuários do microblog, atingindo a marca de 33,3 milhões de perfis cadastrados na plataforma (o Japão possuía 29,9 milhões), ficando atrás apenas dos Estados Unidos da América (EUA) que possuía 107,7 milhões de usuários registrados. (SEMIOCAST, 2012).

Em 2016, quando o microblog completou uma década de existência, o número de usuário ativos (que acessam a mídia social pelo menos uma vez por mês) no site em todo o mundo passou a ser de 313 milhões ${ }^{121}$ de acordo com números divulgados pelo próprio Twitter, sendo que $82 \%$ desses utilizam o microblog via telefone celular. A partir de pesquisa realizada pela

\footnotetext{
${ }^{119} \mathrm{O}$ cálculo foi realizado em relação a todas as contas criadas no Twitter até 01 de janeiro de 2002, ou seja, não se limita aos usuários ativos.

${ }^{120}$ A Semiocast é uma empresa francesa de consultoria em análise e pesquisas de dados em mídias sociais.

${ }^{121}$ O Twitter disponibiliza apenas os números oficiais de usuários ativos no microblog e não o a totalidade de usuários cadastrados.
} 
empresa Statista ${ }^{122}$, é possível observar que os brasileiros ainda estão entre os principais usuários ativos no Twitter atualmente. A pesquisa divulgou que os EUA apresentam o maior número de páginas ativas na plataforma (67,54 milhões), seguido pela Índia (41,19 milhões), Indonésia (24,4 milhões), Japão (22,4 milhões), China (19,19 milhões) e Brasil, que aparece em sexta posição com 17,97 milhões de usuários ativos no microblog ${ }^{123}$. (NUMBER..., 2016).

Interessante pontuar que, em novembro de 2015, impulsionados pela utilização intensa do Twitter pelos brasileiros, os responsáveis pelo microblog disponibilizaram no Brasil o “Twitter Moments", sessão no próprio site em que é possível ter acesso de forma mais rápida aos assuntos mais importantes e mais comentados do dia. O país foi o segundo a receber a possibilidade de utilização dessa ferramenta, seguindo-se aos EUA. (JUNQUEIRA, 2014).

Antes de estudarmos o perfil dos usuários brasileiros no Twitter torna-se necessário contextualizarmos o acesso à internet no país. A pesquisa mais recente divulgada em abril de 2016 pelo Instituído Brasileiro de Geografia e Estatística (IBGE) e realizada durante o ano de 2014 sobre o acesso à internet no Brasil, 54,4\% da população brasileira com idade a partir de 10 anos (95,4 milhões de pessoas) possuem acesso à internet. $\mathrm{O}$ ano de 2014 foi o primeiro em que esse índice superou a metade do contingente populacional brasileiro - em 2013 essa parcela era de 49,4\%. Uma das causas dessa ascensão foi o crescimento do número de pessoas que possuem telefones celulares, que aumentou para 136,6 milhões, alcançando 77,9\% da população brasileira. Tal expansão contribuiu, também, para que o acesso à internet (e, consequentemente, às mídias sociais) via telefone celular superasse quantitativamente a conexão por meio de computadores. (INSTITUTO BRASILEIRO DE GEOGRAFIA E ESTATÍSTICA, 2016).

As regiões brasileiras que possuem os índices mais elevados de acesso são a região Sudeste $(61,8 \%)$ e a Sul $(51,2 \%)$ - embora a Nordeste tenha apresentado o maior crescimento no número de acessos no comparativo entre 2013 e 2014, passando de 38,6\% para 45,2\%. A conexão é feita, sobretudo, entre os jovens de 15 a 17 anos (81,8\%), 18 e 19 anos (81,1\%) e 20 a $24 \operatorname{anos}(78,5 \%)$. Em relação à renda, o acesso é maior entre os que recebem mais de 10 salários mínimos $(91,5 \%)$, mais de cinco salários mínimos $(88,1 \%)$ e entre 3 a 5 salários mínimos (80,8\%), ainda que o crescimento mais considerável no comparativo entre 2013 e 2014 tenha se dado na faixa dos que recebem até meio salário mínimo - que apresentou expansão de $33,8 \%$ para 40,3\%. A investigação ressalta que o acréscimo considerável no acesso à internet

\footnotetext{
${ }^{122}$ A Statista é uma empresa alemã que se destina a investigar dados estatísticos coletados na internet.

${ }^{123}$ Necessário pontuar que a população brasileira - em termos quantitativos - é expressivamente inferior à dos demais países citados (EUA, Índia, Indonésia, Japão e China). Dessa forma, o Brasil apresenta significativa porcentagem de participação no microblog, se comparado a esses mesmos países.
} 
por camadas da população que possuem renda mais baixa ou por regiões deslocadas do eixo Sul-Sudeste se deve ao crescimento da utilização de telefones celulares no país. (INSTITUTO BRASILEIRO DE GEOGRAFIA E ESTATÍSTICA, 2016).

Ainda em relação ao acesso dos brasileiros à internet destacamos os resultados apresentados em pesquisa realizada pela agência We are Social num universo de 30 países ${ }^{124}$ em 2015. O estudo revelou que no Brasil o usuário passa 5,2 horas navegando na internet via computador e 3,9 horas diárias pelo aparelho celular móvel. Em relação às mídias sociais, o Brasil ocupa o segundo lugar no ranking de países que mais gastam horas utilizando essas mídias - média de 3,3 horas por dia, inferior apenas às Filipinas, onde se gasta, em média, 3,7 horas por dia. (KEMP, 2016).

Especificamente no que tange à utilização do Twitter destacamos a sondagem coordenada pela equipe do Twitter Brasil, na qual é possível observar que a maioria dos usuários brasileiros do microblog é constituída por homens (58\%) que possuem entre 25 e 44 anos (44\%). Em relação ao rendimento familiar, $27 \%$ possui ganho médio, $24 \%$ possuem proventos elevados e $18 \%$ possuem remuneração baixa. Os dados apresentados por esse estudo são reflexo direto do perfil de acesso à internet no país, como visto na pesquisa divulgada pelo IBGE em 2016.

Esse cenário foi a temática abordada pelo vice-presidente do Twitter para a América Latina, Guilherme Ribenboim, em entrevista ao portal de notícias GizModo, quando elencou quatro motivações principais dos brasileiros para a utilização do microblog: 70\% utilizam-no para buscar e compartilhar informações; $67 \%$ para acompanhar personalidades; $70 \%$ acessam o Twitter para seguir eventos em tempo real; e $60 \%$ aproveitam o site como "segunda tela" processo em que o usuário acompanha programas televisivos e, simultaneamente, compartilha informações sobre esses eventos no microblog (JUNQUEIRA, 2014). Oportuno lembrar, também, que $70 \%$ dos brasileiros acessam o Twitter via telefone celular, o que amplia o caráter de agilidade e mobilidade do acesso à plataforma (ZARIFE, 2017). Sobre essa característica do microblog em se constituir como rede de fluxos de informações em tempo real, Fiamma Zarife, diretora de desenvolvimento do Twitter Brasil, em entrevista ao canal de notícias Mobile Time, discorreu que o Twitter

[...] é uma rede de interesses. [...]. É a plataforma que te mostra o que está acontecendo agora dentro daquilo que te interessa, que pode ser [sobre] esportes, notícias, música, programas de TV etc. Você tem a notícia fresca e rápida de uma forma simplificada, além das conversas em volta desse acontecimento. Isso é o Twitter. Tem redes que

\footnotetext{
${ }^{124}$ Argentina, Austrália, Brasil, Canadá, China, Egito, França, Alemanha, Hong Kong, Índia, Indonésia, Itália, Japão, Malásia, México, Nigéria, Filipinas, Polônia, Rússia, Arábia Saudita, Singapura, África do Sul, Coreia do Sul, Espanha, Tailândia, Turquia, Emirados Árabes, Reino Unido, Estados Unidos e Vietnã.
} 
são de buscas, outras de conexões pessoais, onde estão seus amigos, seus inimigos, ou sua família... E o Twitter é uma rede de interesses. É uma ferramenta de comunicação extremamente poderosa. [...]. (ZARIFE, 2017).

Ressaltamos que, como discutido no segundo capítulo desta tese, a mobilidade e a possibilidade de maior agilidade do acesso a informações em curto espaço de tempo proporcionadas pelo Twitter fez com que essa mídia social se tornasse essencial enquanto plataforma de mobilização social e espaço opinativo sobre temas políticos em tempo real. Tais funções do microblog contribuem em grande medida para que possamos compreender a circulação de narrativas ocorridas nos quatro contextos de análise da crise política de 2016 sobre os quais discorremos no capítulo anterior, quais sejam: as manifestações sociais a favor do impeachment e as manifestações sociais contra o golpe e as votações do processo de impeachment na Câmara dos Deputados e no Senado Federal; eventos que, como visto anteriormente, foram divulgados pelos principais meios de comunicação do país - com destaque para as votações na Câmara e no Senado, transmitidas ao vivo -, o que gerou a espetacularização midiática dos acontecimentos políticos analisados por esta tese.

\subsection{Coleta de dados e pré-observação empírica}

Feita a contextualização do ambiente em que será realizada a pesquisa empírica deste estudo, discorreremos nesse tópico sobre a coleta dos dados e a pré-observação empírica dos mesmos. Oportuno mencionar que ao se propor uma investigação sobre ou na internet podem ser encontradas várias armadilhas, a grande maioria das quais recai sobre a dicotomia entre o otimismo e o pessimismo em relação a essa plataforma e suas consequências sociais. Tal bipartição aumenta consideravelmente as chances de o pesquisador passar a diferenciar o ambiente online do off-line ao transformar em divergentes os fatos que ocorrem "dentro" e os que se dão "fora" da internet. Entendemos que esse processo de diferenciação dificulta a compreensão do contexto social como um todo, bem como o funcionamento da comunicação e das questões que englobam os problemas de pesquisa.

Essa temática é investigada por Fragoso, Recuero e Amaral (2013) em estudo sobre os métodos de pesquisa para internet e esses autores defendem que essas armadilhas são consequência de "modismos" principalmente nas pesquisas realizadas na década de 1990, que destacavam, entre outras coisas, “o hype acerca do próprio surgimento da internet; a polarização real versus virtual e o entendimento da internet como esfera autônoma, distinta do real.". (FRAGOSO; RECUERO; AMARAL, 2013). Com o aumento do número de acessos à internet 
a partir dos anos 2000, os estudos passaram a investigar as dinâmicas do ambiente online inseridas no cotidiano social ao se comparar, por exemplo, a mídia digital com outros meios de comunicação, como a televisão.

Essa alteração do foco das pesquisas no ambiente virtual se deu, principalmente, devido às variadas possibilidades de investigação social que surgiram a partir do crescimento acelerado de informações em circulação no âmbito online, na medida em que os conteúdos ficam armazenados e podem ser coletados e observados a qualquer momento por meio de ferramentas de busca ou softwares específicos. A partir da variedade de informações disponíveis tornou-se necessária então a construção de metodologias de pesquisa bem estruturadas que possibilitassem a análise mais precisa destes dados. É o que ressaltam os pesquisadores:

\begin{abstract}
A internet é um universo de investigação particularmente difícil de recortar, em função de sua escala (seus componentes contam-se aos milhões e bilhões), heterogeneidade (grande variação entre as unidades e entre os contextos) e dinamismo (todos os elementos são permanentemente passíveis de alteração e a configuração do conjunto se modifica a cada momento). (FRAGOSO; RECUERO; AMARAL, 2013, p. 55).
\end{abstract}

Dessa forma, os pesquisadores chamam atenção para o fato de que a internet pode ser tanto "objeto de pesquisa (aquilo que se estuda), quanto local de pesquisa (ambiente onde a pesquisa é realizada) e, ainda, instrumento de pesquisa (por exemplo, ferramenta para coleta de dados sobre um dado tema ou assunto).”. (FRAGOSO; RECUERO; AMARAL, 2013). Para melhor compreensão do que se pretende estudar em relação à internet é necessário levar em consideração, portanto, o contexto envolvido no problema de investigação especificado, os objetivos que se pretende alcançar, bem como as condições de análise e coleta dos dados disponíveis. Feitas essas observações ressalta-se que a metodologia adotada na presente tese compreende a internet tanto como instrumento de pesquisa - por utilizar a mesma como fonte na coleta de dados -, como local de pesquisa - já que a pesquisa empírica será realizada no ambiente online.

As informações utilizadas para a análise foram obtidas por meio da ferramenta intitulada Netlytic, definida pelos próprios desenvolvedores como "um analisador de texto e redes sociais baseado em nuvem que pode automaticamente resumir e descobrir redes sociais de conversas on-line em sites de mídia social.”. (GRUZD, 2016, tradução nossa) ${ }^{125}$. A ferramenta, disponível online (www.netlytic.com), foi desenvolvida pelo professor Anatoliy Gruzd, que leciona na

\footnotetext{
${ }^{125 " A}$ cloud-based text and social networks analyzer that can automatically summarize and discover social networks from online conversations on social media sites.”. (GRUZD, 2016).
} 
área de Social Media Data Stewardship (Administração de Dados de Mídias Sociais) na Ryerson University, localizada em Toronto, no Canadá, e pelo grupo de pesquisa Social Media Lab (Laboratório de Mídias Sociais) ${ }^{126}$, coordenado por Gruzd. (SILVA, T; 2016).

O Netlytic permite, entre outras funções, coletar dados de mídias sociais tais como Twitter, Facebook, YouTube ${ }^{127}$ e Instagram $^{128}$; descobrir os assuntos ou tópicos mais populares; encontrar e explorar temas emergentes de discussões; construir, visualizar e analisar redes sociais online, além de mapear dados geográficos codificados em redes sociais.

Por se tratar de ferramenta criada e desenvolvida por pesquisadores, o Netlytic apresentase como importante aliado para estudos acadêmicos sobre as redes socais que se formam na internet e disponibiliza planos com melhor custo-benefício para estudantes e/ou pesquisadores. $\mathrm{Na}$ presente pesquisa optamos pelo plano que permite a coleta de 300 datasets (ou buscas) com 100.000 ocorrências (ou tweets) cada, o que possibilita o recebimento de um volume de cerca de 30 milhões de ocorrências por ano. (SILVA, T; 2016).

A coleta de dados no Twitter pelo Netlytic pode ser programada para buscar tweets que mencionam perfis específicos (ou usernames), hashtags ou palavras-chave e essa busca pode ser ajustada para ocorrer de 15 em 15 minutos, sendo que a cada coleta ou a cada 15 minutos a ferramenta disponibiliza um total de 1000 tweets $^{129}$. Sendo assim, nesta pesquisa ajustamos a ferramenta para coletar mensagens (ou tweets) que foram publicadas no Twitter nos meses de março, abril e maio de 2016 e que apresentavam a palavra-chave "Lula" em seu conteúdo. O período escolhido para a coleta diz respeito aos quatro contextos discorridos no capítulo anterior em relação à crise política brasileira de 2016, quais sejam: as manifestações sociais a favor do impeachment de Dilma Rousseff, as manifestações sociais contra o golpe, a votação pela continuidade do processo de impeachment na Câmara dos Deputados e a votação no Senado

\footnotetext{
126“O Social Media Lab é um laboratório de pesquisa multidisciplinar e interdisciplinar na Faculdade de Gestão Ted Rogers da Ryerson University em Toronto, Canadá. O laboratório estuda como as mídias sociais estão mudando as formas como as pessoas se comunicam, disseminam informações, conduzem negócios e formam comunidades, e como essas mudanças afetam as estruturas sociais, econômicas e políticas da sociedade moderna.”. (SOCIAL MEDIA LAB, 2015, tradução nossa).

${ }_{127}$ Disponível em: $<$ http://www.youtube.com>.

${ }^{128}$ Disponível em: $<$ http://www.instagram.com $>$.

${ }^{129}$ Relevante mencionar que a coleta realizada pelo Netlytic não disponibiliza o total de tweets publicados que correspondem à busca específica (a maioria dos softwares trabalha dessa forma). Isso se deve ao fato de a Interface de Programação de Aplicativos (API) utilizada pelo Netlytic para buscar informações no Twitter ser baseada na função "REST API v1.1", que faz com que o serviço de busca de dados no microblog não seja uma "fonte exaustiva de Tweets" e, por isso "nem todos os Tweets [são] indexados ou disponibilizados através da interface de pesquisa.". (GRUZD, 2016, tradução nossa). Ressaltamos, ainda, que a coleta é feita apenas em perfis públicos, não estendendo às contas bloqueadas pelos usuários. Mesmo com essas limitações reafirmamos que as características da API do Twitter torna mais simples a procura pelos conteúdos gerados no site em comparação à API de outras mídias sociais, como a do Facebook, por exemplo, que permite a coleta de dados apenas em páginas ou perfis específicos, não estendendo a busca para todos os usuários que utilizam a plataforma.
} 
Federal com consequente afastamento da então presidenta de seu cargo pelo período de 180 dias. Já a palavra-chave escolhida tem por objetivo selecionar apenas as mensagens que mencionavam o ex-presidente no período em questão.

Além do conteúdo dos tweets, ressaltamos ainda que, a partir dos dados disponibilizados pelo Netlytic, obtivemos as seguintes informações adicionais sobre cada tweet coletado: a $\mathrm{URL}^{130}$ que direciona para o tweet, a data em que o tweet foi publicado, o nome do perfil do usuário que publicou a mensagem, a bio do usuário, a localização do usuário e o idioma em que a mensagem foi publicada. Esclarecemos também que foram recolhidas as informações referentes às redes sociais estabelecidas a partir dos tweets coletados, ou seja, obtivemos dados sobre possíveis conexões estabelecidas entres os usuários que publicaram mensagens com a palavra-chave "Lula" durante o período recortado (entre março e maio de 2016). Assim como o conteúdo do tweet, também os dados sobre os usuários responsáveis pelas publicações e as informações sobre as redes socais estabelecidas entre esses usuários serão utilizados na análise empírica a ser detalhada mais adiante.

Em pré-observação dos subsídios obtidos notou-se que foi coletada quantidade excessiva de informações - obtivemos cerca de 1.705.117 tweets por mês, ou seja, uma média total de mais de 5 milhões de postagens. O número exorbitante de dados impediria a melhor validação dos resultados da pesquisa devido ao fato de a pesquisadora ter realizado a investigação individualmente, bem como limitações computacionais em função da incapacidade dos recursos tecnológicos disponíveis para a sondagem em processar um número tão elevado de informações.

Optamos então por utilizar no presente estudo, o tipo de amostragem intencional que, de acordo com Fragoso, Recuero e Amaral (2013), procura compreender e selecionar os elementos mais significativos de uma determinada gama de dados de pesquisa e, para tanto, se baseia na intenção do pesquisador em delimitar objetivos para esclarecer sua problemática inicial. Dentro dessa amostra intencional, há dois subtipos que também serão utilizados nesta tese: a) um teórico ou conceitual - no qual a seleção dos dados é dirigida por construções teóricas relativas ao problema de pesquisa; b) e outro emergente - em que há seleções adicionais ao longo da pesquisa em função das novas oportunidades surgidas durante a coleta de dados ou de novos elementos decorrentes dos resultados parciais. Como bem apontam esses autores, por ser uma pesquisa intencional ela possui caráter fluido, ou seja, algumas escolhas iniciais podem revelar

\footnotetext{
${ }^{130}$ A URL é a sigla referente à expressão inglesa "Uniform Resource Locator" (ou Localizador Uniforme de Recursos) e diz respeito ao endereço de uma página (ou site) específica na internet.
} 
situações ao longo do processo que sugerem observações antes não programadas. Dessa forma, o estudo se tornou um movimento cíclico entre os dados obtidos e a análise realizada.

Isto posto, a partir da pré-observação dos dados coletados optamos pelo recorte da análise em datas específicas. Foram analisados os tweets que mencionavam a palavra-chave "Lula" e postados nos dias 12 e 13 de março; 17 e 18 de março; 17 e 18 de abril; 12 e 13 de maio - datas referentes a 2016. Optamos por esses períodos específicos devido aos acontecimentos discorridos no capítulo anterior, quais sejam: as manifestações sociais a favor do impeachment ocorridas em 13 de março, as protestações contra o golpe em 18 de março, a votação na Câmara dos Deputados em 17 de abril e a votação no Senado Federal em 12 de maio) ${ }^{131}$.

Esclarecemos que a opção por coletar dados referentes a datas anteriores às manifestações se deve ao fato de buscarmos compreender as mensagens publicadas não só durante as manifestações, mas, também, o conteúdo publicado na mobilização para as mesmas. Já as datas de coleta posteriores às votações do processo de impeachment se justificam pelo fato de optarmos por compreender não só o conteúdo das postagens realizadas durante o processo decisório dos parlamentares, mas, também, a repercussão posterior ao resultado dessas votações.

Esse recorte reduziu o corpus total de análise para 437.286 tweets. As datas supracitadas foram, então, agrupadas em quatro contextos previamente abordados no capítulo anterior. Para melhor visualização do recorte da análise empírica dispomos os quatro contextos no Quadro 1, a seguir:

\section{Quadro 1 - Contextos analisados na pesquisa empírica}

\begin{tabular}{cc}
\hline Contextos analisados & $\begin{array}{c}\text { Período de postagem dos tweets } \\
\text { (datas referentes ao ano de 2016) }\end{array}$ \\
\hline $\begin{array}{c}\text { Contexto } 1 \\
\text { Manifestações sociais a favor do impeachment }\end{array}$ & 12 e 13 de março \\
\hline $\begin{array}{c}\text { Contexto } 2 \\
\text { Manifestações sociais contra o golpe } 18 \text { de março }\end{array}$ \\
\hline Contexto 3
\end{tabular}

${ }^{131}$ Interessante pontuar que Becker et al. (2016), em artigo intitulado "Manifestações e votos ao impeachment de Dilma Rousseff na primeira página de jornais brasileiros" publicado pela Revista Latino Americana de Ciencias de la Comunicación (ALAIC), também elegeram os contextos das manifestações ocorridas em 13 e 18 de março e as votações do processo de impeachment ocorridas na Câmara e no Senado respectivamente em 17 de abril e 12 de maio de 2016 como pano de fundo para análise de estudo sobre a cobertura dos jornais O Globo, Folha de São Paulo e $O$ Estado de São Paulo sobre os acontecimentos supramencionados. Ressaltamos que a escolha dos autores reitera a relevância dos quatro contextos na atual conjuntura política brasileira e corrobora o acerto da metodologia empregada na presente pesquisa. 


\begin{tabular}{cc}
\hline Votação na Câmara dos Deputados & 17 e 18 de abril \\
\hline Votação no Sento 4 \\
\end{tabular}

Fonte: Elaborado pela autora.

Apresentamos no Gráfico 1, a seguir, o número de total de tweets obtidos nas oito datas específicas recortadas para a análise empírica.

Gráfico 1. Número de tweets obtidos por meio da coleta de dados do Netlytic 


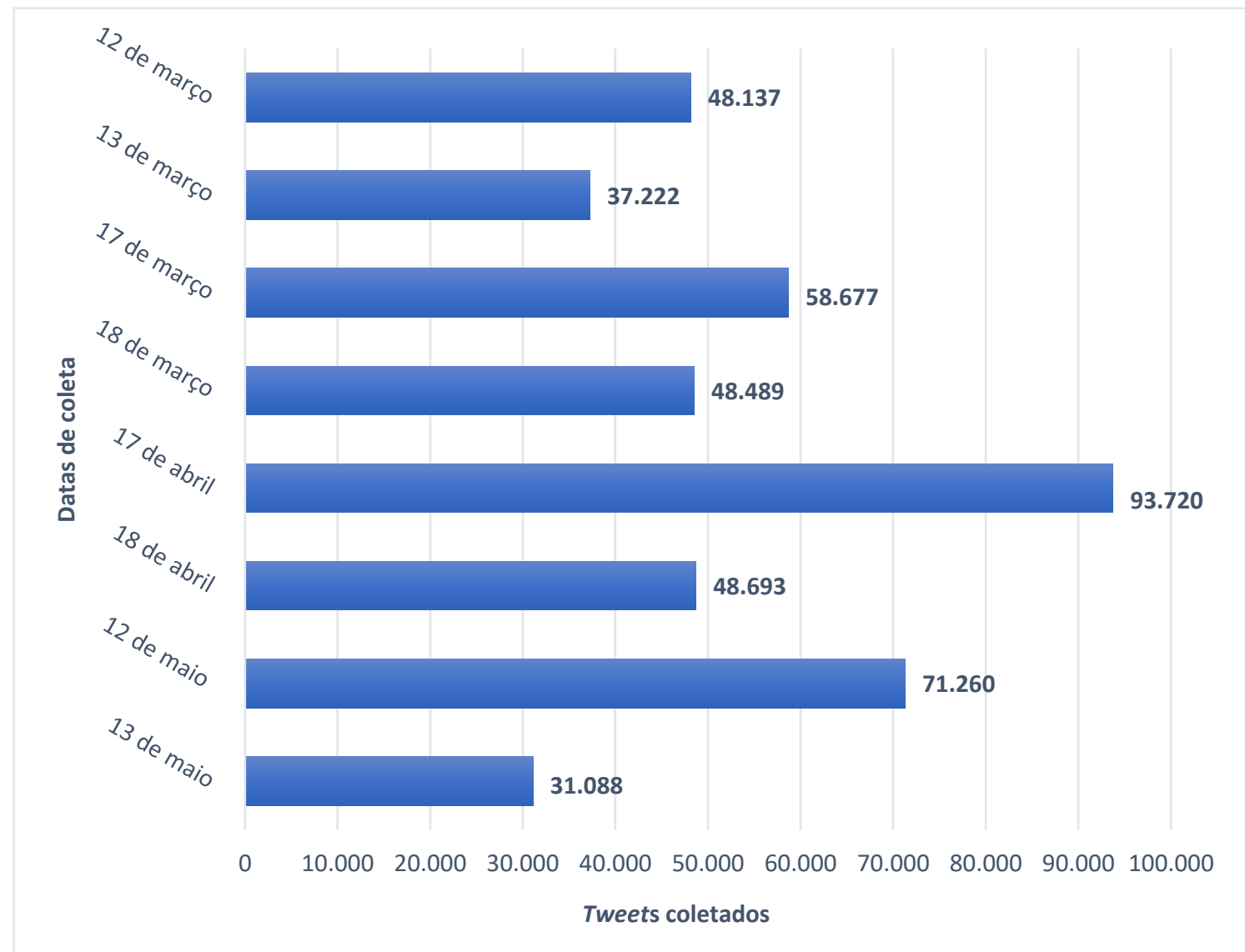

Fonte: Elaborado pela autora.

Como pode ser observado no gráfico acima, o pico de postagens se deu em 17 de abril de 2016 (93.720 tweets coletados), quando ocorreu a votação na Câmara dos Deputados pela continuação do processo de impeachment de Dilma Rousseff. O elevado número de tweets publicados nessa data reflete o impacto gerado pela espetacularização midiática da votação em questão que, como apontado anteriormente, pôde ser acompanhada ao vivo pelos brasileiros pela transmissão instantânea dos veículos de comunicação. A segunda data com maior número de postagens coletadas foi 12 de maio de 2016, quando houve a votação favorável no Senado pelo afastamento de Dilma do cargo da Presidência da República pelo período de até 180 dias, que, da mesma forma que a votação na Câmara, pôde também ser acompanhada ao vivo por meio dos veículos de comunicação. Interessante ressaltar, em ambos os casos, a importância do Twitter enquanto "segunda tela", fenômeno sobre o qual discorremos no tópico anterior sobre as características do microblog. 


\subsection{Análise empírica}

Feita a coleta dos dados e a pré-observação dos mesmos, organizamos a análise empírica em duas fases que se entrecruzam na medida em que colaboram entre si com inferências importantes para os resultados finais da pesquisa. A primeira dessas etapas foi realizada a partir da análise de redes sociais e a segunda consiste na apreciação do conteúdo das narrativas em circulação no Twitter. Nos tópicos a seguir descrevemos o passo a passo dessas fases.

\subsection{1 $1^{\mathrm{a}}$ fase: Análise de redes sociais}

A primeira fase da análise empírica foi realizada a partir do método de Análise de Redes Sociais (ARS), que, como bem aponta Janna Omena (2017) em estudo sobre as redes sociais na internet, permite que possamos explorar determinados tipos de associações entre os usuários, bem como conexões inesperadas entre os mesmos; identificar os atores (ou nós) mais influentes ou mesmo aqueles que são marginais à rede e mapear alianças e oposições entre os usuários da rede. Nesse sentido, a ARS foi aplicada para que fosse possível compreender as relações estabelecidas entre os usuários do Twitter que publicaram mensagens com a palavra-chave "Lula" durante os quatro contextos recortados para a análise empírica. A seguir elencamos os principais apontamentos sobre esse método de análise, seus precedentes e como ele foi utilizado na presente pesquisa para a realização da ARS no Twitter.

\subsubsection{Análise de redes sociais: fundamentos}

As redes sociais na internet são necessário objeto de estudo nas relações comunicacionais contemporâneas, mas, como visto no segundo capítulo, os estudos sobre o conceito de redes sociais passaram a ser importantes para o entendimento da sociedade bem antes do avanço das pesquisas no âmbito online. Como bem aponta Linton C. Freeman (2004), as investigações que passaram a analisar essas redes foram influenciadas pelas pesquisas estruturalistas ao focarem as análises nas relações que conectavam os indivíduos em grupamento ao invés dos indivíduos isoladamente. Esses estudos compreendiam as redes sociais a partir de nós (os atores sociais) e arestas (as conexões estabelecidas entre os atores).

Mizruchi (2006) explica que os estudos do campo da ciência social que passaram a compreender os fenômenos a partir do conceito de redes sociais partiam do princípio de que a relação estabelecida entre os atores de uma rede tem consequências importantes para esses 
indivíduos, ou seja, "a análise de redes é um tipo de sociologia estrutural que se baseia numa noção clara dos efeitos das relações sociais sobre o comportamento individual e grupal.”. (MIZRUCHI, 2006, p. 73). Para o pesquisador de redes sociais, portanto, a estrutura das relações sociais é determinante para compreensão do conteúdo dessas relações.

O método de pesquisa nas ciências sociais que analisa essas conexões entre diferentes indivíduos é chamado de Análise de Redes Sociais (ARS) e, na visão de Freeman (2004), é geralmente utilizado no estudo de relações entre indivíduos únicos (seres humanos), embora possa também ser empregado para compreender relações entre outros tipos de atores sociais como organizações, grupos, países etc.

Já para John Scott (2000) a ARS se consolidou como metodologia de pesquisa a partir de duas linhas de estudo desenvolvidas entre as décadas de 1930 e 1940: a) uma delas é a sociometria analítica, que ficou conhecida principalmente pelos estudos do pesquisador e psicólogo Jacob Moreno. Segundo Scott (2000), nesses estudos Moreno compreendia as redes sociais a partir da teoria dos grafos, que consiste numa representação gráfica das redes sociais estabelecidas entre os indivíduos ${ }^{132}$.

Esta análise recebe também as considerações de Recuero, Bastos e Zago (2015), segundo os quais Jacob Moreno desenvolveu, ainda, quatro elementos definidores da ARS, são eles: “dados baseados nas escolhas dos laços sociais (quem está conectado a quem), a observação dos padrões de conexão entre os indivíduos, a análise dos tipos de conexões e os papéis sociais desses indivíduos.”. (RECUERO; BASTOS; ZAGO, 2015, p. 44). Essa representação gráfica da rede social é estabelecida a partir da tabulação dos dados coletados sobre as relações estabelecidas nesse circuito.

A seguir apresentamos um exemplo da representação de uma rede social em grafo, sendo que para esse exemplo elaboramos uma situação fictícia em que cada pessoa de um determinado grupo de amigos nomeou outra como possível convidado para um algum evento. Esses dados foram dispostos na Quadro 2 e apresentados em grafo na Figura 2. Nota-se que, no grafo, os nós são representados pelos pontos e as arestas, pelas linhas que ligam esses pontos:

\footnotetext{
${ }^{132}$ Importante ressaltar que a teoria dos grafos já havia sido utilizada pelo matemático Leonard Euler em 1736, quando o mesmo buscou compreender todas as possibilidades de conexões que poderiam ser estabelecidas na cidade de Königsberg (Alemanha), a partir das pontes que faziam a ligação entre as duas ilhas da cidade. De acordo com Recuero, Bastos e Zago (2015), “o problema consistia em verificar se era possível atravessar todas as pontes apenas uma vez, saindo e retornando ao mesmo ponto [...] O autor transformou as pontes em conexões e as cidades (e suas partes), em nós.”. Apesar do reconhecimento desse estudo como pioneiro na utilização de grafos como forma de visualização de redes sociais, foram as pesquisas de Jacob Moreno nas décadas de 1930 e 1940 que efetivamente colaboraram para consolidar a metodologia de Análise de Redes Socais como a conhecemos hoje em dia.
} 
Quadro 2 - Apresentação em tabela dos dados de uma rede social de amigos e seus respectivos convidados

\begin{tabular}{cl}
\hline Amigo & Convidado \\
\hline Mariana & Felipe \\
\hline Júlia & Felipe \\
\hline Tiago & Felipe \\
\hline Felipe & Pedro \\
\hline Pedro & Marcos \\
\hline Marcos & Mariana \\
\hline Luiz & Mariana \\
\hline Clara & Felipe \\
\hline
\end{tabular}

Fonte: Elaborado pela autora.

Figura 2 - Representação em grafo da rede social apresentada no Quadro 2

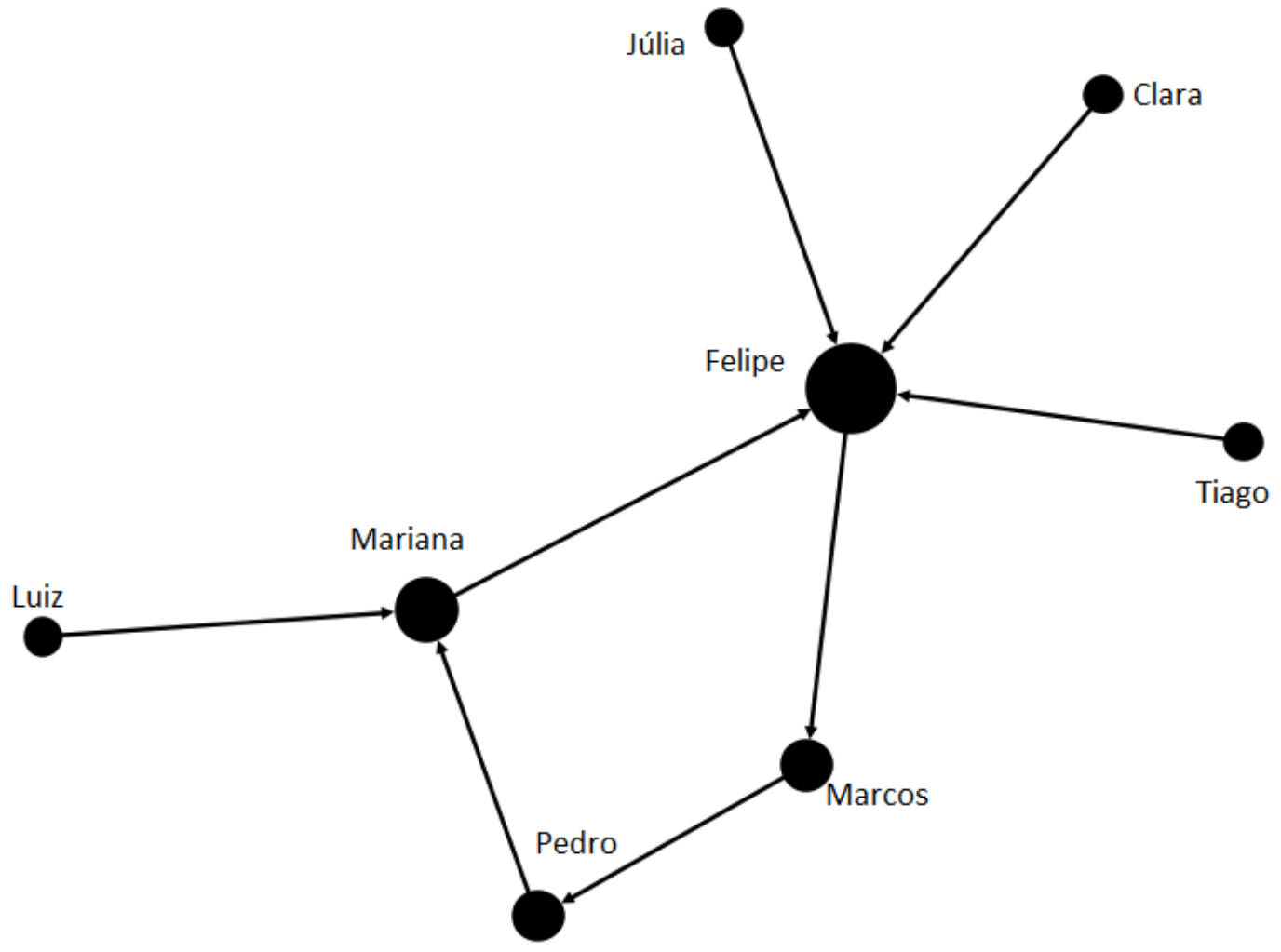

Fonte: Grafo elaborado pelo software Gephi ${ }^{133}$.

b) A outra linha de estudo consiste na teoria dos clusters (ou subgrupos), que ficou mais conhecida com os trabalhos do antropólogo Radcliffe-Brown. Essa teoria compreende as redes sociais a partir de padrões de relações interpessoais: os clusters ou subgrupos eram formados dentro das redes sociais em consequência de determinadas afinidades entre os nós da rede. $\mathrm{Na}$

${ }^{133}$ Discorremos sobre o software Gephi em maiores detalhes adiante. 
Figura 3 é possível visualizar a representação em grafo de uma rede social que foi subdividida em clusters - note-se que cada cluster é representado por uma cor diferente.

Figura 3 - Exemplo de rede social representada em grafo e subdividida em clusters

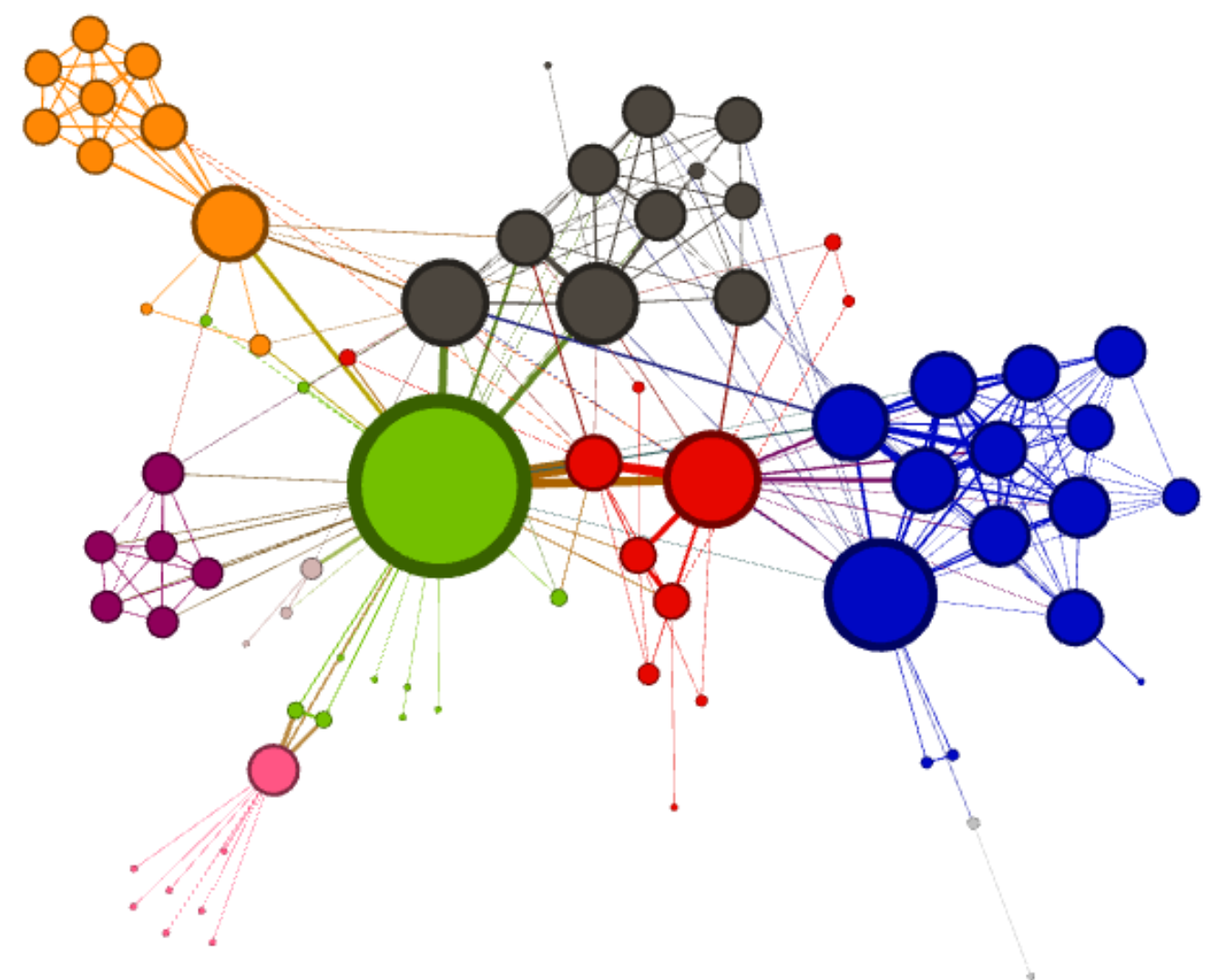

Fonte: Grafo elaborado pelo software Gephi.

De acordo com Scott (2000), ambas as teorias, tanto a dos grafos, abordada por Moreno, quanto a dos clusters, referida por Radcliffe-Brown, são responsáveis por basear e direcionar os estudos posteriores e contemporâneos da ARS. Scott (2000) lembra ainda que foi a partir de 1970, com os estudos dos sociólogos Harrison White e Mark Granovetter da Universidade de Harvard nos Estados Unidos, que o método de ARS atingiu consolidação teórica importante e se popularizou.

Recorre-se novamente a Recuero, Bastos e Zago (2015), para quem essa popularização se deu com a consolidação de "trabalhos mais 'técnicos' [que] passaram a demarcar com mais força os principais conceitos que vão construir a Análise de Redes Sociais e, em especial, com um foco sociométrico.”. (RECUERO; BASTOS; ZAGO, 2015, p. 42). Essas pesquisas diziam respeito às numerosas aplicações sociológicas das técnicas de ARS que foram realizadas pelos 
pesquisadores de Hardvard na década de 1970 - exemplo dessas aplicações é o estudo de Granovetter intitulado Getting a Job e lançado em 1974, no qual o pesquisador buscou compreender como as pessoas conseguiam encontrar emprego. No estudo em questão, Granovetter realizou uma investigação sobre como as pessoas adquiriam informações sobre oportunidades de trabalho a partir dos contatos (ou laços) sociais informais que elas possuíam. (SCOTT, 2000).

A partir do avanço nos estudos das redes sociais no campo sociológico, Freeman (2004) postula quatro pilares que constituem a ARS contemporânea:

1. A análise da rede social é motivada por uma intuição estrutural baseada em laços que ligam atores sociais; 2. Baseia-se em dados empíricos sistemáticos; 3. Baseia-se fortemente em imagens gráficas; e 4. Baseia-se no uso de métodos matemáticos e / ou computacionais... (FREEMAN, 2004, p. 3, tradução nossa). ${ }^{134}$

Queila Souza e Carlos Quandt (2008), em perspectiva semelhante à de Freeman (2004), definem o método de Análise de Redes Sociais como:

(...) uma ferramenta metodológica de origem multidisciplinar (psicologia, sociologia, antropologia, matemática, estatística) cuja principal vantagem é a possibilidade de formalização gráfica e quantitativa de conceitos abstraídos a partir de propriedades e processos característicos da realidade social. (SOUZA; QUANDT, 2008, p.31).

As possibilidades de utilização da ARS foram ampliadas significativamente após a consolidação do estudo enquanto método de pesquisa. Como exemplifica Freeman (2004), esse método de análise passou a ser empregado, entre outras formas, para:

[...] o estudo da mobilidade profissional, o impacto da urbanização dos indivíduos, o sistema político e econômico no mundo, tomada de decisão comunitária, apoio social, comunidade, grupo de resolução de problemas, difusão, interligação empresarial, sistemas de crença, cognição social, mercados, sociologia da ciência, intercâmbio e poder, consenso e influência social bem como a formação de coalisões... estudos de primatas, comunicação mediada por computador, estudos intra e interorganizacionais e marketing [...].”. (FREEMAN, 2004, p. 4, grifo nosso, tradução nossa). ${ }^{135}$

\footnotetext{
134 1. Social network analysis is motivated by a structural intuition based on ties linking social actors; 2 . It is grounded in systematic empirical data; 3. It draws heavily on graphic imagery; and 4. It relies on the use of mathematical and/or computational models. (FREEMAN, 2004. p. 3).

135 “[...] the study of occupational mobility, the impact of urbanization on individuals, the world political and economic system, community decision-making, social support, community, group problem-solving, diffusion, corporate interlocking, belief systems, social cognition, markets, sociology of science, exchange and power, consensus and social influence, and coalition formation...primate studies, computer-mediated communication, intra- and inter-organizational studies, and marketing [...].”. (FREEMAN, 2004, p. 4, grifo nosso)
} 
Como observado na citação acima, o campo dos estudos da Comunicação Mediada pelo Computador (CMC) foi um dos que se apropriaram amplamente do método de ARS para compreender as relações estabelecidas entre os atores sociais via internet. As mídias sociais e as possibilidades de conexão entre os usuários das mesmas contribuíram em grande medida para a ampliação dos estudos sobre os laços sociais contemporâneos a partir da metodologia estabelecida pela $\mathrm{ARS}^{136}$. No tópico a seguir discorreremos sobre a aplicação do método de ARS para as mídias sociais - especificamente para o Twitter.

\subsubsection{Aplicação da análise de redes sociais para o Twitter}

Para melhor entendimento de como o método será empregado na presente pesquisa abordaremos, a seguir, quatro tópicos de suma importância para a compreensão e utilização da ARS aplicada ao Twitter. Para tanto, nos apoiamos em Recuero, Bastos e Zago (2015), que ressaltam que esses tópicos são provenientes da sociometria (ou teoria dos grafos) e da teoria dos clusters, já abordadas.

1. O primeiro tópico que necessitamos explorar para compreender a realização da ARS aplicada ao Twitter diz respeito aos elementos das redes sociais, ou seja, os nós e as arestas. Os nós, também chamados de vértices, de uma rede social representam os atores sociais que compõem essa rede, ou seja, podem representar "[...] pessoas ou estruturas sociais como grupos de trabalho, times, organizações, instituições, estados ou até mesmo países”. (HANSEN; SHNEIDERMAN; SMITH, 2011, p. 34, tradução nossa). ${ }^{137}$.

No caso de redes sociais que ocorrem no âmbito online, esses nós podem representar perfis de usuários do Twitter ou do Facebook, assim como sites ou blogs diversos, vídeos, textos, locais físicos ou virtuais, eventos etc. Ressaltamos que, como o foco da nossa pesquisa são as redes sociais estabelecidas no Twitter, os nós a serem investigados se referem aos usuários do microblog que publicaram mensagens com menção à palavra-chave "Lula" durante os quatro contextos de análise sobre os quais discorremos anteriormente. Pontuamos, ainda,

\footnotetext{
${ }^{136}$ Atualmente no Brasil alguns pesquisadores têm se destacado ao utilizarem a ARS como método de análise das conversações e narrativas em circulação nas mídias sociais. Como exemplo podemos citar os estudos realizados por Raquel Recuero, doutora em Comunicação e professora na Universidade Federal de Pelotas (UFPEL); e as pesquisas de Fábio Malini, doutor em Comunicação, professor na Universidade Federal do Espírito Santo (UFES) e pesquisador integrante do Laboratório de Estudos de Imagem e Cibercultura (LABIC).

137 "[...] people or social structures such as workgroups, teams, organizations, institutions, states, or even countries.”. (HANSEN; SHNEIDERMAN; SMITH, 2011, p. 34).
} 
que esses nós (ou perfis) serão investigados a partir categorias de análise específicas, sendo que tais categorias foram construídas com base no que Thiago Moraes e Doacir Quadros (2016) denominam "tipo de jogador" (ou tipos de usuários do Twitter). Para os autores (2016), existem quatro tipos principais de usuários, sendo eles:

a) Políticos e lideranças (twitters de políticos, partidos políticos ou organizações políticas da sociedade civil como organizações não governamentais [...], organizações da sociedade civil de interesse público [...] dentre outras; b) Meios de comunicação de massa (twitters de jornais, emissoras de rádio e TV, canais de notícia); c) Lideranças sociais e formadores de opinião (artistas, comentadores políticos, jornalistas); d) Players individuais comuns (a maior parte dos usuários da internet, pessoas comuns). (MORAES; QUADROS, 2016, p. 16).

Na presente pesquisa, no entanto, ampliamos as categorias de análise de nós estabelecidas por Moraes e Quadros (2016) apresentadas acima e classificaremos os seis tipos de usuários do Twitter, sendo eles:

a) Lideranças: perfis que pertencem a algum tipo de liderança política ou social (partidos ou figuras políticas, instituições ou organizações da sociedade civil);

b) Veículos jornalísticos: perfis pertencentes à imprensa (jornais impressos, portais de notícia online, canais de televisão ou emissoras de rádio);

c) Blogs jornalísticos: são perfis no Twitter destinados a blogs jornalísticos, predominantemente; blogs que tratam de temas que envolvem abordagens e temáticas políticas;

d) Formadores de opinião: perfis que pertencem a celebridades, artistas, jornalistas ou figuras reconhecidas publicamente;

e) Militância: perfis de militância que se destinam única e exclusivamente à criação, publicação e divulgação de conteúdo militante - seja para um partido, figura ou causa política;

f) Usuários comuns: perfis pertencentes a pessoas comuns.

Feita a observação sobre os nós da rede, discorreremos sobre as arestas (também conhecidas como conexões) de uma rede social, que representam as relações estabelecidas entre os nós ou perfis no Twitter. Para Hansen, Shneiderman e Smith (2011):

Arestas podem representar muitos tipos diferentes de relacionamentos como proximidade, colaborações, parentesco, amizade, parcerias comerciais, citações, investimentos, hyperlinking, transações e atributos compartilhados. Pode-se dizer que 
um laço existe se tem algum estatuto oficial, é reconhecido pelos participantes, ou é observado por troca ou interação entre eles. Uma ligação é qualquer forma de relacionamento ou conexão entre duas entidades. (HANSEN; SHNEIDERMAN; SMITH, 2011, p. 34, tradução nossa). ${ }^{138}$

Ainda de acordo com esses estudiosos, há dois tipos de conexões que podem ser estabelecidas entre os nós de uma rede social: a) as conexões direcionadas (ou assimétricas) possuem origem e destino demarcados - na representação gráfica essas vinculações são observadas por setas que direcionam as ligações, por exemplo: se um ator "A" empresta dinheiro a um ator "B" essa ligação será representada com uma seta que tem origem no nó que representa o ator "A" e que está direcionada para o nó que representa o ator "B". Essas vinculações direcionadas podem ser recíprocas ou não, como no exemplo supracitado o ator "B" pode não ter emprestado dinheiro ao ator "A", apesar de ter recebido a verba desse último. Essas conexões assimétricas podem ser estabelecidas, por exemplo, no âmbito do Twitter quando um usuário segue outro e não necessariamente é seguido de volta; b) as conexões não direcionadas (ou simétricas) não possuem origem e destino claros e são, necessariamente, mútuas. Um exemplo desse tipo de conexão pode ser observado a partir da participação de dois atores sociais em uma organização específica. Outro exemplo são as amizades estabelecidas no Facebook que necessitam de aprovação dos dois nós envolvidos no processo para que ocorra a ligação - ou seja, o vínculo é recíproco e só pode existir nessa forma. As conexões simétricas são representadas nos grafos de rede como linhas que conectam dois nós, mas que não possuem setas direcionais de origem e destino dessa ligação.

Por se tratar de uma pesquisa no ambiente do Twitter o presente estudo analisará, portanto, as conexões do tipo assimétricas, ou seja, com direcionamentos claros de origem e destino. Nesse sentido, à luz de Recuero, Bastos e Zago (2015), entendemos que as conexões estabelecidas no microblog são construídas quando um usuário cita outro ou responde a outro (menções), quando um usuário compartilha informações publicadas por outro (retweets) ou, ainda, quando um usuário segue outro.

2. O segundo tópico relativo ao método de ARS aplicado ao Twitter diz respeito aos tipos de redes sociais que podem ser encontrados. Como bem apontam esses estudiosos, há dois

\footnotetext{
138 "Edges can represent many different types of relationships like proximity, collaborations, kinship, friendship, trade partnerships, citations, investments, hyperlinking, transactions, and shared attributes. A tie can be said to exist if it has some official status, is recognized by the participants, or is observed by exchange or interaction between them. A tie is any form of relationship or connection between two entities. (HANSEN; SHNEIDERMAN; SMITH, 2011, p. 34).
} 
tipos principais de redes: as egocentradas (ou redes ego) e as inteiras e esses tipos de redes têm relação direta com a forma de coleta dos dados. As redes conhecidas como redes ego são aquelas formadas em torno de um nó específico (RECUERO, BASTOS, ZAGO, 2015). No Twitter uma rede ego é encontrada quando se coleta dados sobre as conexões estabelecidas por um único usuário, por exemplo, uma figura política. Assim, a rede será estabelecida pelas menções realizadas ao perfil da figura política em questão, bem como pelas menções que essa figura política faz a outros usuários. A intenção da coleta de dados pela rede ego é compreender as relações sociais criadas e estabelecidas em função de um único nó na rede.

Já a rede inteira é formada não a partir das conexões formadas em relação a um único nó, mas, sim, a partir de dados coletados em torno de interesses ou assuntos específicos. Dessa maneira, esclarecemos que a presente pesquisa trabalha com o método de rede inteira ao buscar investigar como os usuários do Twitter se relacionam e criam conexões em torno da temática ou da palavra-chave "Lula" no período pré-determinado da coleta. Apoiamo-nos em Recuero, Bastos e Zago (2015), que apontam que a abordagem da rede inteira "gera menos centralização da rede e, por isso, permite que se observe melhor como o grupo coletado está estruturado.”. (RECUERO, BASTOS, ZAGO, 2015, p. 60).

3. O terceiro tópico necessário à compreensão da utilização da ARS aplicada ao Twitter diz respeito às métricas de análise das redes sociais. De acordo com Recuero, Bastos e Zago (2015), há dois tipos de métricas: as de nó e as de rede. Em relação às métricas de nó, esses pesquisadores ressaltam que elas se referem, principalmente, à centralidade de um determinado nó em certa rede. As métricas de nó são, portanto, referência de centralidade (ou da importância de um nó na rede). Ressaltamos que, das cinco principais métricas de nó - quais sejam: grau do nó, grau de intermediação, grau de proximidade, grau centralidade de autovetor e PageRank (RECUERO, BASTOS, ZAGO, 2015) -, utilizaremos na presente pesquisa apenas a métrica relativa ao grau do nó.

Essa métrica determina o número de conexões que um nó ou perfil no Twitter possui e, como é baseada na noção de centralidade, quanto mais conexões esse nó possuir mais central ele será na rede. Como tratamos de conexões assimétricas, ou seja, não necessariamente recíprocas, ressaltamos que o grau do nó pode ser identificado de duas maneiras: o grau de entrada (indegree), ou seja, o número de conexões que o nó recebe - no caso do Twitter essas conexões recebidas podem ser citações ou menções a algum perfil, ou então retweets de uma publicação desse mesmo perfil; e o grau de saída (outdegree), que se refere ao número de conexões que um nó realiza com outros na rede - no Twitter essa conexão pode ser estabelecida 
quando um usuário cita ou compartilha publicações de outro perfil. Assim, quando um perfil "A" menciona ou retweeta um perfil "B" no Twitter, o grau de entrada de B aumenta e o grau de saída de A também. (RECUERO, ZAGO, BASTOS, 2015).

Pontuamos que a função do retweet se torna de suma importância para a circulação de informações nas redes sociais no Twitter (RECUERO, ZAGO, 2012) por garantir maior grau de entrada (ou maior centralidade na rede) a determinados perfis devido ao fato das mensagens publicadas por eles serem compartilhadas inúmeras vezes por outros usuários do microblog. Sendo assim, como visto no capítulo 2, a chamada "economia do retweet" (RECUERO, ZAGO, 2012) dá poder (ao garantir maior grau de entrada) a determinados nós na rede, ou seja, atribui referenciabilidade, visibilidade e credibilidade ao usuário que criou o tweet respostado. $\mathrm{O}$ retweet se torna, portanto, um importante "'motor' da difusão de informações no Twitter, pois gera visibilidade para a informação e para a fonte que originalmente a publicou.". (RECUERO, ZAGO, 2012).

Em relação às métricas de rede, esses estudiosos ressaltam que "o que se busca investigar é a rede como um todo, e não os nós de forma particular.". (RECUERO, BASTOS, ZAGO, 2015, p. 75). As métricas de rede ajudam o pesquisador a encontrar clusters ou grupos específicos na rede e podem auxiliar, também, na verificação da densidade desses grupos. Das cinco métricas de rede elencadas por Recuero, Bastos e Zago (2015) (densidade, grupabilidade, buracos estruturais, modularidade e centralização), utilizaremos, na presente pesquisa, a métrica de modularidade, que nos auxilia na descoberta de grupos ou clusters a partir do cálculo da "separação dos nós da rede em módulos (ou comunidades). Essas comunidades [...] são definidas como grupos de nós densamente interligados entre si e fragilmente conectados com o resto da rede.". (RECUERO, BASTOS, ZAGO, 2015, p. 84).

O cálculo de modularidade (realizado por meio de softwares específicos) classifica que grupos que possuem modularidade mais elevada (próxima de 1,0), tendem a apresentar conexões densas entre seus nós e poucas conexões estabelecidas com nós de outros grupos na rede. Assim, "uma comunidade (cluster) com alta grupabilidade apresentará um coeficiente de modularidade mais alto e uma taxa de transmissão de informação mais eficiente se comparada com uma comunidade com poucas conexões entre si.". (RECUERO, ZAGO, BASTOS, 2015, p. 86). Os clusters se formam, predominantemente, devido a temáticas ou engajamentos similares em relação a determinados assuntos e isso auxilia no processo de compreensão de como se dá a circulação de informações no Twitter. 
4. Por fim necessita-se abordar a questão da visualização dos dados das redes sociais a serem analisadas. Em relação às redes sociais estabelecidas na internet, especificamente no Twitter, a visualização dessas redes requer a utilização de ferramentas específicas. Na presente pesquisa optamos pela utilização do software Gephi para a visualização das redes sociais estabelecidas no microblog durante os quatro contextos do recorte da análise empírica. Sendo assim, os dados coletados a partir do Netlytic foram exportados para o Gephi para que fosse possível visualizarmos os grafos representativos dessas redes. O Gephi é caracterizado por Bastian, Hymann e Jacomy (2009) como:

Um software de código aberto para gráficos e análise de rede. Ele usa um mecanismo
de renderização 3D para exibir grandes redes em tempo real e acelerar a exploração.
A arquitetura flexível e multitarefa [disponibilizada pelo Gephi] traz novas
possibilidades para trabalhar com conjuntos de dados complexos e produzir resultados
visuais valiosos. (BASTIAN; HEYMANN; JACOMY, 2009, p. 361, tradução
nossa) $)^{139}$.

Como bem apontam Tarcízio Silva e Max Stabile (2016), o Gephi possui vantagens em relação ao processamento de grande volume de dados e possibilita melhor manuseio no sentido de visualização desses dados por disponibilizar uma "customização de elementos visuais", apresentando "diferentes tipos de layouts, exportação em diversos formatos, limpeza de dados, adição de mapas, visualização 3D, filtragem de cluster", entre outros (SILVA; STABILE, 2016, p. 256).

Pelo extenso volume de dados e para melhor visualização das redes pelo software, consideramos cada um dos quatro contextos da análise empírica como uma rede específica e dividimos os dados coletados em cada contexto para que pudessem ser analisados separadamente. $\mathrm{O}$ estudo das redes constituídas nos quatro contextos foi feito, então, a partir de quatro etapas ${ }^{140}$ listadas a seguir:

- Etapa 1 - Identificação dos 20 perfis com maior grau de entrada e os 20 com maior grau de saída na rede;

- Etapa 2 - Definição, por meio da métrica de modularidade, dos 5 cluster ou grupos principais da rede;

\footnotetext{
$139[\ldots]$ an open source software for graph and network analysis. It uses a 3D render engine to display large networks in real-time and to speed up the exploration. A flexible and multi-task architecture brings new possibilities to work with complex data sets and produce valuable visual results. (BASTIAN; HEYMANN; JACOMY, 2009, p. 361).

${ }^{140}$ Ressaltamos que essas etapas foram aplicadas a cada um dos 4 contextos separadamente.
} 
- Etapa 3 - Medição e análise do grau de conectividade estabelecido entre os 5 clusters definidos na etapa 2;

- Etapa 4 - Classificação dos 10 nós com maior grau de entrada e dos 10 com maior grau de saída em cada um dos 5 clusters.

A partir das 4 etapas acima discorridas foi possível averiguar quais perfis mais receberam conexões (ou obtiveram maior grau de entrada) na circulação de mensagens ocorrida em cada um dos contextos. Ressaltamos que esses perfis, ou seja, os que possuíam maior grau de entrada, obtiveram maior número de citações ou de compartilhamento (retweets) de suas publicações e, portanto, são considerados perfis influentes (ou centrais) na rede. Além disso, pudemos observar quais perfis realizaram mais conexões com outros usuários; esses perfis também se tornam influentes no sentido de serem responsáveis pela distribuição do conteúdo entre os nós da rede em que estão inseridos.

Pontuamos, ainda, que a definição dos 5 clusters ou grupos principais, bem como a observação sobre o grau de conectividade entre os mesmos, nos permitiu inferir que houve polarização nas redes estabelecidas nos 4 contextos de análise no sentido de separar os perfis em grupos opositores a Lula, nos quais circulavam narrativas de desconstrução da imagem pública do ex-presidente e em grupos apoiadores do ex-presidente, em que circulavam narrativas de construção da imagem pública do mesmo.

Ressaltamos que as inferências obtidas a partir da ARS aplicada ao Twitter foram utilizadas como base para a realização da segunda fase da pesquisa empírica que consiste na análise de conteúdo dos tweets coletados. Descreveremos essa fase no tópico a seguir.

\subsubsection{2 $2^{\mathrm{a}}$ fase: Análise de narrativas}

A segunda fase do processo metodológico utilizado na presente pesquisa consiste na análise das narrativas em circulação no Twitter a partir dos 437.286 tweets recortados na préobservação empírica. Esse processo de pesquisa foi baseado no método de análise de conteúdo (BARDIN, 1977; BAUER, 2008). Como bem aponta Recuero (2014b), o método de Análise de Conteúdo tem sido cada vez mais recorrente em pesquisas que procuraram compreender o incontável número de publicações realizadas diariamente, seja por meio do Twitter, do Facebook, em blogs, ou qualquer site da internet. Como visto no segundo capítulo da presente tese, as características apresentadas por Boyd (2010) sobre as mídias sociais - quais sejam: 
persistência (os conteúdos e informações online são automaticamente registrados e arquivados); replicabilidade (o compartilhamento das informações é feito de forma mais rápida, já que elas são constituídas por dados; escalabilidade (o enorme potencial de alcance e de compartilhamento das informações); e buscabilidade (o conteúdo gerado pode ser encontrado a partir de pesquisa) - contribuíram em grande medida para o avanço do método de Análise de Conteúdo como forma de compreender os efeitos, impactos, bem como as condições de produção e recepção desse enorme contingente de dados.

Esta tese busca em Laurence Bardin (1977) as duas funções principais da análise de conteúdo: a função heurística, que tem por objetivo a descoberta de algo que ainda não se tem certeza ou conhecimento prévio do funcionamento; e a função de administração de provas, que consiste em criar hipóteses para serem resolvidas a partir da análise. As duas funções podem coexistir em uma mesma pesquisa na medida em que uma reforça a outra. Tem-se então que:

\footnotetext{
A análise "às cegas" [heurística] [...] pode fazer surgir hipóteses que, servindo então de guias, conduzirão o analista a elaborar as técnicas mais adequadas à sua verificação. Enquanto que, por outro lado, os analistas já orientados à partida para uma problemática teórica, poderão, no decorrer da investigação, "inventar" novos instrumentos susceptíveis, por sua vez, de favorecer novas interpretações. (BARDIN, 1977, p. 30).
}

Sendo assim, Bardin (1977) compreende o método de análise de conteúdo como "um conjunto de técnicas de análise das comunicações, que utiliza procedimentos sistemáticos e objectivos de descrição do conteúdo das mensagens.”. (BARDIN, 1977, p. 38). Além disso, a análise de conteúdo quando aplicada a um determinado texto, discurso, narrativa ou fala tem por objetivo inferir "conhecimentos relativos às condições de produção (ou, eventualmente, de recepção)" (BARDIN, 1977, p. 38) dos mesmos. Essas inferências podem ser adquiridas a partir de indicadores quantitativos ou qualitativos.

Ressaltamos que, como bem aponta Martin W. Bauer (2008), para que se obtenha inferências objetivas sobre o que está se pesquisando, a análise de conteúdo deve considerar duas dimensões: a sintática, que descreve os meios de expressão, ou seja, como algo é dito ou escrito; e a semântica, que se refere estritamente ao conteúdo do que é dito. Na visão desse autor, "Tais conjecturas podem inferir os valores, atitudes, estereótipos, símbolos e cosmovisões de um texto sobre o qual pouco se sabe.”. (BAUER, 2008, p. 193). Para além do entendimento de como algo é dito e qual o conteúdo desse discurso, pontuamos a importância da observação sobre quem produziu tal fala. Nesse sentido, adiantamos que a análise de 
conteúdo das narrativas produzidas no Twitter no período proposto será realizada a partir dessa tríade - "como diz, o que diz e quem diz".

Continuando seu raciocínio, Bauer (2008) reforça que a Análise de Conteúdo, ao ser aplicada a materiais textuais escritos, trabalha com dois tipos de textos: os "que são construídos no processo de pesquisa, tais como transcrições de entrevista e protocolos de observação; e textos que já foram produzidos para outras finalidades quaisquer [...].”. (BAUER, 2008, p. 195). Sendo assim, pontuamos que a presente pesquisa utilizará o segundo tipo citado pelo autor, qual seja: o texto que já foi produzido para outro fim, ou seja, as mensagens publicadas pelos usuários do Twitter.

Retornamos às considerações de Bardin (1977), que destaca que há três fases (ou polos cronológicos) imprescindíveis à aplicação do método de Análise de Conteúdo: 1) a pré-análise; 2) a exploração do material; e 3) o tratamento dos resultados obtidos e a interpretação dos mesmos. (BARDIN, 1977, p. 95). A seguir discorreremos sobre como essas fases foram aplicadas à presente pesquisa.

1) Pré-análise: a primeira fase do método de análise de conteúdo consiste na organização analítica dos dados coletados. De acordo com Bardin (1977, p. 95), essa fase "corresponde a um período de intuições" e objetiva "tornar operacionais e sistematizar as ideias iniciais, de maneira a conduzir a um esquema preciso do desenvolvimento das operações sucessivas, num plano de análise.”. (BARDIN, 1977, p. 95). A fase de pré-análise consiste, portanto, na escolha e recorte dos dados a serem analisados e na formulação de operacionalizações que servirão como base para a exploração desses dados. (BARDIN, 1977; BAUER, 2008).

Sendo assim, pontuamos que os dados analisados na análise de conteúdo da presente pesquisa (ou o corpus de análise) se referem aos 437.286 tweets recortados após a préobservação da coleta de dados discorrida anteriormente. Devido ao extenso número de mensagens a serem analisadas, julgamos necessário decodificar o conteúdo sem que as inferências sobre o mesmo fossem prejudicadas. Observamos que a análise dos tweets obteria melhor resultado a partir da regra de representatividade (BARDIN, 1977), ou seja, o conteúdo total reunido foi analisado a partir de uma representação do mesmo. Para tanto optamos por verificar quais foram os termos ou unidades sintáticas (BAUER, 2008) mais frequentemente mencionados no corpus de análise. Ressaltamos que, com o intuito de analisarmos os quatro contextos empíricos separadamente, assim como foi feito na ARS decidimos por verificar quais foram os termos que mais se repetiram em cada um dos contextos. 
Essa seleção dos termos mais mencionados foi realizada a partir do que Bardin (1977) chama de "tratamento informático" ou "ordenador", devido ao fato de termos recorrido a um programa de computador capaz de verificar quantitativamente as unidades sintáticas que foram mais vezes mencionadas no conteúdo dos tweets em questão. O programa escolhido para tal objetivo, o AntConc, foi criado e desenvolvido pelo professor Laurence Anthony, da Faculdade de Ciências e Engenharia da Universidade de Waseda, no Japão. Esse programa, disponível online com acesso gratuito, disponibiliza ao pesquisador um conjunto de ferramentas de análise textual de fácil operacionalização. (ANTHONY, 2016).

Nas quatro tabelas a seguir (Tabelas 2, 3, 4 e 5) estão dispostos os resultados obtidos em relação aos termos mais mencionados nos tweets publicados em cada um dos quatro contextos de análise. 
Tabela 2 - Termos mais frequentes no Contexto 1: manifestações sociais a favor do impeachment

\begin{tabular}{|c|c|c|c|}
\hline Termo & Frequência & Termo & Frequência \\
\hline Dilma & 12837 & @ telesurtv & 1002 \\
\hline Brasil & 8146 & sítio & 980 \\
\hline prisão & 6370 & país & 950 \\
\hline PT & 4642 & triplex & 949 \\
\hline ex-presidente & 3999 & @blogdopim & 938 \\
\hline cofre & 3975 & ministério & 931 \\
\hline Globo & 3177 & @o_antagonista & 857 \\
\hline pedido & 2760 & democracia & 852 \\
\hline apoio & 2669 & preventiva & 825 \\
\hline $\mathrm{SP}$ & 2651 & @mashirafael & 823 \\
\hline $\mathrm{PF}$ & 2368 & procuradores & 812 \\
\hline preso & 1893 & cristo & 806 \\
\hline ato & 1884 & \#marchadoscorruptos & 799 \\
\hline PM & 1826 & crucifixo & 783 \\
\hline Lava jato & 1786 & guerrero & 781 \\
\hline @VEJA & 1749 & golpe & 773 \\
\hline MP & 1706 & Aécio & 751 \\
\hline Moro & 1687 & polícia & 745 \\
\hline promotores & 1580 & acervo & 742 \\
\hline defesa & 1532 & Maduro & 733 \\
\hline povo & 1422 & FHC & 695 \\
\hline manifestantes & 1295 & impeachment & 689 \\
\hline pró & 1271 & operação & 679 \\
\hline arte & 1270 & Mandela & 678 \\
\hline casa & 1270 & Paulista & 661 \\
\hline justiça & 1251 & @dilmabr & 654 \\
\hline \#vemprarua & 1247 & líderes & 653 \\
\hline \#vempraruabrasil & 1239 & objetos & 652 \\
\hline @inst_lula & 1154 & protesto & 648 \\
\hline ruas & 1148 & Época & 624 \\
\hline jornal & 1141 & $@$ ptbrasil & 615 \\
\hline advogados & 1130 & corrupção & 614 \\
\hline juíza & 1130 & $@$ tijolaco & 558 \\
\hline governo & 1127 & ladrão & 555 \\
\hline $\mathrm{JN}$ & 1104 & acusação & 524 \\
\hline manifestação & 1084 & corrupto & 443 \\
\hline investigação & 1083 & condenado & 429 \\
\hline @folha & 1072 & oposição & 386 \\
\hline cadeia & 1017 & golpista & 345 \\
\hline joias & 1006 & \#lulanacadeia & 313 \\
\hline
\end{tabular}

Fonte: Elaborado pela autora. 
Tabela 3 - Termos mais frequentes no Contexto 2: manifestações sociais contra o golpe

\begin{tabular}{|c|c|c|c|}
\hline Termo & Frequência & Termo & Frequência \\
\hline Dilma & 23324 & áudio & 936 \\
\hline ministro & 14431 & Maduro & 931 \\
\hline Brasil & 10846 & SP & 897 \\
\hline posse & 9008 & @estadao & 891 \\
\hline Moro & 6241 & $@$ jornaloglobo & 886 \\
\hline Casa Civil & 5038 & decisão & 867 \\
\hline presidente & 4187 & gravação & 837 \\
\hline STF & 4023 & protesto & 827 \\
\hline nomeação & 3718 & crises & 788 \\
\hline suspende & 3551 & vergonha & 764 \\
\hline juiz & 3192 & apoio & 748 \\
\hline Gilmar & 2937 & cadeia & 714 \\
\hline grampo & 2899 & @telesurtv & 721 \\
\hline PT & 2930 & @ danilogentili & 673 \\
\hline golpe & 2572 & defesa & 671 \\
\hline governo & 2331 & \#vemprademocracia & 643 \\
\hline justiça & 2214 & advogado & 629 \\
\hline liminar & 1950 & Brasília & 625 \\
\hline Paulista & 1941 & divulgação & 573 \\
\hline conversa & 1849 & Venezuela & 563 \\
\hline @VEJA & 1744 & \#ocupabrasilia & 561 \\
\hline pobre & 1658 & @uolnoticias & 558 \\
\hline $\mathrm{PF}$ & 1614 & jornal & 521 \\
\hline prisão & 1559 & mediático & 507 \\
\hline preso & 1479 & @o_antagonista & 502 \\
\hline povo & 1438 & Aécio & 500 \\
\hline manifestantes & 1420 & corrupto & 499 \\
\hline país & 1371 & mídia & 496 \\
\hline ministério & 1278 & DF & 494 \\
\hline rico & 1266 & MPF & 485 \\
\hline ato & 1244 & @blogdonoblat & 478 \\
\hline Lava jato & 1221 & investigação & 476 \\
\hline \#quedadoplanalto & 1186 & renuncia & 458 \\
\hline @blogdopim & 1139 & @nicolasmaduro & 457 \\
\hline cargo & 1081 & @1obaoeletrico & 446 \\
\hline impeachment & 1059 & @globonews & 438 \\
\hline planalto & 1055 & Temer & 424 \\
\hline democracia & 1001 & suspensão & 421 \\
\hline @folha & 1001 & líder & 398 \\
\hline$@$ dilmabr & 997 & @ cartacapital & 398 \\
\hline
\end{tabular}

Fonte: Elaborado pela autora. 
Tabela 4 - Termos mais frequentes no Contexto 3: votação na Câmara dos Deputados

\begin{tabular}{|c|c|c|c|}
\hline Termo & Frequência & Termo & Frequência \\
\hline Dilma & 55910 & cargo & 851 \\
\hline Brasil & 9786 & destruição & 816 \\
\hline impeachment & 9767 & Aécio & 799 \\
\hline $\mathrm{PT}$ & 8793 & Feliciano & 799 \\
\hline Cunha & 5623 & Renan & 799 \\
\hline derrota & 4271 & @o_antagonista & 798 \\
\hline presidente & 4018 & @ revistaepoca & 763 \\
\hline $\begin{array}{l}\text { Temer } \\
\text { ministro }\end{array}$ & $\begin{array}{l}3415 \\
3396\end{array}$ & $\begin{array}{c}\text { corruptos } \\
@ \text { reinaldoazevedo }\end{array}$ & $\begin{array}{l}740 \\
704\end{array}$ \\
\hline golpe & 3216 & acabou & 675 \\
\hline voto & 3141 & @blogdonoblat & 672 \\
\hline deputados & 3081 & @genpenaloza & 648 \\
\hline STF & 2984 & propina & 593 \\
\hline governo & 2785 & posse & 590 \\
\hline Venezuela & 2782 & advogado & 589 \\
\hline @blogdojefferson & 2263 & justiça & 576 \\
\hline cadeia & 2256 & corrupção & 576 \\
\hline humilhante & 2021 & renunciar & 575 \\
\hline \#impeachmentday & 1720 & democracia & 549 \\
\hline preso & 1680 & chefe & 562 \\
\hline povo & 1678 & processo & 542 \\
\hline Maduro & 1642 & pagamento & 532 \\
\hline @nelsonbocaranda & 1555 & contabilidade & 529 \\
\hline Lava jato & 1294 & Teori & 518 \\
\hline$@$ marcoscastro & 1200 & articulador & 516 \\
\hline Dirceu & 1154 & \#olhoemlewandowski & 511 \\
\hline derecha & 1115 & \#tchauquerida & 499 \\
\hline Lewandowski & 1097 & @ folha & 458 \\
\hline$@$ pburelli & 1087 & $\mathrm{PF}$ & 457 \\
\hline izquierda & 1084 & resistência & 360 \\
\hline pobreza & 1063 & petistas & 360 \\
\hline carreira & 1036 & senado & 355 \\
\hline enterrado & 1036 & FHC & 348 \\
\hline homologa & 1013 & @VEJA & 342 \\
\hline @blogdopim & 1019 & @lobaoeletrico & 312 \\
\hline partido & 969 & bandido & 310 \\
\hline julgamento & 951 & investigação & 300 \\
\hline @ dilmabr & 927 & \#noalgolpeadilma & 239 \\
\hline Bolsonaro & 901 & socialismo & 238 \\
\hline Cristina & 890 & golpista & 223 \\
\hline
\end{tabular}


Tabela 5 - Termos mais frequentes no Contexto 4: votação no Senado Federal

\begin{tabular}{|c|c|c|c|}
\hline Termo & Frequência & Termo & Frequência \\
\hline Dilma & 35507 & @VEJA & 840 \\
\hline Temer & 12482 & Cardozo & 825 \\
\hline ministros & 9739 & juiz & 822 \\
\hline Lava Jato & 9223 & abatido & 747 \\
\hline Brasil & 8086 & quadrilha & 735 \\
\hline PT & 6932 & \#golpeenbrasil & 729 \\
\hline investigados & 6650 & partido & 720 \\
\hline presidente & 5133 & chefe & 711 \\
\hline Moro & 4466 & mandato & 703 \\
\hline foro privilegiado & 3778 & @o_antagonista & 692 \\
\hline governo & 3257 & @zehdeabreu & 679 \\
\hline golpe & 3062 & @ptbrasil & 677 \\
\hline STF & 2761 & Petrobrás & 655 \\
\hline impeachment & 2125 & @blogdojefferson & 638 \\
\hline @genpenaloza & 1772 & chavismo & 606 \\
\hline povo & 1710 & populismo & 603 \\
\hline cadeia & 1690 & ladrão & 599 \\
\hline posse & 1642 & corrupto & 581 \\
\hline @dilmabr & 1637 & nomeado & 566 \\
\hline preso & 1634 & gabinete & 564 \\
\hline derecha & 1553 & guerra & 547 \\
\hline \#tchauquerida & 1361 & luta & 547 \\
\hline ministério & 1359 & $@$ revistaepoca & 516 \\
\hline internacional & 1265 & MPF & 499 \\
\hline @nicolasmaduro & 1255 & @lulapelobrasil & 477 \\
\hline @inst_lula & 1223 & @ stanleyburburin & 474 \\
\hline imperialismo & 1221 & manifestantes & 472 \\
\hline nomeação & 1179 & Gilmar & 471 \\
\hline corrupção & 1074 & Fidel & 461 \\
\hline cargo & 1067 & \#lutopelademocracia & 463 \\
\hline Cuba & 1160 & democracia & 455 \\
\hline @folha & 1031 & @ conversaafiada & 436 \\
\hline Maduro & 1019 & Venezuela & 417 \\
\hline discurso & 990 & despedida & 411 \\
\hline @pirescarol & 985 & $\mathrm{PF}$ & 398 \\
\hline exonerado & 983 & Cristina & 392 \\
\hline Casa civil & 960 & investigações & 392 \\
\hline @estadao & 883 & Chávez & 323 \\
\hline Cunha & 855 & petista & 311 \\
\hline Curitiba & 841 & afastamento & 308 \\
\hline
\end{tabular}


2) Exploração do material: Após a pré-análise dos dados e a decisão de operacionalizar a análise de conteúdo a partir da seleção dos termos mais frequentemente mencionados nos quatro contextos examinados, foi possível explorar o material de forma a compreender as temáticas mais acionadas pelos usuários do Twitter, tanto na desconstrução como na construção da imagem pública política de Lula. Pontuamos, ainda, que a exploração do material, ou seja, a exploração dos tweets coletados, foi feita de forma intencional. Desta forma, optamos por selecionar determinados exemplos de publicações que nos permitiram realizar uma análise mais aprofundada do conteúdo das narrativas publicadas em cada uma das temáticas observadas. Ressaltamos que a exploração do material também foi realizada por meio de uma extensa análise documental dos tweets exemplificados.

A partir da observação sobre as principais temáticas mencionadas nos quatro contextos de análise objetivou-se compreender como as narrativas do mito político foram acionadas no processo de (des)construção da imagem pública de Lula. Para que isso fosse possível optamos por utilizar a técnica de análise categorial que, de acordo com Bardin (1977), é a prática mais antiga e também a mais utilizada na análise de conteúdo e "funciona por operações de desmembramento do texto em unidades, em categorias segundo reagrupamentos analógicos" (BARDIN, 1977, p. 153). As categorias utilizadas na presente pesquisa foram construídas a partir das narrativas do mito político propostas por Girardet (1987), quais sejam: a narrativa da

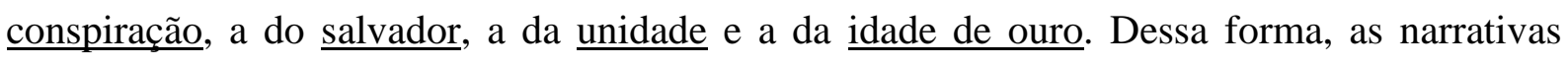
utilizadas no Twitter, tanto para a desconstrução como para a construção da imagem pública de Lula durante o período analisado, foram analisadas a partir dessas quatro categorias.

3) $\underline{O}$ tratamento dos resultados obtidos e a interpretação dos mesmos: a última etapa da análise de conteúdo, na perspectiva de Bardin (1977), consiste na fase em que "os resultados brutos são tratados de maneira a serem significativos e válidos.”. (BARDIN, 1977, p. 101). Tal significação e validação dos resultados obtidos pela análise de conteúdo devem atender aos objetivos propostos pela pesquisa. Nessa terceira etapa, portanto, lançamos luz sobre as inferências obtidas nas etapas anteriores (pré-análise e exploração do material) de forma a atingir o objetivo principal da análise empírica: compreender como se deu o processo de (des)construção da imagem pública de Lula durante os quatro contextos de análise da crise política de 2016 e de que forma as narrativas do mito político foram acionadas nesse processo. 


\section{AS REDES SOCIAIS NO TWITTER NOS QUATRO CONTEXTOS DA ANÁLISE EMPÍRICA}

O presente capítulo se destina à apresentação e inferências sobre as redes sociais estabelecidas no Twitter durante os quatro contextos da análise empírica. Como demonstrado no capítulo anterior sobre a metodologia de pesquisa da ARS aplicada ao Twitter, separamos as conjunturas a serem estudadas a partir do recorte em datas específicas da coleta de dados. Assim, o Contexto 1 compreende os tweets postados em 12 e 13 de março de 2016; o Contexto 2 constitui-se de tweets de 17 e 18 de março de 2016; o Contexto 3 é formado pelas postagens realizadas em 17 e 18 de abril; e o 4 está focado nos tweets postados em 12 e 13 de maio.

\subsection{Contexto 1: Manifestações sociais a favor do impeachment}

A rede formada pelos tweets postados em 12 e 13 de março de 2016 possui, ao todo, 41.499 nós e 75.988 arestas. Na visualização da rede (Figura 4) é possível observar que os rótulos dos nós (ou nomes dos perfis dos usuários do Twitter) estão em tamanhos variados isto ocorre porque estabelecemos a visualização dos nós por grau de entrada, ou seja, os nós que possuem maior número de conexões recebidas (que foram mencionados mais vezes) aparecem com rótulos maiores ${ }^{141}$.

\footnotetext{
${ }^{141}$ A partir das possibilidades de visualização do grafo da rede disponibilizadas pelo software Gephi optamos por utilizar a distribuição ForceAtlas 2 em primeira instância e, em seguida, a distribuição OpenOrd. Ressaltamos ainda que esse procedimento foi utilizado na visualização dos grafos das redes de todos os contextos.
} 
Figura 4 - Rede inteira do Contexto 1

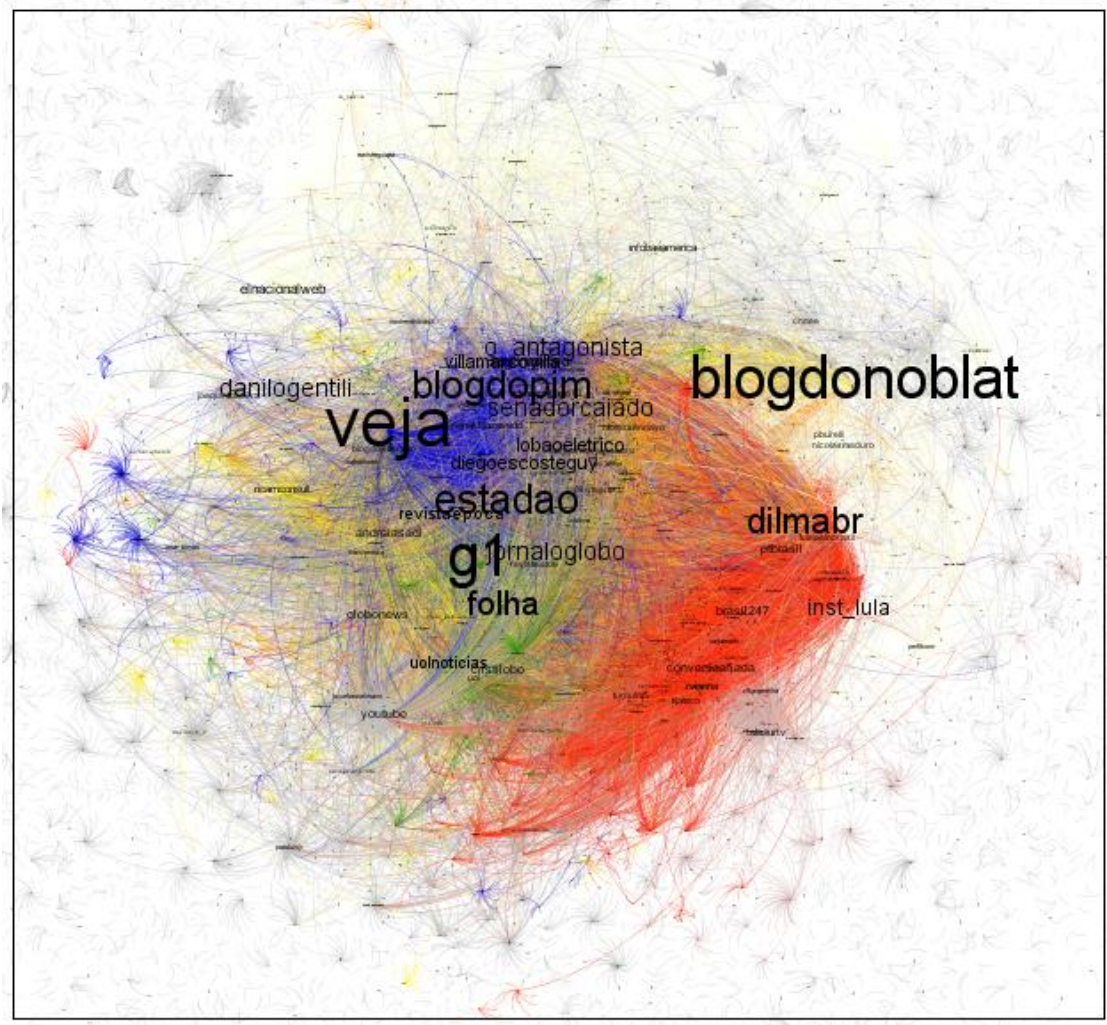

Fonte: Reprodução Gephi.

A partir da análise de métrica de modularidade realizada pelo software Gephi, encontramos um total de 2.010 clusters na rede inteira e grau de modularidade de 0,655 (Figura 5). Ressaltamos que quanto mais alto o grau de modularidade, ou seja, quanto mais próximo de 1, maior o número de conexões entre os nós de um determinado cluster e menor o número de conexões estabelecidas entre clusters diferentes na rede. 
Figura 5 - Gráfico de modularidade da rede inteira do Contexto 1

\section{Results:}

Modularity: 0,655

Modularity with resolution: 0,655

Number of Communities: 2725

\section{Size Distribution}

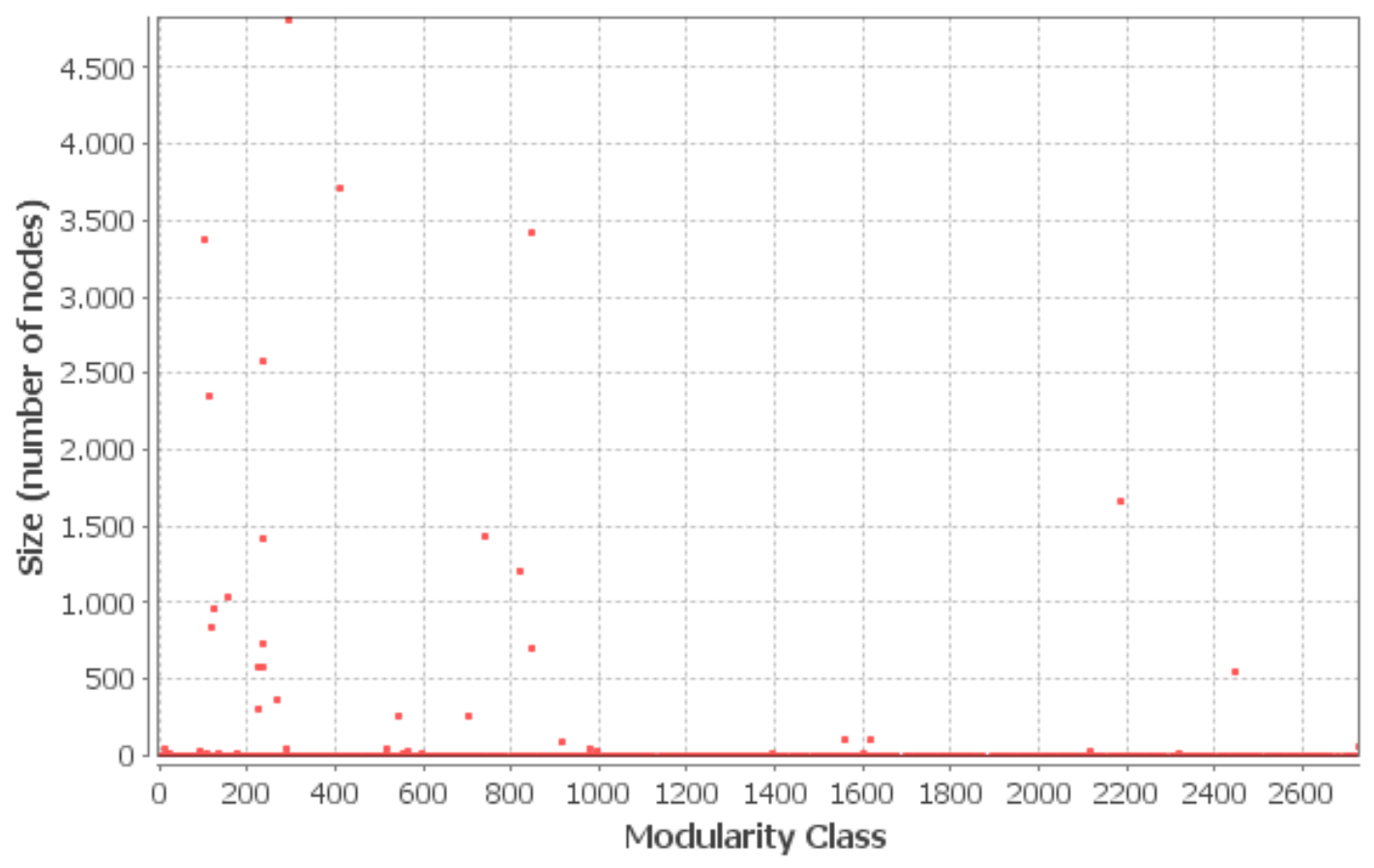

Fonte: Reprodução Gephi.

Do total de 2.010 comunidades, destacamos as cinco principais por possuírem número elevado de nós conectados entre si. Na Tabela 6 enumeramos os cinco clusters de acordo com o número de componentes (ou nós) conectados e com a porcentagem de conexões que cada grupo apresenta em relação à rede inteira ${ }^{142} \mathrm{e}$ à cor de representação dos grupos no grafo.

Tabela 6 - Cinco principais clusters da rede inteira - Contexto 1

\begin{tabular}{lccc}
\hline Cluster & Componentes conectados & $\begin{array}{c}\text { \% de } \\
\text { conexões }\end{array}$ & Cor de representação no grafo \\
\hline Cluster 1 & 4828 & $15,33 \%$ & Vermelho \\
\hline Cluster $\mathbf{2}$ & 3724 & $7,91 \%$ & Azul \\
\hline Cluster $\mathbf{3}$ & 3385 & $7,72 \%$ & Laranja \\
\hline Cluster $\mathbf{4}$ & 2589 & $4,47 \%$ & Amarelo \\
\hline Cluster $\mathbf{5}$ & 2366 & $3,70 \%$ & Verde \\
\hline
\end{tabular}

Fonte: Elaborado pela autora.

\footnotetext{
${ }^{142}$ Esta porcentagem é calculada a partir da quantidade de conexões estabelecidas na rede inteira. O software calcula, portanto, qual o total de nós e o de arestas da rede inteira e gera o valor de quantas conexões foram realizadas em cada cluster.
} 
O grau de conexão entre os clusters também é de suma importância para melhor compreensão do funcionamento da rede. Em cálculo realizado pelo software Gephi observamos que apenas $13,36 \%$ do total de arestas que compõem a rede são estabelecidas entre os cinco clusters principais, o que demonstra circulação limitada de informação entre esses grupos. Apresentamos, a seguir, a classificação das conexões entre os cinco clusters em ordem crescente em relação ao grau de conectividade ${ }^{143}$ :

1. Cluster 1 e Cluster $4(0,60 \%)$;

2. Cluster 1 e Cluster $5(0,64 \%)$;

3. Cluster 5 e Cluster $6(0,69 \%)$;

4. Cluster 1 e Cluster $2(0,82 \%)$;

5. Cluster 3 e Cluster $6(0,89 \%)$.

6. Cluster 3 e Cluster $1(1,06 \%)$;

7. Cluster 2 e Cluster $5(1,23 \%)$;

8. Cluster 3 e Cluster $4(1,70 \%)$;

9. Cluster 2 e Cluster $4(2,00 \%)$.

10. Cluster 2 e Cluster $3(3,73 \%)$.

Com vistas a destacarmos a influência dos nós na circulação de informações do Contexto 1, classificamos na Tabela 7 os 20 perfis da rede inteira que possuem maior grau de entrada. Nota-se que o Cluster 3 é o único que não possui nós presentes nessa Tabela, enquanto o Cluster 2 se sobressai como o que apresenta maior número de perfis na mesma. Observa-se, ainda, que os cinco nós com maior grau de entrada, ou seja, que recebem o maior número de menções, são classificados como perfis de veículos jornalísticos, a exemplo do perfil da revista Veja (@veja), do jornal O Estado de S. Paulo (@estadao) e do portal de notícias online do Grupo Globo (@g1); e blogs jornalísticos como o de Ricardo Noblat, que é vinculado ao jornal O Globo (@ blogdonoblat), e o de Felipe Moura Brasil ${ }^{144}$, ligado à revista Veja (@blogdopim).

\footnotetext{
${ }^{143} \mathrm{O}$ cálculo é realizado em relação ao número de conexões estabelecidas entre todos os clusters da rede inteira, sendo que o total dessas conexões equivale a $100 \%$.

${ }^{144}$ Felipe Moura Brasil é responsável pela organização do livro intitulado "O Mínimo Que Você Precisa Saber Para Não Ser Um Idiota”, publicado em 2013 pela Editora Record. A publicação é composta por 193 textos escritos pelo jornalista e filósofo Olavo de Carvalho entre 1997 e 2003 e divulgados em jornais e revistas brasileiros, tais como Folha de S. Paulo, O Globo e Época. O trabalho contém um capítulo - "Petismo" - constituído pelo subtópico "Lula", no qual Carvalho faz duras críticas à gestão do governo do ex-presidente. Necessário ressaltar que Carvalho possui posicionamento político de direita, sendo considerado como um dos principais articuladores do antipetismo na atualidade, bem como "pioneiro na criação de espaços discursivos ideológicos antiesquerdistas na internet.". (SANTOS JUNIOR, 2016, p. 116). Oportuno pontuar também que Felipe Moura Brasil já foi citado por Olavo de Carvalho (no texto "A luta de classes no Brasil", publicado no portal de notícias Diário do Comércio,
} 
Tabela 7 - Nós com maior grau de entrada nos cinco clusters principais Contexto 1

\begin{tabular}{cccccccc}
\hline & Nó & $\begin{array}{c}\text { Grau de } \\
\text { entrada }\end{array}$ & Cluster & & Nó & $\begin{array}{c}\text { Grau de } \\
\text { entrada }\end{array}$ & Cluster \\
\hline $\mathbf{1}$ & blogdonoblat & 1235 & Cluster 4 & $\mathbf{1 1}$ & villamarcovilla & 437 & Cluster 2 \\
$\mathbf{2}$ & veja & 1124 & Cluster 2 & $\mathbf{1 2}$ & diegoescosteguy & 431 & Cluster 4 \\
$\mathbf{3}$ & g1 & 998 & Cluster 5 & $\mathbf{1 3}$ & revistaepoca & 416 & Cluster 2 \\
$\mathbf{4}$ & estadao & 776 & Cluster 5 & $\mathbf{1 4}$ & uolnoticias & 371 & Cluster 5 \\
$\mathbf{5}$ & blogdopim & 755 & Cluster 2 & $\mathbf{1 5}$ & diogomainardi & 353 & Cluster 2 \\
$\mathbf{6}$ & dilmabr & 735 & Cluster 1 & $\mathbf{1 6}$ & andreiasadi & 325 & Cluster 4 \\
$\mathbf{7}$ & folha & 691 & Cluster 5 & $\mathbf{1 7}$ & globonews & 325 & Cluster 4 \\
$\mathbf{8}$ & senadorcaiado & 552 & Cluster 2 & $\mathbf{1 8}$ & conversaafiada & 324 & Cluster 1 \\
$\mathbf{9}$ & o_antagonista & 527 & Cluster 2 & $\mathbf{1 9}$ & ptbrasil & 298 & Cluster 1 \\
$\mathbf{1 0}$ & inst_lula & 468 & Cluster 1 & $\mathbf{2 0}$ & brasil247 & 296 & Cluster 1 \\
\hline
\end{tabular}

Fonte: Elaborado pela autora.

Na Figura 6 é possível visualizar o desenho da rede composta pelos cinco clusters e os respectivos nós distribuídos por grau de entrada.

em 09 de fevereiro de 2013), como um dos principais jornalistas contemporâneos que constituem "militância de direita" no Brasil constituída por "um conjunto de atores que atua à margem dos sistemas político e midiático tradicionais, com uma agenda que privilegia o antiesquerdismo, em nível internacional e nacional, se opõe ao PT, entendido como figura e ator principal do esquema de dominação socialista, e nega o establishment, manipulado pelos valores e ideias esquerdistas.". (SANTOS JUNIOR, 2016, p. 121). 


\section{Figura 6 - Cinco clusters principais do Contexto 1 com nós distribuídos por grau de entrada}

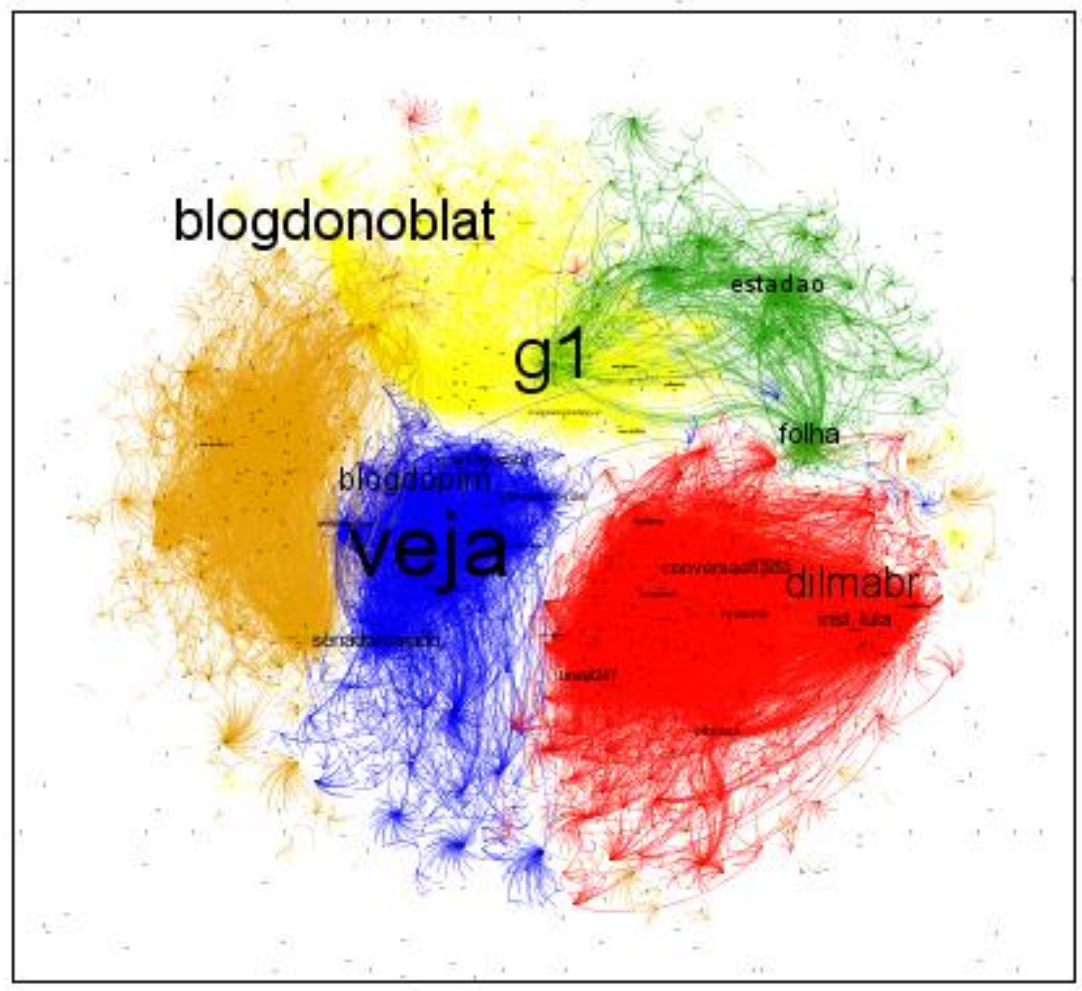

Fonte: Reprodução Gephi.

Visando ainda melhor visualização da rede classificamos (Tabela 8) os nós que apresentam maior número de conexões realizadas com outros usuários, ou seja, aqueles que possuem máximo grau de saída. Esses perfis também são considerados importantes na rede por serem responsáveis por postarem ou replicarem grande número de mensagens.

Interessante observar que, dos 20 perfis que mais estabelecem conexões com outros, 10 fazem parte do Cluster 3 - que não possui nenhum perfil dentre os 20 mais citados. Nota-se também que 18 perfis pertencem a usuários comuns ${ }^{145}$ e outros dois se enquadram na classificação de perfis de militância. Um desses perfis, o "Franca Verdade" (@francaverdade), destina-se a publicar conteúdos favoráveis ao governo petista, e, portanto, à Lula, ao passo que o perfil "Dilma Mentiu” (@dilmamentiu) tem por objetivo principal a disseminação de conteúdos contrários ao governo do PT, e, em consequência, contrários à Lula.

\footnotetext{
${ }^{145}$ Por questões éticas optamos por não disponibilizar os nomes dos usuários comuns. Os dados referentes a esses tipos de perfis serão, portanto, classificados em numerações (exemplo: usuário 1, usuário 2, usuário 3 etc.).
} 
Tabela 8 - Nós com maior grau de saída nos cinco clusters principais Contexto 1

\begin{tabular}{cccccccc}
\hline & Nó & $\begin{array}{c}\text { Grau de } \\
\text { saída }\end{array}$ & Cluster & & Nó & $\begin{array}{c}\text { Grau de } \\
\text { saída }\end{array}$ & Cluster \\
\hline $\mathbf{1}$ & usuário1 & 94 & Cluster 2 & $\mathbf{1 1}$ & usuário10 & 55 & Cluster 3 \\
$\mathbf{2}$ & usuário2 & 87 & Cluster 3 & $\mathbf{1 2}$ & usuário11 & 53 & Cluster 3 \\
$\mathbf{3}$ & usuário3 & 84 & Cluster 2 & $\mathbf{1 3}$ & usuário12 & 52 & Cluster 1 \\
$\mathbf{4}$ & usuário4 & 78 & Cluster 3 & $\mathbf{1 4}$ & usuário13 & 52 & Cluster 5 \\
$\mathbf{5}$ & usuário5 & 66 & Cluster 3 & $\mathbf{1 5}$ & usuário14 & 51 & Cluster 3 \\
$\mathbf{6}$ & usuário6 & 65 & Cluster 4 & $\mathbf{1 6}$ & usuário15 & 50 & Cluster 3 \\
$\mathbf{7}$ & usuário7 & 63 & Cluster 2 & $\mathbf{1 7}$ & usuário16 & 50 & Cluster 3 \\
$\mathbf{8}$ & usuário8 & 61 & Cluster 3 & $\mathbf{1 8}$ & usuário17 & 48 & Cluster 2 \\
$\mathbf{9}$ & usuário9 & 58 & Cluster 2 & $\mathbf{1 9}$ & usuário18 & 47 & Cluster 3 \\
$\mathbf{1 0}$ & francaverdade & 58 & Cluster 1 & $\mathbf{2 0}$ & dilmamentiu & 47 & Cluster 3 \\
\hline
\end{tabular}

Fonte: Elaborado pela autora.

A partir dos dados apresentados sobre a rede e da delimitação dos cinco clusters principais, analisaremos no tópico a seguir cada cluster separadamente, com vistas a estabelecer inferências acerca da circulação de informações na rede de interações do Contexto 1, qual seja, aquelas ocorridas nos dias 12 e 13 de março de 2016, que intitulamos "Manifestações sociais a favor do impeachment".

\subsubsection{Visualização e análise dos clusters}

Cluster 1: O maior cluster do grafo, de acordo com o número de conexões existentes entre os nós que o compõe, é formado por perfis favoráveis a Lula. Como pode ser observado na Figura 7 a seguir, dentre os 10 perfis com maior grau de entrada no grupo, dois são blogs jornalísticos, sendo eles: Conversa Afiada (@ conversaafiada) que, como visto no capítulo 3, foi criado pelo jornalista Paulo Henrique Amorim; e Tijolaço (@tijolaco) organizado pelo jornalista Fernando Brito $^{146}$. Outros dois perfis se enquadram na classificação veículo jornalístico, os portais de notícia online Carta Maior (@cartamaior) que se identifica como "o portal de esquerda"; e Brasil 247 (@brasil247) criado pelo jornalista Leonardo Attuch.

Destacamos que tanto os blogs como os portais de notícia citados são bastante influentes na publicação de notícias jornalísticas favoráveis a partidos à esquerda do espectro político e reconhecidos por fazerem um jornalismo opositor aos conglomerados jornalísticos brasileiros

\footnotetext{
146 O nome "tijolaço" é inspirado em termo cunhado por Leonel Brizola, fundador do PDT (Partido Democrático Trabalhista), único partido brasileiro integrante da Internacional Socialista. Brizola passou a utilizar o termo em matérias escritas entre 1984 e 1998 que tinham como objetivo confrontar as notícias sobre ele que eram veiculadas pela imprensa brasileira hegemônica. (BRITO, 2015).
} 
representados, principalmente, pela revista Veja, pelo Grupo Globo e pelos jornais Folha de S. Paulo e Estado de S. Paulo.

Ainda em relação aos 10 nós com maior número de menções no Cluster 1 destacamos a presença do perfil do formador de opinião, Rodrigo Vianna (@ rvianna), que, em 2006 fez duras críticas à cobertura da Rede Globo (onde trabalhou como jornalista entre 1995 e 2006) acusando a emissora de manipular midiaticamente informações veiculadas durante a campanha eleitoral naquele ano de forma a prejudicar a candidatura de Lula à reeleição (DEMITIDO..., 2006); e do perfil de Turquim (@turquim5), que se enquadra na classificação de militância por ser um perfil anônimo e destinado à publicação de conteúdo favorável aos governos petistas. Enfatizamos, ainda, que na bio do Twitter do perfil de @ turquim5 há a seguinte declaração que justifica a classificação do perfil como militante: "luto pelo bem do país. Mídia golpista não me representa! Sou Lula \& Dilma. Os melhores Programas Sociais da história”.

Os outros quatro perfis que estão entre os 10 com maior grau de entrada do Cluster 1 pertencem a contas oficiais do governo do PT e se enquadram na classificação de perfis de lideranças, quais sejam: o perfil oficial de Dilma Rousseff (@dilmabr), o do Instituto Lula (@inst_lula),o oficial do PT (@ptbrasil) e o perfil oficial de Lula (@lulapelobrasil). (Figura 7).

Chamamos atenção ainda: dentre os 10 perfis com maior grau de saída ${ }^{147}$, ou seja, os que mais estabelecem conexões nesse grupo, oito são de usuários comuns e dois, de perfis que classificamos como sendo de militância e que se destinam à proliferação de narrativas favoráveis a Lula. Um dos perfis militantes é o Franca Verdade (@francaverdade) que, como visto anteriormente, consta na classificação dos 20 com maior grau de saída na rede inteira; o outro perfil é intitulado Finada Democracia (@golpenuncamais).

O fato de o Cluster 1 possuir baixo grau de conectividade com os demais do grafo nos leva a inferir que as narrativas que circulam nesse grupo tendem a não entrar em circulação nos outros clusters da rede inteira. Dessa forma, as narrativas de construção da imagem pública de Lula que estão fortemente inseridas nessa comunidade permanecem em circulação apenas entre os nós que a compõe e a informação não se estende a outros grupos.

\footnotetext{
${ }^{147}$ Por questões éticas optamos por não ilustrar o grafo com nós distribuídos por grau de saída devido ao fato de a vasta maioria referir-se a perfis de usuários comuns.
} 
Figura 7 - Cluster 1 - nós distribuídos por grau de entrada

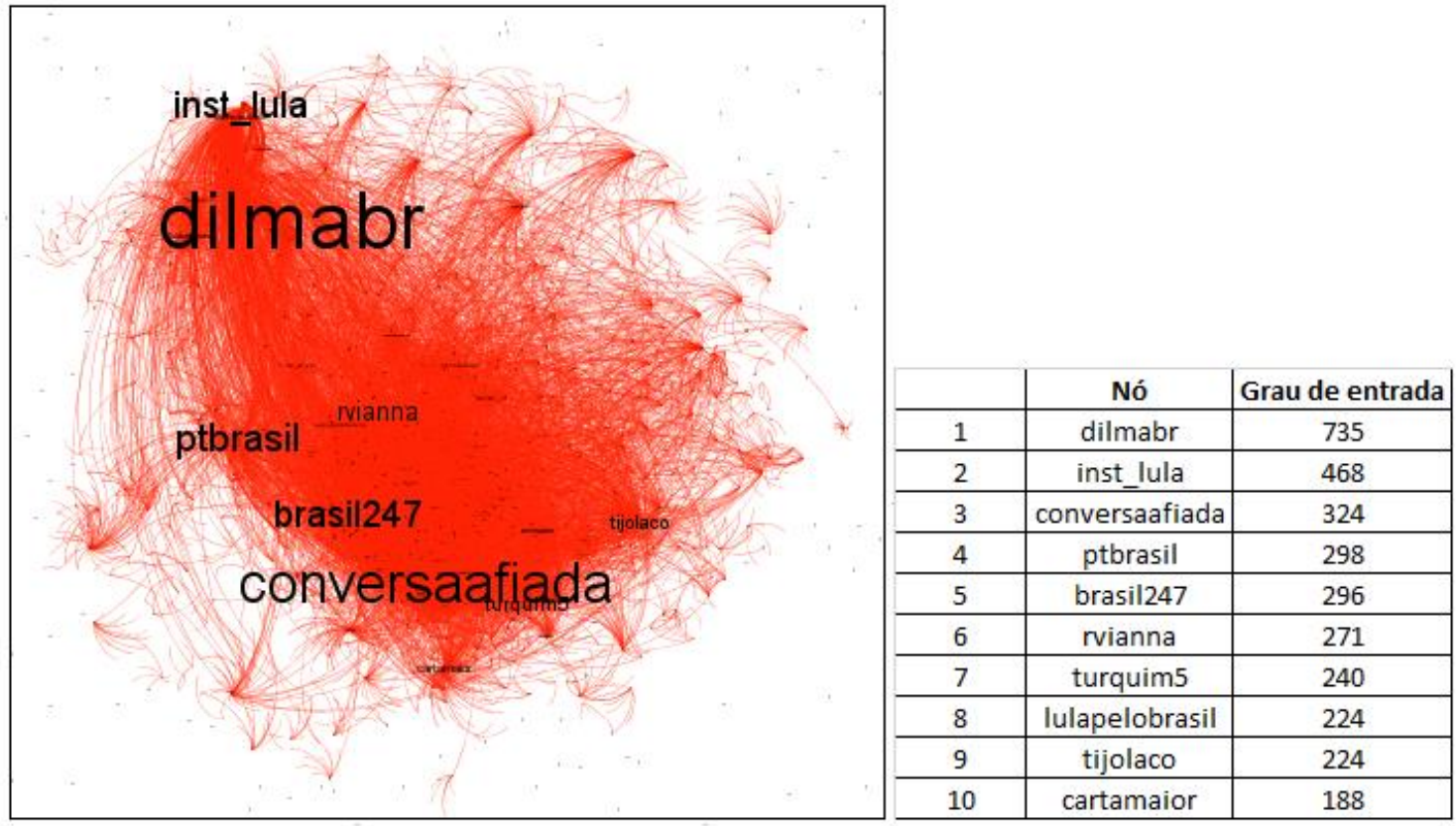

Fonte: Elaborado pela autora.

Cluster 2: Dentre os 10 nós de maior relevância que compõem o Cluster 2 (Figura 8), segundo maior cluster na rede, quatro são perfis de veículos jornalísticos, sendo eles: as revistas Veja (@veja), Isto É (@revistaistoe) e Época (@revistaepoca); e o jornal O Globo (@oglobopolitica).

Outros três perfis pertencem a formadores de opinião reconhecidos por apresentarem posicionamento político contrário à Lula. São eles: Diogo Mainardi ${ }^{148}$ (@ diogomainardi), comentarista do canal de televisão GloboNews (do Grupo Globo) e ex-colunista da revista Veja; Reinaldo Azevedo ${ }^{149}$ (@reinaldoazevedo), jornalista e colunista da Folha de S. Paulo e então responsável por um blog jornalístico também vinculado à revista Veja, e Marco Antonio Villa ${ }^{150}$ (@villamarcovilla), historiador, escritor e comentarista da Jovem Pan e TV Cultura, além de colunista na revista Isto É e no jornal O Globo.

\footnotetext{
148 Diogo Mainardi (2007) publicou em 2007 o livro intitulado Lula é minha anta, no qual o jornalista reuniu uma coletânea de crônicas em referência ao escândalo do mensalão - com apontamentos críticos, principalmente a Lula. Essas crônicas haviam sido publicadas na coluna semanal de Mainardi na revista Veja.

${ }^{149}$ Reinaldo Azevedo $(2008 ; 2012)$ é autor dos livros O país dos petralhas e O país dos petralhas II: o inimigo agora é o mesmo, publicados em 2008 e 2012, respectivamente. Em ambos os livros há um copilado de textos contrários aos governos petistas publicados no blog de Reinaldo Azevedo, vinculado à revista Veja. Esclarecemos que o termo "petralha", cunhado por Reinaldo Azevedo, faz referência à junção das características de um político petista - ou apoiadores do partido - com a quadrilha de ladrões conhecidas como Irmãos Metralha (personagens fictícios criados pela Disney).

${ }^{150}$ Marco Antonio Villa (2013) publicou, em 2013, livro Década perdida: dez anos de PT no governo, no qual fez críticas tanto em relação aos dois mandatos de Lula como presidente do Brasil quanto aos dois primeiros anos do mandato inicial de Dilma na Presidência do país.
} 
Outros dois perfis são de blogs jornalísticos, sendo eles: 1) O Antagonista (o_antagonista), criado em janeiro de 2015 pelos jornalistas Diogo Mainardi e Mário Sabino, (ex-redator chefe da revista Veja). Ressalta-se que Cláudio Dantas (ex - editor da revista Istoé), considerado pelos próprios criadores do blog O Antagonista como "o jornalista mais bem informado sobre a Lava Jato" (O NOVO..., 2015) - em referência à Operação Lava Jato do MPF -, e também passou a ser parte integrante do O Antagonista a partir de agosto de 2015; 2) e o Blog do Pim (@blogdopim), do jornalista Felipe Moura, vinculado à revista Veja. Ambos os blogs supracitados fazem oposição aos governos petistas.

A lista dos 10 nós com maior grau de entrada no cluster 2 é composta, ainda, por um perfil de liderança pertencente ao senador Ronaldo Caiado, do partido Democratas (@ senadorcaiado), que igualmente faz oposição ao PT. Válido ressaltar que, em análise sobre o cenário das eleições de 2014, Marcelo Alves dos Santos Junior (2016) destacou a página oficial do senador Ronaldo Caiado no Facebook como uma das mais influentes na formação da rede antipetista na internet.

Em relação aos nós de maior grau de saída, grande parte são perfis contrários ao governo do PT e ao ex-presidente Lula, como, por exemplo, a página de militância intitulada "BR sem PT”(@brsempt) ou Brasil sem PT.

Feitas as observações sobre os principais nós do grupo, consideramos que no Cluster 2 circulam as narrativas contrárias ao ex-presidente, ou seja, de desconstrução da imagem pública política de Lula.

Oportuno chamar atenção para o fato de que esse grupo é o que dispõe do maior número de perfis dentre os 20 nós que recebem mais menções na rede do Contexto 1, e, além disso, possui o nó com maior grau de saída nessa rede. Portanto, mesmo não sendo o maior em número de conexões estabelecidas entre seus nós, o Cluster 2 tem grande influência na circulação de informações na rede inteira. Aspecto importante que justifica essa afirmação é o fato do Cluster 2 possuir o mais elevado grau de conexão com os demais clusters do grafo, apresentando baixa conectividade apenas com o Cluster 1.

Válido ressaltar que a baixa conectividade entre o Cluster 1 e o Cluster 2 sinaliza o alto grau de polarização das narrativas em circulação nos dois grupos (o primeiro grupo sendo favorável à Lula e o segundo, contrário ao ex-presidente). 
Figura 8 - Cluster 2 - nós distribuídos por grau de entrada

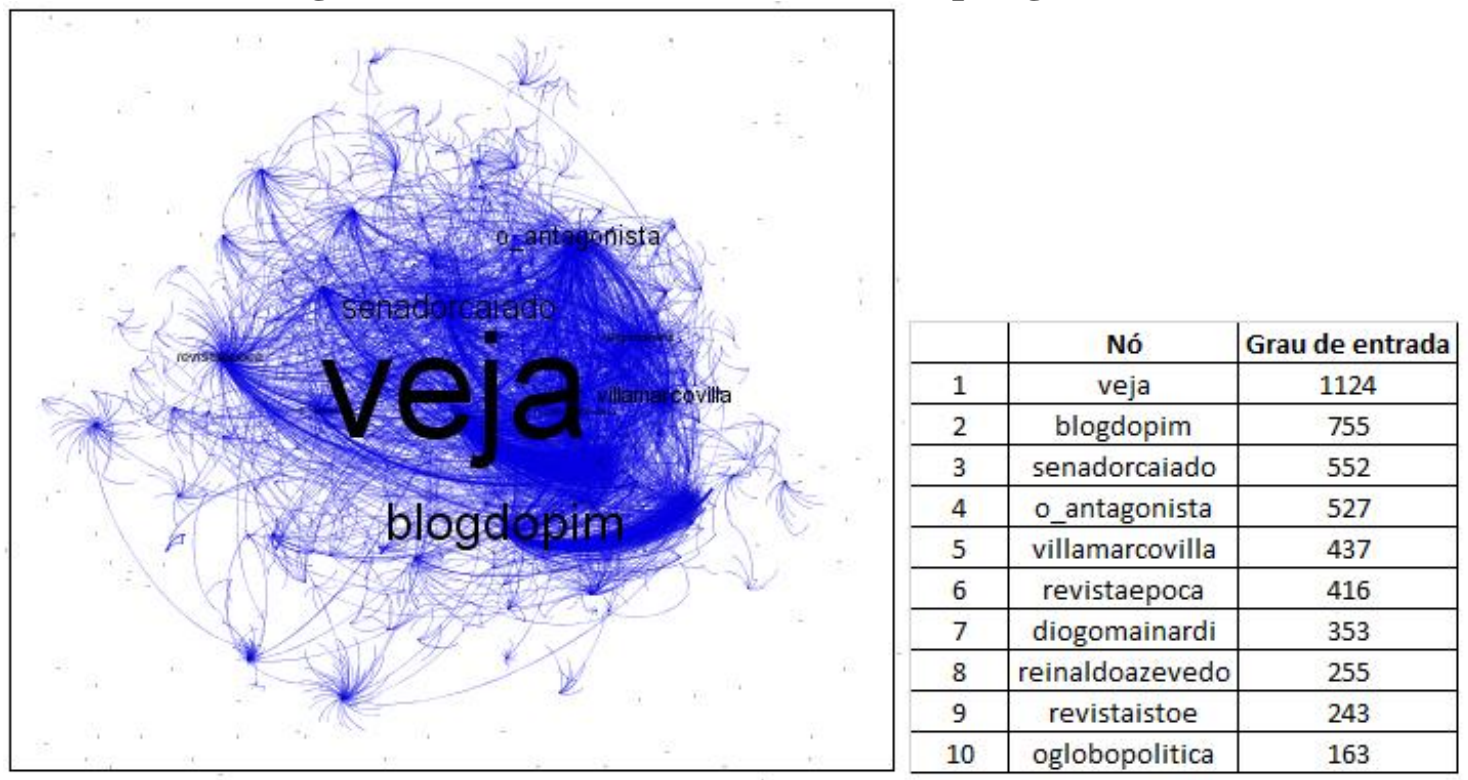

Fonte: Elaborado pela autora.

Cluster 3: O terceiro cluster da rede é composto por perfis de usuários comuns que não apresentam posicionamento explícito em relação à Lula, apenas uma página de usuário (@ usuario2) se diz contrária ao partido do ex-presidente (consta o termo "anti PT” no nome do usuário). Esse perfil em específico se encontra em segundo lugar na classificação dos 20 nós com maior grau de saída na rede inteira. (Figura 9)

O Cluster 3 possui mais homogeneidade em relação ao tamanho dos nós (de acordo com o grau de entrada), ou seja, a conversação no grupo se dá de forma mais horizontal no que se diz respeito à circulação de informações, já que não há formadores de opinião ou veículos de comunicação de grande relevância; isto justifica, também, a ausência de páginas pertencentes a esse cluster na classificação dos 20 nós com maior grau de entrada na rede.

Interessante observar (Figura 9) a presença do perfil oficial do Supremo Tribunal Federal (@stf_oficial),que classificamos como sendo de liderança. A presença dessa página no cluster 3 indica a importância desse nó como fonte de informação no grupo em questão.

Nota-se ainda a presença do perfil do presidente nacional do Partido Trabalhista Brasileiro (PTB) e ex-deputado Roberto Jefferson, que da mesma forma se enquadra na classificação de representação de liderança (Figura 9). É válido ressaltar que Roberto Jefferson denunciou o esquema de corrupção do mensalão, em 2005, durante interrogação sobre a CPI dos Correios. O parlamentar confessou ter feito parte do esquema do mensalão e, por ocasião, foi condenado a 10 anos de prisão (a pena foi diminuída, posteriormente, para sete anos) e, além disso, teve seu mandato cassado em 14 de setembro daquele mesmo ano. (PLENÁRIO..., 2005). 
Lembramos que o ex-deputado ficou conhecido como grande articulador na desconstrução da imagem pública de Lula por delatar os escândalos envolvendo o ex-presidente e seu partido.

Apesar de ser o que menos apresenta perfis com elevado grau de conexões recebidas, o Cluster 3 é o que possui maior quantidade de nós com alto grau de saída; assim, classificamos esse grupo como o que possui maior grau de difusão de informações na rede do Contexto 1 .

Importante mencionar ainda que o grau de conectividade entre o Cluster 3 e o Cluster 2 se destaca como o maior dentre os cinco clusters - o que indica circulação de informações com o mesmo posicionamento, ou seja, Cluster 3 tem potencial para ser difusor de narrativas contrárias à Lula.

Figura 9 - Cluster 3 - nós distribuídos por grau de entrada

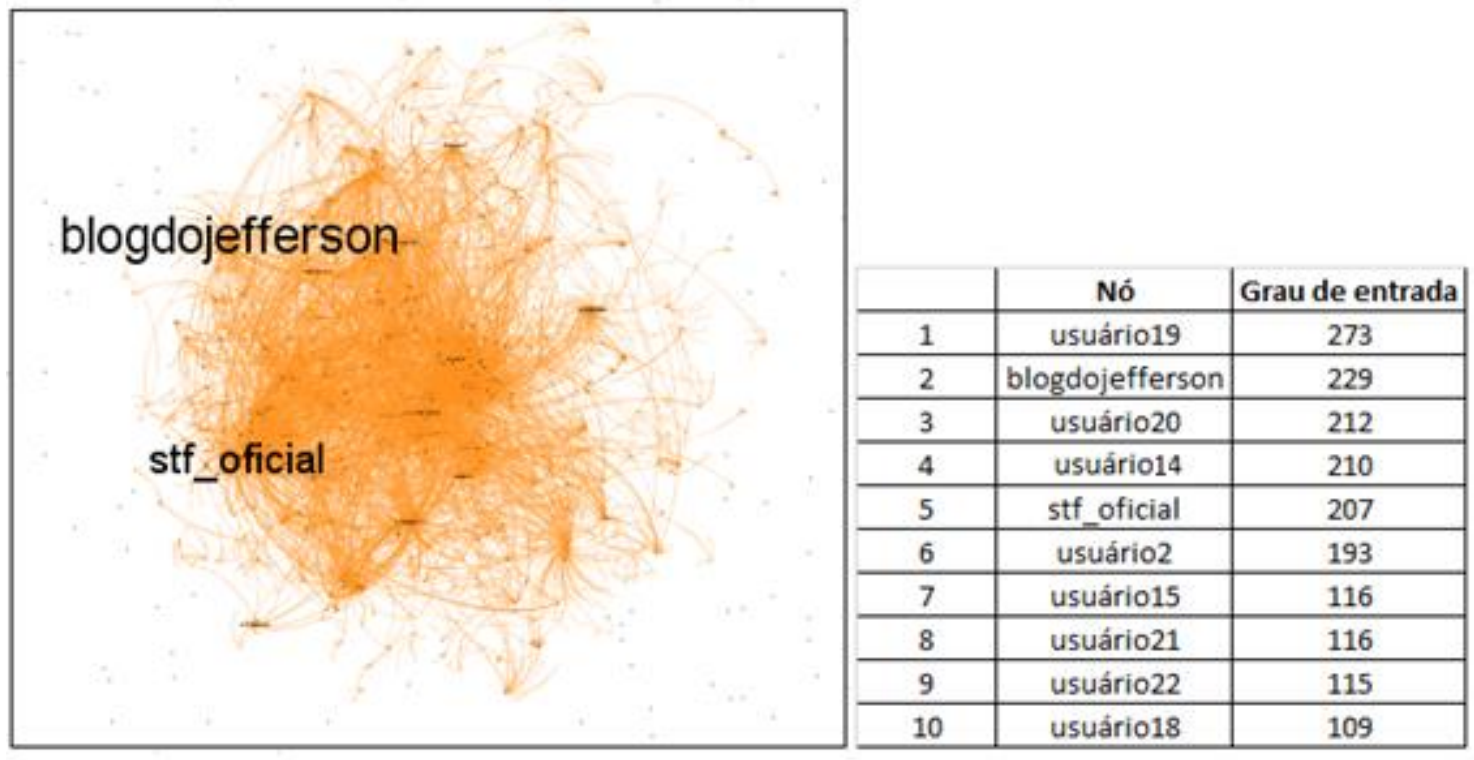

Fonte: Elaborado pela autora.

Cluster 4: Dentre os 10 nós com maior grau de entrada no Cluster 4, dois se enquadram na classificação de veículos jornalísticos, sendo eles: o perfil do canal de televisão GloboNews (@globonews) e o do jornal Valor Econômico (@valoreconomico). Outras cinco páginas são de formadores de opinião: Diego Escostesguy (@diegoescostesguy), jornalista e então diretorchefe da revista Época; Andreia Sadi (@andreiasadi), Ricardo Amorim (@ricamconsult), Thaís Heredia (@thaisheredia) e Caio Blinder (@caioblinder), sendo todos esses quatro últimos jornalistas e repórteres da GloboNews. E há, também, um perfil de liderança pertencente ao deputado federal Onyx Lorenzoni (@ onyxlorenzoni), que pertence à bancada do DEM, partido de oposição ao PT. (Figura 10).

Observa-se (Figura 10) que o Cluster 4 possui o nó com maior número de conexões recebidas na rede entre os cinco analisados e também na rede inteira no Contexto 2; este nó 
corresponde ao perfil do Blog do Noblat (@blogdonoblat), que, como visto anteriormente, é vinculado ao portal de notícias da Rede Globo e pertencente ao jornalista Ricardo Noblat, que apresenta posicionamento contrário em relação à Lula e aos governos petistas. Pontuamos que a página oficial de Noblat no Facebook também foi apontada por Santos Junior (2016) como uma das principais articuladoras da rede antipetista na internet a partir das eleições de 2014, o que reforça a inferência de que tal perfil no Twitter contribui para a circulação de narrativas contrárias à Lula.

É válido ressaltar que o Cluster 4 estabelece maior grau de conexão com o Cluster 2, no qual há presença de perfis reconhecidos por serem detratores da imagem de Lula, e menor grau de conexão com o Cluster 1, que é constituído por perfis favoráveis ao ex-presidente. Inferimos, portanto, que o Cluster 4 também é composto de informações de posicionamento negativo em relação à Lula.

Figura 10 - Cluster 4 - nós distribuídos por grau de entrada

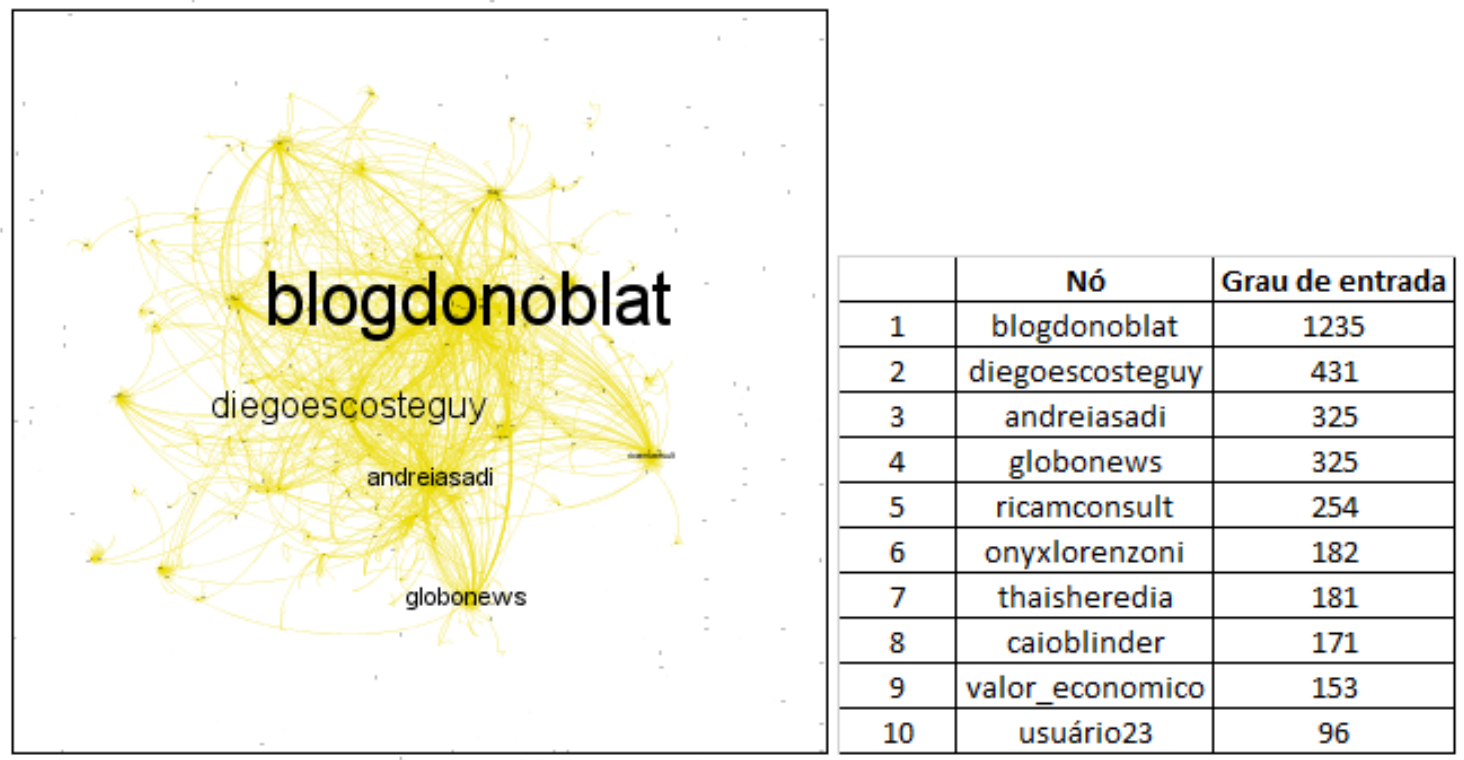

Fonte: Elaborado pela autora.

Cluster 5: Como pode ser observado na Figura 11, dentre os 10 principais nós que compõem o Cluster 5, sete são perfis de veículos jornalísticos: o portal de notícias online da Rede Globo (@g1), o Jornal O Estado de S. Paulo (@estadao), o Jornal Folha de S. Paulo (@folha e @folha_poder), o portal de notícias UOL (@uolnoticias), o jornal Zero Hora (@zerohora), a revista Exame (@exame). Este cluster também é composto pelo perfil de formador de opinião, pertencente à colunista do jornal Estado de S. Paulo e comentarista na Globo News, Eliane Cantanhêde (@ecantanhede), que possui posicionamento contrário aos governos petistas e à Lula. 
Ressaltamos, igualmente, a presença do perfil de militância "Bolsonaro Zuero" (@bolsonarozuero) que, de acordo com a bio do perfil, “foi criado de forma voluntária e exclusivamente para apoiar Jair Messias Bolsonaro ${ }^{151}$ e toda direita”. Sobre esse perfil em específico é válido explicar que na análise sobre o cenário das eleições de 2014 e a formação da rede antipetista na internet, realizada por Santos Junior (2016), o autor destacou a página do Facebook "Bolsonaro Zuero" como uma das principais responsáveis pela criação e divulgação de conteúdo anti-PT e anti-Lula. Essa observação nos permite inferir que tal perfil no Twitter se constitui como sendo de militância contrária ao ex-presidente.

Apesar de ser majoritariamente jornalístico, ressalta-se que o maior grau de conectividade estabelecido pelo Cluster 5 se dá em relação ao Cluster 2 (composto por narrativas opostas à imagem de Lula), enquanto o menor grau de conectividade é estabelecido com o Cluster 1 (que possui narrativas com teor positivo em relação ao ex-presidente) - diante disso entendemos que as narrativas negativas em relação ao ex-presidente possuem maior potencial de circulação também no Cluster 5.

\section{Figura 11 - Cluster 5 - nós distribuídos por grau de entrada}

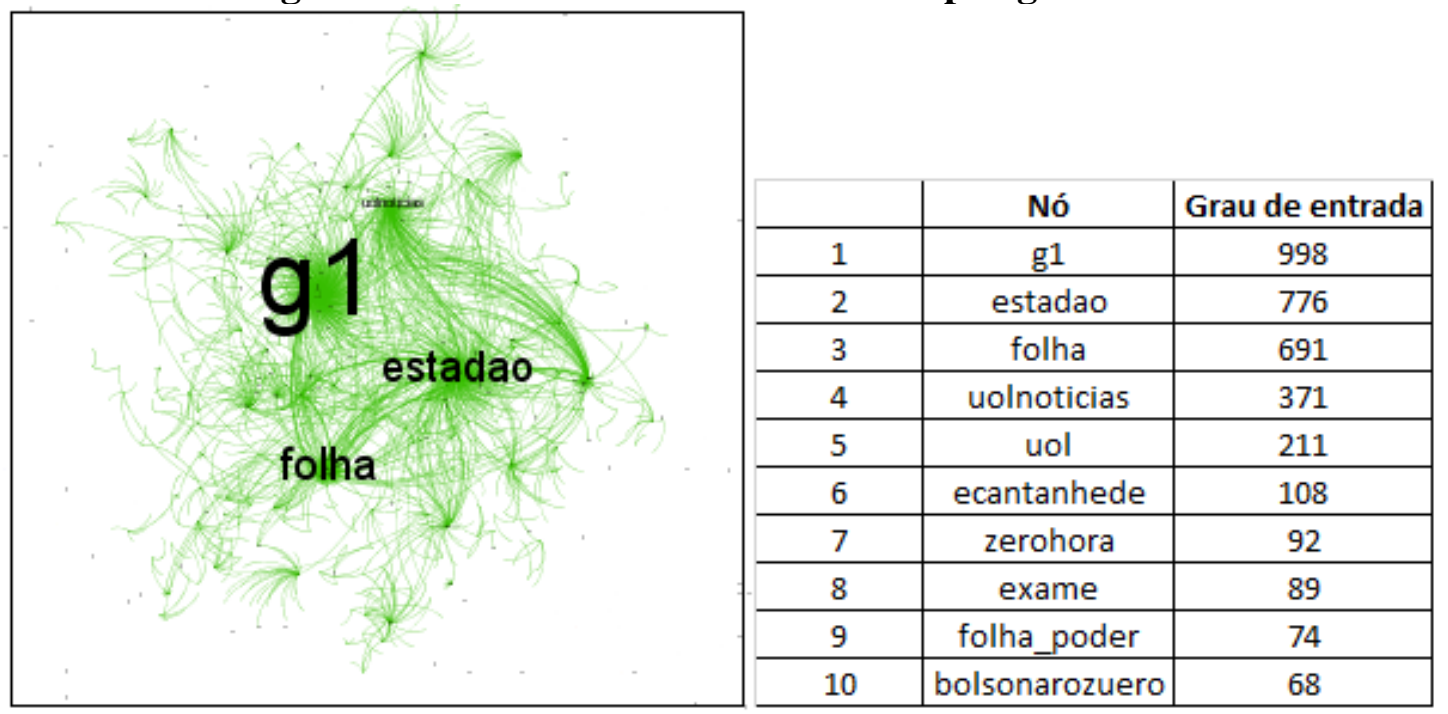

Fonte: Elaborado pela autora.

Em relação ao Contexto 1, consideramos por fim que, apesar de o Cluster 1 ser o que apresenta maior porcentagem de conexões entre seus nós, as narrativas favoráveis à Lula não são as que mais circularam na rede, na medida em que nos demais clusters (Cluster 2, Cluster 3, Cluster 4 e Cluster 5) circularam narrativas com posicionamento negativo em relação à

${ }^{151}$ Jair Messias Bolsonaro é ex-militar e atual deputado federal pelo estado do Rio de Janeiro filiado ao Partido Social Cristão (PSC). Bolsonaro representa as ideologias de extrema-direita no Brasil, acionando narrativas ultraconservadoras em seus discursos e projetos políticos. 
imagem do ex-presidente. Ressaltamos, ainda, o alto grau de conectividade entre o Cluster 2 (que apresenta narrativas com teor negativo em relação à imagem de Lula) e os Clusters 3, 4 e 5 , o que reforça o maior potencial de propagação de narrativas contrárias ao ex-presidente pela rede no primeiro contexto.

\subsection{Contexto 2: Manifestações sociais contra o golpe}

Foram detectados 56.509 nós e 76.374 arestas na rede de interações no Twitter estabelecida no Contexto 2 (17 e 18 de abril de 2016), cujo grafo está apresentado na Figura 12, a seguir, com os rótulos dos nós distribuídos por grau de entrada.

Figura 12 - Rede inteira do Contexto 2

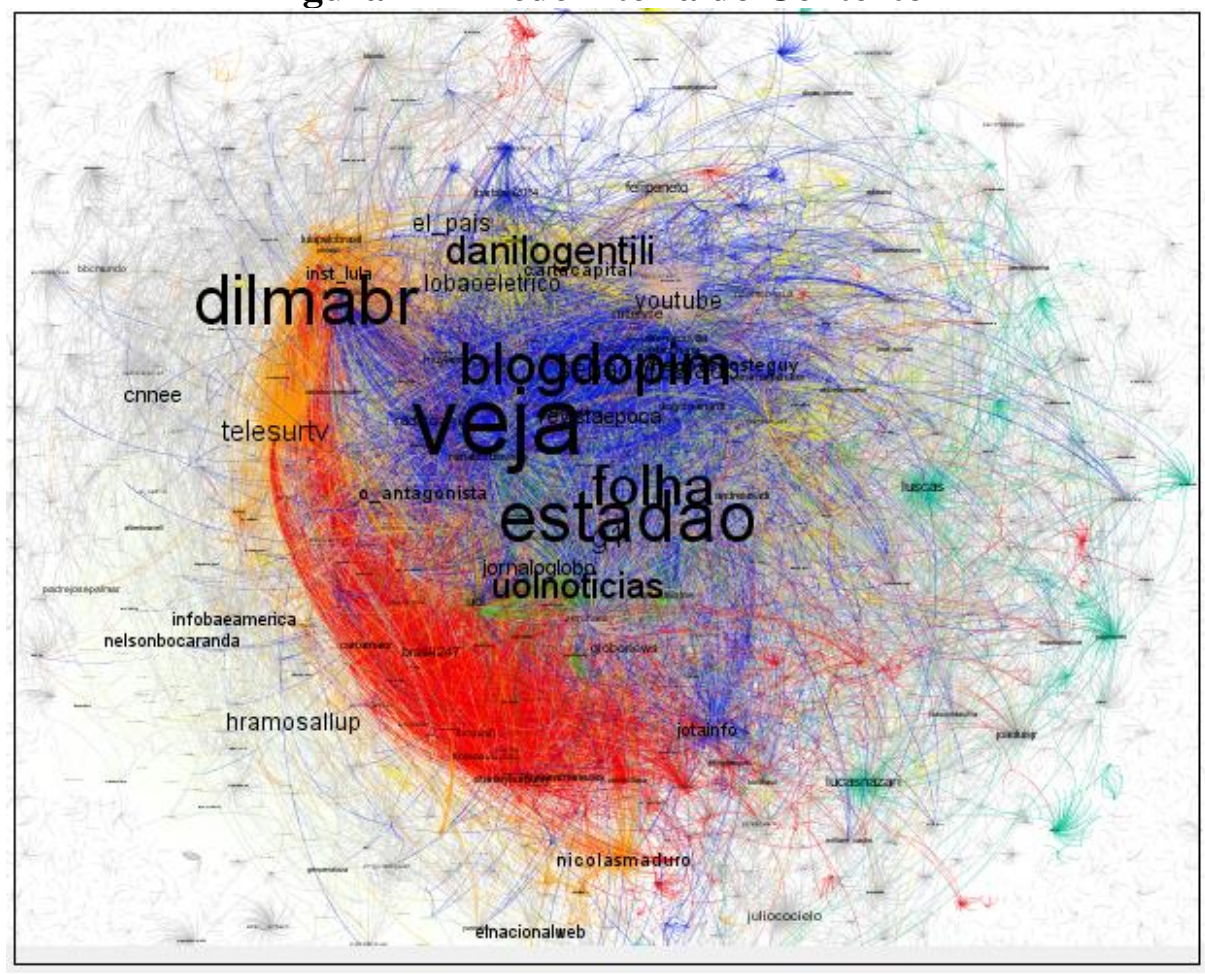

Fonte: Elaborado pela autora.

A rede formada no Contexto 2 possui, ao todo, 4.587 comunidades ou clusters encontrados a partir da análise de modularidade realizada com auxílio do software Gephi, sendo que desse total foram detectados cinco clusters mais importantes ou que apresentaram número superior de nós conectados entre si. O grau de modularidade encontrado na rede inteira do Contexto 2 foi de 0,780 (Figura 13). 
Figura 13 - Gráfico de modularidade da rede inteira do Contexto 2

\section{Results:}

Modularity: 0,780

Modularity with resolution: 0,780

Number of Communities: 4597

\section{Size Distribution}

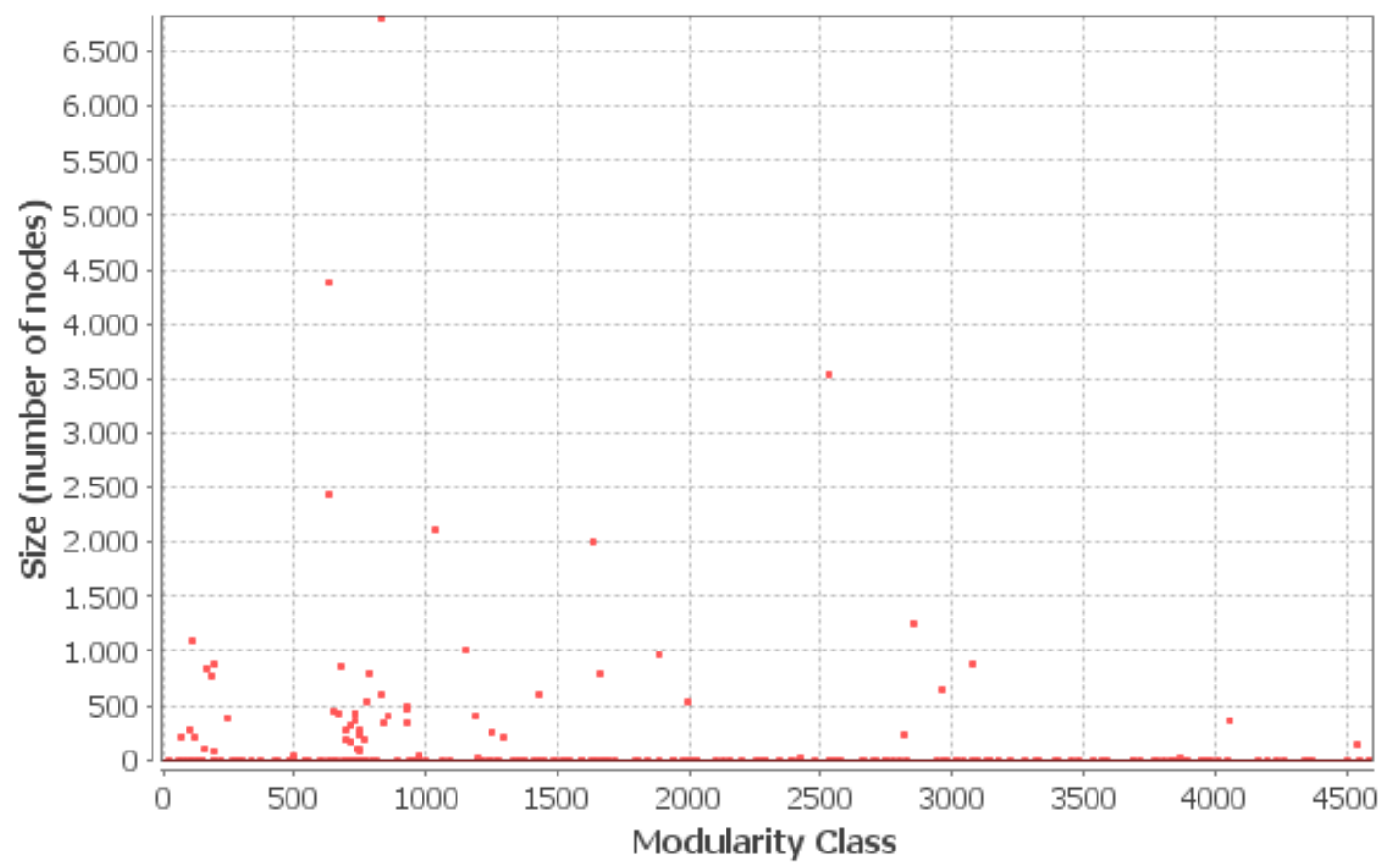

Fonte: Elaborado pela autora.

Na Tabela 9 enumeramos os cinco principais clusters segundo o número de componentes conectados, a porcentagem de conexões em relação à rede inteira ${ }^{152}$ e a cor de representação no grafo.

Tabela 9 - Cinco principais clusters da rede inteira - Contexto 2

\begin{tabular}{cccc}
\hline Cluster & $\begin{array}{c}\text { Componentes } \\
\text { conectados }\end{array}$ & \% de conexões & Cor de representação no grafo \\
\hline Cluster 6 & 6824 & $14,83 \%$ & Azul \\
Cluster 7 & 4406 & $9,90 \%$ & Vermelho \\
Cluster 8 & 2449 & $4,45 \%$ & Laranja \\
Cluster 9 & 2127 & $3,45 \%$ & Amarelo \\
Cluster 10 & 2024 & $2,99 \%$ & Verde \\
\hline
\end{tabular}

Fonte: Elaborado pela autora.

152 Essa porcentagem é calculada a partir da quantidade de conexões estabelecidas na rede inteira. O software calcula, portanto, qual o total de nós e o de arestas da rede inteira e gera um valor de quantas conexões foram realizadas em cada cluster. 
Em cálculo realizado pelo software Gephi descobrimos que do número total de arestas que compõem a rede no Contexto 2 apenas 5,23\% são estabelecidas entre os cinco clusters principais dessa rede ${ }^{153}$. A seguir enumeramos, em ordem do menor para o maior grau de conexões, as relações entre os cinco clusters apresentados anteriormente (Tabela 9):
11. Cluster 8 e Cluster $10(0,07 \%)$;
12. Cluster 8 e Cluster $9(0,11 \%)$;
13. Cluster 9 e Cluster 7 (0,15\%);
14. Cluster 9 e Cluster $10(0,20 \%)$;
15. Cluster 7 e Cluster $10(0,35 \%)$.
16. Cluster 6 e Cluster $8(0,45 \%)$;
17. Cluster 7 e Cluster $6(0,59 \%)$;
18. Cluster 7 e Cluster $8(0,75 \%)$;
19. Cluster 6 e Cluster $9(1,21 \%)$
20. Cluster 6 Cluster $10(1,35 \%)$

Na Tabela 10, a seguir, estão classificados os 20 perfis da rede inteira que possuem maior grau de entrada. Nota-se que o Cluster 6 apresenta a maior quantidade de nós nesta Tabela, enquanto o Cluster 7 possui apenas um perfil nessa classificação. Ressalta-se, assim, como no Contexto 1, a influência marcante dos perfis de veículos jornalísticos.

\begin{tabular}{cccccccc}
\multicolumn{7}{c}{ Tabela 10 - Nós com maior grau de entrada nos cinco clusters principais - Contexto 2 } \\
\hline & Nó & $\begin{array}{c}\text { Grau de } \\
\text { entrada }\end{array}$ & Cluster & & Nó & $\begin{array}{c}\text { Grau de } \\
\text { entrada }\end{array}$ & Cluster \\
\hline $\mathbf{1}$ & veja & 1009 & Cluster 6 & $\mathbf{1 1}$ & diegoescosteguy & 309 & Cluster 6 \\
$\mathbf{2}$ & estadao & 841 & Cluster 10 & $\mathbf{1 2}$ & o_antagonista & 301 & Cluster 6 \\
$\mathbf{3}$ & dilmabr & 818 & Cluster 8 & $\mathbf{1 3}$ & cartacapital & 296 & Cluster 7 \\
$\mathbf{4}$ & blogdopim & 736 & Cluster 6 & $\mathbf{1 4}$ & nicolasmaduro & 295 & Cluster 8 \\
$\mathbf{5}$ & folha & 703 & Cluster 10 & $\mathbf{1 5}$ & jotainfo & 273 & Cluster 6 \\
$\mathbf{6}$ & danilogentili & 558 & Cluster 9 & $\mathbf{1 6}$ & inst_lula & 264 & Cluster 8 \\
$\mathbf{7}$ & uolnoticias & 515 & Cluster 10 & $\mathbf{1 7}$ & uol & 252 & Cluster 10 \\
$\mathbf{8}$ & telesurtv & 412 & Cluster 8 & $\mathbf{1 8}$ & radaronline & 249 & Cluster 6 \\
$\mathbf{9}$ & senadorcaiado & 396 & Cluster 6 & $\mathbf{1 9}$ & mblivre & 243 & Cluster 9 \\
$\mathbf{1 0}$ & lobaoeletrico & 350 & Cluster 9 & $\mathbf{2 0}$ & brasil247 & 228 & Cluster 7 \\
\hline
\end{tabular}

Fonte: Elaborado pela autora.

${ }^{153} \mathrm{O}$ cálculo é realizado em relação ao número de conexões estabelecidas entre todos os clusters da rede inteira, sendo que a totalidade das conexões equivale a $100 \%$. 
Na Figura 14 é possível visualizar o desenho da rede composta pelos cinco clusters principais do Contexto 2 com os nós distribuídos por grau de entrada.

\section{Figura 14 - Cinco clusters principais do Contexto 3 com nós distribuídos por grau} de entrada

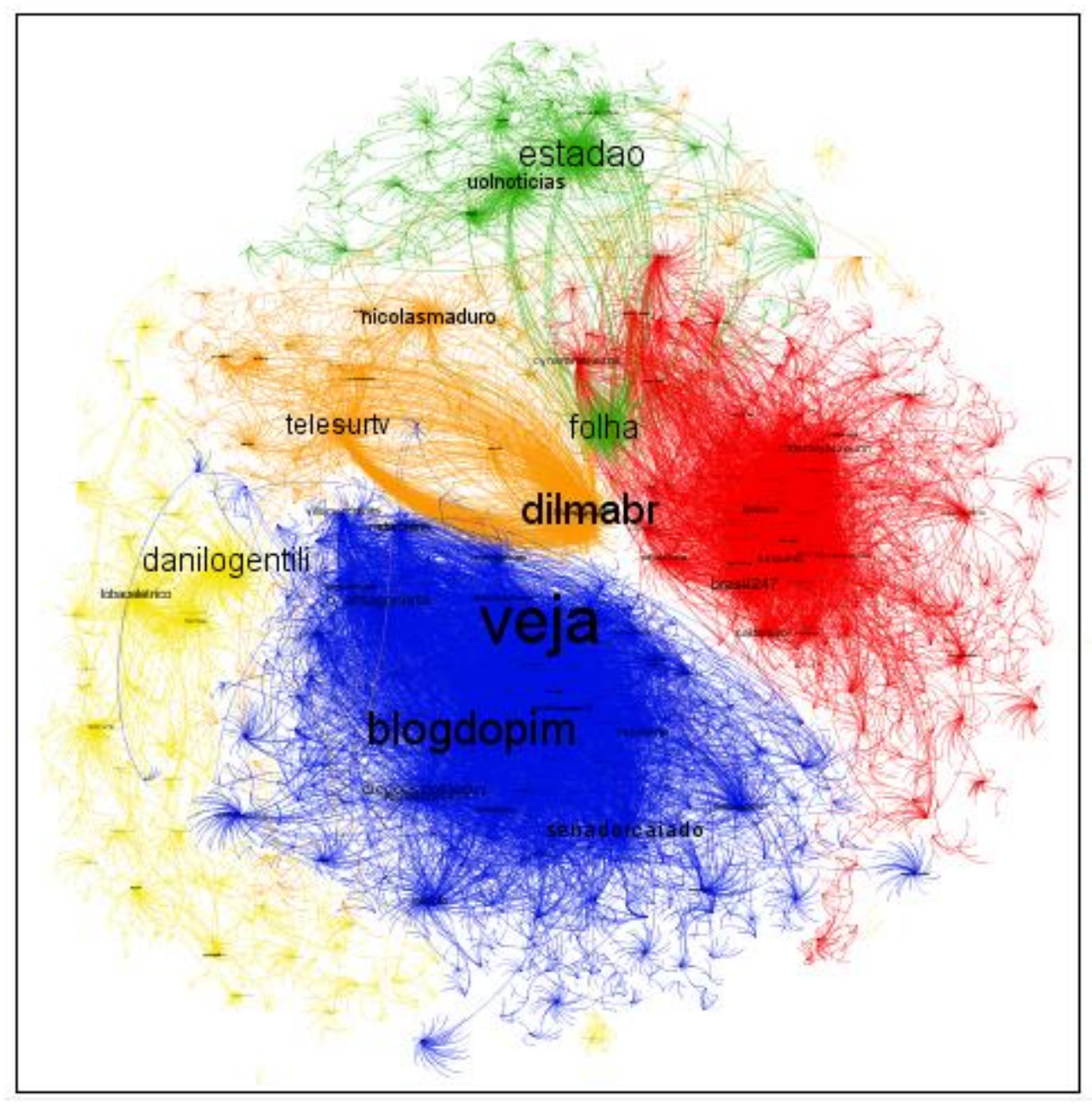

Fonte: Reprodução Gephi.

Na Tabela 11 classificamos os nós que apresentam número superior de conexões realizadas com outros usuários, ou seja, aqueles que possuem maior grau de saída. Nota-se que todos os 20 nós classificados correspondem a usuários comuns e, além disso, dos 20 perfis que mais realizam conexões com outros, 13 estão presentes no Cluster 6. Esclarecemos que não há presença de perfis que pertençam aos Clusters 9 e 10. 
Tabela 11 - Nós com maior grau de saída nos 5 clusters principais Contexto 2

\begin{tabular}{ccclcccc}
\hline & Nó & $\begin{array}{c}\text { Grau de } \\
\text { saída }\end{array}$ & Cluster & & Nó & $\begin{array}{c}\text { Grau de } \\
\text { saída }\end{array}$ & Cluster \\
\hline $\mathbf{1}$ & usuário19 & 49 & Cluster 7 & $\mathbf{1 1}$ & usuário29 & 39 & Cluster 6 \\
$\mathbf{2}$ & usuário21 & 48 & Cluster 6 & $\mathbf{1 2}$ & usuário30 & 34 & Cluster 7 \\
$\mathbf{3}$ & usuário22 & 46 & Cluster 6 & $\mathbf{1 3}$ & usuário31 & 34 & Cluster 8 \\
$\mathbf{4}$ & usuário22 & 45 & Cluster 6 & $\mathbf{1 4}$ & usuário32 & 33 & Cluster 7 \\
$\mathbf{5}$ & usuário23 & 45 & Cluster 6 & $\mathbf{1 5}$ & usuário33 & 31 & Cluster 7 \\
$\mathbf{6}$ & usuário24 & 44 & Cluster 6 & $\mathbf{1 6}$ & usuário34 & 31 & Cluster 6 \\
$\mathbf{7}$ & usuário25 & 42 & Cluster 6 & $\mathbf{1 7}$ & usuário18 & 29 & Cluster 6 \\
$\mathbf{8}$ & usuário26 & 41 & Cluster 6 & $\mathbf{1 8}$ & usuário35 & 29 & Cluster 6 \\
$\mathbf{9}$ & usuário27 & 40 & Cluster 6 & $\mathbf{1 9}$ & usuário36 & 29 & Cluster 7 \\
$\mathbf{1 0}$ & usuário28 & 40 & Cluster 6 & $\mathbf{2 0}$ & usuário37 & 29 & Cluster 7 \\
\hline
\end{tabular}

Fonte: Elaborado pela autora.

A partir dos dados apresentados sobre a rede e da delimitação dos cinco clusters principais analisaremos, no tópico a seguir, cada cluster separadamente com o objetivo de estabelecer inferências acerca da circulação de informações ocorrida na rede instituída no Contexto 2, qual seja, das "Manifestações sociais contra o golpe".

\subsubsection{Visualização e análise dos clusters}

Cluster 6: Esse grupo é o que exibe mais nós conectados entre si e, por isso, torna-se o maior cluster do Contexto 2. Pontuamos que o Cluster 6 se assemelha ao Cluster 2 (que pertence ao Contexto 1) por também apresentar perfis com características opositoras à Lula.

Como pode ser observado pela Figura 15, dentre os 10 nós com maior grau de entrada nesse grupo, 3 são páginas de veículos jornalísticos: revista Veja (@ veja) e portais de notícias online Jota Info (@jotainfo) e Radar Online (@ radaronline). Outros dois perfis são de blogs jornalísticos, sendo eles o Blog do Pim (@blogdopim) e O Antagonista (o_antagonista). Dois perfis são de formadores de opinião: os jornalistas Diego Escostesguy (@ diegoescosteguy) e Mário Sabino (@ mariosabinof), também responsável pelo blog O Antagonista.

O grupo é formado, ainda, por dois perfis de militância: Muylaerte (@ Muylaerte), página anônima e produtora de conteúdo opositor ao PT, e Joaquim Barbosa 2014 (@jbarbosa2014), perfil igualmente anônimo que, em sua biografia, se considera "contra o comunismo, o socialismo e o petismo". Compõe ainda o grupo um perfil de liderança pertencente ao senador Ronaldo Caiado (@senadorcaiado). 
Constatamos que o perfil da revista Veja (@veja) é o nó que recebe maior número de menções na rede inteira do Contexto 2, o que demonstra elevado grau de influência das narrativas desse perfil na circulação de informações ocorrida no contexto.

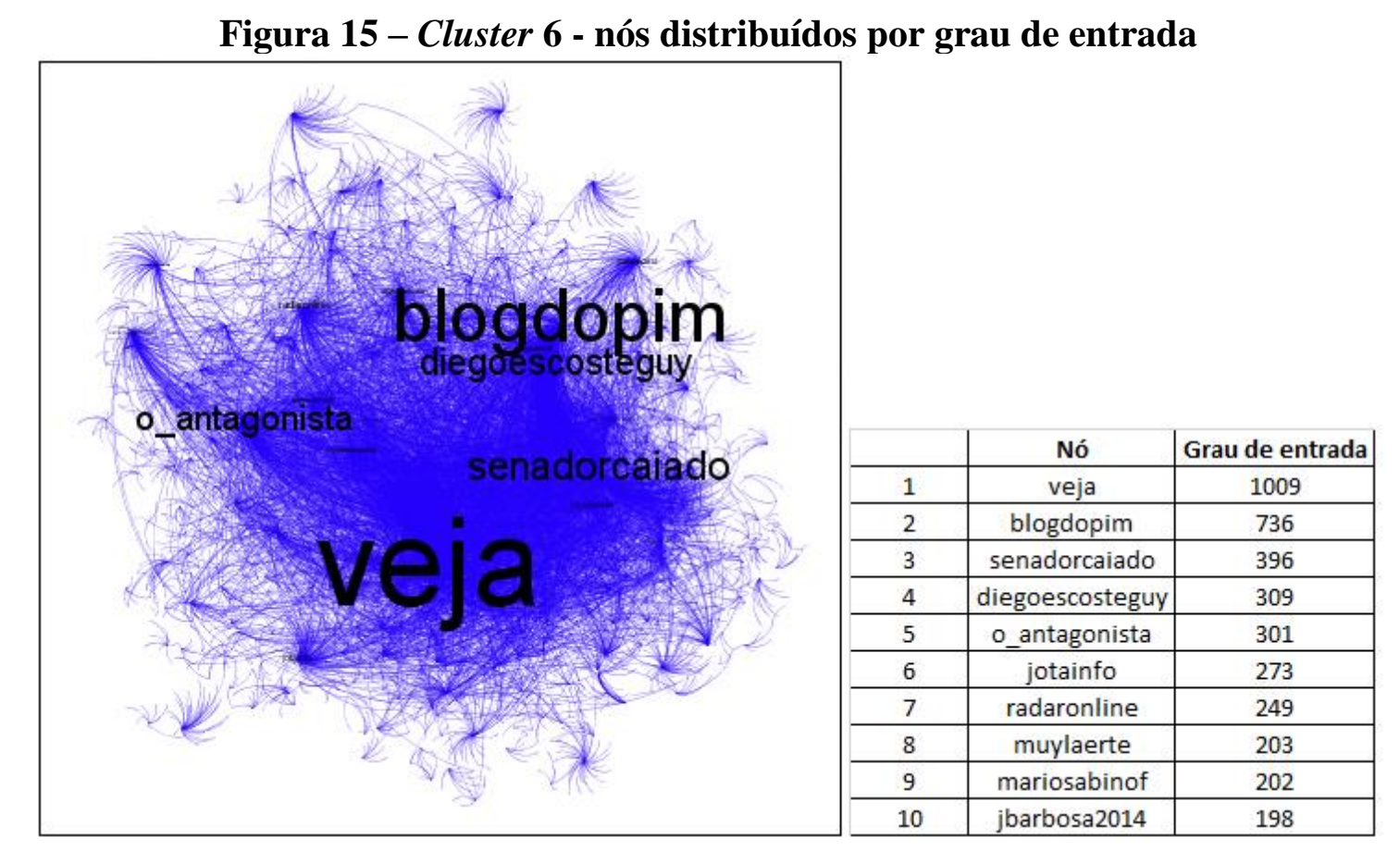

Fonte: Elaborado pela autora.

Ressaltamos, ainda, que todos os 10 perfiz que apresentaram maior grau de saída no Cluster 6 são de usuários comuns e fazem parte da classificação dos 20 que mais realizam conexões na rede inteira. Importante considerar que, como dito anteriormente, dos 20 perfis com maior grau de saída na rede estabelecida no $2^{\circ}$ Contexto, 13 pertencem ao Cluster 2, indicando que esse grupo possui grande poder de difusão da informação no contexto em questão.

Cluster 7: Dentre os 10 perfis com maior número de menções recebidas no Cluster 7, três são de blogs jornalísticos, sendo eles: Tijolaço (@tijolaco), Conversa Afiada (@conversaafiada)e Brasil 247 (@ brasil247). Destacamos, também, quatro perfis de formadores de opinião: Cynara Menezes (@cynaramenezes), jornalista; Pablo Villaça (@pablovillaca), crítico de cinema, e Xico Sá (@xicosa), jornalista e escritor; bem como a presença de um perfil de veículo jornalístico: Carta Maior (@ cartamaior). Necessário pontuar que todos os perfis supracitados se posicionam de forma favorável - ou mesmo militante - em relação à Lula. 
Dentre os 10 principais nós desse grupo destacam-se, ainda, dois perfis de militância, sendo eles: Turquim (@turquim5) e Stanley Burburin (@ stanleyburburin), ambos de anônimos reconhecidos pela criação e divulgação de conteúdo favorável aos governos petistas (Figura 16).

Chamamos atenção da mesma forma para o fato de que o perfil que realiza a maior quantidade de conexões no Cluster 7 é, também, o que alcança maior número de vinculações na rede inteira do Contexto 2 (@usuário19) - o que indica que houve bom investimento desse cluster na difusão das informações. Apesar de o grau de conectividade entre o Cluster 6 e o Cluster $7(0,59 \%)$ ser classificado como um dos mais altos no Contexto 2, esse índice é mais baixo do que o encontrado no Contexto 1 entre os Clusters 1 e $2(0,82 \%)$, reforçando a percepção da alta polarização das narrativas nos dois contextos.

\section{Figura 16 - Cluster 7 - nós distribuídos por grau de entrada}

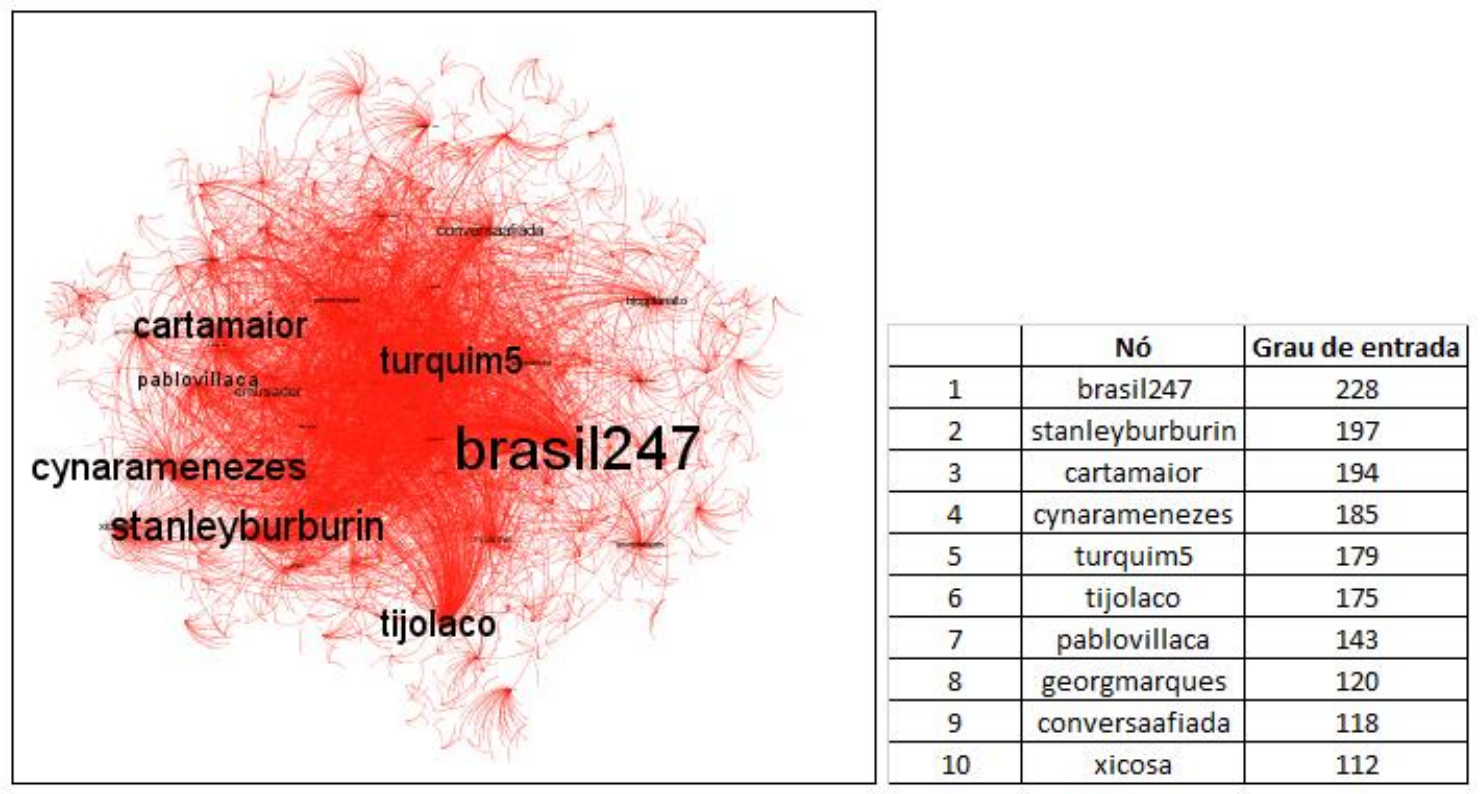

Fonte: Elaborado pela autora.

Cluster 8: Como poder ser observado na Figura 17, dentre os 10 perfis com maior grau de entrada no Cluster 8 metade se enquadra na classificação de perfis de liderança, sendo que quatro deles estão ligados a perfis oficiais do governo petista: o perfil oficial de Dilma (@dilmabr), o do InstitutoLula (@inst_lula),o de Lula (@lulapelobrasil)e odo PT (@ptbrasil). Outro perfil de liderança pertence a Nicolas Maduro (@ nicolasmaduro), então presidente da Venezuela e sucessor de Hugo Chávez, que possui discursos enfáticos em defesa de Lula e dos governos de esquerda na América Latina.

Outros três perfis são de veículos jornalísticos: o canal de televisão estatal Venezuelano TeleSurTV (@telesurtv), o canal de televisão RT en español (@actualidadrt), que desde 2014 
começou a ser transmitido na Venezuela, e o portal de notícias Brasil de Fato (@brasil_de_fato), que tem por objetivo apresentar uma "visão popular do Brasil e do Mundo".

Os outros dois perfis que compõem o grupo dos 10 nós com maior grau de entrada são classificados como sendo de militância: Dilma Bolada (@ diimabr - humorístico que se tornou amplamente conhecido a partir das eleições de 2010 por fazer paródia com a figura de Dilma Rousseff e, por vezes, publicar conteúdos favoráveis aos governos petistas. Integra o grupo ainda o perfil formador de opinião que pertence ao cientista político e analista de política internacional Juan Manuel Karg (@jmkarg), que possui vínculos com os canais TeleSurTV e RT em español.

Por ser constituído majoritariamente por perfis da comunicação do governo petista e outros venezuelanos favoráveis a esse governo, inferimos que no Cluster 8 também circulam narrativas favoráveis a Lula, da mesma forma que foi percebido no Cluster 7. Pontuamos que a conexão entre esses dois clusters é das mais fortes dentre os cinco principais grupos no Contexto 2.

Figura 17 - Cluster 8 - nós distribuídos por grau de entrada

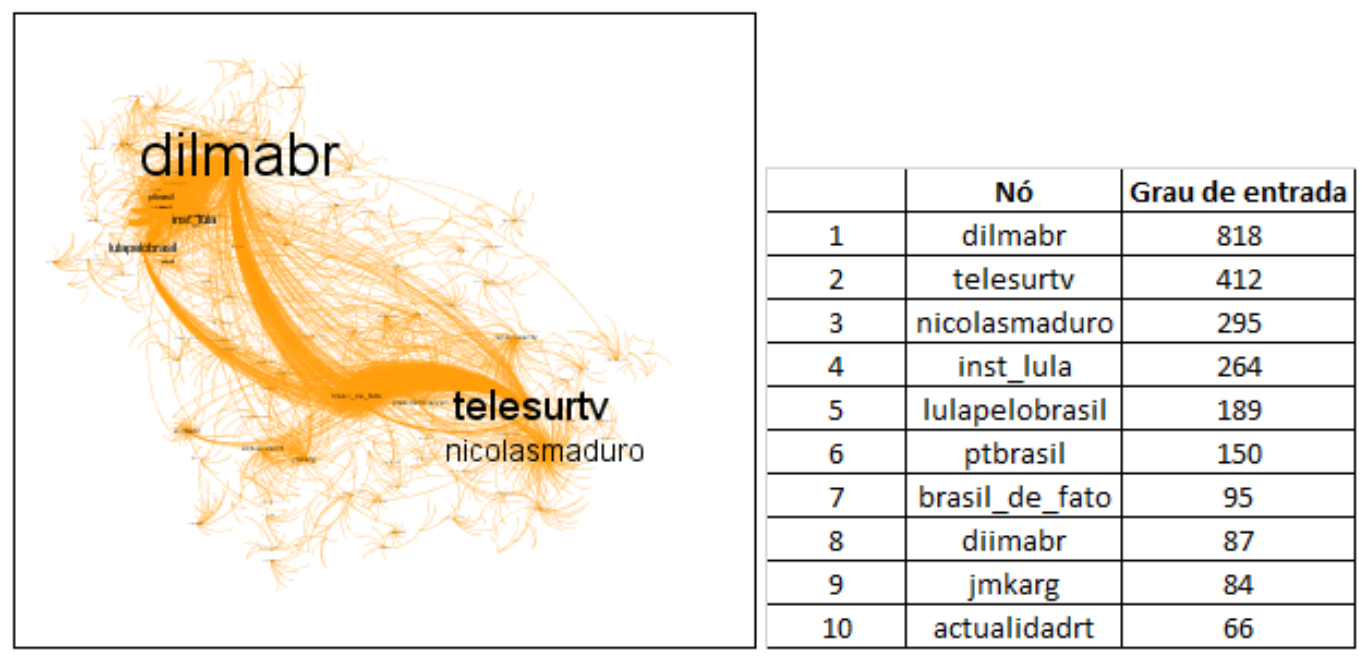

Fonte: Elaborado pela autora.

Cluster 9: Como pode ser observado na Figura 18 os dois nós mais influentes no Cluster 9 são, respectivamente, do comediante e apresentador de televisão Danilo Gentili (@danilogentili)e do músico e compositor Lobão (@lobaoeletrico). Ambos os perfis se enquadram na 
classificação de formadores de opinião e são reconhecidos por proferirem narrativas contrárias ao ex-presidente Lula e ao PT nas mídias sociais ${ }^{154}$.

Nota-se que @lobaoeletrico, ao mesmo tempo que é o segundo nó a receber maior número de menções, está em primeiro na classificação dos que mais realizam conexões no Cluster 9, o que demonstra intensa participação deste perfil na circulação de informações desse grupo.

O terceiro nó com maior grau de entrada no cluster se enquadra na classificação de perfil de militância e pertence ao Movimento Brasil Livre (@mblivre), que, como visto no capítulo 3 dessa tese, se consagrou como um dos mais importantes grupos de oposição ao governo petista a partir das manifestações favoráveis ao impeachment de Dilma em 2015.

Destacamos que devido à importância dos três perfis supracitados é possível inferir que no grupo em questão circulam narrativas de desconstrução da imagem pública política de Lula. Essa inferência também se justifica pelo fato de haver alto grau de conexão entre o Cluster 9 e Cluster 6.

Figura 18 - Cluster 9 - nós distribuídos por grau de entrada

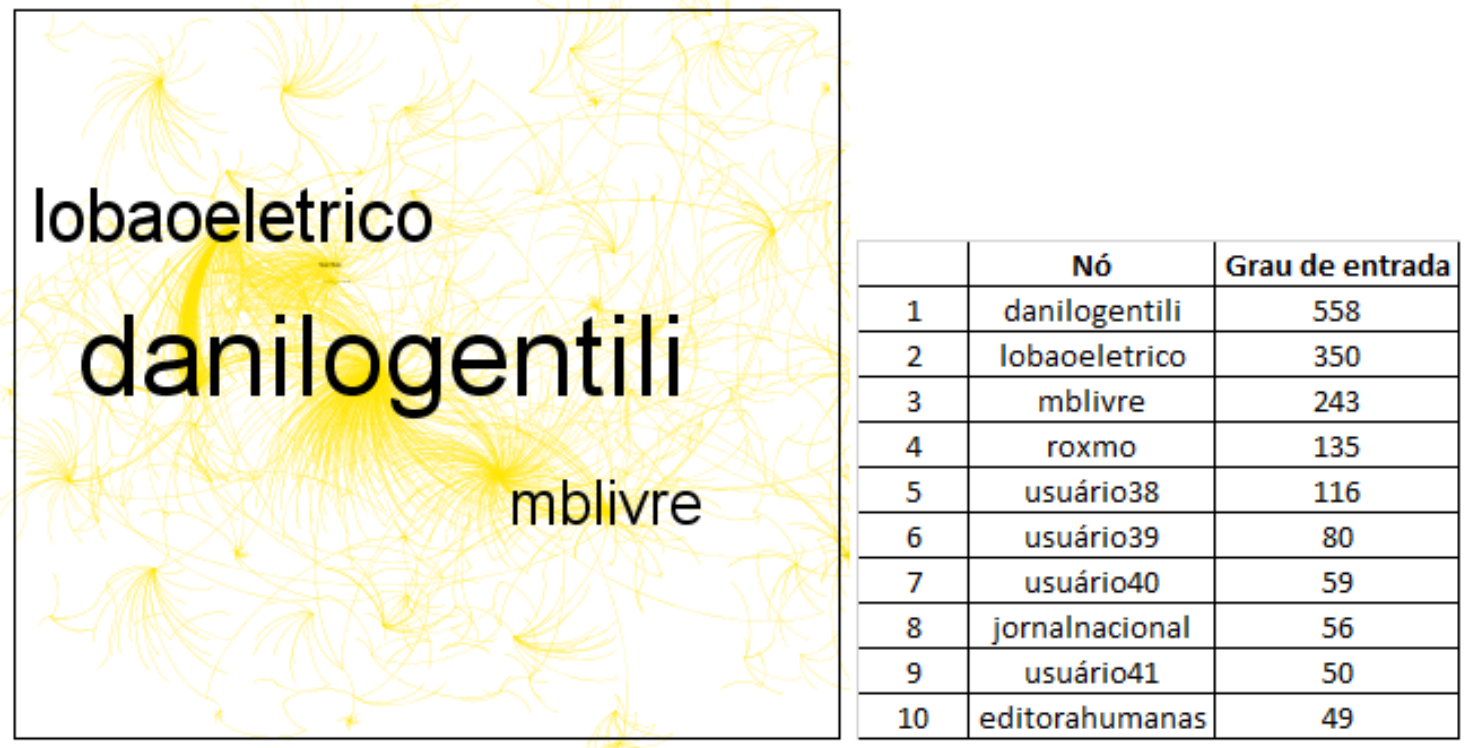

Fonte: Elaborado pela autora.

Cluster 10: Como pode ser observado na Figura 19, todos os 10 principais nós que compõem o Cluster 5 são perfis de veículos jornalísticos. E todos os 10 nós com maior grau de saída desse cluster referem-se a usuários comuns. Consideramos, assim, que o Cluster 10 é o grupo responsável pela circulação de informações de cunho jornalístico na rede inteira.

\footnotetext{
${ }^{154}$ Lobão, em entrevista à revista Veja, afirmou que iria participar das manifestações a favor do impeachment de Dilma que seriam realizadas em março de 2016 e que Lula seria o verdadeiro culpado pela corrupção no país. Intitulou o ex-presidente de "pai disso tudo" - em referência à crise por que passava o Brasil. (BARROS, 2015).
} 
Ressalta-se, no entanto, que o maior grau de conectividade estabelecido entre os cinco clusters no Contexto 2 ocorre entre o Cluster 10 e o Cluster 6, composto por narrativas com posicionamento negativo em relação à imagem de Lula. Já o menor grau de conectividade ocorre entre os Clusters 10 e 8, que possui narrativas com posicionamento positivo em relação ao ex-presidente. Por esses dados entendemos que o Cluster 10 possui potencial de circulação de narrativas contrárias à Lula.

Figura 19 - Cluster 10 - nós distribuídos por grau de entrada

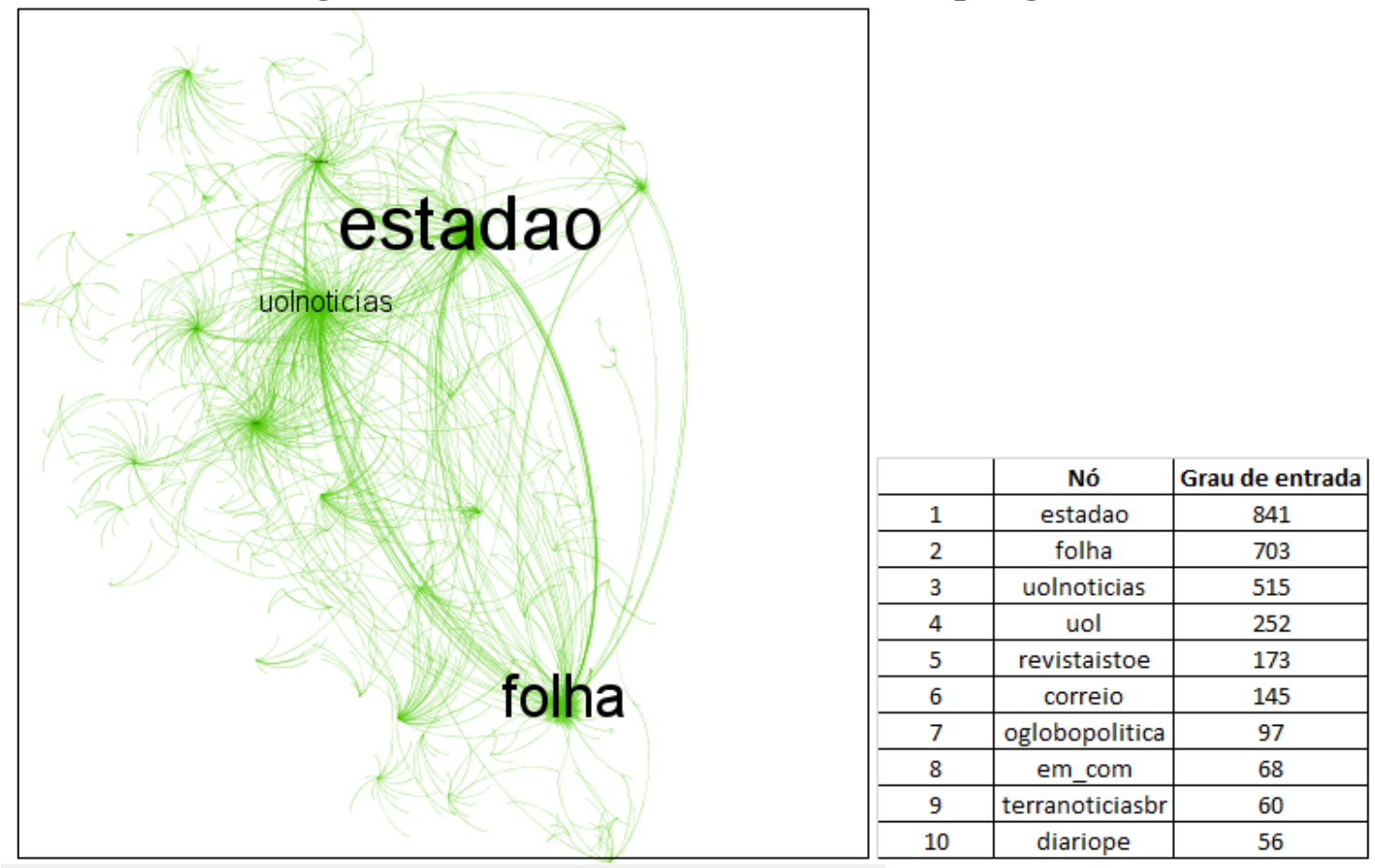

Fonte: Elaborado pela autora.

Necessário pontuar que apesar de o Contexto 2 estar relacionado às manifestações sociais contra o golpe, não foi observada a predominância de grupos mobilizadores dessa causa, mas, ao contrário, a maioria dos clusters (Clusters 6,9 e 10) apresentou potencial detrator em relação ao governo petista, o que indica maior possibilidade de circulação de narrativas contrárias à Lula na rede inteira desse contexto. Os grupos que apresentam condição de construção da imagem pública de Lula (clusters 7 e 8) são constituídos, majoritariamente, por perfis de militância, formadores de opinião ou lideranças reconhecidos pelo apoio a Lula. 


\subsection{Contexto 3: Votação na Câmara dos Deputados}

Na rede de interações estabelecida no Twitter durante o Contexto 3 (17 e 18 de abril de 2016) foram identificados 66.399 nós e 75.734 arestas. O grafo está apresentado na Figura 20 com os rótulos dos nós distribuídos por grau de entrada.

Figura 20 - Rede inteira do Contexto 3

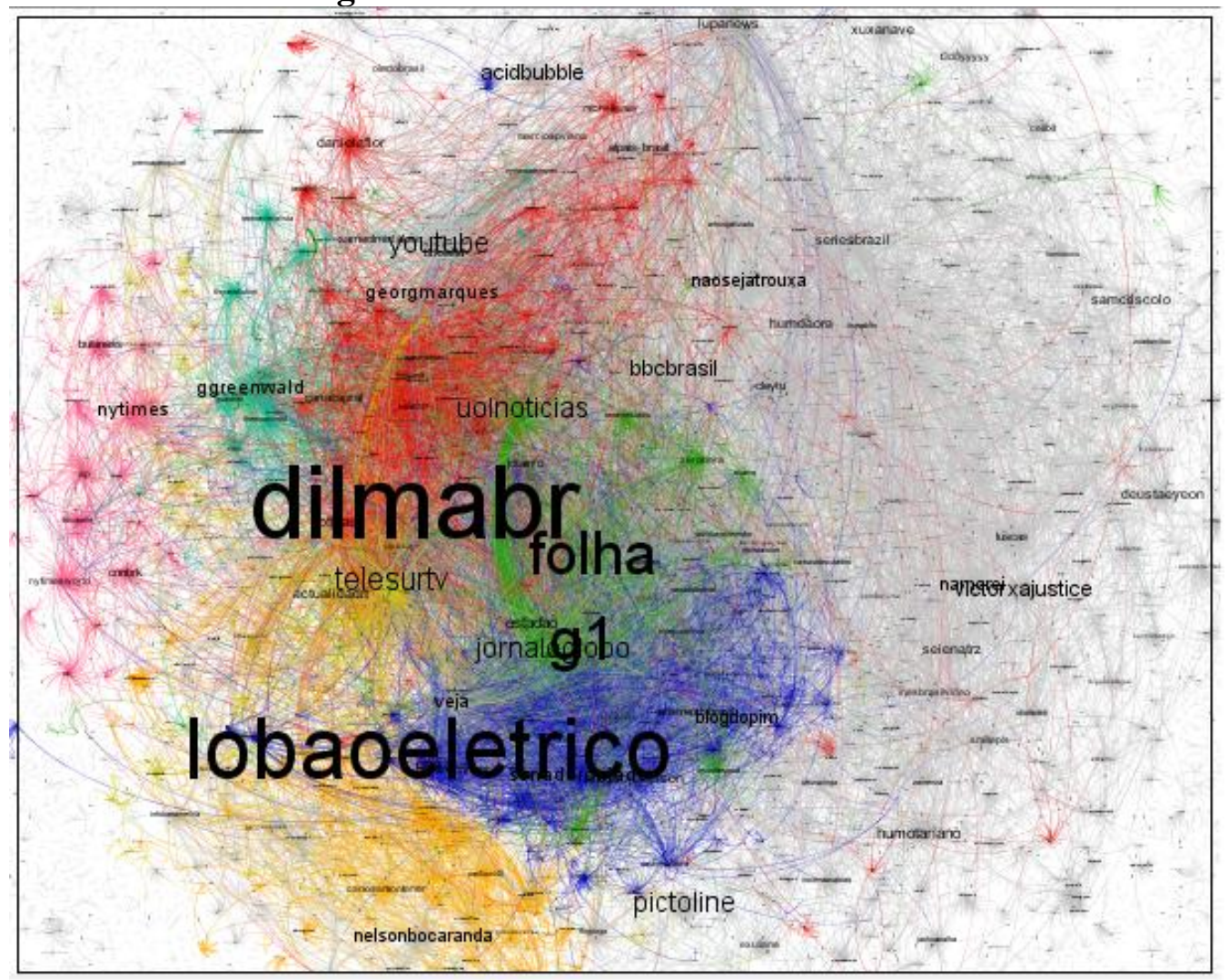

Fonte: Reprodução Gephi.

A partir da análise de métrica de modularidade realizada pelo software Gephi encontramos um total de 6.562 clusters na rede inteira e um grau de modularidade de 0,869 (Figura 21). 
Figura 21 - Gráfico de modularidade da rede inteira do Contexto 3

\section{Results:}

Modularity: 0,869

Modularity with resolution: 0,869

Number of Communities: 6562

\section{Size Distribution}

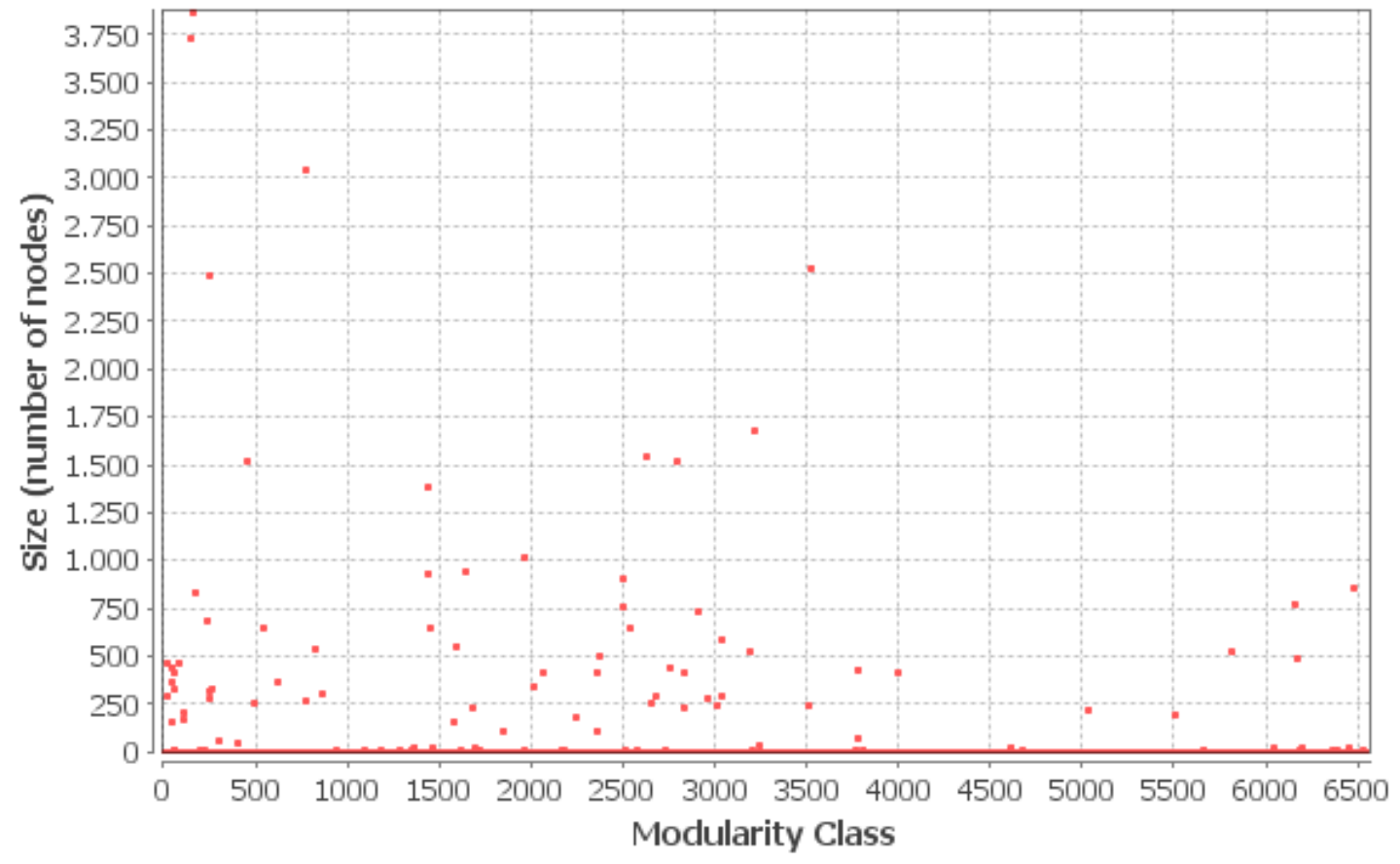

Fonte: Reprodução Gephi.

Do total de comunidades encontradas foram detectados cinco clusters mais importantes ou que apresentam maior número de nós conectados entre si. Na Tabela 12 enumeramos os cinco principais clusters, de acordo com o número de componentes conectados, com a porcentagem de conexões em relação à rede inteira ${ }^{155}$ e a cor de representação no grafo.

Tabela 12 - Cinco principais clusters da rede inteira - Contexto 3

\begin{tabular}{cccc}
\hline Cluster & $\begin{array}{c}\text { Componentes } \\
\text { conectados }\end{array}$ & \% de conexões & Cor de representação no grafo \\
\hline Cluster 11 & 3876 & $6,54 \%$ & Vermelho \\
\hline Cluster 12 & 3742 & $6,89 \%$ & Azul \\
\hline Cluster 13 & 3049 & $4,60 \%$ & Verde \\
\hline Cluster 14 & 2503 & $4,37 \%$ & Laranja \\
\hline Cluster 15 & 1696 & $2,48 \%$ & Amarelo \\
\hline
\end{tabular}

Fonte: Elaborado pela autora.

155 Essa porcentagem é calculada a partir da quantidade de conexões estabelecidas na rede inteira. O software calcula, portanto, qual o total de nós e o de arestas de toda a rede e gera um valor de quantas conexões foram realizadas em cada cluster. 
Dois pontos são importantes de serem observados a partir dos dados apresentados na Tabela acima: 1) os três primeiros clusters apresentam números muito próximos em termos de nós conectados; 2) o Cluster 12 apresenta maior porcentagem de conexões entre seus nós, o que nos leva a inferir que os perfis do Cluster 12 são os que mais interagem entre si dentre os cinco clusters analisados.

Em cálculo realizado pelo software Gephi descobrimos que há um grau muito baixo de conectividade ${ }^{156}$ entre os cinco clusters do Contexto 3. Do total de arestas que compõem a rede inteira no Contexto 3, apenas $2,77 \%$ são realizadas entre os cinco clusters principais dessa rede. A seguir enumeramos, em ordem do menor para o maior grau de conexões, as relações entre os cinco clusters (Tabela 12).

21. Cluster 14 e Cluster 15 (0,02\%);

22. Cluster 11 e Cluster 15 (0,02\%);

23. Cluster 13 e Cluster 15 (0,03\%);

24. Cluster 12 e Cluster 14 (0,05\%);

25. Cluster 12 e Cluster 15 (0,05\%).

26. Cluster 13 e Cluster 14 (0,06\%);

27. Cluster 11 e Cluster 12 (0,24\%);

28. Cluster 11 e Cluster 13 (0,33\%);

29. Cluster 12 e Cluster 13 (0,62\%)

30. Cluster 11 e Cluster 14 (1,35\%).

Na Tabela 13 estão classificados os 20 perfis da rede que possuem maior grau de entrada. Nota-se que o perfil oficial de Dilma Rousseff (@dilmabr) é o mais mencionado na rede - esse alto grau de entrada se justifica pelo fato de o Contexto 3 se estabelecer durante a votação do processo de impeachment de Dilma e, portanto, o perfil da mesma foi intensamente mencionado no Twitter. O Cluster 12 apresenta o maior número de nós nesta Tabela e o Cluster 15 não possui nenhum nó nessa classificação. Nota-se, também, a presença influente de perfis de veículos jornalísticos, sendo três deles brasileiros (@folha, @g1 e @jornaloglobo), além de um venezuelano (@telesurtv).

${ }^{156}$ O cálculo é realizado em consonância com o número de conexões estabelecidas entre todos os clusters da rede inteira, sendo que o total dessas conexões equivale a $100 \%$. 
Tabela 13 - Nós com maior grau de entrada nos cinco clusters principais Contexto 3

\begin{tabular}{cccccccc}
\hline & Nó & $\begin{array}{c}\text { Grau de } \\
\text { entrada }\end{array}$ & Cluster & & Nó & $\begin{array}{c}\text { Grau de } \\
\text { entrada }\end{array}$ & Cluster \\
\hline $\mathbf{1}$ & dilmabr & 1169 & Cluster 11 & $\mathbf{1 1}$ & blogdojefferson & 193 & Cluster 12 \\
$\mathbf{2}$ & folha & 745 & Cluster 13 & $\mathbf{1 2}$ & uol & 190 & Cluster 13 \\
$\mathbf{3}$ & g1 & 740 & Cluster 13 & $\mathbf{1 3}$ & ptbrasil & 187 & Cluster 11 \\
$\mathbf{4}$ & telesurtv & 403 & Cluster 14 & $\mathbf{1 4}$ & actualidadrt & 177 & Cluster 14 \\
$\mathbf{5}$ & jornaloglobo & 373 & Cluster 13 & $\mathbf{1 5}$ & jotainfo & 172 & Cluster 12 \\
$\mathbf{6}$ & uolnoticias & 364 & Cluster 13 & $\mathbf{1 6}$ & br45ilnocorrupt & 160 & Cluster 12 \\
$\mathbf{7}$ & lobaoeletrico & 359 & Cluster 12 & $\mathbf{1 7}$ & cartacapital & 160 & Cluster 11 \\
$\mathbf{8}$ & senadorcaiado & 257 & Cluster 12 & $\mathbf{1 8}$ & zerohora & 134 & Cluster 13 \\
$\mathbf{9}$ & blogdopim & 244 & Cluster 12 & $\mathbf{1 9}$ & revistaepoca & 121 & Cluster 13 \\
$\mathbf{1 0}$ & cnn & 219 & Cluster 12 & $\mathbf{2 0}$ & exame & 120 & Cluster 13 \\
\hline
\end{tabular}

Fonte: Elaborado pela autora.

Na figura 22 é possível visualizar o desenho da rede composta pelos cinco clusters acima apresentados. Os nós foram distribuídos por grau de entrada em conformidade com a classificação estabelecida na Tabela 13.

Figura 22 - Cinco clusters principais do Contexto 3 com nós distribuídos por grau de entrada

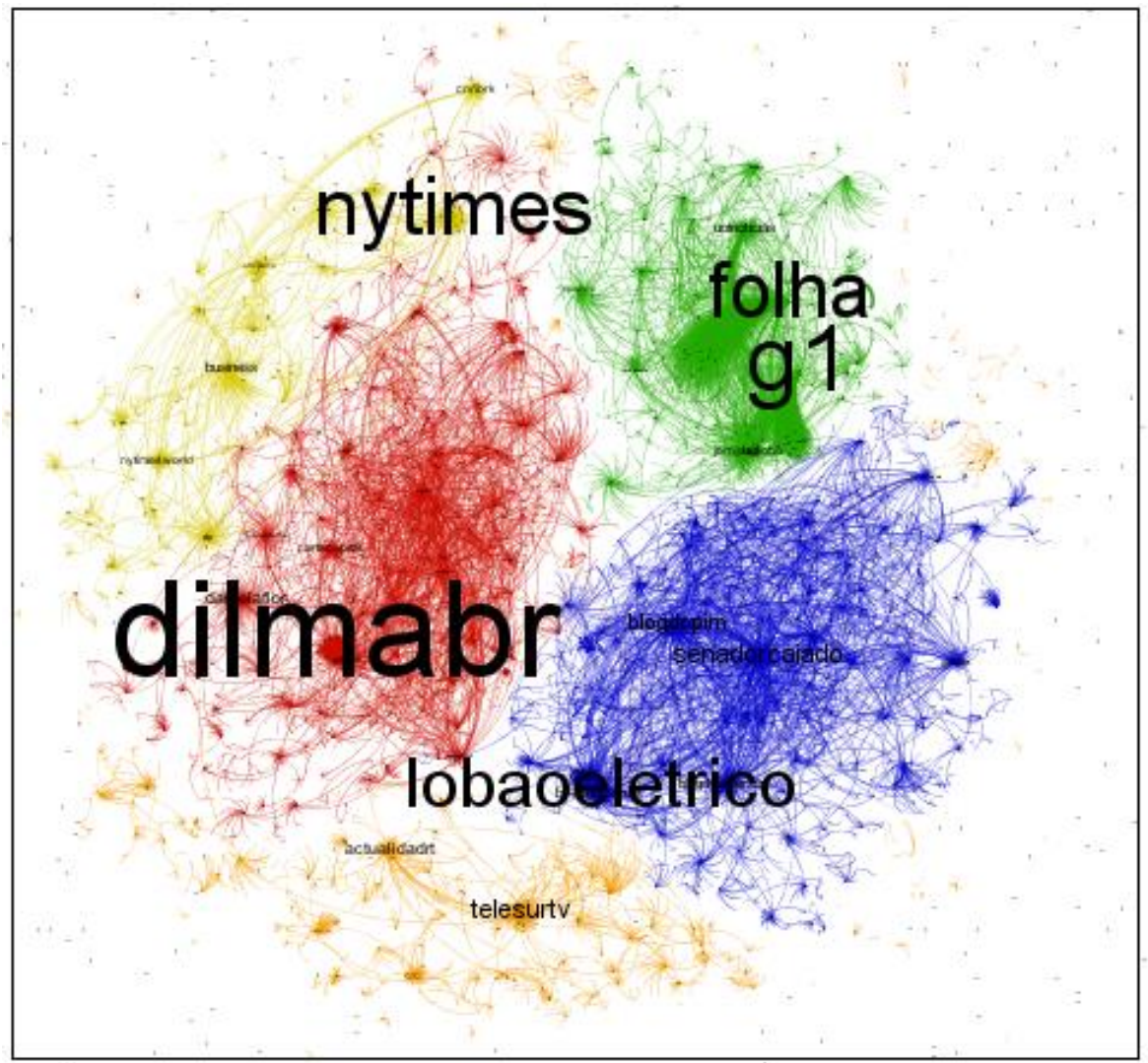

Fonte: Reprodução Gephi. 
Na Tabela 14 estão classificados os nós que possuem maior grau de saída no Contexto 3 , na qual podemos observar que metade dos nós são do Cluster 11 e que não há perfis pertencentes aos Clusters 13 e 14. Além disso, apenas três perfis não são de usuários comuns. São eles: @ cartasmarottas, perfil de militância destinado à divulgação de conteúdo favorável ao governo petista e à Lula; @fusca_brasil, que também é perfil de militância, mas focado na divulgação de conteúdo detrator em relação à Lula; e @press2releasewe, que se enquadra na classificação de blogs jornalísticos e não apresenta posicionamento explícito em relação ao expresidente.

Tabela 14 - Nós com maior grau de saída nos cinco clusters principais Contexto 3

\begin{tabular}{cccccccc}
\hline & Nó & $\begin{array}{c}\text { Grau de } \\
\text { saída }\end{array}$ & Cluster & & Nó & $\begin{array}{c}\text { Grau de } \\
\text { saída }\end{array}$ & Cluster \\
\hline $\mathbf{1}$ & usuário42 & 33 & Cluster 12 & $\mathbf{1 1}$ & usuário51 & 17 & Cluster 11 \\
$\mathbf{2}$ & usuário43 & 24 & Cluster 11 & $\mathbf{1 2}$ & usuário52 & 17 & Cluster 12 \\
$\mathbf{3}$ & usuário44 & 24 & Cluster 11 & $\mathbf{1 3}$ & usuário53 & 17 & Cluster 12 \\
$\mathbf{4}$ & usuário45 & 24 & Cluster 11 & $\mathbf{1 4}$ & usuário54 & 17 & Cluster 12 \\
$\mathbf{5}$ & usuário46 & 21 & Cluster 11 & $\mathbf{1 5}$ & usuário55 & 17 & Cluster 11 \\
$\mathbf{6}$ & usuário47 & 20 & Cluster 11 & $\mathbf{1 6}$ & usuário56 & 16 & Cluster 12 \\
$\mathbf{7}$ & cartasmarottas & 20 & Cluster 11 & $\mathbf{1 7}$ & usuário57 & 16 & Cluster 15 \\
$\mathbf{8}$ & usuário48 & 19 & Cluster 12 & $\mathbf{1 8}$ & fusca_brasil & 16 & Cluster 12 \\
$\mathbf{9}$ & usuário49 & 19 & Cluster 11 & $\mathbf{1 9}$ & usuário58 & 16 & Cluster 11 \\
$\mathbf{1 0}$ & usuário50 & 18 & Cluster 11 & $\mathbf{2 0}$ & press2releasewe & 15 & Cluster 14 \\
\hline
\end{tabular}

Fonte: Elaborado pela autora.

Analisamos, no tópico a seguir, cada um dos cinco clusters com o objetivo de estabelecer inferências acerca da circulação de informações estabelecida no Twitter durante o Contexto 3, intitulado "Votação na Câmara dos Deputados", que corresponde aos dados coletados em 17 e 18 de abril de 2016.

\subsubsection{Visualização e análise dos clusters}

Cluster 11: O maior cluster do grafo, considerando o número de conexões existentes entre os nós que o compõe, é formado por perfis com posicionamento favorável à Lula e se assemelha ao Cluster 1 (Contexto 1) e ao Cluster 7 (Contexto 2), analisados anteriormente. Essa semelhança é maior com o Cluster 1 pelo fato de o Cluster 11 (Figura 23) possuir, ao mesmo tempo, perfis de lideranças petistas (@dilmabr; @ptbrasil) e outros referentes a veículos jornalísticos reconhecidos por serem favoráveis ao ex-presidente, como os portais de notícias 
online Brasil 247 (@ brasil247) e Pragmatismo Político (@Pragmatismo_) criado pelo jornalista Luis Soares em 2009, bem como a revista Carta Capital (@ cartacapital). Os três perfis citados são reconhecidos por fazerem um jornalismo opositor aos conglomerados jornalísticos brasileiros.

As diferenças apresentadas pelo Cluster 11 em relação aos Clusters 1 e 7 referem-se à presença de dois perfis de veículos jornalísticos que pertencem à EBC (empresa de comunicação pública do Brasil) (@ebcnarede; @agenciabrasil); a presença de dois perfis de militância que se destinam a divulgar conteúdos favoráveis à Lula: o "Esquerda Valente" (@erquerdavalente) e o “Muda mais”(@mudamais), sendo que o segundo ganhou notoriedade em 2014 nas mídias sociais por contribuir com postagens a favor do PT na campanha eleitoral daquele ano.

O Cluster 11 é constituído por 10 perfis dentre os 20 que mais realizam conexões na rede. A partir desse dado pode-se inferir que houve intensa tentativa de disseminação das narrativas favoráveis a Lula na conversação estabelecida no Contexto 3. Mas ressalta-se que, por conta do baixo grau de conectividade entre os clusters, essa narrativa se manteve dentro dos limites do Cluster 11.

\section{Figura 23 - Cluster 11 - nós distribuídos por grau de entrada}

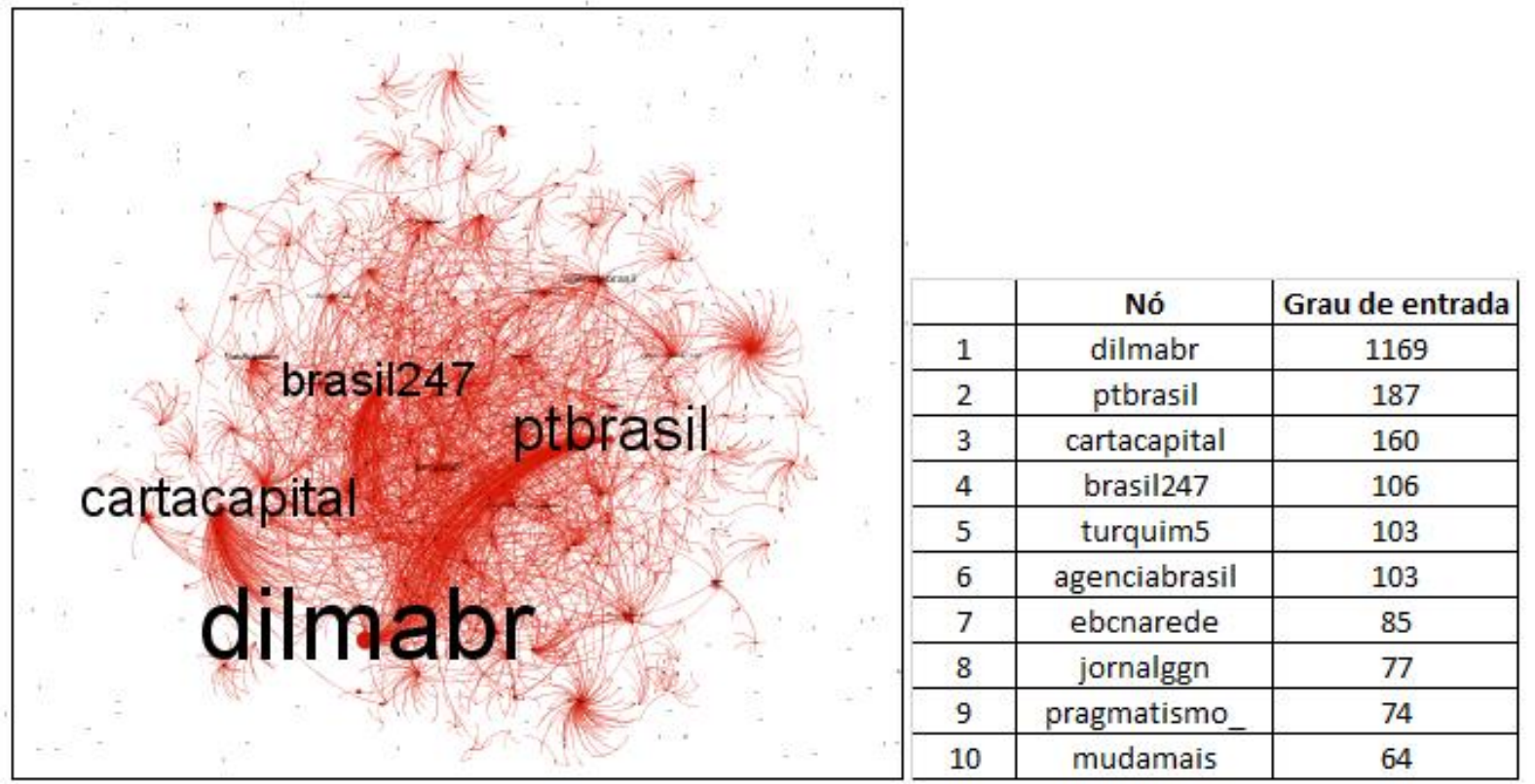

Fonte: Elaborado pela autora.

Cluster 12: Dentre os 10 perfis com maior grau de entrada nesse grupo, três são de formadores de opinião: Lobão Elétrico (@lobaoeletrico), Andréia Sadi (@andreiasadi) e o Pastor Silas 
Malafaia (@pastormalafaia); esse último reconhecido pelos discursos ultraconservadores e por apoiar eleições do PSDB, inclusive a de Aécio Neves em 2014.

Nesse grupo há também um perfil de blog jornalístico, o Blog do Pim (@blogdopim) e dois perfis de lideranças: Roberto Jefferson (@blogdojefferson) e Ronaldo Caiado (@ senadorcaiado), que fazem oposição à Lula. O grupo é constituído, ainda, por dois perfis de veículos jornalísticos: Cable News Network (@cnn) e Jota Info (@ jotainfo), e por um perfil de militância intitulado "Brasil No Corrupt" (@br45nocorrupt), que divulga conteúdo contrário ao PT e favorável ao PSDB - nota-se a utilização do número 45 no nome do perfil que faz referência ao código eleitoral do PSDB em eleições. (Figura 24).

O Cluster 12 se sobressai com o maior número de nós com grau de entrada na rede, ou seja, há considerável influência das narrativas desse grupo nas conversações ocorridas no Contexto 3. Entendemos que apesar de o grau de conectividade entre o Cluster 11 e o Cluster 12 ser dos maiores na rede estabelecida no Contexto 3, essa vinculação é muito baixa se comparada a conexões estabelecidas nos demais contextos. Foram encontradas apenas 184 arestas que conectam esses dois clusters, o que demonstra a continuidade da alta polarização das narrativas em circulação.

\section{Figura 24 - Cluster 12 - nós distribuídos por grau de entrada}

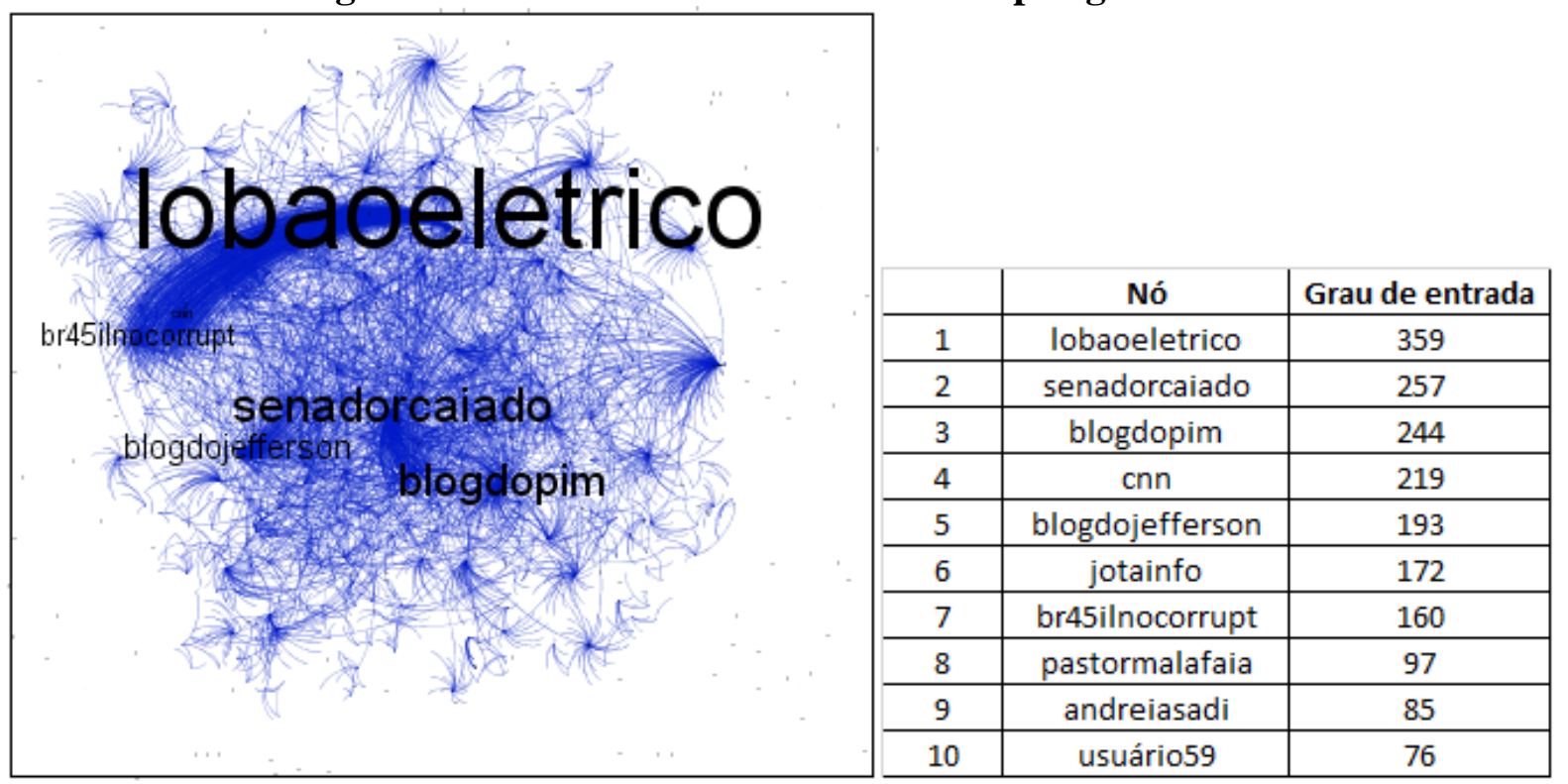

Fonte: Elaborado pela autora.

Cluster 13: O Cluster 13 (Figura 25) é composto predominantemente por perfis de veículos jornalísticos e, por isso, se assemelha ao Cluster 10 (Contexto 2). Ressalta-se que a conexão estabelecida entre os Clusters 13 e 12 é a segunda maior na rede estabelecida no Contexto 3, o 
que demonstra proximidade no conteúdo das narrativas entre esses grupos. Em face da conectividade entre os nós dos dois grupos, inferimos que no Cluster 13 circulam narrativas de desconstrução da imagem pública de Lula.

\section{Figura 25 - Cluster 13 - nós distribuídos por grau de entrada}

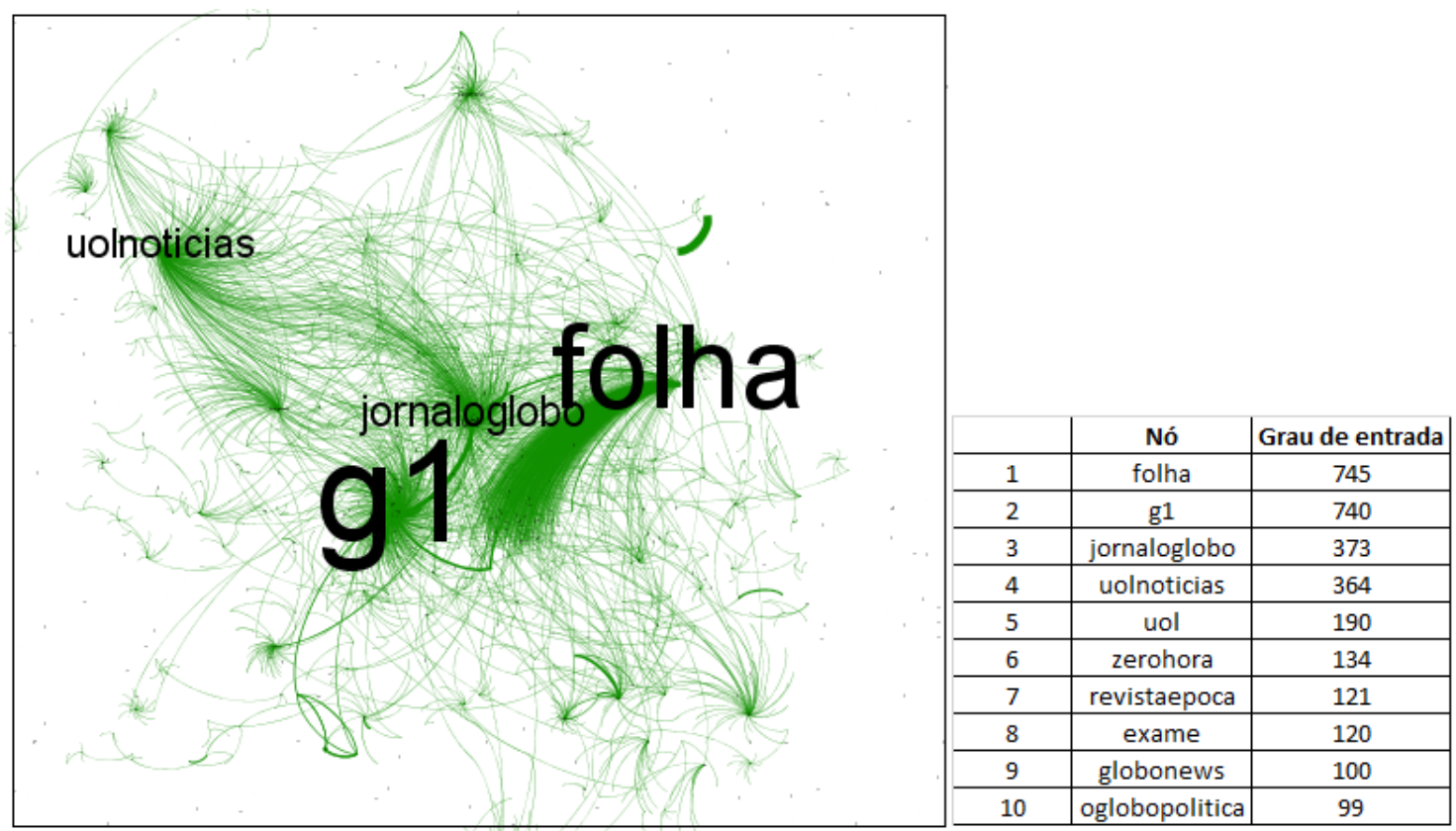

Fonte: Elaborado pela autora.

Cluster 14: Os nós mais influentes que compõem o Cluster 14 (Figura 26) são, majoritariamente, de veículos jornalísticos latino-americanos, como o canal de televisão venezuelano TeleSUR ( @ telesurtv), o quarto nó mais influente na rede do Contexto 3; o "RT en español" (@actualidadrt); o perfil em língua espanhola da Agence France-Presse, que tem sede no Uruguai (@afpespanol); e o canal online de notícias da Argentina "Notienred" (@notienred).

Necessário realçar que o maior grau de conectividade estabelecido entre clusters do Contexto 3 ocorre entre os Clusters 14 e 11, o que nos permite inferir que o Cluster 14 possui potencial de circulação de narrativas de construção da imagem pública de Lula. 
Figura 26 - Cluster 14 - nós distribuídos por grau de entrada

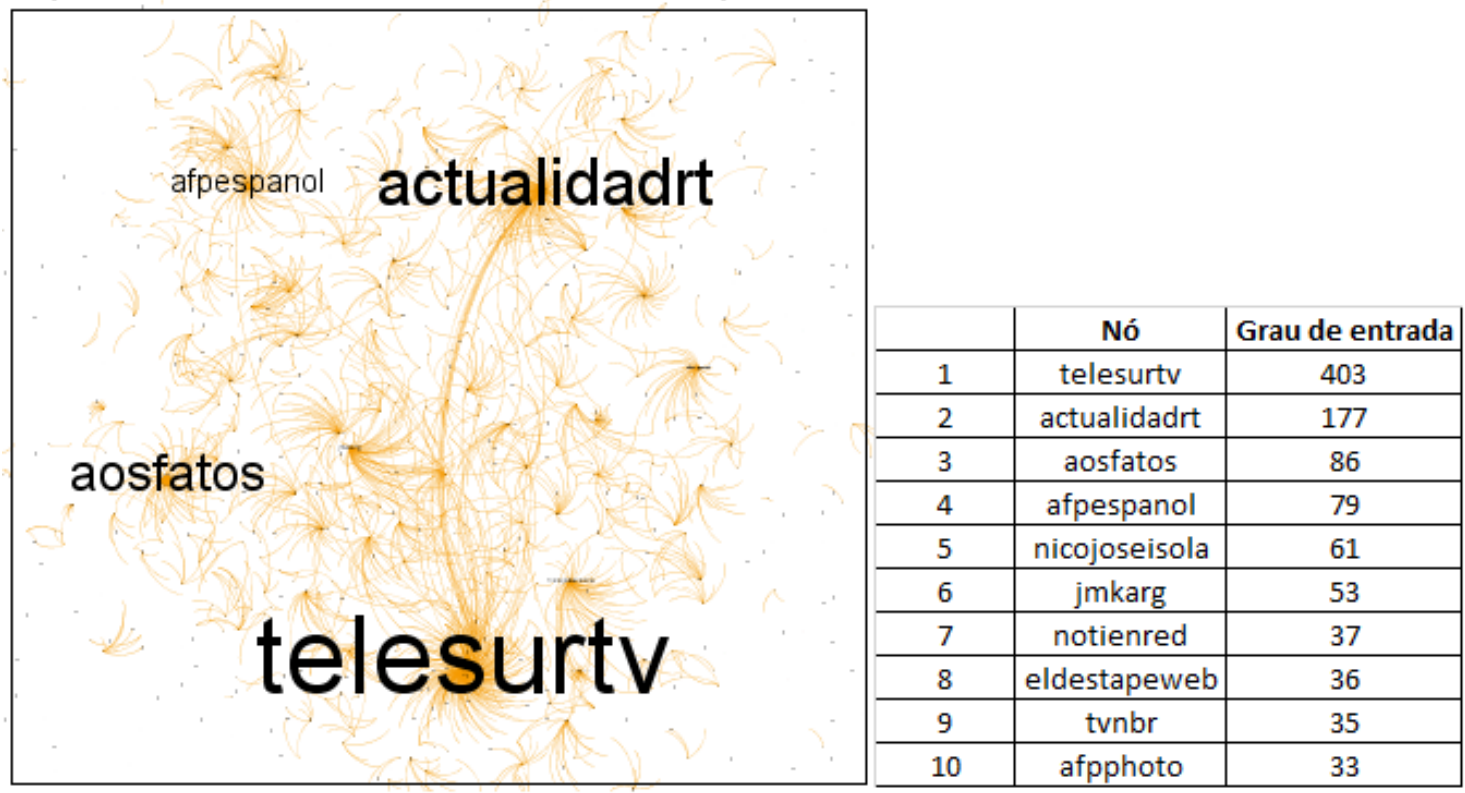

Fonte: Elaborado pela autora.

Cluster 15: Como pode ser observado na Figura 27, esse grupo é composto pelos principais veículos jornalísticos internacionais, como o jornal The New York Times (@ nytimes), a agência de notícias Bloomberg (@business) e os canais de televisão CNN (@cnnbrk) e BBC (@bbcworld). O Cluster 15 estabelece pouco grau de conexão com os outros quatro principais da rede inteira, sendo o seu maior grau de conectividade estabelecido com o Cluster 12 - o que sugere potencial de difusão de narrativas desfavoráveis à Lula.

Figura 27 - Cluster 15 - nós distribuídos por grau de entrada

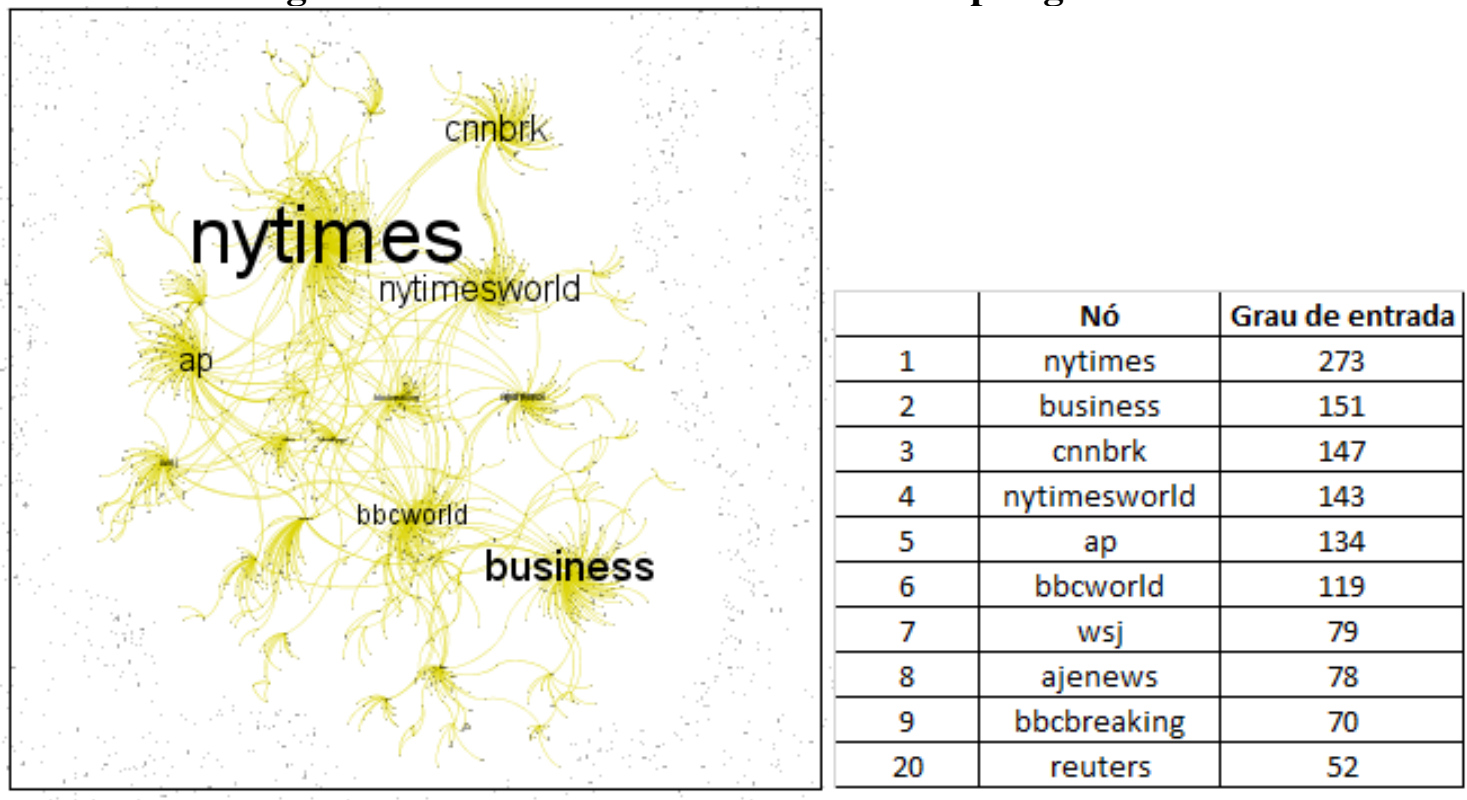

Fonte: Elaborada pela autora. 
Consideramos que há forte polarização das narrativas no Contexto 3 que se concentram no Cluster 11, nas quais circulam relatos favoráveis à imagem de Lula, e no Cluster 12, que contém descrições contrárias à imagem do ex-presidente. Apesar de os outros três clusters principais da rede inteira serem compostos por perfis que se enquadram na classificação de veículos jornalísticos, há maior aproximação do Cluster 11 ao 14 e do Cluster 12 ao 13 e ao 15, o que reforça a ideia da polarização de narrativas.

\subsection{Contexto 4: Votação no Senado}

$\mathrm{Na}$ rede de interações estabelecida no Twitter durante o Contexto 4 (12 e 13 de maio de 2016) foram identificados 48.543 nós e 83.978 arestas. O grafo está apresentado na figura 28 com os rótulos dos nós distribuídos por grau de entrada.

Figura 28 - Rede inteira do Contexto 4

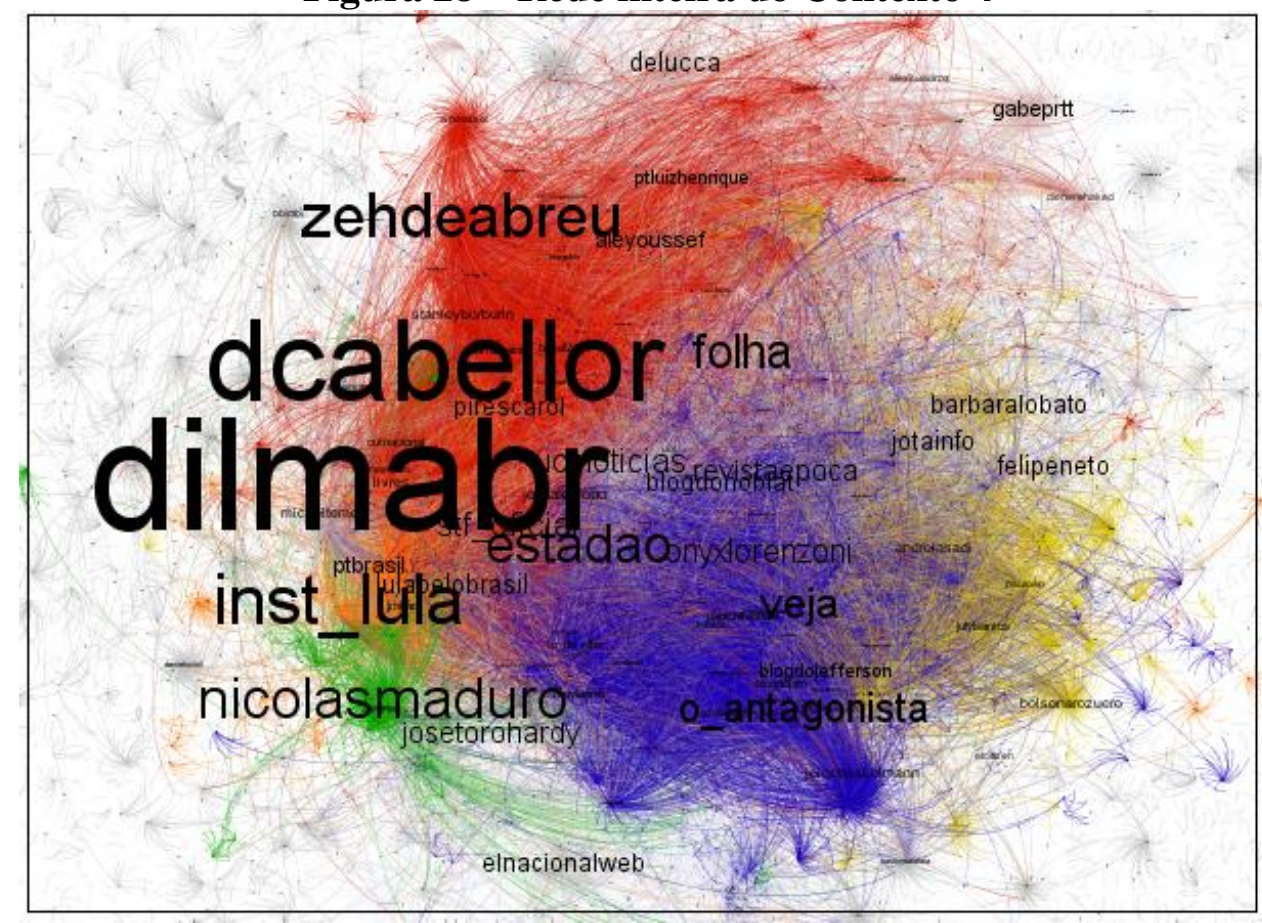

Fonte: Reprodução Gephi.

A partir da análise de métrica de modularidade realizada pelo software Gephi, encontramos um total de 2.602 clusters na rede inteira e grau de modularidade de 0,716 (Figura 29). 


\section{Figura 29 - Gráfico de modularidade da rede inteira do Contexto 4}

Results:

Modularity: 0,716

Modularity with resolution: 0,716

Number of Communities: 2602

\section{Size Distribution}

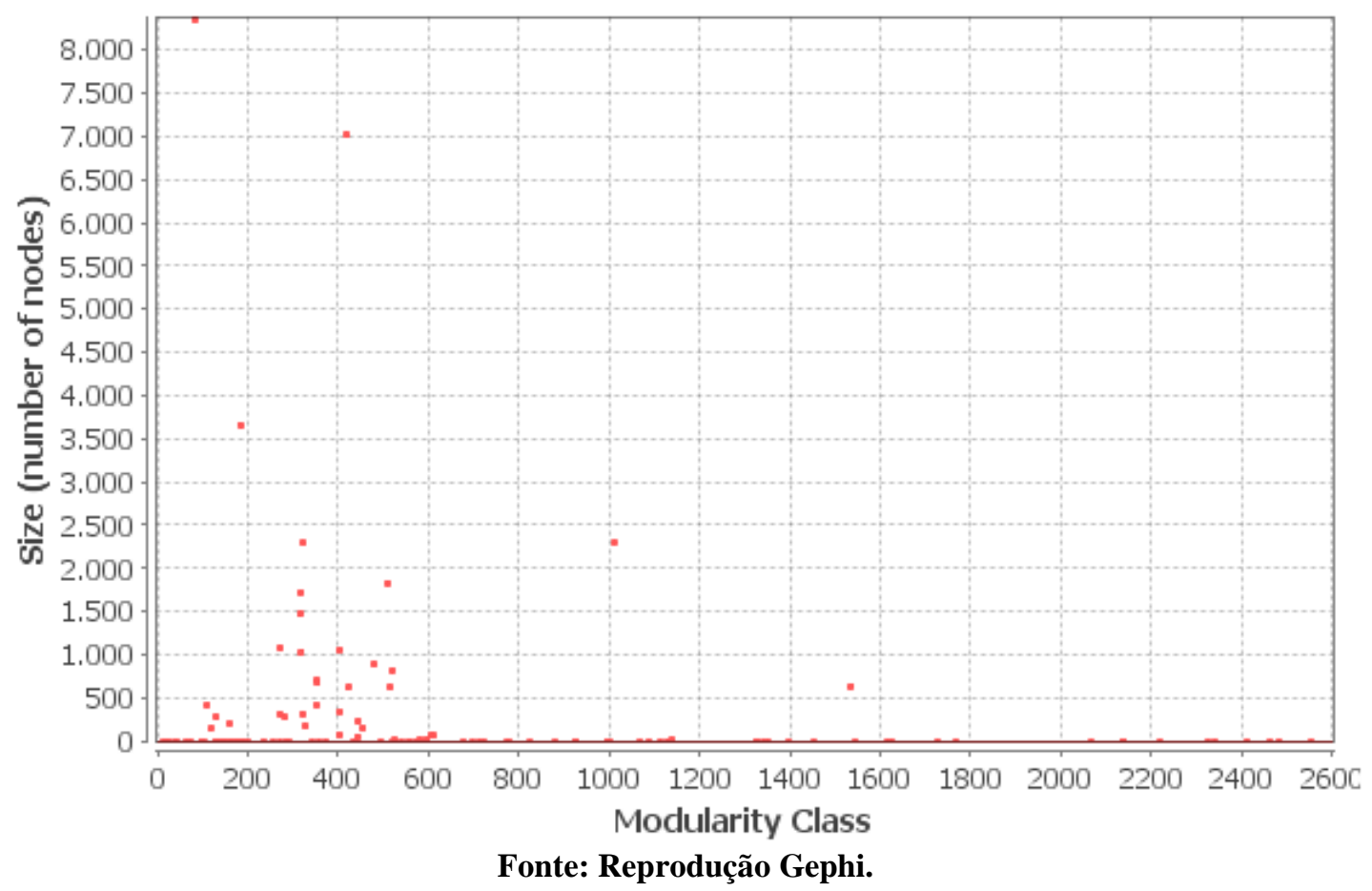

Do total de comunidades encontradas foram detectados cinco clusters mais importantes, ou seja, os cinco grupos que apresentam número superior de conexões entre os nós que os compõem (esse cinco clusters formam 49,61\% do total de conexões da rede inteira). Na Tabela 15 enumeramos esses grupos de acordo com a quantidade de componentes conectados, a porcentagem de ligações em relação à rede inteira ${ }^{157}$ e a cor de representação no grafo. Importante observar que há elevada concentração do número de conexões nos dois primeiros clusters (Cluster 16 e Cluster 17) e juntos eles somam 37,59\% do total de vinculações estabelecidas na rede inteira.

157 Essa porcentagem é calculada a partir da quantidade de conexões estabelecidas na rede inteira. O software calcula, portanto, qual o total de nós e o de arestas da rede inteira e gera um valor de quantas conexões foram realizadas em cada cluster. 
Tabela 15 - Cinco principais clusters da rede inteira - Contexto 4

\begin{tabular}{cccc}
\hline Cluster & $\begin{array}{c}\text { Componentes } \\
\text { conectados }\end{array}$ & \% de conexões & Cor de representação no grafo \\
\hline Cluster 16 & 8374 & $22,65 \%$ & Azul \\
Cluster 17 & 7036 & $14,94 \%$ & Vermelho \\
Cluster 18 & 2324 & $5,46 \%$ & Laranja \\
Cluster 19 & 2315 & $3,43 \%$ & Amarelo \\
Cluster 20 & 1861 & $3,14 \%$ & Verde \\
\hline
\end{tabular}

Fonte: Elaborada pela autora.

Em cálculo realizado pelo software Gephi em relação ao grau de conectividade ${ }^{158}$ dos clusters, descobriu-se que do número total de conexões estabelecidas na rede, $6,48 \%$ delas são estabelecidas entre os cinco clusters principais. A seguir enumeramos, em ordem do menor para o maior grau de conexões, as relações entre os cinco clusters apresentados na Tabela 15.

31. Cluster 19 e Cluster $20(0,01 \%)$;

32. Cluster 16 e Cluster 20 (0,07\%);

33. Cluster 16 e Cluster $18(0,13 \%)$;

34. Cluster 17 e Cluster 19 (0,18\%);

35. Cluster 18 e Cluster 19 (0,19\%).

36. Cluster 16 e Cluster 17 (0,27\%);

37. Cluster 18 e Cluster 20 (1,07\%);

38. Cluster 17 e Cluster 20 (1,28\%);

39. Cluster 16 Cluster 19 (1,52\%);

40. Cluster 17 e Cluster $18(1,76 \%)$.

Na Tabela 16 estão classificados os 20 perfis da rede que possuem maior grau de entrada. Nota-se, pelos dados apresentados, que o Contexto 4 se diferencia dos demais contextos analisados no que se refere aos nós com maior grau de entrada. Nos três primeiros contextos os nós que recebiam maior número de conexões eram de perfis de veículos jornalísticos. Já no Contexto 4 os perfis com maior número de menções são de lideranças - sendo dois deles ligados ao governo petista: o perfil oficial de Dilma Rousseff (@dilmabr) e o do Instituto Lula (@int_lula); outros dois pertencem a figuras políticas venezuelanas: o perfil de Diosdado Cabello (@ dcabellor), então presidente da Assembleia Nacional da Venezuela e vice-presidente

\footnotetext{
${ }^{158} \mathrm{O}$ cálculo é realizado com base na relação do número de conexões estabelecidas entre todos os clusters da rede inteira, sendo que o total de tais conexões equivale a $100 \%$.
} 
do Partido Socialista Unido da Venezuela (PSUV) (fundado por Hugo Chávez); o perfil de Nicolás Maduro (@nicolasmaduro) e um perfil pertencente a um usuário comum (o @ usuario60, que não apresenta posicionamento explícito em relação à Lula).

Tabela 16 - Nós com maior grau de entrada nos cinco clusters principais do Contexto 4

\begin{tabular}{cccccccc}
\hline & Nó & $\begin{array}{c}\text { Grau de } \\
\text { entrada }\end{array}$ & Cluster & & Nó & $\begin{array}{c}\text { Grau de } \\
\text { entrada }\end{array}$ & Cluster \\
\hline $\mathbf{1}$ & dilmabr & 1170 & Cluster 18 & $\mathbf{1 1}$ & cartamaior & 521 & Cluster 17 \\
$\mathbf{2}$ & dcabellor & 987 & Cluster 20 & $\mathbf{1 2}$ & veja & 502 & Cluster 16 \\
$\mathbf{3}$ & usuário60 & 747 & Cluster 17 & $\mathbf{1 3}$ & o_antagonista & 483 & Cluster 16 \\
$\mathbf{4}$ & inst_lula & 724 & Cluster 18 & $\mathbf{1 4}$ & onyxlorenzoni & 432 & Cluster 16 \\
$\mathbf{5}$ & nicolasmaduro & 670 & Cluster 20 & $\mathbf{1 5}$ & revistaepoca & 411 & Cluster 16 \\
$\mathbf{6}$ & youtube & 658 & Cluster 16 & $\mathbf{1 6}$ & lulapelobrasil & 389 & Cluster 18 \\
$\mathbf{7}$ & pirescarol & 621 & Cluster 17 & $\mathbf{1 7}$ & barbaralobato & 380 & Cluster 19 \\
$\mathbf{8}$ & zehdeabreu & 610 & Cluster 17 & $\mathbf{1 8}$ & ptbrasil & 362 & Cluster 18 \\
$\mathbf{9}$ & stf_oficial & 560 & Cluster 17 & $\mathbf{1 9}$ & blogdojefferson & 331 & Cluster 16 \\
$\mathbf{1 0}$ & usuário61 & 523 & Cluster 17 & $\mathbf{2 0}$ & usuário62 & 319 & Cluster 17 \\
\hline
\end{tabular}

Fonte: Elaborada pela autora.

Na figura 30 é possível visualizar o desenho da rede composta pelos cinco clusters do Contexto 4. Pontuamos que os rótulos dos nós foram distribuídos por grau de entrada, de acordo com a classificação estabelecida na Tabela 16.

\section{Figura 30 - Cinco clusters principais do Contexto 4 com nós distribuídos por grau de entrada}

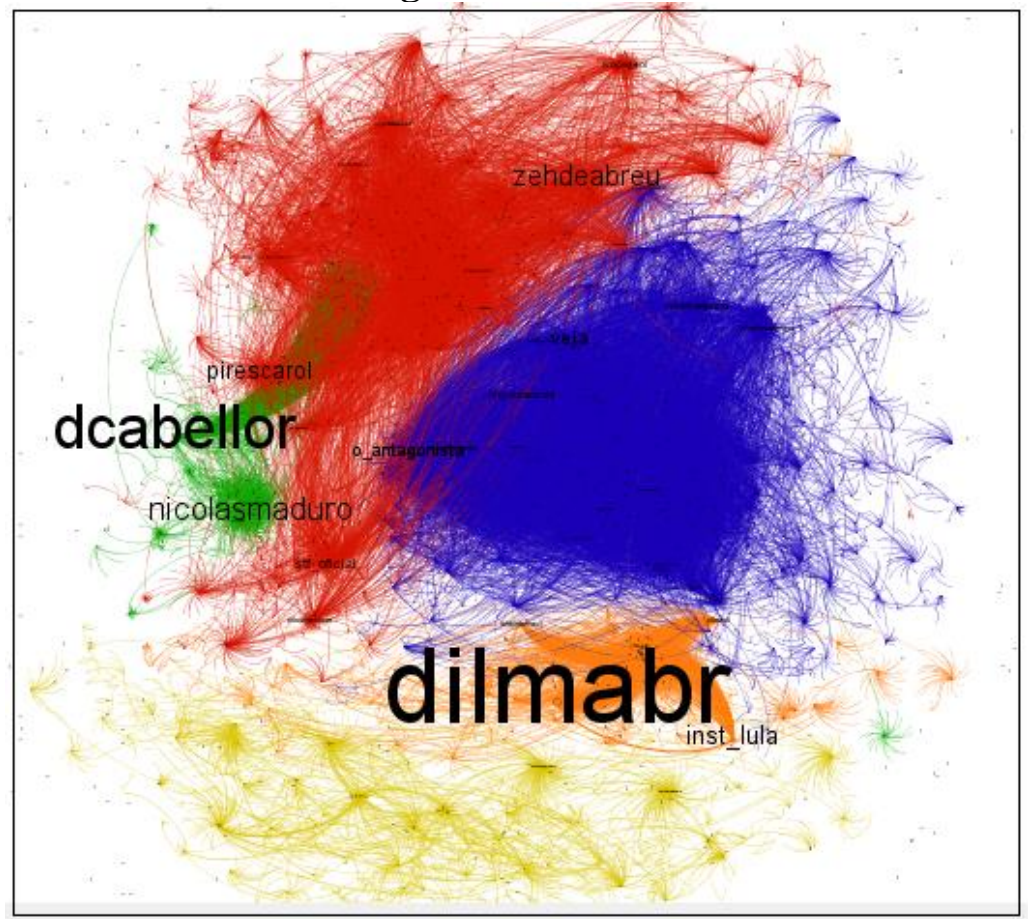

Fonte: Reprodução Gephi. 
Na Tabela 17 classificamos os nós que apresentam maior número de conexões realizadas com outros usuários - aqueles que possuem maior grau de saída. Nota-se que dos 20 nós classificados nessa Tabela fazem parte do Cluster 16. Por outro lado, os Clusters 17, 18 e 19 apresentam, cada um, apenas um nó nessa classificação. Não há nós pertencentes ao Cluster 20.

Tabela 17 - Nós com maior grau de saída nos cinco clusters principais do Contexto 4

\begin{tabular}{cccccccc}
\hline & Nó & $\begin{array}{c}\text { Grau de } \\
\text { Saída }\end{array}$ & Cluster & & Nó & $\begin{array}{c}\text { Grau de } \\
\text { saída }\end{array}$ & Cluster \\
\hline $\mathbf{1}$ & usuário63 & 93 & Cluster 16 & $\mathbf{1 1}$ & ganchodedireita & 49 & Cluster 19 \\
$\mathbf{2}$ & usuário64 & 92 & Cluster 16 & $\mathbf{1 2}$ & usuário73 & 49 & Cluster 16 \\
$\mathbf{3}$ & usuário65 & 76 & Cluster 16 & $\mathbf{1 3}$ & usuário74 & 47 & Cluster 17 \\
$\mathbf{4}$ & usuário66 & 72 & Cluster 16 & $\mathbf{1 4}$ & marchemosbrasil & 45 & Cluster 18 \\
$\mathbf{5}$ & usuário67 & 70 & Cluster 16 & $\mathbf{1 5}$ & troca_de_canal & 45 & Cluster 16 \\
$\mathbf{6}$ & usuário68 & 70 & Cluster 16 & $\mathbf{1 6}$ & usuário75 & 44 & Cluster 16 \\
$\mathbf{7}$ & usuário69 & 60 & Cluster 16 & $\mathbf{1 7}$ & usuário76 & 44 & Cluster 16 \\
$\mathbf{8}$ & usuário70 & 55 & Cluster 16 & $\mathbf{1 8}$ & usuário77 & 43 & Cluster 16 \\
$\mathbf{9}$ & usuário71 & 52 & Cluster 16 & $\mathbf{1 9}$ & usuário78 & 43 & Cluster 16 \\
$\mathbf{1 0}$ & usuário72 & 50 & Cluster 16 & $\mathbf{2 0}$ & usuário79 & 42 & Cluster 16 \\
\hline
\end{tabular}

Fonte: Elaborada pela autora.

A partir desses dados apresentados sobre a toda a rede e da delimitação dos cinco clusters principais, analisamos, no tópico a seguir, cada cluster separadamente com o objetivo de estabelecer inferências acerca da conversação ocorrida na rede de interações do Contexto 4 referente aos dados coletados em 12 e 13 de maio de 2016 e intitulado "Votação no Senado".

\subsubsection{Visualização e análise dos clusters}

Cluster 16: Como pode ser observado na Figura 31, o Cluster 16 se assemelha aos Clusters 2, 6 e 12 apresentados nos contextos anteriores por apresentar, na sua classificação dos 10 nós mais influentes, formadores de opinião, veículos jornalísticos, $\underline{\text { blogs jornalísticos e lideranças }}$ reconhecidos por suas narrativas contrárias à Lula.

Percebe-se que diferença estrutural do Cluster 16 para os demais acima citados se dá pela presença do perfil do YouTube (@youtube) como o nó mais mencionado no grupo. O YouTube, site de compartilhamento de vídeos mais acessado no mundo, foi mencionado com extrema frequência devido a um vídeo postado por Joice Hasselmann (@joicehasselmann), jornalista e ativista política crítica ao governo petista e à Lula, intitulado "PETEZADA CHORA. TEORI ACERTA NA MOSCA. LULA CHAMA MILITÂNCIA”. (HASSELMANN, 2016). 
No vídeo em questão, que foi amplamente compartilhado no Contexto 4, Hasselmann (2016) aparece discursando sobre a votação no Senado sobre o processo de impeachment de Dilma Rousseff. Em sua fala no vídeo a jornalista afirma que “o PT está acabando, Dilma vai ser demitida, Lula vai afundar com ela e o PT vai junto [...] os três [serão] enterrados politicamente, que é o que o Brasil precisa.”. (HASSELMANN, 2016). Por essa narrativa inferimos que o perfil do YouTube no cluster 16 foi citado de forma a desconstruir a imagem pública de Lula.

Os nós que compõem o Cluster 16 estabelecem $22,65 \%$ do total de conexões da rede no Contexto 4. Relevante mencionar que dos 20 perfis com maior grau de saída nesse contexto, 17 fazem parte do Cluster 16. Essas duas observações demonstram a grande influência do Cluster 16 na circulação de narrativas estabelecidas no contexto em que ocorreu a votação do processo de impeachment no Senado Federal.

Figura 31 - Cluster 16 - nós distribuídos por grau de entrada

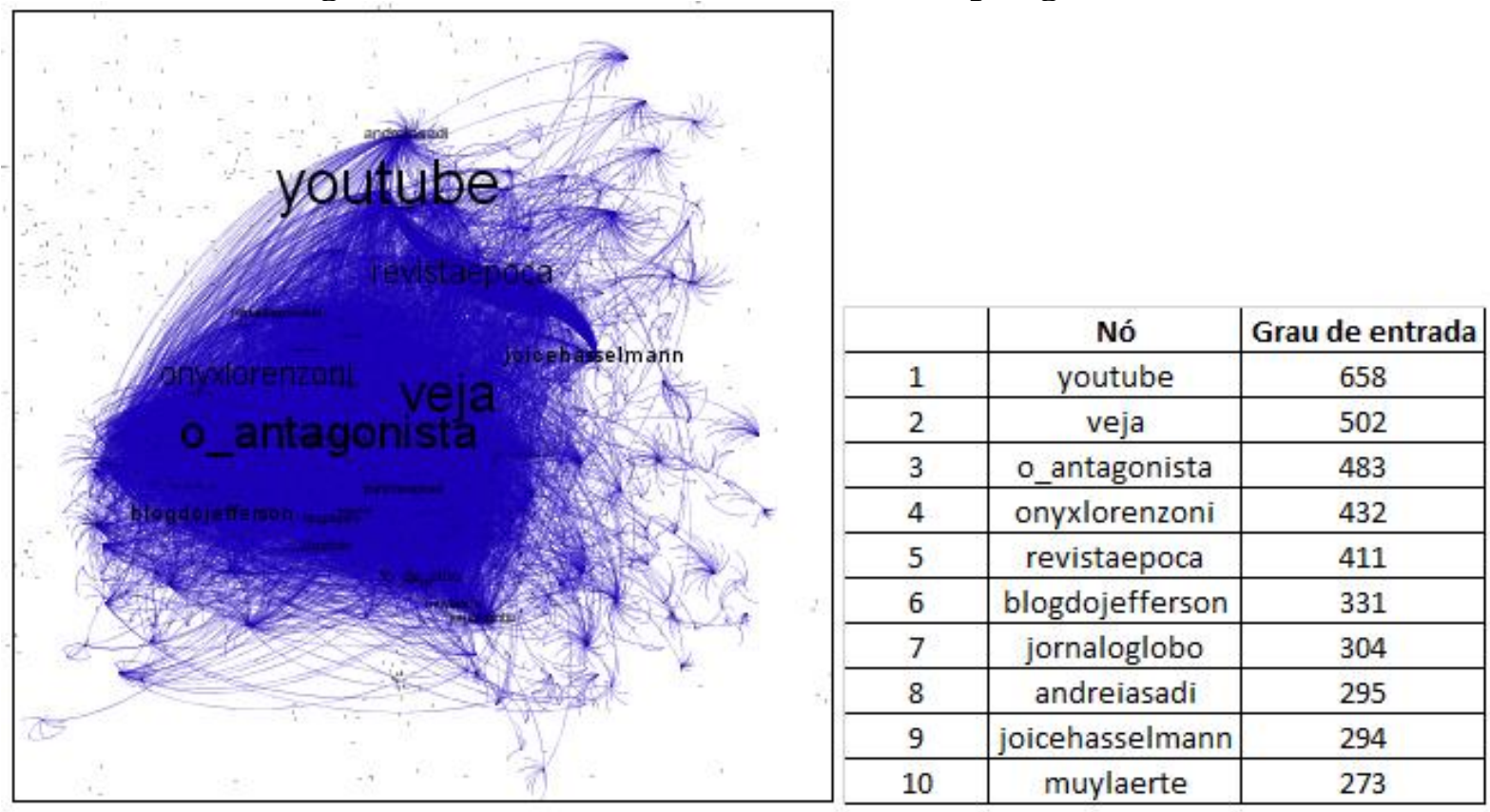

Fonte: Elaborada pela autora.

Cluster 17: Esse grupo (Figura 32) se assemelha estruturalmente aos Clusters 1, 7 e 11, analisados nos contextos anteriores por ser constituído por perfis favoráveis à Lula. No entanto, há alguns pontos específicos sobre o Cluster 17 que merecem destaque:

1) o primeiro ponto relaciona-se à presença de três perfis de usuários comuns dentre os 10 nós com maior grau de entrada, sendo que um deles (@usuário60) é o que recebe mais menções no 
cluster, sendo também o terceiro com maior grau de entrada na rede inteira do Contexto $4^{159}$. Esse dado nos permite inferir que há significativa influência de usuários comuns na circulação de informações favoráveis à imagem de Lula, fato que não ocorreu nos contextos anteriores; 2) o segundo ponto se manifesta pela influência de três perfis: o oficial da CUT (Central Única dos Trabalhadores), que se enquadra na classificação de perfis de lideranças, e, como visto no capítulo 3, foi uma das principais organizadoras das manifestações contra o golpe a partir de 2015; o perfil de José de Abreu (@zehdeabreu), ator da Rede Globo reconhecido por sua forte militância favorável ao PT nas mídias sociais, o qual classificamos como formador de opinião; e o perfil de veículo jornalístico intitulado Jornalistas Livres (@j_livres), rede de coletivos que se destina a contrapor as narrativas dos conglomerados jornalísticos brasileiros;

3) o terceiro ponto se refere à presença do perfil oficial do Supremo Tribunal Federal (@stf), que classificamos como sendo de liderança.

\section{Figura 32 - Cluster 17 - nós distribuídos por grau de entrada}

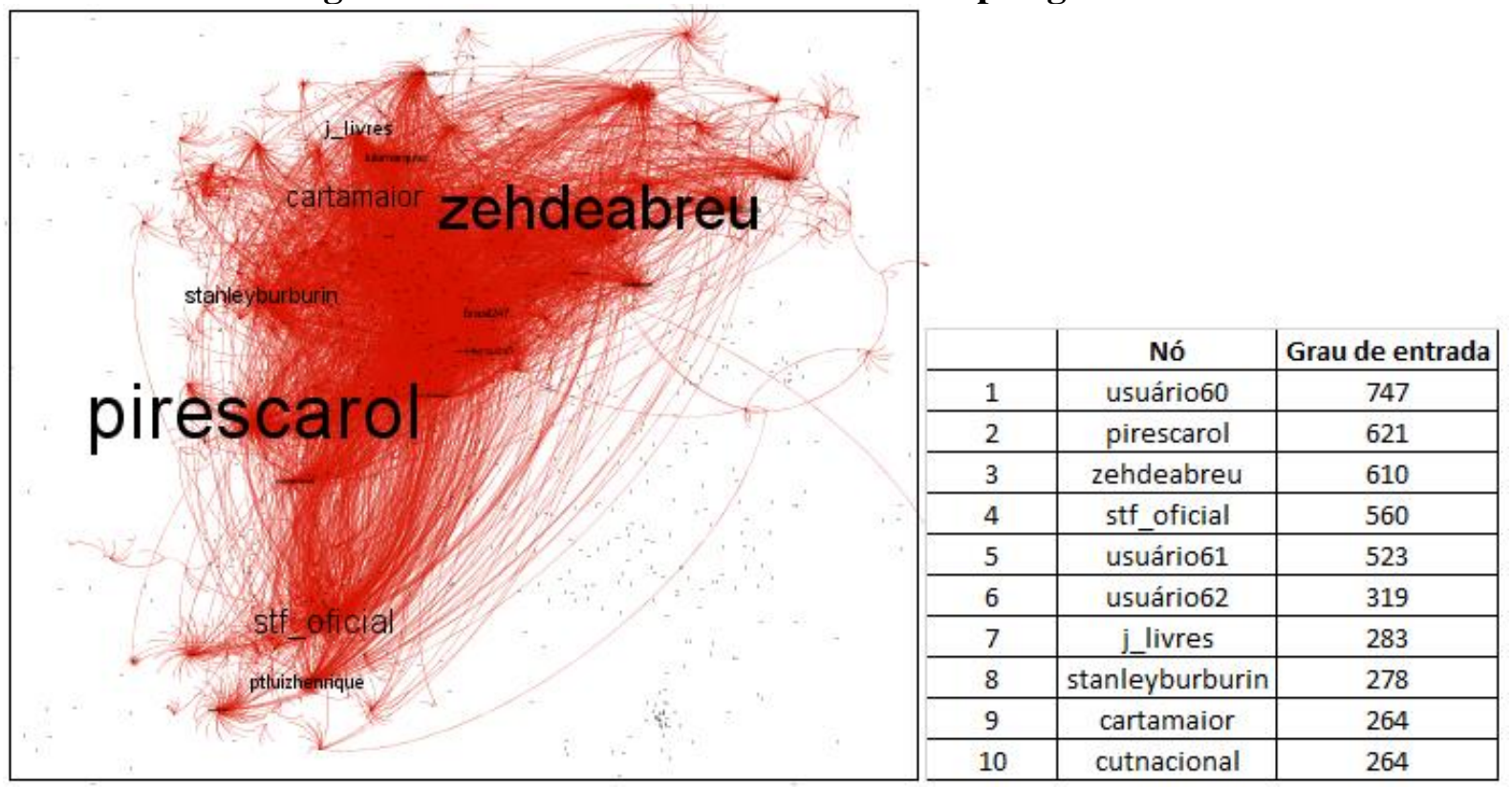

Fonte: Elaborada pela autora.

Cluster 18: Os nós com maior número de menções que compõem o Cluster 18 (Figura 33) são perfis de lideranças ligadas ao governo petista, como o de Dilma (@dilmabr), o do Instituto Lula (@inst_lula),o oficial do próprio Lula (@lulapelobrasil), o oficial do PT (@ptbrasil)e o perfil O Brasil da Mudança (@ brasildamudança), vinculado ao site do Instituto Lula, e se volta a publicar conteúdos favoráveis às políticas públicas instituídas pelos governos do ex-

\footnotetext{
${ }^{159}$ Por questões éticas optamos por ocultar os nomes dos perfis de usuários comuns.
} 
presidente. Por ser composto por esses perfis, esse grupo se torna semelhante aos Clusters 1,8 e 11 dos contextos anteriores.

A diferença do Cluster 18 para os demais supracitados encontra-se na influência de outros perfis de liderança que também têm ligação direta com o PT, como o de Gleisi Hoffmann, senadora do estado do Paraná eleita pelo PT (@ gleisi); o de Jorge Viana, senador do estado do Acre igualmente eleito pelo PT (@jorgevianaacre); e o perfil do então presidente nacional do PT, Rui Falcão (@rfalcao13) ${ }^{160}$. Outro ponto interessante a ser ressaltado sobre o Cluster 18 refere-se à influência do perfil @cubaminrex, que pertence ao Ministério das Relações Exteriores de Cuba e que também se enquadra na classificação de perfis de liderança.

Ressalta-se que o maior grau de conectividade estabelecido dentre os cinco clusters da rede do Contexto 4 ocorre entre os Clusters 18 e 17, o que nos permite inferir que há circulação de narrativas favoráveis à Lula entre esses grupos.

Figura 33 - Cluster 18 - nós distribuídos por grau de entrada

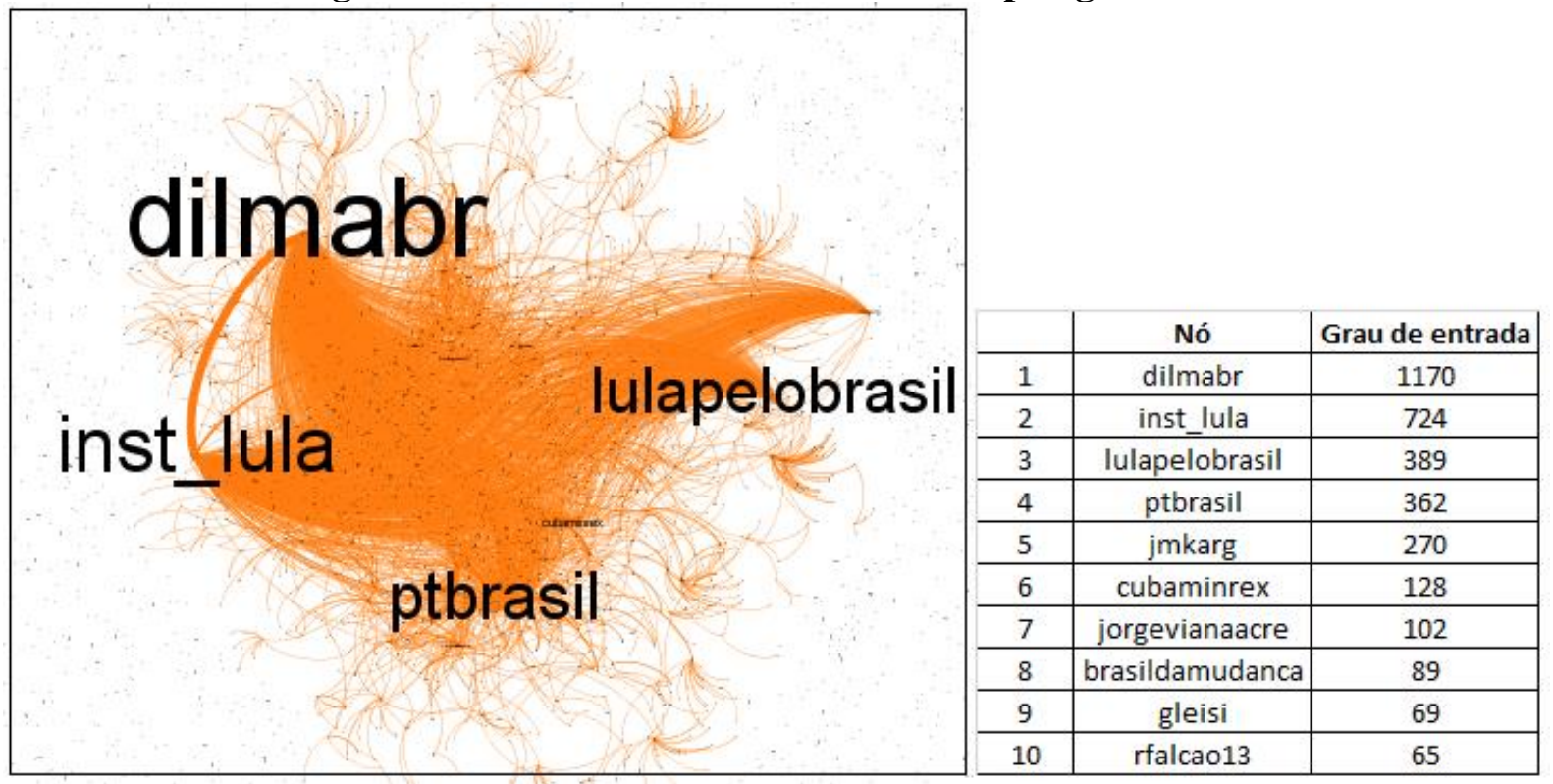

Fonte: Elaborada pela autora.

Cluster 19: Ilustrado na Figura 34, o Cluster 19 é composto por quatro perfis de usuários $\underline{\text { comuns }}^{161}$; dois perfis de lideranças: o perfil do senador Cristovam Buarque (@ sen_cristovam), do Partido Popular Socialista (PPS), e o perfil da deputada federal Jandira Fehgali, do Partido Comunista do Brasil (PCdoB (@andira_feghali); e dois perfis de formadores de opinião: o da jornalista Barbara Lobato (@barbaralobato) e do músico Nando Moura (@moura_101) -

\footnotetext{
${ }^{160}$ Gleisi Hoffman assumiu o cargo da presidência do PT em 03 de junho de 2017 em substituição a Rui Falcão.

${ }^{161}$ Por questões éticas optamos por ocultar os nomes dos perfis de usuários comuns.
} 
importante mencionar que nenhum dos dois formadores de opinião apresenta posicionamento explícito em relação à Lula. Há, ainda, a presença do perfil Bolsonaro Zuero (@bolsonarozuero) que, como visto, é de militância contrária ao PT e à Lula; além de um perfil não identificado (@estadohiramico) $)^{162}$.

Destacamos que o alto grau de conectividade do Cluster 19 com o Cluster 16 demonstra probabilidade elevada de narrativas contrárias ao ex-presidente também circularem por esse grupamento.

Figura 34 - Cluster 19 - nós distribuídos por grau de entrada

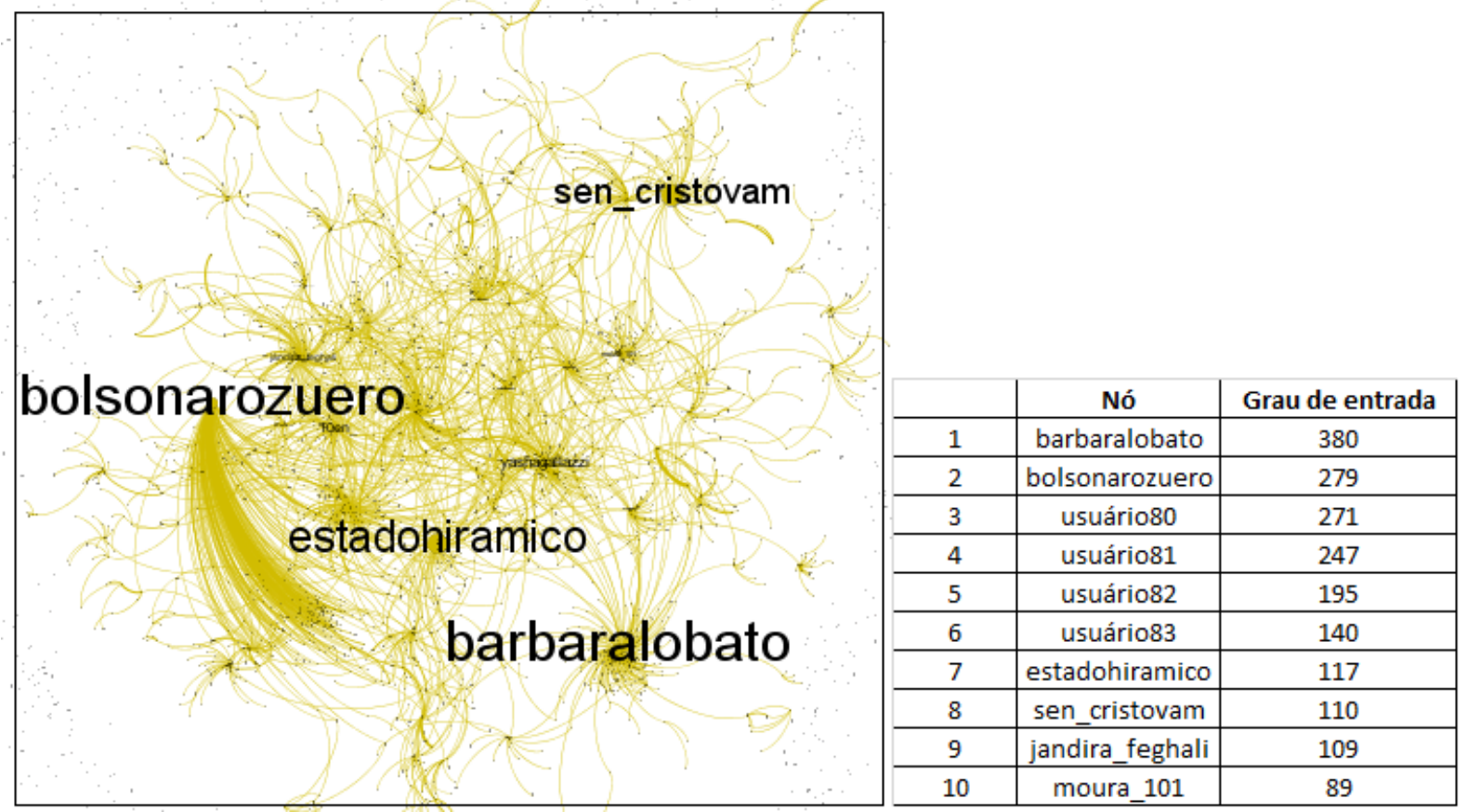

Fonte: Elaborada pela autora.

Cluster 20: Esse grupo se destaca pela forte presença de perfis venezuelanos entre os 10 nós que recebem maior número de menções. Dentre esses 10 nós principais, quatro correspondem a perfis de lideranças políticas, sendo eles: o de Diosdado Cabello (@dcabellor), o do PSUV (@partidopsuv), o de Nicolás Maduro, atual presidente da Venezuela (@ nicolasmaduro), e o perfil do deputado federal Paulo Pimenta, pelo Rio Grande do Sul (PT). Destacamos que todos os perfis supracitados são favoráveis à Lula.

O grupo é constituído, ainda, por um perfil de formador de opinião referente à jornalista venezuelana Teresa Maniglia (@tmaniglia); três perfis de veículos jornalísticos: o não oficial da imprensa da Presidência venezuelana (@presidencialven), o do portal de notícias Brasil 247

162 O perfil foi deletado do Twitter ainda em 2016, o que nos permite considerar que provavelmente se trata de um bot - robôs criados para disseminar determinado tipo de conteúdo nas mídias sociais, ou seja, não são perfis reais. 
Latinoamerica (@brasil247latam), e o do canal de televisão do governo venezuelano VTV

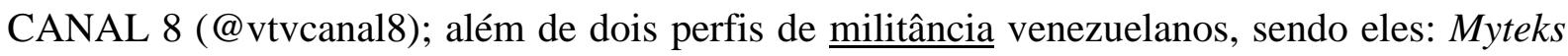
Media Labs (@myteks) e La guerrera \#GAR (@mayvenezoelana) - ambos militantes de partidos de esquerda (Figura 35).

A forte presença de perfis venezuelanos que apoiam Lula e o significativo grau de conectividade entre o Cluster 20 e o Cluster 17 nos permitem inferir que há circulação de informações positivas em relação ao ex-presidente nesse grupo.

Figura 35 - Cluster 20 - nós distribuídos por grau de entrada

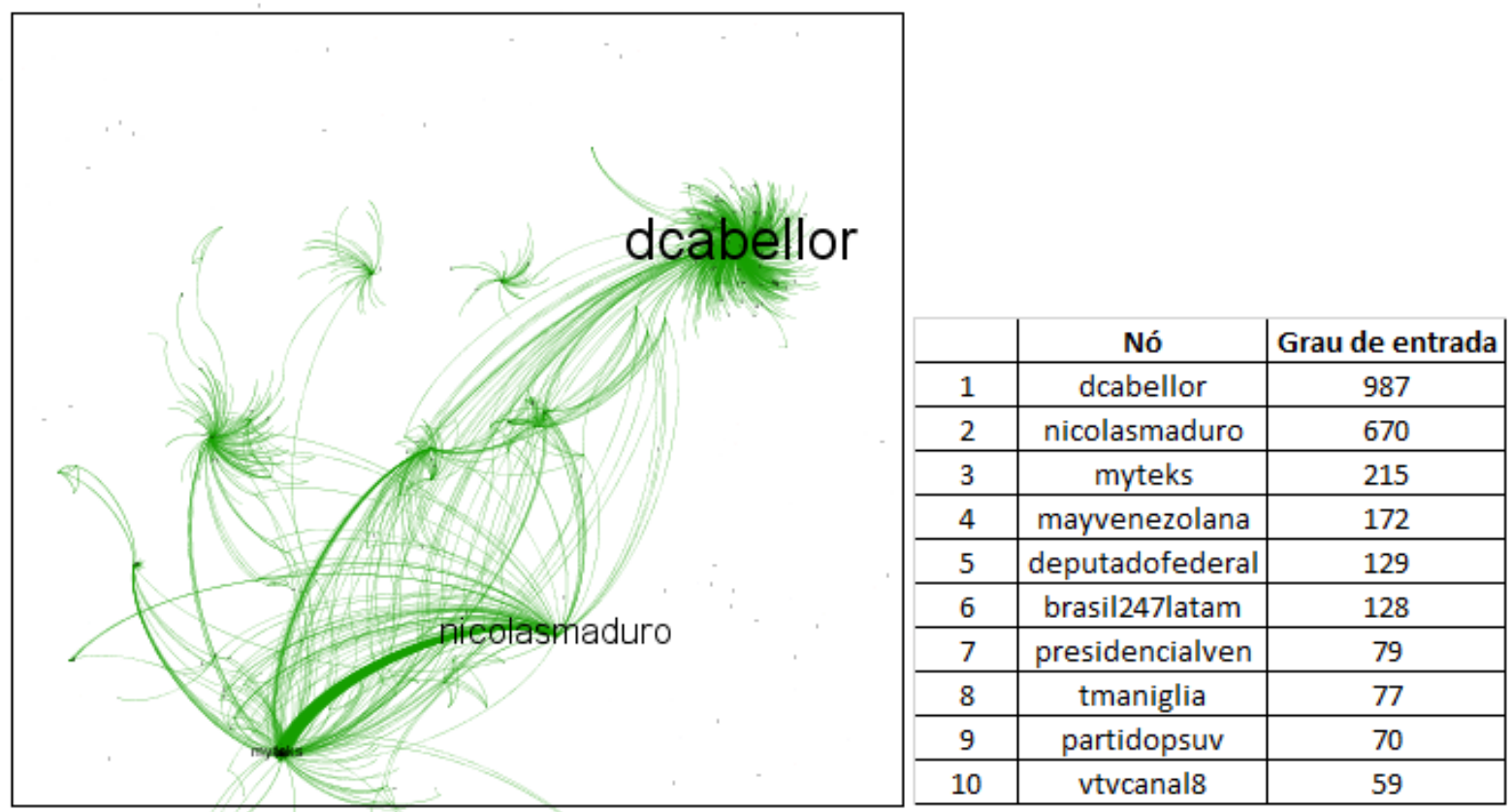

Fonte: Elaborada pela autora.

Destacamos que o Contexto 4 - referente à votação do processo de impeachment no Senado Federal e o afastamento de Dilma Rousseff do cargo da Presidência do Brasil pelo prazo inicial de 180 dias - foi o único que apresentou maior número de grupos nos quais circularam narrativas de construção da imagem pública de Lula.

\subsection{A rede polarizada: opositores versus apoiadores}

Após a análise das conexões estabelecidas entre os usuários do Twitter durante os quatro contextos da crise política de 2016, ressaltamos a principal inferência obtida a partir dessa exploração, qual seja: a polarização das narrativas entre os 20 clusters analisados. Essa 
polarização é explicada pelo baixo grau de modularidade encontrado nas redes sociais apresentadas nos quatro contextos analisados, como pode ser observado na Tabela 18, a seguir.

\section{Tabela 18 - Distribuição dos contextos por modularidade e por grau de conectividade}

\begin{tabular}{ccc} 
Contexto & Modularidade & $\begin{array}{c}\text { Conexões entre os } \\
\text { clusters }^{\mathbf{1 6 3}}\end{array}$ \\
\hline Contexto 1 & 0,655 & $13,36 \%$ \\
\hline Contexto 2 & 0,780 & $5,23 \%$ \\
\hline Contexto 3 & 0,869 & $2,77 \%$ \\
\hline Contexto 4 & 0,716 & $6,48 \%$ \\
\hline
\end{tabular}

Fonte: Elaborada pela autora.

Sobre os dados apresentados na Tabela acima destacamos que a rede estabelecida no Contexto 1 (manifestações sociais a favor do impeachment de Dilma Rousseff), foi a que apresentou menor modularidade, ou seja, obteve maior grau de conexão entre seus clusters. Isso se deve ao fato de que, nesse primeiro contexto, observou-se a presença de apenas um grupo no qual os principais perfis eram favoráveis ao ex-presidente (Cluster 1), pois os demais grupos desse primeiro contexto (Cluster 2, 3, 4 e 5) refletiram potencial detrator da imagem de Lula. Sendo assim, o maior grau de conectividade do Contexto 1 não representa menor polarização, na medida em que as narrativas favoráveis à Lula se mantiveram dentro das conexões estabelecidas apenas no cluster 1; as narrativas de desconstrução da imagem do ex-presidente circularam entre os demais grupos.

Já o Contexto 3, relativo à votação do processo de impeachment na Câmara dos Deputados, apresentou a rede com maior modularidade dentre os contextos analisados, ou seja, houve menor grau de conectividade entre seus grupos. A polarização nesse terceiro contexto se deu entre os Clusters 11 e 14, nos quais circularam narrativas favoráveis à Lula, e os Clusters 12,13 e 15 em que circulavam narrativas opositoras à figura do ex-presidente.

Assim como ocorreu no terceiro contexto, no Contexto 2 - sobre as manifestações contra o golpe - observou-se dois clusters com perfis que apresentaram narrativas de construção da imagem de Lula (Clusters 7 e 8 ) e outros três em que circularam relatos contrários ao expresidente (Clusters 6, 9 e 10). Já o Contexto 4 - referente à votação no Senado Federal - foi o único que apresentou predominância de clusters com narrativas de construção da imagem de Lula. Nele foram observados três grupos com perfis favoráveis ao ex-presidente (Clusters 17, 18 e 20) e outros dois com perfis detratores (Clusters 16 e 19).

\footnotetext{
${ }^{163} \mathrm{O}$ cálculo foi realizado a partir da relação ao número de conexões estabelecidas entre todos os clusters da rede inteira, sendo que o total de tais ligações equivale a $100 \%$.
} 
A predominância de narrativas de construção da imagem pública política de Lula apenas no Contexto 4 condiz com o fato de que os perfis com maior número de menções nesse contexto, ao contrário do que foi observado nos três primeiros, não eram perfis de veículos jornalísticos, mas, sim, de lideranças ligadas ao PT (como o perfil oficial de Dilma Rousseff e o do Instituto Lula), o que indica intensa mobilização da comunicação do governo petista no contexto. Foi observada, também, forte presença de perfis de lideranças políticas venezuelanas, como o do então presidente da Venezuela, Nicolás Maduro, e o de Diosdado Cabello, então presidente da Assembleia Nacional da Venezuela e vice-presidente do PSUV, partido fundado por Hugo Chávez.

Feitas essas observações destacamos que, apesar da polarização dos principais clusters observados nas redes constituídas nos quatro contextos de análise, os grupos nos quais circulavam narrativas desfavoráveis à Lula foram predominantes em relação aos grupos partidários ao ex-presidente.

Ressaltamos, ainda, que nos grupos em que circulavam narrativas de desconstrução da imagem pública de Lula observou-se a forte influência dos veículos jornalísticos hegemônicos (Folha de S. Paulo, jornal O Globo, revista Veja, revista Época), dos blogs jornalísticos ligados a esses veículos e de formadores de opinião contrários à Lula; enquanto nos grupos favoráveis à Lula foi observada predominância de perfis de lideranças políticas diretamente ligadas ao PT e lideranças políticas latino-americanas, bem como a presença de perfis de formadores de

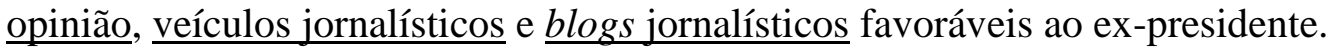




\section{AS NARRATIVAS DE (DES)CONSTRUÇÃO DA IMAGEM PÚBLICA DE LULA NO CONTEXTO DA CRISE POLÍTICA DE 2016}

A partir das inferências possibilitadas pelo diagnóstico das redes constituídas no Twitter nos quatro contextos da análise empírica, objetivamos, no presente capítulo, compreender o conteúdo das narrativas em circulação nesses grupos. Para tanto, utilizaremos como base referencial os termos mais mencionados nos tweets publicados durante o período focalizado eles podem ser observados nas Tabelas 2, 3, 4 e 5 dispostas no capítulo dedicado aos procedimentos metodológicos -, assim como a polarização observada no capítulo anterior entre opositores e apoiadores de Lula para que seja possível compreender tanto o conteúdo das narrativas de desconstrução quanto o substancial dos relatos de construção da imagem pública política do ex-presidente. Aproveitaremos, ainda, as quatro categorias de estudo do mito político baseadas na abordagem de Girardet (1987) - a narrativa da conspiração, a narrativa do $\underline{\text { salvador}}$, a narrativa da unidade e a narrativa da $\underline{\text { idade de ouro }}$ - para compreensão do modo como essas narrativas foram acionadas pelos usuários do Twitter no processo de (des)construção da imagem pública de Lula durante os quatro contextos de análise da crise política de 2016.

\subsection{Narrativas de desconstrução}

Observamos, a partir dos termos mais mencionados nos tweets publicados no período analisado, a predominância de duas narrativas de desconstrução da imagem pública de Lula: a primeira delas visava associar a representação dele a escândalos de corrupção - destacamos que esse relato foi o mais utilizado pelos usuários do Twitter dentre todos os outros observados (tanto nas narrativas de desconstrução quanto naquelas de construção da imagem pública de Lula) no período analisado; a segunda estratégia discursiva de desconstrução tinha por objetivo principal afirmar que o impeachment de Dilma Rousseff teria significado uma derrota para Lula.

Pontuamos que nos tweets em que se observou a presença de relatos de denegrir a imagem pública de Lula houve predominância daqueles publicados por veículos jornalísticos, como os jornais O Estado de S. Paulo e Folha de S. Paulo; as revistas Veja e Época; o portal de notícias Uol; $\underline{b l o g s}$ jornalísticos, como O Antagonista e Blog do Pim; e por perfis de formadores de opinião, como Danilo Gentili e Lobão - nota-se que, como visto na análise de redes sociais realizada no capítulo anterior, tanto os perfis de veículos e blogs jornalísticos como os de formadores de opinião supracitados foram classificados como os mais mencionados em clusters 
ou grupos nos quais circulavam narrativas contrárias a Lula. Destacamos, ainda, que nas narrações de desconstrução foram observados tweets publicados por usuários comuns que, em sua maioria, se apresentavam como militância opositora ao ex-presidente.

Necessário ressaltar que os perfis de veículos jornalísticos (@VEJA; @ folha; @estadao; @ revistaepoca; @uolnoticias),os de blogs jornalísticos (@o_antagonista e @blogdopim)e os de formadores de opinião (@danilogentili; @ lobaoeletrico) foram qualificados entre os termos mais referidos nos quatro contextos de análise, como pode ser observado nas tabelas dispostas no quarto capítulo desta investigação. A presença desses termos entre os mais frequentes enfatiza a forte influência dos três tipos de perfis nas narrativas de desconstrução da imagem pública de Lula que foram observadas na análise de redes sociais no Twitter realizada no capítulo anterior.

Nos dois tópicos a seguir discorreremos sobre a análise de conteúdo dos tweets (publicados durante os quatro contextos específicos do estudo empírico) que buscaram desconstruir a imagem pública de Lula, bem como sobre o modo como os usuários do Twitter acionaram as narrativas do mito político nesse processo.

\subsubsection{Escândalos de corrupção: a conspiração de Lula}

A principal narrativa de desconstrução da imagem pública política de Lula observada pelos termos mais citados nos tweets postados nos quatro contextos focados foi elaborada de forma a associar a imagem do ex-presidente à de um político corrupto. Pontuamos que a recorrência a esse relato foi observada a partir de cinco circunstâncias específicas contextualizadas no terceiro capítulo da presente tese, sendo elas: a) a possibilidade de prisão de Lula; b) a gravação e divulgação da conversa telefônica entre Lula e Dilma; c) a nomeação de Lula para o cargo de ministro da Casa Civil; d) a Operação Lava Jato; e) as manifestações sociais a favor do impeachment de Dilma Rousseff. A seguir discutiremos a análise das narrativas publicadas no Twitter em cada uma dessas cinco ocorrências.

a) A circunstância que se referia à possibilidade de prisão de Lula dizia respeito a três episódios principais: 1) a condução coercitiva de Lula realizada pelo Ministério Público de São Paulo, em 04 de março de 2016, durante a 24 a fase de investigação da Operação Lava Jato; 2) a operação na qual a PF-SP catalogou 136 objetos recebidos por Lula durante seus dois mandatos como presidente da república - essa operação ocorreu na mesma data do evento anterior e também fazia parte da $24^{\mathrm{a}}$ fase da Operação Lava Jato; 3) o pedido de prisão 
preventiva de Lula apresentado por três promotores do MP-SP - Cássio Conserino, José Carlos Blat e Fernando Henrique Araujo - em 09 de março de 2016.

Apesar desses três episódios não estarem incluídos no recorte de análise (as datas de 04, 10 e 11 e março de 2016 nas quais ocorreram tais eventos são anteriores ao primeiro contexto de análise que engloba os tweets postados em 12 e 13 de março de 2016), eles foram a temática em destaque no Twitter, principalmente durante os Contextos 1 (sobre as manifestações sociais a favor do impeachment) e 2 (sobre as manifestações sociais contra o golpe).

Destacamos que houve predominância de três tipos de perfis do Twitter na circulação de narrativas que mencionavam a possibilidade da prisão de Lula: os perfis de veículos jornalísticos, os de $\underline{b l o g s ~ j o r n a l i ́ s t i c o s ~ e ~ o s ~ d e ~ u s u a ́ r i o s ~ c o m u n s . ~ A ~ s e g u i r ~ d i s c o r r e r e m o s ~ s o b r e ~}$ as narrativas utilizadas por cada um deles.

- Veículos e blogs jornalísticos: os tweets publicados por esses tipos de perfis mencionaram termos como "prisão", "promotores", "procuradores" e "defesa", como pode ser observado nos três exemplos a seguir:

1. O Estado de S. Paulo (@Estadao).“600 promotores e procuradores apoiam colegas que querem Lula na prisão http://bit.ly/1QPirmg .” 12 mar. 2016. Tweet.

Sobre o tweet acima, ressaltamos a presença da URL "http://bit.ly/1QPirmg" que fazia ligação dele (tweet) à página do portal de notícias online do mesmo jornal, na qual estava disponível a matéria intitulada "600 promotores e procuradores apoiam colegas que querem Lula na prisão" (MACEDO, BRANDT, AFFONSO, 2016). Essa matéria, publicada em 12 de março de 2016, (durante o Contexto 1), tinha o principal objetivo de divulgar o texto completo do manifesto ${ }^{164}$ assinado por 627 promotores e procuradores em apoio a Cássio Conserino, José

\footnotetext{
${ }^{164}$ A seguir, o texto do manifesto publicado pelo O Estado de S. Paulo: "MANIFESTO EM APOIO AOS PROMOTORES DE JUSTIÇA DO CASO BANCOOP: Os membros do Ministério Público brasileiro [...] vêm a público externar seu apoio ao trabalho dos Promotores de Justiça no caso BANCOOP, que envolve o exPresidente da República Luiz Inácio Lula da Silva. A atuação firme e independente demonstrada neste caso é fruto de meses de trabalho sério, dedicação e esforço em prol da sociedade brasileira. No exercício de suas funções constitucionais, muitas vezes o Ministério Público enfrenta forças políticas e econômicas de diferentes grandezas. Mesmo diante das dificuldades, a Instituição sempre prestou serviços cuja relevância é reconhecida pela sociedade, destinatária dos nossos trabalhos. Esse reconhecimento se deve à qualidade técnica, combatividade e independência com que as atividades ministeriais são conduzidas - mesmos atributos que nortearam o trabalho dos Promotores de Justiça no caso BANCOOP. Em tempos de crise, a força do Direito e das Instituições Democráticas é colocada à prova. Por isso, é indispensável atravessar a turbulência sem pôr em risco conquistas históricas, entre as quais a independência funcional e o poder investigatório dos membros do Ministério Assim, convictos dos fundamentos acima expostos, nós desejamos força e depositamos toda confiança
} 
Carlos Blat e Fernando Henrique Araujo, promotores do MP de São Paulo que pediram a prisão de Lula em 09 de março daquele mesmo ano. O texto ressaltava ainda que no dia 13 de março, data das manifestações sociais a favor do impeachment, o manifesto poderia atingir - destacase aqui o caráter hipotético da enunciação - até 1092 assinaturas, o que reforçava a ideia de que Lula poderia ser, de fato, culpado pelos crimes dos quais os promotores Conseino, Blat e Araujo o teriam acusado.

Ressalta-se que o perfil de O Estado de S. Paulo no Twitter (@estadao) foi classificado durante a análise de redes sociais (capítulo anterior) como o quarto nó com maior número de menções no Contexto 1 e o segundo mais mencionado no Contexto 2, o que demonstra importância das narrativas publicadas por esse perfil nesses dois contextos.

2. Revista Veja (@VEJA). "Leia na VEJA: Lula é denunciado por crime de falsidade ideológica e ocultação de patrimônio on.fb.me/1Xjo38Y.” 12 mar. 2016. Tweet.

Como pode ser observado, o tweet publicado pela revista Veja foi composto pelo texto "Leia na VEJA: Lula é denunciado por crime de falsidade ideológica e ocultação de patrimônio", que fazia referência à matéria publicada em 09 de março de 2016 no Blog do Pim, vinculado à revista Veja ${ }^{165}$. Tal matéria, escrita pelo jornalista Felipe Moura Brasil responsável por esse Blog -, discorreu sobre o caso envolvendo Lula e a possível compra irregular do apartamento triplex em Guarujá (SP), ressaltou a importância da revista Veja ao “antecipar" a denúncia (como visto no terceiro capítulo, a revista Veja foi o primeiro veículo jornalístico a publicar matéria relacionada à denúncia, em edição de 10 de março de 2010), parabenizou o promotor Cássio Conserino, do Ministério Público de São Paulo, por ter denunciado o ex-presidente e abordou, ainda, um suposto desespero de Lula (a quem o jornalista chamou de "ministro", devido à especulação de que Lula seria nomeado ministro da Casa Civil do governo de Dilma Rousseff) diante de tantas acusações de corrupção. A seguir é possível observar a matéria completa publicada no Blog do Pim:

O Ministério Público de São Paulo denunciou nesta quarta-feira o ex-presidente Lula por ocultação de patrimônio, uma modalidade de lavagem de dinheiro, e falsidade ideológica no caso do tríplex no Guarujá, reservado e reformado para sua família, com gastos de cerca de R\$ 1 milhão, pela empreiteira OAS, envolvida no escândalo do petrolão. Antecipada por VEJA, a denúncia feita e protocolada na Justiça pelo

no trabalho dos colegas Cássio Conserino, Fernando Henrique de Moraes Araújo e José Carlos Blat, pois devidamente alinhado à Constituição e às Leis da República.". (MACEDO; BRANDT; AFFONSO, 2016).

${ }^{165}$ A matéria em questão estava publicada na integra na página oficial da revista Veja no Facebook e poderia ser acessada a partir da URL “on.fb.me/1Xjo38Y” apresentada no conteúdo do tweet em questão. 
promotor Cássio Conserino é resultado de investigação independente sobre construção e venda dos apartamentos do condomínio Solaris e, portanto, nada tem a ver com a Operação Lava Jato e a condução coercitiva do petista na última sexta-feira (4). A mulher de Lula, Marisa Letícia; o filho Fábio Luís Lula da Silva, o Lulinha; o ex-presidente da OAS, Léo Pinheiro; e o ex-tesoureiro do PT João Vaccari Neto também foram denunciados. Pelo menos 100 pessoas já foram ouvidas na investigação em São Paulo, entre elas moradores, corretores e funcionários do prédio. Os promotores paulistas suspeitam que Lula tenha comprado o triplex e, se a denúncia for aceita pela Justiça, ele passará a ser réu na ação. Parabéns, Cássio Conserino! Com tantos crimes em jogo, dá para entender o desespero do "ministro" jararaca.". (BRASIL, F; 2016).

Pontuamos que, além do conteúdo textual, o tweet postado pelo perfil da revista Veja no Twitter foi composto pela imagem de capa do mesmo periódico, edição de 11 de março de 2016 que pode ser observada a seguir:

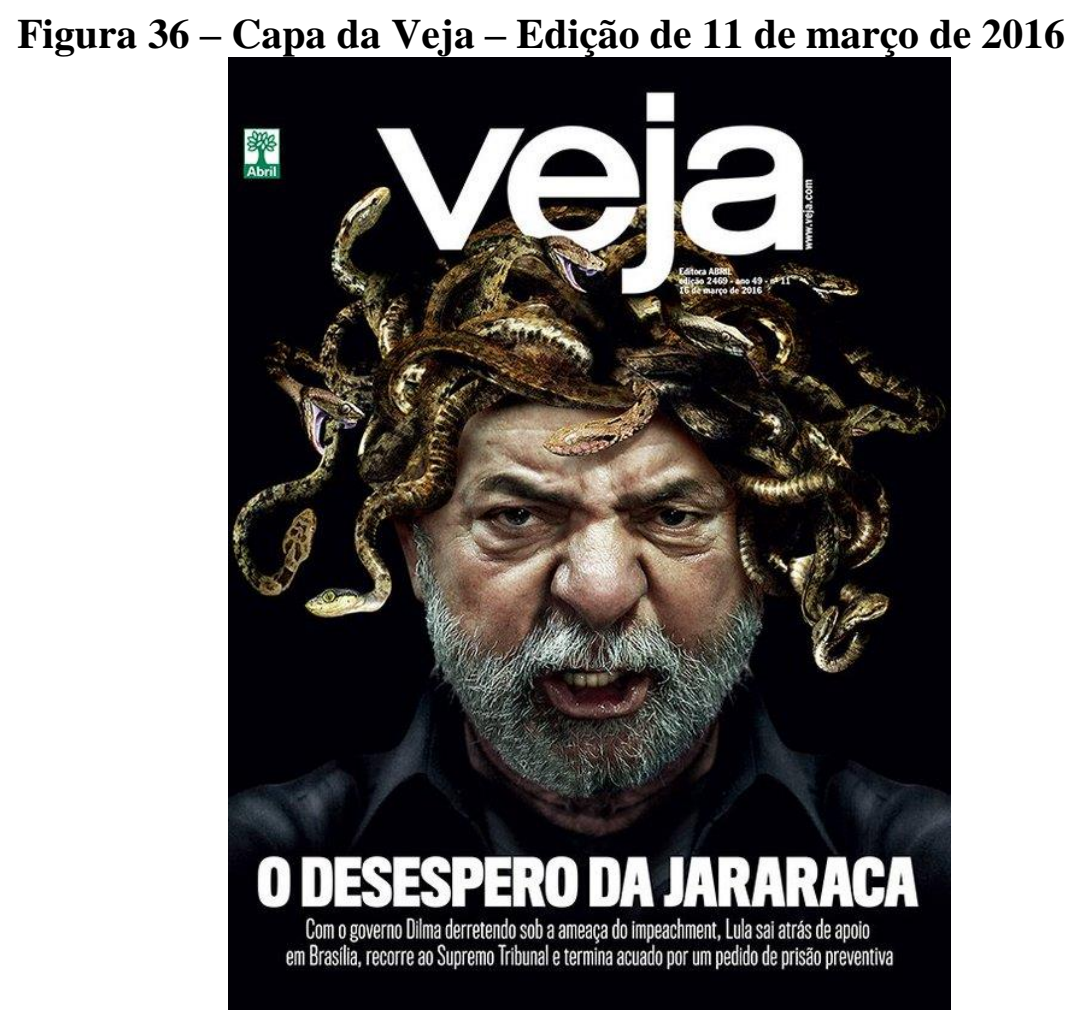

Fonte: Veja, 2016.

Como se pode ver na figura acima, Lula foi retratado com semblante raivoso e cobras em volta da cabeça, o que se configurou como um símbolo extremamente significativo em relação à desconstrução da imagem pública política do ex-presidente. O título da edição, “O desespero da Jararaca", fazia alusão a uma frase proferida por Lula em 04 de março de 2016, quando, em pronunciamento oficial, ele falou sobre sua condução coercitiva ocorrida naquele mesmo dia. Em seu depoimento, ele comparou-se a uma jararaca (espécie de serpente) ao comentar que a 
condução coercitiva não teria sido suficiente para abatê-lo: "Se quiseram matar a jararaca, não fizeram direito, pois não bateram na cabeça, bateram no rabo, porque a jararaca está viva.". (LULA apud “A JARARACA...”, 2016). Observou-se que, a capa da edição da revista Veja, além de utilizar essa comparação feita pelo próprio Lula, classificou como desesperadas as atitudes do ex-presidente (procurar apoio de congressistas em Brasília ou recorrer ao Supremo Tribular Federal) em relação aos acontecimentos daquele momento, como a possibilidade de sua prisão e o impeachment de Dilma Rousseff - o mesmo desespero relatado por Felipe Moura Brasil na matéria publicada em 09 de março de 2016, citada anteriormente.

Ressalta-se que tanto o perfil do blog jornalístico de Felipe Moura Brasil (Blog do Pim), como o da revista Veja no Twitter foram observados na análise de redes sociais dentre os nós com maior número de menção em grupos contrários a Lula. O perfil desse Blog foi um dos que apresentou maior quantidade de menção tanto no Cluster 6 (Contexto 2 - sobre as manifestações sociais contra o golpe), quanto no Cluster 12 (Contexto 3 - votação na Câmara e resultado favorável à continuação do processo de impeachment). Já o perfil da revista Veja apresentou o maior número de menções no Cluster 2 (Contexto 1 - sobre as manifestações sociais a favor do impeachment), Cluster 6 (Contexto 2) e Cluster 16 (Contexto 4 - votação no Senado). Em todos esses grupos verificou-se a circulação de narrativas contrárias a Lula.

Destaca-se, ainda, que o perfil da revista Veja foi um dos principais nós na circulação de narrativas em três dos quatro contextos analisados: no Contexto 1 o perfil @VEJA foi o segundo com mais menções; já no Contexto 2 foi o nó com maior grau de entrada na rede inteira; e no Contexto 4 foi o décimo segundo na classificação dos 20 nós com maior número de menções na rede.

3. Blog O Antagonista (@o_antagonista). “Em defesa da prisão de Lula: https://t.co/yqGLLC7xlt”. 12 mar. 2016. Tweet.

No tweet acima do perfil de O Antagonista (blog jornalístico gerido pelos jornalistas Diogo Mainardi, Mário Sabino e Cláudio Dantas), nota-se que há um apelo no sentido de desconstruir a imagem de Lula a partir da "defesa da sua prisão" que leva o leitor a compreender que o blog (e os jornalistas responsáveis por ele) é, também, favorável à prisão de Lula.

Ao final desse tweet há uma URL que direciona para a matéria completa intitulada "Em defesa da prisão de Lula", publicada em O Antagonista em 12 de março de 2016 (durante o Contexto 1). Os jornalistas argumentaram em defesa do pedido de prisão preventiva de Lula baseados, principalmente, na fala do juiz Nelson Augusto Bernardes - que fora entrevistado 
pelo jornal O Estado de S. Paulo (também em 12 de março de 2016). Na ocasião da entrevista o juiz afirmou que a postura do MP diante do pedido de prisão de Lula teria sido coerente com o que deve ser feito em casos graves de denúncia. A seguir destacamos a fala do juiz Nelson Bernardes reproduzida por O Antagonista:

\footnotetext{
"Vejo que a posição do Ministério Público, que está sendo muito criticada, ela é coerente com o que Ministério Público sempre faz em qualquer caso grave. Ele denuncia e pede a prisão.".

"Esse estrépito que estão fazendo por causa da postura do Ministério Público acho exagerado. Porque não fez nada além do que faria em qualquer outro caso. Ou seja, se a situação é grave, o que faz o Ministério Público do Estado de São Paulo, sempre? Denuncia, imputa crime e pede prisão, é simples".

"Se o Ministério Público pautasse a sua conduta pela qualidade política ou econômica de determinado acusado, aí, sim, teria uma anomalia na atuação do Ministério Público.”. (BERNARDES apud EM DEFESA..., 2016).
}

Ao final dessa mesma matéria os jornalistas de O Antagonista, baseando-se ainda no depoimento do juiz Nelson Augusto Bernardes, afirmaram que "condenável teria sido privilegiar Lula apenas porque ele é Lula.”. (EM DEFESA..., 2016). Interessante notar que a partir da expressão "apenas porque ele é Lula" - que evidencia a grandiosidade da figura do expresidente diante do imaginário coletivo brasileiro -, a estratégia de desconstrução da imagem pública de Lula se deu pela ressignificação da importância da figura do ex-presidente, ou seja, os jornalistas procuraram evidenciar que a grandiosidade da imagem pública política de Lula de nada adiantaria e, mais do que isso, não deveria se transformar em privilégio para ele próprio diante das investigações dos esquemas de corrupção.

Algumas observações realizadas durante a análise de redes sociais no Twitter no capítulo anterior devem ser destacadas para melhor entendimento sobre a narrativa de desconstrução da imagem pública política de Lula utilizada nesse tweet: a primeira delas diz respeito ao perfil de Diogo Mainardi - um dos jornalistas responsáveis pelo blog O Antagonista - que esteve presente entre os nós com maior grau de entrada (perfis com mais conexões recebidas) do Cluster 2, que reunia detratores em relação a Lula no Contexto 1 (sobre as manifestações sociais a favor do impeachment de Dilma Rousseff).

Observa-se da mesma forma que o perfil do blog O Antagonista se configurou como um dos mais influentes na rede por estar presente entre os 20 nós com maior grau de entrada em três dos quatro contextos de análise: no Contexto 1, sobre as manifestações sociais a favor no impeachment; no Contexto 2, acerca das manifestações sociais contra o golpe, e no Contexto 4, a respeito da votação no Senado Federal. Além disso, constatou-se também que o perfil de $\mathrm{O}$ 
Antagonista no Twitter possuía considerável influência em grupos detratores de Lula como os Clusters 6 (Contexto 1) e 16 (Contexto 4).

- Usuários comuns ${ }^{166}$ : as postagens realizadas por esses perfis que tinham relação com a circunstância da possibilidade de prisão de Lula mencionaram termos como "ladrão", "bandido", "preso", "cadeia”, "condenado", bem como a hashtag "\#lulanacadeia”. A seguir é possível observar dois exemplos dessas mensagens:

1. Usuário Comum. "Lula rasgou a Constituição até pra roubar arte sacra, acervo artísticocultural do país. \#LulaNaCadeia.”. 12 mar. 2016. Tweet.

Como se vê, esse tweet foi postado durante o Contexto 1 (das manifestações a favor do impeachment) e fazia referência à operação de 04 de março de 2016, realizada pela Polícia Federal que visava investigar objetos pertencentes a Lula e que foram encontrados em uma salacofre do Banco do Brasil, em São Paulo. Nesse tweet o "usuário comum" acusa Lula de ter ignorado a Constituição Brasileira e de ter roubado acervo cultural do país. A mensagem possui, ainda, a hashtag \#LulaNaCadeia, que se constitui palavra de ordem utilizada pelos usuários do Twitter em referência à possibilidade de Lula ser preso naquela operação.

Importante observar, para além do conteúdo da mensagem, a forma como o usuário se apresenta no microblog a partir de sua bio que continha a seguinte frase: "É tempo de construir uma nova América Latina. \#ForaForodeSaoPaulo" (tradução nossa) ${ }^{167}$. O Foro de São Paulo, como especificado no terceiro capítulo, é uma conferência de partidos e movimentos de esquerda da América Latina e do Caribe, sendo Lula um dos principais fundadores e articuladores da iniciativa. A frase em questão foi originalmente escrita em inglês porque, apesar de o usuário se autodeclarar brasileiro no perfil no microblog, sua localização indicava a cidade de Nova Iorque (Estados Unidos).

2. Usuário Comum. "O CANALHA, o VERME do Luiz Inácio LADRÃO da Silva VULGO \#LULA @inst_lula@dilmabr@ptbrasil \#LulaNaCadeia.”. 12 mar. 2016. Tweet.

\footnotetext{
166 Por questões éticas optamos por ocultar o nome de perfis classificados como usuários comuns, desta forma, ao longo do texto utilizaremos o termo "usuário comum" para nos referirmos a esses tipos de perfis.

167"It's time to build a better Latin America. \#ForaForodeSaoPaulo".
} 
Nesse segundo tweet, o usuário comum utilizou termos pejorativos como "canalha ${ }^{168 ",}$ "verme" e "ladrão" para a desconstrução da imagem pública de Lula, e, ainda há referência a três perfis pertencentes ao PT: o do Instituto Lula ${ }^{169}$, o oficial de Dilma Rousseff e o oficial do PT no Twitter. Necessário pontuar que o usuário comum responsável pela publicação do tweet apresentava como bio a frase "Anti-PT, Anti-Lula e Anti-Dilma”, o que reforçava o posicionamento contrário a Lula e expresso no conteúdo da sua postagem.

As observações acima realizadas em relação aos tweets postados por usuários comuns nos permitem inferir que as narrativas de desconstrução da imagem de Lula sob o tema da possibilidade de prisão do ex-presidente foram utilizadas no Twitter que já se apresentavam contrários a ele. Houve, portanto, considerável força da militância opositora a Lula nas narrativas prejudiciais à sua imagem pública política.

b) A segunda circunstância observada dentre as narrativas que associavam Lula a questões de corrupção remetia à conversa telefônica entre o ex-presidente e Dilma Rousseff, ocorrida em 16 de março de 2016. O relato de desconstrução da imagem pública política de Lula, utilizado principalmente pelos veículos jornalísticos nesse episódio da gravação, se deu a partir do termo "golpe" pelo fato de essas empresas considerarem que o áudio dessa conversa revelava um acordo de nomeação de Lula para o cargo de ministro da Casa Civil como forma de evitar a continuação da Operação Lava Jato.

O tema da conversa telefônica entre Lula e Dilma se tornou recorrente no segundo contexto de análise dessa pesquisa e aí foram observados tweets publicados, sobretudo, por perfil de veículos jornalísticos e usuários comuns. A seguir discorreremos sobre essas narrativas:

- Veículos jornalísticos: Termos como "grampo", "conversa", “áudio", "gravação" e "divulgação" foram os mais mencionados nos tweets publicados por esses tipos de perfis como pode ser observado a seguir:

\footnotetext{
${ }^{168}$ Termo compreendido como "pessoa vil, infame, reles". (FERREIRA, 1986, p. 265).

${ }^{169}$ Nota-se que o usuário menciona o perfil do Instituto Lula (@insti_lula) como se fosse o perfil oficial do expresidente no Twitter. Tal menção é equivocada, já que o perfil oficial de Lula no microblog é o @lulapelobrasil. Essa observação demonstra desconhecimento público em relação à comunicação oficial do ex-presidente no âmbito do Twitter.
} 
1. Revista Veja. (@VEJA) “Grampos revelam golpe de Lula e Dilma contra Lava Jato, e multidão volta às ruas https://t.co/uSOQ1ZpYDb”. 17 mar. 2016. Tweet.

O tweet publicado pelo perfil da revista Veja foi composto pelo texto "Grampos revelam golpe de Lula e Dilma contra Lava Jato, e multidão volta às ruas" ${ }^{170}$, que fazia alusão ao título de uma reportagem publicada em 16 de março de 2016 no portal de notícias online da Veja e também a uma imagem em que Lula aparece conversando com Dilma ao pé do ouvido (Figura 37):

Figura 37 - Imagem que compõe o tweet da Revista Veja

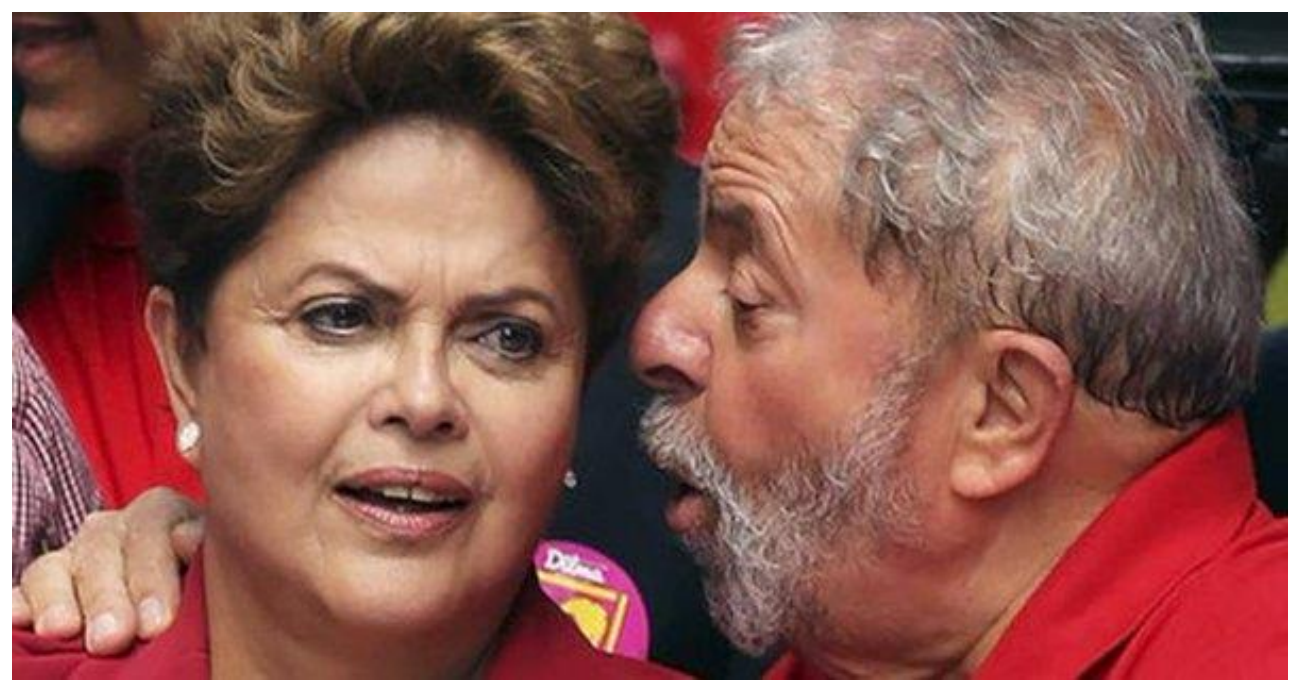

Fonte: Veja, 2016.

Nota-se que a revista Veja utilizou, novamente, a estratégia imagético-visual além da textual para a desconstrução da imagem pública política de Lula. A reportagem citada no tweet discorre sobre o conteúdo da conversa entre Dilma e Lula, que, na avaliação de Veja, revelava a tática de nomeação de Lula como ministro da Casa Civil para evitar a possibilidade de ele ser preso por corrupção na Operação Lava Jato ${ }^{171}$. A fotografia utilizada pela revista (Figura 37) para ilustrar tal notícia possibilitava que o leitor, tanto do tweet como da matéria jornalística completa, compreendesse o uso da palavra "golpe" enquanto sinônimo de trama ou trapaça, o que colaborava para denegrir a imagem do ex-presidente.

\footnotetext{
${ }^{170} \mathrm{O}$ tweet também é composto por uma URL (https://t.co/uSOQ1ZpYDb) que faz a ligação da mensagem postada no Twitter ao portal de notícias online da Veja em que é possível ler a matéria na íntegra.

${ }^{171}$ A reportagem mencionava, ainda, a manifestação ocorrida na mesma data de 16 de março contrária a Lula e Dilma, que teria sido convocada pelos grupos opositores aos governos petistas (tais como MBL e Vem pra Rua). A manifestação, no entanto, não foi expressiva em relação ao número de participantes.
} 
2. Blog do Pim (@blogdopim) "Copacabana grita na rua Renuncia!", após revelação dos grampos de \#LulaGolpista e Dilma.”. 16 mar. 2016. Tweet.

Nesse tweet o jornalista Felipe Moura Brasil, responsável pelo Blog do Pim, noticiou o protesto de manifestantes ocorrido em 16 de março de 2016 no bairro de Copacabana, na cidade do Rio de Janeiro, contra as supostas revelações que teriam sido divulgadas a partir do áudio da conversa telefônica entre Lula e Dilma. O jornalista afirmou ainda que tais manifestantes pediam a renúncia de Rousseff. O blogueiro utilizou a hashtag \#LulaGolpista como forma de acionar a narrativa de desconstrução da sua imagem pública a partir da palavra "golpe", que foi empregada também pela revista Veja no exemplo anterior. Observou-se, para além do conteúdo textual, que esse tweet foi composto por uma estratégia imagético-visual para dar maior credibilidade ao conteúdo textual. A mensagem no tweet estampou uma fotografia da manifestação em área nobre da cidade do Rio de Janeiro, no bairro de Copacabana, o que demonstra o caráter elitista do protesto. Essa imagem compõe a Figura 38, a seguir:

Figura 38 - Imagem que compõe o tweet do Blog do Pim

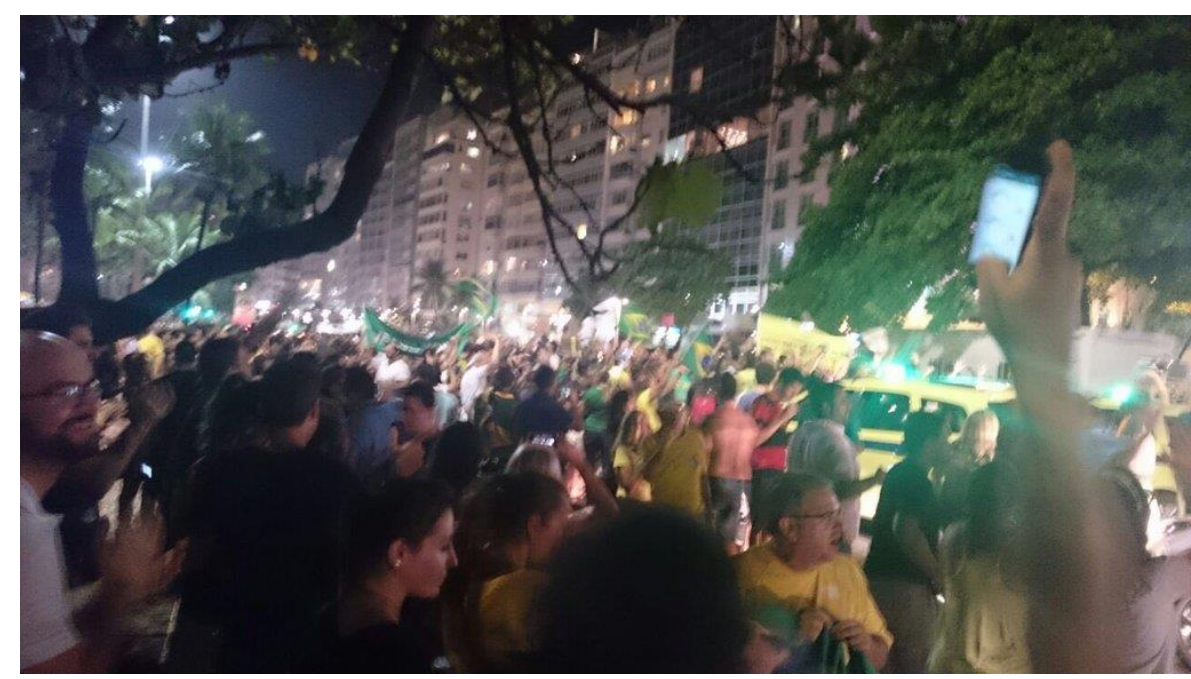

Fonte: Blog do Pim, 2016.

- Usuários comuns: Além dos tweets postados por veículos jornalísticos, constatou-se que perfis de usuários comuns da mesma forma se manifestaram sobre o tema da divulgação da conversa telefônica entre Lula e Dilma. Veja, a seguir, um exemplo da narrativa: 
Usuário comum. "Os áudios revelam o verdadeiro LULA: Misógino, corrupto, autoritário, fascista, machista, homofóbico, sem vergonha. Em suma: um canalhocrata”. 17 mar. 2016. Tweet.

É possível observar nesse tweet que o usuário utiliza termos depreciativos como "misógino", "corrupto", "autoritário", "fascista", "machista", "homofóbico", "sem vergonha" e "canalhocrata" como forma de manchar a imagem pública de Lula. Além disso, o uso do adjetivo "verdadeiro" é nova tentativa de denegrir a figura política dele pelo usuário comum. Tal narrativa está diretamente relacionada à ideia do ex-presidente como golpista ou trapaceiro destacada pelos veículos de comunicação já citados. Ao afirmar que os áudios da conversa entre Lula e Dilma teriam revelado a verdade sobre Lula, o usuário comum afirmou ainda que o expresidente estaria fingindo ser algo que não é, ou seja, utilizando de estratégia de falseamento - ou golpe - em sua própria imagem. Observa-se, portanto, que o relato dos usuários comuns estava em consonância com aquele empregado pelos veículos jornalísticos, sobretudo pela revista Veja.

c) A nomeação de Lula para ministro da Casa Civil, oficializada pelo Palácio do Planalto em 16 de março de 2016 e sua posterior suspensão pelo ministro do Supremo Tribunal Federal (STF), também se configuraram como tema das narrativas de desconstrução da imagem pública de Lula.

Dois pontos importantes foram observados sobre esse assunto: um deles se refere ao nome de Gilmar Mendes, ministro do STF, que foi um dos mais termos citados em três dos quatro contextos analisados; outro ponto diz respeito à ausência do tema da nomeação de Lula para ministro da Casa Civil dentro do Contexto 1 - esse fato se justifica pelas datas de recorte dos contextos de análise, já que o Contexto 1 é composto por postagens realizadas em 12 e 13 de março de 2016, período anterior à nomeação de Lula para ocupar o cargo de ministro.

Principalmente no Contexto 2, ocorrido logo após a nomeação e a suspensão de Lula como ministro, há predominância de termos como "nomeação", "ministro", "posse", “ministério", “Casa Civil", "STF”, "suspensão", “decisão" e “cargo". A seguir é possível examinar dois exemplos de narrativas que utilizaram esses termos, sendo o primeiro publicado por um veículo jornalístico: 
Blog do Pim. (@blogdopim) "Petistas desesperados gritam "Golpistas!" contra oposição na Câmara, horas após a Justiça suspender o verdadeiro golpe da nomeação de Lula.”. 17 mar. 2016. Tweet.

Já o segundo exemplo foi exposto num perfil de usuário comum:

Usuário comum. "Golpe é querer colocar o Lula como ministro para que ele saia da investigação da Lava Jato e tenha foro privilegiado no STF!!! \#ImpeachmentDay". 17 abr. 2016. Tweet.

A partir dessas amostras é possível observar que a estratégia de utilização da narrativa de golpe foi novamente explorada e igualmente notada no tema sobre a conversa telefônica entre Lula e Dilma. O tweet publicado pelo Blog do Pim enfatizou a ideia de que o "verdadeiro golpe" não seria o do impeachment de Dilma, mas, sim, o da nomeação de Lula para o Ministério da Casa Civil. Da mesma forma o usuário comum afirma que "golpe é querer colocar o Lula como ministro".

Outra constatação importante em relação ao assunto da nomeação de Lula para a Casa Civil foi a recorrente menção aos termos "pobre" e "rico" nos tweets analisados, o que ocorreu devido ao alto índice de compartilhamento do tweet postado pelo perfil do formador de opinião Danilo Gentili (@danilogentili), em 15 de março de 2016. A mensagem de Gentili, citada a seguir, foi amplamente compartilhada a partir do Contexto 2:

Gentili, Danilo. (@danilogentili) “No Brasil é assim: quando um pobre rouba, vai para a cadeia, mas quando um rico rouba, ele vira ministro"” - Lula, 1988.". Tweet. 15 mar. 2016. Tweet.

Nota-se que a data de postagem do tweet de Gentili é anterior à nomeação oficial de Lula para o ministério, pois a especulação da possibilidade de Lula se tornar ministro já se fazia presente dias antes do ocorrido, notadamente nas notícias veiculadas pelos principais jornais e revistas do Brasil, como, por exemplo, pelo portal de notícias online da Globo (G1), também em 15 de março de 2016, e intitulada "Lula pode virar ministro e ganhar foro privilegiado no STF” ${ }^{172}$. Essa notícia tinha como principal conteúdo a informação de que o Palácio do Planalto

${ }^{172}$ Notícia disponível em: http://g1.globo.com/politica/noticia/2016/03/lula-pode-virar-ministro-e-ganhar-foro- 
não teria confirmado oficialmente a nomeação de Lula para o Ministério até aquele momento, mas que, de acordo com o então ministro da Casa Civil, Jaques Wagner, a possibilidade de tal nomeação era "real e concreta".

No tweet citado Danilo Gentili fez uma citação direta de uma frase dita por Lula em 1988, quando ele assumia o cargo de deputado federal pelo PT de São Paulo. Naquela ocasião Lula fazia oposição ao governo federal, liderado por José Sarney (PMDB). A frase - "No Brasil é assim: quando um pobre rouba, vai para a cadeia, mas quando um rico rouba, ele vira ministro" - foi originalmente publicada em fevereiro de 1988 no jornal O Globo e reproduzida na mesma época pela Folha de S. Paulo em matéria intitulada "Governo deveria prender e não só acusar, diz Lula". No texto o ex-presidente afirmava que o governo de Sarney deveria tomar atitudes mais concretas em relação aos acusados de corrupção punindo-os devidamente. (STYCER, 2016).

A citação feita naquela ocasião pelo ex-presidente Lula (que voltou a ser publicada em 1996 no livro "O Brasil em Mil Frases - O melhor publicado nos 20 anos da seção Frases da Folha de São Paulo", de Mauricio Stycer) viralizou ${ }^{173}$ no Twitter a partir do elevado número de compartilhamentos do tweet de Danilo Gentili. Observa-se no tweet que a estratégia de desconstrução da imagem de Lula se deu a partir do recurso da ironia ${ }^{174}$. Assim, com a nomeação de Lula para o Ministério da Casa Civil, o ex-presidente, seria, de acordo com Gentili, o "rico que rouba e vira ministro". É possível perceber que a estratégia de utilizar tal passagem com a intenção de afirmar que Lula, ao ter se envolvido em escândalos de corrupção, estaria se tornando ministro para se livrar de possíveis acusações reforça a ideia de que ele estaria dando um "golpe".

Ressalta-se que o perfil de Danilo Gentili foi classificado durante a análise de redes sociais (no capítulo anterior) como o sexto nó com maior quantidade de referências na rede inteira do Contexto 2 (sobre as manifestações sociais contra o impeachment de Dilma); além disso, o perfil desse formador de opinião foi observado como um dos mais influentes no Cluster 9 (Contexto 2), grupo contrário a Lula.

\footnotetext{
privilegiado-no-stf.html. Acesso em 16 de novembro de 2016.

${ }^{173}$ A viralização é o indicativo do alto grau de repercussão de determinado assunto, vídeo, texto, mensagem, foto ou qualquer conteúdo publicado na internet.

${ }^{174}$ A ironia pode ser compreendida como um "modo de exprimir-se que consiste em dizer o contrário daquilo que se está pensando ou sentindo, [...] com intenção depreciativa e sarcástica em relação a outrem.”. (FERREIRA, 1986, p. 785)
} 
d) A quarta circunstância relativa à estratégia discursiva de desconstrução da imagem pública política de Lula pelo viés da corrupção, observada a partir dos termos mais frequentemente mencionados nos contextos de análise, se referia à Operação Lava Jato, conduzida pelo MPF. O assunto aparece com frequência em todos os quatro contextos analisados e sobre ele foram examinadas publicações feitas por perfis de veículos jornalísticos e usuários comuns.

- Veículos jornalísticos: Os tweets que faziam referência à Lava Jato e que foram publicados por perfil de veículos jornalísticos mencionavam termos como "Moro", em referência ao juiz federal Sérgio Moro - responsável direto pela Operação; "promotores”, "procuradores", investigação", "STF” “operação", "Lava Jato" e "Petrobrás". Veja o exemplo a seguir:

Revista Época (@revistaepoca). “EXCLUSIVO: STF homologa delação que cita plano de Dilma e Lula para melar a Lava Jato http://glo.bo/1MEfy8s”. 18 abr. 2016. Tweet.

A narrativa de denegrir da imagem pública política de Lula utilizada no tweet postado pela revista Época também se assemelha à narrativa de golpe incluída no tema sobre a gravação de conversa telefônica entre Lula e Dilma (no tweet publicado pela revista Veja e pelo Blog do Pim), bem como no tema da nomeação do ex-presidente para o cargo de ministro da Casa Civil (observado, novamente, em um tweet no Blog do Pim e, também, por um usuário comum). Há que se pontuar, no entanto, que, na revista Época o termo "golpe" foi substituído por "plano".

Uma semelhança entre os tweets de Veja e Época está na estratégia de utilizar a narrativa imagético-visual para corroborar o texto publicado no tweet em questão. Como se pode notar na Figura 39, a imagem utilizada na revista Época mostra Dilma conversando ao pé do ouvido de Lula em sinal de que ambos estariam planejando algo. 
Figura 39 - Imagem que compõe o tweet da revista Época

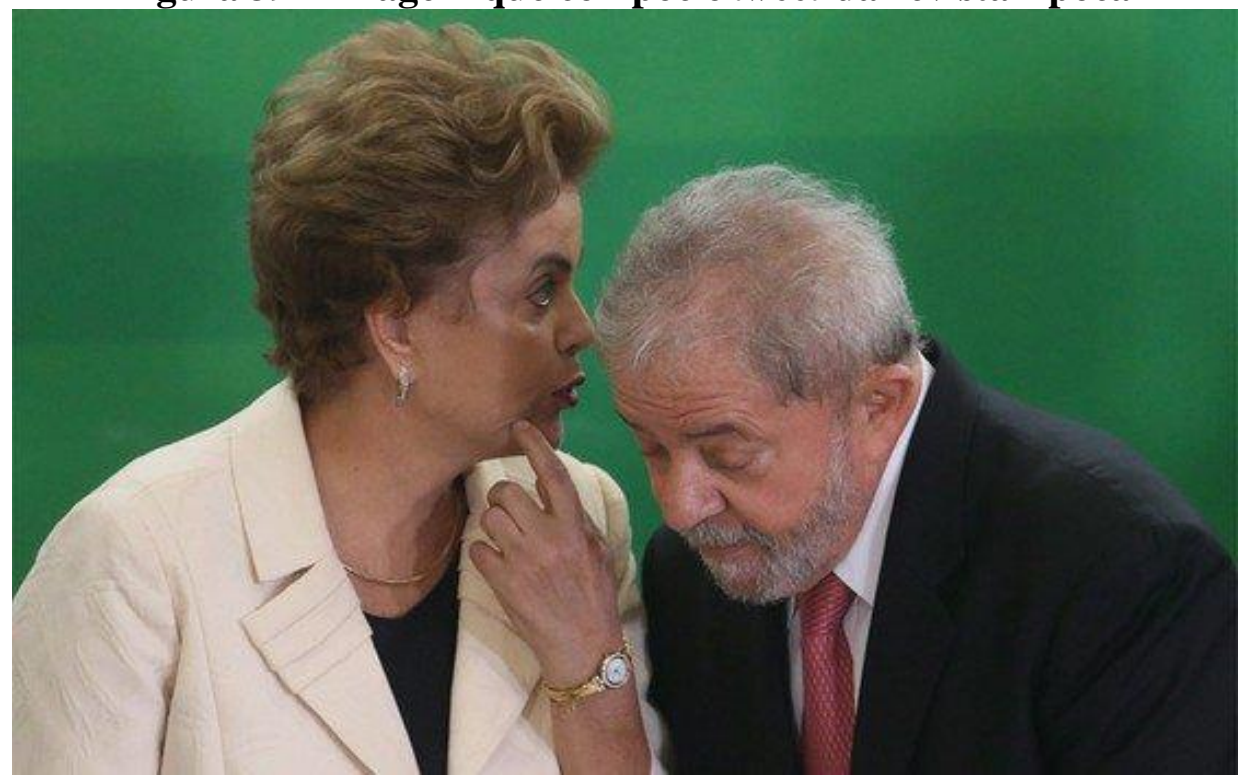

Fonte: Época, 2016.

Em relação à utilização de figuras nos tweets cabe pontuar que, em análise sobre as estratégias discursivas de Veja e Época na construção da imagem pública dos candidatos à Presidência do Brasil nas eleições de 2006, Silva (2011) ressalta que para ambas as revistas o conteúdo visual (seja por meio de fotografias ou ilustrações) se compõe como uma das principais estratégias na desconstrução ou construção dos candidatos - no caso específico analisado por Silva (2011), as revistas utilizaram recursos visuais de forma a prejudicar o conceito de Lula e, ao contrário, enaltecer a imagem de seu principal opositor, Geraldo Alckmin (PSDB) -, sendo assim o recurso visual para as revistas assume a função de reforçar, dialogar e explicar o texto verbal.

Dessa forma, "a escolha das imagens se dá a partir da interface com o projeto de dizer do produtor do texto.”. (SILVA, 2011, p. 154). Ressaltamos que ao incluírem nos tweets acima exemplificados fotografias de Lula e Dilma em que ambos são retratados de forma pejorativa (como se estivessem confabulando ou tramando algo), as revistas exploraram o conteúdo visual de forma a "reforçar o aspecto crítico em relação ao[s] participante[s] representado[s]". (SILVA, 2011, p. 154).

Válido ressaltar que, como observado na análise de redes sociais no Twitter, o perfil da revista Época foi um dos 20 nós que mais receberam menções no Contexto 1 (sobre as manifestações sociais a favor no impeachment), no Contexto 3 (relatos acerca da votação na Câmara dos Deputados e resultado favorável à continuação do processo de impeachment) e no Contexto 4 (votação no Senado e afastamento de Dilma do cargo da Presidência). O perfil da 
revista Época foi encontrado, ainda, entre os nós mais influentes no Cluster 2 (Contexto 1), onde circulavam narrativas contrárias a Lula.

- Usuários comuns: ainda sobre o tema da Lava Jato, observou-se a presença do termo "corrupto" que aparece com recorrência em tweets postados por perfis de usuários comuns, como pode ser apreciado nos três exemplos a seguir:

1. Usuário comum. "LULA É UM CORRUPTO. TRAIDOR DA NAÇÃO. LADRÃO DO DINHEIRO PÚBLICO”. 17 mar. 2016. Tweet.

2. Usuário Comum. "Lula é um bandido, corrupto, ladrão... Tem que ser preso pelos crimes que cometeu". 18 abr. 2016. Tweet.

3. Usuário comum. "Lava Jato e Sérgio Moro tem meu total apoio. Que todos corruptos sejam presos e a prioridade é o chefão, Lula.”. 13 mai. 2016.

Observa-se, portanto, que a narrativa de desconstrução da imagem pública política de Lula sob o tema da Lava Jato se deu de forma a associar o ex-presidente a termos pejorativos como "ladrão", "traidor" e "bandido". A narrativa da "traição", utilizada no primeiro caso, também está diretamente associada ao relato de "golpe", marca em exemplos anteriormente.

Ressaltamos, ainda, que o terceiro exemplo mencionado em que Lula é indicado como o "líder" da corrupção, o usuário comum usa recurso imagético-visual para creditar sua afirmação. O expediente utilizado era baseado em um vídeo em que o ex-presidente aparecia, primeiramente, de terno e gravata, sobreposto a uma fotografia do Congresso Nacional. Após essa imagem inicial as roupas de Lula eram trocadas (por recurso de programas de computador) por outras vestimentas com listras pretas e brancas - em alusão ao traje de presidiários - nas quais estavam impressos os dizeres: "No. 171"175. Ao final do vídeo uma grade surge à frente da foto de Lula simbolizando que o mesmo estaria ocupando uma cela na cadeia. A partir da Figura 40, a seguir, é possível analisar a primeira e a segunda imagem utilizada no vídeo descrito acima.

\footnotetext{
${ }^{175}$ De acordo com o Código Penal brasileiro (Decreto Lei no 2.848 de 07 de dezembro de 1940), o artigo 171 faz referência ao crime de estelionato no qual o acusado e/ou culpado pelo ato visa "obter, para si ou para outrem, vantagem ilícita, em prejuízo alheio, induzindo ou mantendo alguém em erro, mediante artifício, ardil, ou qualquer outro meio fraudulento.”. (BRASIL, 2017).
} 
Figura 40 - Imagem ilustrativa do vídeo que compõe o tweet do usuário comum ${ }^{176}$
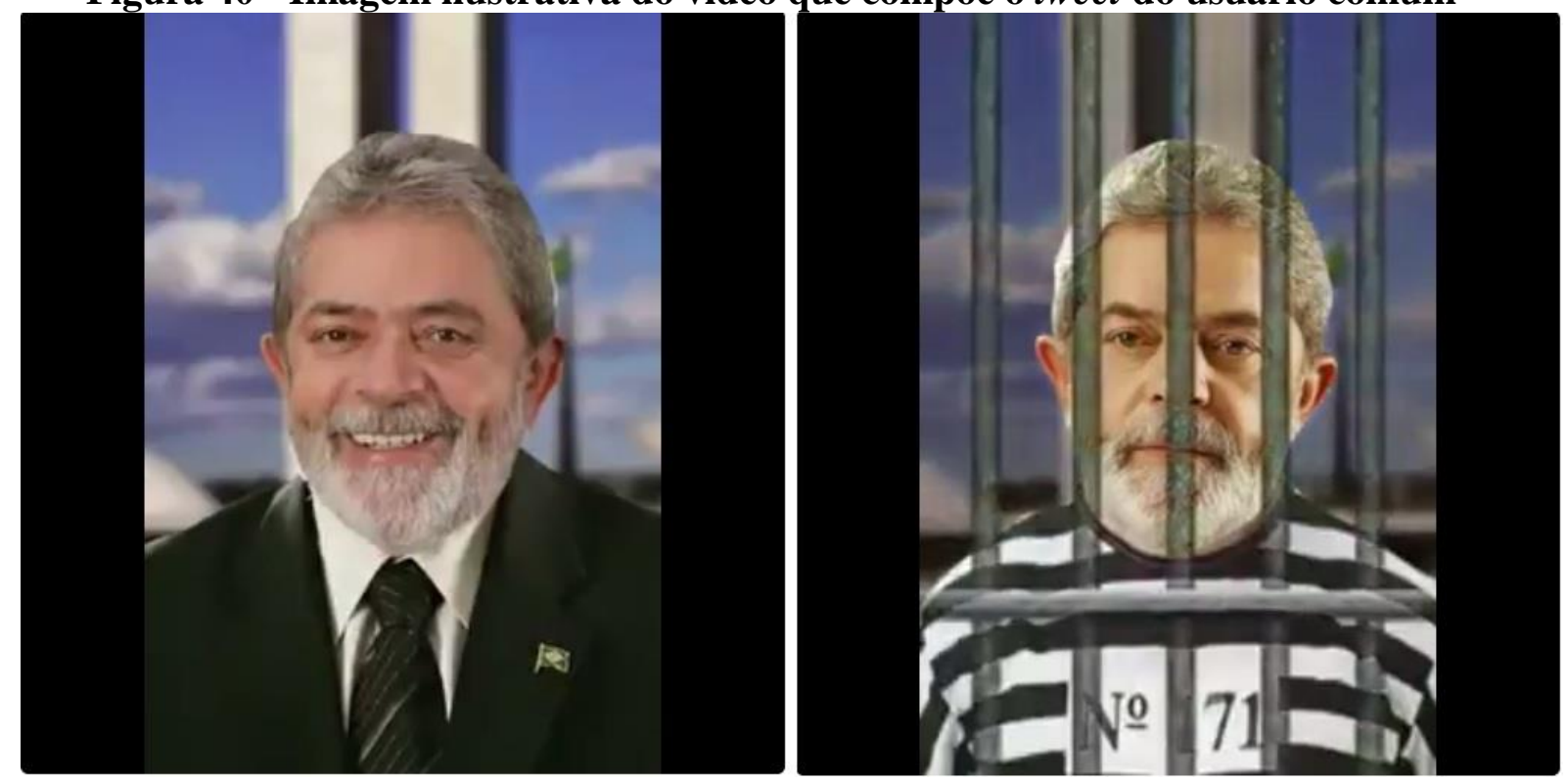

Ainda em relação aos tweets acima exemplificados é válido ressaltar que a terceira publicação foi realizada por um usuário comum que, em sua página no Twitter, apresentava como capa de seu perfil (a imagem escolhida para constar no topo de sua página pessoal no microblog) a fotografia de Sérgio Moro ao lado da frase "sua hora chegou, Lula" -, em que faz alusão à possibilidade de prisão do ex-presidente pela Operação Lava Jato, coordenada por Moro. Essa observação nos permite entender, novamente, a ideia de que as narrativas de desconstrução da imagem do ex-presidente foram postadas por usuários que já se apresentavam contrários a Lula também em seus perfis, ou seja, essa observação indica a presença de militância contrária ao ex-presidente e responsável pelos relatos com vistas a denegrir a imagem pública política do mesmo.

e) A quinta e última circunstância relativa às narrativas que buscaram desconstruir a imagem pública política de Lula pelo viés da corrupção tratou das manifestações sociais ocorridas no mês de março de 2016. É valido recordar que no Contexto 1, especificamente no dia 13 de março de 2016, ocorreram os atos públicos a favor do impeachment, enquanto no Contexto 2 foram realizados os protestos contra o golpe, que se concentraram principalmente no dia 18 de março de 2016. No tema específico observou-se a predominância de hashtags

\footnotetext{
${ }^{176}$ Por questões éticas a fonte da imagem, que se refere ao perfil no Twitter pertencente a um usuário comum, não foi divulgada.
} 
mobilizadoras como "\#vemprarua" e "\#vempraruabrasil"177, que foram utilizadas principalmente por usuários comuns para manifestação de posicionamento contrário a Lula no Twitter. A seguir é possível examinar três exemplos de postagens com uso das hashtags supracitadas:

1. Usuário comum. "Prendam Lula por roubo, incitação à desordem e ao vandalismo e porque ele é a maior ameaça ao país. \#VemPraRua”. 12 mar. 2016. Tweet.

2. Usuário comum. "Fora Dilma e que o ex-presidente seja preso pelo que ele fez. Prisão pro Lula. \#VemPraRuaBrasil”. 13 mar. 2016. Tweet.

3. Usuário comum. "Lula ladrão seu lugar é na prisão \#VemPraRuaBrasil". 13 mar. 2016. Tweet.

Essas mensagens nos permitem destacar a estratégia de utilização das palavras "ladrão", "prisão", "preso" e "roubo" como forma de desconstrução da imagem de Lula pelo viés da corrupção a partir do tema das manifestações sociais ocorridas, principalmente, no primeiro contexto de análise, em que ocorreram as manifestações a favor do impeachment de Dilma Rousseff.

Observamos, para além dessa estratégia, dois pontos importantes diretamente relacionados ao primeiro tweet acima exemplificado: o primeiro se refere à forma como o usuário comum responsável pelo tweet se apresenta no Twitter em sua bio, que era composta à época pela seguinte frase: “Anticomunismo: \#ForaPT \& \#ForoDeSãoPaulo. [...] \#Socialismo é merda.”. Essa apresentação reforça a observação realizada em temas anteriores quanto à predominância de uma militância contrária a Lula nas narrativas de ataque à imagem pública do ex-presidente.

O segundo ponto sobre o primeiro tweet diz respeito ao conteúdo no qual o usuário utiliza a ideia de que Lula seria “a maior ameaça do país”. Observa-se que, mais uma vez, Lula foi considerado a principal liderança no que diz respeito a escândalos de corrupção no Brasil, assim como exemplificado no tweet em que o usuário comum, na temática sobre a Operação Lava Jato, afirma que o ex-presidente é o "chefão" dos corruptos. Atente-se para o fato de que, ao

\footnotetext{
177 Nota-se que ambas as hashtags fazem referência ao "Vem pra Rua", um dos principais grupos organizadores das manifestações sociais a favor do impeachment.
} 
considerar Lula "a maior ameaça ao país” o usuário comum também utiliza a narrativa de golpe ou traição que foi observada em assuntos anteriormente analisados.

Essa estratégia de recorrência à ideia de que Lula seria responsável por um golpe, uma traição, um plano ou uma ameaça, predominantemente percebida durante a análise da narrativa de desconstrução da imagem pública do ex-presidente pelo viés da corrupção, nos permite fazer dois apontamentos relevantes: o primeiro deles diz respeito à estratégia - utilizada pelos detratores da imagem pública de Lula no período analisado - de ressignificar a narrativa do golpe que, como visto na contextualização realizada no terceiro capítulo, foi legitimada por manifestantes, intelectuais, jornalistas, formadores de opinião e lideranças políticas contrárias ao processo de impeachment de Dilma Rousseff, bem como por apoiadores de Lula. No entanto as mensagens exemplificadas acima mostram que os usuários do Twitter que recorreram a ações visando desconstruir a imagem pública do ex-presidente sob o viés da corrupção buscaram utilizar a narrativa do golpe de forma a transformá-la em principal estratégia no processo de desqualificação da figura de Lula.

O segundo apontamento que devemos ressaltar relaciona-se ao significativo impacto da narrativa da conspiração nos tweets que buscaram desconstruir a imagem pública de Lula pela temática da corrupção. Ressaltamos, no entanto, que essa conspiração, pelo entendimento dos usuários do Twitter que recorreram a tal relato, era orquestrada e comandada por Lula e não contra ele; assim, o ex-presidente foi constantemente retratado como golpista e traidor da nação, sendo, portanto, a principal ameaça ao Brasil. A recorrência à narrativa da conspiração foi utilizada, portanto, não de forma a enaltecer Lula enquanto mito político, mas, sim, de forma a infamar sua imagem pública diante dos escândalos de corrupção em que ele estaria envolvido.

\subsubsection{O fim do salvador: o "impeachment de Lula"}

A partir da análise dos termos mais mencionados nos quatro contextos da pesquisa empírica, observamos que a segunda narrativa de desconstrução da imagem pública política de Lula mais predominante nos tweets analisados diz respeito ao que nomeamos como o “impeachment de Lula". Esse relato foi usado como forma de associar o impeachment sofrido por Dilma em 2016 com a destruição da carreira política Lula, ou seja, como se o afastamento de Rousseff da Presidência do Brasil fosse, na verdade, uma derrota para o ex-presidente.

Sobre essa observação torna-se importante ressaltar, como visto no terceiro capítulo, que as estratégias de construção da imagem pública de Dilma a partir dos pleitos eleitorais tanto de 2010 como de 2014 ocorreram no sentido de unir a imagem de Lula à da então candidata à 
sucessão de seu governo a partir da transferência de prestígio eleitoral conquistado pelo expresidente durante seus dois mandatos. Dessa forma, durante o Horário Gratuito de Propaganda Eleitoral (HGPE) de Dilma - em ambas as campanhas - a principal tática na construção da imagem pública da candidata foi ressaltar a ideia de que quem votasse em Dilma estaria votando em Lula - ou seja, o ethos institucional de Lula foi utilizado como principal estratégia discursiva durante as empreitadas eleitorais de Dilma Rousseff.

Constatamos, no entanto, que as mensagens publicadas no Twitter durante o período de análise da presente pesquisa empírica nos levam a concluir que a utilização da narrativa "Dilma é igual a Lula" - utilizada como estratégia eleitoral pelo PT - foi empregada como forma de desconstrução da imagem pública do ex-presidente no sentido de afirmar que Lula seria tão responsável pela crise no país quanto Dilma, por ter apadrinhado a candidatura dela, e, por conseguinte, ter tido forte influência no governo da presidenta.

Ressalta-se que o modelo de discurso do "impeachment de Lula" foi observado em todos os quatro contextos de análise. Termos como "enterrado", "destruição", "acabou”, "derrota”, "humilhante" e "despedida" foram os mais mencionados pelos usuários que utilizaram essa narrativa, bem como as hashtags "\#impeachmentday" ("dia do impeachment") que liderou os trending topics mundiais (assuntos mais comentados no Twitter no mundo) no dia 17 de abril de 2016, data da votação na Câmara dos Deputados; e "\#tchauquerida", hashtag criada a partir de uma fala de Lula proferida durante a conversa telefônica com Dilma divulgada em março de 2016 - na ocasião da conversa o ex-presidente se despediu de Dilma dizendo "Tchau, querida" e desde então os apoiadores do impeachment de Rousseff passaram a utilizar a hashtag como forma de afirmação de seu posicionamento político favorável ao processo de afastamento da então presidente do Brasil.

Um episódio importante pautou a utilização da narrativa do "impeachment de Lula", qual seja: as votações do processo de impeachment na Câmara dos Deputados e no Senado, ocorridas, respectivamente, no Contexto 3 e no Contex to 4. A partir desses episódios, três temas foram mencionados: a) a "morte" da carreira política de Lula; b) o fim de Lula como herói; c) e a superação do governo populista do ex-presidente. A seguir detalharemos como foram tratados tanto o episódio principal como os temas que surgiram em decorrência dele.

Em relação ao episódio sobre as votações do processo de impeachment de Dilma na Câmara dos Deputados (Contexto 3, em 17 de abril de 2016) e no Senado (durante o Contexto 4, em 12 de maio de 2016) e o consequente afastamento de Dilma do cargo da Presidência da república pelo período inicial de 180 dias, houve predominância de tweets publicados por perfis 
de veículos jornalísticos que faziam a cobertura desses acontecimentos. A seguir podem-se observar três exemplos dessas narrativas:

1. Blog O Antagonista. (@o_antagonista). "Lula não vai escapar" -
https://t.co/4Qc0X15Pr0”. 17 abr. 2016. Tweet.

A partir desse tweet publicado em $\mathrm{O}$ Antagonista, nota-se novamente o apelo textual utilizado por esse blog no sentido de publicar argumento imperativo e representativo na desconstrução da imagem pública política de Lula. A frase "Lula não vai escapar" fazia referência à possibilidade de prisão dele e era título de matéria completa publicada no mesmo blog em 17 de abril de 2016, data da votação do processo de impeachment na Câmara dos Deputados (a matéria poderia ser acessada pela URL “https://t.co/4Qc0X15Pr0", parte do tweet citado).

Em tal publicação os jornalistas basearam o argumento da prisão de Lula após depoimento do ex-deputado Roberto Jefferson, no qual ele teria afirmado que, com o impeachment de Dilma (processo sobre o qual o blog O Antagonista se refere como o "fim de Dilma"), Lula não conseguiria mais escapar e seria preso. Ao final da matéria os jornalistas afirmaram, ainda, que o ex-deputado estava sendo constantemente parabenizado por tal afirmação. (LULA..., 2016). Necessário pontuar que, como visto na análise de redes sociais, o perfil de Jefferson foi extremamente influente em grupos com posicionamento detrator em relação a Lula, como os Clusters 3, 12 e 16. O perfil de Roberto Jefferson foi, também, um dos termos mais citados tanto no Contex to 3 como no Contexto 4.

2. Folha de S. Paulo (@folha).“'Eu vou pra casa', diz Lula, abatido após Dilma deixar o Planalto http://uol.com/bfjL1P .”. 12 mai. 2016. Tweet.

Necessário ressaltar em relação ao tweet acima exemplificado que o perfil do jornal Folha de S. Paulo foi observado entre os 20 com maior número de menções tanto no Contexto 1 (sétimo perfil mais mencionado), como no Contexto 2 (quinto perfil com maior número de menções) e Contexto 3 (o segundo mais mencionado, atrás apenas do perfil oficial de Dilma Rousseff no Twitter), além disso foi um dos termos (@folha) mais citados em todos os quatro contextos analisados. Tal constatação reforça a influência do jornal na circulação de narrativas no Twitter no período analisado. 
Observa-se, a partir do tweet publicado pelo jornal, três estratégias de desconstrução da imagem pública de Lula: 1) uma delas foi a de utilizar o termo "abatido" como forma de depreciar o estado em que se encontrava o ex-presidente Lula durante a votação no Senado Federal para abertura do processo de impeachment e consequente afastamento de Dilma; 2) outra diz respeito à frase "eu vou para casa", que teria sido dita por Lula na ocasião do afastamento de Dilma da Presidência. A reprodução dessa frase pelo jornal demonstra claramente a narrativa de desconstrução da imagem do ex-presidente pelo "impeachment de Lula", já que ele estaria se afastando do Planalto junto com Dilma; c) a terceira estratégia está relacionada à utilização da palavra "Planalto" como referência ao lugar que não é mais habitado por Lula e Dilma; essa tática é significativa no sentido de utilizar o Palácio do Planalto como simbologia de detenção de poder ou um "lugar de poder", ou seja, de acordo com o jornal, quem era afastado do "Planalto", no caso Lula e Dilma, não mais possuía a característica de liderança política.

Nesse tweet a Folha utilizou, ainda, a estratégia imagético-visual (como foi observado nos tweets das revistas Veja e Época já analisados) para dar credibilidade ao seu conteúdo textual. Como é possível verificar na imagem que compõe tal tweet (Figura 41), Lula foi retratado com semblante triste e abatido ao ser acolhido por simpatizantes na área externa do Planalto. Ao final do tweet há uma URL (http://uol.com/bfjL1P) que direciona o leitor para a matéria completa do jornal publicada no portal de notícias online da Folha e intitulada “'Eu vou pra casa', diz Lula, abatido após Dilma deixar o Planalto”.

\section{Figura 41 - Imagem que compõe o tweet do jornal Folha de S. Paulo}

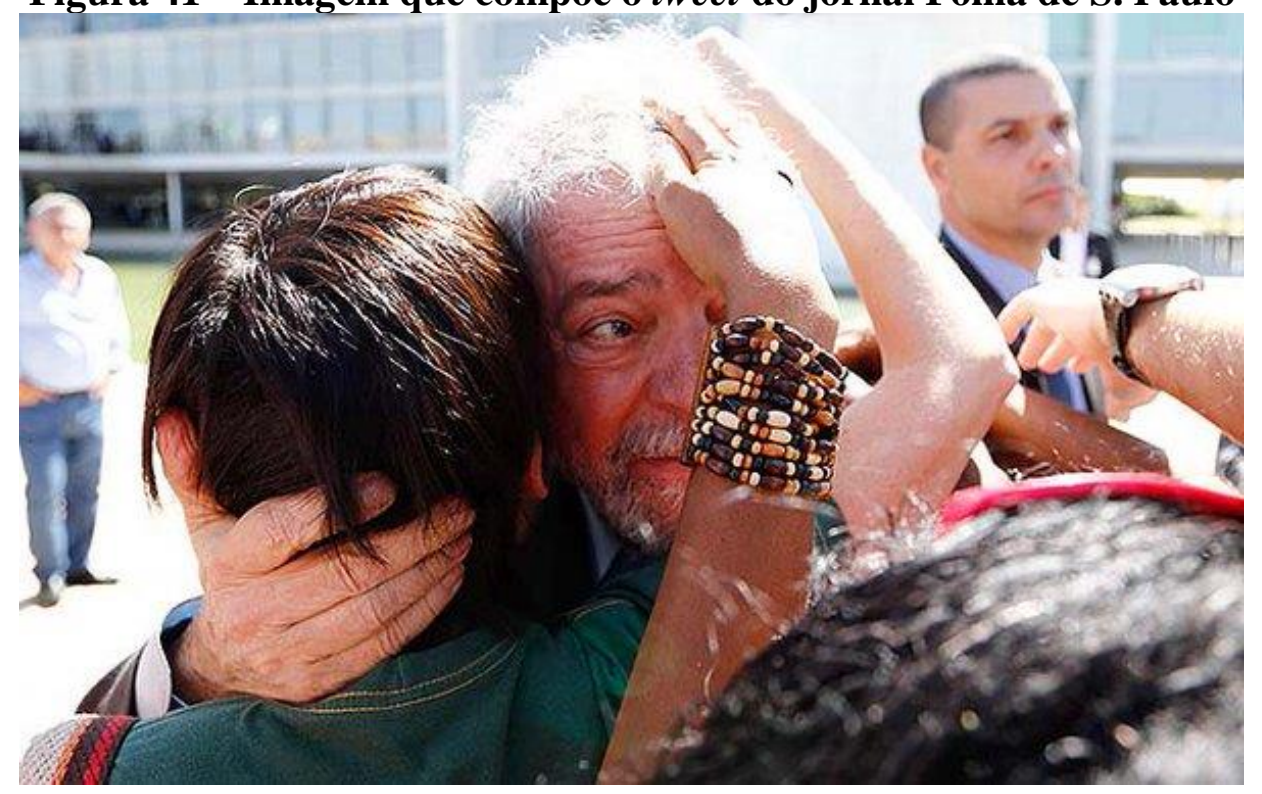

Fonte: Folha, 2016. 
3. Uol Notícias (@uolnoticias). "Emocionados, Dilma e Lula se abraçaram após afastamento http://bit.ly/27kN2iZ “. 13 mai. 2016. Tweet.

Como se pode ver, da mesma forma que a Folha de S. Paulo utilizou o termo "abatido" no tweet citado anteriormente como forma de depreciar a imagem pública de Lula, o portal de notícias online Uol Notícias empregou o termo "emocionado" para simbolizar que Lula, assim como Dilma, estava triste ou desapontado com o resultado da votação na Câmara dos Deputados ocorrida em 12 de maio de 2016. Percebe-se, também, que o portal Uol optou pelo termo "afastamento" em relação tanto a Dilma quanto a Lula, já que, no conteúdo do tweet, não é especificado qual dos dois estaria sendo afastado.

O Uol Notícias também usou o recurso imagético-visual para corroborar com o texto "Emocionados, Dilma e Lula se abraçaram após afastamento", publicado no tweet. A imagem utilizada nessa publicação, que pode ser observada na Figura 42, retrata Lula e Dilma se abraçando entre um grupo de pessoas. Interessante observar que o abraço entre as duas figuras políticas, assim como na imagem verificada no tweet da Folha de S. Paulo, foi retratado na área externa do Palácio do Planalto. O deslocamento imagético-visual para o exterior do Planalto simboliza o "afastamento" ou a retirada de Lula e Dilma do "lugar de poder" e contribui para deslegitimar a imagem pública dos mesmos enquanto lideranças políticas.

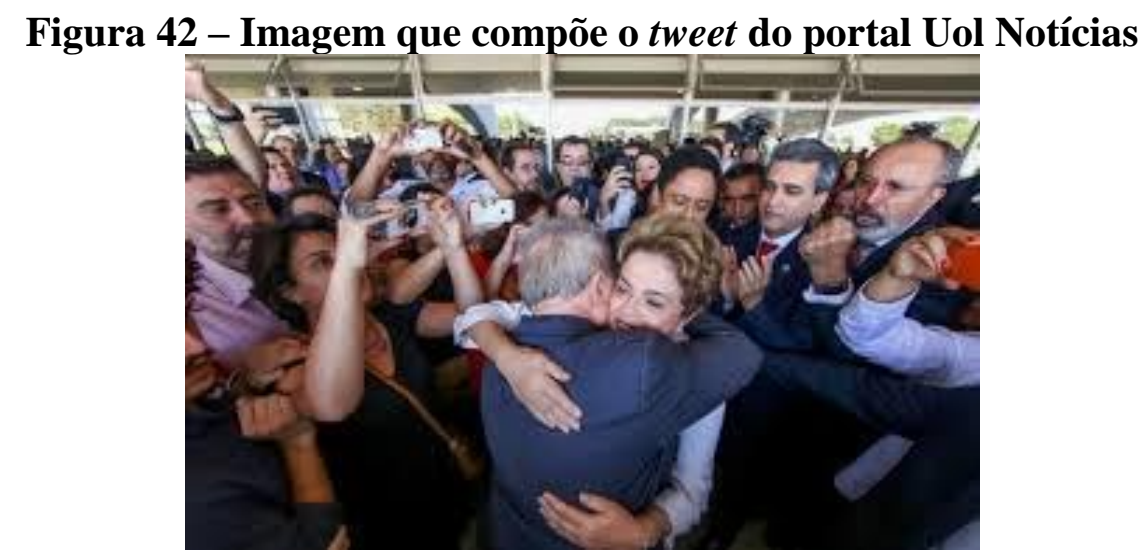

Fonte: UOL, 2016.

Feita a análise sobre as votações do processo de impeachment na Câmara dos Deputados e no Senado Federal, discorreremos a seguir sobre os três temas mencionados pelos usuários do Twitter no período investigado a partir desse episódio. 
a) Em relação à temática sobre a "morte" da carreira política de Lula, observou-se a presença de tweets publicados por formadores de opinião e usuários comuns. A seguir analisaremos essas publicações.

1. Lobão. (@lobaoeletrico). “LULA ESTÁ MORTO POLITICAMENTE. PRENDAM ESSE SALAFRÁRIO O QUANTO ANTES!”. 17 mar. 2016. Tweet.

Observa-se que o tweet, publicado durante o segundo contexto de análise - um dia após o anúncio oficial de Dilma sobre a nomeação de Lula para o cargo de ministro da Casa Civil e depois da divulgação do áudio das conversas telefônicas entre os dois -, no qual Lobão se posiciona claramente contrário a Lula ao referir-se ao ex-presidente como "salafrário", faz referência a um sujeito imoral ou desonesto, além de exigir a prisão dele. No tweet o formador de opinião busca desconstruir a imagem pública de Lula empregando a estratégia discursiva do fim da atuação política do ex-presidente ao usar a frase "Lula está morto politicamente".

Ressaltamos que, como visto na análise de rede sociais, o perfil de Lobão no Twitter foi encontrado entre os mais influentes, tanto no Cluster 9 (dentro do Contexto 2, sobre as manifestações sociais contra o impeachment), quanto no Cluster 12 (Contexto 3, relacionado à votação na Câmara dos Deputados e resultado favorável pela continuação do processo de impeachment) - por esses grupos circulavam relatos de desconstrução da imagem pública de Lula. Soma-se a essa análise o fato de o perfil de Lobão ter sido classificado como décimo nó com maior número de menções no Contexto 2, sendo também o sétimo nó com mais referências no Contexto 3. Pontuamos, ainda, que o termo “@lobaoeletrico” foi qualificado entre os mais aludidos no Contexto 2 e no Contexto 3. Todas essas observações contribuem para se ter uma ideia da grande influência das narrativas de Lobão no Twitter nos contextos analisados.

2. Usuário comum. " 17 de abril de 2016, na data de hoje, morre politicamente, Luiz Inácio Lula da Silva. Acabou a era das trevas desse bandido. Parabéns!!!”. 17 abr. 2016. Tweet.

3. Usuário Comum. “\#ImpeachmentDay 367 votos provaram que Lula tá morto, falta só enterrar. Tchau, querida!”. 17 abr. 2016. Tweet.

Nos dois tweets acima exemplificados a estratégia discursiva de desconstrução da imagem pública política de Lula também foi utilizada no sentido da "morte política" do expresidente. Dessa forma, as afirmações: “na data de hoje morre politicamente Luiz Inácio Lula 
da Silva" - em alusão ao dia 17 de abril de 2016, quando houve votação na Câmara com resultado favorável à continuação do processo de impeachment - e "Lula está morto", utilizadas pelos usuários em suas publicações, demonstram consonância com a narrativa utilizada por Lobão para destacar que Lula estaria "morto" politicamente.

Ressaltamos que o segundo tweet acima citado foi publicado por um usuário comum que, em sua página no Twitter enfatizou como sendo sua bio a frase "Acabamos com o PT ou eles acabam com o Brasil". Essa apresentação reforça a interpretação realizada em temas anteriores em relação à predominância de militância contrária a Lula nas narrativas de desconstrução da imagem pública do ex-presidente.

4. Azevedo, Reinaldo. (@reinaldoazevedo). "Lula sofre a derrota mais humilhante de sua carreira e deve ser enterrado junto com Dilma https://t.co/zxx01j2Goi”. 18 abr. 2016. Tweet.

No tweet acima Reinaldo Azevedo - cujo perfil foi classificado como um dos 10 principais no Cluster 2, que reúne narrativas contrárias a Lula - utiliza os termos "derrota" e "humilhante" como estratégia para denegrir a imagem pública política de Lula ao afirmar que ele teria sofrido a pior derrota de sua carreira - nota-se que o termo "enterrado" também faz referência à narrativa da "morte" da carreira política de Lula utilizada nos tweets anteriormente exemplificados.

Ao final desse tweet a URL (https://t.co/zxx0lj2Goi) direciona o usuário do Twitter para a matéria completa "Lula sofre a derrota mais humilhante de sua carreira e deve ser enterrado junto com Dilma”, publicada no blog de Reinaldo de Azevedo, vinculado à revista Veja. Na matéria Azevedo destaca: “o grande derrotado da votação deste domingo (17 de abril de 2016), quando a Câmara autorizou o Senado a abrir o processo de impeachment por 367 votos a 137, chama-se Luiz Inácio Lula da Silva.”. (AZEVEDO, 2016). Essa afirmação é bastante significativa no que diz respeito à tática de prejudicar a imagem de Lula a partir da centralidade do mesmo diante do processo de impeachment. Sendo assim, Azevedo utilizou a estratégia de transformar Lula no protagonista do contexto em questão para que ele se tornasse figura central da situação de crise política.

Necessário ressaltar, ainda, que o perfil “@reinaldoazevedo” foi classificado entre os mais citados no Contexto 3, o que demonstra importância significativa da narrativa publicada por esse formador de opinião.

A partir das análises acima elaboradas em relação ao resultado das votações do processo de impeachment na Câmara e no Senado e principalmente à temática do fim da carreira de Lula, 
torna-se necessário relembrar a pesquisa sobre intenção de voto para a eleição presidencial de 2018 no Brasil, realizada pelo Instituto DataFolha e divulgada em 11 de abril de 2016 sobre a qual discorremos na introdução da presente tese. Na pesquisa em questão Lula foi o candidato mais citado. (DATAFOLHA, 2016b). O resultado dessa sondagem nos permite inferir que houve estratégia discursiva utilizada tanto pelos veículos jornalísticos hegemônicos quanto pelos principais formadores de opinião opositores a Lula no sentido de criar a narrativa da suposta "morte" política do ex-presidente com vistas a contradizer ou mesmo silenciar o resultado da pesquisa apresentada pelo DataFolha que, como demonstrado, reforçava não o fim da carreira de Lula, mas, sim, ascensão da imagem pública do ex-presidente enquanto liderança política no eleitorado brasileiro em 2016.

b) No segundo tema que dizia respeito ao fim de Lula como herói observou-se predominância de tweets publicados por usuários comuns. A seguir discorreremos sobre três exemplos dessas publicações:

1. Usuário comum. "LULA DE HERÓI NACIONAL A VERGONHA MUNDIAL \#ForaDilma". 18 mar. 2016. Tweet.

2. Usuário comum. "Que Vergonha, Lula. Vc tinha tudo pra ser um Grande líder, um Estadista pra ficar na nossa história como herói, não como um molusco corrupto". 18 mar. 2016. Tweet.

3. Usuário comum. "Lula que em 2002 era herói, hoje se corrompeu e é apenas mais um ladrão". 12 mai. 2016. Tweet.

Vê-se que os usuários buscaram desconstruir a representação pública de Lula a partir da ideia de que essa imagem teria passado por um processo de transformação ao longo do tempo. Essa modificação - ou ressignificação - teria feito com que ele deixasse de ser visto como herói para ser percebido como alguém inferior, desqualificado. Nota-se que essa ressignificação é feita de maneira contraditória já que, ao mesmo tempo em que os usuários admitem o heroísmo de Lula (ou a possibilidade de concretude desse heroísmo), ou seja, constroem a imagem do expresidente de forma positiva, buscam no contexto da crise política de 2016 elementos que justifiquem a desconstrução dessa imagem. Há, portanto, tentativa de diferenciação entre o Lula do passado (herói nacional, grande líder, estadista) e o Lula do presente (corrupto, ladrão). 
No primeiro tweet a estratégia do usuário para ilustrar essa diferenciação foi a de utilizar comparação entre a "antiga" imagem de Lula - herói nacional - e a "atual" - "vergonha mundial". Já no segundo caso, o responsável pela publicação utilizou o argumento "você [Lula] tinha tudo [...] para ficar na nossa história como herói” como estratégia de diferenciação entre um suposto potencial da imagem pública de Lula - no passado -, mas deixou de ter - no presente. O usuário utiliza, ainda, o termo "molusco" como depreciativo da imagem do expresidente, o que se torna simbólico no sentido de compreender a imagem dele como um animal, ou seja, um ser irracional - ou até mesmo inferior.

No terceiro tweet a estratégia utilizada para a diferenciação entre presente e passado pauta-se em datas específicas, já que o usuário afirma que em 2002 Lula teria conquistado o status de herói - ao se eleger presidente do Brasil -, mas com o decorrer do tempo passou a se corromper, o que contribuiu para a desconstrução de sua imagem.

c) $\mathrm{O}$ terceiro tema relacionado à narrativa do "impeachment de Lula" tinha como principal estratégia associar a imagem do ex-presidente à de um político populista. A partir dessa observação se faz necessário esclarecer, de antemão, alguns apontamentos sobre o conceito de populismo que já foi amplamente discutido e explorado por historiadores, sociólogos e cientistas políticos, mas a definição e delimitação não são unânimes dentre as teorias que buscam compreendê-lo. Pontuamos, ainda, que há diferenciação na forma como o populismo - ou o político populista - é compreendido, pois muita das vezes usa-se esse termo de forma pejorativa, como foi observado nas narrativas empregadas pelos usuários do Twitter no período analisado.

Mitre (2008) discorre que o termo populismo foi primeiramente utilizado na Rússia no século XIX por meio de ideais socialistas na tentativa de implantação de uma democracia camponesa. Já no século XX ele se referia a um projeto político que "propunha o incentivo à pequena agricultura através de uma política econômica que favorecesse a expansão da base monetária e o crédito.”. (CAPELATO, 2013, p. 58).

Após a década de 1930 o termo passou a ganhar força na América Latina em função de três circunstâncias políticas, quais sejam: o governo de Lázaro Cárdenas ou "cardenismo" no México (1934-1940), o de Getúlio Vargas ou “varguismo” no Brasil (1930-1945 e 1950-1954) e o de Perón ou "peronismo" argentino (1946-1955). (CAPELATO, 2013). Importante que se saiba que houve inúmeros aspectos diferentes no comparativo entre os três governos que serviram de base para a construção do conceito de populismo latino-americano - o que faz com que sua compreensão seja questionada por generalizar experiências diversas como sendo 
comparáveis ou mesmo igualáveis -, no entanto Capelato (2013) aponta algumas características comuns entre os três governos supracitados:

\footnotetext{
1) projeto de modernização do país baseado num Estado intervencionista e promotor do desenvolvimento econômico com ênfase na industrialização; 2) presença de um líder político carismático que conquista o apoio das massas; preocupação com a questão social e formulação de leis trabalhistas. (CAPELATO, 2013, p. 58).
}

Capelato (2013) explica que a construção do conceito de populismo baseado nessas experiências se deu a partir da década de 1950 pelos sociólogos argentinos (de origem italiana) Gino Germani e Torquato di Tella e da teoria da modernização dos Estados, segundo a qual o populismo teria surgido "num contexto de migração dos trabalhadores do campo para a cidade como fruto da transição de uma sociedade tradicional para uma sociedade moderna" (CAPELATO, 2013, p. 59). Essa migração dos trabalhadores rurais para a cidade teria gerado a massa populacional designada como "classe trabalhadora" e eles "careciam de experiência de luta política organizada e não tinham consciência de seus direitos e deveres, [o que] tornava-os vulneráveis à manipulação dos líderes carismáticos”. (CAPELATO, 2013, p. 59). A ideia da presença do líder carismático e da suposta manipulação da classe trabalhadora contribuiu para que o termo "populismo" passasse a designar formas de governo contrárias ao bom funcionamento das instituições e da democracia - transmitindo assim um caráter pejorativo ao conceito.

No Brasil o termo populismo passou a ser explorado, em primeira instância, por um conjunto de intelectuais intitulado "Grupo Itatiaia"178, bem como pelo cientista político Francisco Weffort e pelo sociólogo Otaviano Ianni. Influenciados pela teoria da modernização apresentada por Germani e di Tella, esses intelectuais formularam as primeiras teorias sobre a ocorrência do populismo na política brasileira a partir da década de 1950 (CAPELATO, 2013).

De acordo com Ferreira (2001), a construção do conceito de populismo na política brasileira deve ser compreendida a partir de três fases principais: 1) o populismo de primeira geração (entre 1950 e 1960), no qual prevaleceram as ideias e formulações do conceito apresentadas pelo "Grupo Itatiaia" e por Francisco Weffort, que o compreendiam como "uma política de massas voltada para trabalhadores que migraram do campo para a cidade e que desconheciam as formas de organização e prática política do 'proletariado' urbano"

\footnotetext{
${ }^{178} \mathrm{O}$ "Grupo Itatiaia" foi formado em 1952 e tinha como objetivo "discutir os problemas políticos, econômicos e sociais relacionados ao desenvolvimento do país" (CAPELATO, 2013, p. 60) durante reuniões que ocorriam em Itatiaia (município do estado Rio de Janeiro). Dentre os principais intelectuais que compunham o grupo se destacavam os sociólogos Hélio Jaguaribe e Guerreiro Ramos. (CAPELATO, 2013).
} 
(CAPELATO, 2013, p. 59) e que deveria ser (a política) combatida ou superada. A pesquisadora reforça que, em resumo, a construção do conceito do populismo no Brasil na primeira etapa ou fase clássica - foi baseada em três aspectos principais: "um proletariado sem consciência de classe, uma classe dirigente em crise de hegemonia e um líder carismático manipulador das massas". (CAPELATO, 2013, p. 59);

2) no populismo de segunda geração (ocorrido durante a transição da década de 1970 e 1980) as ideias apresentadas principalmente por Weffort, tais como a repressão estatal e a manipulação política, permaneceram como base teórica. Ferreira (2001, p. 121) chama atenção para a importância da imprensa, dos militares, da direita civil, da Igreja e das classes médias conservadoras para a construção do conceito de populismo a começar dessa segunda fase. Essas considerações se apoiam também em outros estudiosos. Capelato (2013) e Anjos (2012) destacam os estudos publicados por Otaviano Ianni como uma das referências fundamentais para a constituição do conceito de populismo entre os anos de 1954 e 1964 - com ênfase no período histórico da política brasileira que antecedeu o golpe militar de 1964. Já Reis Filho (2001, p. 349) assinala que a segunda etapa de construção do conceito de populismo no Brasil contribuiu em grande medida "para formar uma corrente de interpretação da República contemporânea brasileira que ainda hoje é largamente hegemônica nos meios acadêmicos e políticos". Para ele, a preeminência do sentido do "populismo" tem como principal característica o "apagamento da memória da tradição trabalhista" (REIS FILHO, 2001, p. 349).

3) a terceira fase da construção do conceito de populismo, de acordo com Ferreira (2001), seria o próprio colapso do populismo ocorrido na década de 1980 a partir da tentativa de compreensão dos governos latino-americanos considerados "populistas" sob outros vieses que não a limitação atribuída ao conceito pelas duas etapas anteriores. Na percepção desse pesquisador, a problemática da utilização do termo populismo para designar um conjunto variável de governos - tanto de direita como de esquerda - se dá a partir do momento em que "populista" é sempre uma designação do outro, inferiorizado, desvalorizado, sem credibilidade. Sendo assim, Ferreira (2001, p. 124) esclarece que "o populista, portanto, é o adversário, o concorrente, o desafeto. O populista é o outro.”. Ainda de acordo com esse autor, tal designação pejorativa de governos ditos "populistas" partiu de uma construção conceitual elitista e depreciativa das classes trabalhadoras, o que nos leva a entender que o conceito de populismo não deve ser utilizado como meio de compreensão ou análise das circunstâncias políticas modernas por ser limitador e equivocado.

Esta investigação recorre ainda a Ernesto Laclau (2013), que a partir da obra $A$ Razão Populista, se tornou uma das referências para a compreensão do populismo de forma positiva 
- ao invés de negar a existência do conceito, como propôs Ferreira (2001). A proposta apresentada por Laclau (2013) visa compreender o populismo como formação de identidades coletivas sob as quais o povo se torna protagonista de ações contrárias às estruturas elitistas e dominantes pré-estabelecidas. Portanto, para Laclau o populismo (2013) é a própria lógica política ou o ato político que "assegura o 'bem-estar' ou defesa dos interesses do povo, emergindo quando a classe, ou 'demanda', se opõe ao bloco de poder dominante". (ANJOS, 2012, p. 90).

Observa-se, então, que o termo possui imprecisas definições e, como bem aponta Capelato (2013, p. 63), "a construção de tipologias que procuraram agregar formas distintas do fenômeno e agrupá-las em categorias deram conta das historicidades dessas experiências". Nota-se, entretanto, que algumas características sobressaltam sobre as perspectivas analisadas, quais sejam: o povo, as classes trabalhadoras e o líder carismático.

Ambas as características contribuíram em grande medida para a predominância do sentido pejorativo do termo "populismo" até os dias atuais. Capelato (2013) avança a discussão sobre o sentido desfavorável do termo a partir de análises sobre como a mídia brasileira passou a definir governos "populistas". Sobre as análises em questão Capelato (2013) reforça que os meios de comunicação no país durante a década de 1940 utilizavam o sentido de populismo/populismo de forma positiva, como sinônimo de "popular", mas desde as décadas de 1950 e 1960 passaram a ser empregados como forma de depreciar o governo de Getúlio Vargas e, portanto, a serem usados de forma "fortemente pejorativa porque se transformou em arma de luta política" (CAPELATO, 2013, p. 66) entre imprensa e governo.

Mais recentemente governos latino-americanos considerados de esquerda passaram a ser intitulados como populistas - tais como o de Fidel Castro, ex-presidente de Cuba; o de Hugo Chávez, ex-presidente da Venezuela; de Cristina Kirchner, ex-presidente da Argentina, bem como o de Lula, no Brasil - seja pela imprensa, por intelectuais opositores a esses governos ou pelos próprios cidadãos. A classificação ou categorização desses variados tipos de governos como "populistas" reflete a vagueza do conceito, já que busca compreender contextos políticos imensamente complexos a partir de um padrão pré-estabelecido de análise, ou seja, faz com que todos os governos supracitados - entre outros - se tornem semelhantes, sendo que, cada um, apresenta inúmeras divergências estruturais ${ }^{179}$.

\footnotetext{
${ }^{179} \mathrm{~A}$ título de exemplificação em relação a essas diferenças pontuamos que Fidel Castro estabeleceu uma ditadura em Cuba, fato que fez com que seu governo tenha sido extremamente divergente - e oposto - daqueles estabelecidos por Chávez, Correa, Kirchner e Lula em seus países.
} 
Especificamente em relação ao governo Lula, Pires e Castro (2014) ao buscarem compreender como a imprensa brasileira - especificamente editorialistas e colunistas do jornal Folha de S. Paulo ${ }^{180}$ - passou a utilizar o termo "populista" como forma de depreciar a gestão do ex-presidente elaboraram importantes apontamentos sobre essa questão. Um dos principais fatores identificados na análise elaborada por Pires e Castro (2014) aponta que o surgimento do termo "lulismo" (que, como visto no terceiro capítulo desta tese, nasceu no decorrer das eleições de 2006) contribuiu para que junto com "populismo" eles fossem enquadrados, noticiosamente, como semelhantes - como se vê, houve uma ressignificação do termo "lulismo" para que ele passasse a ser compreendido de forma pejorativa.

Esse novo significado de lulismo se deu, predominantemente, a partir das características populares do governo de Lula - criticadas pela imprensa -, tais como as políticas de redistribuição de renda e assistência às camadas mais pobres do país, o carisma intrínseco à figura do ex-presidente e o forte apelo de aproximação com o "povo", particularidades presentes em seus discursos desde a época sindical e intensificadas a partir da eleição de 2002. Sendo assim, o "lulismo" - ressignificado como "populismo" pela imprensa e igualmente por formadores de opinião opositores aos governos de Lula - passou a designar "um fenômeno que se caracteriza por uma política de massas, um estilo de governo que se assenta na manipulação e na tutela estatal dos trabalhadores" (PIRES; CASTRO, 2014, p. 29).

Feita a contextualização da construção pejorativa do termo "populismo", pontuamos que a narrativa depreciativa da imagem pública de Lula que tinha por objetivo associar a imagem do ex-presidente à de um político populista observada no Twitter durante os quatro contextos de análise foi encontrada, sobretudo, em dois grupos de palavras: a) o primeiro foi formado por conceitos como "socialismo", “chavismo", “esquerda", além do próprio "populismo". Esses termos aparecem, especialmente, nos Contextos 3 e 4, nos quais ocorreram as votações na Câmara dos Deputados e no Senado sobre o impeachment de Dilma Rousseff; b) o segundo grupo foi composto pelo nome de figuras políticas latino-americanas como Nicolás Maduro (Venezuela), Cristina Kirchner (Argentina), Fidel Castro (Cuba) e Hugo Chávez (Venezuela). Essas palavras foram mencionadas com frequência, sobretudo no Contexto 4, em que houve a votação no Senado para a abertura do processo de impeachment de Dilma e o afastamento dela do cargo. Em ambos os grupos foram observados tweets postados por usuários comuns e por formadores de opinião. Discorreremos sobre essas narrativas a seguir:

\footnotetext{
${ }^{180}$ Nesse estudo Pires e Castro (2014) analisaram editoriais e colunas publicados pela Folha de S. Paulo durante as campanhas eleitorais de 2006 e 2010.
} 
1. Usuário comum. "A História mostra que os "salvadores da pátria" não são solução: Fidel, Chávez, Maduro, Lula, Perón...”. 12 mai. 2016. Tweet.

Nesse tweet o usuário utiliza a expressão "salvadores da pátria" entre aspas, de maneira a associar essa condição (do político como salvador) de modo pejorativo, ou seja, tais atores políticos são nomeados ou reconhecidos como "salvadores", mas, de acordo com o usuário comum, não possuem atitudes que justifiquem tal atribuição. Para corroborar com essa afirmação o usuário utiliza, ainda, a defesa de que tais políticos vistos como "salvadores" não teriam sido solução durante o curso da história; e exemplifica essa declaração com nomes como Fidel Castro, Hugo Chávez, Nicolás Maduro, Juan Domingo Perón (Argentina) e Lula.

Importante pontuar que o termo "história" foi utilizado pelo usuário para expressar o passado como exemplificação para o tempo presente. Esse recurso é chamado por Capelato (2013, p. 69) de "usos políticos do passado" que "nunca são inocentes e deformam a história". Ainda de acordo com a autora, essa utilização errônea do passado como forma de justificar contextos políticos atuais compõe uma das principais estratégias adotadas pela oposição para depreciar as ações de determinado governo ou de determinada figura política. Como exemplo desse "uso político do passado" pelo usuário comum no tweet, pontuamos a comparação realizada pelo internauta entre Lula e Perón, sendo esse último, como visto anteriormente, reconhecido por ter sido um político "populista” nas décadas de 1940 e 1950 na Argentina.

2. Usuário comum. "O Brasil está vencendo o populismo irresponsável e destrutivo de esquerda imposto por Lula, o maior CANALHA desse país. \#TchauQueridaDay”. 12 mai. 2016. Tweet.

Nota-se, que nesse tweet o usuário comum atribui a Lula a responsabilidade pela implantação do que ele chamou de "populismo irresponsável e destrutivo de esquerda" no Brasil. Observa-se, ainda, que o tweet foi publicado durante o quarto contexto de análise, no dia 12 de maio de 2016 - data em que ocorreu a votação do processo de impeachment no Senado e o afastamento de Dilma da Presidência. Dessa forma, de acordo com o usuário, o impeachment de Rousseff representava, na verdade, a superação do modo "irresponsável e destrutivo" de governar instaurado por Lula. Ele afirma, ainda, que Lula é o maior "canalha" do país, o que contribui para a centralidade ou a responsabilidade do ex-presidente diante do contexto da crise política. 
3. Hardy, Jose T. (josetorohardy). "A era Kirshner e a era Lula chegam ao fim assim como está chegando ao fim a era do chavismo. O populismo moribundo.”. 12 mai. 2016. Tweet. Tradução nossa ${ }^{181}$.

O formador de opinião José Toro Hardy, responsável por esse tweet, é um conhecido economista venezuelano, ex-diretor da companhia Petróleos da Venezuela (PDVSA), autor de obras críticas sobre a economia do governo chavista na Venezuela. No tweet Hardy atribui o conceito de populismo ao que denomina "eras" da política latino-americana, quais sejam: o kirshnerismo (Argentina) - representado pelo governo de Nestor Kirshner (presidente entre 2003 e 2007) e de sua esposa, Cristina Kirshner (dirigente por dois mandatos consecutivos, com eleição em 2007 e 2015); o lulismo no Brasil - implantado pelos governos de Lula e Dilma; e o chavismo (Venezuela - figurado pelo governo de Hugo Chávez, presidente entre 1999 e 2013, e pelo seu sucessor político Nicolás Maduro). Na visão de Hardy, esses três tipos de governos estariam morrendo - a expressão "populismo moribundo" utilizada no tweet é bastante simbólica - sendo que essa "morte" ou o fim desses governos estaria sendo representada pelo processo de impeachment de Dilma.

Feita a análise da narrativa de desconstrução da imagem pública de Lula a partir da temática do seu "impeachment", faz-se necessário pontuar duas observações: a primeira delas diz respeito à influência dos perfis de veículos jornalísticos hegemônicos e blogs jornalísticos ligados a esses veículos, bem como dos perfis de formadores de opinião contrários a Lula na circulação dessa narrativa no microblog durante o período analisado. Sobre essa influência torna-se necessário pontuar o caráter de referenciabilidade, visibilidade e credibilidade (RECUERO, ZAGO, 2012) adquirido pelas narrativas publicadas por esses perfis supramencionados na circulação de informações sobre Lula no Twitter durante o período analisado.

Uma segunda apreciação que devemos ressaltar em relação ao relato do "impeachment" de Lula diz respeito ao acionamento do mito político pela narrativa do salvador - em especial nos dois últimos temas apresentados, quais sejam: o fim de Lula como herói e a superação do governo populista supostamente imposto pelo ex-presidente ao Brasil. Como visto no segundo capítulo desta tese, a narrativa do salvador tem por objetivo elevar um grupo ou um sujeito à

${ }^{181}$ Hardy, Jose T. (@josetorohardy). “La era Kirshner y la era Lula llegan a su fin, tal como está llegando a su fin la era del chavismo. El populismo moribundo.”. 12 mai. 2016. Tweet. 
condição de herói ou messias responsável por elevar determinada sociedade à condição de prosperidade. Essa apreciação permite inferir que Lula foi apresentado por vezes como herói ou mesmo como "salvador da pátria", o que caracterizaria uma construção da imagem pública dele; no entanto, a narrativa do salvador foi utilizada pelos usuários do Twitter no espaçotemporal abordado como forma de depreciar a imagem do ex-presidente no sentido de afirmar que sua suposta responsabilidade diante do contexto de crise política em 2016 contribuiu para que o "herói” Lula fosse substituído por um ser inferior - "ladrão", "corrupto" - que não mais apresentava soluções positivas para o país.

\subsection{Narrativas de construção}

Assim como observado nas narrativas de desconstrução, igualmente as de construção da imagem pública de Lula publicadas no Twitter durante o período analisado foram divididas em duas: a primeira delas compreendia o processo de impeachment de Dilma Rousseff como um golpe sofrido, também, por Lula; a segunda visava enaltecer as conquistas econômicas e sociais dos governos petistas.

Consideramos oportuno destacar que a quantidade de termos - dentre os mais mencionados nos tweets analisados - que faziam referência a estratégias de construção da imagem pública política de Lula foi significativamente menor do que a de termos que se referiam a narrativas de desconstrução. Assim, ressaltamos que os relatos dos apoiadores de Lula obtiveram menor expressividade na circulação de informação no Twitter nos quatro contextos da crise política de 2016. Essa constatação é justificada pela predominância de grupos detratores da imagem pública do ex-presidente no período em questão, como visto na análise das redes sociais realizada no capítulo anterior.

As narrativas de construção da imagem pública de Lula foram publicadas, predominantemente, por perfis de lideranças políticas ligadas ao PT como o perfil oficial do partido (@ptbrasil), bem como lideranças latino-americanas como Nicolás Maduro (@nicolasmaduro), Diosdado Cabello (@ dcabellor) (então presidente da Assembleia Nacional da Venezuela e vice-presidente do Partido Socialista Unido daquele país/PSUV) e Rafael Correa (@MashiRafael) (Equador). Observamos também a presença de publicações de formadores de opinião, como José de Abreu (@zehdeabreu), e de perfis de usuários comuns e de militâncias favoráveis ao PT e a Lula. Como visto na análise de redes sociais do capítulo anterior, grande parte dos perfis citados foi classificada como os nós com maior número de conexões recebidas em grupos em que circulavam narrativas favoráveis a Lula. 
6.2.1 A conspiração contra o salvador: o golpe em Lula

O relato utilizado pelos usuários do Twitter com o intuito de afirmar que o impeachment sofrido por Dilma Rousseff em 2016 teria sido um golpe também para Lula foi o mais predominante dentre os modelos discursivos de construção da imagem pública política do expresidente, como se pode perceber pela análise dos termos mais mencionados no tweets publicados nos quatro contextos de análise. Essa narrativa foi encontrada a partir de três temáticas principais: a) o golpe político; b) o golpe midiático; c) e o golpe como um embate. A seguir discorreremos sobre cada um deles:

a) O tema que fazia referência ao golpe político foi encontrado em todos os quatro contextos de análise, sendo que as palavras mais mencionadas foram "golpe" e "democracia", bem como as hashtags "\#noalgolpeadilma” (não ao golpe em Dilma), "\#golpeenbrasil” (golpe no Brasil), "\#lutopelademocracia" e "\#vemprademocracia" - sobre essa última é interessante enfatizar a ressignificação realizada nas hashtags \#vemprarua e \#vempraruabrasil utilizadas na desconstrução da imagem pública de Lula e que diziam respeito ao grupo Vem Pra Rua, um dos principais organizadores das manifestações sociais a favor do impeachment.

A principal estratégia dos usuários que utilizaram a narrativa do golpe político foi a de afirmar que Dilma, Lula e a democracia brasileira necessitavam ser defendidos ou protegidos diante do processo de impeachment em curso. Ressaltamos, ainda, que na temática golpe político foram encontrados tweets publicados por perfis de lideranças políticas, militância, formadores de opinião e usuários comuns, sobre os quais discorreremos a seguir:

- Lideranças políticas: foi observado, pela análise dos termos mais citados nos tweets publicados nos quatro contextos de análise, que os principais termos relacionados à temática do golpe político, além de se referirem às palavras "golpe" e "democracia", faziam referência a páginas no Twitter pertencentes a lideranças políticas ligadas ao governo petista como, por exemplo, o próprio perfil oficial do PT (@ptbrasil). A seguir exemplificamos uma das publicações realizadas por esse perfil na temática em questão:

1. PT Brasil. (ptbrasil). "Atos estão marcados em todo o Brasil para defender a Democracia e o ex-presidente Lula. https://t.co/DXkIkt8w3z”. 12 mar. 2016. Tweet. 
Como pode ser observado no exemplo acima, o tweet foi publicado pelo perfil oficial do PT no Twitter durante o Contexto 1. Apesar de no primeiro campo de análise terem ocorrido as manifestações sociais a favor do impeachment de Dilma, esse tweet mobilizava os usuários do microblog para os atos públicos que ocorreriam durante o Contexto 2, ou seja, as protestações contra o golpe ocorridas em 18 de março de 2016.

Ao final desse tweet a URL "https://t.co/DXkIkt8w3z" direcionava o leitor da publicação para uma página no Facebook referente ao evento de convocação para as manifestações de 18 de março intitulado "Nas Ruas Contra o Golpe, em Defesa da Democracia”. O evento foi criado pela Frente Brasil Popular, que, como visto no terceiro capítulo, foi um dos principais grupos articuladores das manifestações contra o golpe em 2016.

Nota-se que o verbo "defender" no perfil do PT no Twitter transmitia a ideia de que tanto o ex-presidente Lula quanto a democracia brasileira eram vítimas do golpe e precisavam ser protegidos - no caso desse tweet a forma de proteção ou defesa seria por meio das manifestações sociais ocorridas em 18 de março daquele ano. Observa-se, também, a estratégia do partido em centralizar a circunstância do golpe político não na figura de Dilma, mas, sim, na de Lula, o que demonstra o protagonismo da representação pública do ex-presidente no período analisado.

- Formador de opinião: ainda sobre o golpe político, observamos a presença da narrativa publicada pelo ator brasileiro José de Abreu e formador de opinião (@zehdeabreu). Lembramos que seu perfil foi classificado como o oitavo com maior número de menções no Contexto 4 (em que houve afastamento de Dilma da Presidência pelo processo de impeachment) e também como o terceiro perfil com mais alusões no Cluster 17 (Contexto 4), grupo em que havia predominância de perfis favoráveis a Lula. Além disso, @zehdeabreu foi um dos termos mais citados no quarto contexto. Todas essas observações nos permitem inferir sobre a influência de José de Abreu na circulação de narrativas de construção da imagem pública de Lula, com destaque durante o Contexto 4 - sobre a votação do processo de impeachment no Senado. A seguir é possível averiguar um tweet postado por esse perfil no contexto supracitado:

Abreu, José de. (zehdeabreu). "Como impediram o Lula de assumir e agora permitem 7 ministros na Lava-Jato? Só com \#Golpe". 12 mai. 2016. Tweet.

Esse exemplo mostra que José de Abreu discorreu sobre sua opinião acerca da nomeação de ministros feita por Michel Temer quando assumiu o cargo provisório de presidente do Brasil. Na ocasião (em 12 de maio de 2016) Temer nomeou 23 ministros para integrarem seu governo, 
sendo que ao menos sete deles teriam sido citados ou estavam sendo investigados pela Operação Lava Jato - Geddel Vieira Lima (PMDB) e Henrique Eduardo Alves (PMDB), que passaram a ter foro privilegiado após a nomeação como ministros; Romero Jucá (PMDB), Mendonça Filho (DEM), Raul Jungmann (PPS), Bruno Araújo (PSDB) e Ricardo Barros (PP).

O tweet revela ainda que José de Abreu considerou golpe o fato de Temer ter nomeado ministros envolvidos em escândalos de corrupção, sendo que, em 18 de março de 2016, Lula teria sido impedido de assumir o cargo de ministro da Casa Civil ainda no governo Dilma sob justificativa de que ele estaria evitando ser investigado na Operação Lava Jato e buscava ter foro privilegiado. Nota-se, novamente, a relação entre a ideia de golpe e a vitimização de Lula perante a situação política da época como forma de construção da imagem pública do expresidente.

- Militância: a seguir é possível examinar exemplo de tweet publicado pelo perfil Esquerda Vermelha (@EsquerdaV), qualificado como de militância devido ao fato de ter por objetivo principal a publicação de conteúdo - tanto textual como imagético-visual - favorável à ideologia política de esquerda.

1. Esquerda Vermelha (@EsquerdaV) “\#VemPraDemocracia defender DILMA, LULA E A NAÇÃO \#NãoVaiTerGolpe \#DilmaPresidente e \#LulaMinistro". 18 mar. 2016. Tweet.

Nota-se a ideia de que Dilma, Lula e a "nação" (utilizada, no conteúdo em questão, em referência ao Brasil) deveriam ser defendidos, o que sugere, novamente, uma representação de proteção às vítimas daquela situação política - o processo de impeachment. A utilização da hashtag "VemPraDemocracia" demonstra a tentativa de mobilizar os usuários do Twitter a participarem das manifestações sociais contra o impeachment que ocorreram em 18 de março de 2016, mesmo dia da publicação do tweet aqui examinado. O usuário utilizou, ainda, hashtags afirmativas, ou palavras de ordem, como "\#NãoVaiTerGolpe", "\#DilmaPresidente" e "LulaMinistro" - essa última em alusão à nomeação de Lula para o cargo de ministro da Casa Civil.

- Usuários comuns: as narrativas utilizadas pelos usuários comuns sobre o tema do golpe foram observadas em maior número nos Contextos 3 e 4, espaço temporal em que ocorreram as votações na Câmara dos Deputados e no Senado (respectivamente) pelo processo de 
impeachment de Dilma. A seguir é possível acompanhar dois exemplos de tweets publicados por esses perfis:

1. Usuário comum. "NÃO AO GOLPE: 'TEMOS AS RUAS, TEMOS O LULA, E NÃO VAMOS RECUAR NA DEFESA DA DEMOCRACIA’ Deputado Paulo Pimenta”. 17 abr. 2016. Tweet.

Observa-se que o usuário responsável pela publicação do tweet, além de utilizar da narrativa do golpe, recorreu à imagem de Lula como solução contra esse golpe. Para tanto, empregou a frase "temos as ruas, temos o Lula, e não vamos recuar na defesa da democracia" (grifo nosso), proferida pelo deputado Paulo Pimenta (PT - Rio Grande do Sul) em 17 de abril de 2016, logo após o encerramento da votação na Câmara dos Deputados pela continuação do processo de impeachment de Dilma ${ }^{182}$. Na "palavra de ordem" as expressões "temos as ruas" e "temos o Lula" se referiam à ideia de que tanto as manifestações sociais quanto a figura pública do ex-presidente seriam fortes estratégias na defesa da democracia, ou seja, na defesa contra o golpe. Observa-se, ainda, que o usuário se dirige a um grupo de pessoas específico já que utiliza a conjugação verbal no plural - "temos". Tal grupo, ao que nos parece, é constituído por militância favorável a Lula que também compreende a imagem pública do ex-presidente como força ou estratégia de defesa da democracia contra o golpe.

2. Usuário comum. "Esse golpe espúrio na democracia ressuscita Lula. Ou golpistas conseguem prendê-lo ou ele vencerá em 2018 no $1^{\circ}$ turno. Aguardemos.”. 12 mai. 2016. Tweet.

Por esse tweet acima nota-se que o usuário recorre à narrativa do golpe no sentido de compreender a situação política daquele momento - o processo de impeachment - como fortalecimento ou engrandecimento da imagem pública política de Lula. Para tanto, ele afirmou que o golpe na democracia "ressuscitaria" Lula, ou seja, faria com que o ex-presidente se destacasse novamente no cenário político brasileiro. Ao mencionar esse termo o internauta utilizou, assim como em relatos de desconstrução da imagem pública de Lula analisados

\footnotetext{
${ }^{182} \mathrm{~A}$ frase "temos as ruas, temos o Lula, e não vamos recuar na defesa da democracia", citada no tweet foi proferida pelo deputado Paulo Pimenta (PT) em vídeo no qual ele fez um pronunciamento crítico sobre o resultado favorável à continuação do processo de impeachment de Dilma após votação na Câmara dos Deputados em 17 de abril de 2016 - o vídeo foi publicado, na mesma data, na página no Facebook "O Estadista" disponível em: < https://www.facebook.com/OEstadista/> e acessada em 15 mai. 2016.
} 
anteriormente, a ideia de que o impeachment poderia ser a "morte" de Lula, ou seja, o seu fim político. Mas, ao contrário das narrativas de desconstrução, o usuário opina que o impeachment seria, na verdade, uma situação capaz de fazer ressurgir ou renascer a carreira política do expresidente.

Ele afirmou, ainda, que o golpe teria dois fins possíveis: a prisão de Lula (compreendida como a "morte de Lula") ou a reeleição dele para presidente do Brasil em 2018, sendo que essa possível vitória de Lula nas urnas seria a maior consequência do fortalecimento da sua imagem. Percebemos que a estratégia de enaltecer a possibilidade de ascensão política de Lula no pleito eleitoral de 2018 contrasta com a narrativa de desconstrução utilizada pelos opositores ao expresidente em que os mesmos afirmaram que Lula estaria "morto" politicamente, ou seja, que sua carreira política teria acabado juntamente com o processo de impeachment de Rousseff. Entendemos que essa estratégia discursiva utilizada pelo usuário comum reforça os resultados da sondagem realizada pelo Instituto DataFolha sobre a qual discorremos anteriormente em que Lula foi indicado pelos entrevistados como principal candidato para as eleições presidenciais de 2018.

b) O tema que fazia referência ao golpe midiático como narrativa de construção da imagem pública de Lula foi observado mediante a citação do termo "mídia", predominantemente durante o Contexto 2 (em que ocorreram as manifestações sociais contra o golpe - foram estudados tweets publicados por lideranças políticas, formadores de opinião e usuários comuns). A seguir discorreremos sobre essas publicações.

- Liderança política: O principal perfil de liderança política que utilizou o tema do golpe midiático foi o pertencente a Nicolás Maduro (Venezuela) e é reproduzido aqui:

Maduro, Nicolás. (NicolasMaduro). "Levantemos a voz da solidariedade mundial com Dilma e Lula contra o Golpe Midiático-Judicial no Brasil...”. 17 mar. 2016. Tweet. Tradução $\operatorname{nossa}^{183}$.

Maduro utilizou a expressão "golpe midiático-judicial" para se referir ao processo impeachment de Dilma Rousseff e afirmar que tal processo seria uma trama arquitetada tanto pelos veículos de comunicação como pela Justiça brasileira. Ressaltamos que ao utilizar a expressão "golpe midiático", Maduro recorreu a narrativas comumente atribuídas

\footnotetext{
${ }^{183}$ Maduro, Nicolás (NicolasMaduro). "Levantemos la Voz de la Solidaridad Mundial con Dilma y Lula ante el
} Golpe Mediático-Judicial en Brasil...”. 17 mar. 2016. Tweet. 
a discursos proferidos por Hugo Chávez, ex-presidente da Venezuela e um dos principais líderes da esquerda latino-americana. Oportuno explicar que nesses pronunciamentos Chávez, repetidas vezes, culpava os veículos de comunicação privados da Venezuela por atentarem contra os seus ideais de governo. (PASSOS, 2012).

No tweet Maduro utilizou ainda a narrativa de mobilização no sentido de impulsionar os usuários do Twitter a se solidarizarem com Dilma e Lula contra o golpe. Tal narrativa se justifica pelo fato de o tweet ter sido publicado em 17 de março de 2016 (Contexto 1), o dia anterior às manifestações sociais contra o impeachment.

Ressaltamos que o perfil do presidente venezuelano no Twitter foi classificado como um dos 20 mais referenciados nos Contexto 2 (onde foi publicado o tweet aqui relatado) e no 4 (em que houve o afastamento de Dilma Rousseff. A página de Maduro também foi classificada como um nó com grande influência tanto no Cluster 8 (Contexto 2) como no Cluster 20 (Contexto 4), em que havia predominância de perfis favoráveis a Lula. Tais observações nos permitem entender a importância e influência da publicação de Maduro no Twitter em relação às narrativas de construção da imagem pública de Lula.

- Formador de opinião e usuário comum: os tweets publicados por esses dois tipos de perfis utilizaram a temática do golpe da mídia para se referirem, principalmente, à divulgação da conversa telefônica entre Lula e Dilma em 16 de março de 2016. A seguir discorreremos sobre três exemplos dessas publicações. Importante ressaltar que o primeiro tweet foi publicado pela jornalista Hildegard Angel, reconhecida pelo seu apoio explícito aos governos petistas, tanto de Lula como de Dilma Rousseff.

1. Angel, Hildegard. (hilde_angel). "Li a transcrição da conversa trivial Lula e Dilma. Nada nada. Qual motivo do escândalo da mídia? Querer criar uma situação para golpe. Só pode ser". 17 mar. 2016. Tweet.

2. Usuário comum. "O desespero é tanto por não conseguirem NADA ilegal do Lula que pegam normais e utilizam manipulação pesada da mídia”. 17 mar. 2016. Tweet.

3. Usuário comum. "Até agora o grande ponto de interrogação: cadê as tais provas contra Lula? É o circo midiático orquestrado...”. 17 mar. 2016. Tweet. 
Nota-que, ao examinar os exemplos acima, que o conteúdo do tweet publicado por Hildegard Angel possui uma estrutura muito parecida em relação ao que foi publicado pelo usuário comum no segundo tweet. O que se percebe como comum na narrativa dos dois tweets é a ideia central de que houve um "escândalo" e uma "manipulação" dos veículos jornalísticos ao divulgarem os áudios da conversa entre o ex-presidente e Dilma. Nesse sentido, Angel afirmou que a situação de escândalo da mídia em relação ao áudio seria uma condição prévia para criar uma "situação de golpe". Já o usuário comum apontou para um suposto "desespero" dos veículos de comunicação diante do áudio divulgado no sentido de inventarem ilegalidades cometidas por Lula para justificar o golpe.

No terceiro tweet observa-se que o usuário comum utiliza a expressão "circo midiático" para se referir ao tema do golpe da mídia. Essa expressão é a mesma verificada no tweet do perfil de Nicolás Maduro, no qual ele cita um "golpe midiático" para aludir à situação política do processo de impeachment de Dilma. Importante pontuar que esse usuário comum se apresenta em sua bio no Twitter como "militante de esquerda e do PT" - essa observação nos permite inferir que houve significativa participação da militância petista nas narrativas de construção da imagem pública de Lula por meio da ideia do golpe da mídia. Além disso, o usuário, ao se definir como um "militante de esquerda", justifica a utilização que fez da expressão "circo midiático", comumente atribuída a discursos proferidos por líderes políticos de esquerda, como é caso de Maduro e Hugo Chávez.

Ressalta-se, sobre os três exemplos supracitados, a recorrência à estratégia de referir-se ao ex-presidente como vítima - assim como foi observado nos tweets publicados sobre o golpe político nos quais Lula precisava ser defendido ou protegido. No caso específico sobre o golpe midiático Lula seria, para os usuários que utilizaram essa narrativa, vítima de perseguição proveniente de manipulação por parte da mídia hegemônica e do posicionamento editorial da mesma.

c) O terceiro tema empregado pelos usuários do Twitter na construção da imagem pública política de Lula a partir da narrativa foi o do golpe como um embate. Os termos mais mencionados nessa narrativa foram "guerrero", "luta" e "povo". Pontua-se que o termo "guerreiro" em português também foi observado nos tweets sobre o tema em questão apesar de não constar na classificação dos mais mencionados nos quatro contextos de análise.

Importante ressaltar que a ideia de golpe foi tratada não necessariamente a partir da narrativa do impeachment enquanto golpe político, mas, sim, enquanto embate, uma luta ou uma guerra que estaria sendo enfrentada por Lula. Dessa forma, destacamos que não foi 
observada a citação ao termo "golpe" nas publicações sobre o tema, mas a palavra esteve simbolizada nos tweets em referência à ideia de que havia um campo de disputa para o qual Lula deveria se fortalecer diante de supostos inimigos.

Ressaltamos, ainda, que essa disputa que estaria sendo travada pelo ex-presidente remete ao antagonismo sobre o qual discorre Schmitt (1992), que opõe "amigos" - que, no caso da narrativa do golpe como embate estariam representados pelos apoiadores de Lula versus "inimigos" - representados pelos opositores do ex-presidente. Esse antagonismo ou disputa também foi percebido, como visto no terceiro capítulo desta tese, por LattmanWeltman (2015); Solano, Ortellado e Moretto (2016), bem como por Carreiro e Gomes (2017) a partir da polarização do atual contexto político brasileiro acentuada pelo acesso às mídias sociais.

$\mathrm{Na}$ narrativa sobre o golpe como embate foram observados tweets publicados por lideranças políticas e usuários comuns. Discorreremos sobre essas publicações a seguir.

- Lideranças políticas: assim como nas narrativas de construção da imagem pública de Lula anteriormente analisadas, observou-se que o relato de golpe enquanto embate também foi utilizado por lideranças políticas brasileiras ligadas diretamente ao PT ou pertencentes a outros países latino-americanos. Vamos abordar na sequência exemplos de duas dessas publicações no Twitter - uma publicada em 11 de março de 2016 pelo perfil oficial de Rafael Correa (@MashiRafael), então presidente do Equador (nota-se que a data de publicação é anterior ao recorte de análise do Contexto 1, cuja mensagem foi amplamente compartilhada durante esse primeiro contexto); e outra postagem feita por José Nobre Guimarães (@guimaraes13PT), então deputado federal pelo estado do Ceará e líder do governo de Dilma Rousseff na Câmara ${ }^{184}$.

1. Correa, Rafael. (MashiRafael). "Acabei de falar com Lula para expressar nossa solidariedade. Lula é um guerreiro e vai superar esta nova "canalhada". A América Latina te abraça!”. 13 mar. 2016. Tweet. Tradução nossa ${ }^{185}$.

\footnotetext{
184 José Nobre Guimarães é irmão de José Genoíno, ex-presidente do PT que renunciou ao cargo após ser condenado pelo escândalo do mensalão. Em julho de 2005 ficou conhecido pelo escândalo dos "dólares na cueca", no qual seu então assessor político José Adalberto Vieira foi preso no Aeroporto de Congonhas em São Paulo por manter 100 mil dólares escondidos em sua cueca. Em junho de 2012 o STF absolveu José Nobre Guimarães das acusações de envolvimento desse escândalo. (VIANNA, 2012).

185 Correa, Rafael. (@MashiRafael). “Acabo de hablar con Lula para expresarle nuestra solidaridad. Lula es un guerrero, y vencerá esta nueva canallada. ¡Latinoamérica te abraza!”. 11 mar. 2016. Tweet.
} 
Vê-se no tweet acima que Rafael Correa utilizou uma declaração pessoal como forma de dar maior credibilidade à narrativa de construção da imagem pública de Lula. Igualmente discorreu sobre uma conversa que teria tido com Lula durante a qual se solidarizou com a situação vivida pelo ex-presidente do Brasil e afirmou, ainda, que a América Latina estaria “abraçando" Lula. Nota-se por essas observações que Correa também recorreu à narrativa de que Lula é vitimado diante do golpe, já que precisaria de solidariedade e apoio diante dos fatos em ocorrência - o que foi simbolizado pelo "abraço" em Lula.

Nesse tweet o então presidente do Equador afirmou, ainda, que Lula é um guerreiro e que sairia vitorioso diante da nova "canalhada" ${ }^{186}$; percebe-se pelo uso dessas expressões a recorrência à narrativa que fazia referência a um campo de batalha, ou seja, a uma situação de embate no qual Lula deveria vencer a disputa contra um suposto inimigo - os apoiadores do golpe.

2. Guimarães, José Nobre. (@guimaraes13PT). “Todos numa só voz: Lula guerreiro do povo brasileiro. E com Dilma pela democracia”. 13 mar. 2016. Tweet.

No tweet publicado em 13 de março de 2016 pelo perfil oficial do deputado petista José Guimarães, entende-se o emprego da frase "Lula, guerreiro do povo brasileiro" como importante estratégia de construção da imagem pública de Lula. Tal frase, como visto no terceiro capítulo, foi amplamente utilizada pelos apoiadores do ex-presidente, sobretudo após o pleito eleitoral de 2006 como uma espécie de "grito de guerra" em sua defesa e a intensa divulgação do escândalo do "mensalão" pela imprensa hegemônica.

Guimarães afirmou, ainda, estar "com Dilma pela democracia", o que demonstra, novamente, uma diferenciação entre "nós" (Lula, Dilma e democracia) e "eles" (os apoiadores do impeachment), numa disputa entre amigos versus inimigos.

\section{Cabello, Diosdado R. (dcabellor). "A direita internacional e o imperialismo yankee mostram novamente suas garras contra um povo. Com Lula, Dilma e com o Brasil para sempre!!”. 12 mai. 2016. Tweet. Tradução nossa ${ }^{187}$.}

\footnotetext{
${ }^{186}$ O termo "canalhada", utilizado por Rafael Correa, se refere à canalhice ou "ação, modos ou palavras próprias de canalha.”. (FERREIRA, 1986, p. 265).

${ }^{187}$ Cabello, Diosdado R. (@dcabellor). "La derecha internacional y el imperialismo yankee nuevamente saca sus garras contra un Pueblo. Con Lula, Dilma y con Brasil por siempre!!”. 12 mai. 2016. Tweet.
} 
Importante ressaltar sobre o exemplo acima citado que o perfil de Diosdado Cabello (então presidente da Assembleia Nacional da Venezuela e vice-presidente do Partido Socialista Unido da Venezuela (PSUV)), como observado a partir da análise de redes realizada no capítulo anterior, se classificou como o segundo com maior número de referências durante o Contexto 4 (em que esse tweet foi publicado), no qual houve o afastamento de Dilma Rousseff da Presidência do Brasil após votação no Senado e resultado favorável à abertura do processo de impeachment, o que indica forte influência da sua publicação no contexto especificado.

Nessa publicação, Cabello usou expressões e termos como "derecha" (direita) "internacional", "imperialismo yankee" 188 e "povo", muito comuns em discursos proferidos por Hugo Chávez quando ele designava o "imperialismo norte-americano" como inimigo do povo venezuelano, dos ideais do chavismo e dos ideais da esquerda latino-americana (PASSOS, 2012). De acordo com a narrativa publicada por Cabello, a direita internacional e o imperialismo yankee estariam novamente utilizando suas armas contra um povo. A utilização do termo "novamente" reforça a ideia acima observada de que o autor do tweet utilizou recursos narrativos que já haviam sido utilizados em discursos proferidos anteriormente.

Apesar de não usar no conteúdo do tweet a palavra "golpe", Diosdado Cabello, ao final da mensagem publicada, afirmou estar "ao lado" de Dilma, Lula e do Brasil. Tal declaração referia-se à ideia de que esses três personagens seriam vítimas da situação política daquele momento (o processo de impeachment) e que, portanto, deveriam ser protegidos das "garras" da direita e do imperialismo. Entendemos que essa afirmação remete à ideia de que existem dois lados opostos na circunstância política em questão: o lado dos "amigos", constituído pela esquerda latino-americana, Dilma, Lula e o povo brasileiro, e o lado dos "inimigos", formado pelo imperialismo norte-americano e a direita internacional.

- Usuários comuns: os perfis de usuários comuns que utilizaram a narrativa do golpe como embate na construção da imagem pública de Lula durante o período analisado mencionaram com frequência o termo "guerrero" (e a variação em português "guerreiro"), bem como "luta" e "povo". São os próximos exemplos:

\footnotetext{
188 O termo "imperialismo" é definido por Pistone (1998) como uma "expansão violenta por parte dos Estados, ou de sistemas políticos análogos, da área territorial da sua influência ou poder direto, e formas de exploração econômica em prejuízo dos Estados ou povos subjugados, geralmente conexas com tais fenômenos". (PISTONE, 1998, p. 611). Já o termo "yankee" (em português "ianque") é uma expressão da língua inglesa utilizada em referência ao povo norte-americano. (CARVALHO, 1997).
} 
1. Usuário comum. "Afirmação com amor: Lula é o Guerreiro do Povo. Estamos em Luta! \#VemPraDemocracia”. 18 mar. 2016.

Como pode ser observado, assim como visto no tweet do deputado José Guimarães, o usuário comum também utilizou o bordão "Lula é o guerreiro do povo" como elemento central na narrativa de construção da imagem pública do ex-presidente. Nota-se, ainda, a recorrência a "luta" como tática de afirmar que os apoiadores de Lula estariam em situação de embate diante daquele contexto político. Ressalta-se que, como visto anteriormente, o termo "luta" foi intensamente utilizado em discursos proferidos por Lula desde a época de líder sindical em que ele representava as "lutas" da classe trabalhadora contra a elite dominante. Após ser eleito presidente em 2002, Lula passou a representar a "luta" do povo brasileiro por melhores condições de vida e por ascensão social.

Observa-se que o usuário comum responsável pela publicação do tweet acima citado utilizou a hashtag "\#VemPraDemocracia" como forma de mobilizar os internautas do Twitter para a participação das manifestações que ocorreriam em 18 de março de 2016, data da publicação desse tweet. Percebemos que o usuário apresentava como imagem de seu perfil no microblog uma fotografia pessoal na qual estava impressa a hashtag "\#LulaEuConfio" - essa observação nos permite inferir que o usuário é um militante do lulismo.

2. Usuário comum. "LULA: Sem dúvida o presidente mais popular do Brasil! Força Lula! Guerreiro!". 12 mar. 2016. Tweet. Tradução nossa. ${ }^{189}$.

O tweet acima, publicado por um usuário comum da cidade de Santiago, capital do Chile, afirma que Lula é "sem dúvida" o presidente mais popular do Brasil. Nota-se, por essa afirmação, que há recorrência à popularidade do governo do ex-presidente como forma de enaltecer a imagem pública, ou seja, o adjetivo "popular" é acionado na narrativa apresentada pelo usuário como indicativo de aprovação ou positividade de um determinado governo - e não de forma negativa como observado nas narrativas de desconstrução da imagem pública de Lula desde a temática do "populismo". No tweet em questão o usuário menciona, ainda, os termos

${ }^{189}$ Usuário comum. "LULA: Sin duda el presidente más popular de Brasil! ¡Fuerza Lula! ¡Guerrero!”. 12 mar. 2016. Tweet. 
"força" e "guerreiro" que fazem referência à condição de luta, guerra ou embate em que Lula deveria se manter forte diante de seus opositores.

Necessário pontuar, em relação à narrativa de construção da imagem pública de Lula sobre o viés do golpe em Lula acima analisada, que os usuários que recorreram a essa estratégia discursiva discorreram sobre o mito político de duas formas: 1) a partir do relato de conspiração, no sentido transformar Lula em vítima de uma situação política (o processo de impeachment de Dilma Rousseff) orquestrada pelos seus "inimigos” (ou opositores). Sendo assim, a conspiração foi realizada contra o ex-presidente, diferentemente do que foi observado na narrativa de desconstrução da imagem pública de Lula, sobre a qual discorremos anteriormente, em que ele é retratado como o responsável pela conspiração contra o bem-estar dos brasileiros e, portanto, pela crise política daquele momento; 2) os usuários abordaram o mito político também com o relato do salvador ao se referirem a Lula como um "guerreiro do povo brasileiro", ou seja, uma importante liderança - ou mesmo um herói - da nação. A expressão, como visto, foi intensificada a partir da reeleição de Lula em 2006 e voltou a ganhar amplitude e visibilidade no Twitter dentre os apoiadores do lulismo no período da crise política em 2016.

\subsubsection{A idade de ouro: o legado de Lula}

A narrativa que discorria sobre o legado de Lula se constituiu como a segunda estratégia de construção da imagem pública do ex-presidente mais predominante nos tweets publicados nos quatro contextos de análise. Sobre a recorrência ao relato sobre o legado do ex-presidente ressalta-se três pontos importantes: 1) essa foi a narrativa menos expressiva no Twitter durante o período analisado, em comparação com todas as outras anteriormente analisadas - tanto as de construção como as de desconstrução da imagem pública do ex-presidente; 2) a narrativa sobre o legado de Lula foi identificada, predominantemente, a partir da menção ao termo "pobreza", um dos mais citados no Contexto 3 - em que ocorreu a votação na Câmara dos Deputados pela continuação do processo de impeachment de Dilma; 3) observou-se predominância de perfis pertencentes a usuários localizados na Argentina, como é o caso do perfil oficial da Secretaria de Relações Internacionais da Central de Trabalhadores da Argentina (@RRIICTA), que classificamos como sendo de liderança política; o do jornalista Dante L. Foresi (@ DanteForesi), qualificado como de formador de opinião; e o de um usuário comum. A seguir é possível observar três exemplos dessas publicações: 
1. Foresi, Dante L. (DanteForesi). "Os governos de Lula e Dilma retiraram 40 milhões de brasileiros da pobreza onde estavam metidos os que hoje votam pelo impeachment.". 17 abr. 2016. Tweet ${ }^{190}$.

2. Usuário comum. "Lula e Dilma retiraram milhões da pobreza e a direita vai devolvê-los à miséria em um segundo. Eles [a direita] não se importam com os direitos adquiridos.". 17 abr. 2016. Tweet. Tradução nossa ${ }^{191}$.

3. Internacionales CTA. (RRIICTA). "Nós trabalhadores nunca esqueceremos que Lula e Dilma retiraram 40 milhões de irmãos brasileiros da pobreza.”. 18 abr. 2016. Tweet. Tradução nossa ${ }^{192}$.

É possível observar pelos três exemplos acima que a narrativa de construção da imagem pública de Lula a partir de sua herança política foi utilizada de forma parecida entre os três tipos de perfis (lideranças políticas, formadores de opinião e usuários comuns). A ideia central dessa estratégia discursiva era de que milhões de brasileiros teriam deixado a condição de pobreza devido à competência dos governos de Lula e Dilma. Nota-se, ainda, que tanto no tweet publicado pelo jornalista Dante Foresi (@DanteForesi), quanto no da Secretaria de Relações Internacionais da Central de Trabalhadores da Argentina (@RRIICTA) houve o expediente de quantificação do número de brasileiros que teriam saído da pobreza graças aos governos petistas. Assim, o conteúdo desses tweets foi composto pelo número "40 milhões" para validar o argumento da importância de tal legado.

Foi possível constatar pelas publicações no perfil de Dante Foresi no Twitter que ele se posiciona favoravelmente a Lula e aos governos petistas devido à recorrência de publicações favoráveis em relação à imagem pública do ex-presidente do Brasil. Foresi é diretor e criador do portal de notícias "Agencia El Vigía”, reconhecido na Argentina pelo posicionamento partidário a governos de esquerda latino-americanos. Ressaltamos, ainda, que há forte ligação entre a Secretaria de Relações Internacionais da Central de Trabalhadores da Argentina e a CUT, no Brasil - essa identificação pode ser observada, por exemplo, a partir de um manifesto

\footnotetext{
${ }^{190}$ Foresi, Dante L. (@DanteForesi). “Los gobiernos de Lula y Dilma sacaron a 40 millones de brasileños de la pobreza donde los habían metido los que hoy votan por el impeachment.". 17 abr. 2016. Tweet.

${ }^{191}$ Mauripolis. (mauripolis). "Lula e Dilma retiraram milhões da pobreza e a direita vai devolvê-los à miséria em um segundo. Eles [a direita] não se importam com os direitos adquiridos.". 17 abr. 2016. Tweet. Tradução nossa. 192 Internacionales CTA. (@RRIICTA). "Los trabajadores nunca olvidaremos que Lula y Dilma sacaron de la pobreza a 40 millones de hermanos brasileros.". 18 abr. 2016. Tweet.
} 
em defesa de Lula publicado em março de 2016 no portal online da CUT e assinado pela Central de Trabalhadores da Argentina. No documento Lula é reconhecido como um "símbolo de luta e inclusão social”. (CENTRAL ÚNICA DOS TRABALHADORES, 2016). Essas observações nos permitem inferir sobre a presença de uma militância favorável a Lula nas publicações no Twitter que se referiam ao legado do ex-presidente.

A análise sobre a estratégia de utilizar as conquistas sociais do governo Lula como forma de construir a imagem pública dele nos permite enfatizar que os usuários que recorreram a tal método acionaram a narrativa do mito político a partir do discurso da "idade de ouro", sobre a qual Girardet (1987) explica que se refere à época de glória. Esse relato discursivo sobre a idade de ouro, como visto nos capítulos teóricos desta tese, difere presente e passado e constrói um fetiche sob esse último em forma de nostalgia. Pontuamos, ainda, que a narrativa da herança utilizada pelos usuários do Twitter no período analisado está em consonância com aquela proposta pelo lulismo, que se pauta na construção discursiva dos "bons tempos do governo Lula" que merecem ser recordados como os tempos em que houve crescimento econômico e diminuição das desigualdades sociais, período em que, finalmente, o povo brasileiro pôde se perceber otimista em relação aos rumos do Brasil.

Quanto à análise da circulação de narrativas de construção da imagem pública de Lula torna-se necessário ressaltar a ausência de perfis de veículos ou blogs jornalísticos tais como a revista Carta Capital, o blog Conversa Afiada e o portal de notícias Brasil 247 que, apesar de terem sido considerados um dos nós mais influentes em clusters com posicionamento favorável ao ex-presidente - como apresentado na análise das redes sociais constituídas no Twitter nos quatro contextos da crise política de 2016 -, não obtiveram visibilidade significativa de suas publicações nas duas principais narrativas de construção apresentadas acima, quais sejam: a narrativa do golpe contra Lula e a do legado do ex-presidente. Essa observação nos permite inferir sobre a inexpressividade dos relatos publicados pelos jornais, revistas, blogs e portais de notícia favoráveis a Lula durante os contextos investigados.

Constatou-se, no entanto, forte influência de perfis de usuários localizados em países latino-americanos, como Venezuela, Chile e Argentina na circulação dessas narrativas de construção da imagem pública de Lula. Tais usuários, em sua grande maioria, foram representados por perfis de lideranças políticas ou usuários comuns militantes de governos de esquerda na América Latina. 


\section{CONSIDERAÇÕES FINAIS}

Ao propormos analisar como se deu o processo de (des)construção da imagem pública política de Lula no Twitter durante os quatro contextos da crise política brasileira ocorridos entre março e maio de 2016 - quais sejam: as manifestações sociais a favor do impeachment, as protestações contra o golpe, a votação do processo de impeachment na Câmara dos Deputados e em seguida no Senado Federal -, e a forma como se deu a narrativa do mito político nesse processo pudemos observar pontos importantes sobre os quais discorreremos nessas considerações, que visam não a conclusão sobre o tema proposto, mas, sim, possibilitar a discussão e reflexão acerca desses eventos.

Um dos apontamentos a ser ressaltado diz respeito ao elevado grau de influência e, portanto, a centralidade da mídia hegemônica na circulação de narrativas sobre Lula nos contextos analisados. Essa relevância dos meios de comunicação ocorreu devido ao fato de que as narrativas que obtiveram maior referenciabilidade, visibilidade e credibilidade (RECUERO, ZAGO, 2012) foram publicadas por perfis de veículos jornalísticos pertencentes aos grandes conglomerados de mídia no Brasil. São eles: a revista Veja (@VEJA), o jornal Estado de S. Paulo (@estadao), o jornal Folha de S. Paulo (@folha) e o portal de notícias online do Grupo Globo, G1 (@g1), e por perfis de blogs jornalísticos ligados a essas empresas, como o de Ricardo Noblat, vinculado ao jornal O Globo (@blogdonoblat), e o de Felipe Moura Brasil, ligado à revista Veja (@ blogdopim). O blog jornalístico criado por Diogo Mainardi e Mário Sabino, O Antagonista (@o_antagonista),também foi observado como um dos perfis de maior visibilidade na circulação de informações sobre Lula no período analisado.

A influência decisiva dos veículos hegemônicos no processo de circulação de informações sobre o ex-presidente no microblog reforça o posicionamento abordado por Recuero (2011, p. 15), para quem “mesmo com uma participação muito mais direta do público, ainda é aos veículos e instituições jornalísticas que os atores nas redes sociais na Internet recorrem para legitimar, dar credibilidade, organizar e filtrar informações.”. Sendo assim, embora os atores sociais da rede - como os usuários comuns - possam contribuir para a difusão de informações na web a partir dos retweets, por exemplo, os veículos jornalísticos continuam a gerar visibilidade e mesmo relevância a determinadas narrativas.

Chamamos atenção também para o fato de que, como visto nos resultados obtidos pela análise das redes sociais, a circulação de relatos sobre Lula baseou-se na polarização entre grupos que publicaram narrativa de construção da imagem pública do ex-presidente (apoiadores) e os grupos que visavam a desconstrução de sua imagem pública (opositores). No 
entanto, a circulação dessas estratégias discursivas não se deu de forma equânime, já que houve predominância quantitativa dos grupos em que circulavam narrações voltadas a denegrir a imagem pública de Lula no somatório dos 20 principais clusters encontrados nos quatro contextos de análise.

A primeira reflexão que se faz necessária em relação ao apontamento acima discorrido diz respeito à influência da mídia hegemônica e dos blogs ligados a esses veículos nos grupos nos quais circulavam informações detratoras da imagem pública política de Lula. Devido à credibilidade desses sites na circulação de informações no período analisado, os relatos publicados por esses perfis passaram a ser centrais nas conversações informais observadas no período e, portanto, os discursos que visavam desconstruir a imagem pública de Lula foram os mais visíveis nessas conversações.

Oportuno mencionar que a centralidade dos perfis pertencentes à mídia hegemônica nos grupos detratores da imagem pública de Lula reitera apontamentos realizados no capítulo $3 \mathrm{em}$ relação à trajetória política do ex-presidente na qual, em diversos momentos, a mídia hegemônica assumiu um papel decisivo na desconstrução ou mesmo oposição à figura de Lula. Podemos citar como exemplo os escândalos de corrupção denominados - pela própria imprensa - de "mensalão" e "petrolão" divulgados, respectivamente, em 2005 e 2014. Como visto, no caso do mensalão a revista Veja e o jornal Folha de S. Paulo foram os precursores das críticas a Lula em relação ao suposto envolvimento do ex-presidente no esquema; já no evento do petrolão novamente a revista Veja teve atribuição decisiva ao presumir a culpa de Lula. Notase, pelos achados da análise de redes da presente pesquisa empírica, que durante a crise política ocorrida entre março e maio de 2016 os grandes grupos de mídia brasileiros continuaram exercendo função central na veiculação e visibilidade de narrativas antilulistas.

O único contexto em que foi observada predominância de grupos apoiadores de Lula foi o Contexto 4, durante o qual ocorreu a votação do processo de impeachment no Senado Federal e o afastamento de Dilma Rousseff da Presidência da República inicialmente pelo período de 180 dias. Nesse espaço temporal os perfis que obtiveram maior visibilidade, ao contrário do notado nos três primeiros contextos, não eram de veículos jornalísticos, mas, sim, de lideranças políticas ligadas ao PT, como a página de Dilma Rousseff (@dilmabr) e a do Instituto Lula (@inst_lula) - essa última foi muitas vezes mencionada pelos usuários do Twitter na quadra investigada como se fosse o perfil oficial de Lula (@lulapelobrasil), o que indica desconhecimento público em relação à comunicação oficial do ex-presidente no microblog. Importante salientar que a centralidade desses dois perfis - (@dilmabr e @inst_lula) - no contexto averiguado não necessariamente indica maior visibilidade de narrativas de construção 
da imagem pública de Lula, já que ambos os perfis se tornaram lugar comum na conversação informacional online ao serem mencionados tanto por usuários favoráveis a Rousseff e a Lula quanto por usuários opositores às duas figuras políticas.

Além disso, nos grupos nos quais se concentraram os apoiadores de Lula no quarto contexto da análise empírica observou-se a influência de perfis de lideranças políticas venezuelanas, como o do então presidente da Venezuela, Nicolás Maduro (@ nicolasmaduro), e o de Diosdado Cabello (@dcabellor), à época presidente da Assembleia Nacional da Venezuela e vice-presidente do PSUV (partido fundado por Hugo Chávez); assim como de perfis de lideranças ligadas ao governo petista, tais como o próprio perfil do PT (@ ptbrasil), o oficial de Lula (@lulapelobrasil), o de Gleisi Hoffmann (@gleisi), senadora do estado do Paraná eleita pelo PT, e o do então presidente nacional do PT, Rui Falcão (@ rfalcao13). Nos grupos apoiadores do ex-presidente também se observou a visibilidade de nós pertencentes à militância petista, como "Brasil da Mudança" (@brasildamundança) e Stanley Burburin (@stanleyburburin); do ator e formador de opinião José de Abreu (@zehdeabreu), e da CUT nacional (@cutnacional), que classificamos como perfil de liderança.

Essas observações sobre as redes sociais constituídas no Twitter durante o quarto contexto de análise tornam necessário destacar a estratégia da comunicação governamental petista voltada à sua militância (constituída também pelo perfil da CUT nacional e o de José de Abreu) com vistas a enaltecer a imagem pública de Lula diante do resultado favorável ao impedimento de Dilma Rousseff, estratégia que também foi utilizada pelas lideranças políticas venezuelanas. Essa tática de construção da imagem pública do ex-presidente contribuiu para a formação de uma rede pró-Lula que pôde garantir maior visibilidade às suas narrativas apenas no contexto no qual os perfis dos veículos de comunicação hegemônicos não foram centrais na circulação de informações no Twitter.

Ainda sobre os resultados da pesquisa empírica baseada na análise de redes sociais destacamos a inexpressividade do que chamamos mídia contra-hegemônica na circulação de narrativas sobre Lula no período da crise política ocorrida entre maço e maio de 2016. Essa mídia contra-hegemônica é representada por perfis de veículos jornalísticos tais como o da revista Carta Capital (@ cartacapita), classificado apenas como o $13^{\circ}$ nó mais visível no Contexto 2 e o $17^{\circ}$ no Contexto 3; dos portais de notícias Carta Maior (@ cartamaior)e Brasil 247 (@brasil247), qualificados, respectivamente, como o $11^{\circ}$ perfil com maior visibilidade no Contexto 4 e o $20^{\circ}$ no Contexto 2; bem como o blog jornalístico criado e gerido por Paulo Henrique Amorim, o Conversa Afiada (@conversaafiada), observado como o $18^{\circ}$ nó mais referenciado no Contexto 1 . Necessário ressaltar que esses perfis foram destaque em grupos 
apoiadores de Lula nos quatro contextos analisados e a inexpressividade dos mesmos caracteriza, consequentemente, a invisibilidade das narrativas de construção da imagem pública de Lula publicadas por eles.

Em face dessas observações e reflexões acerca do exame das redes sociais, pontuamos que o modo como as narrativas sobre Lula circularam no período ponderado gerou reflexo decisivo no que foi observado na etapa de análise de conteúdo. Percebeu-se tal ressonância num primeiro momento a partir dos termos mais mencionados nos quatro contextos investigados, bem como na predominância de temáticas que visavam desconstruir a imagem pública do expresidente. Como observado, a partir dessas temáticas duas narrativas principais se constituíram como as mais visíveis nos quatro períodos verificados: a que visava associar Lula aos escândalos de corrupção e aquela que tinha por objetivo reforçar o fim da carreira política do ex-presidente diante do processo de impeachment sofrido por Rousseff. Dentre esses dois relatos ressaltamos a centralidade da estratégia dos opositores de Lula em reforçar a presunção de culpa (LIMA, 2006) do ex-presidente diante dos fatos ocorridos em março de 2016 - tais como a condução coercitiva dele realizada pela Operação Lava Jato e o pedido de prisão do expresidente apresentado pelo MP-SP. Ressaltamos, ainda, o expediente de atribuir à imagem pública de Lula a característica de um político populista no sentido pejorativo do termo - como um líder político que, pelo seu carisma, manipula o povo ou as classes economicamente desfavoráveis.

Em menor intensidade que as narrativas prejudiciais à imagem pública de Lula foram observadas duas estratégias discursivas de construção da imagem pública dele, quais sejam: a que compreendia o processo de impeachment de Dilma como um golpe em Lula e a que objetivava enaltecer as conquistas sociais e econômicas dos governos petistas. Em relação a esses dois relatos ressalta-se a predominância da estratégia de instituir ao ex-presidente a condição de vítima, ou seja, alguém que precisava ser protegido diante dos acontecimentos ocorridos nos contextos analisados.

Dessa forma, refletimos que a polarização de sentidos observada pela nossa pesquisa empírica se deu a partir de uma disputa entre usuários do Twitter que publicaram narrativas que visavam culpabilizar o ex-presidente pela situação vivida no país e os perfis que se referiam a ele como vítima dessa mesma situação. O embate "amigos versus inimigos" (LATTMANWELTMAN, 2015; SOLANO, ORTELLADO, MORETTO, 2017) ocorreu, portanto, entre os apoiadores de Lula, representados por lideranças políticas petistas e lideranças venezuelanas, bem como pela militância lulista, e os opositores do ex-presidente, vinculados, por sua vez, à mídia hegemônica e blogueiros ligados a esses veículos. Ressaltamos, ainda, que dentre os 
perfis centrais de grupos opositores a Lula foi observada a presença de dois perfis de formadores de opinião: o do humorista Danilo Gentili (@danilogentili) e do cantor e compositor Lobão (@lobaoeletrico).

Esse embate se deu incisivamente a partir de intensa disputa pelo sentido do termo "golpe", que, como verificado, foi utilizado tanto na narrativa em que Lula era apresentado como culpado pela crise política brasileira quanto nos relatos que o apresentavam como vítima dos fatos em ocorrência. Como bem aponta Miguel (2000) no livro sobre mito e discurso político,

algumas palavras são bens altamente valorizados [...] e cada um que se dispõe a se associar a elas torce-lhes o sentido [...] Assim, a disputa em torno de palavras e um grau razoável de imprecisão no seu uso, são inevitáveis: essa disputa é constitutiva do próprio discurso político. (MIGUEL, 2000, p. 66).

Sobre essa batalha de sentidos em relação à narrativa do golpe torna-se necessário refletir sobre a estratégia utilizada pelos veículos jornalísticos hegemônicos para ressignificar o sentido dessa narrativa, que foi empregada e reforçada (capítulo 3) por opositores ao processo de impeachment de Dilma Rousseff. Válido ressaltar que os grupos legitimadores da narrativa do impeachment enquanto golpe acusavam a mídia hegemônica de ser uma das principais articuladoras da trama contra a democracia brasileira. Nessa perspectiva, portanto, os veículos de comunicação seriam golpistas. Mas o que se percebeu na pesquisa empírica foi o estratagema dessa mesma mídia em reverter tal acusação, ou seja, o responsável pelo golpe passou a ser Lula e não mais os veículos de comunicação. Essa estratégia foi notada, também, em narrativas publicadas pelos formadores de opinião acima mencionados (Lobão e Danilo Gentili) e usuários comuns que, em sua maioria, se apresentavam no microblog como uma militância antilulista.

Destaca-se que devido à credibilidade conferida aos perfis dos veículos de comunicação hegemônicos na circulação de informações no período considerado, a narrativa que enquadrava Lula como golpista foi a que gerou maior visibilidade dentre os quatro contextos da análise empírica, o que contribuiu para a inexpressividade do relato em que o ex-presidente seria vítima de um golpe.

Ainda sobre essa mesma disputa de sentidos empregada à narrativa do golpe observou-se que o principal relato do mito político acionado pelos usuários do Twitter no período analisado foi o da conspiração que, justamente, implica na existência de uma trama, uma ameaça. Como já abordado (capítulo 2 desta tese), Girardet (1987) demonstra que a narrativa da conspiração estabelece força a partir de uma ruptura no imaginário coletivo que faz com que todos estejam 
unidos contra um "mal" exterior Dessa forma é criada uma espécie de complô diante de um "outro" capaz de interromper ou prejudicar as "boas” ações pretendidas pelo grupo legitimador da narrativa conspiratória. A conspiração é, portanto, “[...] definida e desenvolvida a partir de um obscuro sentido de ameaça, testemunho de incerteza e pânico". (GIRARDET, 1987, p. 62). Em face dessa observação destacamos que foi possível inferir pela análise de conteúdo da pesquisa empírica que houve também disputa de sentidos pela narrativa da conspiração: enquanto a rede opositora a Lula acionou tal estratégia discursiva de forma a nomear o expresidente como o "outro" ameaçador - ou seja, responsável pela crise brasileira contemporânea-, a rede apoiadora buscou acionar o relato da conspiração como se esse "outro" estivesse representado pela mídia hegemônica, o sistema judiciário brasileiro e os partidos de oposição ao PT. Sendo assim, para os apoiadores de Lula a conspiração foi realizada contra o ex-presidente e não por ele.

Como constatado pela pesquisa, a narrativa do salvador também foi acionada pelos usuários do Twitter no período avaliado. Em relação à ocorrência desse acionamento pontuamos que para os apoiadores de Lula o ex-presidente foi considerado o salvador, o "guerreiro do povo brasileiro" que precisava ser protegido e salvo das tentativas de destruição impostas pelos seus “inimigos" - a mídia e a oposição petista. Já para os contrários, o contexto da crise política brasileira decretava o fim do "herói Lula". Interessante observar que em ambas as narrativas tanto as de edificação como as de desconstrução da imagem pública do ex-presidente - há o reconhecimento do heroísmo de Lula; no entanto, para seus adversários esse heroísmo teria chegado ao fim. Sobre tal percepção torna-se necessário refletir que a trajetória política de Lula de fato contribuiu para que ele fosse percebido pelo imaginário coletivo brasileiro como o salvador da pátria e o grande unificador do país em busca de rumos melhores, no entanto, observou-se que durante a crise política ocorrida em 2016 as opiniões acerca da continuidade dessa representação se tornaram antagônicas.

Necessário traçar um paralelo entre o achado da nossa pesquisa empírica com os dados da verificação sobre intenção de voto para a eleição presidencial de 2018 realizada pelo Instituto DataFolha e divulgada em 11 de abril de 2016, na qual Lula foi apontado como o candidato à Presidência do país pelos entrevistados. No entanto, a mesma investigação mediu o índice de rejeição eleitoral dos nomes incluídos nos cenários apresentados e, apesar do resultado favorável a Lula, o nome do ex-presidente foi o que teve o maior índice de rejeição pelos respondentes. (DATAFOLHA, 2016b). Nota-se, portanto, que essa dubiedade do eleitorado brasileiro se refletiu na conversação sobre Lula nos quatro contextos analisados - houve quem 
pregasse a ressurreição do "herói Lula" e quem decretasse a morte desse mesmo herói diante da crise política instaurada pelo processo de impeachment de Dilma Rousseff em 2016.

Ainda em relação às estratégias discursivas do mito político diante da circulação de informações sobre Lula nos quatro contextos da análise empírica é válido ressaltar a pouca expressividade da narrativa da idade de ouro em comparação às já observadas: a do salvador e a da conspiração. Retomando as ideias apresentadas por Girardet (1987), a narrativa da idade de ouro é responsável por transformar o mito político em nostalgia ao construir um fetiche sobre tempos passados (GIRARDET, 1987). Entendemos igualmente que a narrativa da unidade, responsável por cortejar com suposta união e harmonia dentro de determinada sociedade (GIRARDET, 1987), não foi acionada pelos usuários do Twitter no período averiguado.

Como já verificado (capítulo 3), a narrativa da unidade se tornou forte diante do imaginário coletivo brasileiro desde a primeira eleição de Lula à Presidência da República, em 2002, quando ele passou a representar a possibilidade de união dos brasileiros - pertencentes tanto às classes menos favorecidas economicamente quanto à elite - por um bem comum: a prosperidade do país. Já a narrativa da idade de ouro se tornou influente a partir do fim do seu segundo mandato, já em 2010, período no qual ele obteve índices recordes de popularidade. Após aquela ocasião notou-se o acionamento da narrativa nostálgica dos "tempos de Lula", o que contribuiu sobremaneira para a eleição de Dilma Rousseff em continuidade ao projeto político implantado por Lula. Diante dos resultados da pesquisa empírica entendemos que tais narrativas perderam força diante do contexto da crise política ocorrida em 2016.

O que nos parece central na investigação realizada na presente pesquisa diz respeito ao protagonismo da mídia hegemônica diante do processo de (des)construção da imagem pública de Lula na crise política brasileira instituída em 2016. Muitas foram as narrativas em circulação no período analisado, mas cabe perceber que o poder dos veículos hegemônicos - ao adotarem o mesmo posicionamento sobre o ex-presidente - se deu em decorrência de sua capacidade em tornar determinadas narrativas mais visíveis que outras. Houve, portanto, um jogo de forças entre a rede pró-Lula, constituída pela comunicação governamental, lideranças latinoamericanas e a militância petista, e o grupo opositor, composta pelos veículos hegemônicos, os blogueiros ligados a esses veículos, formadores de opinião e usuários comuns contrários ao expresidente. Nessa disputa por visibilidade, a referenciabilidade e a credibilidade adquiridas pelos opositores fizeram com que as narrativas de desconstrução da imagem pública de Lula se tornassem mais evidentes. Tal observação pouco difere do que foi observado na trajetória política do ex-presidente, na qual a mídia exerceu papel central para a desestabilização da reputação de Lula diante do imaginário coletivo brasileiro, o que demonstra que a circulação 
de informações online, apesar de ampliar espaços de discussão e conversações civis, reforça hierarquias informativas já estabelecidas no âmbito offline.

Com base nessa reflexão, torna-se oportuno trazer a discussão para o panorama político brasileiro de 2017 no qual a imagem pública de Lula mantém protagonismo, na medida em que ele lidera as principais pesquisas de intenção de voto para as eleições de 2018. Em pesquisa divulgada pela Confederação Nacional dos Transportes (CNT) em 15 de fevereiro de 2017, Lula obteve 30,5\% das intenções de voto. (DECAT, 2017).

Paralelamente a esse fato, em 12 de julho de 2017, o juiz Sérgio Moro, responsável pela Operação Lava Jato, condenou Lula a 9 anos e meio de prisão por aquisição irregular de um apartamento triplex em Guarujá (litoral de São Paulo). Se a sentença for confirmada, ele se tornará inelegível para as eleições de 2018 (DANTAS; SCHMITT, 2017). A condenação contribuiu para o que ex-presidente voltasse a acionar narrativas do mito político sobre as quais discorremos ao longo dessa tese ao afirmar se sentir perseguido e vítima de um golpe elaborado pelas elites do país. Em discurso proferido em 15 de julho de 2017 na sede do diretório do PT em Diadema (São Paulo) e reproduzido na página oficial do ex-presidente no Twitter, Lula pronunciou que o golpe só se fecha caso ele seja condenado. Afirmou, ainda, que o Jornal Nacional, principal programa jornalístico da Rede Globo de Televisão, apesar de buscar constantemente desconstruir sua imagem não irá conseguir destruir sua reputação. $\mathrm{O}$ expresidente ressaltou ainda: "E por que eles não conseguem me quebrar? Porque eu não sou eu, eu sou vocês. Eles não conseguem me derrubar porque as asas que eu voo não são minhas, são as asas dos trabalhadores e dos jovens desse país.”. (LULA PELO BRASIL, 2017).

A partir dessas observações acreditamos que futuras investigações, ao se basearem nos procedimentos metodológicos aqui revelados, poderão contribuir para a compreensão da dubiedade acima discorrida relacionada à imagem pública do presidente mais popular do país e como isso repercutirá nos próximos pleitos eleitorais. O que nos parece necessário questionar diz respeito ao embate entre os grandes grupos de mídia no Brasil e o lulismo, ou seja: a visibilidade, credibilidade e referenciabilidade concedidas às narrativas de desconstrução da imagem pública de Lula divulgadas pelos veículos hegemônicos nos ambientes das redes sociais online continuarão pautando as conversações informacionais sobre o ex-presidente? Outra pergunta: qual será o efeito dessa influência para sua reputação diante do eleitorado brasileiro - em crise de representação política?

Esta pesquisa nos permite assumir a hipótese de que as narrativas do mito político presentes na trajetória de Lula podem ser forte componente simbólico na luta por essa representação, mas poderão servir de proteção à reputação do ex-presidente caso consigam 
maior visibilidade diante das conversações civis em comparação aos relatos hegemônicos que buscam desconstruir a representação mítica de Lula e torná-lo um homem comum, ordinário, não mais "acima do bem e do mal". 


\section{REFERÊNCIAS}

6 DIFERENÇAS entre as manifestações de 13 e 15 de março. Veja, 16 mar. 2015. Disponível em: <http://veja.abril.com.br/politica/6-diferencas-entre-as-manifestacoes-de-13-e-15-demarco/>. Acesso em: 15 mar. 2016.

A JARARACA está viva: veja as melhores frases de Lula se defendendo. UOL Notícias, São Paulo, 04 mar. 2016. Disponível em: <https://noticias.uol.com.br/politica/ultimasnoticias/2016/03/04/a-jararaca-esta-viva-confira-trechos-do-pronunciamento-de-lula-sobre-alava-jato.htm>. Acesso em: 15 mar. 2016.

AB'SÁBER, Tales. Lulismo, carisma pop e cultura anticrítica. São Paulo: Hedra, 2011.

ABC DE LUTA. Greve geral dos metalúrgicos do ABC. 1979. Disponível em:

<http://www.abcdeluta.org.br/materia.asp?id_CON=208>. Acesso em: 18 ago. 2015.

$\mathrm{ABC}$ reage à intervenção. Folha de $\mathbf{S}$. Paulo, Banco de Dados Folha, acervo online.

Publicado na Folha de São Paulo, sábado, 24 de março de 1979. Disponível em:

<http://almanaque.folha.uol.com.br/brasil_24mar1979.htm>. Acesso em: 18 ago. 2015.

AGÊNCIA BRASILEIRA DE PROMOÇÃO DE EXPORTAÇÕES E INVESTIMENTOS. Análise Apex-Brasil: conjuntura e estratégia. As exportações brasileiras e os ciclos de commodities: tendências recentes e perspectivas. Apex-Brasil, jul. 2011. Disponível em: <http://www.apexbrasil.com.br/Content/imagens/5a438c3e-ddd0-4807-8820a0f6650bd379.pdf>. Acesso em: 15 de ago. 2011.

ALBUQUERQUE, Afonso de. Aqui você vê a verdade na tevê: a propaganda política na televisão. 1999. 240f. Dissertação (Mestrado) - Universidade Federal Fluminense, Instituto de Arte e Comunicação Social, Niterói, 1999.

ALBUQUERQUE, Andréa Moreira; GOMES, Isaltina Maria de Azevedo Mello. O discurso do medo versus o discurso da esperança: a disputa de sentidos decisiva das eleições 2002. In: COMPÓS, 12., 2004, São Bernardo do Campo. Anais... São Bernardo do Campo, SP, 2004. Disponível em: 〈http://www.compos.org.br/data/biblioteca_569.pdf >. Acesso em: 12 jul. 2015.

ALDÉ, Alessandra; FIGUEIREDO, M. F; MENDES, G. Imprensa e eleições presidenciais: natureza e consequências da cobertura das eleições de 2002 e 2006. In: LIMA, Venício Artur de. (org.). A Mídia nas Eleições de 2006. São Paulo: Fundação Perseu Abramo, 2007. p.6587.

ALDÉ, Alessandra; VASCONCELLOS, Fábio. Ao vivo, de Brasília: escândalo político, oportunismo midiático e circulação de notícias. Revista de Ciências Sociais, v. 39, n. 2, p.6169, 2008. Disponível em:

<http://www.periodicos.ufc.br/index.php/revcienso/article/download/508/491>. Acesso em: 24 set. 2015.

ALMEIDA, Jorge. Evolução de imagem do governo Lula e comportamento eleitoral em 2006. Política \& Sociedade, v.6, n. 10, p.117-152, abr. 2007. 
ALMEIDA, Rodrigo de. À sombra do poder: os bastidores da crise que derrubou Dilma Rousseff. São Paulo: Leya, 2016.

AMARAL, Oswaldo E. do; RIBEIRO, Pedro Floriano. Por que Dilma de novo? Uma análise exploratória do Estudo Eleitoral Brasileiro de 2014. Revista de Sociologia e Política, Curitiba, v. 23, n. 56, p. 107-123, dez. 2015.

AMARAL, Ricardo Batista. A vida quer é coragem: a trajetória de Dilma Rousseff, a primeira presidenta do Brasil. Rio de Janeiro: Primeira Pessoa, 2011.

AMORIM, Paulo Henrique. Não me calarão. Conversa Afiada. 24 ago. 2008. Disponível em: <https://www.conversaafiada.com.br/nao-me-calarao〉. Acesso em: 15 mar. 2015.

AMOSSY, Ruth (Org.). Imagens de si no discurso: a construção do ethos. São Paulo: Contexto, 2008.

ANDERSON, Perry. A crise no Brasil. 21 abr. 2016. Disponível em:

$<$ https://blogdaboitempo.com.br/category/colaboracoes-especiais/perry-anderson/>. Acesso em: 15 mai. 2016.

ANDERSON, Perry. O Brasil de Lula. Tradução de Alexandre Barbosa de Souza e Bruno Costa. Novos Estudos, São Paulo, n. 91, p. 23-52, nov. 2011.

ANJOS, Elisa Roubert Lage dos. Uma nova perspectiva sobre populismo: Ernesto Laclau e a formação das identidades coletivas. Revista Contemporânea, Niterói, v. 2, n. 2, p.76-98, 2012.

ANTHONY, Laurence. AntConc: a freeware corpus analysis toolkit for concordancing and text analysis. 2016. Disponível em: <http://www.laurenceanthony.net/software.html>. Acesso em: 15 mar. 2015.

ANTOUN, Henrique; MALINI, Fabio. Ontologia da liberdade na rede: a guerra das narrativas na internet e a luta social na democracia. Revista Famecos, Porto Alegre, v. 17, n.3 p. 286294, set./dez.2010.

ANTUNES, Ricardo. O novo sindicalismo no Brasil. 2. ed. rev. e ampl. Campinas: Pontes, 1995.

AZEVEDO, Fernando. Corrupção, mídia e escândalos midiáticos no Brasil. Em Debate, Belo Horizonte, v.2, n.3, p. 14-19, mar. 2010. Disponível em:

<http://www.pucsp.br/neamp/artigos/arquivos/artigo_97.pdf>. Acesso em: 10 ago. 2016.

AZEVEDO, Reinaldo. Lula sofre a derrota mais humilhante de sua carreira e deve ser enterrado junto com Dilma. Veja, 18 abr. 2016. Disponível em: <http://veja.abril.com.br/blog/reinaldo/lula-sofre-aderrota-mais-humilhante-de-sua-carreira-e-deve-ser-enterrado-junto-com-dilma/>. Acesso em: 20 maio 2016.

AZEVEDO, Reinaldo. O país dos petralhas. São Paulo: Record, 2008. 
AZEVEDO, Reinaldo. O país dos petralhas II: o inimigo agora é o mesmo. São Paulo: Record, 2012.

AZEVEDO, Reinaldo. Passaram a mão no nosso Cristo, Jesus! Estava num cofre de Lula. Blog do jornalista Reinaldo Azevedo: política, governo, PT, imprensa e cultura. Veja, 11 mar. 2016a. Disponível em: <http://veja.abril.com.br/blog/reinaldo/passaram-a-mao-no-nossocristo-jesus-estava-num-cofre-de-lula/> . Acesso em: 15 ago. 2016.

AZEVEDO, Rita. Veja íntegra da fala de Cardozo em defesa de Dilma no Senado. Exame, 29 abr. 2016b. Disponível em: <http://exame.abril.com.br/brasil/veja-integra-da-fala-de-cardozoem-defesa-de-dilma-no-senado/>. Acesso em: 15 ago. 2016.

BACZKO, Bronislaw. A imaginação social. In: LEACH, Edmund et al. Anthropos-homem. Lisboa, Imprensa Nacional/Casa da Moeda, 1985. p. 296-332.

BALANDIER, Geordies. O Poder em Cena. Brasília: Editora Universidade de Brasília, 1980.

BAPTISTA, Erica Anita; CONTREIRAS, Patrícia. Corrupção política e mídia: o caso dos submarinos em 2010 em Portugal. Em Debate, Belo Horizonte, v.8, n.1, p.22-40, mar. 2016. Disponível em: < http://www.opiniaopublica.ufmg.br/site/files/artigo/3Dossie-EricaePatriciamarc-o-RE.pdf $>$. Acesso em: 12 mar. 2016.

BAPTISTA, Erica Anita. Corrupção política e avaliação de governo: o caso da Lava Jato. In: CONGRESSO DA ASSOCIAÇÃ̃O BRASILEIRA DE PESQUISADORES EM COMUNICAÇÃO E POLÍTICA, 7., 2017, Porto Alegre. Democracia em crise? Mídia, opinião pública e instituições dos Brasil contemporâneo. Porto Alegre: Compolítica, 2017. GT 4. Disponível em: <https://drive.google.com/file/d/0B4ZGK8qAQTozMG1ZaUw2cWViRIU/view>. Acesso em: 20 jun. 2017.

BAQUERO, Marcello. Eleições e capital social: uma análise das eleições presidenciais no Brasil (2002-2006). Opinião Pública, Campinas, v. 13, n. 2, p. 231-259, nov. 2007.

Disponível em:

$<$ https://www.researchgate.net/publication/250984512_Eleicoes_e_capital_social_Uma_anali se_das_eleicoes_presidenciais_no_Brasil_2002-2006>. Acesso em: 21 mar. 2016.

BARBÉ, Carlos. Golpe de Estado. In: BOBBIO, Norberto; MATTEUCCI, Nicola; PASQUINO, Gianfranco. Dicionário de política. 11. ed. Tradução de Carmen C. Varriale et al. Brasília: Editora Universidade de Brasília, 1998. p.545-547. Disponível em: <https://mpassosbr.files.wordpress.com/2013/03/dicionario_de_politica.pdf>Acesso em: 15 mar. 2016.

BARBOSA, Bia. Operação Aletheia e a nova aula global de manipulação midiática. Carta Capital, 05 mar. 2016. Disponível em:

$<$ https://www.cartacapital.com.br/blogs/intervozes/operacao-aletheia-e-a-nova-aula-globalde-manipulacao-midiatica>. Acesso em: 15 maio 2016.

BARDIN, L. Análise de conteúdo. Lisboa: Edições 70, 1977. 
BARREIROS, Tomás Eon; AMOROSO, Danilo. Jornalismo estrábico: Veja e Carta Capital na cobertura do "escândalo do mensalão". Perspectivas de la Comunicación, Temuco, Chile, v. 1, n. 1, p.120-131, 2008. Disponível em:

<http://publicacionescienciassociales.ufro.cl/index.php/perspectivas/article/viewFile/16/15>. Acesso em: 04 abr. 2016.

BARRETO, Fernando. Mídias Sociais e Mobilização social. In: BRAMBILLA, Ana (Org.). Para entender as mídias sociais. Brasil: Creative Commons, 2011. p. 162-165. Disponível em: < http://www.posemcomunicacaodigital.com.br/wpcontent/files/biblioteca/Para_entender_as_mdias_sociais.pdf>. Acesso em: 18 jul. 2014.

BARROS, Mariana. Lobão: 'O pai disso tudo é o Lula'. Veja, 12 mar. 2015. Disponível em: <http://veja.abril.com.br/politica/lobao-o-pai-disso-tudo-e-o-lula/>. Acesso em: 15 mar. 2016.

BARTHES, Roland. Introdução à análise estrutural da narrativa. In. BARTHES, Roland (Org.). Análise estrutural da narrativa: pesquisas semiológicas. Rio de Janeiro: Vozes, 1971. P.19-60.

BARTHES, Roland. Mitologias. 7. ed. Rio de Janeiro: DIFEL, 2013.

BASTIAN, Mathieu; HEYMANN, Sebastien; JACOMY, Mathieu. Gephi: an open source software for exploring and manipulating networks. In: INTERNATIONAL ICWSM CONFERENCE, 3., 2009. Proceedings ... p. 361-362. Disponível em: <http://www.aaai.org/ocs/index.php/ICWSM/09/paper/download/154/1009>. Acesso em: 15 mar. 2015.

BAUER, Martin W. Análise de conteúdo clássica: uma revisão. In: BAUER, Martin W.; GASKELL, George. (Ed.). Pesquisa qualitativa com texto, imagem e som: um manual prático. Petrópolis: Vozes, 2008. p.189-217.

BECKER, Camila et al. Manifestações e votos ao impeachment de Dilma Rousseff na primeira página de jornais brasileiros. Revista Latinoamericana de Ciencias de la Comunicación, v. 13, n. 24, jun. 2016. Disponível em: <

http://www.alaic.org/revistaalaic/index.php/alaic/article/view/736>. Acesso em: 15 jun. 2017.

BENKLER, Yochai. The wealth of networks: how social production transforms markets and freedom. New Haven and London, Yale University Press, 2006. Disponível em:

<http://www.benkler.org/Benkler_Wealth_Of_Networks.pdf>. Acesso em: 20 fev. 2012.

BERELSON, B. R.; LAZARSFELD, P. F.; MCPHEE, W. N. Voting: a study of opinion formation in a Presidential campaign. Chicago: University of Chicago Press, 1954.

BERNARDES, Nelson Augusto. Em defesa da prisão de Lula. 12 mar. 2016. Disponível em: <http://www.oantagonista.com/posts/em-defesa-da-prisao-de-lula>. Acesso em: 15 mar. 2016.

BEZERRA, Ada Kesea Guedes. Carisma e mitologias políticas: a narrativa legendária de Luíz Inácio Lula da Silva, "o operário presidente". In: ENCONTRO NACIONAL DE HISTÓRIA ORAL, 10., 2010, Recife. Testemunhos: história e política. Recife: UFPE, 2010. p.1-16. Disponível em: 
<http://www.encontro2010.historiaoral.org.br/resources/anais/2/1269142073_ARQUIVO_Art igo-Enc.Historia.pdf>. Acesso em: 10 de mar. 2015.

BLOG DO PIM. Twitter. Disponível em: <www.twitter.com/blogdopim>. Acesso em: 15 jun. 2016.

BEZERRA, Ada Kesea Guedes. O mito Lula: política, discursos e cenário midiático. 2011. 273f. Tese (Doutorado em Ciências Sociais) - Centro de Humanidades, Universidade Federal de Campina Grande , Campina Grande, 2011.

BOBBIO, Noberto. Política. In: BOBBIO, Norberto; MATTEUCCI, Nicola; PASQUINO, Gianfranco. Dicionário de política. Tradução de Carmen C. Varriale et al. 11. ed. Brasília: Editora Universidade de Brasília, 1998, p. 954 - 962. Disponível em:

<https://mpassosbr.files.wordpress.com/2013/03/dicionario_de_politica.pdf>. Acesso em: 15 mar. 2016.

BONAZZI, Tiziano. Mito político. In: BOBBIO, Norberto; MATTEUCCI, Nicola; PASQUINO, Gianfranco. Dicionário de política. Tradução de Carmen C. Varriale et al. 11. ed. Brasília: Editora Universidade de Brasília, 1998, p. 754-762. Disponível em: <https://mpassosbr.files.wordpress.com/2013/03/dicionario_de_politica.pdf>. Acesso em: 15 mar. 2016.

BOURDIEU, Pierre. A representação política. Elementos para uma teoria do campo político. In:___ O poder simbólico. Rio de Janeiro: Bertrand Brasil, 1989, cap. 7, p. 163-207.

BOURDIEU, Pierre. O campo político. Revista Brasileira de Ciência Política, Brasília, n. 5, p. 193-216, July 2011.

BOYD, Danah.; GOLDER, Scott; LOTAN, Gilad. Tweet, Tweet, Retweet: conversational aspects of retweeting on Twitter. In: HAWAII INTERNATIONAL CONFERENCE ON SYSTEM SCIENCES (HICSS), 43., 2010, Honolulu. E-government track. Honolulu: IEEE, 2010. Disponível em: <https://www.danah.org/papers/TweetTweetRetweet.pdf>. Acesso em: 25 mar. 2016.

BOYD, Danah. Social Network sites as networked publics: affordances, dynamics, and implications. In: PAPPACHARISSI, Zizi (Ed.). Networked self: identity, community, and culture on social network sites. New York: Routledge, 2011. Cap. 2, p. 39-58. Disponível em: < https://www.danah.org/papers/2010/SNSasNetworkedPublics.pdf >. Acesso em: 10 ago. 2015.

BOYD, Danah; ELLISON, Nicole B. Social Network sites: definition, history, and scholarship. Journal of Computer-Mediated Communication, v. 13, n. 1, p. 210-230, Oct. 2008.

BRAMATTI, Daniel. Parte do eleitorado de Serra é também 'lulista'. O Estado de S. Paulo, São Paulo, 24 maio 2010. Disponível em: <http://politica.estadao.com.br/noticias/geral,partedo-eleitorado-de-serra-e-tambem-lulista,556131>. Acesso em: 10 de ago. 2015.

BRANDÃO, Aline Lima. Empreiteiras e impeachment: os agentes privados na cobertura midiática de escândalos de corrupção. In: CONGRESSO DA ASSOCIAÇÃO BRASILEIRA 
DE PESQUISADORES EM COMUNICAÇÃO E POLÍTICA, 7., 2017, Porto Alegre. Democracia em crise? Mídia, opinião pública e instituições dos Brasil contemporâneo. Porto Alegre: Compolítica, 2017. GT 6. Disponível em: Disponível em: <http://www.compolitica.org/home/wpcontent/uploads/2017/06/BRANDAO_AlineLima-Empreiteiras-e-impeachment-template.pdf>. Acesso em: 29 mar. 2016.

BRANDÃO, Aline Lima. Impeachment presidencial e a nova instabilidade política na América Latina. Revista Compolítica, [S.1], vol. 6, n. 2, p. 83-103, 2016. Disponível em: <http://compolitica.org/revista/index.php/revista/article/view/281/176>. Acesso em: 16 set. 2017.

BRANDÃO, Marcelo. Diretório Nacional do PT discute manifestações de apoio ao governo. Agência Brasil. 14 dez. 2015. Disponível em: $<$ http://agenciabrasil.ebc.com.br/politica/noticia/2015-12/diretorio-nacional-do-pt-discutemanifestacoes-de-apoio-ao-governo>. Acesso em: 19 jan. 2016.

BRANDT, Ricardo et al. PF encontra sala-cofre com joias, medalhas e obras de arte de Lula. O Estado de S. Paulo, 11 mar. 2016. Disponível em:

<http://politica.estadao.com.br/blogs/fausto-macedo/pf-encontra-sala-cofre-com-joiasmedalhas-e-obras-de-arte-de-lula/> . Acesso em: 18 set. 2016.

BRASIL. Decreto no 2.848, de 07 de dezembro de 1940. Estelionato. Art. 171 do Código Penal. Decreto Lei 2848/40. [S.d]. Disponível em:

$<$ https://www.jusbrasil.com.br/topicos/10617301/artigo-171-do-decreto-lei-n-2848-de-07-dedezembro-de-1940>. Acesso em: 15 mar. 2017.

BRASIL, Felipe Moura. Lulaé denunciado por lavagem de dinheiro e falsidade ideológica no caso do tríplex.. Chora, amarelão! Veja, 09 mar. 2016. Disponível em: <http://veja.abril.com.br/blog/felipemoura-brasil/lula-e-denunciado-por-lavagem-de-dinheiro-e-falsidade-ideologica-no-caso-dotriplex-chora-amarelao/>. Acesso em: 10 mar. 2016.

BRASIL. Ministério da Saúde. Sistema Único de Saúde. Bolsa família: o que é... Datasus, [S.d]. Disponível em: <http://bolsafamilia.datasus.gov.br/w3c/bfa.asp>. Acesso em: 16 set. 2015.

BRASIL. Ministério do Planejamento. Sobre o PAC. [S.d.].Disponível em: <http://www.pac.gov.br/sobre-o-pac>. Acesso em: 12 mar. 2016.

BRAZIL takes off. Now the risk for Latin America's big success story is hubris. The Economist, London, 12 nov. de 2009. Disponível em: < http://www.economist.com/node/14845197>. Acesso em: 15 jun. 2016.

BRITISH BROADCASTING CORPORATION BRASIL. Brasil passa a ser $4^{\mathrm{a}}$ maior fonte de mensagens no Twitter. O Estado de S. Paulo, 05 jul. 2010. Disponível em:

$<$ http://www.estadao.com.br/noticias/geral,brasil-passa-a-ser-4-maior-fonte-de-mensagensno-twitter,576626>. Acesso em: 15 mai. 2016.

BRITO, Fernando. Como nasceram os “tijolaços” do Brizola. 07 fev. 2015. Disponível em: <http://www.tijolaco.com.br/blog/como-nasceram-os-tijolacos-do-brizola/>. Acesso em: 15 
mar. 2016.

BUCCI, Eugênio. A forma bruta dos protestos: das manifestações de junho de 2013 à queda de Dilma Rousseff em 2016. São Paulo: Companhia das Letras, 2016.

BURNIER, José Roberto. Fotos mostram visita de Lula a triplex em Guarujá. G1, Globo. 03 mar. 2016. Disponível em: <http://g1.globo.com/sao-paulo/noticia/2016/03/fotos-mostramvisita-de-lula-triplex-em-guaruja.html>. Acesso em: 15 maio 2016.

CALGARO, Fernanda; MATOSO, Filipi. Dilma nega 'atos ilícitos' e se diz indignada com decisão de Cunha. G1, Globo. 02 dez. 2015. Disponível em:

<http://g1.globo.com/politica/noticia/2015/12/dilma-diz-que-recebeu-com-indignacaoabertura-de-impeachment.html>. Acesso em: 18 jan. 2016.

CÂMARA DOS DEPUTADOS. Cardozo entrega defesa de Dilma e diz que não houve crime de responsabilidade. Agência Câmara Notícias, 04 abr. 2016. Disponível em: $<$ http://www2.camara.leg.br/camaranoticias/noticias/POLITICA/506408-CARDOZOENTREGA-DEFESA-DE-DILMA-E-DIZ-QUE-NAO-HOUVE-CRIME-DERESPONSABILIDADE.html>. Acesso em: 18 set. 2016.

CÂMARA DOS DEPUTADOS. Comissões Parlamentares de Inquérito.[S.d.]. Disponível em: <http://www2.camara.leg.br/atividade-legislativa/comissoes/comissoestemporarias/parlamentar-de-inquerito>. Acesso em: 15 ago. 2015.

CÂMARA DOS DEPUTADOS. Papel e história da Câmara: como funciona. [S.d.].Disponível em: <http://www2.camara.leg.br/a-camara/conheca/como-funciona>. Acesso em: 15 mar. 2016.

CAPELATO, Maria Helena. Mídia e Populismo/Populismo e Mídia. Revista Contracampo, Niterói, v. 28, n. 3, p. 52-72, dez. /mar. 2013.

CARDOSO Gustavo; DI FÁTIMA, Branco. Movimento em rede e protestos no Brasil: qual gigante acordou? Dossiê Mídia, Intelectuais e Política, [S.l.], v. 16, n. 2, p. 143-176, maio/ago. 2013. Disponível

em: <https://revistas.ufrj.br/index.php/eco_pos/article/view/1182/1123>. Acesso em: 26 mar. 2016.

CARRARO, A. et al. É a Economia, Companheiro: uma análise empírica da reeleição de Lula com base em dados municipais. Ibmec MG Working Paper, v. 41, 2007.

CARREIRO, Rodrigo; GOMES, Wilson. Discussão política online no Brasil: ocorrência e manutenção da discordância política no Facebook. In: CONGRESSO DA ASSOCIAÇÃO BRASILEIRA DE PESQUISADORES EM COMUNICAÇÃO E POLÍTICA, 7., 2017, Porto Alegre. Democracia em crise? Mídia, opinião pública e instituições dos Brasil contemporâneo. Porto Alegre: Compolítica, 2017. GT 5. Disponível em: < http://www.compolitica.org/home/wp-content/uploads/2017/05/CARREIRO_GOMES_Discuss\%C3\%A3o-pol\%C3\%ADtica-online-no-brasil.pdf $>$. Acesso em: 15 jun. 2016.

CARTA, Mino. É golpe sim! Carta Capital, [S.1], 05 abr. 2016. Disponível em: 
<https://www.cartacapital.com.br/revista/895/e-golpe-sim>. Acesso em: 15 ago. 2016.

CARTAZES das manifestações. G1, Globo, 21 jun. 2013. Disponível em:

<http://g1.globo.com/brasil/cartazes-das-manifestacoes/platb/>. Acesso em: 15 mar. 2015.

CARVALHO, Olavo de; BRASIL, Felipe Moura (Org.). O mínimo que você precisa saber para não ser um idiota. Rio de Janeiro: Record, 2013. Disponível em:

$<$ http://politicaedireito.org/br/wp-content/uploads/2017/02/O-minimo-que-voce-precisasaber-Olavo-de-Carvalho.pdf>. Acesso em: 15 mar. 2016.

CARVALHO, Ulisses Wehby de. Yankee: qual é o significado e a tradução de "YANKEE"? 1997. Disponível em: < http://www.teclasap.com.br/qual-e-o-significado-de-yankee/>. Acesso em: 15 mar. 2016.

CASO Bancoop: MP investiga transferência de imóveis para OAS. G1, Globo, São Paulo, 09 mar. 2016. Disponível em: <http://g1.globo.com/sao-paulo/noticia/2016/03/caso-bancoopmp-investiga-transferencia-de-imoveis-para-oas.html>. Acesso em: 15 ago. 2016.

CASSIRER, Ernst. O mito do Estado. Tradução de Álvaro Cabral. Rio de Janeiro: Zahar, 1976.

CASTAÑEDA; Eugenia Cecilia Gómez; VEIGA, Luciana Fernandes. A construção da imagem de Cristina Kirchner e de Dilma Rousseff nas eleições presidenciais. Em Debate, Belo Horizonte, v.4, n.3, p.57-65, jun. 2012.

CASTELLS, Manuel. A galáxia da internet: reflexões sobre a internet, os negócios e a sociedade. Rio de Janeiro: Zahar, 2003.

CASTELLS, Manuel. Internet e sociedade em rede. In: MORAES, Dênis de (Org.). Por uma outra comunicação: mídia, mundialização cultural e poder. Rio de Janeiro: Record, 2003, p. 255-287. (Trabalho original publicado em 2000)

CENTRAL ÚNICA DOS TRABALHADORES. Apoios internacionais a Lula só aumentam. 2016. Disponível em:

<http://cut.org.br/imprimir/news/c3a9a84be9721f0e5b9ff199e07b8280/>. Acesso em: 15 mar. 2016.

CHARAUDEAU, Patrick. Discurso político. 2. ed. São Paulo: Contexto, 2013.

CHEGOU a hora de dizer: basta! O Estado de S. Paulo, 13 mar. 2016. Disponível em: <http://opiniao.estadao.com.br/noticias/geral,chegou-a-hora-de-dizer-basta,10000020896>. Acesso em: 18 abr. 2016.

COIMBRA, Marcus. A mídia teve algum papel durante o processo eleitoral de 2006? In: LIMA, Venício A. de (Org.). A mídia nas eleições de 2006. São Paulo: Fundação Perseu Abramo, 2007. P.187-210.

COMISSÃO NACIONAL PROVISÓRIA. Carta de princípios. Maio, 1979. Disponível em: <http://www.pt.org.br/wp-content/uploads/2014/03/cartadeprincipios.pdf> Acesso em: 18 ago. 2015. 
CONFEDERAÇÃO NACIONAL DA INDÚSTRIA. Manifestações populares. Retratos da sociedade brasileira - Manifestações Populares, Brasília, n. 31, p.1-11, abr. 2016.

Disponível em:

<http://www.ibopeinteligencia.com/arquivos/RSB_31_manifesta\%C3\%A7\%C3\%B5es_popul ares.pdf $>$. Acesso em: 17 de ago. 2016.

CONFEDERAÇÃO NACIONAL DA INDÚSTRIA. Pesquisa CNI - IBOPE: avaliação do governo e expectativa em relação ao novo governo. Brasília, dez. 2010. Disponível em: <http://www.ibopeinteligencia.com/inteligencia/downloads/2010/JOB_192-19_BRASIL__Relatorio_de_tabelas_(imprensa).pdf/>. Acesso em: 15 mar. 2016.

CONFEDERAÇÃO NACIONAL DA INDÚSTRIA. Pesquisa CNI - IBOPE: avaliação do governo. Brasília, v. 5, n. 1, mar. 2015. Disponível em: <http://www.ibope.com.br/ptbr/noticias/Documents/Pesquisa\%20CNI-IBOPE\%20Aval\%20do\%20governo\%20\%20mar2015.pdf>. Acesso em: 15 mar. 2016.

CONFEDERAÇÃO NACIONAL DO TRANSPORTE. Pesquisa CNT/Ibope: manifestações. Job: 13/0948, jun, 2013. Disponível em: <http://www.cnt.org.br/Pesquisa/pesquisa-cntmanifestacoes-junho-2013>. Acesso em: 19 abr. 2016

\section{CONFEDERAÇÃO NACIONAL DO TRANSPORTE. Pesquisa de opinião pública} nacional. Rodada 59. Sensus, 19 a 23 jan. 2003. Disponível em:

<http://cms.cnt.org.br/Imagens\%20CNT/Site\%202015/Pesquisas\%20PDF/Pequisa\%20CNT\% 20de\%20Opini\%C3\%A3o/59\%C2\%AA\%20Pesquisa\%20CNT-\%20Sensus.pdf> Acesso em: 19 nov. 2015.

COSTA, Flávio; AZEVEDO, Guilherme. Em sindicato da CUT, Lula se oferece como candidato a presidente em 2018. UOL Notícias, São Paulo, 04 mar. 2016. Disponível em: <https://noticias.uol.com.br/politica/ultimas-noticias/2016/03/04/lula-se-oferece-comocandidato-a-presidencia-da-republica-em-2018.htm?cmpid=copiaecola $>$. Acesso em: 15 mar. 2016.

COSTA, Florência. Capitalismo de resultados. ISTOÉ, n. 1715, 09 ago. 2002. Disponível em: < http://istoe.com.br/22811_CAPITALISMO+DE+RESULTADOS/>. Acesso em: 18 set. 2015.

COSTA, Henrique. Impeachment deputado Marco Maia PT vota não. YouTube. 17 abr. 2016. Disponível em: <https://www.youtube.com/watch?v=QPAPftjlIvo>. Acesso em: 15 ago. 2016.

COSTAS, Ruth. O legado dos 13 anos do PT no poder em seis indicadores internacionais. BBC Brasil, São Paulo, 03 maio 2016. Disponível em: <http://www.bbc.com/portuguese/noticias/2016/05/160505_legado_pt_ru>. Acesso em: 15 jun. 2016.

COURTINE, Jean-Jacques. Os deslizamentos do espetáculo político. In.: GREGOLIN, Maria do Rosário (Org.). Discurso e mídia: a cultura do espetáculo. São Carlos: Claraluz, 2003, p. 21-34. 
CUNHA, Fernando Whitaker da. O poder legislativo e o "impeachment". Revista de Informação Legislativa, Brasília, v. 29, n. 116, p.31-38, out./dez. 1992. Disponível em: <http://www2.senado.leg.br/bdsf/bitstream/handle/id/176024/000472124.pdf?sequence=1>. Acesso em: 15 mar. 2016.

DAHLBERG, Lincoln. Democracy via cyberespace: mapping the rhetorics and practices of three prominent camps. New Media Society, v. 3, n. 2, p. 157-177, 2001.

DANTAS, Dimitrius; SCHMITT, Gustavo. Moro condena Lula a 9 anos e meio de prisão no caso do tríplex. O Globo. 12 jul. 2017. Disponível em:

$<$ https://oglobo.globo.com/brasil/moro-condena-lula-9-anos-meio-de-prisao-no-caso-dotriplex-21580819>. Acesso em: 14 jul. 2017.

DANTAS JÚNIOR, Altino (Ed.). Lula sem censura: “...e aí a peãozada partiu pro pau”. Petrópolis: Vozes, 1981.

DATAFOLHA. 48\% DOS QUE PROTESTARAM contra impeachment aprovam estão (sic) Dilma. Datafolha, São Paulo, 21 mar. 2016. Disponível em:

$<$ http://datafolha.folha.uol.com.br/opiniaopublica/2016/03/1752481-46-dos-que-protestaramcontra-impeachment-aprovam-estao-dilma.shtml>. Acesso em: 15 ago. 2016.

DATAFOLHA. Aprovação a governo Dilma Rousseff cai 27 pontos em três semanas. Datafolha, São Paulo, 29 jun. 2013. Disponível em:

$<$ http://datafolha.folha.uol.com.br/opiniaopublica/2013/06/1303659-aprovacao-a-governodilma-rousseff-cai-27-pontos-em-tres-semanas.shtml >. Acesso em: 30 nov. 2015.

DATAFOLHA. Aprovação cai, reprovação continua subindo, e Lula atinge pior avaliação de seu mandato. Datafolha, 12 ago. 2005. Disponível em: < http://datafolha.folha.uol.com.br/opiniaopublica/2005/08/1222913-aprovacao-cai-reprovacaocontinua-subindo-e-lula-atinge-pior-avaliacao-de-seu-mandato.shtml>. Acesso em: 15 ago. 2015.

DATAFOLHA. Corrupção lidera pela primeira vez pauta de problemas do país. Datafolha, São Paulo, 30 nov. 2015. Disponível em: $<$ http://datafolha.folha.uol.com.br/opiniaopublica/2015/11/1712972-corrupcao-lidera-pelaprimeira-vez-pauta-de-problemas-do-pais.shtml>. Acesso em: 30 nov. 2015.

DATAFOLHA. Dilma atinge sua melhor avaliação, mas brasileiros preferem Lula para 2014. Datafolha, São Paulo, 20 abr. 2012. Disponível em: <http://datafolha.folha.uol.com.br/opiniaopublica/2011/03/1211069-dilma-e-aprovada-por47-dos-brasileiros.shtml>. Acesso em: 30 de nov. 2015.

DATAFOLHA. Dilma é aprovada por $\mathbf{4 7 \%}$ dos brasileiros. Datafolha, São Paulo, 21 mar. 2011. Disponível em: <http://datafolha.folha.uol.com.br/opiniaopublica/2011/03/1211069dilma-e-aprovada-por-47-dos-brasileiros.shtml>. Acesso em: 30 de nov. 2015.

DATAFOLHA. Intenção de voto para presidente da República: PO813859 07 e 08/04/2016. Datafolha, São Paulo, 11 abr. 2016b. Disponível em: <http://media.folha.uol.com.br/datafolha/2016/04/11/intencao_de_voto_presidente.pdf >. Acesso em: 15 mar. 2017. 
DATAFOLHA. Maior manifestação política da história de SP reúne 500 mil na Paulista. DataFolha, São Paulo, 14 mar. 2016a. Disponível em: $<$ http://datafolha.folha.uol.com.br/opiniaopublica/2016/03/1749713-maior-manifestacaopolitica-da-historia-de-sp-reune-500-mil-na-paulista.shtml>. Acesso em: 10 ago. 2016.

DATAFOLHA. Manifestação na avenida paulista. DataFolha, São Paulo, 15 mar. 2015a. Disponível em: <http://media.folha.uol.com.br/datafolha/2015/03/17/manifestacao-1503.pdf>. Acesso em: 19 maio 2016.

DATAFOLHA. Primeiro ano de Dilma tem a maior aprovação desde redemocratização. Datafolha, São Paulo, 20 jan. 2012a. Disponível em: $<$ http://datafolha.folha.uol.com.br/opiniaopublica/2012/01/1211074-primeiro-ano-de-dilmatem-a-maior-aprovacao-desde-redemocratizacao.shtml>. Acesso em: 30 de nov. 2015.

DEBORD, Guy. A sociedade do espetáculo: comentários sobre a sociedade do espetáculo. Rio de Janeiro: Contraponto, 1997.

DEMITIDO, repórter acusa TV Globo de manipulação na cobertura eleitoral. UOL Notícias, São Paulo, 20 dez. 2006. Disponível em: < https://noticias.uol.com.br/ultnot/2006/12/20/ult23u280.jhtm>. Acesso em: 26 mar. 2016.

DIONÍSIO, Bibiana. PF estima que prejuízo da Petrobras com comupção pode ser de R $\$ 42$ bi. G1, Globo, 12 nov. 2015. Disponível em: < http://g1.globo.com/pr/parana/noticia/2015/11/pf-estima-queprejuizo-da-petrobras-com-corrupcao-pode-ser-de-r-42-bi.html>. Acesso em: 15 mar. 2016.

DOMENACH, Jean-Marie. A propaganda política. São Paulo: Difusão Europeia do Livro, 1963.

DURAND, Gilbert. As estruturas antropológicas do imaginário. Lisboa: Presença, 1997.

DURAND, Gilbert. O imaginário: ensaio acerca das ciências e da filosofia da imagem. Rio de Janeiro: DIFEL, 1998.

D’URSO, Luiz Flávio Borges. Em defesa da presunção de inocência. O Estado de S. Paulo, São Paulo, 01 jun. 2007. Disponível em: <http://www.oabsp.org.br/sobre-oabsp/palavra-dopresidente/2007/artigo-em-defesa-da-presuncao-de-inocencia>. Acesso em: 18 ago. 2015.

ELIADE, Mircea. Mito e realidade. São Paulo: Perspectiva, 2013.

ÉPOCA. Twitter. Disponível em: 〈www.twitter.com/revistaepoca〉. Acesso em: 15 jun. 2016.

ESTEVES, J. P. Os novos media na perspectiva da democracia deliberativa: sobre redes e tecnologias de informação e comunicação. In: PIRES, E. B. (Org.). Espaços públicos, poder e comunicação, Porto: Edições Afrontamento, 2007. p. 209-224.

FALCÃO, Rui. Terça-feira é a posse do Lula, o ministro da esperança. 16 mar. 2016 Disponível em: <https://twitter.com/rfalcao13/status/710131211163865088>. Acesso em: 15 ago. 2016. 
FARIA, Glauco. O jornal do golpe. In: ROVAI, Renato (Org.). Golpe 16. São Paulo: Publisher Brasil, 2016. p. 97-103.

FAUSTO NETO, Antônio. Entre os cruzamentos de sentidos. In: FAUSTO NETO, Antônio; VERÓN, Eliseo (Org.); RUBIM, Antonio Albino Canelas. Lula presidente: televisão e política na campanha eleitoral. São Paulo: Hacker; São Leopoldo, RS: Unisinos, 2003. p.6583.

FAUSTO NETO, Antônio. Fragmentos de uma "analítica" da midiatização. Matrizes, São Paulo, n. 2, p. 89-105, 2008.

FERREIRA, Aurélio Buarque de Holanda. Novo Dicionário Aurélio da Língua Portuguesa. 1 ed. 14a. impressão. Rio de Janeiro: Nova Fronteira, 1986.

FERREIRA, Bernardo. O risco do político: crítica ao liberalismo e teoria política no pensamento de Carl Schmitt. Belo Horizonte: Editora UFMG, 2004.

FERREIRA, Jorge. O nome e a coisa: o populismo na política brasileira. In: $\mathbf{O}$ populismo e sua história: debate e crítica. Rio de Janeiro: Civilização Brasileira, 2001. p.59124.

FILGUEIRAS, Fernando de Barros. Notas críticas sobre o conceito de corrupção: um debate com juristas, sociólogos e economistas. Revista de Informação Legislativa, Brasília, v. 41, n. 164, p.125-148, out. /dez. 2004.

FIRMINO, Gustavo Casasanta. Conservadorismo liberal e classes médias: uma análise do 'Vem Pra Rua' e do 'Movimento Brasil Livre". 2016. Disponível em:

<http://www.canal6.com.br/x_sem2016/artigos/9A-05.pdf>. Acesso em: 02 maio 2016.

FOLHA de S. Paulo. Twitter. Disponível em: <www.twitter.com/folha>. Acesso em: 15 jun. 2016.

FRAGOSO, Suely; RECUERO, Raquel; AMARAL, Adriana. Métodos de pesquisa para internet. Porto Alegre: Sulina, 2013.

FREEMAN, Linton C. The development of social Network analysis: a study in the sociology of science. Vancouver: Empirical Press, 2004.

FRENTE BRASIL POPULAR. Compromissos da Militância. Belo Horizonte, 05 set. 2015. Disponível em: <http://www.frentebrasilpopular.org.br/conteudo/compromissos-damilitancia/>. Acesso em: 15 mar. 2016.

GALGARO, Fernanda; MOTOMURA, Marina. Dilma quer plebiscito que autorize Constituinte para reforma política. Uol Notícias, 24 jun. 2013. Disponível em: $<$ https://noticias.uol.com.br/cotidiano/ultimas-noticias/2013/06/24/dilma-anuncia-que-vaipedir-plebiscito-por-reforma-politica.htm?cmpid=copiaecola $>$. Acesso em: 15 mar. 2016.

GARDIN, Lucas; PANKE, Luciana. A transferência de ethos de Lula para Dilma na campanha eleitoral de 2010. Revista Eletrônica de Ciência Política, Curitiba, vol. 6, n. 1, p.167-186, 2015. Disponível em: <http://revistas.ufpr.br/politica/article/view/39791/25772>. 
Acesso em: 15 de ago. 2015.

GIRARDET, Raoul. Mitos e mitologias políticas. São Paulo: Companhia das Letras, 1987.

GLASENAPP, Ricardo Bernd; FARIAS, Alessandra de. O processo de impeachment na Constituição Federal de 1988 e sua aplicação no caso Dilma Roussef. Revista Paradigma, Ribeirão Preto, v. 25, n. 1, p. 79-101, jan. /jun. 2016.

GOMES, Marcelo Bolshaw. A imagem pública de Lula no horário eleitoral nas quatro campanhas à presidência. 2006. 212f. Tese (Doutorado em Ciências Sociais) - Centro de Ciências Humanas, Letras e Artes, Universidade Federal do Rio Grande do Norte, Natal, 2006. Disponível em: < http://docplayer.com.br/43949475-Marcelo-bolshaw-gomes.html>. Acesso em: 20 fev. 2016.

GOMES, Wilson. 90 anos de comunicação e política. Revista Contemporânea de Comunicação e Cultura, v. 9, n.03. set./dez. 2011, p. 336-343.

GOMES, Wilson. A política na timeline: crônicas de comunicação e política em redes sociais digitais. Salvador: EDUFBA, 2014.

GOMES, Wilson. Apontamentos sobre o conceito de esfera pública política. In: MAIA, R.; CASTRO, M.C.P.S. (Org.). Mídia, esfera pública e identidades coletivas. Belo Horizonte: Editora UFMG, 2006. p. 49-62.

GOMES, Wilson. Da discussão à visibilidade. In: GOMES, W.; MAIA, R.C.M.. (Org.). Comunicação e Democracia: problemas e perspectivas. São Paulo: Paulus, 2008, v. 1, p. 117-162.

GOMES, Wilson. Internet e participação política em sociedades democráticas. Revista FAMECOS. Porto Alegre, n. 27, ago. 2005. Disponível em:

<http://www.revistas.univerciencia.org/index.php/famecos/article/view/440/367>. Acesso em: 15 mar. 2016.

GOMES, Wilson. Propaganda política, ética e democracia. In: MATOS, Heloiza (Org.). Mídia, Eleições e Democracia. São Paulo: Scritta, 1994.

GOMES, Wilson. Transformações da política na era da comunicação de massa. São Paulo: Paulus, 2004.

GRAMSCI, Antonio. Maquiavel, a Política e o Estado Moderno. 3. ed. Rio de Janeiro: Civilização Brasileira, 1978.

GREIMAS, Algirdas Julien. Semântica estrutural. São Paulo: Cultrix/EdUSP, 1973.

GREVES do ABC. Memória Globo, 2013. Disponível em:

$<$ http://memoriaglobo.globo.com/programas/jornalismo/coberturas/greves-doabc/videos.htm>. Acesso em: 18 ago. 2015.

GRUPO GLOBO. Somos um grupo de mídia que cria, produz e distribui conteúdos de qualidade que informam, educam e divertem. Globo, c2015. Disponível em: 
<http://grupoglobo.globo.com/>. Acesso em: 18 ago. 2015.

GRUZD, A. Research with Netlytic. Netlytic: Software for Automated Text and Social Network Analysis. c2017. Disponível em: <https://netlytic.org/home/?page_id=49>. Acesso em: 15 mar. 2015.

GUEDES, Éllida Neiva. Espaço público contemporâneo: pluralidade de vozes e interesses. Biblioteca Online de Ciencias da Comunicação, [S.1], 2010. Disponível em: <http://www.bocc.ubi.pt/pag/guedes-ellida-espaco-publico-contemporaneo.pdf >. Acesso em: 10 de fev. 2015.

HABERMAS, J. Direito e democracia: entre facticidade e validade. Rio de Janeiro: Tempo Brasileiro, 2003.

HABERMAS, J. Mudança estrutural da esfera pública. Rio de Janeiro: Tempo Brasileiro, 2002.

HANSEN, Derek; SHNEIDERMAN, Ben; SMITH, Marc A. Social network analysis: measuring, mapping and modeling collections of connection. In: Analyzing social media networks with NodeXL: insights from a connected world. Burlington (MA): Elsevier, 2011. Cap. 3, p. 31-50.

HASSELMANN, Joice. Petezada chora. Teori acerta na mosca. Lula chama militância. YouTube, 11 maio 2016. Disponível em: <https://www.youtube.com/watch?v=d6efkoPXuT0\&feature=youtu.be\&a>. Acesso em: 15 mai. 2016.

HEPP, Andreas. As configurações comunicativas de mundos midiatizados: pesquisa da midiatização na era da "mediação de tudo". Matrizes, São Paulo, v. 8, n. 1. p. 45-64, jan./jun. 2014.

HJARVARD, Stig. Midiatização: teorizando a mídia como agente de mudança social e cultural. Matrizes, São Paulo, v. 5, n.2. p. 53-91, 2012.

HOFFMANN, Bruno. Lula: "Se o MP quisesse me ouvir, era só ter me chamado". 04 mar. 2016. Disponível em: <http://www.pt.org.br/lula-se-o-mp-quisesse-me-ouvir-era-so-ter-mechamado/>. Acesso em: 15 maio 2016.

HONEYCUTT, Courtenay; HERRING, Susan C. Beyond Microblogging: Conversation and Collaboration via Twitter. 2009. Disponível em:

<http://ella.slis.indiana.edu/ herring/honeycutt.herring.2009.pdf>. Acesso em: 20 mar. 2016.

HOVLAND, C.; LUMSDAINE, A.; SHEFFIELD, F. D. Experiments on mass communication. Clinton, Mass.: Colonial Press, 1949.

IMPEACHMENT de Dilma Rousseff marca ano de 2016 no Congresso e no Brasil. Senado Notícias, Agência Senado, 12 dez. 2016. Disponível em: $<$ http://www12.senado.leg.br/noticias/noticias/materias/2016/12/28/impeachment-de-dilmarousseff-marca-ano-de-2016-no-congresso-e-no-brasil>. Acesso em: 14 jan. 2017. 
INDONÉSIA, Brasil e Venezuela lideram aumento global de uso do Twitter. Reston (VA): comScore, 11 ago. 2010. Disponível em: <http://www.comscore.com/por/Imprensa-eeventos/Press-Releases/2010/8/Indonesia-Brazil-and-Venezuela-Lead-Global-Surge-inTwitter-Usage?cs_edgescape_cc=BR>. Acesso em: 16 mar. 2014.

INSIDE Twitter: an in-depth look inside the Twitter world. Jun. 2009. Sysomos. Disponível em: <https://sysomos.com/inside-twitter/>. Acesso em: 15 mar. 2016.

INSTITUTO BRASILEIRO DE GEOGRAFIA E ESTATÍSTICA. Acesso à internet e à televisão e posse de telefone móvel celular para uso pessoal 2014. IBGE, 2016. Disponível em: < http://www.ibge.gov.br/home/estatistica/populacao/acessoainternet2014/default.shtm>. Acesso em: 15 mar. 2015.

INSTITUTO LULA. Missão. c2017. Disponível em: <http://www.institutolula.org/missao>. Acesso em: 15 maio 2016.

JAKETAPPER. The significance of president Obama praising Lula's "good looks". ABC News. 2 abr. 2009. Disponível em: < http://blogs.abcnews.com/politicalpunch/2009/04/thatsmy-man-ri.html>. Acesso em: 15 de jun. 2016.

JAVA, Akshay et al. Why we twitter: understanding microblogging usage and communities. In: PROCEDINGS OF THE JOINT 9TH WEBKDD AND 1ST SNA-KDD WORKSHOP 2007, 12 Aug. 2007. Disponível em:

<http://www.cs.rochester.edu/twiki/pub/Main/HarpSeminar/Why_We_Twitter-

_Understanding_Microblogging_Usage_and_Communities.pdf >. Acesso em: 15 ago. 2014.

JORNAIS e revistas continuam avançando em 2017 com suas edições digitais. Poder 360, 05 abr. 2017. Disponível em: <http://www.poder360.com.br/midia/jornais-e-revistas-continuamavancando-em-2017-com-suas-edicoes-digitais/> . Acesso em: 15 abr. 2017.

JUNQUEIRA, Daniel. Qual é o perfil dos usuários do Twitter no Brasil? 19 mar. 2014. Disponível em: <http://gizmodo.uol.com.br/perfil-twitter-brasil/>. Acesso em: 15 mar. 2015.

KEMP, Simon. Digital in 2016. We Are Social, London, 27 jan. 2016. Disponível em: <https://wearesocial.com/uk/special-reports/digital-in-2016>. Acesso em: 15 mar. 2016.

KUCINSKI, Bernardo. O antilulismo na campanha de 2006 e suas raízes. In: LIMA, Venício Artur de. (org.). A mídia nas eleições de 2006. São Paulo: Fundação Perseu Abramo, 2007. p.133-144.

KWAK, Haewoon et al. What is Twitter: a social network or a news media? Raleigh, NC, 2010. p. 591- 600. Disponível em:

<http://www.ambuehler.ethz.ch/CDstore/www2010/www/p591.pdf >. Acesso em: 15 mar. 2016.

LACLAU, Ernesto. A razão populista. São Paulo: Três Estrelas, 2013.

LASSWELL, Harold Dwight. A Linguagem da Política. Brasília: Editora Universidade de Brasília, 1979. 
LASSWELL, Harold Dwight. Propaganda technique in World War. London: Kegan Paul, 1927.

LATTMAN-WELTMAN, F. Democracia e revolução tecnológica em tempos de cólera: influência política e midiática e radicalização militante. In: CONGRESSO DA ASSOCIAÇÃO BRASILEIRA DE PESQUISADORES EM COMUNICAÇÃO E POLÍTICA, 6., 2015, Rio de Janeiro. Anais... Rio de Janeiro: Compolítica, 2015. p.1-22.

LAVAREDA, Antonio. Entrevista: Antonio Lavareda. Especialista em marketing político afirma que dificuldade de Dilma será substituir a figura do presidente no imaginário do eleitorado. Entrevista concedida a Hugo Marques e Octávio Costa. Istoé, 16 set. 2009. Disponível em:

<http://istoe.com.br/18177_E+MUITO+DIFICIL+LULA+TRANSFERIR+AFETO>. Acesso em: 15 mar. 2015.

LAZARSFELD, P. F.; BERELSON, B.; GAUDET, H. The people's choice: How the voter makes up his mind in a Presidential campaign. New York: Columbia University Press, 1944.

LÉVY, Pierre. Cibercultura. São Paulo: Editora. 34, 1999.

LIMA, Denilso de. O que significa 'twitter'? [S.d]. Disponível em:

$<$ https://www.inglesnapontadalingua.com.br/2009/03/o-que-significa-twitter.html>. Acesso em: 15 ago. 2016.

LIMA, Maurício. Impeachment é bomba atômica. Veja, 20 mar. 2015. Disponível em: <http://veja.abril.com.br/blog/radar-on-line/impeachment-e-bomba-atomica/>. Acesso em: 15 abr. 2016.

LIMA, Venício Artur. Presunção de culpa: a cobertura da crise política de 2005-2006. In: p. $11-49$ Mídia: crise política e poder no Brasil. São Paulo: Fundação Perseu Abramo, 2006.

LIPPMANN, W. Public opinion. New York: Mcmillan, 1922.

LOPES, Mauro. As quatro famílias que decidiram derrubar o governo democrático. In: JINKINGS, Ivana; DORIA, Kim; CLETO, Murilo (Orgs.). Por que gritamos golpe? Para entender o impeachment e a crise política no Brasil. São Paulo: Boitempo, 2016. p. 119-126

LÖWY, Michael. Da tragédia à farsa: o golpe de 2016 no Brasil. In: JINKINGS, Ivana; DORIA, Kim; CLETO, Murilo (Orgs.). Por que gritamos golpe? Para entender o impeachment e a crise política no Brasil. São Paulo: Boitempo, 2016. p. 61-68.

LULA não vai escapar. 14 abr. 2016. Disponível em:

<http://www.oantagonista.com/posts/lula-nao-vai-escapar?platform=hootsuite>. Acesso em: 17 maio 2016.

LULA PELO BRASIL. Twitter. Disponível em: <www.twitter.com/lulapelobrasil>. Acesso em: 15 jul. 2017.

LUNA, Luísa; MAIA, Rousiley. A construção da imagem pública e a disputa de sentidos na 
mídia: Lula em dois momentos. Media \& Jornalismo, Coimbra, n. 7, p. 95-124, 2005. Disponível em:

<http://www.revistas.univerciencia.org/index.php/mediajornalismo/article/view/6191/5615>. Acesso em: 16 mar. 2016.

MACEDO, Fausto; BRANDT, Ricardo; AFFONSO, Julia. Mais de mil promotores e procuradores já apoiam colegas que querem Lula preso. O Estado de S. Paulo, [S.1.], 12 mar. 2016. Disponível em: <http://politica.estadao.com.br/blogs/fausto-macedo/600-promotores-eprocuradores-apoiam-colegas-que-querem-lula-na-prisao/>. Acesso em: 15 mar. 2016.

MACHADO, Sibá. Em nota, bancada do PT na Câmara repudia manobra golpista do PSDB. 07 jul. 2015. Disponível em: <http://www.pt.org.br/em-nota-bancada-do-pt-nacamara-repudia-manobra-golpista-do-psdb/> Acesso em 15 ago. 2016.

MAINARDI, Diogo. Lula é minha anta. São Paulo: Record, 2007.

MALINI, Fábio et al. \#VemPraRua: narrativas da revolta brasileira. 2014. Disponível em: <http://labic.net/wp-content/uploads/VemPraRua-Narrativas-da-Revolta-brasileira.pdf>. Acesso em: 20 mar. 2016.

MANIFESTANTES fazem atos em defesa de Dilma em 25 estados e no DF. G1, Globo, 20 ago. 2015. Disponível em: <http://g1.globo.com/politica/noticia/2015/08/manifestantesprotestam-favor-do-governo-dilma-em-cidades-do-brasil.html>. Acesso em: 16 maio 2016.

MANIN, Bernard. As metamorfoses do governo representativo. Revista Brasileira de Ciências Sociais, São Paulo, n. 29, p.5-34, out.1995.

MAQUIAVEL. O Príncipe. Tradução, introdução e notas de Antônio D’Elia. São Paulo: Cultrix, 1995.

MARQUES, Ângela. A conversação informal na internet: condições interacionais e contribuições para uma análise qualitativa. In: BRAGA, J. L.; LOPES, M. I. V.; MARTINO, L. C. (orgs.). Pesquisa empírica em comunicação. São Paulo: Paulus, 2010. p. 315- 340.

MARQUES, Jamil. Debates políticos na internet: a perspectiva da conversação civil. Opinião Pública, Campinas, v. 12, n. 1, p. 164-187, abr./maio 2006.

MARTINS, Joyce Miranda Leão. Imágenes de Dilma candidata: performance e imaginario social en el horário electoral gratuito de 2012. In: CONGRESO URUGUAYO DE CIENCIA POLÍTICA, 4., 2012, Universidad Católica del Uruguay. Foro global de democracia directa. Uruguay: Asociación Uruguaya de Ciencia Política, 2012. Disponível em:

$<\mathrm{http}$ ///www.aucip.org.uy/docs/cuarto_congreso/11121912\%20-

\%20Le\%C3\%A3o\%20Martins,\%20Joyce\%20Miranda.pdf>. Acesso em: 30 de ago. 2015.

MASSUCHIN, Michele Goulart et al. A construção da campanha eleitoral majoritária no HGPE: uma análise comparada das estratégias usadas pelos presidenciáveis de 2014. Política \& Sociedade, Florianópolis, v. 15, n. 32, p.171-203, jan./abr. 2016. Disponível em: $<$ https://periodicos.ufsc.br/index.php/politica/article/view/45421/32078>. Acesso em: 30 ago. 2015. 
MATAIS, Andreza; ROSA, Vera; BULLA, Beatriz. PSDB de Aécio Neves pede auditoria na votação. O Estado de S. Paulo, São Paulo, 20 out. 2014. Disponível em: < http://politica.estadao.com.br/noticias/geral,psdb-de-aecio-neves-pede-auditoria-navotacao,1585755>. Acesso em: 15 mar. 2015.

MATOSO, Filipi. Lula terá os poderes necessários para ajudar, afirma Dilma. G1,Globo, Brasília, 16 mar. 2016. Disponível em: <http://g1.globo.com/politica/noticia/2016/03/lulatera-os-poderes-necessarios-para-ajudar-afirma-dilma.html>. Acesso em: 16 ago. 2016.

MENDONÇA, Ricardo. Ato da CUT em São Paulo teve 41 mil participantes, mostra DataFolha. Folha de S. Paulo, São Paulo, 13 mar. 2015. Disponível em: <http://www1.folha.uol.com.br/poder/2015/03/1602671-ato-da-cut-em-sao-pauto-teve-41mil-participantes-mostra-datafolha.shtml>. Acesso em: 15 mar. 2016.

MENSALÃO: saiba quem são os 25 réus do mensalão que foram condenados pelo STF. Uol Notícias, [S.1.], 29 set. 2012. Disponível em: <https://noticias.uol.com.br/politica/listas/saibaquais-reus-do-mensalao-ja-foram-condenados-pelo-stf.htm>. Acesso em: 15 ago. 2015.

MICHAELIS. Ironia. In: Dicionário Brasileiro de Língua Portuguesa. [S.1.]: Melhoramentos, c2017. Disponível em: 〈http://michaelis.uol.com.br/busca?id=QwG3x>. Acesso em: 15 mar. 2016.

MÍDIA NINJA. Sobre. [S.1], Facebook, 2016. Disponível em: <https://ptbr.facebook.com/pg/MidiaNINJA/about/?ref=page_internal>. Acesso em: 15 mar. 2015.

MIGUEL, Luis Felipe. A democracia na encruzilhada. In: JINKINGS, Ivana; DORIA, Kim; CLETO, Murilo (Orgs.). Por que gritamos golpe? Para entender o impeachment e a crise política no Brasil. São Paulo: Boitempo, 2016. p. 31-38.

MIGUEL, Luis Felipe. A eleição visível: a Rede Globo descobre a política em 2002. Dados, Revista de Ciências Sociais, Rio de Janeiro, v.46, n.2, p.289-310, 2003.

MIGUEL, Luis Felipe. Capital político e carreira eleitoral: algumas variáveis na eleição para o congresso brasileiro. Revista de Sociologia e Política, Curitiba, 20, p. 115-134, jun. 2003a, p. 115-134.

MIGUEL, Luis Felipe; COUTINHO, Aline Almeida. A crise e suas fronteiras: oito meses de "mensalão" nos editoriais dos jornais. Opinião Pública, Campinas, v. 13, n. 1, p.97-123, jun. 2007.

MIGUEL, Luis Felipe. Dossiê "Mídia e Política". Revista de Sociologia e Política, Curitiba, n.22, p. 7-12, jun. 2004.

MIGUEL, Luis Felipe. Eleições, opinião pública e mídia: reflexões a partir das eleições brasileiras de 2002. Revista Política \& Sociedade, Florianópolis, v.2, n. 02, p. 41-66, abr. 2003b. Disponível em:

<https://periodicos.ufsc.br/index.php/politica/article/viewFile/4954/4313>. Acesso em: 17 ago. 2015. 
MIGUEL, Luis Felipe. Mídia e eleições: a campanha de 1998 na Rede Globo. Dados, Rio de Janeiro, v.42, n.2, p.253-276, 1999.

MIGUEL, Luis Felipe. Mídia e manipulação política no Brasil: a Rede Globo e as eleições presidenciais de 1989 a 1998. Comunicação \& Política, Rio de Janeiro, v.6, n. 2 e 3, p.119138, maio/dez.1999a.

MIGUEL, Luis Felipe. Mito e discurso político: uma análise a partir da campanha eleitoral brasileira de 1994. Campinas: Editora da Unicamp; São Paulo: Imprensa Oficial, 2000.

MIGUEL, Luis Felipe. Os meios de comunicação e a prática política. Lua Nova, São Paulo, n. 55-56, p.155-184, 2002.

MIGUEL, Luis Felipe. Quatro poderes e um golpe. In: FREIXO, Adriano de; RODRIGUES, Thiago. (Org.). 2016: o ano do golpe. Rio de Janeiro: Oficina Raquel, 2016b. v. 1, p.96-115.

MISCHAUD, E. Twitter: expressions of the whole self. An investigation into a appropriation of a web-based communications platform. 2007. 53f. Dissertation (Master's degree in Politics and Communication) - London School of Economics and Political Science, London, 2007. Disponível em:

<http://www.lse.ac.uk/media@ @lse/research/mediaWorkingPapers/MScDissertationSeries/Past /Mishaud_Final.pdf $>$. Acesso em: 15 mar. 2016.

MITRE, Antônio Fernando. As peregrinações de um conceito: populismo na América Latina. Cadernos de História, Belo Horizonte, v.10, n.13, p.9-23, $1^{\circ}$ sem. 2008.

MIZRUCHI, Mark S. Análise de redes sociais: avanços recentes e controvérsias atuais. Revista de Administração de Empresas (RAE), São Paulo, v. 46, n.3, p.72-86, jul. /set. 2006.

MOISÉS, José Álvaro; MENEGUELLO, Rachel. (Org). A desconfiança política e os seus impactos na qualidade da democracia. São Paulo: Edusp, 2013. Disponível em: <http://nupps.usp.br/downloads/relatorio2013/Anexo_65_Livro_EDUSP_2013_versao_envia da.pdf>. Acesso em: 20 mar. 2016.

MORAES, Thiago P. B.; QUADROS, Doacir G. A crise do governo Dilma Rousseff em 140 caracteres no Twitter: do \#Impeachment ao \#ForaDilma. Em Debate, Belo Horizonte, v. 8, p. 14-41, 2016.

MOREIRA, Ardilhes. 'Se eu for multado, vou trazer a conta para vocês', disse Lula em Osasco. G1, O Globo, São Paulo, 25 mar. 2010. Disponível em: <http://g1.globo.com/Noticias/Politica/0,,MUL1544742-5601,00$\mathrm{SE}+\mathrm{EU}+\mathrm{FOR}+\mathrm{MULTADO}+\mathrm{VOU}+\mathrm{TRAZER}+\mathrm{A}+\mathrm{CONTA}+\mathrm{PARA}+\mathrm{VOCES}+\mathrm{DISSE}+\mathrm{LULA}$ + EM+OSASCO.html>. Acesso em: 30 de ago. 2015.

MOROZOV, Evgeny. Hugo Chavez would like to welcome you to the Spinternet. In: The Net Delusion: the dark side of internet freedom. New York: PublicAffairs, 2011. Cap. 5, p.113-141.

MOVIMENTO PASSE LIVRE. Não começou em Salvador, não vai terminar em São Paulo. 
In: MARICATO, Ermínia et al. Cidades rebeldes: passe livre e as manifestações que tomaram as ruas do Brasil. São Paulo: Boitempo, Carta Maior, 2013. p.13.

NORRIS, P. Digital divide: Civic Engagement, Information: Poverty and the Internet in Democratic Societies. New York: Cambridge University Press, 2001.

NUMBER of active Twitter users in leading markets as of May 2016 (in millions). 2016. Statista, The Statistics portal. Disponível em:

$<$ https://www.statista.com/statistics/242606/number-of-active-twitter-users-in-selectedcountries/>. Acesso em: 15 ago. 2016.

O NOVO antagonista. 03 ago. 2015. Disponível em: <http://www.oantagonista.com/posts/onovo-antagonista>. Acesso em: 15 mar. 2016.

OLVEIRA, Jorge. Lula pede desculpas pelo mensalão. Discurso do Presidente da

República, Luiz Inácio Lula da Silva, na abertura da reunião ministerial. Granja do Torto, 12 de agosto de 2005. YouTube, 23 maio 2012. Disponível em:

<https://www.youtube.com/watch?v=Qj-w3i9_hpQ>. Acesso em: 15 ago. 2015.

OLIVEIRA, Luiz Ademir de; MARTINS, Thamires Franco; LEAL, Paulo Roberto Figueira. As estratégias midiáticas de Dilma Rousseff (PT) na eleição presidencial de 2014. Revista eCom, Belo Horizonte, v. 8, n. 2, p.1-15, 2015. Disponível em:

<http://revistas.unibh.br/index.php/ecom/article/view/1624/940>. Acesso em: 15 abr. 2015.

OLIVEIRA, Patrícia. Janaína Paschoal: denúncia é formada por pedaladas fiscais e investigações da Lava Jato. Agência Senado. 28 abr. 2016. Disponível em:

$<$ http://www12.senado.leg.br/noticias/materias/2016/04/28/janaina-paschoal-denuncia-eformada-por-pedaladas-fiscais-e-investigacoes-da-lava-jato>. Acesso em: 14 jan. 2017.

OMENA, Janna Joceli C. Approaches of data analysis: networks generated through social media. Lisbon: Smart Social Media Research Techniques. 2017. p. 1-26. Disponível em: $<$ https://www.slideshare.net/jannajoceli/approaches-of-data-analysis-networks-generatedthrough-social-media?from_m_app=ios>. Acesso em: 15 mar. 2016.

OMS, Carolina; CASADO, Letícia. PSDB pede que Supremo suspenda posse de Lula. Valor Econômico, Brasília, 17 mar. 2016. Disponível em:

http://www.valor.com.br/politica/4486582/psdb-pede-que-supremo-suspenda-posse-de-lula>. Acesso em: 15 set. 2016.

ORTELLADO, Pablo; SOLANO, Esther. Nova direita nas ruas? Uma análise do descompasso entre manifestantes e os convocantes dos protestos antigoverno de 2015.

Revista Perseu, São Paulo, v. 7. n. 11, p. 169-180, 2016.

PARTIDO DA SOCIAL DEMOCRACIA BRASILEIRA. Inserção nacional do PSDB 08/15: PSDB apoia as manifestações do dia 16/08. YouTube. 6 ago. 2015a. Disponível em: <https://www.youtube.com/watch?v=1NtJXQeRDVU>. Acesso em: 15 mar. 2016.

PARTIDO DA SOCIAL DEMOCRACIA BRASILEIRA. Nota oficial do PSDB sobre as manifestações populares convocadas para o dia 15 de março. 11 mar. 2015. Disponível em: <http://www.psdb.org.br/acompanhe/nota-oficial-psdb-sobre-manifestacoes-populares- 
convocadas-para-o-dia-15-de-marco/>. Acesso em: 15 mar. 2016.

PARTIDO DA SOCIAL DEMOCRACIA BRASILEIRA. Os sete pecados que levaram a presidente Dilma Rousseff ao impeachment. 17 abr. 2016. Disponível em:

<http://www.psdb.org.br/acompanhe/os-sete-pecados-que-levaram-presidente-dilma-rousseffao-impeachment/>. Acesso em: 17 maio 2016.

PARTIDO DOS TRABALHADORES. PT apoia manifestações de 13 de março convocadas pela CUT. 06 mar. 2015. Disponível em: <http://www.pt.org.br/pt-apoiamanifestacoes-de-13-de-marco-convocadas-pela-cut/>. Acesso em: 18 ago. 2015.

PANKE, Luciana. Lula, do sindicalismo à reeleição: um caso de comunicação, política e discurso. Guarapuava: Unicentro; São Paulo: Horizonte, 2010.

PARANÁ, Denise. A história de Lula: o filho do Brasil. Rio de Janeiro: Objetiva, 2009.

PASSARINHO, Natália; CARNEIRO, Fausto. TSE determina multa de R\$10 mil a Lula por propaganda eleitoral antecipada. G1, O Globo, Brasília, 25 mar. 2010. Disponível em: $<$ http://g1.globo.com/Noticias/Politica/0,,MUL1545317-5601,00TSE+DETERMINA+MULTA+DE+R+MIL+A+LULA+POR+PROPAGANDA+ELEITORA L+ANTECIPADA.html>. Acesso em: 15 de mar. 2012.

PASSOS, Andréia; MICHELSOHN, David; LIMA, José Antônio. Os golpes de estado na América Latina, Época, 02 jul. 2009. Disponível em:

$<$ http://revistaepoca.globo.com/Revista/Epoca/0,EMI80186-15227,00-

OS+GOLPES+DE+ESTADO+NA+AMERICA+LATINA.html> . Acesso em: 18 ago. 2016.

PASSOS, Mariana Rezende dos. O Twitter como trincheira de luta: um estudo sobre o microblog de Hugo Chávez. 2012. 111 f. Dissertação (Mestrado) - Pontifícia Universidade Católica de Minas Gerais, Programa de Pós-Graduação em Comunicação Social.

PEREIRA, Merval. Tendências e denúncias. 24 out. 2014. Disponível em:

<http://blogs.oglobo.globo.com/merval-pereira/post/tendencias-denuncias-553108.html>. Acesso em: 15 fev. 2016.

PÉREZ-LIÑÁN, Aníbal S. Presidential impeachment and the new political instability in Latin America. Cambridge: University Press. 2007.

PEW RESEARCH CENTER. Iran and the "twitter revolution". Washington, 25 June 2009. Disponível em: <http://www.journalism.org/2009/06/25/iran-and-twitter-revolution/>. Acesso em: 16 jun. 2014.

PF CUMPRE mandado de busca e apreensão em triplex em Guarujá. G1, O Globo, Santos, 04 mar. 2016. Disponível em: <http://g1.globo.com/sp/santos-regiao/noticia/2016/03/pfcumpre-mandado-de-busca-e-apreensao-em-triplex-em-guaruja.html>. Acesso em: 15 abr. 2016.

PIRES, Teresinha Maria de Carvalho Cruz. A construção da imagem política de Dilma Rousseff como mãe do povo brasileiro. Revista Debates, Porto Alegre, v. 5, n. 1, p. 139-162, jan./jun. 2011. 
PIRES, Teresinha Maria de Carvalho Cruz; CASTRO, Maria Céres Pimenta Spínola. Lulismo: entre o popular e o populismo. Revista Contracampo, Niterói, v. 30, n. 2, p. 24-43, ago./nov. 2014.

PISTONE, Sergio. Imperialismo. In: BOBBIO, Norberto; MATTEUCCI, Nicola; PASQUINO, Gianfranco. Dicionário de política. 11. ed. Tradução de Carmen C. Varriale et al. Brasília: Editora Universidade de Brasília, 1998. p.611-621. Disponível em: <https://mpassosbr.files.wordpress.com/2013/03/dicionario_de_politica.pdf> Acesso em: 15 mar. 2016.

PLENÁRIO da Câmara aprova cassação de Roberto Jefferson. Folha de S. Paulo, 14 set. 2005. Disponível em: <http://www1.folha.uol.com.br/folha/brasil/ult96u72362.shtml>. Acesso em: 15 mar. 2016.

POLÍTICOS comentam pedido de prisão de Lula; veja o que disseram. G1, Globo, Brasília, 10 mar. 2016. Disponível em: <http://g1.globo.com/politica/noticia/2016/03/parlamentarescomentam-pedido-de-prisao-de-lula-veja-o-que-disseram.html>. Acesso em: 15 ago. 2016.

PRADO, Aidar; MOASSAB, Andréia. O Programa Bolsa Família na revista Veja: assistencialismo governamental ou ressentimento midiático? Revista da Associação Nacional dos Programas de Pós-Graduação em Comunicação, E-compós, Brasília, v.14, n.1, jan./abr. 2011. Disponível em: < http://www.compos.org.br/seer/index.php/ecompos/article/view/531/509>. Acesso em: 10 set. 2015.

PRIBIRAM. Dicionário Priberam. Embate. In: Dicionário Priberam, 2013. Disponível em: <https://www.priberam.pt/dlpo/embate>. Acesso em: 17 set. 2016.

QUEIROZ, Caio Cardoso de. Normatividade jornalística em circulação. Cultura Midiática, Paraíba, v. 9, n. 17, jul-dez, 2016. Disponível em: <http://periodicos.ufpb.br/ojs2/index.php/cm>. Acesso em: 15 mar. 2017.

RECUERO, Raquel. A conversação em rede: comunicação mediada pelo computador e redes sociais na Internet. Porto Alegre: Sulina, 2012.

RECUERO, Raquel. Contribuições da análise de redes sociais para o estudo das redes sociais na Internet: o caso da hashtag \#Tamojuntodilma e \#CalaabocaDilma. Revista Fronteiras, São Leopoldo, v. 16, n.2, p.60-77, maio/ago.2014.

RECUERO, Raquel. "Deu no Twitter, alguém confirma?” Funções do jornalismo na era das redes sociais. In: ENCONTRO NACIONAL DE PESQUISADORES EM

JORNALISMO, 9., 2011, Rio de Janeiro. Rio de Janeiro: ECO - Universidade Federal do Rio de Janeiro, 2011. Disponível em:

<http://www.raquelrecuero.com/arquivos/sbpjorrecuero.pdf>. Acesso em: 15 ago. 2016.

RECUERO, Raquel et al. Hashtags functions in the protests across Brazil. Sage Open, v. 1, p. 1-14, 2015. Disponível em:

<http://journals.sagepub.com/doi/abs/10.1177/2158244015586000>. Acesso em: 15 ago.

2016. 
RECUERO, Raquel. \#ProtestosBR: análise comparativa do discurso dos veículos jornalísticos. In: ENCONTRO NACIONAL DE PESQUISADORES EM JORNALISMO, 12., 2014, Santa Cruz do Sul. Anais... Brasília: SBPJor, 2014a, p.1-20.

RECUERO, Raquel. Redes sociais na internet. 2. ed. Porto Alegre: Sulina, 2011a.

RECUERO, Raquel; ZAGO, Gabriela. A Economia do Retweet: Redes, Difusão de Informações e Capital Social no Twitter. Revista Contracampo, Niterói, v. 24, n. 1, p. 19-43, jul. 2012a.

RECUERO, Raquel. ZAGO, Gabriela; BASTOS, Marcos. Análise de redes para mídia social. Porto Alegre: Sulina, 2015a.

RECUERO, Raquel; ZAGO, Gabriela; BASTOS, Macros. O Discurso dos \#ProtestosBR: análise de conteúdo do Twitter. Galaxia (São Paulo, Online), n. 28, p. 199-216, dez. 2014b.

REIS FILHO, Daniel Aarão. O colapso do colapso do populismo ou a propósito de uma herança maldita. In: FERREIRA, Jorge. (Org.). O populismo e sua história: debate e crítica. Rio de Janeiro: Civilização Brasileira, 2001. p.319-389.

REIS, Patrícia Cerqueira. Rio de Janeiro, uma cidade global? Uma reflexão sobre a construção da marca Rio. 2016. 446f. Tese (Doutorado) - Escola de Comunicação e Artes, Universidade de São Paulo, São Paulo, 2016.

RENNÓ, Lúcio R. Escândalos e voto: as eleições presidenciais brasileiras de 2006. Opinião Pública, Campinas, v. 13, n.2, p.260-282, nov. 2007.

RIBEIRO, Ivan Morais. O que é, afinal, a condução coercitiva? Canal Ciências Criminais, 04 mar. 2016. Disponível em: <https://canalcienciascriminais.com.br/o-que-e-afinal-aconducao-coercitiva/>. Acesso em: 12 ago. 2016.

RIBEIRO, Ricardo Lodi. Parecer. consulente: Alessandro Lucciola Molon. Objeto: pedido de impeachment da presidente Dilma Rousseff - aspectos orçamentários - normas de direito financeiro falta de amparo jurídico do pedido. Consultório Jurídico. [S.d]. Disponível em: <http://s.conjur.com.br/dl/parecer-ricardo-lodi-impeachment.pdf>. Acesso em: 13 jan. 2016.

RODRIGUES, Fernando. Pesquisas eleitorais: $1^{\circ}$ turno 2006, $2^{\circ}$ turno 2006. Uol Notícias, [S.l, S.d.]. Disponível em:

$<$ https://noticias.uol.com.br/fernandorodrigues/arquivos/pesquisas/pais/2006/1turno/pe_presid ente-2006.jhtm>. Acesso em: 15 nov. 2015.

ROUSSEFF, Dilma. Discurso da Presidenta da República, Dilma Rousseff, durante cerimônia de posse dos novos Ministros de Estado Chefe da Casa Civil, Luiz Inácio Lula da Silva; da Justiça, Eugênio Aragão; da Secretaria de Aviação Civil, Mauro Lopes e do Chefe de Gabinete Pessoal da Presidenta da República, Jaques Wagner. Palácio do Planalto, 17 mar. 2016. Disponível em: <http://www2.planalto.gov.br/acompanhe-oplanalto/discursos/discursos-da-presidenta/discurso-da-presidenta-da-republica-dilmarousseff-durante-cerimonia-de-posse-dos-novos-ministros-de-estado-chefe-da-casa-civil-luizinacio-lula-da-silva-da-justica-eugenio-aragao-da-secretaria-de-aviacao-civil-mauro-lopes-edo-chefe-de-gabinete-pessoal>. Acesso em: 15 ago. 2016. 
ROVAI, Renato. Um golpe não é, um golpe vai sendo... In: ROVAI, Renato (Org.). Golpe 16. São Paulo: Publisher Brasil, 2016. p. 9-21.

RUBIM, Antonio Albino Canelas. As imagens de Lula presidente. In: FAUSTO NETO, Antônio; RUBIM, Antonio Albino Canelas; VERÓN, Eliseo (Org.). Lula presidente: televisão e política na campanha eleitoral. São Paulo: Hacker; São Leopoldo: Unisinos, 2003. p. 43-64.

RUBIM, Antonio Albino Canelas. Cultura e política na eleição de 2002: as estratégias de Lula presidente. In: ENCONTRO ANUAL DA ASSOCIAÇÃO NACIONAL DOS PROGRAMAS DE PÓS-GRADUAÇÃO EM COMUNICAÇÃO (COMPÓS), 12., 2003, Recife. Anais... Brasília: Compós, 2003a, p.1-22. Disponível em:

<http://www.compos.org.br/data/biblioteca_930.pdf >. Acesso em: 15 mar. 2016.

RUBIM, Antonio Albino Canelas. Espetacularização e midiatização da política. In: RUBIM, Antonio Albino Canelas (Org.). Comunicação e Política: conceitos e Abordagens. Salvador: EdUFBA, 2004. p. 182-221.

RUBIM, Antonio Albino Canelas. Espetáculo, política e mídia. Biblioteca online de ciências da comunicação. BOCC - Biblioteca On Line de Ciências da Comunicação, 2002. Disponível em: <http://www.bocc.ubi.pt/pag/rubim-antonio-espetaculo-politica.pdf >. Acesso em: 15 ago. 2014.

RUBIM, Antonio Albino Canelas. Ética da política e ética na política nas eleições de 2006. In: LIMA, Venício Artur de (Org.). A mídia nas eleições de 2006. São Paulo: Fundação Perseu Abramo, 2007. p.159-168.

RUBIM, Antonio Albino Canelas. Mídia e Política: Transmissão de Poder. In. Heloiza Matos et al., Mídia, eleições e democracia. São Paulo: Página Aberta, 1994, p. 31-52.

SAAD-FILHO, Alfredo. Mass protests under 'Left Neoliberalism': Brazil, June-July 2013. Critical Sociology, London, v.39, n.5, p. 657-669, 2013.

SALES, Robson. PIB brasileiro cresce 0,5\% em 2014 após revisão. Valor Econômico, Rio de Janeiro, 17 nov. 2016. Disponível em: < http://www.valor.com.br/brasil/4778851/pibbrasileiro-cresce-05-em-2014-apos-revisao>. Acesso em: 15 mar. 2017.

SAMUELS, David. A evolução do petismo (2002-2008). Opinião Pública, Campinas, v. 14, n. 2, p. 302-318, nov. 2008.

SAMUELS, David. As bases do petismo. Opinião Pública, Campinas, v. 10, n. 2, p. 221 241, out. 2004.

SANCHES, Mariana. A real história do Cristo de Lula. Época, [S.1], 26 fev. 2016. Disponível em: <http://revistaepoca.globo.com/Revista/Epoca/0,„EMI214549-15223,00-

A+REAL+HISTORIA+DO+CRISTO+DE+LULA.html>. Acesso em: 15 ago. 2016.

SANTAELLA, Lucia; LEMOS, Renata. Redes sociais digitais: a cognição conectiva do Twitter. São Paulo: Paulus, 2010. 
SANTOS JUNIOR, Marcelo Alves dos. Vai pra Cuba!!! A rede antipetista na eleição de 2014. 2016. 197f. Dissertação (Mestrado em Comunicação) - Instituto de Arte e Comunicação Social, Universidade Federal Fluminense, Niterói, 2016.

SÃO PAULO (Estado). Ministério Público. Autos PIC 94.0002.0007273/2015-6. Promotor de Justiça da Capital : CASSIO ROBERTO CONSERINO. Promotor de Justiça do Patrimônio - Capital: JOSÉ CARLOS GUILLEM BLAT. Promotor de Justiça Criminal: FERNANDO HENRIQUE DE MORAES ARAÚJO. 09 mar. 2016. Disponível em: <http://s.conjur.com.br/dl/arquivo-pedido-prisao-lula-mp-sp.pdf>. Acesso em: 15 ago. 2016.

SÃO PAULO faz o maior comício. Folha de S. Paulo, Banco de dados Folha, acervo online, 17 abr. 1984. Disponível em: 〈http://almanaque.folha.uol.com.br/brasil_17abr1984.htm〉. Acesso em: 18 ago. 2015.

SCARTEZINI, Natalia. A fascistização da indignação: as manifestações de 2015 no Brasil. Cadernos de Campo, Araraquara, n. 20, p. 183-206, jan./jun. 2016.

SCHMITT, Carl. O conceito do político. Petrópolis: Vozes, 1992.

SCOTT, John. Social Network Analysis: a handbook. London: Sage Publications, 2000.

SEMIOCAST. Brazil becomes 2nd country on Twitter, Japan 3rd Netherlands most active country. Paris, France. 31 jan. 2012. Disponível em:

<http://semiocast.com/publications/2012_01_31_Brazil_becomes_2nd_country_on_Twitter_s uperseds_Japan>. Acesso em: 15 ago. 2014.

SENA, Cristina. Usar a crise para chegar ao poder é 'versão moderna de golpe', declara Dilma. Partido dos Trabalhadores, 16 set. 2015. Disponível em: < http://www.pt.org.br/usara-crise-para-chegar-ao-poder-e-versao-moderna-de-golpe-declara-dilma/>. Acesso em: 15 ago. 2016.

SERELLE, Márcio Vasconcellos.; PIRES, T. M. C. P.; CASTRO, A. L. The construction of the celebrity LULA: life history, mediatization and public face. In: WORLD CONGRESS OF SOCIOLOGY, 17., 2010, Gothenburg. Anais... Gothenburg, 2010.

SERRA, Bruna. Serra diz que Lula está acima do bem e do mal. O globo, Reuters/Brasil, 13 jun. 2010. Disponível em: <http://oglobo.globo.com/politica/serra-diz-que-lula-esta-acimado-bem-do-mal-3008611\#ixzz4P9xOQa4z>. Acesso em: 30 ago. 2015.

SILVA, João Carlos Rodrigues da. Época, Veja e o e(leitor): estratégias discursivas na construção da imagem de presidenciáveis. 2011. 206f. Tese (Doutorado em Linguística) Instituto de Letras, Universidade de Brasília, Brasília, 2011.

SILVA, Luiz Inácio Lula da. Discurso de Lula 18/03/2016 completo. Manifestação em São Paulo. YouTube. 20 mar. 2016. Disponível em:

<https://www.youtube.com/watch?v=cV4VcEMFATo>. Acesso em: 15 ago. 2016.

SILVA, Luiz Inácio Lula da. Discurso de Lula na quadra do Sindicato dos Bancários. Expresidente Lula fala para 5 mil pessoas durante de ato de apoio após ter sido conduzido 
coercitivamente a depor na PF. 07 mar. 2016a. Disponível em:

<http://www.pt.org.br/discurso-de-lula-na-quadra-do-sindicato-dos-bancarios/>. Acesso em: 15 ago. 2016.

SILVA, Tarcízio. Como monitorar mídias sociais com a Netlytic. Blog do IBPAD. 13 mai. 2016. Disponível em: < http://www.ibpad.com.br/blog/comunicacao-digital/como-monitorarmidias-sociais-com-a-netlytic/>. Acesso em: 20 abr. 2016.

SILVA, Tarcízio; STABILE, Max. Análise de redes em mídias sociais. In:

Monitoramento e pesquisa em mídias sociais: metodologias, aplicações e inovações. São Paulo: Uva Limão, 2016. p. 235-260.

SILVA, Washington Luiz. Carl Schmitt e o conceito limite do Político. KRITERION, Belo Horizonte, $\mathrm{n}^{\circ}$ 118, Dez./2008, p. 449-455.

SINGER, André Vitor. Os sentidos do lulismo: reforma gradual e pacto conservador. São Paulo: Companhia das Letras, 2012.

SINGER, André Vitor. Raízes sociais e ideológicas do lulismo. Novos Estudos, n. 85, nov. 2009. Disponível em: <http://www.scielo.br/pdf/nec/n85/n85a04.pdf>. Acesso em: data.

SINGER, André. Brasil, junho de 2013: classes e ideologias cruzadas. Revista Novos Estudos, São Paulo, n. 97, p. 23-40, nov. 213.

SIQUEIRA, Carol. Câmara autoriza instauração de processo de impeachment de Dilma com 367 votos a favor e 137 contra. Agência Câmara de Notícias. 17 abr. 2016. Disponível em: <http://www2.camara.leg.br/camaranoticias/noticias/POLITICA/507325-CAMARAAUTORIZA-INSTAURACAO-DE-PROCESSO-DE-IMPEACHMENT-DE-DILMA-COM367-VOTOS-A-FAVOR-E-137-CONTRA.html>. Acesso em: 15 ago. 2016.

SOCIAL MEDIA LAB. Welcome to the Social Media Lab. Making sense of a networked world since 2010. Toronto, [S.d]. Disponível em: <http://socialmedialab.ca/>. Acesso em: 15 mar. 2015.

SODRÉ, Muniz. As estratégias sensíveis: afeto, mídia e política. Petrópolis, RJ: Vozes, 2006.

SOLANEY, Expedito. Março de 2015 não é Março de 1964. Central Única dos Trabalhadores (CUT). 01 abr. 2015. Disponível em: <http://www.cut.org.br/artigos/marco-de-2015-nao-emarco-de-1964-ae90/>. Acesso em: 16 ago. 2016.

SOLANO, Esther. ORTELLADO, Pablo; MORETTO, Marcio. 2016: o ano da polarização? Friedrich Ebert Stifung Brasil, Análise, n. 22, 2017.

SOREL, Georges. Reflexões sobre a violência. São Paulo: Martins Fontes, 1992.

SOUZA, Jessé. A radiografia do golpe: entenda como e por que você foi enganado. Rio de Janeiro: Leya, 2016.

SOUZA, Nivaldo; CARAM, Bernardo. Congresso eleito é o mais conservador desde 1964, 
afirma Diap. O Estado de S. Paulo, São Paulo, 06 out. 2015. Disponível em: $<$ http://politica.estadao.com.br/noticias/eleicoes,congresso-eleito-e-o-mais-conservadordesde-1964-afirma-diap,1572528>. Acesso em: 15 mar. 2016.

SOUZA, Queila R.; QUANDT, Carlos O. Metodologia de análise de redes sociais. In: DUARTE, Fábio; QUANDT, Carlos; SOUZA, Queila. (Org.). O Tempo das Redes. São Paulo: Perspectiva, 2008. p. 31-63.

STANLEY, J. W.; WEARE, C.; MUSSO, J. Participation, deliberative democracy, and the internet: lessons from a National Forum on Commercial Vehicle Safety. In: SHANE, P. (Ed.) Democracy online: the prospects for political renewal through the internet. New York: Routledge, 2004. p. 167-169.

STONE, Biz. What's Happening? 19 nov. 2009. Disponível em:

<https://blog.twitter.com/2009/whats-happening>. Acesso em: 15 ago. 2015.

STROMER-GALLEY, J. Measuring deliberation's content: a coding scheme. Journal of Public Deliberation, vol. 3, issue 1, 2007, p. 1-35. Disponível em: < http://www.publicdeliberation.net/cgi/viewcontent.cgi?article=1049\&context=jpd $>$. Acesso em: 17 ago. 2015.

STROMER-GALLEY, J.; WICHOWSKI, A. Democratic discourse online. In: CONSALVO, M.; ESS, C.; BURNETT, R. (Ed.). Blackwell handbook of internet studies. London: Blackwell. 2011. p.168-187.

STYCER, Mauricio. Frase de Lula de 1988 sobre impunidade de ministros vira meme. UOL Notícias, [S.1.], 16 mar. 2016. Disponível em: <https://noticias.uol.com.br/politica/ultimasnoticias/2016/03/16/frase-de-lula-de-1988-sobre-impunidade-de-ministros-vira-meme.htm>. Acesso em: 15 de ago. 2016.

TAGATIBA, Luciana; TRINDADE, Thiago; TEIXEIRA, Ana Cláudia Chaves. Protestos à direita no Brasil (2007-2015). In: CRUZ, Sebastião Velasco ; KAYSEL, André; CODAS, Gustavo (Org.). Direita, volver! O retorno da direita e o ciclo político brasileiro. São Paulo: Fundação Perseu Abramo, 2015. p. 197-212.

TEIXEIRA, Rodrigo Alves; PINTO, Eduardo Costa. A economia política dos governos FHC, Lula e Dilma: dominância financeira, bloco no poder e desenvolvimento econômico.

Economia e Sociedade, Campinas, v. 21, n. Especial, p. 909-941, dez. 2012. Disponível em: <http://www.scielo.br/pdf/ecos/v21nspe/v21nspea09.pdf>. Acesso em: 15 de abr. 2013.

TELLES, Helcimara de Souza; PIRES, Teresinha Maria de Carvalho Cruz. Criador e criatura: petismo e lulismo nas retóricas discursivas do HGPE de Dilma Rousseff. In: CONGRESSO DA ASSOCIAÇÃO BRASILEIRA DE PESQUISADORES EM COMUNICAÇÃO E POLÍTICA, 5., 2013, Curitiba. Anais... Curitiba: Compolítica, 2013. p.1-31. Disponível em: <http://www.compolitica.org/home/wpcontent/uploads/2013/05/GT02-Midias-e-eleicoes-HelcimaraDeSouzaTelles1.pdf>. Acesso em: 30 de ago. 2015.

THE OPEN Graph Viz platform. Gephi. Disponível em: <https://gephi.org/>. Acesso em: 08 mar. 2015. 
THOMPSON, John B. O escândalo político: poder e visibilidade na era da mídia. Petrópolis: Vozes, 2002.

TUFEKCI, Z.; WILSON, C. Social Media and the decision to participate in political protest: observations from Tahrir Square. Journal of Communication, local de publicação, v.62, p. 363-379, 2012.

TWIPLOMACY study. 31 maio 2016. Disponível em: <http://twiplomacy.com/blog/twiplomacy-study-2016/>. Acesso em: 26 jun. 2016.

USUÁRIO COMUM. Twitter. Disponível em: <www.twitter.com/AnaPaulaDlamari> . Acesso em: 15 jun. 2016.

UOL Notícias. Twitter. Disponível em: <www.twitter.com/uolnoticias>. Acesso em: 15 jun. 2016.

VALLE, Taisa Dalla et al. Ciberativismo em ação: a cobertura do coletivo Mídia Ninja, no Facebook, durante as manifestações de junho de 2013, no Brasil. In: ENCONTRO NACIONAL DE HISTÓRIA DA MÍDIA, 10., 2015, Porto Alegre. Anais... Porto Alegre: Alcar, 2015. p.1-13.

VEJA. Twitter. Disponível em: 〈www.twitter.com/veja〉. Acesso em: 15 jun. 2016.

VENCESLAU, Pedro. PSDB oficializa apoio a protesto do dia 15, mas Aécio diz que não vai participar. O Estado de S. Paulo. 11 mar. 2015. Disponível em: < http://politica.estadao.com.br/noticias/geral,psdb-oficializa-apoio-a-protesto-do-dia-15-masaecio-diz-que-nao-vai-participar,1648678>. Acesso em: 15 ago. 2015.

VERÓN, Eliseo. Teoria da midiatização: uma perspectiva semioantropológica e algumas de suas consequências. Matrizes, São Paulo, v. 8, n. 1. p. 13-19, 2014.

VIANNA, Andrea. Justiça livra José Guimarães de investigação dos dólares na cueca. O Estado de S. Paulo, 28 jun. 2012. Disponível em: <http://politica.estadao.com.br/blogs/joaobosco/justica-livra-jose-guimaraes-de-investigacao-dos-dolares-na-cueca/>. Acesso em: 10 mar. 2016.

VIEIRA, Vivian Patrícia Peron. O papel da comunicação digital na Primavera Árabe: apropriação e mobilização social. . In: CONGRESSO DA ASSOCIAÇÃO BRASILEIRA DE PESQUISADORES EM COMUNICAÇÃO E POLÍTICA, 5., 2013, Curitiba. Anais...

Curitiba: Compolítica, 2013. p.1-23. Disponível em: <http://www.compolitica.org/home/wpcontent/uploads/2013/05/GT-05-Comunicacao-e-Sociedade-Civil-Vivian-Peron1.pdf>. Acesso em: 15 abr. 2015.

VILLA, Marco Antonio. Década perdida: dez anos de PT no governo. Rio de Janeiro: Record, 2013.

VILLAVERDE, João. Perigosas pedaladas: os bastidores da crise que abalou o Brasil e levou ao fim o governo Dilma Rousseff. São Paulo: Geração Editorial, 2016. 
VILLAVERDE, João; FERNANDES, Adriana. As 'pedaladas fiscais' do governo Dilma. O Estado de S. Paulo, São Paulo, [S.1., S.d.], 2016. Disponível em:

<http://infograficos.estadao.com.br/public/economia/pedaladas-fiscais/index>. Acesso em: 30 ago. 2016.

WEBER, Maria Helena. Comunicação e espetáculos da política. Porto Alegre: Ed. UFRGS, 2000.

WEBER, Maria Helena. Imagem Pública. In: RUBIM, Antonio Albino Canelas. (Org.). Comunicação e política: conceitos e abordagens. Salvador: EdUFBA, 2004. p. 259-308.

WEBER, Max. Economia e Sociedade: fundamentos da sociologia compreensiva. Brasília: Editora Universidade de Brasília, 1999.

WINNER, Langdon. Artefatos têm política? In: . The whale and the reactor: a search for limits in an age of high technology. Chicago: The University of Chicago Press, 1986. p.19-39. Disponível em:

<http://www.necso.ufrj.br/Trads/Artefatos\%20tem\%20Politica.htm>. Acesso em: 25 mar. 2012.

ZANETTI, Lorenzo. O "novo" no sindicalismo brasileiro: características, impasses e desafios. 1993. 181f. Dissertação (Mestrado em Educação) - Instituto de Estudos Avançados em Educação, Fundação Getúlio Vargas, Rio de Janeiro, 1993. Disponível em: < http://bibliotecadigital.fgv.br/dspace/bitstream/handle/10438/9188/000060898.pdf?sequence= 1\&isAllowed=y >. Acesso em: 15 mar. 2016.

ZARIFE, Fiamma. Entrevista: Fiamma Zarife. Base de usuários do Twitter no Brasil cresceu 18\% em 2016. Entrevista concedia a Fernando Paiva. MOBILETIME. 23 fev. 2017.

Disponível em:

<http://www.mobiletime.com.br/23/02/2017/basedeusuariosdotwitternobrasilcresceu18em201 6/466822/news.aspx>. Acesso em: 15 mar. 2017. 